Universidade de São Paulo

Faculdade de Filosofia, Letras e Ciências Humanas

Departamento de Ciência Política

Rafael Moreira Dardaque Mucinhato

\title{
Dos autênticos aos governistas: Gênese e trajetória do PMDB (1979 a 2002)
}

Versão corrigida

São Paulo 
Universidade de São Paulo

Faculdade de Filosofia, Letras e Ciências Humanas

Departamento de Ciência Política

Rafael Moreira Dardaque Mucinhato

\section{Dos autênticos aos governistas: Gênese e trajetória do PMDB (1979 a 2002)}

Tese apresentada ao Programa de Pós-Graduação do Departamento de Ciência Política da Universidade de São Paulo como requisito parcial para a obtenção do título de Doutor em Ciência Política.

Orientador: Prof. Dr. Glauco Peres da Silva

Versão corrigida

São Paulo 
Autorizo a reprodução e divulgação total ou parcial deste trabalho, por qualquer meio convencional ou eletrônico, para fins de estudo e pesquisa, desde que citada a fonte.

Catalogação na Publicação

Serviço de Biblioteca e Documentação

Faculdade de Filosofia, Letras e Ciências Humanas da Universidade de São Paulo

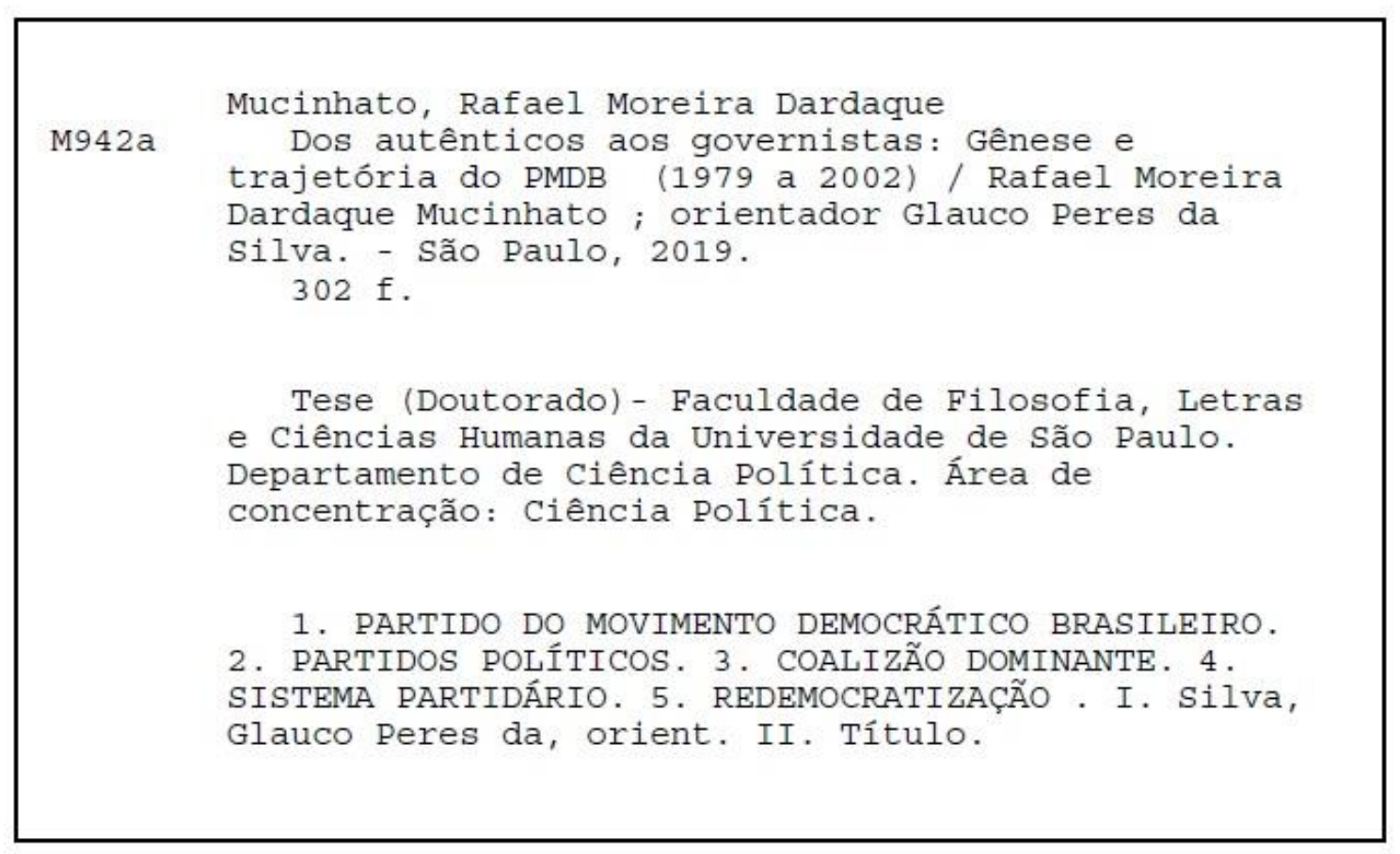




\title{
ENTREGA DO EXEMPLAR CORRIGIDO DA DISSERTACC̃̃O/TESE \\ Termo de Ciência e Concordância do (a) orientador (a)
}

\author{
Nome do (a) aluno (a): Rafael Moreira Dardaque Mucinhato \\ Data da defesa: 20/03/2019 \\ Nome do Prof. (a) orientador (a): Glauco Peres da Silva \\ Nos termos da legislação vigente, declaro ESTAR CIENTE do conteúdo deste EXEMPLAR \\ CORRIGIDO elaborado em atenção às sugestões dos membros da comissão Julgadora na \\ sessão de defesa do trabalho, manifestando-me plenamente favorável ao seu \\ encaminhamento e publicação no Portal Digital de Teses da USP.
}

São Paulo, 29/03/2019

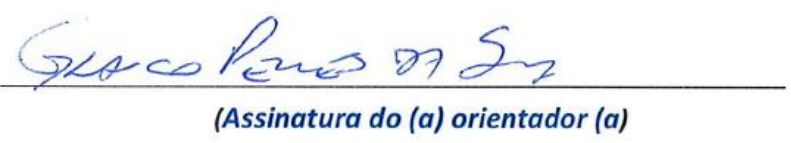


A todas e todos que lutam pela democracia. 


\section{Agradecimentos}

A conclusão desta tese encerra um longo ciclo da minha vida. Um ciclo que teve início mais de dez anos atrás, enquanto ingressante no curso de Ciências Sociais da USP, e passou pela realização de uma Licenciatura na Faculdade de Educação, um intercâmbio na Universidade Autônoma de Barcelona, um Mestrado no Departamento de Ciência Política, terminando agora com a conclusão deste Doutorado. Sendo assim, não são poucas as pessoas às quais devo agradecer por terem de alguma forma contribuído, das mais variadas maneiras, para que pudesse chegar onde estou, pois sem elas nada disso que fiz teria sido possível. Dada a emoção do momento e o longo período que engloba este agradecimento, de antemão peço sinceras desculpas aos que a caso não tenham sido mencionados. Saibam que, independentemente de seus nomes estarem ou não aqui presentes, mando meus mais honestos sentimentos de gratidão.

Começo, então, agradecendo a toda a população brasileira, sobretudo a sua camada menos privilegiada economicamente, que por meio dos impostos, proporcionalmente mais incidentes sobre o seu consumo que ao dos restantes, permitem a manutenção tanto do ensino superior público quanto das agências de fomento à pesquisa ligadas a estas universidades no Brasil. Afinal, o presente trabalho foi realizado com apoio financeiro da Coordenação de Aperfeiçoamento de Pessoal de Nível Superior (CAPES), do Conselho Nacional de Desenvolvimento Científico e Tecnológico $(\mathrm{CNPq})$ e a realização dos dois períodos de trabalho de campo em Brasília só foi possível por ter contado com o apoio da CAPES/PROEX.

Meu ingresso numa universidade pública não teria ocorrido caso não tivesse recebido o apoio e o incentivo à educação despendidos por parte da minha família. Agradeço então a minha mãe, Cláudia Moreira Dardaque Mucinhato, a minha irmã, Raísa Moreira Dardaque Mucinhato, companhia cotidiana durante o processo de produção desta tese, meus avós Norma e Eduardo Dardaqui, e todos os demais familiares que foram incentivadores e entusiastas da caminha carreira até aqui. A entrada no Ensino Superior também não teria ocorrido não fosse o apoio de Sharon e Augie Lucidi, a quem também sempre chamei de pais desde que fui hospedado em sua casa ainda no colegial, e aos professores Lígia e Garcia (in memorian), que durante os anos de cursinho me apresentaram as Ciências Sociais e colaboraram para minha aprovação no vestibular da FUVEST. Foi naquele mesmo espaço que se formou a "Família COC 2005-2006", fundamental para que eu aprendesse que o estudo se dá de maneira colaborativa e não competitiva, e onde fiz amizades que me ajudaram a ingressar numa universidade e que seguem desde então: Jessica Voigt, Aline Sharlene (a quem agradeço pela transcrição da quase totalidade das entrevistas realizadas para este estudo), Gustavo Quintella, Andressa Saboya, Bruna Duarte, Isadora Moreira, Isadora Alonso, "Didi" Rodrigues, Tales Lima, Mayra Figo, Nicole Dias, Daniel e Tassiana Barreto, Theo Lubliner, Caio Alves, e Caio Guerra. Agradeço também a alguns de meus amigos de Santos, alguns dos quais me acompanham desde a infância, que acompanham 
e incentivam minha trajetória desde então, apesar do desconhecimento da parte de muitos outros em relação à minha profissão e área de atuação: Bruno Oliveira, Erica Fuji, Eliane Santos, Fernanda Fuzeto, Fernando e Lucas De Santis, Gisela Lopes, Lidio Tavares, Rafael Nery, Thiago Souto.

Em se tratando da minha passagem pela USP, começo agradecendo ao nosso quadro de servidores. Agradeço às funcionárias e funcionários da Biblioteca Florestan Fernandes, da Faculdade de Filosofia, Letras e Ciências Humanas (FFLCH), a todas e todos que trabalham na manutenção dos prédios da nossa faculdade e que nos dão as condições para desenvolvermos nossos estudos, aos funcionários e funcionárias da Administração da FFLCH, que muitas vezes nos tiram dúvidas e ajudam na solução de problemas burocráticos que muitas vezes parecem intransponíveis, e a todas e todos que trabalham ou trabalharam no Departamento de Ciência Política com os quais tive contato nos últimos seis anos, como Vasne, Márcia, Leo, Mari Rai e muitos outros, que cumprem um papel fundamental para que nosso Departamento tenha o destaque que tem, tanto em âmbito nacional quanto internacional. Estendo também meu agradecimento à Vera Cecília e Regina dos Santos, analistas acadêmicas do Núcleo de Pesquisa de Políticas Públicas (NUPPs), que tanto me ajudaram nas pesquisas que desenvolvi enquanto estive vinculado ao Núcleo.

Na graduação, fiz amizades que permanecem até hoje, e o acúmulo que pude ter nas mais variadas áreas das Ciências Sociais só foi possível pelo que aprendi na convivência cotidiana com muitos dos ingressantes do curso naquele turbulento ano de 2007. Apesar de vê-los pouco nos últimos anos, até por conta das exigências da pósgraduação, o contato e o aprendizado com vocês segue. Agradeço então a Jean Gustavo, Amanda Carneiro, Victor Savarese, Mariel Deak, Victor Secco (a quem também agradeço pela parceria no período de intercâmbio em Barcelona e pelas constantes conversas ao redor do mundo), Rodrigo Chiquetto, Leticia Shimoda, Yuri Tambucci, Alvaro Kanasiro, Michel Mustafa, Thiago Aguiar, Franco Ortiz, Fernanda Ticianelli, Mariana Hangai, Sol Robles, Marianne Estermann, Marina Finicelli, e Maiara Beckrich. Agradeço também as amigas e amigos dos outros anos do curso, como Almir Oliveira (a quem agradeço pelo apoio nas mudanças em São Paulo), Renata Albuquerque (que me ensinou a importância do tema gênero durante nossa militância no movimento estudantil) e a todas e todos que tive o prazer de conhecer e atuar lado a lado nos anos em que participei de gestões do CeUPES, o Centro Acadêmico do curso de Ciências Sociais da USP.

Durante todo o período em que vivi em São Paulo, tive o prazer de compartilhar um teto com aqueles que se tornaram minha segunda família, numa casa que passou a ser conhecida como "República Mais Feliz do Mundo", de cuja tônica das convivências já temos noção pelo nome. O convívio com vocês durante tanto tempo me tornou uma pessoa melhor a cada dia e foi fundamental para que tivesse um espaço onde pudesse me dedicar aos meus estudos e ao mesmo tempo reconhecer a importância do convívio social com pessoas que só querem o bem uns dos outros. Agradeço então a Theo Carvalho, Bruno Portolesi, Tâmara Kovacs (a quem também agradeço pela meticulosa 
revisão textual desta tese), Fabrício Morais, Jefferson Ferreira, Thiago Teixeira, Tom Laterza, Ramon Miranda, Thales Gayean, Lucia Amorosi, Filippo Temporin, Natália Lourenço, Karla Silva, Ana Bernardino, e Ritinha.

Com relação ao meu período de realização da pós-graduação, agradeço ao quadro docente do Departamento de Ciência Política, que ao longo da minha formação acadêmica contribuiu das mais variadas maneiras para que este estudo pudesse dar a sua pequena contribuição para a área da Ciência Política. Cito aqui Eunice Ostrensky, por proporcionar meu primeiro contato com a área não enquanto uma disciplina obrigatória a ser cumprida, mas sim como um assunto de estímulo e enriquecimento intelectual, por meio de seu grupo de estudos de Teoria Política, José Álvaro Moisés, pela orientação enquanto estive vinculado ao NUPPs e que representou minha primeira experiência de pesquisa na nossa área, André Singer, pela sólida orientação em minha pesquisa de mestrado, que serviu como pontapé inicial para este estudo de doutorado, e Fernando Limongi, pelos vários comentários em relação a este estudo em diferentes momentos da pós-graduação. Finalmente, mas não menos importante, agradeço especialmente ao meu orientador Glauco Peres, que me acolheu como orientando em um momento difícil tanto da minha pesquisa quanto da minha vida, e sustentou minha motivação para seguir nesta pesquisa e nesta área de estudos, conduzindo uma orientação não só neste estudo mas também na minha atuação profissional de uma maneira exemplar. Sem o seu apoio e nosso constante e franco diálogo esta tese não teria sido concluída.

Agradeço também aos colegas de pós-graduação que muito contribuíram para minha formação intelectual nas mais variadas áreas temáticas da ciência política ao longo dos últimos anos: Vinícius do Valle, Camila Rocha, Barbara Regina, Joyce Luz, Juliana Souza Oliveira, Gabriel Madeira, Mariana Silveira, Christiane Ferreira, Mariana Ruivo, Lucas Mingardi, Carla Bezerra, Patrícia Brasil, Leonardo Menezes, Henrique Costa, Danilo Fiore, e Maria Letícia. Agradeço especialmente a Fabricio Vasselai, a quem sempre tive como um "co-orientador" durante o período em que pudemos trabalhar conjuntamente, que sempre colaborou com insights e me apresentou acúmulos que a literatura de ciência política tem que eu nem poderia imaginar anteriormente, Beatriz Sanchez, pesquisadora e militante exemplar, e a pessoa que mais me ensinou sobre a importância de se levantar questões ligadas à desigualdade de gênero na política e no Brasil, um agradecimento que estendo às outras pesquisadoras que fazem parte do GEPÔ - Grupo de Estudos de Gênero e Política/DCP-USP, como Daniela Constanzo e Hannah Maruci, e finalmente a Sergio Simoni Jr., pela colaboração acadêmica nos últimos anos, da parte de alguém que admiro e que sei que terá um brilhante caminho pela frente na nossa área.

Agradeço também pelos comentários a esta pesquisa às cientistas políticas Melani Cammett (Harvard University) e Natalia Suzuki (Departamento de Ciência Política da USP), assim como a todas e todos os colegas do curso sobre o uso de entrevistas em pesquisas de métodos mistos, ministrado por ambas, como parte da 9th Annual IPSA-USP Summer School. O aprendizado ali acumulado foi de grande valia para a realização do trabalho de campo e das entrevistas para esta tese. Só aqueles 
pesquisadores que trabalham com entrevistas em seus estudos sabem das dificuldades e habilidades necessárias para se gerar uma informação importante para a sua pesquisa, a partir de uma entrevista que muitas vezes pode levar meses para ser agendada e poucos minutos para ser encerrada.

No que concerne ao período de realização do trabalho de campo deste estudo, em Brasília e São Paulo, também devo um grande agradecimento a muitos. Agradeço primeiramente a todas as que me ajudaram compartilhando seus contatos no meio político para que eu pudesse realizar as entrevistas que tanto contribuíram para este estudo: as jornalistas Viviane Cezarino e Mariana Schreiber Ribeiro, e a socióloga Thandara Santos. Para além dos contatos que me foram dados, também agradeço enormemente ao cientista político Danilo Silvestre, ao internacionalista Pedro Lara e à pesquisadora Carolina Dubeux, que me hospedaram em mais de uma ocasião na nossa capital federal me dando um suporte que foi fundamental para que pudesse realizar este estudo. Além dos dois, agradeço também a todos que me apresentaram enquanto estive na cidade e que se tornaram parte do meu círculo de amigos, tornando os períodos de trabalho de campo muito mais agradáveis apesar do difícil cotidiano imposto pela nossa conjuntura política.

Agradeço aos parlamentares, ex-parlamentares, políticos e demais profissionais que contribuíram para a construção desta pesquisa dispondo parte de seu tempo e me concedendo entrevistas: João Carlos Brum Torres, Pedro Simon, Tonico Ramos, Luiz Carlos Bresser Pereira, Jarbas Vasconcelos, Airton Sandoval, Sônia Carneiro, Roberto Requião, Jader Barbalho, Mauro Benevides, Marcelo Barbieri, Pedro Pinheiro Chaves, Flaviano Melo, Marcelo Castro, Rogério "Peninha" Mendonça, Saraiva Felipe, Raimundo Lira, Rose de Freitas, Raymundo Urbano, Celso Maldaner, Mauro Lopes, Garibaldi Alves, Miro Teixeira, Cássio Cunha Lima, e Heráclito Fortes. Estendo também este agradecimento aos assessores e funcionários de gabinetes parlamentares que tanto ajudaram na intermediação pra realização dessas entrevistas.

Agradeço às funcionárias Valéria Lossani e Maria Rita Navarro, da unidade de São Paulo da Fundação Ulysses Guimarães, e a todos na sede nacional da Fundação, que dispuseram parte do seu tempo para me atender e me apresentar o acervo mantido pelas unidades. Agradeço também a José Wilton Alves Freire (chefe da seção) e demais funcionários da Seção de Gerenciamento de Dados Partidários do Tribunal Superior Eleitoral (SEDAP-TSE), assim como pelas constantes acolhidas, cafés, e sobretudo sorrisos no corrido cotidiano no Congresso Nacional, à Giulia Tadini, a Sandro Lobo, Bruna Menezes, Patricia Isabel, Mariane Andrade e Flávio Elias.

Esta tese não teria sido concluída não fosse o apoio de alguns profissionais exemplares em suas áreas de atuação e que me ajudaram a recuperar e a manter tanto a minha saúde física quanto minha saúde mental. Agradeço então às minhas instrutoras de yoga, Jô Camargo e Débora Oliveira, aos médicos Cláudio e Constantina Coy, ao meu acupunturista, José Henrique Veiga (assim como a sua esposa Magaly, sempre atenciosa quando precisei) e a minha psicóloga, Luciana Lima, fundamental para o meu equilíbrio 
ao longo deste doutorado. Sem a ajuda profissional de vocês esta pesquisa definitivamente não teria sido concluída.

Por fim, agradeço ainda àqueles que, sem saber, me acolheram durante meu retorno à cidade de Santos e me fizeram relembrar que não estou sozinho no que diz respeito àquilo que acredito, nem em minha militância, nem em minha vida: Débora Camilo, Everton Vieira, Guilherme Prado, Cesar Vale, Aline Leal e Sandoval Goes.

Cabe aqui dizer também que este texto e esta pesquisa foram levados adiante apesar de todas as dificuldades impostas pelos governantes e ex-governantes tanto de nosso estado quanto de nosso país, que nos últimos anos cada vez mais têm dificultado o caminho dos pesquisadores que tentam, a duras penas, com todo seu esforço e sacrifício, usar a maior parte do precioso tempo de suas vidas e da sua energia para a produção de conhecimento científico. Apesar disso, torço pra que as reflexões aqui produzidas possam ser úteis à sociedade que nos cerca. E como de praxe, advirto a todas e todos os leitores deste estudo que nenhuma das pessoas ou instituições aqui citadas têm qualquer responsabilidade pelas falhas desta tese, as quais são exclusivamente minhas. 
"Escrever a história de um partido significa nada mais do que escrever a história geral de um país a partir de um ponto de vista monográfico, pondo em destaque um seu aspecto característico (sic). Um partido terá maior ou menor significado e peso precisamente na medida em que sua atividade particular tiver maior ou menor peso na determinação da história de um país." Antonio Gramsci, em "Cadernos do cárcere, 13" (2000: 87).

"As coalizões dominantes mudam e, com elas, mudam os partidos." Angelo Panebianco, em "Modelos de partido. Organização e poder nos partidos políticos" (2005: 344). 


\section{Resumo}

Esta tese investiga a história de um dos mais longevos partidos políticos do nosso sistema partidário, o Partido do Movimento Democrático Brasileiro (PMDB). A partir de uma perspectiva nacional e diacrônica, analisamos sua história interna cobrindo mais de duas décadas de sua trajetória, de 1979 a 2002, com o intuito de compreender como o partido passou do protagonismo ao pano de fundo da política nacional, mas mantendose, ainda assim, um ator determinante em nosso arranjo político institucional. Levando em conta o peso que os órgãos de direção têm na definição dos rumos dos partidos políticos brasileiros, assim como a forte presença de parlamentares nesses órgãos no que se refere especificamente ao PMDB (Ribeiro, 2014), fazemos uso do conceito de coalizão dominante de Panebianco (2005) para analisar a face diretiva do partido (Katz e Mair, 1993) e argumentamos que a compreensão da dinâmica interna dos seus principais órgãos de direção contribui para entender as mudanças ocorridas nas estratégias políticas e eleitorais adotadas pelo PMDB, sobretudo no que tange às disputas pelo cargo de Presidente da República. Para realizar esse objetivo, a tese apoiase tanto em um amplo levantamento documental quanto em entrevistas em profundidade, realizadas com políticos importantes para a história do partido em seus respectivos estados, um esforço pioneiro nos estudos em relação a este objeto. Ainda nesse sentido, este estudo divide-se em duas partes. A primeira delas investiga o recorte histórico de 1979 a 1988, período no qual as transformações internas do partido estiveram mais ligadas às constantes entradas e saídas de quadros. Incluem-se nesse período, entre outros eventos, a refundação da sigla em 1979, a incorporação do Partido Popular em 1982, a entrada de José Sarney no partido em 1985, a legalização dos partidos comunistas em 1985 e a formação do PSDB em 1988. Por sua vez, na segunda parte deste estudo investigamos o recorte histórico de 1989 a 2002. Neste segundo período, as transformações internas na coalizão dominante e consequentemente as estratégias eleitorais adotadas estiveram mais ligadas a disputas internas entre suas diferentes alas. Incluem-se nesse período as breves hegemonias ulyssista e quercista, que levaram Ulysses Guimarães e Orestes Quércia a serem os candidatos presidenciais respectivamente em 1989 e 1994, a indefinição quanto a lançar candidatura própria ou coligar-se com outro partido nas eleições presidenciais de 1998 e, por fim, a chegada de Michel Temer à presidência do partido em 2001, consolidando o bloco chamado de "governista" enquanto coalizão dominante do partido a partir de então. Sugerimos que o estudo deste partido em específico de maneira aprofundada, dados o tamanho e a complexidade do PMDB, permitem-nos uma compreensão de processos e dinâmicas que vão além dele. Seu estudo proporciona uma visão, a partir de um ponto de vista específico, da história política do Brasil durante e após a transição democrática, e nos permite, também, lançar luz sobre outros aspectos do nosso sistema político-partidário, como, por exemplo, a dinâmica de bipolarização das disputas presidenciais no país entre candidaturas de PT e PSDB, que se consolida durante o recorte histórico aqui estudado.

\section{Palavras-chave}

Partido do Movimento Democrático Brasileiro (PMDB), partidos políticos, coalizão dominante, sistema partidário, redemocratização. 


\section{Abstract}

This thesis investigates the history of one of the longest-lived political parties in our party system, the Party of the Brazilian Democratic Movement (PMDB). From a national and diachronic perspective, we analyze its internal history covering more than two decades, from 1979 to 2002, in order to understand how the party moved from the protagonism to the background of national politics, but remaining yet as a determining actor in our political system. Taking into account the weight that the governing bodies have in defining the directions of the Brazilian political parties, as well as the strong presence of parliamentarians in these bodies with regard to the PMDB (Ribeiro, 2014), we use the concept of ruling coalition of Panebianco (2005) to analyze the party in central office (Katz and Mair, 1993) and argue that the understanding of the internal dynamics of its main governing bodies contributes to understanding the changes in the political and electoral strategies adopted by the PMDB, especially regarding the presidential elections. In order to achieve this goal, the thesis is based on a wide documentary investigation and on in-depth interviews with important politicians to the history of the party in their states, a pioneering effort in the studies related to this object. In this sense, this study is divided into two parts. The first one investigates the time period from 1979 to 1988, a moment in which the internal transformations of the party were more linked to the constant flow of politicians in and out of it. This period includes, among other events, the refoundation of the party in 1979, the incorporation of the Popular Party in 1982, the entry of José Sarney in 1985, the legalization of the communist parties in 1985 and the formation of the PSDB in 1988. On the other hand, in the second part of this study we investigate the time period from 1989 to 2002. In this second period, the internal transformations in the ruling coalition and consequently the electoral strategies adopted were more related to internal disputes between its different wings. Included in this period were the brief Ulyssist and Quercist hegemonies, which led Ulysses Guimarães and Orestes Quércia to be the presidential candidates respectively in 1989 and 1994, the indefiniteness in launching their own candidacy or joining with another party in the 1998 presidential elections and, finally the arrival of Michel Temer to the presidency of the party in 2001, consolidating the wing called "governists" as the party's ruling coalition thereafter. We suggest that the in depth study of this particular party, given the size and complexity of the PMDB, allow us an understanding of processes and dynamics that go beyond it. His study provides a view, from a specific point of view, of Brazil's political history during and after the democratic transition, and also allows us to shed light on other aspects of our politicalparty system, such as the dynamics of bipolarisation of the presidential elections in the country between PT and PSDB candidacies, which has consolidated during the time period studied here.

\section{Keywords}

Party of the Brazilian Democratic Movement (PMDB), political parties, ruling coalition, party system, democratic transition. 


\section{Sumário}

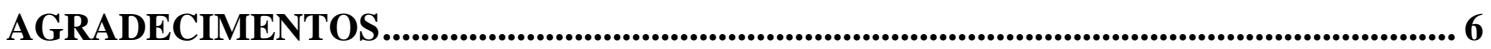

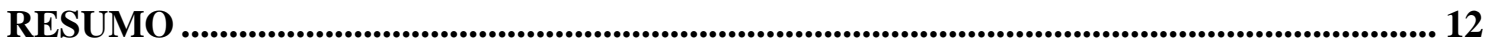

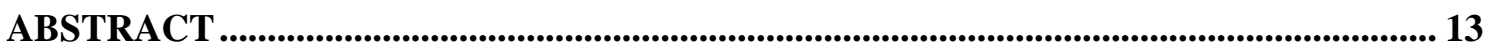

LISTA DE TABELAS, GRÁFICOS E FIGURAS ......................................................... 17

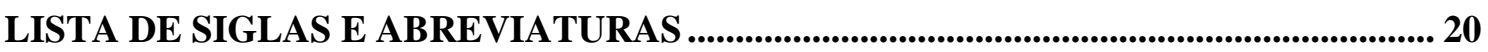

INTRODUÇÃ

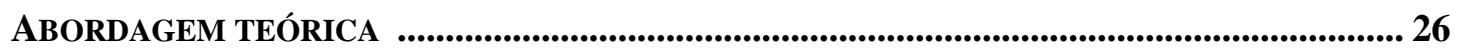

ASPECTOS GERAIS DO PMDB: O QUE SE SABE SOBRE O PARTIDO? ................................... 31

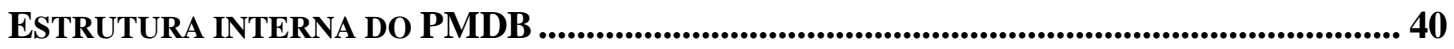

FONTES DE PESQUISA..................................................................................................................... 43

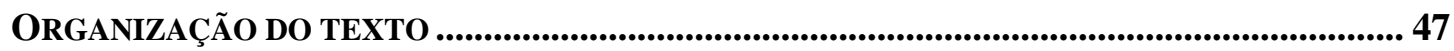

PARTE 1 - DA REFUNDAÇÃO À CONSTITUINTE: A TRAJETÓRIA DO PMDB DE

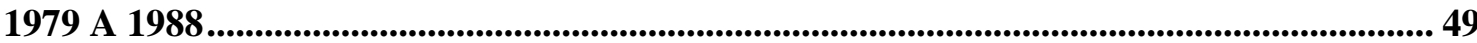

CAPÍTULO 1 - DA REFUNDAÇÃO NA OPOSIÇÃO À CHEGADA AO PODER (1979-1985) .......... 50

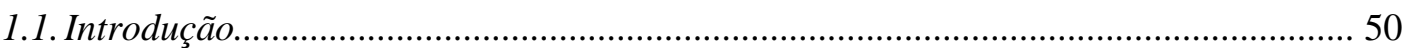

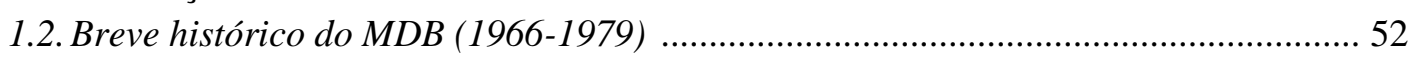

1.3. O processo de refundação do MDB: surge o PMDB (1979-1980) .............................. 54

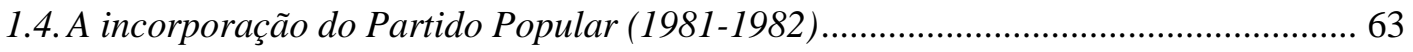

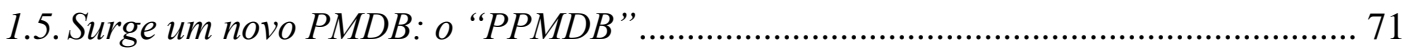

1.6. O primeiro teste nas urnas: panorama geral do PMDB nas eleições de 1982 ............ 75

1.7. Diretas-Já ou Colégio Eleitoral? Surge o bloco "Unidade" e o PMDB chega ao poder

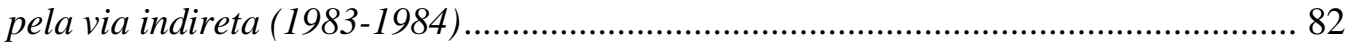

1.8. Considerações finais: o PMDB no Colégio Eleitoral de 1985..................................... 88

CAPÍTULO 2 - O PMDB NO PODER: NOVAS CHEGADAS E NOVAS SAÍDAS (1985-1988) ....... 90

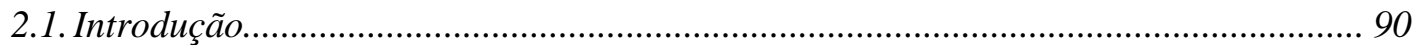

2.2 O PMDB chega ao poder com José Sarney (1985) ................................................. 92

2.3 A promulgação da Emenda Constitucional $n$. 25: novos partidos entram em cena..... 97

2.4 Os "pragmáticos" crescem e ganham terreno nos órgãos de decisão do partido e no

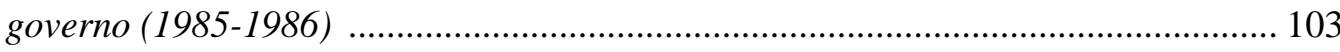

2.5 O partido cresce e "incha" nas urnas: panorama geral do PMDB nas eleições de

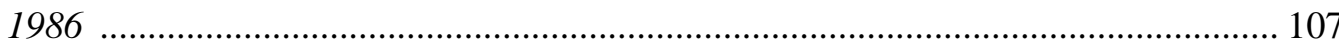

2.6 O PMDB na Assembleia Nacional Constituinte (1987-1988): o inchaço se evidencia

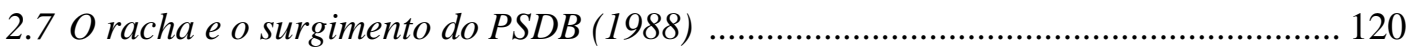

2.8 Considerações finais: o PMDB pós-1988 ................................................................. 127 
CAPÍTULO 3 - AS BREVES HEGEMONIAS "ULYSSISTA" E "QUERCISTA" (1989-1994)...... 130

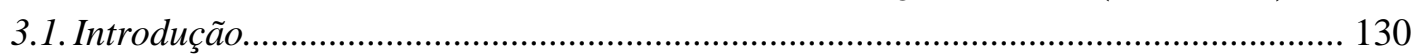

3.2. A breve hegemonia ulyssista: a candidatura direta do "Doutor Ulysses" (1989)..... 132

3.3. Começa o ciclo de decadência eleitoral: panorama geral do PMDB nas eleições de 1990

3.4. Orestes Quércia assume a presidência do partido: a era "PMDB do Q" (1991-1994)

3.5. O PMDB e a política perdem Ulysses Guimarães (1992) .......................................... 153

3.6. O PMDB e o governo Itamar: as divisões internas se evidenciam (1993-1994) ...... 157

3.7. A segunda candidatura direta do PMDB: a hora e a vez de Oestes Quércia (1994). 161

3.8. Estabilidade nas urnas: panorama geral das eleições de 1994 ................................... 166

3.9. Considerações finais: o PMDB após as eleições de 1994.......................................... 172

CAPÍtulo 4 - A ALA governista SE TORNA Hegemônica (1994-2002) ........................ 174

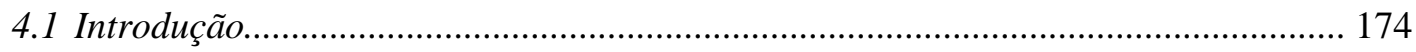

4.2 Participação no primeiro governo FHC: governistas versus oposicionistas (19941997)

4.3 A gradual ascensão da ala governista: Michel Temer chega à presidência da Câmara

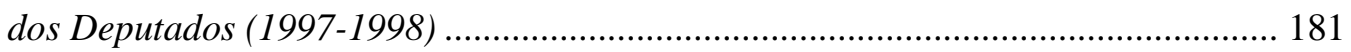

4.4 As eleições presidenciais de 1998: lançar ou não um candidato próprio?................. 185

4.5 Nova queda nas urnas: o desempenho do PMDB nas eleições de 1998 ..................... 191

4.6 Os governistas conquistam a hegemonia no interior do partido (2001) .................... 199

4.7 A estratégia dos governistas se consolida: a candidatura de Rita Camata à vice-

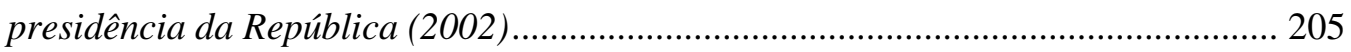

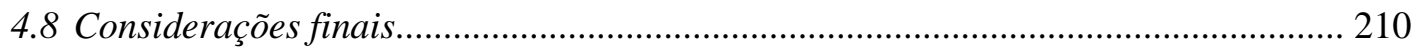

CONSIDERAÇÕES FINAIS: DE PARTIDO PROTAGONISTA A PARTIDO

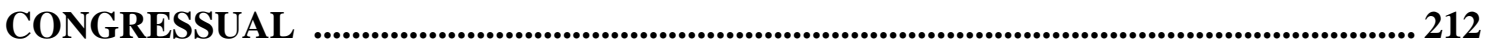

POSFÁCIO: O OCASO DO PMDB E AS ELEIÇÕES DE 2018 …..................................... 220

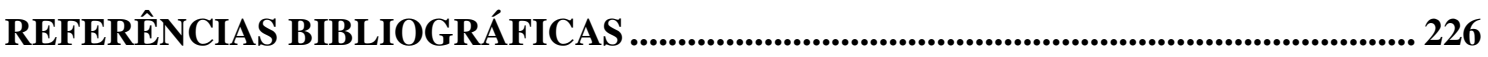

ANEXO 1 - MANIFESTO DOS FUNDADORES DO PMDB À NAÇÃO .......................... 243

ANEXO 2 - PEDIDO DE REGISTRO DEFINITIVO DO PMDB NO TSE....................... 248

ANEXO 3 - COMPOSIÇÃO DAS COMISSÕES EXECUTIVAS NACIONAIS DO PMDB

ANEXO 4 - PEDIDO DE REGISTRO DEFINITIVO DO PP NO TSE............................... 266

ANEXO 5 - NOTA PÚBLICA DO “PACOTE DE NOVEMBRO"....................................... 276

ANEXO 6 - COMPOSIÇÃO DOS DIRETORIOS NACIONAIS DO PMDB ................... 277 
ANEXO 7 - PEDIDO DE REGISTRO DEFINITIVO DO PMDB NO TSE APÓS A INCORPORAÇÃO DO PP ....................................................................................................... 280

ANEXO 8 - CARTA COMPROMISSO DA ALIANÇA DEMOCRÁTICA...................... 289

ANEXO 9 - LISTA DE PARLAMENTARES FUNDADORES DO PSDB.......................... 292

ANEXO 10 - CARTA RENÚNCIA DE ORESTES QUÉRCIA À PRESIDENCIA DO

PMDB

ANEXO 11 - CARTA DO PMDB PARANAENSE NA FOLHA DE S. PAULO............... 295

ANEXO 12 - RESULTADO DAS ELEIÇÕES PRÉVIAS DO PMDB DE 1994 ............... 296

ANEXO 13 - VOTAÇÃO DO CONSELHO NACIONAL DO PMDB REUNIDO EM 21/09/1993.

ANEXO 14 - NOTA DO CONSELHO NACIONAL DO PMDB DECLARANDO SEU

INGRESSO NO GOVERNO FHC 298

ANEXO 15 - NOTAS PUBLICADAS PELAS ALAS GOVERNISTA E OPOSICIONISTA QUANTO A POSTURA A SER ADOTADA PELO PARTIDO NA ELEIÇÃO

PRESIDENCIAL DE 2002 
Lista de tabelas, gráficos e figuras

TABELA 1. BANCADAS DO PMDB NA POSSE APÓS CADA ELEIÇÃO E PORCENTAGEM DE CADEIRAS CONQUISTADAS (1982-2014) 32

TABELA 2. NÚMERO DE GOVERNADORES ELEITOS PELO PMDB (1982-2014).... 33

TABELA 3. NÚMERO DE PREFEITOS ELEITOS PELO PMDB E PORCENTAGEM

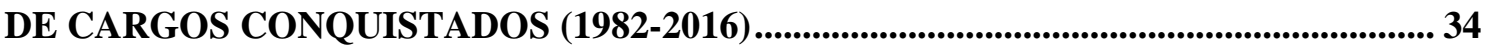

TABELA 4. COALIZÕES DE GOVERNO NO BRASIL (1988-2010) .................................. 35

TABELA 5. DISTRIBUIÇÃO DE MINISTÉRIOS E SECRETARIAS ESPECIAIS COM STATUS MINISTERIAL OCUPADOS PELO PMDB AO LONGO DOS GOVERNOS PÓS-REDEMOCRATIZAÇÃO (1985-2010).................................................................. 36

TABELA 6. FILIAÇÃO AO MDB E Á ARENA DOS MEMBROS DOS ANTIGOS PARTIDOS NA CÂMARA DOS DEPUTADOS 53

TABELA 7. COMPOSIÇÃO DA CÂMARA DOS DEPUTADOS APÓS A REFORMA PARTIDÁRIA DE 1979. 58

TABELA 8. COMPOSIÇÃO DO SENADO FEDERAL APÓS A REFORMA PARTIDÁRIA DE 1979 58

TABELA 9. DISTRIBUIÇÃO PARTIDÁRIA NO CONGRESSO ANTES E APÓS A INCORPORAÇÃO DO PP AO PMDB 70

TABELA 10. COMPARAÇÃO ENTRE A FILIAÇÃO PARTIDÁRIA PRÉVIA DOS COMPONENTES DO DIRETÓRIO NACIONAL DO PMDB ELEITOS NA PRIMEIRA CONVENÇÃO NACIONAL E APÓS A CONVENÇÃO QUE ACEITOU A INCORPORAÇÃO DO PP 72

TABELA 11. GOVERNADORES ELEITOS EM 1982 77

TABELA 12. CADEIRAS OBTIDAS, PERCENTUAL DO TOTAL DE CADEIRAS E VOTAÇÃO TOTAL POR PARTIDO NAS ELEIÇÕES PARA AS ASSEMBLEIAS LEGISLATIVAS EM 1982 78

TABELA 13. TAMANHO DAS BANCADAS PARTIDÁRIAS NA CÂMARA DOS DEPUTADOS E NO SENADO FEDERAL APÓS AS ELEIÇÕES DE 1982 79

TABELA 14. FILIAÇÃO PRÉVIA DA BANCADA DO PMDB NA CÂMARA DOS DEPUTADOS (1980-1982) 80

TABELA 15. 22. FILIAÇÃO PRÉVIA DA BANCADA DO PMDB NO SENADO FEDERAL (1980-1982) 81

TABELA 16. RESULTADO DA VOTAÇÃO DA EMENDA DANTE DE OLIVEIRA ... 86 TABELA 17. FILIAÇÃO PRÉVIA DOS MEMBROS DA EXECUTIVA NACIONAL DO PMDB (1980-1989) 107

TABELA 18. GOVERNADORES ELEITOS EM 1986 109 
TABELA 19. CADEIRAS OBTIDAS, PERCENTUAL DO TOTAL DE CADEIRAS E VOTAÇÃO TOTAL POR PARTIDO NAS ELEIÇÕES PARA AS ASSEMBLEIAS LEGISLATIVAS EM 1986

TABELA 20. TAMANHO DAS BANCADAS PARTIDÁRIAS NA CÂMARA DOS DEPUTADOS E NO SENADO FEDERAL APÓS AS ELEIÇÕES DE 1986

TABELA 21. FILIAÇÃO PRÉVIA DA BANCADA DO PMDB NA CÂMARA DOS DEPUTADOS (1980-1986)

TABELA 22. FILIAÇÃO PRÉVIA DA BANCADA DO PMDB NO SENADO FEDERAL (1980-1986)

TABELA 23. POSICIONAMENTO DO PMDB EM ALGUMAS VOTAÇÕES NO CONGRESSO CONSTITUINTE

TABELA 24. FILIAÇÃO PRÉVIA DOS PARLAMENTARES FUNDADORES DO PSDB QUE ERAM FILIADOS AO PMDB 125

TABELA 25. FILIAÇÃO PRÉVIA DOS MEMBROS DA BANCADA DO PMDB NO ÚLTIMO DIA DA ASSEMBLEIA NACIONAL CONSTITUINTE (5/10/1988). 125

TABELA 26. FILIAÇÃO PRÉVIA DOS MEMBROS DA EXECUTIVA NACIONAL DO PMDB (1980-1991) 134

TABELA 27. RESULTADOS DO PRIMEIRO TURNO DA ELEIÇÃO PRESIDENCIAL DE 1989 140

TABELA 28. GOVERNADORES ELEITOS EM 1990 142

TABELA 29. CADEIRAS OBTIDAS, PERCENTUAL DO TOTAL DE CADEIRAS E VOTAÇÃO TOTAL POR PARTIDO NAS ELEIÇÕES PARA AS ASSEMBLEIAS LEGISLATIVAS EM 1990

TABELA 30. TAMANHO DAS BANCADAS PARTIDÁRIAS NA CÂMARA DOS DEPUTADOS E NO SENADO FEDERAL APÓS AS ELEIÇÕES DE 1990 144

TABELA 31. FILIAÇÃO PRÉVIA DA BANCADA DO PMDB NA CÂMARA DOS DEPUTADOS (1980-1990)

TABELA 32. FILIAÇÃO PRÉVIA DA BANCADA DO PMDB NO SENADO FEDERAL (1980-1990) 146

TABELA 33. RESULTADOS DO PRIMEIRO TURNO DA ELEIÇÃO PRESIDENCIAL DE 1994 165

TABELA 34. GOVERNADORES ELEITOS EM 1994 167

TABELA 35. CADEIRAS OBTIDAS, PERCENTUAL DO TOTAL DE CADEIRAS E VOTAÇÃO TOTAL POR PARTIDO NAS ELEIÇÕES PARA AS ASSEMBLEIAS LEGISLATIVAS EM 1994

TABELA 36. TAMANHO DAS BANCADAS PARTIDÁRIAS NA CÂMARA DOS DEPUTADOS E NO SENADO FEDERAL APÓS AS ELEIÇÕES DE 1994 169

TABELA 37. FILIAÇÃO PRÉVIA DA BANCADA DO PMDB NA CÂMARA DOS DEPUTADOS (1980-1994) 
TABELA 38. FILIAÇÃO PRÉVIA DA BANCADA DO PMDB NO SENADO FEDERAL (1980-1994)

TABELA 39. COMPORTAMENTO DA BANCADA DO PMDB NA CÂMARA DOS DEPUTADOS NA VOTAÇÃO DAS REFORMAS CONSTITUCIONAIS 180

TABELA 40. RESULTADOS DO PRIMEIRO TURNO DA ELEIÇÃO PRESIDENCIAL DE 1998 191

TABELA 41. GOVERNADORES ELEITOS EM 1998 192

TABELA 42. CADEIRAS OBTIDAS, PERCENTUAL DO TOTAL DE CADEIRAS E VOTAÇÃO TOTAL POR PARTIDO NAS ELEIÇÕES PARA AS ASSEMBLEIAS LEGISLATIVAS EM 1998

TABELA 43. TAMANHO DAS BANCADAS PARTIDÁRIAS NA CÂMARA DOS DEPUTADOS E NO SENADO FEDERAL APÓS AS ELEIÇÕES DE 1998 195

TABELA 44. FILIAÇÃO PRÉVIA DA BANCADA DO PMDB NA CÂMARA DOS DEPUTADOS (1980-1998)

TABELA 45. FILIAÇÃO PRÉVIA DA BANCADA DO PMDB NO SENADO FEDERAL (1980-1998)

TABELA 46. RESULTADOS DO PRIMEIRO TURNO DA ELEIÇÃO PRESIDENCIAL DE 2018

TABELA 47. BANCADAS DO PMDB NA POSSE APÓS CADA ELEIÇÃO E PORCENTAGEM DE CADEIRAS CONQUISTADAS (1982-2018)

GRÁFICO 1. PROPORÇÃO DE CADEIRAS OCUPADAS PELO PMDB NA POSSE

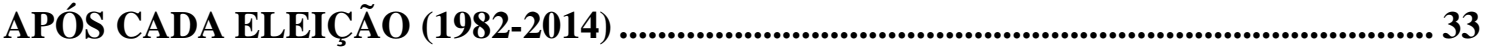

GRÁFICO 2. NÚMERO DE PREFEITOS ELEITOS PELO PMDB (1982-2016)............... 34 GRÁFICO 3. EVOLUÇÃO DO ÍNDICE DE INFLAÇÃO EM 1994 .................................. 164 GRÁFICO 4. EVOLUÇÃO NA PORCENTAGEM DE CADEIRAS OCUPADAS PELO PMDB NAS ASSEMBLEIAS LEGISLATIVAS ESTADUAIS (1982-1998) 194

GRÁFICO 5. FILIAÇÃO PRÉVIA EM PORCENTAGEM DOS PARLAMENTARES DO PMDB NA CÂMARA DOS DEPUTADOS (1980-1998)

GRÁFICO 6. FILIAÇÃO PRÉVIA EM PORCENTAGEM DOS PARLAMENTARES DO PMDB NO SENADO FEDERAL (1980-1998) 198

GRÁFICO 7. BANCADAS DO PMDB NA POSSE APÓS CADA ELEIÇÃO (1982-2018)

FIGURA 1. LINHA DO TEMPO (1979-2002) 25

FIGURA 2. ESTRUTURA ORGANIZATIVA INTERNA DO PMDB 43

FIGURA 3. COMPOSIÇÃO PARTIDÁRIA DA ASSEMBLEIA NACIONAL CONSTITUINTE 117

FIGURA 4. TRANSFORMAÇÕES INTERNAS DO PMDB DE 1979 A 1988 128 


\section{Lista de siglas e abreviaturas}

\section{Partidos Políticos 1945-1965}

PSD- Partido Social Democrático

PTB- Partido Trabalhista Brasileiro

UDN- União Democrática Nacional

MTR- Movimento Trabalhista Renovador

PDC- Partido Democrata Cristão

PL- Partido Libertador

PSP- Partido Social Progressista

PR- Partido Republicano

PRP- Partido de Representação Popular

PRT- Partido Republicano Trabalhista

PSB- Partido Socialista Brasileiro

PST- Partido Social Trabalhista

PTN- Partido Trabalhista Nacional

\section{Partidos Políticos 1966-1979}

ARENA- Aliança Renovadora Nacional

MDB - Movimento Democrático Brasileiro

\section{Partidos Políticos pós-1979}

PMDB - Partido do Movimento Democrático Brasileiro

PDS - Partido Democrático Social

PP - Partido Popular

PT - Partido dos Trabalhadores

PSDB - Partido da Social Democracia Brasileira

PCB - Partido Comunista Brasileiro

PCdoB - Partido Comunista do Brasil

PSB - Partido Socialista Brasileiro

PPL - Partido Pátria Livre

PFL - Partido da Frente Liberal

DEM - Democratas

PTB - Partido Trabalhista Brasileiro

PDT - Partido Democrático Trabalhista

PV - Partido Verde

PPS - Partido Popular Socialista

PL - Partido Liberal

PMB - Partido Municipalista Brasileiro

PDC - Partido Democrata Cristão

PSC - Partido Social Cristão

PTR - Partido Trabalhista Renovador

PASART - Partido Agrário Renovador Trabalhista

PMN - Partido da Mobilização Nacional

PTN - Partido Tancredista Nacional

PH - Partido Humanista

PMC - Partido Municipalista Comunitário 
PND - Partido Nacionalista Democrático

PPB - Partido do Povo Brasileiro

PS - Partido Socialista

PCN - Partido Comunitário Nacional

PRT - Partido Reformador Trabalhista

PJ - Partido da Juventude

PDI - Partido Democrático Independente

PN - Partido Nacionalista

PNR - Partido da Nova República

PRP - Partido Reformador Trabalhista

PRN - Partido da Reconstrução Nacional

PRS - Partido das Reformas Sociais

PST - Partido Social Trabalhista

PSD - Partido Social Democrático

PNT - Partido Nacionalista dos Trabalhadores

PPR - Partido Progressista Reformador

PSL - Partido Social Liberal

PRONA - Partido da Reconstrução Nacional

\section{Demais siglas}

MR-8 - Movimento Revolucionário 8 de outubro

$\mathrm{AI}$ - Ato Institucional

AC - Ato Complementar

PL - Projeto de Lei

PEC - Proposta de Emenda Constitucional

PLP- Projeto de Lei Complementar

DVS - Destaque para votação em separado

ANC - Assembleia Nacional Constituinte

TSE - Tribunal Superior Eleitoral

DN - Diretório Nacional

CEN - Comissão Executiva Nacional

$\mathrm{CN}$ - Conselho Nacional

UNE - União Nacional dos Estudantes

AL - Assembleia Legislativa

PRI - Partido Revolucionário Institucional

EC - Emenda Constitucional

MUP - Movimento Unidade Progressista

DIAP - Departamento Intersindical de Assessoria Parlamentar

ECA - Estatuto da Criança e do Adolescente

LRF - Lei de Responsabilidade Fiscal 


\section{Introdução}

No ano de 2016, após impedimento da então presidenta Dilma Rousseff, o Partido do Movimento Democrático Brasileiro (PMDB) chegava pela segunda vez em sua história à presidência da República sem nunca ter elegido algum de seus candidatos de maneira direta. A primeira dessas ocasiões ocorreu em 1985. Naquele ano, após vencer a disputa no Colégio Eleitoral com a chapa Tancredo Neves-José Sarney o partido elegeu o primeiro presidente civil após 21 anos de Regime Militar. Porém, com o falecimento de Tancredo às vésperas de sua posse, acabou sendo José Sarney, um recém-filiado ao partido, quem assumiu a presidência e completou o seu mandato até 1990. Quase trinta anos depois, o PMDB chegava mais uma vez à presidência da República. Após uma coalizão com o Partido dos Trabalhadores (PT) que já durava mais de uma década, o PMDB optou por desembarcar do governo de Dilma Rousseff em março de 2016, enquanto tramitava no Congresso o seu processo de impeachment, para depois retornar ao governo do país em 12 de maio do mesmo ano por meio do até então vice-presidente Michel Temer, empossado na presidência da República de maneira interina e posteriormente definitiva. O PMDB se via a partir de então na condição de partido-chefe da coalizão governista do Brasil mais uma vez.

Entretanto, ao longo dessa trajetória, o partido atravessou profundas transformações. Sendo refundado em 1979 na passagem do bipartidarismo para o pluripartidarismo, o PMDB se tornou naquele momento a principal sigla de oposição ao regime militar. Com crescente protagonismo ao longo do processo de transição democrática, o partido passou a ser um ator central da política brasileira já em seus primeiros anos de existência, com seus líderes adquirindo destaque na campanha pela retomada das eleições diretas para presidente da República, o movimento pelas "Diretas-Já" em 1983 e 1984. Pouco tempo depois, o partido elegeu a sua chapa de candidatos a presidente e vice-presidente da República no Colégio Eleitoral de 1985, além de quase todos os governadores de estado nas eleições de 1986 (22 de 23). Como consequência do seu desempenho naquelas eleições, no início dos trabalhos da Assembleia Nacional Constituinte em 1987, o partido detinha a maior bancada partidária, com seus representantes comandando o processo de elaboração da nossa atual Constituição. Devido a essa atuação e por conta de seu capital político acumulado nesses momentos a literatura de ciência política apontava o PMDB como sendo a sigla que possuía os maiores índices de identificação partidária ao final daquela década (Carreirão e Kinzo 2004; Kinzo, 2005; Samuels e Zucco, 2013; Melo, 2013). Essa caracterização, porém, contrasta fortemente com aquelas atribuídas mais recentemente ao partido.

A partir do final dos anos 1990 a atuação do PMDB no sistema políticopartidário mudou bastante, passando do protagonismo ao pano de fundo. Se nos anos de 1985, 1989 e 1994 o partido lançou candidatos próprios à presidência da República (ainda que em 1985 o tenha feito de maneira indireta por meio do Colégio Eleitoral), 
das eleições de 1998 até as de 2014 o partido não mais adotou esse comportamento, ora não formalizando uma coligação com qualquer outra candidatura (como em 1998 e em 2006), ora as compondo como candidatos à vice-presidência da República coligado a candidaturas do PSDB (como em 2002) ou do PT (como em 2010 e 2014). Além disso, mesmo nos anos em que o PMDB adotou a estratégia de ter candidaturas próprias não obteve bom desempenho, com Ulysses Guimarães amargando o $7^{\circ}$ lugar no pleito de 1989, com aproximadamente 4\% dos votos, Orestes Quércia com o $4^{\circ}$ lugar e os mesmos 4\% dos votos nas eleições de 1994, e Henrique Meirelles, com apenas 1,2\% dos votos válidos e o $7^{\circ}$ lugar nas eleições de 2018.

Além dessas mudanças, as caracterizações atribuídas à sigla também se alteraram bastante, tanto na imprensa e na percepção popular quanto na literatura acadêmica. De partido protagonista caracterizado pela literatura como uma sigla de centro-esquerda em seus primeiros anos (Kinzo, 1988: 210; Figueiredo, 2009: 88), o PMDB passou a ser visto como um partido com uma postura excessivamente clientelista e pragmática (Reis, 2010: 73), heterogêneo na composição de seus quadros (Maiwaring e Liñan, 1998: 120), voltado para a maximização de cargos (Melo, 2006: 169) e classificado quase unanimemente como um partido de centro (Limongi e Figueiredo, 1999; Melo, 2000; e Pasquarelli e Bizzarro Neto, 2013, entre vários outros). No entanto, apesar dessas transformações e das quedas tanto nos seus índices de identificação partidária quanto no desempenho eleitoral a partir dos anos 1990 (Oliveira, 2012; Melo, 2013), o partido ainda assim se manteve como coadjuvante importante da política nacional. Elegendo sempre grandes bancadas no Congresso Nacional e mantendo um grande número de prefeitos e governadores eleitos pela sigla (Oliveira, ibidem; Mucinhato, 2015), o PMDB compôs boa parte das coalizões governantes no período pós-1985 (as exceções ficaram a cargo do governo Collor e do primeiro mandato de Lula ${ }^{1}$ ), sustentando-se como um ator importante no nosso arranjo institucional chamado de presidencialismo de coalizão (Limongi e Figueiredo, 1999).

Diante destas constatações, que evidenciam a ocorrência de um processo de transformação do partido, o objeto de estudo desta tese será o próprio PMDB, abordado a partir de uma perspectiva nacional e diacrônica. Tendo como foco seus principais órgãos diretivos, a saber, seu Diretório Nacional e sua Comissão Executiva Nacional, mas por vezes recorrendo a dados a respeito de suas bancadas parlamentares, partimos das seguintes perguntas: como o partido foi do ponto A ao ponto B nesse processo de transformação? Ou seja, como o partido passa de protagonista ao pano de fundo da política nacional? A sua dinâmica interna pode ter contribuído para as mudanças ocorridas nas estratégias políticas e eleitorais adotadas pelo partido ao longo de sua história?

Esta pesquisa busca então, dentro de seu recorte histórico, responder a estes questionamentos e assim preencher algumas lacunas apresentadas pela literatura a

\footnotetext{
${ }^{1}$ Apesar de o PMDB possuir dois ministérios desde 2004 no primeiro mandato de Lula, o partido passa a ter mais espaço no governo e compor oficialmente sua coalizão apenas após a eclosão do chamado "escândalo do mensalão".
} 
respeito da sigla, mencionadas adiante nesta introdução, traçando um quadro geral de sua história interna. Partindo do pressuposto que diferentes fatores podem ter contribuído para as mudanças aqui descritas e considerando que as instâncias decisórias centrais cumprem papéis fundamentais na condução de um partido (Ribeiro, 2014), acreditamos que um dos fatores explicativos para as transformações pelas quais a sigla atravessou e que nos auxiliam a compreender o que a levou a adotar diferentes estratégias eleitorais são as mudanças na correlação de forças internas do partido e as consequentes mudanças na sua coalizão dominante. Assim, por meio das fontes consultadas, analisamos como as estratégias político-eleitorais adotadas pelo PMDB entre os anos de 1979 e 2002, sobretudo no que tange à disputa pelo cargo de presidente da República, foram resultado direto de suas disputas internas. Essas disputas levaram a mudanças sucessivas na sua cúpula dirigente e, a depender da coalizão de lideranças que formava os órgãos de direção do partido, diferentes estratégias eleitorais foram sendo adotadas ao longo de sua história. Em outras palavras, iremos destacar que para compreender o partido "para fora" é necessário primeiro entendermos o que ocorria dentro dele.

A escolha de nosso recorte histórico não se deu por acaso. O ano de 1979 marca tanto a refundação do partido quanto o restabelecimento do pluripartidarismo, momento no qual há um aumento da oferta de siglas partidárias, antes restritas apenas a MDB e ARENA, e que se reflete nas primeiras mudanças ocorridas na elite dirigente do PMDB devido à evasão de quadros. Ademais, como será mostrado adiante, a literatura sobre o partido deu pouca ênfase aos eventos ocorridos no interior do partido no início dos anos 1980, lacuna esta que procuramos preencher. Por sua vez, o marco final deste estudo, definido como o ano de 2002, marca o momento no qual a estratégia eleitoral adotada pela ala denominada pela literatura de "governista" no interior do partido (Maciel, 2014; Ferreira, 2002) torna-se predominante. Depois de anos disputando com a ala dos "oposicionistas" o controle das instâncias de decisão da sigla, os governistas consolidam sua hegemonia com a chegada de Michel Temer à presidência do PMDB em 2001, sendo ele próprio reeleito sucessivas vezes para o cargo até a conclusão deste estudo e tornando-se o mais longevo presidente do partido em sua história.

A partir desse recorte histórico, a linha do tempo descrita a seguir inclui os acontecimentos que marcaram a história do partido dentro desse período, auxiliando na compreensão dos eventos que tiveram consequências para a análise feita. A linha cumpre assim a função de ser um roteiro de leitura desta tese, como um "mapa", elencando de maneira cronológica fatos históricos que tiveram impacto na correlação de forças interna do partido e consequentemente alteraram a composição de seus órgãos de direção. 
Figura 1. Linha do tempo (1979-2002):
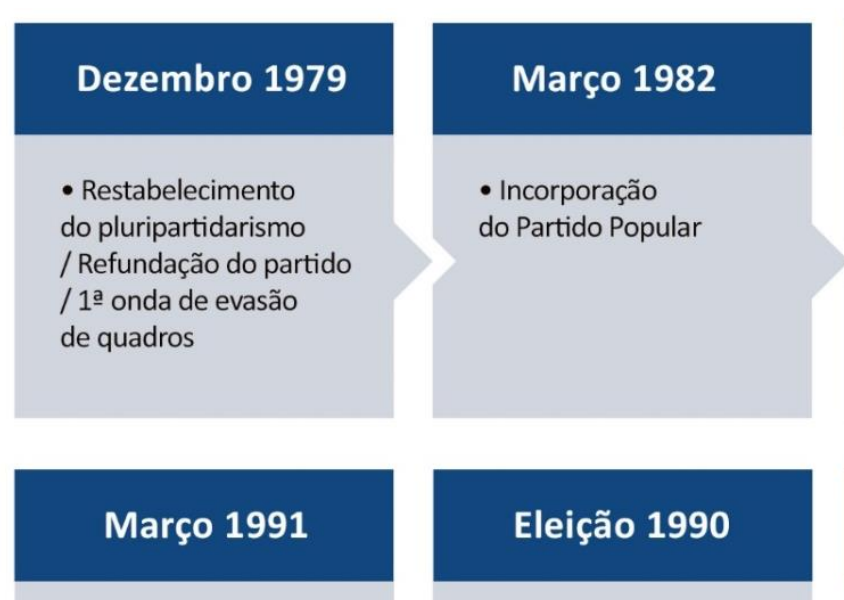

- Orestes Quércia assume a presidência do partido
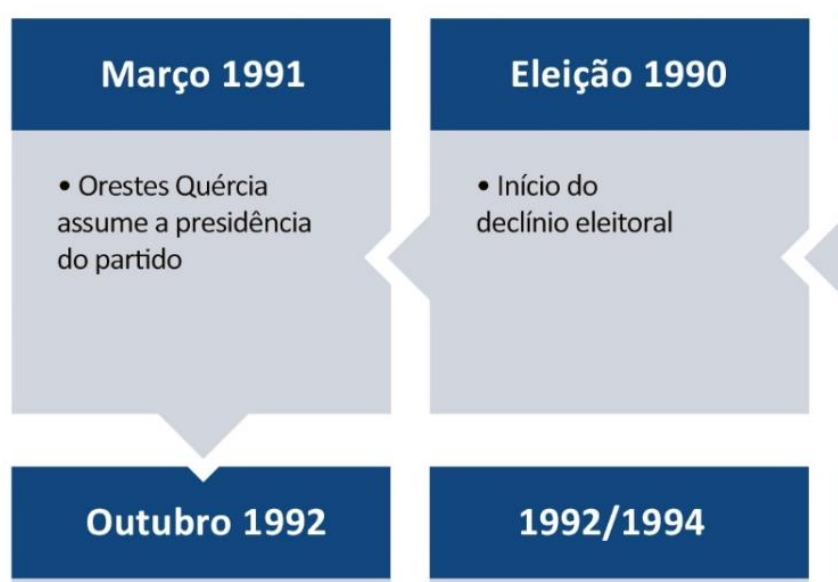

- Falecimento de

Ulysses Guimarães

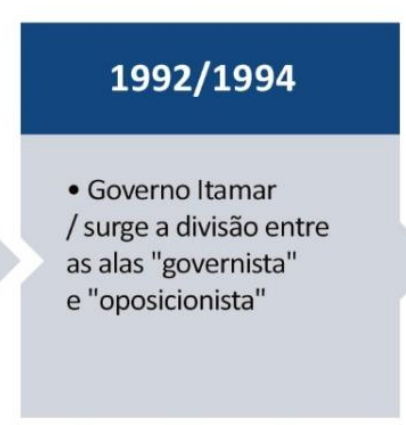

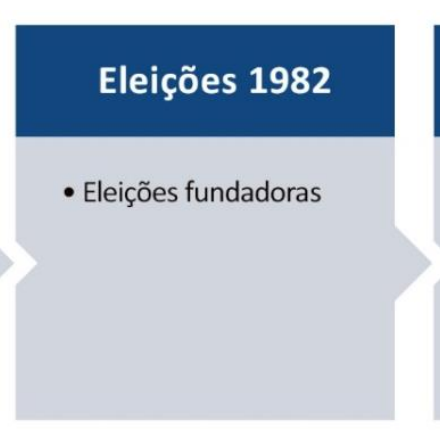

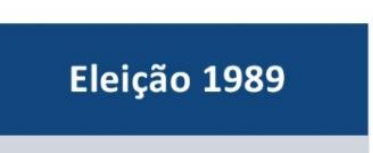

- Eleição presidencial

/ Candidatura de

Ulysses Guimarães
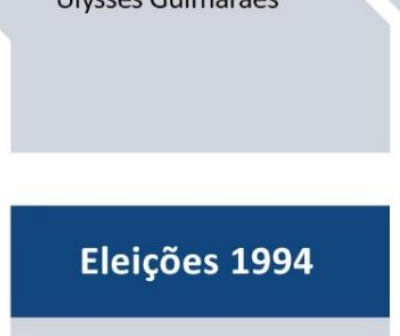

- Eleição presidencial

/ Candidatura de

Orestes Quércia
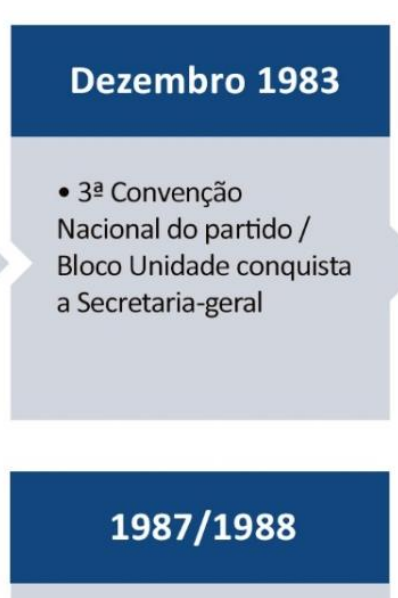

- Assembleia Nacional Constituinte / Fundação do PSDB / 3 a onda de evasão de quadros
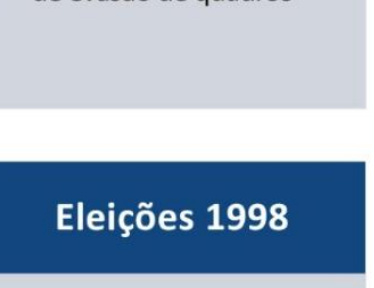

- PMDB define pela primeira vez não lançar candidato próprio à Presidência da República

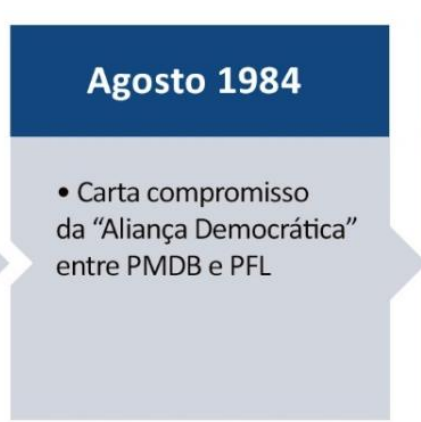

\section{Eleições 1986}

• "Inchaço" eleitoral

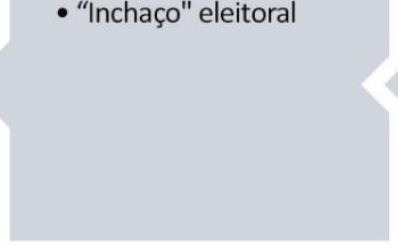

\section{Setembro 2001}

- Michel Temer chega à Presidência do PMDB / Ala dos governistas assume o controle dos órgãos de direção

\section{Janeiro 1985}

- Filiação de José Sarney

/ Vitória da chapa

Tancredo-Sarney no

Colégio Eleitoral

/ PMDB no poder

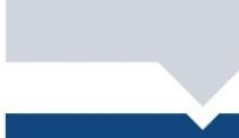

\section{Maio 1985}

- Aprovação da Emenda Constitucional $n^{\circ} 25$ / Fundação de novos partidos / 2a onda de evasão de quadros

Fonte: elaboração própria. 
Levando em conta os acontecimentos aqui mencionados e o recorte histórico citado, esta pesquisa se mostra pioneira entre aqueles estudos que se debruçaram sobre o PMDB. Em primeiro lugar, dado o seu amplo recorte histórico, trata-se do primeiro esforço de periodização da história do partido em escala nacional (tal como fez Maria D’Alva Kinzo em seu estudo clássico sobre o MDB - Kinzo, 1988), feito em constante diálogo com os estudos já realizados sobre a sigla até então. E em segundo lugar, pelo acesso a documentos históricos e pelo número de entrevistas realizadas com atores políticos que são ou foram relevantes para história do partido em um grande número de estados. Sabemos que o estudo de partidos políticos já extintos costuma colocar grandes dificuldades aos pesquisadores, como o acesso a documentos, a busca por acervos e a falta de possíveis fontes de história oral. Porém, realizar uma pesquisa sobre um partido ainda existente e com uma longa trajetória, num momento em que a conjuntura política se colocou como um grande obstáculo para um estudo como este (seja pelo fato de o partido estar em grande evidência pelo mandato de Michel Temer na presidência da República, seja pelas sucessivas denúncias de corrupção envolvendo suas principais lideranças no âmbito da Operação Lava-Jato) não é menos difícil, mas como será visto ao longo do texto, estes problemas puderam ser superados.

Nesse sentido, além desta discussão inicial, esta introdução inclui, antes de passarmos à parte empírica deste estudo, outras cinco seções. Nas próximas duas apresentamos a abordagem teórica que norteia esta pesquisa assim como o acúmulo da literatura de ciência política sobre o partido aqui estudado. Em seguida, nas seções subsequentes, apresentamos uma descrição da estrutura interna do PMDB e as fontes de pesquisa utilizadas. Por fim, descrevemos como se divide o núcleo desta tese, com o seu conteúdo empírico divido entre as duas partes que compõem esta pesquisa.

\section{$\underline{\text { Abordagem teórica }}$}

Os partidos políticos há muito têm sido objeto de estudo sistemático por parte da ciência política e da historiografia política, e apesar de haver um período de refluxo nos anos 1980 (Lawson e Merkl, 1988, apud Amaral, 2013: 33) gerou-se uma ampla literatura a respeito do tema em questão. Estudos como o de Ostrogorski (1902), Michels (1915), Kirchheimer (1966), Duverger (1970), Katz e Mair (1992, 1994), Panebianco (2005), entre outros, tornaram-se clássicos, criando conceitos que se tornaram fundamentais para a compreensão dos pilares que estruturam e sustentam os sistemas político-partidários. Estes conceitos, por sua vez, acompanharam as transformações pelas quais os próprios partidos políticos atravessaram, como a dicotomia entre partidos de quadros e partidos de massa, na tipologia elaborada por Duverger (1970), o conceito de partido catch-all criado por Kirchheimer (1966), a compreensão de partidos como organizações que são ao mesmo tempo burocracias e associações voluntárias, como destacou Panebianco (2005), e mais recentemente a ideia de partido cartel elaborada por Katz e Mair (1995), apenas para mencionar alguns dos estudos mais importantes. Ademais, distintas abordagens passaram a ser utilizadas para 
a compreensão do fenômeno partidário e há vigoroso consenso a respeito de sua importância e de seu caráter imprescindível para a viabilidade das democracias contemporâneas (Braga, 2013: 2) .

No que concerne aos estudos elaborados mais recentemente e que compreendem os partidos enquanto organizações políticas (Panebianco, 2005), a distinção feita por Katz e Mair (1992, 1993, 1994, 2002) entre as três faces distintas apresentadas pelos partidos políticos requalificou o debate acerca do seu aspecto organizacional e muito contribui para este estudo. Se antes os partidos eram muitas vezes compreendidos como unidades indivisíveis, eles passaram a ser estudados em relação a: 1 . sua face pública, o party in public office, isto é, o partido enquanto parte do governo ou do parlamento, sendo formada pelos seus membros que ocupam cargos no Poder Executivo ou no Poder Legislativo; 2. sua base partidária, o party on the ground, ou seja, a sua relação com os filiados, militantes, contribuintes e eleitores; e, 3. a direção nacional organizativa do partido, ou o party in central office, que em teoria seria organizacionalmente distinta da sua face pública e que ao mesmo tempo organiza e é representativa das bases partidárias (Katz e Mair, 1993: 594).

Com relação a sua direção nacional, os autores apontam que ela corresponde aos membros dos seus principais órgãos de direção, como seu Diretório Nacional e sua Comissão Executiva Nacional, assim como seu secretariado e staff, que corresponderiam aos burocratas do alto escalão do partido. Entre suas funções principais estariam: 1. ser o núcleo por meio do qual as outras faces se formam, por exemplo, formando militantes que possam organizar o partido on the ground, para que futuramente essa mesma estrutura sirva para eleger representantes para o partido in public office; 2. coordenar campanhas nacionais, o que pode significar uma supervisão ou controle dos membros e militantes do partido em benefício dos seus representantes; 3. de maneira oposta à função anterior, cabe às suas lideranças supervisionar a atuação dos seus representantes em prol dos seus filiados; 4. proporcionar uma série de serviços que podem beneficiar o partido como um todo, como estruturar uma rede de comunicação, desenvolver pesquisas acadêmicas, arrecadar recursos, etc.

Os recursos disponíveis para sua direção, ainda segundo os autores, seriam sua centralidade (que muitas vezes também acaba por ser geográfica), sua expertise e sua posição formal como o topo da organização partidária, que lhe permitem ser o locus central dos seus processos de tomada de decisão. Entretanto, muitos dos seus membros podem também ser lideranças das outras faces do partido, o que gera uma ambiguidade. Quando o partido estiver unido, as suas instâncias centrais podem também se beneficiar dos recursos provenientes das suas outras faces e, assim, seus órgãos principais de direção se tornam de fato o principal espaço onde as decisões partidárias são tomadas. Porém, quando seus membros não estiverem unidos, seu status de líderes das outras faces do partido pode transformar essas instâncias em "campos de batalha", ou então

\footnotetext{
2 Para um amplo levantamento da literatura internacional sobre partidos políticos ver Gunther e Montero (2002).
} 
tornar esses espaços de tomada de decisão esvaziados ou deslegitimados (idem ibidem: 598-601).

Em se tratando especificamente dos partidos políticos brasileiros, Ribeiro (2014: 121) apontou que quase nada sabemos sobre as cúpulas dirigentes dos partidos políticos, ou o party in central office, nos termos de Katz e Mair (1993), espaços de coagulação de disputas, negociações e deliberações acerca de aspectos relevantes da vida política nacional - como a costura de chapas e alianças para as eleições presidenciais, as decisões relativas ao apoio ou oposição ao governo federal e as intervenções sobre diretórios e convenções estaduais e locais, com potencial para afetar (e até reverter) processos de seleção de candidatos nesses níveis ${ }^{3}$. Ademais, soma-se a isso a dificuldade de obtenção de dados precisos e confiáveis sobre as organizações partidárias, obstáculo que não se restringe ao caso brasileiro (Ribeiro, 2013: 228). Segundo o autor, um dos poucos aspectos que de fato conhecemos é o controle exercido por parlamentares de alguns partidos sobre suas instâncias internas centrais, fenômeno no qual se enquadra o PMDB e que corresponde à sobreposição das lideranças de diferentes faces de um partido político. Assim, ainda segundo ele, não seria um exagero tomar a Comissão Executiva Nacional (CEN) de alguns partidos como um prolongamento das suas bancadas no Congresso. De fato, ocorreu de entre os entrevistados para este estudo este aspecto ser mencionado, o que nos motivou a verificar como essa dinâmica se deu durante o recorte histórico aqui adotado em se tratando do PMDB. Foi o caso, por exemplo, do senador Airton Sandoval (SP):

“(...) Como eu te disse, quem comanda o partido é o Senado e a Câmara. Um pouco os governadores, por conta de um certo controle que têm sobre os deputados, mas as bases do partido brigam e morrem na praia, porque as decisões acabam saindo daqui."

"Como deputado, eu conhecia bem como funciona isso daqui, o partido funciona em razão da bancada do Senado e da Câmara. As decisões que ocorrem no PMDB partem definitivamente desses dois segmentos. Bases do partido não têm decisão nenhuma."

O estudo dessas instâncias centrais de decisão, sobretudo no que diz respeito a CEN do PMDB, também se dá pelo peso que estas instâncias têm na definição dos rumos do partido. Entre as tarefas cumpridas pela CEN, por exemplo, está convocar ou não uma Convenção Nacional, que por sua vez é quem define se o partido irá lançar ou não uma candidatura própria para o cargo de presidência da República. Ademais, em praticamente todos os grandes partidos as Executivas subverteram o papel que lhes é conferido pelos estatutos, convertendo-se nas instâncias decisórias centrais nos períodos entre as convenções e congressos partidários (Ribeiro, 2014: 127) e também em palco

\footnotetext{
${ }^{3}$ Para uma ampla revisão dos estudos feitos sobre os partidos políticos brasileiros ver Nicolau (2010) e Braga (2013).
} 
de disputas entre suas diferentes alas. Como apontado por Manffré (2014: 63), o conflito pelo poder entre grupos intrapartidários é um aspecto fundamental da estrutura e dos processos de tomada de decisões internos e externos a um partido. Portanto, esta pesquisa se propõe a contribuir, dentro de suas limitações, para os estudos a respeito do PMDB focando nos conflitos e nas sucessivas transformações na correlação de forças de suas principais instâncias de direção em nível federal, o seu party in central office, nos termos de Katz e Mair (1993), cientes de que as mudanças na sua composição foram determinantes para os rumos que o partido tomou no decorrer dos anos.

Para além dos autores já mencionados, a obra de Panebianco (2005) também tem servido como referência a muitos pesquisadores que desenvolvem estudos monográficos sobre os partidos políticos brasileiros, compreendidos como aqueles estudos cujo enfoque se detém sobre um partido em específico, seja em âmbito nacional, seja em âmbito estadual (Mucinhato, 2015: 28). Assim, o autor também será um marco teórico importante para este estudo, dada a nossa abordagem diacrônica.

De acordo com Panebianco a dimensão histórica adquire um caráter central no estudo dos partidos políticos (ibidem: 311), pois um dos fatores de maior incidência em sua ordem organizativa, que explica sua fisionomia e o seu funcionamento, é a sua história organizativa (o seu passado), juntamente com as relações que vai estabelecendo com os inconstantes ambientes externos (ibidem: 91) nos quais estão inseridos. Nesse sentido, retroceder ao momento de criação de um partido, ou ao seu "modelo originário" nos termos do autor (ibidem: 92), torna-se o ponto de partida natural para o estudo de um partido político por meio de uma narrativa histórica.

Considerando então que os partidos não são estruturas estáticas e que se transformam ao longo do tempo, segundo Panebianco, a evolução organizativa de um partido pode ser considerada como o produto da interação entre as características do seu modelo originário, a sua posição no sistema político (no governo ou na oposição) na fase de consolidação organizativa e, finalmente, a conformação com os "ambientes" nos quais o partido está atuando (ibidem: 282). Sua abordagem nos traz, assim, um instrumental teórico de grande utilidade para a compreensão interpretativa de um partido político com uma história como a do PMDB: um partido que fora fundado no campo da oposição a um regime autoritário, num momento de restabelecimento do pluripartidarismo, adquiriu protagonismo na luta por uma transição democrática e, contudo, após contribuir para conquistá-la passa a ser caracterizado pela literatura de maneira distinta à do seu período de formação, sendo visto como uma sigla que possui uma postura excessivamente clientelista e pragmática (Reis, 2010: 73), entre outros aspectos.

Outro elemento constitutivo importante para se compreender a evolução de um determinado partido político é a compreensão de sua elite dirigente, ou da sua "coalizão dominante", nos termos do autor. A coalizão dominante de um partido seria composta por aqueles agentes formalmente internos e/ou externos à organização, que controlam as 
suas zonas de incerteza ${ }^{4}$ mais vitais para a manutenção de sua existência. O controle sobre esses recursos, por sua vez, faz da coalizão dominante o principal centro de distribuição de incentivos organizativos no interior do partido (ibidem: 74). Essa conceituação ampla de elite dirigente do partido considera importantes não apenas os líderes nacionais, mas também um certo número de elites intermediárias e/ou locais (ibidem: 73), figuras que, em se tratando do PMDB, adquirem grande proeminência política, mesmo estando fora do seu principal órgão de direção, a sua Comissão Executiva Nacional.

Assim, fazendo uso do conceito de coalizão dominante do autor, tal como o fizeram outros estudos sobre diferentes partidos políticos brasileiros (Keck, 1991; Amaral, 2010; Manffré, 2014; Barbosa, 2014 entre outros), o objeto de análise central desta pesquisa será a composição da elite dirigente nacional do PMDB e suas estratégias adotadas ao longo de pouco mais de duas décadas (de 1979 a 2002). Tal elite dirigente, por sua vez, será compreendida principalmente por meio de sua Comissão Executiva Nacional (CEN), órgão decisório do PMDB que corresponde a sua real cúpula, à qual compete entre outras coisas cuidar do patrimônio e das contas do partido (Maciel, 2014: 46), e seu Diretório Nacional (DN), órgão responsável pela escolha da Comissão Executiva Nacional. Por vezes, dada a sobreposição existente entre as diferentes faces do PMDB, também recorreremos neste estudo a dados a respeito de suas bancadas no Congresso (espaço no qual o partido sempre teve grande representatividade), que evidenciam possíveis transformações que porventura tenham ocorrido na face pública do partido, ou o party in public office, nos termos de Katz e Mair (1993).

Em uma perspectiva mais ampla, sugerimos que a compreensão desses aspectos internos ao PMDB pode gerar reflexões que vão além do próprio partido. Seu estudo aprofundado pode jogar luz não apenas sobre o processo de perda de protagonismo do partido, mas também sobre a dinâmica das disputas presidenciais nacionais nos últimos 30 anos, período no qual presenciou-se um padrão estável de competição nas eleições basicamente entre candidatos do Partido dos Trabalhadores (PT) e do Partido da Social Democracia Brasileira (PSDB) (Braga, 2010; Melo, 2010; Limongi e Cortez, 2010; Carreirão, 2014; Cervi, 2016, entre outros), cada qual apoiado por um determinado bloco de partidos, um dos quais contando sempre (ou quase sempre) com o PMDB em sua coligação eleitoral ou de governo. Assim, ao nos aprofundarmos no estudo de uma sigla que tem cumprido um papel importante no nosso arranjo institucional praticamente desde a sua fundação, contribuímos também para a compreensão do funcionamento do nosso sistema político-partidário assim como do próprio processo de transição democrática brasileiro, que, como dito anteriormente, teve o PMDB como um de seus atores centrais.

\footnotetext{
${ }^{4}$ Para Panebianco (ibidem: 65-72) as zonas de incerteza mais vitais para a organização de um partido são: a) a competência; b) a gestão das relações com o ambiente; c) as comunicações internas; d) as regras formais; e) o financiamento da organização; e f) o recrutamento.
} 


\section{Aspectos gerais do PMDB: o que se sabe sobre o partido?}

Apesar de ter havido uma ampliação significativa da agenda de estudos das temáticas envolvendo os partidos políticos brasileiros nas últimas décadas (Braga, 2013: 12), uma ampliação que também se expressa na maior atenção dada por parte dos pesquisadores em relação ao PMDB em anos recentes (Sá, 2011; Oliveira, 2012; Bizzarro Neto, 2013; Melo, 2011, 2013; Barbosa, 2014; Maciel, 2014; Mucinhato, 2015; Palmeira, 2015), há ainda uma assimetria na literatura. Enquanto abundam pesquisas sobre os partidos que tiveram origem no campo da esquerda, sendo o Partido dos Trabalhadores sem dúvida nenhuma o que mais despertou o interesse dos estudiosos (Mucinhato, 2015: 18) ${ }^{5}$, entre os partidos individuais faltam estudos aprofundados sobre a atuação das organizações situadas ao centro e, particularmente, à direita do espectro político ideológico (Braga, 2013: 17) ${ }^{6}$, assim como estudos que explorem a dimensão organizacional para o estudo dos partidos (Bizzarro Neto, 2013: 23). Ademais, com a multiplicidade de siglas que fazem parte do nosso sistema partidário - são 35 os partidos registrados no momento de elaboração deste estudo ${ }^{7}$ - a literatura ainda carece de estudos monográficos sobre muitos dos partidos que o compõem, sobretudo com uma abordagem nacional e com um amplo recorte histórico, tal como fizeram alguns estudos monográficos a partir dos anos 1980 sobre partidos políticos brasileiros já extintos (como Benevides, 1981; Sampaio, 1982; D’Araujo, 1996 e Hippolito, 2012, entre outros $)^{8}$.

No que se refere aos estudos específicos sobre o PMDB, podemos dividir a literatura em três enfoques: os estudos regionais, compreendidos como aqueles que têm como foco a dimensão estadual do partido (sobre o estado de São Paulo: Sadek, 1989a, Melhem, 1998; Bizzarro Neto, 2013; Piauí: Sá, 2011; e Mato Grosso do Sul: Barbosa, 2014), os estudos comparativos, que como o próprio nome indica comparam algum aspecto do PMDB com o de outro partido político brasileiro (Ferreira, 2002), e por fim os estudos monográficos em nível nacional (Oliveira, 2012; Melo, 2013; Maciel, 2014; Mucinhato, 2015) ${ }^{9}$.

\footnotetext{
${ }^{5}$ Para uma revisão bibliográfica a respeito do Partido dos Trabalhadores, ver Menegozzo (2013, 2017).

${ }^{6}$ Como dito na Introdução, apesar de o PMDB ser classificado como um partido de centro-esquerda na sua origem (Kinzo, 1988), ele passa a ser classificado como um partido de centro a partir do final dos anos 1990 (Limongi e Figueiredo, 1999; Melo, 2000; Rodrigues, 2002; Fleischer, 2007; Pasquarelli e Bizzarro Neto, 2012). Uma visão também compartilhada por seus filiados e ex-filiados, como em Mesquita (2016) e em parte das entrevistas com políticos realizadas para este estudo, como as entrevistas de Celso Maldaner, Flaviano Melo e de Marcelo Barbieri, entre outros. Ademais, o "centro" dos sistemas político-partidários também parece ter despertado pouco interesse por parte dos cientistas políticos de outros países (Scully, 1992: 180).

${ }^{7}$ http://www.tse.jus.br/partidos/partidos-politicos/registrados-no-tse.

8 Para uma ampla revisão dos estudos monográficos sobre os partidos políticos brasileiros, ver Mucinhato (2015).

9 Para além dos estudos científicos temos também as obras de caráter jornalístico e/ou biográfico/autobiográfico sobre o PMDB ou algum de seus políticos, algumas das quais serão usadas como referências documentais para esta pesquisa, com o seu devido distanciamento. Trata-se de Capistrano Filho e Citadini, (1982), Silva e Delgado (1985), Dimenstein et al. (1985), Melhem e Russo (1987, 2004), Bresser-Pereira (1987), Scartezini (1993), Leonelli e Oliveira (2004), Delgado (2006).
} 
De maneira geral, o principal aspecto destacado da parte daqueles que estudaram o PMDB em âmbito nacional é o seu desempenho eleitoral. De fato, desde o restabelecimento do pluripartidarismo, em 1979, o partido sempre se manteve como uma das principais forças políticas do país, tanto no aspecto regional quanto no âmbito municipal, elegendo sempre grandes bancadas tanto no Congresso quanto nas Assembleias Legislativas. Analisando seu desempenho de maneira diacrônica, o partido apresentou um desempenho eleitoral crescente ao longo dos anos 1980, decaindo a partir dos anos 1990 e posteriormente se estabilizando nos anos 2000, mas sempre se mantendo com bancadas no Congresso Nacional significativamente relevantes para a manutenção da governabilidade de qualquer que fosse a coalizão de governo e continuando a ser um partido determinante no jogo político.

Com relação às eleições para o Congresso Nacional, um locus permanente de destaque do partido (Mucinhato, 2015: 16-17), durante o período que vai de 1982 a 2014 e que engloba nove Legislaturas, em quatro delas o PMDB deteve a maior bancada da Câmara dos Deputados $\left(48^{\mathrm{a}}, 49^{\mathrm{a}}, 50^{\mathrm{a}}\right.$ e $53^{\mathrm{a}}$ Legislaturas) e, no Senado,

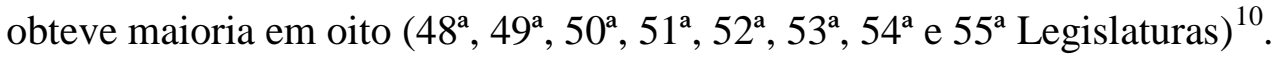

Tabela 1. Bancadas do PMDB na posse após cada eleição e
porcentagem de cadeiras conquistadas $(1982-2014)$

\begin{tabular}{|c|c|c|c|c|c|c|c|c|c|}
\hline Eleições & $\begin{array}{c}1982 \\
\text { Leg47 }\end{array}$ & $\begin{array}{c}1986 \\
\text { Leg48 }\end{array}$ & $\begin{array}{c}1990 \\
\text { Leg49 }\end{array}$ & $\begin{array}{c}1994 \\
\text { Leg50 }\end{array}$ & $\begin{array}{l}1998 \\
\text { Leg51 }\end{array}$ & $\begin{array}{c}2002 \\
\text { Leg52 }\end{array}$ & $\begin{array}{l}2006 \\
\text { Leg53 }\end{array}$ & $\begin{array}{c}2010 \\
\text { Leg54 }\end{array}$ & $\begin{array}{r}2014 \\
\text { Leg55 }\end{array}$ \\
\hline $\begin{array}{l}\text { Cadeiras na } \\
\text { Câmara }\end{array}$ & 200 & 260 & 108 & 107 & 83 & 74 & 89 & 79 & 66 \\
\hline Porcentagem & 41.8 & 53.4 & 21.5 & 20.9 & 16.2 & 14.4 & 17.3 & 15.3 & 12.8 \\
\hline $\begin{array}{l}\text { Cadeiras no } \\
\text { Senado }\end{array}$ & 21 & 45 & 27 & 22 & 27 & 20 & 15 & 20 & 18 \\
\hline Porcentagem & 30.4 & 62.5 & 33.3 & 27.2 & 33.3 & 24.7 & 18.5 & 24.7 & 22.2 \\
\hline
\end{tabular}

Fontes: Elaboração própria com dados do Tribunal Superior Eleitoral (TSE), Nicolau (1998), Mucinhato (2015), Mainwaring (2001), base de dados online do Prof. Jairo Nicolau (disponível em https://jaironicolau.github.io/deb/) e múltiplas fontes jornalísticas.

\footnotetext{
${ }^{10}$ Importante destacar que ao longo do período há mudanças na quantidade de representantes tanto da Câmara dos Deputados quanto do Senado Federal. Na Câmara, em 1982 havia 479 parlamentares, em 1986 havia 487, em 1990, 503, e a partir de 1994 passou a haver 513 deputados federais. No Senado, em 1982 havia 69 parlamentares, em 1986, 72 parlamentares e a partir de 1990 passou a haver 81 senadores.
} 
Gráfico 1. Proporção de cadeiras ocupadas pelo PMDB na posse após cada eleição (1982-2014)

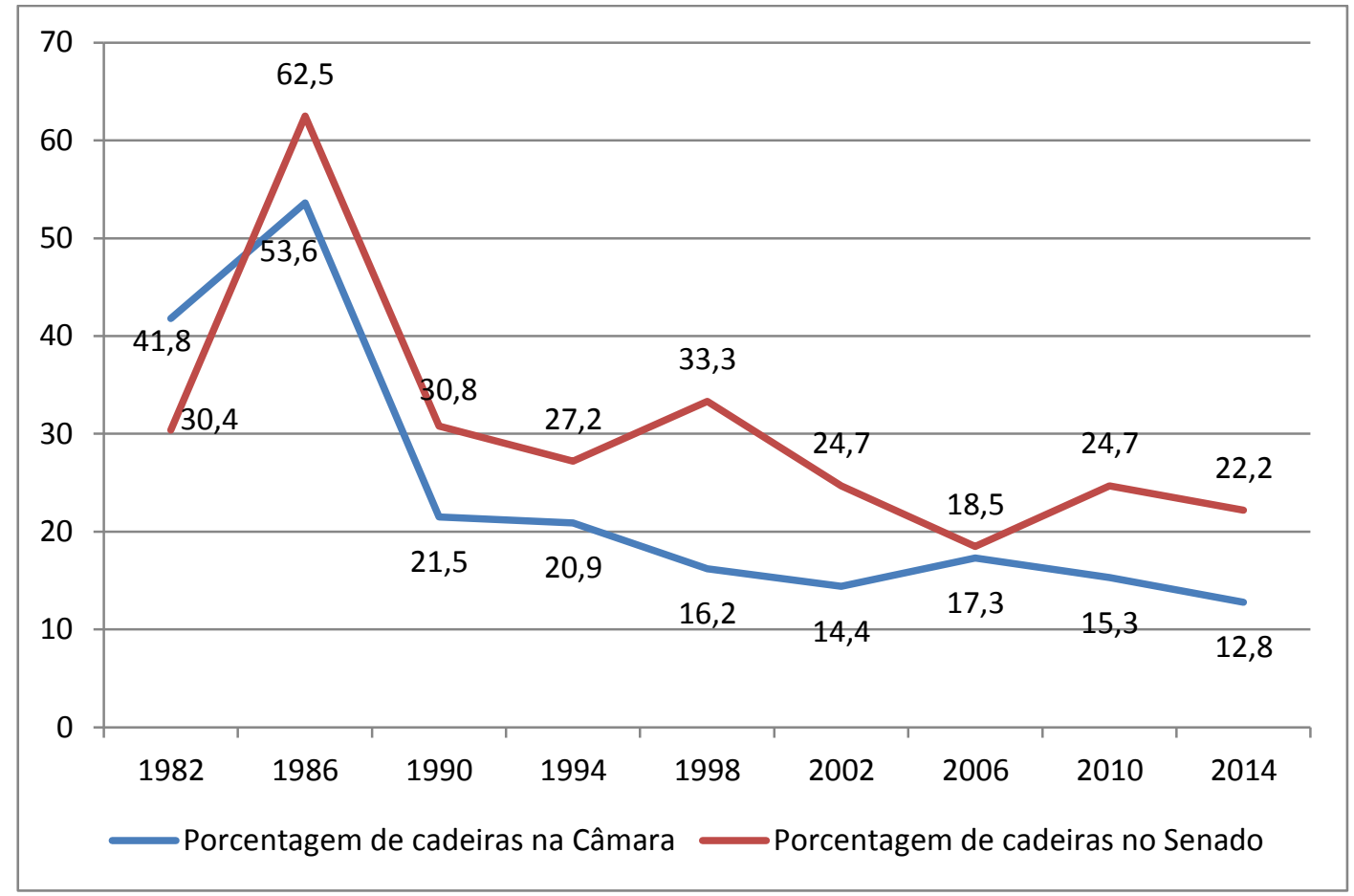

Fontes: Elaboração própria.

Regionalmente o partido também se mostrou bastante forte ao longo de sua história. No período de 1982 a 2014 a sigla elegeu 78 governadores de Estado, atingindo o seu auge nas eleições de 1986, quando o partido elegeu mais de $95 \%$ dos governadores (22 de um total de 23, perdendo apenas no estado de Sergipe para uma candidatura do PFL) no esteio do Plano Cruzado. Apesar da queda no número de eleitos, desde 1990 o partido manteve pelo menos cinco governadores de Estado eleitos pela sua legenda a cada eleição.

Tabela 2. Número de governadores eleitos pelo PMDB (1982 2014 )

\begin{tabular}{lccccccccc}
\hline Eleições & 1982 & $\mathbf{1 9 8 6}$ & $\mathbf{1 9 9 0}$ & $\mathbf{1 9 9 4}$ & $\mathbf{1 9 9 8}$ & $\mathbf{2 0 0 2}$ & $\mathbf{2 0 0 6}$ & $\mathbf{2 0 1 0}$ & $\mathbf{2 0 1 4}$ \\
\hline Governadores & 9 & 22 & 8 & 9 & 6 & 5 & 7 & 5 & 7 \\
Porcentagem & 40.9 & 95.7 & 29.6 & 33.3 & 22.2 & 18.5 & 25.9 & 18.5 & 25.9 \\
\hline
\end{tabular}

Fontes: Tribunal Superior Eleitoral (TSE), Nicolau (1998).

No que se refere ao nível municipal, o PMDB é o partido com a maior força eleitoral do país desde o final da década de 1980. Seguindo sua tendência nacional, o partido obteve um desempenho crescente ao longo dos anos 1980. Entretanto, 
diferentemente da sua tendência mais geral, apesar de o partido decair em termos numéricos a partir dos anos 1990, ele nunca foi alcançado por nenhuma outra sigla. Em sua estreia nas eleições municipais em 1982, o PMDB foi superado pelo partido que sustentava o Regime Militar (o Partido Democrático Social, PDS), mas de $1988 \mathrm{em}$ diante o partido conservou a maior proporção de prefeitos eleitos por todo o país.

\section{Tabela 3. Número de prefeitos eleitos pelo PMDB e porcentagem de cargos conquistados (1982-2016)}

\begin{tabular}{lcccccccccc}
\hline Eleições & $\mathbf{1 9 8 2}$ & $\mathbf{1 9 8 5}$ & $\mathbf{1 9 8 8}$ & $\mathbf{1 9 9 2}$ & $\mathbf{1 9 9 6}$ & $\mathbf{2 0 0 0}$ & $\mathbf{2 0 0 4}$ & $\mathbf{2 0 0 8}$ & $\mathbf{2 0 1 2}$ & $\mathbf{2 0 1 6}$ \\
\hline Prefeitos & 1.377 & 127 & 1.606 & 1.605 & 1.295 & 1.257 & 1.060 & 1.201 & 1.024 & 1.035 \\
Porcentagem & 34.9 & 63.2 & 37.5 & 33.7 & 24.1 & 22.6 & 19 & 21.6 & 18.4 & 18.5 \\
\hline
\end{tabular}

Fontes: Tribunal Superior Eleitoral (TSE), Nicolau (1998) e Mucinhato (2015)

*As eleições de 1985 ocorreram apenas nas capitais de estado, estâncias hidrominerais, áreas de segurança nacional e alguns novos municípios.

\section{Gráfico 2. Número de prefeitos eleitos pelo PMDB (1982-2016)}

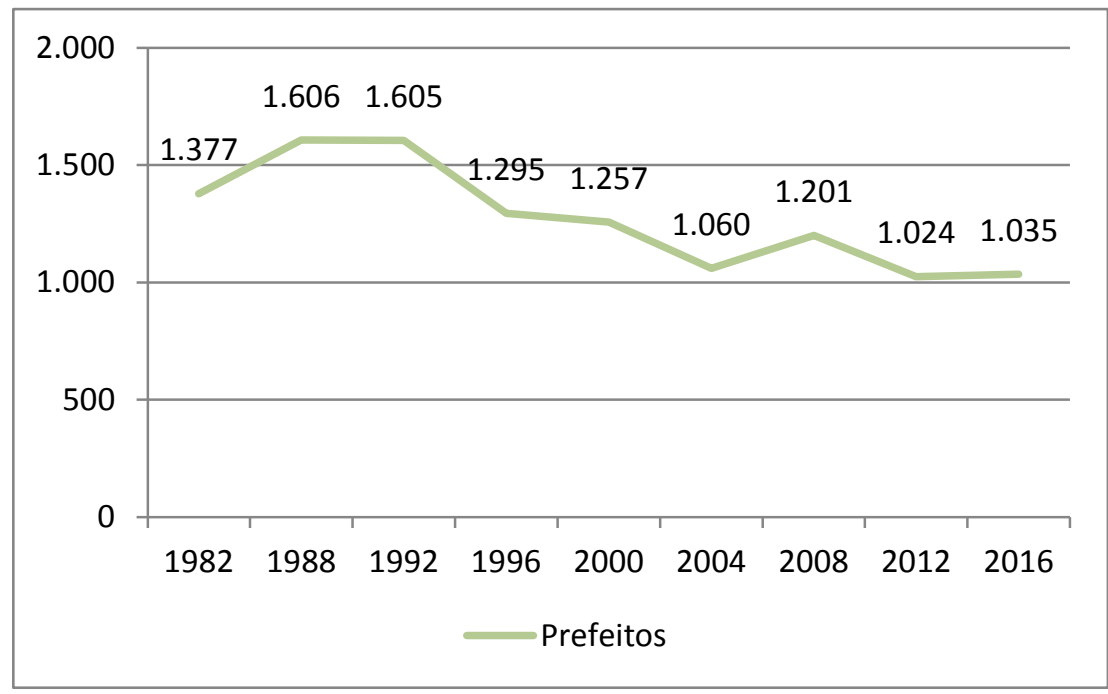

Fontes: Elaboração própria.

Concomitantemente à queda no seu desempenho eleitoral na passagem dos anos 1980 para os anos 1990, o partido começou a passar ao pano de fundo da política brasileira, ofuscado pelo aumento do protagonismo na política brasileira de PT e PSDB. No entanto, essa perda de protagonismo do partido não significou uma ausência da sigla no Poder Executivo. De 1992 até 2002, recorte histórico incluído nesta pesquisa, o partido esteve presente quase que ininterruptamente nas coalizões governantes, como mostra a tabela abaixo.

\footnotetext{
11 Importante mencionar que há um aumento na quantidade de municípios no Brasil ao longo desse recorte histórico. Em 1980 o país possuía 3.991 municípios; em 1991 esse número salta para 4.991, em 2000, para 5.507 e, em 2010, para 5.565 municípios (IBGE, 2011).
} 
Tabela 4. Coalizões de governo no Brasil (1988-2010)

\begin{tabular}{|c|c|c|c|c|c|c|}
\hline \multirow{2}{*}{$\begin{array}{l}\text { Coalizão/ } \\
\text { Presidente }\end{array}$} & \multicolumn{2}{|c|}{ Data da coalizão } & \multirow{2}{*}{$\begin{array}{c}\text { Partidos } \\
\text { da } \\
\text { coalizão }\end{array}$} & \multirow{2}{*}{$\begin{array}{c}\text { Evento de } \\
\text { início da nova } \\
\text { coalizão }\end{array}$} & \multirow{2}{*}{$\begin{array}{l}\text { Cadeiras } \\
\text { da } \\
\text { coalizão }\end{array}$} & \multirow{2}{*}{$\begin{array}{c}\text { \% de } \\
\text { cadeira } \\
\text { s da } \\
\text { coalizão }\end{array}$} \\
\hline & Início & Fim & & & & \\
\hline Sarney 2 & 06/out/88 & $14 / \mathrm{mar} / 90$ & $\begin{array}{c}\text { PMDB- } \\
\text { PFL }\end{array}$ & $\begin{array}{c}\text { Promulgação } \\
\text { da } \\
\text { Constituição }\end{array}$ & 313 & 64.3 \\
\hline Collor 1 & $15 / \mathrm{mar} / 90$ & 12/out/90 & PRN - PFL & $\begin{array}{c}\text { Eleição } \\
\text { presidencial }\end{array}$ & 119 & 24 \\
\hline Collor 2 & 13/out/90 & 31/jan/91 & $\begin{array}{l}\text { PRN - PFL } \\
\text { - PDS }\end{array}$ & PDS entra & 151 & 30.5 \\
\hline Collor 3 & $01 / \mathrm{fev} / 91$ & 14/abr/92 & $\begin{array}{l}\text { PRN - PFL } \\
\text { - PDS }\end{array}$ & $\begin{array}{c}\text { Eleição } \\
\text { Legislativa }\end{array}$ & 167 & 33.2 \\
\hline Collor 4 & 15/abr/92 & $30 /$ set/92 & $\begin{array}{l}\text { PRN - PFL } \\
\text { - PDS - } \\
\text { PTB - PL }\end{array}$ & $\begin{array}{l}\text { PTB e PL } \\
\text { entram }\end{array}$ & 212 & 42.1 \\
\hline Itamar 1 & 01/out/92 & 30/ago/93 & $\begin{array}{l}\text { PFL - PTB } \\
\text { - PMDB - } \\
\text { PSDB - } \\
\text { PSB }\end{array}$ & $\begin{array}{l}\text { Impeachment } \\
\text { de Collor }\end{array}$ & 268 & 52.3 \\
\hline Itamar 2 & 31/ago/93 & 24/jan/94 & $\begin{array}{l}\text { PFL - PTB } \\
\text { - PMDB - } \\
\text { PSDB - PP }\end{array}$ & $\begin{array}{l}\text { PSB sai e PP } \\
\text { entra }\end{array}$ & 296 & 59 \\
\hline Itamar 3 & 25/jan/94 & $31 / \mathrm{dez} / 94$ & $\begin{array}{c}\text { PFL - } \\
\text { PMDB - } \\
\text { PSDB - PP }\end{array}$ & PTB sai & 275 & 55.5 \\
\hline FHC I 1 & 01/jan/95 & 25/abr/96 & $\begin{array}{l}\text { PSDB - } \\
\text { PFL - } \\
\text { PMDB - } \\
\text { PTB }\end{array}$ & $\begin{array}{c}\text { Eleições } \\
\text { presidenciais e } \\
\text { legislativas }\end{array}$ & 290 & 56.5 \\
\hline FHC I 2 & 26/abr/96 & $31 / \mathrm{dez} / 98$ & $\begin{array}{l}\text { PSDB - } \\
\text { PFL - } \\
\text { PMDB - } \\
\text { PTB - PPB }\end{array}$ & PPB entra & 396 & 77 \\
\hline FHC II 1 & 01/jan/99 & 05/mar/02 & $\begin{array}{l}\text { PSDB - } \\
\text { PFL - } \\
\text { PMDB - } \\
\text { PPB }\end{array}$ & $\begin{array}{c}\text { Eleições } \\
\text { presidenciais e } \\
\text { legislativas }\end{array}$ & 354 & 69 \\
\hline FHC II 2 & 06/mar/02 & 31/dez/02 & $\begin{array}{l}\text { PSDB - } \\
\text { PMDB - } \\
\text { PPB }\end{array}$ & PFL sai & 232 & 45 \\
\hline Lula I 1 & 01/jan/03 & 22/jan/04 & $\begin{array}{c}\text { PT - PL - } \\
\text { PCdo B - } \\
\text { PSB - PTB } \\
\text { - PDT - } \\
\text { PPS - PV }\end{array}$ & $\begin{array}{c}\text { Eleições } \\
\text { presidenciais e } \\
\text { legislativas }\end{array}$ & 249 & 48.5 \\
\hline Lula I 2 & 23/jan/04 & 31/jan/05 & $\begin{array}{l}\text { PT - PL - } \\
\text { PCdo B - }\end{array}$ & $\begin{array}{c}\text { PDT sai e } \\
\text { PMDB entra }\end{array}$ & 319 & 62.2 \\
\hline
\end{tabular}




\begin{tabular}{|c|c|c|c|c|c|c|}
\hline & & & $\begin{array}{c}\text { PSB - PTB } \\
\text { - PPS - PV } \\
\text { - PMDB }\end{array}$ & & & \\
\hline Lula I 3 & 01/fev/05 & 19/mai/05 & $\begin{array}{c}\text { PT - PL - } \\
\text { PCdo B - } \\
\text { PSB - PTB } \\
\text { - PV - } \\
\text { PMDB }\end{array}$ & PPS sai & 307 & 59.8 \\
\hline Lula I 4 & 20/mai/05 & 22/jul/05 & $\begin{array}{l}\text { PT - PL - } \\
\text { PCdo B - } \\
\text { PSB - PTB } \\
\text { - PMDB }\end{array}$ & PV sai & 299 & 58.9 \\
\hline Lula I 5 & 23/jul/05 & 31/dez/06 & $\begin{array}{l}\text { PT - PL - } \\
\text { PCdo B - } \\
\text { PSB - PTB } \\
\text { - PMDB - } \\
\text { PP }\end{array}$ & PP entra & 356 & 69.4 \\
\hline Lula II 1 & 01/jan/07 & 01/abr/07 & $\begin{array}{c}\text { PT - PL - } \\
\text { PCdo B - } \\
\text { PSB - PTB } \\
\text { - PMDB - } \\
\text { PP }\end{array}$ & $\begin{array}{c}\text { Eleições } \\
\text { presidenciais e } \\
\text { legislativas }\end{array}$ & 308 & 60 \\
\hline Lula II 2 & 02/abr/07 & $31 / \mathrm{dez} / 10$ & $\begin{array}{c}\text { PT - PR - } \\
\text { PCdo B - } \\
\text { PSB - PTB } \\
\text { - PMDB - } \\
\text { PP - PDT - } \\
\text { PRB }\end{array}$ & $\begin{array}{c}\text { Entra PDT e } \\
\text { PRB }\end{array}$ & 348 & 68 \\
\hline
\end{tabular}

Fontes: Medeiros et al. (2013) apud Melo (2013: 154) e Figueiredo (2007) apud Maciel (2014).

Essa participação do PMDB no governo federal enquanto partícipe das coalizões governantes se deu principalmente por meio da ocupação de Ministérios e Secretarias Especiais (com status de Ministério). Como indica a tabela a seguir, desde o governo Sarney os representantes da sigla têm ocupado postos com esse caráter, fosse qual fosse o partido do presidente da República na conjuntura.

Tabela 5. Distribuição de Ministérios e Secretarias Especiais com status ministerial ocupados pelo PMDB ao longo dos governos pós-redemocratização (1985-2010)

\begin{tabular}{lcc}
\hline Governo & $\begin{array}{c}\text { Número de Ministros/ } \\
\text { Secretários Especiais }\end{array}$ & $\begin{array}{c}\text { \% de Secretários } \\
\text { Especiais/ } \\
\text { Ministros do partido }\end{array}$ \\
\hline Sarney & 36 & $52 \%$ \\
Collor & $1^{*}$ & $3,1 \%$ \\
Itamar & 8 & $14,2 \%$ \\
FHC 1 & 7 & $15,9 \%$ \\
FHC 2 & 6 & $10,5 \%$ \\
\hline
\end{tabular}




\begin{tabular}{llc}
\hline Lula 1 & 5 & $7,8 \%$ \\
Lula 2 & 9 & $12,5 \%$ \\
\hline
\end{tabular}

Fontes: Oliveira (2012), Meneguello (1996), Mucinhato (2015).

* Durante o breve governo Collor, o PMDB ocupou apenas um gabinete ministerial, o Ministério da Justiça, e por um curto intervalo de tempo, de março a outubro de 1990, com José Bernardo Cabral.

Em seu estudo sobre o partido, Oliveira (2012) apontou que seu destacado desempenho eleitoral no período de 1982 a 2010 e a participação de seus membros nos ministérios e secretarias dos referidos governos pós-redemocratização estariam diretamente relacionados a uma estratégia deliberada utilizada pelo partido. A "vocação governista" do partido consistiria numa estratégia calculada de obtenção de recursos políticos através de uma estreita ligação com o Estado (ibidem:130). Sua origem no MDB, implantado e fortalecido primeiramente nas esferas local e estadual, permitiu ao partido montar uma estrutura organizacional com grande capilaridade e heterogeneidade pelo país. Essa estrutura permitiu ao partido focar-se nas disputas locais e regionais, lançando um grande número de candidatos e conquistando um alto número de mandatos legislativos, e ao mesmo tempo isentar-se de lançar candidato próprio à presidência. Nesse sentido, ao focar-se nas eleições legislativas e conquistar amplas bancadas no Congresso Nacional, segundo a autora o partido se coloca numa posição privilegiada para a conquista de cargos dentro do arranjo do nosso presidencialismo de coalizão, viabilizando a manutenção constante de sua participação nos governos pós-1985. Entretanto, a autora não leva em conta o fato de que o partido, em duas ocasiões distintas em sua história, apresentou candidaturas próprias para disputar a presidência da República, e que em outras ocasiões muitos de seus filiados tentaram se tornar candidatos pela sigla, o que carece, portanto, de explicação em seu estudo.

Por sua vez, a obra de Ferreira (2002) analisa o impacto do federalismo em uma perspectiva comparativa entre o PMDB e o Partido da Frente Liberal (PFL). Tendo como recorte histórico o período de 1982 a 2000, a autora aponta que o federalismo e as características de sua origem poderiam ser elementos balizadores das disputas internas do PMDB, assim como seu posicionamento frente ao governo federal no referido período. Ferreira pouco aborda os primeiros anos do partido, dando maior destaque à sua história após a chegada ao governo, em 1985, até o ano de 2002, e ao tocar na questão da composição de seus órgãos de direção conclui que no período houve três grandes grupos que disputaram espaço: ulyssistas (ligados a Ulysses Guimarães), moderados e históricos (ibidem: 203). Porém, segundo a autora, essas correntes foram apenas uma das faces da descentralização do PMDB, que deu-se também de maneira regional e levou a um cenário onde coexistiram vários PMDBs, nos quais cada líder regional acabava por comandar e controlar o partido em sua respectiva base de influência, com grande autonomia entre as diferentes instâncias de poder (ibidem: 206). O fenômeno da regionalização do partido não será investigado neste estudo, porém, no que tange aos grupos que disputaram espaço nos órgãos de direção do partido, apontaremos a dinâmica de interação entre eles, usando uma nomenclatura diferente da 
utilizada pela autora para analisar os anos 1980, mas fazendo uso da mesma divisão interna utilizada por ela quando trata dos anos 1990.

A fragmentação regional também é apontada por Melo (2013) como uma característica que perpassa toda a história do partido (ibidem: 188). Para o autor, o PMDB se adaptou aos ambientes externos nos quais esteve inserido de diferentes maneiras ao longo da sua história, passando assim por mudanças em sua caracterização. Comparando suas características no momento da fundação do MDB em 1966 e no momento em que escrevia seu estudo ${ }^{12}$, o autor conclui que o partido combina características de dois modelos diferentes de partido, de acordo com a tipologia elaborada por Kirchheimer (1966) e Katz e Mair (1994). Enquanto no início da sua trajetória o MDB podia ser caracterizado como um partido catch all programático, ele teria caminhado em direção a um modelo de partido cartel, no qual a ocupação de cargos e as "redes clientelares"13 passariam a ser mais relevantes para o seu sucesso eleitoral do que o vínculo programático e identitário com os eleitores (Melo, ibidem: 186).

Por fim, em estudo mais recente, a tese de Maciel (2014) apontou para novas clivagens que surgiram no interior do partido a partir dos anos 1990. Se durante o período em que esteve na oposição à ditadura ${ }^{14}$ a questão que dividia o MDB em grupos divergentes seria quanto à ação que o partido deveria tomar frente ao regime militar, se combativa ou mais moderada, a questão central que passaria a dividir o PMDB mais claramente a partir da década de 1990 é se a organização deve fazer parte do governo ou não (ibidem: 73). A partir de então, dois grandes grupos se formaram no interior do partido: os governistas e os oposicionistas, ou dissidentes, mesma terminologia a ser empregada neste estudo quando tratamos desse recorte histórico. Após a morte de Ulysses Guimarães, em 1992, que era visto como um elemento importante de negociação interna do partido, o grupo governista passa a ocupar a direção do partido, centralizando cada vez mais as decisões e silenciando a minoria oposicionista (ibidem: 90). A ascensão e a hegemonia obtidas pela ala dos governistas será também aqui considerada, porém, apontaremos evidências de que essa divisão se fazia presente já no governo de Itamar Franco, antes do momento apontado pela autora.

Como se pode ver, no que diz respeito ao acúmulo que a literatura de ciência política possui a partir dos estudos que tiveram como objeto central o PMDB, o processo de transformação interno pelo qual o partido passou em suas primeiras décadas de existência nunca foi objeto central de qualquer estudo sobre a sigla. De maneira marginal, seja em estudos que não tinham como objeto de análise central o partido, seja naqueles que tinham, alguns autores apontaram que algo pode ter ocorrido em seu interior. Autores como Power (1997: 76), Mainwaring, Meneguello e Power (2000: 53), Mainwaring (2001: 142) e Bizzarro Neto (2013: 30) apontaram que houve uma

\footnotetext{
${ }^{12} \mathrm{O}$ autor considera haver uma continuidade linear entre MDB e PMDB, aspecto do qual discordamos.

${ }^{13} \mathrm{O}$ termo foi criado pelo autor do estudo.

${ }^{14}$ A autora, assim como Ferreira (2002) e Melo (2013), aponta uma continuidade linear entre MDB e PMDB, e dá pouco destaque aos anos 1980.
} 
"infiltração" de quadros arenistas no partido que deu a ele uma grande ala conservadora, levando a agudas divisões internas (fazendo referência ao surgimento do PSDB em 1988), e a uma mudança em sua feição. Rodrigues (1987: 53) talvez tenha sido o autor que mais notou esse processo, quando em seu estudo a respeito do perfil dos parlamentares constituintes apontou:

"Na contabilidade geral de entrada e saída do PMDB, este partido cresceu absorvendo um bom número de deputados da antiga ARENA e liberando uma proporção bem menor de deputados que passaram para os partidos à esquerda. (...) Consequentemente, no conjunto, o PMDB caminhou mais à direta. Este deslocamento deve se manter ou se acentuar: por ser o grande partido governamental, organizado em escala nacional, o PMDB deverá, em comparação com o passado, atrair políticos mais pragmáticos das classes altas, capazes de obter melhores resultados na competição pelo controle da máquina partidária, disputas de vagas nas listas eleitorais e obtenção de melhores resultados nos diferentes pleitos."

De maneira similar, Tarouco e Madeira (2013) analisaram minuciosamente os programas partidários registrados no TSE e por meio dos seus dados fica evidente também um deslocamento do partido do campo da centro-esquerda para o centro do espectro ideológico-partidário ao longo das duas primeiras décadas de sua existência. No entanto, nenhum desses autores se dedicou a estudar esse fenômeno e apontá-lo como um processo de longo prazo.

Enfim, nota-se que a literatura a respeito do PMDB ainda é bastante escassa em comparação a outros partidos políticos brasileiros, sobretudo em se tratando de análises historiografico-políticas mais minuciosas que ao mesmo tempo não deixem de lado certos aspectos organizacionais do partido, tal como, entre outras coisas, a variação na composição dos seus principais órgãos de direção ao longo do tempo. Outro aspecto que pode ser notado é o fato de que os estudos pouco se aprofundaram sobre o partido nos anos 1980, período extremamente rico historicamente e que reúne eventos importantes que alteraram profundamente a composição interna da sigla, deixando marcas permanentes na sua história. Nota-se também que nenhum dos estudos aqui citados deu a devida atenção às alterações na composição interna do PMDB e às consequentes mudanças nas suas estratégias político-eleitorais. Assim sendo, esta pesquisa se insere nesse esforço recente de parte da literatura sobre os partidos políticos brasileiros que toma como foco o estudo sobre o partido em nível federal, contribuindo, dentro das suas limitações, com novas reflexões e cobrindo um amplo recorte histórico. 


\section{$\underline{\text { Estrutura interna do PMDB }}$}

Antes de passarmos à análise da dinâmica interna pela disputa dos órgãos de direção do PMDB, cabe aqui descrevermos brevemente a estrutura organizativa do partido de acordo com o seu Estatuto aprovado em Convenção de $1996^{15}$. Apesar de outros Estatutos terem sido aprovados em anos mais recentes, eles estão fora do recorte histórico desta pesquisa, e ainda assim pouco ou quase nada alteraram a organização interna do partido ${ }^{16}$, mantendo o cerne da estrutura organizativa do citado Estatuto de $1996^{17}$. De acordo com ele, são órgãos do partido: as Convenções, os Diretórios, o Conselho Nacional, as Comissões Executivas, as Comissões de Ética e Disciplina, os Conselhos Fiscais, a Fundação Ulysses Guimarães e as bancadas parlamentares ${ }^{18}$.

A Convenção Nacional é o órgão máximo de deliberação do partido, por isso uma instância bastante presente no estudo aqui realizado. Ela pode apenas ser convocada ordinariamente pela Comissão Executiva Nacional ${ }^{19}$, e é composta pelos membros do Diretório Nacional, delegados dos estados e do Distrito Federal, representantes do partido no Congresso Nacional e pelos membros do Conselho Nacional que não integrarem o Diretório Nacional ${ }^{20}$. Cabe a esta instância de decisão fixar as diretrizes para a atuação partidária, escolher ou proclamar, quando houver eleição prévia, os candidatos do partido à presidência e vice-presidência da República, decidir sobre coligações com outros partidos, analisar e aprovar a plataforma de governo à presidência da República, aprovar o Estatuto e o Programa Partidário, decidir sobre as propostas de reformas do Programa, do Estatuto e do Código de Ética do Partido, eleger membros titulares e suplentes do Diretório Nacional, bem como os da Comissão Nacional de Ética e Disciplina, decidir sobre a dissolução ou a fusão do

\footnotetext{
${ }^{15}$ Convenção Nacional Extraordinária de 23 de março de 1996. Até aquele ano, a estrutura organizativa e decisória do PMDB até a adequação à Lei Orgânica dos Partidos Políticos (LOPP) de 1995 não era muito diferente daquela apresentada pelos outros grandes partidos brasileiros, exceção feita ao PT (Ribeiro, 2013: 231).

${ }^{16}$ Para Ribeiro (2013: 238), as mudanças adotadas pelo Estatuto de 2007 foram insignificantes frente ao regulamento de 1996. Porém, cabe mencionar aqui três alterações mais recentes: o Estatuto de 2013, que ampliou em duas cadeiras o número de componentes da CEN, a Convenção realizada em 12/03/2016, que ampliou para 22 a quantidade de membros titulares da Comissão Executiva Nacional e o Estatuto de 2018, que eliminou a palavra "Partido" da sigla. Para uma relação dos Estatutos utilizados pelo PMDB em sua história, com exceção do seu primeiro, adotado a partir de 1980 e nos primeiros 15 anos de sua existência, ver http://www.tse.jus.br/partidos/partidos-politicos/partidos-registrados-notse/movimento-democratico-brasileiro, consultado em 1/08/2018.

17 O Estatuto aprovado em 1996 teve como objetivo adaptar a legenda à nova Lei dos Partidos (Lei $n^{\circ}$ 9096/95), que substituiu a Lei Orgânica dos Partidos Políticos - LOPP, Lei $n^{\circ}$ 5682, de 21 de julho de 1971 (Ferreira, 2002: 194). O PMDB, porém, já havia adotado algumas mudanças em seu Estatuto de 1993, que segundo Ferreira (2002 apud Ribeiro, 2013: 243) ampliaram os poderes do Diretório Nacional em comparação aos da Executiva e institucionalizaram a descentralização de cunho federalista ao ampliar e adotar critérios regionais na composição do DN e do Conselho Nacional.

${ }^{18}$ Art. 15 do Estatuto do PMDB de 1996.

${ }^{19}$ Art. 66, ibidem.

${ }^{20}$ Art. 65, ibidem.
} 
partido e, nesses casos, sobre a destinação do seu patrimônio e decidir soberanamente sobre os assuntos políticos e partidários ${ }^{21}$.

As Convenções, por sua vez, também se replicam nos outros níveis nos quais o partido está organizado, a saber, as Convenções Estaduais, Municipais, e Zonais ${ }^{22}$. Cabe a elas, assim como à Convenção Nacional, serem as instâncias de deliberação do partido, sendo convocadas de maneira ordinária por sua respectiva Comissão Executiva para definir os rumos do partido na instância em questão, elegendo os membros do seu Diretório (que por sua vez elege os membros da Comissão Executiva daquele respectivo nível) e definindo suas candidaturas aos cargos eletivos, entre outras coisas ${ }^{23}$.

Em âmbito nacional, foco prioritário deste estudo, a Comissão Executiva Nacional (CEN) é a principal instância responsável pela direção das atividades do partido. No recorte histórico deste estudo ela foi composta de 19 a 23 membros, variando no número de vogais e suplentes de cada gestão, mas mantendo sempre os seguintes cargos de direção em sua composição: Presidente, $1^{\circ}$ Vice-Presidente, $2^{\circ}$ Vice-Presidente, $3^{\circ}$ Vice-Presidente, Secretário-Geral, $1^{\circ}$ Secretário, $2^{\circ}$ Secretário, $1^{\circ}$ Tesoureiro, $2^{\circ}$ Tesoureiro (ou Tesoureiro Adjunto), Líder da bancada do partido na Câmara e Líder da bancada do partido no Senado ${ }^{24}$. Cabe à Comissão dirigir, no âmbito nacional, as atividades do partido, manter a escrituração de sua receita e sua despesa em livros de contabilidade e prestar contas, ao órgão competente da União, das cotas recebidas do Fundo Partidário, administrar o patrimônio social, adquirindo, alienando, arrendando ou hipotecando bens, promover o registro do Estatuto, do Programa e do Código de Ética Partidária junto ao órgão competente, remeter às Comissões Executivas Estaduais cópias das deliberações da Convenção e Diretório Nacional e receber doações, entre outras coisas ${ }^{25}$.

Além da CEN o partido também possui como órgão de direção o Diretório Nacional, responsável pela escolha de quais membros compõem a CEN da sigla. O Diretório tem como membros natos os presidentes dos Diretórios Estaduais, os líderes da bancada do partido na Câmara dos Deputados e no Senado Federal (assim como na CEN) e os ex-presidentes da CEN. Além dos membros natos, o DN também é formado pelos 119 titulares e 40 suplentes eleitos por meio da Convenção Nacional. Cabe ao DN, convocar, por meio da Comissão Executiva Nacional, a Convenção Nacional e fixar normas para o seu funcionamento, assim como eleger os membros titulares e suplentes da Comissão Executiva Nacional, entre outras atribuições ${ }^{26}$.

Ainda em âmbito nacional, uma especificidade do PMDB em relação aos outros partidos políticos brasileiros é a existência de outro órgão de direção, o seu Conselho Nacional (CN), criado em 1993 (exceção feita ao PSDB e ao PFL/DEM, que criaram ou

\footnotetext{
${ }^{21}$ Art. 64, ibidem.

${ }^{22}$ Art. 14, ibidem.

${ }^{23}$ Art. 22, ibidem.

${ }^{24}$ Art. 75 , ibidem.

${ }^{25}$ Art. 76, ibidem.

${ }^{26}$ Art. 69, ibidem.
} 
fortaleceram órgãos similares a partir dos anos 2000 (Ribeiro, 2013) ${ }^{27}$. De acordo com o Estatuto do partido, o Conselho seria um órgão intermediário entre a Comissão Executiva e o Diretório Nacional, destinado a tornar mais ágeis as mais importantes decisões partidárias, sem perda da representatividade do Partido ${ }^{28}$. Ele é composto pelos membros da CEN, pelos presidentes dos Diretórios Estaduais e pelos filiados ao partido que sejam: ex-presidentes nacionais da sigla, ex-presidentes da República, governadores de Estado, presidentes e ex-presidentes da Câmara dos Deputados e do Senado Federal e os ex-líderes do partido nessas casas legislativas. Considerando que o próprio Estatuto do partido veta a participação de alguns desses cargos nas Comissões Executivas dos diferentes níveis do partido ${ }^{29}$, pode-se supor que a criação do Conselho teve entre seus objetivos a inclusão de mais figuras importantes com projeção eleitoral dentro dos órgãos de decisão. Porém, políticos da sigla apontaram que o $\mathrm{CN}$ não se reúne de maneira regular, apenas em situações excepcionais (Ferreira, 2002: 195), quando “ocorre algo extraordinário ou há uma 'agudização' de algum problema"30.

Como dito anteriormente, para além dessas instâncias de sua estrutura organizativa interna, o PMDB conta ainda com dois órgãos de apoio, cooperação e ação partidária. Trata-se do Conselho Fiscal, ao qual compete examinar e emitir pareceres sobre a contabilidade do partido ${ }^{31}$, e a Fundação Ulysses Guimarães. A Fundação, que até o ano de 1999 recebia o nome de Fundação Pedroso Horta, foi renomeada naquele ano a partir da posse de Renan Calheiros na presidência do órgão ${ }^{32}$, em homenagem àquele que é considerado como a principal figura histórica do partido ${ }^{33}$. Entre as suas competências, a Fundação cumpre o papel de dar subsídio teórico à atuação do partido, seja internamente, por meio de simpósios, seminários, estudos e eventos, seja externamente, fornecendo cursos de formação e desenvolvendo publicações sobre a história do partido. Cabe salientar que a Fundação cumpriu diferentes papéis ao longo de sua história. Em seus primeiros anos, quando ainda denominada "Pedroso Horta", a Fundação editava a chamada "Revista do PMDB", que cumpriu o importante papel de meio de divulgação das diretrizes basilares do partido (Palmeira, 2015: 172), com artigos de seus principais quadros acadêmicos, como Fernando Henrique Cardoso, Severo Gomes, José Serra, Raphael de Almeida Magalhães e Almino Affonso, entre outros. Em anos mais recentes, a Fundação parece cumprir também o papel de arregimentar novos quadros para a sigla, sobretudo em pequenos municípios, por meio

\footnotetext{
${ }^{27}$ Ata da 14ạ Convenção Extraordinária do PMDB - 15/08/1993, Acervo SEDAP/TSE.

${ }^{28}$ Art. 71 do Estatuto do PMDB de 1996.

${ }^{29}$ Art. 19 do Estatuto do PMDB de 1996: "São inelegíveis para as Comissões Executivas de qualquer nível o Presidente da República, os Ministros de Estado, os Governadores de Estado, os Secretários de Estado, do Distrito Federal e dos municípios das Capitais".

${ }^{30}$ Mauro Benevides, membro do Diretório Nacional e ex-membro da CEN, em entrevista ao autor.

${ }^{31}$ Art. 52 do Estatuto do PMDB de 1996.

32 Pronunciamento do Senador Renan Calheiros na cerimônia de posse do cargo de Presidente da Fundação, Brasília/DF, 28/09/1999 - Acervo FUG/Brasília.

${ }^{33} \mathrm{Na}$ sede nacional do partido, assim como nos diretórios e sedes da Fundação visitadas, há uma quantidade enorme de quadros de Ulysses Guimarães em todas as paredes. Da mesma forma, boa parte dos entrevistados para este estudo, tenham sido eles próximos ou não à figura de Ulysses ao longo de suas trajetórias políticas, apresentavam em alguma parede uma foto ao lado dele.
} 
dos mais variados cursos de formação política ${ }^{34}$. Esse aspecto, assim como a longevidade do partido, pode ajudar a explicar o fato de o PMDB até os dias atuais ser o partido com o maior número de filiados no Brasil ${ }^{35}$.

Por fim, a figura abaixo sintetiza a estrutura organizativa do PMDB descrita ao longo desta seção. Os órgãos de deliberação do partido são as suas Convenções em três níveis (Municipal, Estadual e Nacional), responsáveis pela eleição dos seus delegados para o nível organizativo acima e dos seus respectivos diretórios, parte dos órgãos de direção do partido. Os diretórios, por sua vez, são os responsáveis pela eleição das suas respectivas Comissões Executivas (mais uma vez, de âmbito Municipal, Estadual e Nacional), outro espaço de direção responsável pela condução do partido, assim como o Conselho Nacional, uma especificidade do PMDB em relação a outros partidos brasileiros.

\section{Figura 2. Estrutura organizativa interna do PMDB}

\section{Órgãos de \\ deliberação}

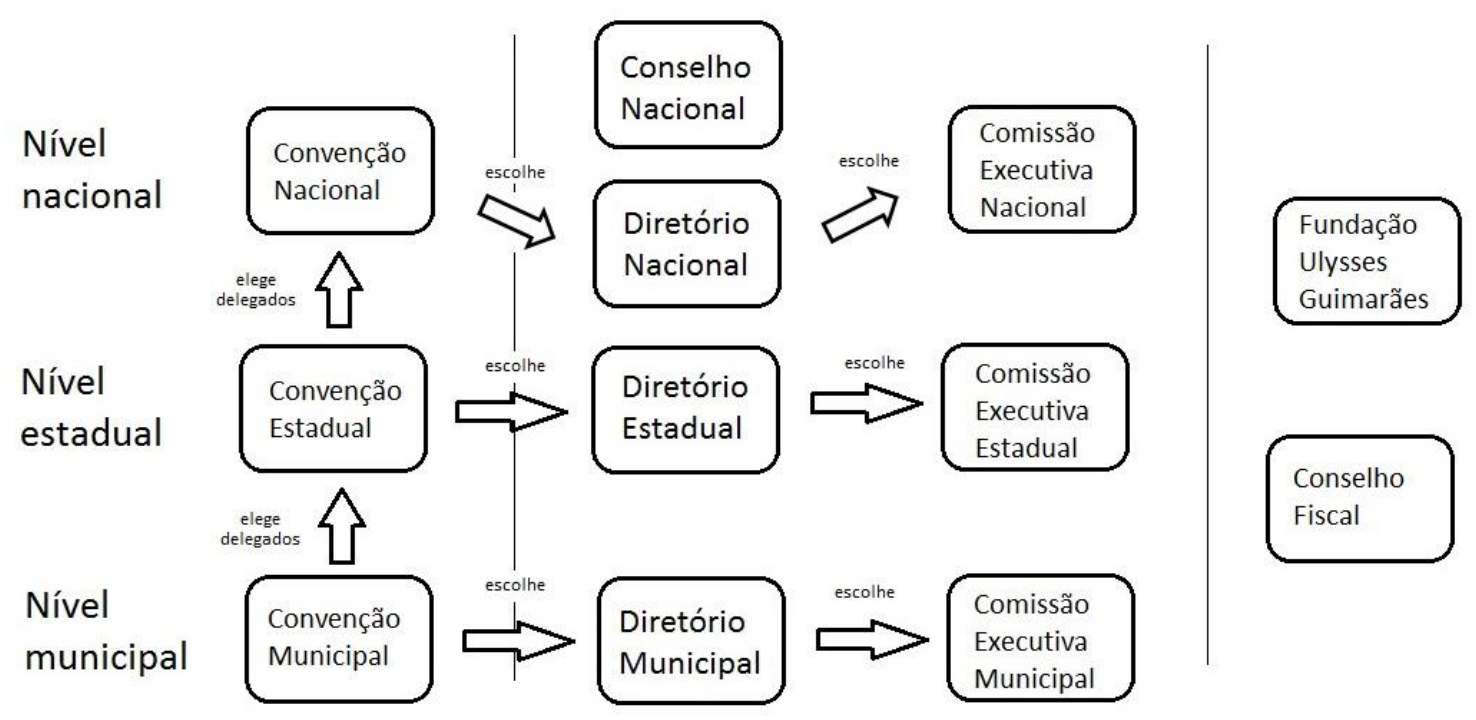

Fonte: adaptado de Guarnieri (2009: 46).

\section{Fontes de pesquisa}

Seguindo a tradição dos estudos monográficos que se tornaram referência sobre os partidos políticos brasileiros, faremos uso da pesquisa documental múltipla. Esse método tem se mostrado o mais seguro para a realização de estudos partidários de fôlego na ciência política brasileira, permitindo ao pesquisador, por meio do cruzamento de múltiplas fontes - documentos e imprensa partidária, dados oficiais, imprensa

\footnotetext{
${ }^{34}$ Conversa informal de uma alta funcionária da Fundação Ulysses Guimarães com o autor.

${ }^{35}$ https://www.nexojornal.com.br/grafico/2018/04/02/Os-filiados-aos-partidos-brasileirosg\%C3\%AAnero-idade-e-distribui\%C3\%A7\%C3\%A3o .
} 
comercial, bem como análises de outros autores (Ribeiro, 2010: 32), construir um quadro que resgate "(...) o papel dos atores políticos, o enredo, vitórias e frustrações, as motivações, os interesses - reais ou supostos (...) situados em cena própria, mas não isolada ou estanque (...)" (Benevides, 1981: 18-19, apud Ribeiro, 2010: 32). Compõe-se assim, por meio de uma multiplicidade de pontos de vista, o rico mosaico que constitui a história do partido a ser estudado da maneira mais fiel possível.

Nesse sentido, as fontes utilizadas nesta pesquisa podem ser divididas em seis tipos, com destaque para a primeira delas:

1. Entrevistas semi-estruturadas e em profundidade com atores políticos importantes para a história do PMDB, filiados ou não ao MDB no momento atual, coletadas pessoalmente ou reproduzidas em documentos históricos.

Foram realizadas pessoalmente e gravadas em áudio 26 entrevistas no total, cada qual com uma duração entre 30 minutos e 1 hora, que incluem 24 políticos de 16 estados distintos ${ }^{36}$, uma jornalista e uma funcionária de alto cargo no partido há mais de 30 anos. As entrevistas constituem um elemento central para este estudo por nos permitirem o cruzamento de uma multiplicidade de narrativas distintas acerca de diferentes momentos da história do partido, e pela sua quantidade trazem também um elemento pioneiro nos estudos sobre o PMDB, representando um diferencial em relação aos outros estudos de maior fôlego sobre o partido ${ }^{37}$.

A realização de longas entrevistas com algumas categorias sociais sempre se mostrou um desafio para os cientistas políticos. Particularmente, entrevistas com elites políticas são ainda mais difíceis ${ }^{38}$, por conta de uma série de fatores que vão além das próprias habilidades pessoais do pesquisador: baixa disponibilidade de tempo dos entrevistados - o fato de terem vidas extremamente ocupadas faz com que este seja um problema endêmico para os pesquisadores que recorrem a entrevistas com elites (Rivera et al., 2002), a dimensão continental do nosso país e por consequência a distância entre os diretórios estaduais do partido, os recursos financeiros disponíveis para o trabalho de

\footnotetext{
${ }^{36}$ São Paulo, Minas Gerais, Espírito Santo, Rio de Janeiro, Rio Grande do Sul, Paraná, Santa Catarina, Goiás, Paraíba, Pernambuco, Ceará, Bahia, Piauí, Rio Grande do Norte, Pará, Acre.

37 Foram entrevistados os seguintes políticos (pela ordem): Pedro Simon, João Carlos Brum Torres, Tonico Ramos, Luiz Carlos Bresser Pereira, Jarbas Vasconcelos, Airton Sandoval, Roberto Requião, Jader Barbalho, Mauro Benevides, Marcelo Barbieri, Pedro Pinheiro Chaves, Flaviano Melo, Marcelo Castro, Rogério Peninha Mendonça, Saraiva Felipe, Raimundo Lira, Rose de Freitas, Raymundo Urbano, Celso Maldaner, Mauro Lopes, Garibaldi Alves, Miro Teixeira, Cássio Cunha Lima e Heráclito Fortes. Além destes foram entrevistadas também a jornalista Sônia Carneiro, que cobriu o cotidiano do Congresso durante toda a transição democrática e que sempre teve uma relação próxima com a cúpula do PMDB, chamada de "sobrinha" por Tancredo Neves (https://oglobo.globo.com/brasil/a-historia-de-moraprovidencial-sobrinha-de-tancredo-neves-5692729) além de uma funcionária de alto cargo no partido por mais de 30 anos, a qual teve a identidade mantida em anonimato dado o teor de sua entrevista.

38 "Os políticos na minha opinião são o segundo pior grupo para se estudar. Eu achava que eram os piores; tem até um ditado russo: 'você sabe quando um político está mentindo? Quando ele abre a boca.' Eles nunca estão disponíveis, nunca querem te receber; quando te recebem estão ao telefone, quando marcam, esquecem e quando lembram não dá mais tempo." (Kuschnir, 2014. "Dez lições da vida acadêmica", Publicado em karinakuschnir.wordpress.com, url "http://wp.me/p42zgF-68". Acesso em 28/05/2018).
} 
campo, a quantidade de intermediários muitas vezes necessária para se acessar o entrevistado, a conjuntura política no momento em que as entrevistas serão realizadas, etc. A maneira encontrada para se contornar parte destas dificuldades foi a realização de dois períodos de trabalho de campo em Brasília, nos quais se deu a maior parte das entrevistas deste estudo.

Na capital federal pudemos ter acesso a políticos (em alguns casos até a expolíticos) de quase todos os estados do país, muitos dos quais ocupam (ou ocuparam) algum cargo de direção no partido ou algum mandato eletivo no Congresso Nacional. A partir do contato com alguns desses personagens e levando em conta o fato de que eram políticos de diferentes perspectivas ideológicas e da maior multiplicidade de estados possível (o que atenua o viés dos não-respondentes - Kapiszewski et al., 2015), fizemos uso do snowball sampling method por meio do qual esse número inicial de entrevistados sugeriu futuros entrevistados, que sugeririam futuros contatos, e assim por diante (Tansey, 2007; Kapiszewski et al., 2015).

A partir dessa lista inicial de possíveis entrevistados, o passo seguinte desta pesquisa foi definir quais aqueles que poderiam de fato ser entrevistados, buscando selecionar prioritariamente lideranças importantes para a história do PMDB, de modo a cobrir o maior número de estados possível, que abarcassem em suas respostas as particularidades da história do partido em seu respectivo estado de procedência. Além disso, foram privilegiados também políticos que em algum momento de sua trajetória tivessem feito parte do Diretório Nacional ou de sua Executiva Nacional, o que por consequência nos levaria a entrevistar políticos que supostamente acompanharam uma quantidade significativa de Convenções Nacionais do partido e presenciaram pessoalmente a sua história interna. A verificação a respeito do fato de cada entrevistado em potencial se encaixar nesses requisitos se deu por meio da elaboração de um breve dossiê sobre a trajetória de vida de cada um deles, por meio de múltiplas fontes, tal como aquelas que constam nos itens 3 e 6 desta seção.

Assim, definidos os nomes e estabelecido o contato com cada político em questão ou com sua respectiva assessoria, o passo final desta etapa da pesquisa foi a realização das entrevistas propriamente ditas, em sua maioria feitas em local definido pelo próprio entrevistado ${ }^{39}$. Todas elas foram gravadas em áudio, transcritas, e por fim codificadas e analisadas por meio do software NVivo 12.

2. Documentos históricos e publicações do partido.

\footnotetext{
${ }^{39}$ É importante fazer a ressalva de que alguns dos previstos para serem entrevistados para esta pesquisa se negaram a conceder entrevistas (em parte por motivos pessoais, em parte por conta da conjuntura política brasileira na qual ela foi desenvolvida), apesar de todos os esforços possíveis que foram feitos nos dois períodos de trabalho de campo realizados em Brasília. Sabemos que a análise pode ter sido prejudicada por este aspecto, mas na medida do possível contornou-se esse problema consultando entrevistas concedidas por esses mesmos políticos para órgãos de imprensa ou instituições que mantêm acervos biográficos ou de história oral da classe política brasileira.
} 
Por meio dos entrevistados e da Fundação Ulysses Guimarães em suas sedes em São Paulo e Brasília foram coletados documentos e publicações do partido dentro do recorte histórico deste estudo. Também foram consultados os acervos mantidos pelos Diretórios Nacional e Paulista do partido $^{40}$, e o acervo mantido pela Seção de Gerenciamento de Dados Partidários (SEDAP) do Tribunal Superior Eleitoral (TSE). Entre os documentos e publicações do partido utilizados neste estudo podemos citar: as "Revistas do PMDB”, publicação nacional do partido com edições ao longo dos anos 1980, os Estatutos, Programas, Manifesto de Fundação, e Manuais de Identidade Visual do PMDB, o jornal "São Paulo HOJE", publicação do PMDB paulista e as Atas de reuniões da Executiva Nacional e do Diretório Nacional do partido disponíveis no TSE, entre outros.

3. Material de imprensa escrita de veículos de grande circulação.

Por meio de seus acervos digitais, a consulta aos veículos de imprensa nos permitiu coletar tanto declarações de políticos no calor dos acontecimentos como descrições mais minuciosas de determinados eventos (ambos tomados em conta com o devido distanciamento). Foram consultados os acervos digitais dos jornais "Folha de $\mathrm{S}$. Paulo" (acervo.folha.uol.com.br), "Jornal da Tarde" (http://www2.senado.leg.br/bdsf/handle/id/35/browse?type=dateissued), "O Estado de S. Paulo" (http://acervo.estadao.com.br/), "Jornal do Brasil", particularmente a seção "Coluna do Castello" (http://www.carloscastellobranco.com.br/sec_coluna.php) e da "Revista Veja" (https://acervo.veja.abril.com.br), assim como matérias pontuais coletadas de outros veículos de imprensa (“Jornal O Globo", "Revista Piauí", "Jornal de Brasília", "O Liberal", "Jornal NEXO", "Valor Econômico", "Folha de Londrina", "Jornal da República", "Correio Braziliense", e "Estado de Minas"), cobrindo o período de 1 de dezembro de 1979 a 31 de dezembro de $2002^{41}$.

\section{Pesquisa bibliográfica.}

Para além do levantamento dos estudos acadêmicos que tomaram como objeto o PMDB, seja em escala regional, seja em escala nacional, também foram consultadas obras de caráter jornalístico publicadas sobre os episódios históricos que envolveram o PMDB (Dimenstein et al., 1985; Leonelli e Oliveira, 2004, entre outras), obras

\footnotetext{
${ }^{40}$ Em relação à sede nacional do PMDB em Brasília, cabe aqui apontar a enorme dificuldade para encontrar a sua localização. No período de realização dos dois trabalhos de campo deste estudo, o endereço oficial da sede não se encontrava publicizado em nenhuma das páginas oficiais do partido, tampouco na página do TSE. Não se sabe se o fato tem relação com a mudança da sede, noticiada pela imprensa em 2017 logo após o vazamento de uma série de áudios envolvendo o Presidente Michel Temer (https://g1.globo.com/distrito-federal/noticia/grupo-fecha-rua-de-sede-do-pmdb-no-df-paraimpedir-saida-de-caminhao-com-caixas.ghtml consultado em 25/05/2018), mas o acesso à sede e ao endereço correto só foram obtidos após o auxílio de um parlamentar.

${ }^{41}$ Cabe aqui destacar que a perda do protagonismo do partido na política nacional depois dos anos 1980 também se refletiu na cobertura jornalística que a imprensa deu ao PMDB. Se até a Constituinte a cobertura que se fazia do partido se dava de maneira quase que diária, com entrevistas e análises sobre tudo aquilo que acontecia em seu interior, a partir dos anos 1990 o espaço que se dava à sigla nos principais jornais do país diminuiu consideravelmente.
} 
publicadas pelo próprio partido ou com o seu apoio contendo a sua "história oficial" (Melhem e Russo, 1987; Delgado, 2006; Fundação Ulysses Guimarães, 2016), assim como biografias e autobiografias de políticos que fizeram parte da história do partido (Silva e Delgado, 1985; Scartezini, 1993; Pessoa, 1994; Câmara dos Deputados, 2009, 2010, 2012, 2016; Corrêa, 2011; Echeverria, 2011; Yazbeck 2011; Fundação Ulysses Guimarães, 2013; Graça, 2013 entre outras).

\section{Dados eleitorais.}

Dados obtidos por meio do Centro de Documentação e Informação da Câmara dos Deputados (CEDI), do Serviço de Informação ao Cidadão do Senado Federal, da base de dados online do Prof. Jairo Nicolau (https://jaironicolau.github.io/deb/) assim como dados disponibilizados de maneira pública pelo TSE sobre as diferentes eleições do período histórico aqui analisado no seu Repositório de Dados Eleitorais (http://www.tse.jus.br/eleicoes/estatisticas/repositorio-de-dados-eleitorais-1/repositoriode-dados-eleitorais).

\section{Acervos de instituições de pesquisa.}

Acervos como aquele mantido por instituições tal como o Centro de Pesquisa e Documentação de História Contemporânea do Brasil (CPDOC/FGV), que disponibiliza para consulta online por meio da página www.fgv.br/cpdoc/acervo/arquivo a base de dados do "Dicionário Histórico Biográfico Brasileiro" (DHBB).

\section{Organização do texto}

Nesta introdução, apontamos que nossa abordagem teórica partirá das reflexões de Katz e Mair (1993) sobre as três diferentes facetas dos partidos políticos para analisar principalmente a face diretiva do PMDB, fazendo uso do conceito de coalizão dominante de Panebianco (2005). Por meio desse arcabouço teórico e compreendendo a importância dessa esfera para a definição dos rumos dos partidos políticos brasileiros (Ribeiro, 2014), analisaremos as mudanças na sua cúpula dirigente durante o recorte histórico de 1979 a 2002, com o intuito de colaborar para a literatura que se debruçou sobre o partido, aqui já mencionada. Para ir além dos estudos já desenvolvidos, argumentamos que a compreensão da dinâmica de disputas pelos seus órgãos de direção nos auxilia a compreender as estratégias político-eleitorais adotadas pela sigla ao longo de sua história e a sua transformação de partido protagonista ao pano de fundo da política brasileira, o que iremos analisar por meio de um amplo levantamento documental e de uma grande quantidade de entrevistas realizadas, reconstruindo o amplo mosaico que compreende sua história interna. Assim, além desta introdução que descreveu esses pontos, este estudo está dividido em outras duas partes, cada qual subdividida em dois capítulos.

Na primeira parte, na qual analisamos o período de 1979 a 1988, destacamos que as estratégias adotadas pelo partido durante este recorte histórico foram decorrentes de 
um processo de transformação interna ligado a mudanças na sua correlação de forças, que por sua vez foram decorrentes das constantes entradas e saídas de quadros do PMDB. Com a incorporação do Partido Popular em 1982 e as três ondas de evasão de quadros do PMDB para a formação de novos partidos políticos (ocorridas de maneira cronológica em 1980, 1985 e 1988), a coalizão dominante do partido esteve em constante transformação. Como será mostrado, com a perspectiva de chegada ao poder após a sua refundação em 1979 e a vitória da chapa Tancredo-Sarney em 1985, que levam o PMDB ao governo federal pela primeira vez em sua história, o partido atravessa um processo de "inchaço" em seus quadros, compreendido como a constante entrada de políticos com histórico ligado à ARENA durante o Regime Militar. Este processo, que havia se tornado mais evidente para a literatura com o resultado das eleições de 1986 mas que já se encontrava em curso anteriormente, acabou por se refletir nas estratégias usadas pelo partido durante aquele período, como a própria decisão de disputar o Colégio Eleitoral de 1985 e colocar um fim ao Regime Militar por meio do próprio arcabouço institucional criado pelo Regime.

Por sua vez, na segunda parte deste estudo tratamos do período de 1989 a 2002, completando o recorte histórico desta pesquisa. Este período compreende o lançamento de duas candidaturas diretas a presidente da República por parte do partido, ocorridas em 1989 e 1994. Entretanto, em comparação à disputa do Colégio Eleitoral de 1985, a estratégia eleitoral adotada pelo PMDB de lançar candidatos próprios está mais ligada a fatores de outra ordem, que diferem daqueles relacionados à candidatura indireta de 1985. Apesar de também estar ligado a mudanças na coalizão dominante do partido, diferentemente do processo analisado na primeira parte desta tese o lançamento de ambas candidaturas está mais relacionado à ascensão de alas internas do partido que passam a deter um controle temporário dos seus órgãos de direção. Ademais, durante esse período começam a surgir novas divisões em seu interior, que levam à formação de duas grandes alas. Se durante o Regime Militar o PMDB e o seu antecessor MDB se dividiam entre os "moderados" e os "autênticos", a partir dos anos 1990 a divisão que marca a coalizão dominante no interior do partido se dá entre as alas "governista" e "oposicionista", formadas a partir da posição de adesão ou não do partido ao mandatotampão de Itamar Franco. Por fim, a ascensão da ala governista leva o partido a sua estratégia adotada nas eleições presidenciais de 2002, quando o PMDB lança pela primeira vez em sua história uma candidatura a vice-presidente numa chapa presidencial encabeçada por outro partido, no caso, aquela apresentada pelo PSDB.

Ao final desta tese apresentamos nossas considerações finais, sintetizando os achados deste estudo e retomando as discussões feitas nesta introdução para demonstrar o quanto os processos ocorridos no interior do PMDB podem servir para explicações que vão além deste objeto de estudo. Apresentamos também um breve posfácio, analisando os desdobramentos ocorridos em relação a este objeto de estudo durante a elaboração desta pesquisa. 


\section{Parte 1}

Da refundação à Constituinte:

a trajetória do PMDB de 1979 a 1988 


\title{
Capítulo 1 - Da refundação na oposição à chegada ao poder $(1979-1985)^{42}$
}

\begin{abstract}
"Quando o MDB se transforma em PMDB foi uma tentativa não muito bem sucedida, pois o MDB era uma frente política, e uma frente se caracteriza por se opor a alguma coisa, enquanto um partido se caracteriza por propor alguma coisa. (...) Então o PMDB não se constituiu na verdade enquanto partido. Acabou sendo um instrumento político, um cartório eleitoral, vinculado a interesses dos estados." Senador Roberto Requião, em entrevista ao autor.
\end{abstract}

"Acho que em 85 já é um pouco o desdobramento do que ocorreu com a fusão do PP em 82. (...) Àquela altura se percebia que era preciso fazer uma aliança. Era preciso trazer pessoas que saíam do apoio à ditadura militar, como é o caso do próprio Sarney, para fracionar a base que sustentava o governo na época e, a partir dessa divisão da base do governo, você criar um ambiente onde se pudesse combater a candidatura que inicialmente era do Mário Andreazza com o Paulo Maluf. (...) E aí quem conseguia catalisar isso era justamente Dr. Tancredo Neves; por conta dessa passagem no PP com um perfil talvez um pouco mais moderado, mais conciliador, ele trazia a segurança e a estabilidade que um momento de transição exigia." Senador Cássio Cunha Lima, em entrevista ao autor.

\subsection{Introducão}

Nascido do Movimento Democrático Brasileiro (MDB) e recentemente renomeado da mesma forma, o PMDB é um dos partidos mais longevos do período pluripartidário restabelecido no final de $1979^{43}$, o que faz do partido uma exceção num país cujos partidos têm apresentado como um de seus traços a baixa longevidade e a descontinuidade (Ferreira, 2002: 135). Nenhuma sigla teve tão longa existência mantendo sua mesma identidade dentro da legalidade em nossa história política: seu

\footnotetext{
42 Este capítulo, em suas seções centrais, incorpora parte dos achados de minha dissertação de mestrado (Mucinhato, 2015), complementados com novas informações e novas fontes de pesquisa, incluindo declarações de políticos coletadas ao longo da pesquisa para esta tese. Cabe apontar que foram os achados daquela primeira pesquisa que motivaram os desdobramentos desta, com um recorte histórico mais amplo e uma análise de mais longo prazo.

${ }^{43}$ A concessão do Registro Definitivo do Partido, da qual originou o processo de registro no 38 , foi deferida em sessão do dia 30 de junho de 1981, publicada no Diário da Justiça de 8 de agosto de 1981 (Pedido de Registro Definitivo - RGP no 38 - Resolução/TSE no 11.042) e encontra-se no Anexo 2.
} 
Manifesto de Fundação, conhecido entre seus membros como o "Livro de Fundadores do Partido", e seu primeiro esboço de Programa Partidário, chamado de "Proposta de Debate", tornaram se públicos no dia 20 de dezembro de 1979, mesmo dia em que a Lei de Reforma Partidária havia sido sancionada. Desde então o partido se manteve com forte presença na política nacional.

Considerando os seus primeiros cinco anos de existência, recorte histórico analisado neste capítulo, o PMDB foi um ator central dos eventos mais marcantes do processo de transição do regime autoritário para a democracia, mantendo-se sempre como uma das maiores bancadas do Congresso Nacional apesar das defecções que sofreu em seus quadros tanto à esquerda quanto à direita para os novos partidos que surgiram $^{44}$.

Porém, poucos anos após sua fundação o partido transformou-se internamente com a incorporação do Partido Popular, em 1982. Se por um lado a incorporação contribuiu para que a sigla apresentasse um bom desempenho eleitoral em seu primeiro teste nas urnas, por outro alterou tanto a sua correlação de forças interna quanto as composições de seus principais órgãos de direção. Fortalecido com a presença e a atuação articulada desses novos quadros, a estratégia política adotada por seu campo político mais "moderado" permitiu ao PMDB finalmente chegar ao poder, por meio da eleição indireta no Colégio Eleitoral de 1985, mesmo após ver derrotada no Congresso a campanha pelas "Diretas-Já" nos anos de 1983 e 1984. Assim, a chapa Tancredo Neves - José Sarney foi eleita em janeiro de 1985, e o PMDB elegeu naquele ano o primeiro Presidente da República civil em 21 anos, mas já enquanto um partido que se mostrava bastante diferente em relação ao seu momento de fundação.

Nesse sentido, o objetivo principal deste capítulo, em diálogo com a problematização colocada na introdução e de acordo com o recorte histórico adotado nesta tese, será analisar os primeiros cinco anos de existência do PMDB, cobrindo o período de dezembro de 1979 a janeiro de 1985. A definição deste recorte se deu pelo fato de assim ser incluída a primeira transformação significativa na correlação de forças interna dos principais órgãos de direção do partido.

Este primeiro capítulo, para além desta introdução, divide-se em outras sete partes. Na próxima seção apresentaremos um breve histórico do MDB, ponto de partida fundamental para compreender os primeiros anos do PMDB. Na seção seguinte, o foco cairá sobre o processo de refundação do partido, destacando o que chamamos de "primeira onda" de evasão de quadros do PMDB. Nas duas seções seguintes, analisamos o processo de incorporação do PP pelo PMDB em 1982 e de que maneira esse evento alterou a correlação de forças interna do partido. Na seção subsequente analisamos o desempenho do partido em seu primeiro teste nas urnas, nas eleições de

\footnotetext{
${ }^{44}$ Não elaboraremos uma caracterização própria para os conceitos de "esquerda" e "direita" neste estudo, até por conta da variação no significado desses termos ao longo do tempo. Faremos uso desses conceitos de acordo com as narrativas e caracterizações feitas pelos próprios entrevistados para este estudo, assim como da conceituação elaborada pela literatura para se referir aos partidos políticos brasileiros aqui citados.
} 
1982. Em seguida, trataremos da formação do bloco "Unidade" e da mudança no equilíbrio de forças interno no partido após a realização da sua $3^{\mathrm{a}}$ Convenção Nacional, um novo turning point para a sua história. E por fim, na última seção, apresentamos uma síntese deste capítulo.

\subsection{Breve histórico do MDB (1966-1979)}

Para uma compreensão mais clara sobre o ponto de partida adotado nesta tese para o estudo do PMDB, cabe aqui retroceder um pouco na história para uma breve retrospectiva sobre o seu antecessor, o MDB. Uma análise mais pormenorizada desse partido, fundado ainda nos primeiros anos do regime militar e que atuou como um agregador, dentro da institucionalidade permitida, de todos os matizes da oposição à ditadura permite a nós compreendermos o que era o PMDB no momento de sua formação inicial ${ }^{45}$.

Após a deflagração do golpe civil-militar de 1964, apesar de todas as cassações e prisões, o regime inicialmente manteve o sistema partidário tal como ele se encontrava naquele momento. Entretanto, após vitórias da oposição em cinco estados nas eleições de 1965 (com destaque para o cargo de governador de estado em dois estados-chave, Minas Gerais e Guanabara - atual cidade do Rio de Janeiro) ${ }^{46}$ parte dos militares atribuiu a conjuntura de crise política à vigência de um sistema multipartidário (Skidmore, 2004: 106). A resposta dos militares então foi a decretação do Ato Institucional $\mathrm{n}^{\circ} 2$ (AI-2, de outubro de 1965) e posteriormente do Ato Complementar $\mathrm{n}^{\circ}$ 4 (AC-4, em novembro do mesmo ano ${ }^{47}$, abolindo todos os partidos políticos existentes no Brasil e estipulando as regras para a formação de novas agremiações. De acordo com a nova legislação, exigia-se um mínimo de 120 deputados e 20 senadores para a formação de novas organizações, o que, de acordo com o tamanho do Congresso Nacional naquele momento (composto por 409 deputados e 66 senadores), permitiria a fundação de três novos partidos políticos. Na prática, o que se deu foi a formação de apenas dois partidos $^{48}$, que por uma exigência da legislação não poderiam adotar $\mathrm{o}$ rótulo de "partido": o partido de sustentação do governo, a ARENA (Aliança

\footnotetext{
${ }^{45}$ Não cabe aqui fazermos uma análise de todos os aspectos que marcaram a trajetória do MDB. Por isso nossa análise nesta seção será focada apenas naquilo que contribui para nossa reflexão posterior sobre o PMDB. Para uma história mais pormenorizada do partido ver Kinzo (1988), Motta (1997) e Melhem (1998).

${ }^{46}$ Os dados completos a respeito das eleições de 1965 encontram-se disponíveis no link http://bd.camara.leg.br/bd/handle/bdcamara/13036, consultado em 22/09/2016.

47 A íntegra dos Atos Institucionais encontra-se disponível no link http://www4.planalto.gov.br/legislacao/legislacao-historica/atos-institucionais, consultado em 05/09/2016.

48 Para um relato sobre os bastidores do debate dentro do governo em torno da criação das novas agremiações ver Viana Filho (1975: 369-373) disponível online na biblioteca do Senado em http://www2.senado.leg.br/bdsf/item/id/98665 consultado em 22/05/2018.
} 
Renovadora Nacional), e o partido que congregava todos os matizes de oposição ao regime, o MDB (Movimento Democrático Brasileiro) ${ }^{49}$.

Como apontou Kinzo (1988: 31-32), em nível nacional a distribuição de forças nos dois novos partidos que surgiram a partir de então não se deu em torno de clivagens claras. Como se pode ver na tabela abaixo, a filiação à ARENA ou ao MDB não resultou de uma cisão claramente definida entre os partidos que existiam anteriormente, com os ex-filiados a partidos conservadores de um lado e os provenientes de partidos reformistas e trabalhistas de outro. Udenistas, petebistas e pessedistas, membros dos três principais partidos do período anterior, se distribuíram pelos dois partidos recémformados levando a uma diversidade de origens partidárias que caracteriza os dois partidos no seu momento de fundação ${ }^{50}$.

\section{Tabela 6. Filiação ao MDB e à ARENA dos membros dos antigos partidos na Câmara dos Deputados}

\begin{tabular}{lccc}
\hline & \multicolumn{2}{c}{ Novos partidos } & Total \\
\hline Partidos dissolvidos & ARENA & MDB & N \\
Conservadores & $N$ & $N$ & 95 \\
UDN & 86 & 9 & 121 \\
PSD & 78 & 43 & 20 \\
PSP & 18 & 2 & 4 \\
PR & 4 & - & 3 \\
PL & 3 & - & 5 \\
PRP & 5 & - & \\
Trabalhistas/ & & & \\
Reformistas & & & 116 \\
PTB & 38 & 78 & 19 \\
PDC & 13 & 6 & 12 \\
PTN & 8 & 4 & 2 \\
PST & 2 & & 4 \\
PRT & 2 & 2 & 3 \\
MTR & - & 3 & 2 \\
PSB & - & 2 & 3 \\
Não filiados & - & - & 409 \\
\hline Total & 257 & 149 & \\
\hline Fol Ko & & & \\
\hline
\end{tabular}

Fonte: Kinzo (1988: 32)

\footnotetext{
49 Para uma análise do funcionamento do sistema bipartidário, ver Fleischer (1980), entre outros. Para uma história mais detalhada da ARENA ver Grinberg (2009) e Manffré (2014). Sobre o MDB consultar as obras já citadas.

50 Porém, como apontou Madeira (2006: 84) essa distribuição acabou ocorrendo de maneira mais clara quando observamos alguns estados em específico. No Rio Grande do Sul (Trindade, 1981) e Ceará (Bonavides, 1968), por exemplo, o MDB é formado pelos remanescentes do trabalhismo, enquanto a ARENA é formada pelos partidos que até então compunham o chamado "anti-PTB" (PSD e UDN principalmente). No entanto, em vários estados esse fenômeno não se repetiu, como na Bahia onde parte significativa dos deputados federais trabalhistas acaba aderindo à ARENA enquanto o MDB é formado principalmente por lideranças do extinto PSD baiano.
} 
Assim, a principal característica dos dois partidos então criados era a confluência das mais variadas tendências em seu interior (idem: 32). No caso do MDB, sempre visto pela literatura como uma "frente oposicionista" à ditadura durante toda a sua existência, havia em seu interior elementos e grupos de um amplo espectro ideológico (idem: 55). Grosso modo, tanto para Melhem (idem: 88) quanto para Kinzo (1988: 57) os setores que compunham o interior do MDB eram agrupados em torno de duas grandes alas: os "autênticos" e os "moderados" 51 . De fato, como dito, essa divisão se dava apenas grosso modo.

No interior do campo autêntico do MDB, que tende a ser visto como aquele onde se agrupavam os políticos com posturas mais radicais no combate ao regime militar e que imprimiam um tom mais incisivo à sua atuação parlamentar, encontravam-se tanto militantes ligados aos partidos políticos que se encontravam na clandestinidade (no caso, o PCB - desde a fundação do MDB um apoiador do partido; o PCdoB - a partir de 1974, após abandonar a estratégia da luta armada; e o MR-8 - a partir de 1978 - Kinzo, 1988), quanto havia também políticos do campo da esquerda mas que não pertenciam a nenhuma organização clandestina. Por sua vez, no campo dos moderados encontravamse desde liberais e democratas-cristãos (grupos regionalmente fortes no MDB do estado de São Paulo, por exemplo) quanto políticos com perfil mais conservador, que se encontravam no MDB por conveniência, unicamente para fazer oposição aos seus arquiinimigos que haviam se apressado em se filiar à ARENA (idem: 56) ${ }^{52}$ e que eram chamados de maneira pejorativa de "adesistas" (pelo fato de constantemente votarem de acordo com a orientação do regime militar, apesar de estarem no partido de oposição).

Assim, o grupo de parlamentares que fundou o partido e que permaneceu no seu interior compondo seus órgãos de direção ao longo do Regime Militar era bastante heterogêneo, e estes poderiam estar momentânea ou definitivamente posicionados na oposição (por razões pessoais, ideológicas, históricas, ocasionais, etc.), apresentando trajetórias políticas diversificadas (por vezes conflitantes) e diferentes concepções de oposicionismo, algumas beirando o adesismo, outras, ao contrário, pressionando por uma oposição radical (Melhem, 1998: 70-71). Tais características são de extrema importância para uma análise mais detida a respeito dos grupos que se transferem do MDB para o PMDB após uma nova lei de reforma partidária promulgada pelo Regime em 1979, assim como para o estudo a respeito dos grupos que optam por não permanecer no PMDB e fundar (ou participar da fundação) de novas organizações partidárias.

\subsection{O processo de refundação do MDB: surge o PMDB (1979-1980)}

\footnotetext{
${ }^{51}$ Sobre os autênticos, ver Nader (1998).

${ }^{52}$ Em entrevista ao autor, Pedro Simon também confirma a existência de filiados ao MDB que se filiaram ao partido apenas por não terem espaço na ARENA.
} 
"A gente tinha, no Brasil, dois partidos, que eram o MDB e a ARENA. Como a ARENA vinha perdendo terreno eleitoral, a decisão do governo foi exigir a obrigatoriedade da colocação, na sigla do partido, da palavra 'Partido', do ' $P$ ' à frente do nome. Então nós recriamos o PMDB e mantivemos as três letras da sigla e só colocamos o ' $P$ ' na frente. Isso foi feito através de uma ata inicial de fundação do partido. Foi uma refundação, como se fosse um partido novo, que exigia a participação $e$ assinatura de um determinado número de parlamentares." Senador Airton Sandoval, em entrevista ao autor.

O período de formação do $\mathrm{PMDB}$, ou de "refundação do MDB", compreende o seu primeiro ano de funcionamento legal após a sanção da Reforma Partidária de 1979. A Reforma, sancionada em 20 de dezembro de 1979 pelo então presidente João Baptista Figueiredo, deu origem à Lei $n^{\circ} 6.767^{53}$, que extinguiu o bipartidarismo e os partidos que haviam sido criados com base no Ato Complementar $n^{\circ} 4$ (MDB e ARENA) ${ }^{54}$ assim como estabeleceu uma nova legislação para a formação de partidos políticos.

Após terem avaliado que o sistema bipartidário não mais funcionava de maneira vantajosa ao Regime Militar, o objetivo de fundo dos estrategistas do regime com a aprovação dessa medida era fragmentar a oposição parlamentar, provocando a desintegração do MDB, mas sem fragmentar seu partido de sustentação no Poder Legislativo, a ARENA (Kinzo, 1988: 205), até então a única aglutinadora da direita partidária no país (Mainwaring, Meneguelllo, Power, 2000: 24). A expectativa por parte dos militares era que se mantivesse intacta sua base de sustentação parlamentar e que se garantisse dessa maneira uma maioria que lhe permitiria controlar o Poder Legislativo por mais tempo durante o processo de transição "lenta, gradual e segura" para uma democracia. Teve início a partir de então um processo de realinhamento de toda a classe política nacional, que incluiu também muitas das lideranças políticas anistiadas poucos meses antes por meio da Lei de Anistia e que eram figuras de expressão na política nacional pré-64 (Mezarobba, 2003; 2006), forçando os políticos a se acomodarem em um cenário partidário mais liberalizante que emergia ${ }^{55}$.

Naquela nova conjuntura, apesar das tentativas de alguns líderes emedebistas de manter a oposição unida, os quadros que formavam o MDB já se encontravam divididos entre aqueles que defendiam a abertura do leque partidário e os que estavam determinados a dar continuidade ao partido como única frente oposicionista (Kinzo,

\footnotetext{
${ }^{53}$ A lei em sua íntegra encontra-se disponível no link www2.camara.leg.br/legin/fed/lei/1970-1979/lei6767-20-dezembro-1979-357280-publicacaooriginal-1-pl.html acessado em 15/02/2016.

54 Resolução Eleitoral do TSE $\mathrm{n}^{\circ}$ 10.786, de 15/02/1980, disponível online no link http://www.tse.jus.br/hotSites/registro_partidario/mdb/arquivos/Cancelamento.pdf , acessado em $11 / 07 / 2018$.

55 Segundo Miyamoto (1980: 130) ARENA e MDB sempre foram considerados insuficientes para abrigar todas as tendências políticas existentes, o que reforçava a visão do Regime de que o MDB se dividiria.
} 
1988: 207). Assim, com a aprovação da nova lei, os políticos emedebistas não se transferiram em sua totalidade para seu principal sucedâneo, o PMDB, passando a construir outros partidos políticos que surgiram oficialmente após a sanção da nova lei (Mucinhato, 2015: 40) ${ }^{56}$. Evidência nesse sentido foi o "Manifesto dos Fundadores do PMDB à nação", documento no qual o novo partido reivindicava para si o legado do extinto MDB e que foi assinado por 20 senadores, 108 deputados federais e 22 "notáveis", considerados figuras públicas de relevo e intelectuais. Ou seja, segundo esses dados, dos 189 deputados que compunham o MDB no momento de sua extinção, são 108 os que assinam o Livro do $\mathrm{PMDB}^{57}$.

Nesse sentido, apesar de o PMDB em sua gênese ter conseguido manter uma forte base de apoio parlamentar herdada do MDB, e a despeito da similaridade entre as siglas, o PMDB em sua fundação não é um sinônimo do MDB em seu momento de extinção ${ }^{58}$. O "novo" partido tratava-se na verdade de um recorte do seu antecessor, e cumpria a exigência imposta pelo Regime de que todas as siglas deveriam ter a palavra "Partido" em seu nome ${ }^{59}$. Assim, a estratégia do Regime Militar teve sucesso e os quadros do antigo MDB se distribuíram por todos os partidos políticos recém-fundados na passagem do bipartidarismo para o pluripartidarismo.

Ao comentar sobre esse aspecto, o Senador Cássio Cunha Lima (PB) em entrevista ao autor deixou claro o quanto o PMDB fora formado por um recorte daquilo que havia sido o MDB:

"O MDB foi, como o próprio nome dizia, um movimento. Era o Movimento Democrático Brasileiro e esse movimento congregava todas as foças políticas que resistiam contra a ditadura. A ARENA de um lado, $M D B$ de outro, e aqueles que tinham esse valor democrático militavam no MDB. Quando surgiu a oportunidade do pluripartidarismo, aí essas diversas facções, digamos assim, ou esses diversos agrupamentos que participavam do movimento, constituíram outros partidos e uma parte ficou com o PMDB. O que remanesceu constituiu um

\footnotetext{
${ }^{56}$ Para uma cronologia do debate sobre a reformulação partidária de 1978 até meados de 1979, assim como para uma análise a respeito da criação de diferentes partidos, ver Kinzo (1980).

${ }^{57}$ No Anexo 1 encontra-se uma reprodução do documento em sua íntegra, retirada da primeira edição da Revista do PMDB publicada em Julho de 1981, p. 11, e que havia sido publicado originalmente no Diário Oficial da União no dia 30/01/1980, contendo a lista de todos os seus signatários, parlamentares e não parlamentares.

${ }^{58} \mathrm{O}$ mesmo ponto de vista foi compartilhado por Benevides (1986). Do ponto de vista do próprio partido, a publicação Revista do Cinquentenário do PMDB Catarinense - Democracia 1966-2016: essa chama nunca se apaga é uma de suas poucas publicações oficiais a reconhecer esse aspecto da sua história, mas alguns parlamentares, em entrevista ao autor, também reproduziram essa visão.

${ }^{59}$ A ideia de criar um partido que seguisse com a sigla MDB acrescentada da letra " $P$ " em seu início foi creditada a diferentes personagens da história do partido a depender da fonte consultada. Alguns dos entrevistados para este estudo, como o ex-deputado federal Marcelo Barbieri (SP), creditam a ideia a Ulysses Guimarães. Porém a versão mais acertada parece ser a que atribui a ideia a Jorge Singh, presidente do Diretório Municipal do MDB de Guarulhos (Yazbeck, 2011). A própria página oficial do PMDB trazia essa versão anteriormente, antes de o partido ser renomeado mais uma vez para MDB.
} 
partido, não mais um movimento amplo como o era na época da ditadura." (grifo nosso)

Como resultado desse processo de migrações partidárias e mudanças na legislação, seis partidos políticos foram fundados, listados pela ordem de tamanho de suas respectivas bancadas no Congresso Nacional: o Partido Democrático Social (PDS, sucedâneo da ARENA e conhecido no jargão jornalístico e popular como "Arenão"60), o Partido do Movimento Democrático Brasileiro (PMDB), o Partido Popular (PP), os dois Partidos Trabalhistas Brasileiros (o PTB brizolista, posteriormente renomeado para Partido Democrático Trabalhista, "PDT", e liderado por Leonel Brizola, e o PTB varguista, liderado por Ivete Vargas, que venceu a disputa pela sigla no Tribunal Superior Eleitoral) e o Partido dos Trabalhadores (PT) ${ }^{61}$.

A composição partidária do Congresso após a fundação destas siglas nos permite visualizar a dispersão dos quadros emedebistas pelo espectro político-partidário assim como posteriormente analisar qual passa a ser a coalizão dominante no interior do recém-fundado PMDB. O PDS havia se tornado o novo partido governista, demonstrando o sucesso da estratégia do governo em manter a maioria de seus parlamentares articulados em apenas uma legenda (Mucinhato, 2015: 41). Em se tratando da Câmara dos Deputados, os dados apresentados na tabela abaixo nos mostram que o partido fora formado majoritariamente por ex-arenistas, que correspondiam a $90 \%$ dos seus 215 deputados federais fundadores, com o restante sendo composto por ex-emedebistas. O PMDB por sua vez passava a ser, a partir de então, com o surgimento de outros partidos de oposição, o principal partido oposicionista ao Regime dentro do Congresso. De maneira oposta ao PDS, o partido fora fundado majoritariamente por ex-emedebistas, que compunham $95 \%$ dos seus 115 deputados federais. Enquanto isso, o PP seria o partido com a terceira maior bancada da Câmara dos Deputados. Porém, diferentemente de PMDB e PDS, o partido era aquele que apresentava em sua formação uma composição equilibrada entre os dois partidos que marcaram o período de 1966 a 1979 (idem: 42), reflexo da sua estratégia de aglutinar o centro do espectro político-partidário, nas palavras do Senador Tancredo Neves (MG), um de seus principais fundadores ${ }^{62}$. Na Câmara dos Deputados sua bancada fora fundada por 69 deputados, dos quais 59\% eram ex-emedebistas e $41 \%$ ex-arenistas.

\footnotetext{
${ }^{60}$ Os partidos sucedâneos da ARENA, assim como os políticos que estiveram a ela filiados, procuraram se descolar de seu passado de apoiadores do Regime Militar (Grinberg, 2009: 25). Nesse sentido, no momento de escolha de uma nova sigla para o partido governista, a ideia principal que norteava os arenistas era escolher uma sigla que não tivesse qualquer semelhança com a ARENA, estigmatizada como o "partido do arbítrio" (idem: 230), e que não reproduzisse nenhuma das siglas extintas em 1965. Cabe apontar aqui que boa parte dos políticos do PMDB que identificamos terem sido filiados à ARENA tenta ocultar isso ao máximo em suas biografias, o que reforça o argumento de Grinberg e coloca mais uma dificuldade que foi enfrentada por esta pesquisa.

${ }^{61}$ Sobre o processo de formação do PP ver Mucinhato (2015). Sobre a formação do PT ver Keck (1991). Com relação aos outros partidos citados não foi encontrado na literatura de ciência política qualquer estudo que tratasse especificamente do momento de sua formação. Apenas Abaide (1990) se dedicou a fazer algumas colocações sobre a fundação desses partidos.

62 Jornal do PMDB SP, agosto de 1984, p. 12.
} 
Tabela 7. Composição da Câmara dos Deputados após a Reforma Partidária de 1979

\begin{tabular}{l|cc|cc|c}
\hline \multicolumn{5}{c}{ Partidos dissolvidos } \\
\hline \multirow{2}{*}{ Novos partidos } & $\mathrm{N}$ & $\%$ do total & $\mathrm{N}$ & $\%$ do total & $\mathrm{N}$ \\
\hline PDS & 193 & $89,8 \%$ & 22 & $10,2 \%$ & 215 \\
\hline PMDB & 6 & $5,2 \%$ & 109 & $94,8 \%$ & 115 \\
\hline PP & 28 & $40,6 \%$ & 41 & $59,4 \%$ & 69 \\
PTB & 3 & $75 \%$ & 1 & $25 \%$ & 4 \\
PDT & 0 & $0 \%$ & 10 & $100 \%$ & 10 \\
PT & 0 & $0 \%$ & 5 & $100 \%$ & 5 \\
Indecisos & 1 & & 1 & & \\
\hline Total & 231 & & 189 & 420 \\
\hline
\end{tabular}

Fonte: Schmitt (2000: 51)

Os dados apresentados na tabela abaixo em relação à nova composição partidária do Senado Federal vão no mesmo sentido da Câmara dos Deputados. No PDS, 97\% dos seus 36 Senadores fundadores eram ex-arenistas, com o restante sendo composto por ex-emedebistas. O PMDB, assim como na Câmara dos Deputados, fora fundado majoritariamente por ex-emedebistas, que compunham $91 \%$ dos seus 22 senadores. $\mathrm{O}$ PP, tal como na Câmara dos Deputados, apresentava uma composição equilibrada entre ex-arenistas e ex-emedebistas, cada qual compondo 50\% dos seus quadros naquela Casa.

Tabela 8. Composição do Senado Federal após a Reforma Partidária de 1979

\begin{tabular}{|c|c|c|c|c|c|}
\hline \multicolumn{6}{|c|}{ Partidos dissolvidos } \\
\hline & \multicolumn{2}{|c|}{ ARENA } & \multicolumn{2}{|c|}{ MDB } & Total \\
\hline Novos partidos & $\mathbf{N}$ & $\%$ do total & $\mathbf{N}$ & $\%$ do total & \\
\hline PDS & 35 & $97 \%$ & 1 & $3 \%$ & 36 \\
\hline PMDB & 2 & $9 \%$ & 20 & $91 \%$ & 22 \\
\hline PP & 4 & $50 \%$ & 4 & $50 \%$ & 8 \\
\hline S/ Partido & & & 1 & & 1 \\
\hline Total & 41 & & 26 & & 67 \\
\hline
\end{tabular}

Fonte: Schmitt (2000: 51)

Como os dados das tabelas anteriores nos mostram, ocorreu uma dispersão dos parlamentares que faziam parte do campo de oposição ao regime militar dentro do Congresso Nacional, que anteriormente se articulavam exclusivamente no MDB, fazendo com que a estratégia do Regime Militar ao aprovar uma nova legislação partidária tivesse sucesso. Uma parcela significativa dos ex-emedebistas (86 parlamentares no total, incluindo deputados federais e senadores) não se transferiram 
para o principal sucedâneo do partido, o PMDB, o que constitui aquilo que chamamos de "primeira onda" de evasão de quadros do partido.

Dentre esses parlamentares, 45 filiaram-se ao PP (41 deputados e 4 senadores), seguindo sobretudo a liderança de Tancredo Neves, e fazendo com que a sigla se tornasse o principal desaguadouro daqueles políticos que faziam parte do MDB mas que optaram por não se filiar ao PMDB. Para além destes, outros 23 parlamentares (22 deputados e 1 senador) migraram para o novo partido governista, o PDS, muitos dos quais seguindo a liderança do pedessista Paulo Maluf (SP). Estes parlamentares representavam os já mencionados "adesistas" do extinto MDB, rótulo pejorativo atribuído a eles pelo fato de terem aderido oficialmente ao regime militar em seus últimos anos no MDB, demonstrando estarem naquele partido por mera ocasião (Kinzo, 1988: 56). Por sua vez, as migrações para os outros três partidos que surgiam, PT, PTB e PDT, foram menores em relação às perdas para PP e PDS. Foram apenas 16 parlamentares e não houve qualquer senador que tenha se filiado a esses partidos.

Sobre esse período, o Senador Garibaldi Alves (PMDB-RN) narrou em entrevista ao autor como viu aquele processo:

"O PMDB perdeu integrantes e uma certa substância, porque o PMDB estava no centro de um arco de alianças em função da redemocratização do país, mas quando isso realmente se concretizou, e os partidos puderam ter uma vida democrática, aí aconteceu essa fuga, que foi assimilada pelo próprio partido, que sabia que não poderia ter os mesmos integrantes que tinha antes."

Considerando então essas evasões do MDB, o PMDB então representava um recorte daquilo que havia sido o MDB no momento de sua extinção. A sigla surgia assim com uma composição de centro-esquerda (Kinzo, 1988: 210; Figueiredo, 2009: 88), perdendo muito menos quadros para partidos mais identificados à sua esquerda, no caso o $\mathrm{PT}$ e o $\mathrm{PDT}^{63}$, que receberam apenas 15 parlamentares emedebistas, do que à sua direita $^{64}$ nesse novo sistema partidário. O Senador Raimundo Lira (PMDB-PB), em entrevista concedida para este estudo, reforça essa perspectiva:

63 O PTB, articulado por Ivete Vargas, é classificado por Power (1997: 76) naquele período como "um
pequeno partido à direita do centro" (tradução nossa). PT e PDT eram comumente classificados como
partidos de "esquerda" (Tarouco e Madeira, 2013). No que se refere às evasões de emedebistas rumo
ao PT elas se deram na passagem de 1979 para 1980 pela gradativa aproximação entre parlamentares
auto-identificados com a "Tendência Popular" do MDB (a ser explicada posteriormente) com um grupo
que contribuía para a formação do PT denominado "Forças da Base" (Keck, 1991: 112-113) devido a
certa afinidade ideológica entre os grupos. Sobre esse processo ver Melhem e Russo (2004: 239-240) e
Mucinhato (2015: 58-60).
64 Este achado vai na contramão do que apontava parte da literatura a respeito do PMDB sobre seus
primeiros anos de formação (como Melhem, 1998: 137), que muitas vezes ignora o fato de que nos
primeiros anos do partido (até a incorporação do PP) a maior parte das defecções foi à direita, e não à
esquerda. Porém, é importante destacar que em alguns estados específicos o impacto maior pode de 
"No momento em que ele, por uma exigência do governo militar, os partidos passaram a ter a letra ' $P$ ', de 'partido', no que deixou de ser movimento para virar partido, então as correntes começaram a encontrar seu próprio caminho. Cada corrente ideológica passou a encontrar seu próprio caminho. Então o PMDB passa a ser um partido de centro-esquerda, onde tinha o maior leque de agentes políticos da República brasileira."

Entretanto, apesar de minoritárias, sob o ponto de vista de alguns políticos essas saídas à esquerda podem ter representado o primeiro marco de uma transformação na identidade do PMDB:

“(...) à medida que abriu o quadro partidário, é óbvio que saíram quadros que foram fundar o PT que faziam política dentro do PMDB. O próprio Brizola, também articulando, criou pelo PDT. Houve perda de substância política e ideológica do $P M D B$ em relação à doutrina expressa pelo partido pelo programa partidário. Eu acho que isso nunca mais se recuperou." Deputado Saraiva Felipe (MG), em entrevista ao autor.

A composição da primeira Comissão Executiva Nacional eleita pela sigla também é uma evidência que reforça a narrativa de que o PMDB não é sinônimo do MDB. Escolhida na sua primeira Convenção Nacional, em dezembro de 1980, momento no qual o partido aprovou também seus primeiros Estatuto e Programa Partidários, a Comissão eleita pelo Diretório Nacional da sigla era formada por 13 membros, juntamente com os líderes da bancada do partido na Câmara dos Deputados e no Senado Federal. Dentre seus 13 membros, 12 haviam sido filiados ao MDB e apenas um havia tido uma passagem pela ARENA, o Senador Teotônio Vilela (AL). Ademais, a correlação de forças entre os próprios ex-emedebistas também havia se alterado significativamente. Se na última CEN do MDB antes de sua extinção ela era formada por quatro autênticos e cinco moderados, a primeira composição da CEN do PMDB era formada por pelo menos sete parlamentares autênticos e apenas um moderado (Mucinhato 2015: 64) ${ }^{65}$. Cabe destacar ainda que uma mudança importante ocorrera no cargo de Secretário-Geral: enquanto no MDB ao final de sua existência a posição era ocupada por um moderado (Thales Ramalho - PE), na primeira CEN do PMDB ele passaria a ser exercido por um "autêntico histórico" (Pedro Simon - RS).

Outro aspecto que reforça o argumento da literatura a respeito do caráter de centro-esquerda do PMDB no momento de sua fundação são as tendências internas do

fato ter sido diferente, com mais evasões à esquerda do que à direita. É o que sugere a entrevista ao autor concedida por João Carlos Brum Torres, quadro histórico do partido no Rio Grande do Sul.

${ }^{65}$ No Anexo 3 encontra-se a composição da última Comissão Executiva Nacional do MDB, a primeira - e única - composição da Comissão Executiva Nacional do PP, assim como a composição de todas as Comissões Executivas Nacionais do PMDB incluídas dentro do recorte histórico deste estudo. 
MDB que, ao se aliarem, transferem-se para ele, com destaque para a manutenção de um bloco à esquerda no seu interior que disputa os rumos do partido ${ }^{66}$. Além do bloco dos "moderados" e "adesistas", citados aqui anteriormente, que ocupavam o campo mais à direita dentro do MDB e que em grande parte migraram para PP e PDS, identificamos outros quatro grupos distintos que se transferiram do MDB para o PMDB: "autênticos históricos", "Tendência Popular" e "esquerda independente", que se autolocalizavam no campo à esquerda; e os "não-alinhados", ao centro.

Como apontado em trabalho anterior (Mucinhato, 2015: 45) as três primeiras subunidades citadas formam o grupo que é caracterizado grosso modo pela literatura como "os autênticos",67. O grupo dos autênticos históricos era composto por políticos que não pertenciam às organizações clandestinas e que em sua maioria haviam sido eleitos pelo MDB em 1970 e 1974. Ainda que dentro da institucionalidade permitida, esses políticos atuavam de maneira mais radicalizada no combate à ditadura em comparação aos moderados desde que se formou pela primeira vez o "grupo dos autênticos" no início da década de 1970. Uma evidência nesse sentido é o caso de quando essa ala se absteve na votação no Colégio Eleitoral de 1974 que teve Ulysses Guimarães como "anti-candidato" do $\mathrm{MDB}^{68}$.

Por sua vez, a "Tendência" era formada por um grupo de políticos que atuava de maneira mais articulada do que os "históricos". Este subgrupo havia se formado poucos meses antes da extinção do MDB e se transferiu inteiro para o PMDB, definindo-se como uma "corrente de opinião interna ao partido" 69 , que procurava atuar de maneira coletiva para aproximar a sigla dos movimentos sociais e das lutas populares. De maneira geral, os seus partidários declaravam que buscariam abrir espaço para a representação popular dentro dos órgãos de decisão do partido e do Parlamento, com o intuito de construir um "partido de massa"70 e, devido ao seu posicionamento, o grupo

\footnotetext{
${ }^{66}$ Neste estudo não faremos uma diferenciação quanto aos diferentes conceitos possíveis de serem usados para definir as subunidades internas que formam o PMDB. Reproduziremos apenas os termos utilizados por essas mesmas subunidades. Para o debate acerca das diferentes tipologias passíveis de serem utilizadas, ver Panebianco (2005: 75, 380-386) e Boucek (2009).

${ }^{67}$ Como já apontava Melhem (1998: 88) havia no MDB uma disputa interna que ia além dos autênticos e dos moderados, e esse agrupamento poderia ser feito apenas a grosso modo, mesmo argumento válido em relação ao PMDB no seu período de formação.

${ }^{68}$ Como exemplos de políticos "autênticos históricos" naquele momento podemos citar o ex-Senador Pedro Simon (RS) - entrevistado nesta pesquisa - e os Deputados Paes de Andrade (CE, futuro presidente do partido) e Marcos Freire (PE). Sobre a origem dos autênticos no MDB, ver Nader (1998).

69 Editorial da Folha de S. Paulo "Por que a Tendência Popular?"- 17/02/1980, escrito por um dos principais articuladores e porta-voz da Tendência o ex-deputado federal Almino Affonso, também exMinistro do Trabalho do governo João Goulart (Dicionário Histórico Biográfico Brasileiro do Centro de Pesquisa e Documentação de História Contemporânea do Brasil, CPDOC/FGV, verbete "Almino Affonso"). O ex-político, infelizmente, faz parte daqueles que se negaram a conceder entrevista para este estudo, o que nos fez recorrer à sua entrevista para o "Programa Memória Política", da TV Câmara, em 13/11/2001 (data da Entrevista: 23/08/2007). Entrevistadoras: Ana Maria Lopes de Almeida, Ivan Santos e Tarcísio Holanda. Link para a transcrição da entrevista: http://www2.camara.leg.br/acamara/conheca/historiaoral/Memoria\%20Politica/Depoimentos/copy_of_almino-affonso/texto.html consultado em 13/03/2018.

${ }^{70}$ Editorial da Folha de S. Paulo de 02/03/1980, "Um partido de massas", também escrito por Almino Affonso; Jornal da República, 27/12/1979; e Revista do PMDB, ano 1, n 1, p. 42.
} 
muitas vezes era caracterizado por políticos de outras correntes como a "esquerda radical" dentro do $\mathrm{PMDB}^{71}$.

A Tendência Popular era formada pela "esquerda independente" (políticos não filiados a qualquer outro partido político) e por militantes de outros grupos políticos organizados, que atuavam na clandestinidade e que haviam decidido atuar politicamente no interior do PMDB (Keck, 1991: 114; Santos, 2011: 9; Cardoso, 1984) ${ }^{72}$, a saber: o Partido Comunista Brasileiro (PCB) ${ }^{73}$, o Movimento Revolucionário 8 de outubro (MR8 - dissidência interna do $\mathrm{PCB})^{74}$ e o Partido Comunista do Brasil (PCdoB - também um racha do Partido Comunista). A aliança dessas três organizações com setores do PMDB nesse período deve-se à sua concepção "etapista" da revolução brasileira, por meio da qual via-se como necessária uma aliança com diferentes setores da sociedade para garantir a transição democrática, primeira etapa necessária para se chegar ao socialismo (Silva, 1987: 155). Com relação ao PCdoB em específico, essa "infiltração" também era parte da estratégia do partido de lutar pelas liberdades políticas e, principalmente, pelo direito à livre organização (Santos, 2011: 10), argumento que também provavelmente se aplicava ao caso do PCB.

Tanto PCB quanto PCdoB permaneceram dentro do PMDB após o restabelecimento do pluripartidarismo devido à dificuldade imposta pela legislação para organizar um partido novo (além, é claro, do rechaço do Regime Militar aos

\footnotetext{
${ }^{71}$ Declaração do então Senador Itamar Franco (MG) à Folha de S. Paulo - 26/12/1979.

${ }^{72}$ Alguns políticos do PMDB que declaravam compor a Tendência Popular no mês de janeiro de 1980 são: os deputados Elquisson Soares e Francisco Pinto, ambos da BA; deputados Airton Soares, Aurélio Peres, Otacilio Almeida e o suplente de senador Fernando Henrique Cardoso, todos de SP; deputado Freitas Diniz, do MA; deputados Edgar Amorim e Tarcisio Delgado, de MG; deputado Osvaldo Macedo, do PR; deputado Aloísio Bezerra, do AC; deputada Cristina Tavares e deputado Fernando Coelho de PE; deputado Iranildo Pereira, do CE; deputado Adhemar Santillo, de GO. Nos primeiros meses de pluripartidarismo parte destes políticos flertam com o processo de formação do futuro Partido dos Trabalhadores, como Airton Soares e Freitas Diniz, mas a maioria se mantém ligada ao PMDB. Marcelo Barbieri, na época atuando na União Nacional dos Estudantes (UNE) e um dos entrevistados nesta pesquisa, fazia parte desse bloco.

${ }^{73}$ Desde seu clandestino VI Congresso em dezembro de 1967 o PCB havia definido a necessidade da criação de uma ampla frente, cujo objetivo era lutar pelas liberdades democráticas e três palavras de ordem: anistia, Constituinte, e eleições diretas (Graça, 2013: 35).

${ }^{74}$ O Movimento Revolucionário 8 de Outubro (MR-8) surge de uma dissidência interna do PCB, ainda na conjuntura pré-1964. Em seu primeiro momento, participou ativamente das ações da luta armada, mas com o aumento da repressão a partir de 1969, sucedem-se os exílios e os "desaparecimentos políticos", colocando o grupo em uma situação crítica. Com a volta do exílio no Chile de parte de sua cúpula, a organização se rearticula pondo fim às ações armadas e optando pelo trabalho de base em sindicatos operários e militando em ações populares, se fortalecendo como ator pelas lutas democráticas. Após a anistia, em 1979, realiza de forma clandestina seu II Congresso, traçando diretrizes para o fortalecimento da "frente popular" com o MDB convertendo-se em um partido popular, com seus membros progressistas ditando as regras do bloco (Camurça e Reis Filho, 2007) . O MR-8 rompeu com o PMDB apenas em 2011 fundando um novo partido, o Partido Pátria Livre (PPL) http://www.tse.jus.br/partidos/partidos-politicos/partido-patria-livre-ppl. Ao longo de sua atuação no interior do PMDB o bloco atuou como um braço político da ala "Quercista" (Melhem, 1998: 148), o que foi confirmado por entrevistas feitas ao autor, como as de Cássio Cunha Lima e a de Heráclito Fortes, que afirmou que "o Quércia que tinha um movimento paralelo que dava muita força a ele, que era o MR-8, chamavam os 'pó-ró-popó'”".
} 
comunistas). Apenas em 1985 os dois grupos passam a ter existência legal, quando deixam o PMDB e obtêm seu registro legal pelo Tribunal Superior Eleitoral ${ }^{75}$, aspecto que será explorado no próximo capítulo.

Por fim, cabe aqui ainda citarmos o bloco dos políticos autodenominados "não alinhados", surgido a partir do Senado mas formado também por deputados federais, e que compreende um grupo que declara ser equidistante ideologicamente entre os moderados e os autênticos. Com um discurso mais liberal e sendo formado por políticos como os senadores Franco Montoro (SP), José Richa (PR) e Orestes Quércia (SP), um de seus principais porta-vozes era o senador mineiro Itamar Franco. O Senador criticava a atuação da Tendência Popular no processo de formação do partido, chegando a declarar que "os não alinhados se reuniriam para reagir à agressividade da ala da esquerda radical - Tendência Popular - que estava procurando dominar o partido"76.

Como já dito, em seu primeiro ano de funcionamento desde o restabelecimento do pluripartidarismo, uma quantidade significativa de políticos do então extinto MDB não se filiou ao PMDB. Esses políticos transferiram-se para outras agremiações em formação, de maneira mais significativa rumo ao PP e PDS, com defecções minoritárias para partidos do campo da esquerda, rumo ao PT ou o PTB brizolista (posteriormente denominado de PDT). Esse processo constituiu aquilo que chamamos de "primeira onda" de evasão de quadros do PMDB. Apesar dessas saídas, o partido manteve em seu interior no seu primeiro ano de funcionamento uma coalizão de forças nas quais se fazia presente uma significativa ala mais combativa, e que levam o PMDB a possuir a maior bancada de oposição ao Regime Militar tanto na Câmara dos Deputados quanto no Senado Federal. Esse processo teve como resultado um PMDB mais homogêneo do que o fora o MDB no momento de sua extinção (Mucinhato, 2015), com uma composição de centro-esquerda (Kinzo 1988: 210; Figueiredo 2009: 88). Porém, esse cenário começaria a mudar a partir do processo de incorporação do PP em 1982, com consequências para as estratégias que o partido passaria a adotar a partir de então no processo de transição democrática. A incorporação é o tema central da próxima seção deste capítulo.

\subsection{A incorporacão do Partido Popular (1981-1982)}

"Havia tensões, inclusive setores do governo ameaçando os que queriam ir para a fusão. Alguns que capitularam,

\footnotetext{
75 Para um amplo histórico do PCdoB durante o Regime Militar, ver Sales (2007). Para um histórico do MR-8 ver Camurça e Reis Filho (2007). Sobre o PCB ver Silva (1987). Para um histórico dos dois Partidos Comunistas e sua atuação sob as siglas MDB e PMDB ver Figueiredo (2009) e a entrevista de Roberto Freire ao Jornal do Commércio do Recife, edição do dia 6 de março de 2005, disponível online em http://www.camara.gov.br/sileg/integras/303766.pdf (acessado em 05/8/2017). Sobre o processo de formação desses partidos políticos a partir de 1985 e a evasão de quadros provenientes do PMDB para esses partidos ver o próximo capítulo.

${ }^{76}$ Folha de S. Paulo - 30/12/1979, p.4.
} 
outros que resistiram. Foi realmente um momento decisivo para a reabertura democrática." Deputado Heráclito Fortes, em entrevista ao autor.

Antes de compreendermos as consequências da incorporação do Partido Popular para a correlação de forças interna do PMDB, cabe aqui caracterizarmos brevemente aquele partido, apontando suas diferenças em relação ao PMDB e o seu perfil ideológico.

Apesar de se manter como a terceira maior bancada do Congresso durante toda a sua curta existência, o PP se extinguiu antes mesmo de ter sido testado eleitoralmente (Mucinhato, 2015: 73-74). O partido representou assim uma efêmera experiência partidária em meio ao processo de abertura política, resultante de um processo de articulação que já vinha ocorrendo antes mesmo da decretação de uma Reforma Eleitoral" $^{77}$. Seu "Programa Básico" e seu "Manifesto de Fundação" dezembro de 1979, mesma data do manifesto do PMDB, e sua extinção oficial se deu no dia 2 de março de 1982, quando o TSE reconhece seu processo de incorporação ao PMDB, pouco após o anúncio da Reforma Eleitoral conhecida como "Pacote de Novembro".

Como dito, o objetivo subjacente dos estrategistas políticos do governo Figueiredo (principalmente o então Ministro da Justiça Petrônio Portella e o Ministrochefe do Gabinete Civil Golbery do Couto e Silva) quando elaboraram e encaminharam seu anteprojeto de reforma partidária ao Congresso era dividir a oposição, que até então se mantinha reunida sob a sigla do MDB e que vinha crescendo eleitoralmente, e manter os governistas reunidos em uma só sigla, mantendo o controle do Poder Legislativo durante o processo de transição democrática. Com o restabelecimento do pluripartidarismo, o Regime articulava também o surgimento de um partido que ocupasse o campo do centro no espectro político-partidário, que atuasse como uma “oposição confiável”. O partido seria formado a partir de moderados do MDB e dissidentes da ARENA, e funcionaria como um "partido auxiliar" ao governo a nível federal, mas a nível estadual seria um forte concorrente oposicionista nas eleições de

\footnotetext{
${ }_{77}^{77}$ Revista Veja, edição 562, 13/06/1979, pp.20-21.

${ }^{78}$ De acordo com matérias publicadas nos jornais à época (Folha de S. Paulo - 21/12/1979, p. 4, e 0 Estado de S. Paulo - 22/12/1979, p. 2), o programa do PP era mais conciso e com críticas mais amenas ao Regime Militar, se comparado aos mesmos documentos emitidos pelo PMDB. A título de exemplo, são dignas de nota as diferenças no campo econômico dos dois programas, onde se percebe a maior moderação das críticas feitas pelo PP ao Regime, do que aquelas feitas pelo PMDB: enquanto o PP reivindicava a restrição do "capitalismo estatal" apenas aos setores indispensáveis, o PMDB coloca como condição fundamental para o cumprimento de seu programa a restrição do poder decisório sobre o campo econômico apenas ao Estado. No mesmo sentido, enquanto o PMDB defende unanimemente a convocação de uma Assembleia Constituinte (expressando isso em seu programa e em seu Manifesto de Fundação), no PP esse tema não é consensual. Havia quadros no partido que argumentavam preferir que o próprio Congresso reformasse a Constituição (como era o caso do Senador Tancredo Neves).
} 
1982 (Fleischer, 1988a: 77) ${ }^{79}$. Congregando dissidentes arenistas e moderados/liberais emedebistas (Trindade, 1985: 20; Lima, 2009: 42), seria possível assim criar um partido para ocupar um espaço inexistente durante a vigência do bipartidarismo ${ }^{80}$.

Ao longo do processo de reforma partidária, esse partido de centro se materializou na criação do Partido Popular (PP), caracterizado pela literatura como um partido equidistante da situação pedessista e da oposição peemedebista (Schmitt, 2000: 49), um "ponto de equilíbrio" do sistema partidário da Nova República (Silva e Delgado, 1985: 43), com uma junção de governistas e oposicionistas (Trindade, 1985: 108). O PP representava assim a agremiação das elites mais conservadoras da antiga oposição, que se agrupavam antes em torno do MDB (Keck, 1991: 108), e o primeiro "racha" na base de sustentação parlamentar do Regime Militar. Sua composição no Congresso Nacional, como visto na seção anterior, era aquela mais equilibrada entre políticos dos extintos MDB e ARENA, o que respalda as caracterizações atribuídas ao partido pela literatura.

Com relação ao seu posicionamento político-ideológico, declarações de políticos atuantes na construção do partido corroboram a visão de que o espaço que o partido procuraria ocupar no sistema político-partidário seria mesmo o centro. Na visão de Olavo Setúbal, presidente da sua seção paulista, o partido seria o "fiel da balança" 81 das futuras eleições, um "algodão entre cristais (no caso, PDS e PMDB)" 82 , "um partido de centro, que teria um diálogo à esquerda e à direita" $"$. Um partido mais moderado em relação ao PMDB, na visão do deputado Heráclito Fortes (PI) ${ }^{84}$. Já do ponto de vista de políticos que não participaram da sua construção, o PP era visto como um partido mais conservador em relação ao PMDB, pois enquanto este procurava ocupar um espaço na centro-esquerda, aquele ocupava um espaço mais ao centro, ou na centro-direita.

As declarações do Senador Cássio Cunha Lima (PB) deixam claras as diferenças entre os dois partidos naquele momento:

“(...) ai surgiu o PP, que era o Partido Popular, acho que na época era essa a nomenclatura, o ' $P$ ' não era de 'progressista', e sim 'popular', que mais adiante veio a se fundir com o próprio PMDB (...). Houve uma fusão. Era um movimento, acho que, naquela altura, liderado por Tancredo Neves. Quando surgiu a perspectiva de disputa no Colégio Eleitoral, aí novamente o PP, que tinha uma visão mais conservadora do que o PMDB... O PMDB

\footnotetext{
${ }^{79}$ Com vistas às eleições de 1982, o partido havia autorizado seus diretórios estaduais a realizarem coligações de acordo com sua conveniência, sem mencionar qualquer barreira a coligações com o PDS.

${ }^{80}$ Durante a vigência do bipartidarismo tentou-se mais de uma vez viabilizar a criação de um terceiro partido, de centro, e com características liberais. Ainda em 1970, Pedro Aleixo tentou arregimentar quadros para a formação de um novo partido político, mas muitos acreditavam que o projeto fracassaria, entre outras coisas pelo fato de o governo ser contrário à empreitada (Grinberg, 2009: 177)

${ }^{81}$ Jornal da Tarde, 12/11/1980

${ }^{82}$ Revista Veja, edição 694, 23/12/1981, p.3-4-6

${ }^{83}$ Folha de S. Paulo, 11/05/1981, p.4

${ }^{84}$ Entrevista ao autor.
} 
tinha, digamos, se fosse rotular, e eu não gosto muito desses rótulos, mas uma posição mais de centro-esquerda e o PP tinha uma posição mais de centro ou centrodireita, era um movimento mais conservador, digamos assim."

Essa visão em relação ao partido também pode ser reflexo da composição dos seus órgãos de direção em comparação ao PMDB. Como mencionado na seção anterior, a primeira CEN do PMDB era formada majoritariamente por ex-emedebistas, enquanto que o oposto se dava no PP, que tinha em seu órgão máximo de direção 12 ex-filiados à ARENA e apenas sete ex-filiados ao $\mathrm{MDB}^{85}$ quando da obtenção do seu registro definitivo ${ }^{86}$.

Os principais articuladores do PP foram o Ministro da Justiça Petrônio Portella (que viria a falecer ainda em princípios de 1980, o que viria a reduzir a quantidade de adeptos ao PP em formação) (Fleischer, 1988a: 77), o deputado e ex-governador de Minas Gerais Magalhães Pinto (diretor do Banco Nacional, forte eleitoral e economicamente desde os tempos em que pertencia à UDN) (Benevides, 1981: 232), e o Senador também mineiro Tancredo Neves (político com longa trajetória no PSD pré1964, e que exercera o cargo de Primeiro Ministro durante o curto período parlamentarista de 1961 a 1963), com destaque para este último, pelo papel que viria a cumprir tanto para a história do PMDB quanto para a história do Brasil.

Tancredo Neves, ao longo de sua trajetória política ${ }^{87}$, sempre fora visto como tendo um perfil ideológico conciliador e moderado ${ }^{88}$, tal como pregava o Partido Popular, ou até mesmo como um conservador para alguns ${ }^{89}$. Segundo Silva e Delgado (1985: 59), Tancredo havia se inspirado na sua longa atuação no PSD para criar aquele novo partido de centro "adaptado aos novos tempos do Brasil urbano". Segundo ele próprio, o PP seria, assim, "o partido da reordenação institucional do Brasil, na lei e na ordem, sem ódios nem revanchismos. (...) Seria o instrumento de transição pacífica do regime autoritário para o democrático" $"$, para "aglutinar o centro político do país" " 1 . Na visão do ex-Senador Mauro Benevides (CE), porém, a criação do partido por parte de Tancredo também estava ligada ao fato de o PMDB ser visto como "muito radical" por parte do político, e por acreditar que era necessário marginalizar o campo da esquerda político-partidária para que se conquistasse a transição democrática dentro da normalidade político-institucional ${ }^{92}$.

\footnotetext{
${ }^{85}$ Ver Anexo 3.

${ }^{86}$ Pedido de Registro Definitivo - RGP no 40 - Resolução/TSE no 11.075 e Acervo CPDOC/FGV. Ver Anexo 4.

${ }^{87}$ Sobre a sua trajetória política, ver a biografia/depoimento Silva e Delgado (1985).

${ }^{88}$ Cássio Cunha Lima e Pedro Simon em entrevista ao autor.

${ }^{89}$ Jarbas Vasconcelos, em entrevista ao autor.

${ }^{90}$ Folha de S. Paulo, 16/08/1980, p. 4.

${ }_{91}$ Jornal São Paulo Hoje, agosto de 1984, p. 12.

${ }^{92}$ Mauro Benevides, em entrevista ao autor.
} 
Ao comentar sobre este aspecto da fundação do PP e sobre o papel cumprido por Tancredo, o deputado mineiro Saraiva Felipe, que acompanhou de perto esse processo, declarou:

\begin{abstract}
“(...) Tancredo tentou ser dono de um partido e fundou o PP. (...) Na verdade acho que ele já vinha trabalhando a questão de ser uma alternativa ao Regime Militar, mas consentida, de certa forma. Ele achou que esse espaço podia ser mais palatável, porque o PMDB na época tinha os autênticos e fazia um discurso duro contra a ditadura. O Dr. Tancredo, que era até uma liderança liberal respeitável pelo golpe militar, ele teve todos os convites, sobretudo do Petrônio Portella, para ir para a ARENA, mas ele, se eu tivesse que situá-lo, tinha um perfil democrata. Então era oposição aos militares, mas ideologicamente não era um sujeito que se coadunava com os autênticos do PMDB."
\end{abstract}

A literatura aponta que a força organizativa principal do PP era definitivamente Minas Gerais (Hagopian, 1996: 216-217), provavelmente por conta de suas duas fortes lideranças mineiras. Porém, o Rio de Janeiro também tinha grande importância, dada a liderança do então governador Chagas Freitas, o que acabou por deixar o PMDB relativamente enfraquecido naqueles dois estados. Ademais, lideranças locais importantes em outros Estados contribuíram para a construção do partido, tanto moderados emedebistas quanto liberais arenistas (Mucinhato, 2015: 77). Entre os exoposicionistas pertencentes ao campo moderado do extinto MDB, temos, no Rio de Janeiro, o próprio governador Chagas Freitas, que levou consigo boa parte da bancada fluminense do MDB para o PP (dos 35 deputados que o MDB possuía no estado do Rio de Janeiro, 19 foram para o PP) ${ }^{93}$; em Santa Catarina, o senador Evilásio Vieira; em Pernambuco, o deputado federal Thales Ramalho e no Rio Grande do Norte o exdeputado federal Aluísio Alves. Dentre os políticos ex-arenistas que articularam o PP muitos haviam sido ex-governadores nomeados pelo Regime Militar: no estado de São Paulo, o ex-governador Paulo Egydio, o ex-prefeito da capital Olavo Setúbal (proprietário do Banco Itaú), o ex-presidente da ARENA paulista Cláudio Lembo e os deputados federais Herbert Levy e Caio Pompeu; no Rio Grande do Sul, o exgovernador Sinval Guazzelli; no Paraná, o ex-governador Jaime Canet; em Goiás, o exgovernador Irapuan Costa Júnior e, na Bahia, o ex-governador Roberto Santos, considerado inimigo político local do grupo liderado por Antonio Carlos Magalhães, do PDS.

O perfil dessas lideranças que fizeram parte do processo de formação do PP teria consequências diretas para a correlação de forças no interior do PMDB após o seu processo de incorporação.

\footnotetext{
${ }^{93}$ Sobre o fenômeno do "chaguismo", ver Diniz (1982), Sarmento (1999), Motta (2000), Cantalejo (2008) e o verbete "Chagas Freitas" do Dicionário Histórico Biográfico Brasileiro do Centro de Pesquisa e Documentação de História Contemporânea do Brasil (CPDOC/FGV).
} 
Institucionalmente, houve uma gradual aproximação entre os dois partidos, que começou em meados de 1980, mas o estopim da formalização da incorporação de um partido ao outro, que se manteve em debate durante todo o ano de 1981, foi de uma possível reforma eleitoral. De fato, todo o período entre 1980 e 1982 foi preenchido por medidas político-eleitorais, ora casuísticas, ora liberalizantes, que visavam construir um cenário aparentemente democrático para a atuação de um PDS fortalecido pelas manobras institucionais (Meneguello, 1989: 27). Assim, para lidar com o contexto de grande insegurança institucional no qual os partidos se encontravam, conforme o Regime sinalizava com alterações "casuísticas" na legislação eleitoral em vigor ${ }^{94}$ que poderiam prejudicá-los ou até inviabilizá-los, as siglas mantinham um constante canal de diálogo, debatendo quanto a possibilidade de uma reunificação de toda a oposição ao Regime em apenas uma sigla partidária. Assim, o processo de aproximação entre os líderes do PP e do PMDB se intensificava ou diminuía de acordo com as medidas adotadas pelo governo (Mucinhato, 2015: 85) ${ }^{95}$.

Após meses de impasses no Congresso Nacional em torno das propostas de reforma eleitoral apresentadas pelos principais partidos, e numa conjuntura em que o PDS se mostrava cada vez menos coeso em sua atuação (poucos meses antes o Congresso havia rejeitado a emenda proposta pelo governo que estendia a adoção das sublegendas para as eleições para o cargo de governador), a alta cúpula do Regime Militar decidiu intervir na questão. Convocando seus ministros para uma reunião extraordinária em 25 de novembro de 1981, poucos dias antes do recesso de final de ano, o então Presidente João Figueiredo e seus Ministros apresentam ao público, por meio de nota lida pelo seu porta-voz Carlos Átila, a sua própria proposta de Reforma Eleitoral $^{96}$. Tornavam-se públicas naquele momento as regras que iriam reger as eleições de 1982, num conjunto de leis que entraria para a história política brasileira como "Pacote de Novembro" e que seria aprovado por decurso de prazo no ano seguinte ${ }^{97}$.

Entretanto, diferentemente da Reforma Partidária de 1979, que ocasionou a criação de novas legendas e a divisão da oposição, a consequência principal desta vez seria a extinção de uma sigla partidária, o PP, e o fortalecimento de uma sigla oposicionista, o PMDB (Mucinhato, 2015: 92), impactando diretamente sua composição interna.

\footnotetext{
94 A literatura a respeito do regime militar classifica como "casuísmo" todas as medidas implantadas com o intuito de beneficiar o partido governista, seja a ARENA no período 1965 a 1979, ou o PDS, de 1979 a 1984. Para uma síntese sobre as essas constantes mudanças durante o período do Regime Militar, ver Fleischer (1988a).

${ }^{95}$ Esse ponto de vista era também compartilhado por algumas lideranças da época, como Magalhães Pinto em entrevista à Folha de S. Paulo, 01/10/1980, p.4.

${ }^{96} \mathrm{O}$ texto integral da nota produzida pelo Palácio do Planalto encontra-se reproduzido no Anexo 5.

97 O Pacote se transformaria na Lei 6978/1982 e sua íntegra encontra-se disponível no site http://www.planalto.gov.br/ccivil_03/leis/1980-1988/L6978.htm
} 
O Pacote impôs uma série de medidas que seriam adotadas para as eleições de 1982: a vinculação do voto do eleitor em todos os níveis, sob pena de nulidade do voto (o que obrigava o eleitor a votar em um mesmo partido para todos os cargos, os quais, pelo fato de as eleições de 1980 terem sido adiadas, seriam os de vereador, prefeito, deputados estadual e federal, senador e governador) ${ }^{98}$; obrigatoriedade de os partidos apresentarem candidatos para todos os cargos em disputa (fato que, na prática, proibia coligações e alianças partidárias nas disputas eleitorais, obrigando os partidos de oposição a disputar entre si pelos votos do eleitorado, mesmo se não quisessem) e a condição de não-desistência das candidaturas a governador, sob pena de nulidade dos votos dados ao partido. O governo "sugeria" também que a bancada do PDS fechasse questão em torno dessas e também de outras medidas que já tramitavam no Congresso naquele momento, garantindo dessa forma a sua aprovação ${ }^{99}$.

Como resposta ao Pacote, conforme a hipótese de uma fusão total das oposições passa a se mostrar inviável devido ao veto por parte de algumas legendas, a possibilidade de uma fusão apenas entre PP e PMDB passa a ganhar força rapidamente no mês de dezembro de 1981, transformando-se em uma proposta de "incorporação" do primeiro ao segundo ao invés de uma "fusão", por conta do prazo mais curto para ser implementada ${ }^{100}$. Apesar de não haver unanimidade em suas bases a respeito dessa solução, a proposta de incorporação ganha a simpatia das cúpulas de ambos os partidos e é levada adiante, sendo aprovada em suas respectivas Convenções Nacionais.

Na Convenção do Partido Popular, na qual seriam necessários 156 votos favoráveis à proposta, o resultado da votação fora de 162 votos a favor e 96 contra, fato que explicita as divergências que existiam no partido ${ }^{101}$. Por sua vez, na Convenção do PMDB, a proposta obteve 331 votos a favor e 41 contra, com votos contrários da parte

\footnotetext{
98 Sob a ótica do Regime, a proposta amparava-se na ideia de que o eleitor iria orientar seu voto primeiramente de acordo com os candidatos de seu município, para os cargos de prefeito e vereador, e a partir deles reproduziria o voto no mesmo partido nos outros níveis. O governo deixava clara, dessa maneira, sua confiança nas bases organizacionais municipais de seu partido, sobretudo nos Estados do Norte e do Nordeste, para manter a sua representação majoritária no Congresso. A ideia de uma "municipalização das eleições" tinha respaldo no resultado das eleições municipais anteriores, de 1976, quando o partido do governo tinha sido o grande vencedor: a ARENA havia ganho 3.176 prefeituras e eleito 27.120 vereadores, frente aos 614 prefeitos e 9.486 vereadores eleitos pelo MDB (Lamounier, 1990, e TSE, Dados estatísticos, vol. 12, 1988).

${ }^{99}$ Caso o partido aprovasse o "Fechamento de questão" em seu Diretório Nacional, o parlamentar que votasse contra a orientação do governo poderia perder o seu mandato. A medida visava também a aprovação de outras medidas casuísticas já em tramitação, como, por exemplo, a criação do Estado de Rondônia. Sobre o "fechamento", medida que vinha sendo colocada em prática pelo governo desde a criação da ARENA, ver Grinberg (2009).

${ }^{100}$ A literatura a respeito dos partidos políticos brasileiros e alguns dos entrevistados que mencionam esse processo não distinguem os termos "fusão" e "incorporação", sendo o primeiro o mais usado, e de maneira errônea, se considerarmos que os dois processos exigem medidas e resultados totalmente distintos. Enquanto a incorporação mantém a existência de uma das siglas, a fusão obrigava a criação de um novo partido político, com uma nova sigla partidária.

${ }^{101}$ Como exemplo temos o caso do diretório paulista do PP, que não aceitava a proposta, alegando que já estava em campanha para a candidatura de Olavo Setúbal ao governo do estado e que contava com uma rede organizativa ampla o suficiente para ultrapassar a barreira mínima de votos necessária para se manter existindo.
} 
dos convencionais fluminenses, onde o Diretório do PMDB era rompido com o pepista Chagas Freitas e seus partidários (Amoroso, 2010: 138), e paraibanos ${ }^{102}$.

No ano seguinte, em 14 de fevereiro de 1982, PP e PMDB realizaram enfim uma Convenção Nacional Conjunta, com os membros de ambos os partidos, para referendar a incorporação do primeiro ao segundo. Apesar de algumas defecções (alguns políticos beneficiados por uma reabertura do prazo de filiação partidária acabam por se tornar espólio para o partido governista), a votação da Convenção foi expressiva: dos 673 presentes, a proposta recebeu 635 votos favoráveis ${ }^{103}$. Na mesma ocasião foram dissolvidos tanto a CEN quanto o DN do PMDB e foram eleitos seus novos membros $^{104}$. O novo DN seria composto por 69 membros, dos quais 46 peemedebistas e 23 ex-pepistas, e a CEN do "novo PMDB", que iria dirigir o partido até dezembro de 1983, teve sua composição formada por nove membros que já eram peemedebistas e quatro ex-pepistas ${ }^{105}$.

Enfim, no dia 2 de março de 1982, o TSE reconheceu e homologou a incorporação do PP pelo PMDB. Extinguia-se assim uma efêmera experiência partidária de nossa história política e enterrava-se por ora o projeto do Regime Militar de criar um sistema partidário com um partido que ocupasse o campo do centro e que pudesse eventualmente se coligar com o partido governista. Por outro lado, surgia um novo PMDB, o "PPMDB", com uma nova composição interna e ainda maior do que fora o extinto MDB (Mucinhato, 2015: 99), mantendo-se na condição de maior partido de oposição ao Regime Militar dentro do Congresso Nacional, como nos mostra a tabela a seguir.

\section{Tabela 9. Distribuição partidária no Congresso antes e após a incorporação do PP ao PMDB}

\begin{tabular}{|c|c|c|c|c|c|c|}
\hline & \multicolumn{3}{|c|}{ Pré-incorporação } & \multicolumn{3}{|c|}{ Pós-incorporação } \\
\hline & Câmara & Senado & Congresso & Câmara & Senado & Congresso \\
\hline PDS & 214 & 37 & 248 & 221 & 36 & 257 \\
\hline PMDB & 121 & 22 & 144 & 180 & 29 & 209 \\
\hline PP & 67 & 8 & 76 & - & - & - \\
\hline PDT & 9 & & 9 & 9 & & 9 \\
\hline PT & 5 & & 5 & 5 & 1 & 6 \\
\hline РTB & 4 & & 4 & 5 & & 5 \\
\hline $\begin{array}{l}\text { Sem } \\
\text { Partido }\end{array}$ & & & & & 1 & 1 \\
\hline Total & 420 & 67 & & 420 & 67 & \\
\hline
\end{tabular}

Fontes: Folha de S. Paulo - 17/11/1981, p. 4; 3/01/1982, p.8; e 6/03/1982, p.4.

\footnotetext{
102 Folha de S. Paulo, 21/12/1981, p. 4.

${ }^{103}$ Revista Veja, edição 703, 24/02/1982, pp. 20-22.

${ }^{104}$ Ver Anexo 6.

${ }^{105}$ Ver Anexo 3.
} 
As consequências internas do processo de incorporação para o PMDB, aspectos fundamentais para compreendermos as estratégias adotadas pelo partido nos anos seguintes, serão analisadas na próxima seção deste capítulo, utilizando como indicadores empíricos a composição do seu novo Diretório Nacional e de sua Executiva Nacional a partir de então ${ }^{106}$.

\subsection{Surge um novo PMDB: o "PPMDB"}

"O grupo mais agressivo, mais oposicionista, denominado de autênticos, já era minoritário e com a adesão desse grupo (proveniente do PP) se tornou mais ainda minoritário. $O$ grupo aumentou a ala conservadora do partido. $O$ Dr. Tancredo era um grande líder, hábil, inteligente, mas extremamente conservador." Deputado Jarbas Vasconcelos, em entrevista ao autor.

Se por um lado a incorporação do Partido Popular aumentou a bancada do PMDB no Congresso Nacional e trouxe para o partido fragmentos de uma importante rede organizacional a nível municipal (Soares, 1984: 111) que, de acordo com reportagens do jornal Folha de S. Paulo ${ }^{107}$ e declarações de seus partidários, fez com que o PMDB passasse dos 2064 diretórios anteriores à incorporação para mais de 3 mil diretórios municipais permanentes (sem caráter provisório), o partido também viu acrescida à sua composição interna uma pequena ala conservadora (Power, 1997: 77). O ingresso dessa nova ala, que era vista com suspeita pelo campo "autêntico" do $\mathrm{PMDB}^{108}$, era o resultado dos acordos previstos no processo de incorporação. Os acordos previam que a composição do Diretório Nacional do PMDB passaria a partir de então a ser proporcional à força representativa que cada partido tinha em nível federal. Um acordo análogo foi aplicado aos Diretórios Regionais, formados de acordo com suas representações dentro de cada Assembleia Legislativa Estadual.

Nesse sentido, os dados a respeito da filiação partidária prévia dos membros dos dois principais órgãos de direção do partido, a saber o DN e a sua CEN, revelam qual o tamanho do impacto acarretado por essas mudanças.

Em seu novo Diretório Nacional, eleito após a Convenção Nacional Conjunta que homologou a incorporação e que consta no Pedido de Registro Definitivo do

\footnotetext{
${ }^{106}$ Não está entre os objetivos desta pesquisa fazer uma análise pormenorizada das razões que levaram os partidos a aceitar a incorporação. Ela é um fato histórico consumado. Cabe apenas apontar que os poucos estudos que citam o processo de incorporação julgam que ele se deu em decorrência das dificuldades colocadas pelo governo para a participação do PP nas eleições de 1982 (Kinzo, 1988: 212; 1989: 9; 1993: 39; Melhem, 1998: 262; Ferreira, 2001: 156; Delgado, 2006: 210; Ferreira, 2006: 193; Correa, 2011: 112), uma visão que pode ser relativizada por conta de algumas evidências empíricas, como a rede organizacional que o partido já havia construído em alguns estados e a liderança nas pesquisas de alguns de seus candidatos a governador de estado.

107 18/04/1982, p.6 e 06/05/1982, p. 6.

${ }^{108}$ Cássio Cunha Lima e Flaviano Melo, em entrevistas ao autor.
} 
$\mathrm{PMDB}^{109}$, os pepistas tiveram direito a um terço de sua composição total. Como dito anteriormente, de um total de 69 membros seriam 23 postos ocupados por políticos advindos de um partido centrista (à direita do PMDB). Desses 23 ex-pepistas, pelo menos 10 deles (23\%) tiveram alguma vinculação com a ARENA durante o Regime Militar $^{110}$. Ou seja, como mostra a tabela a seguir, a partir daquele momento o PMDB passaria a ter menos membros ex-emedebistas em seu Diretório Nacional e passaria a ter 16 ex-arenistas, que engrossaram as fileiras do seu campo moderado e que passaram a disputar o perfil ideológico do partido com suas outras alas, sobretudo a que se identificava como "Tendência Popular". É interessante notar que, ironicamente, a partir daquele momento os herdeiros do MDB, partido que tanto havia lutado contra o Pacote de Abril em 1977, agora viam o PMDB ter em seu Diretório Nacional alguns dos senadores biônicos nomeados justamente por meio daquele Pacote (Mucinhato, 2015: 104).

\section{Tabela 10. Comparação entre a filiação partidária prévia dos componentes do Diretório Nacional do PMDB eleitos na primeira Convenção Nacional e após a Convenção que aceitou a incorporação do PP}

\begin{tabular}{l|cc|rc}
\hline $\begin{array}{l}\text { Origem } \\
\text { partidária }\end{array}$ & \multicolumn{2}{c}{1980} & \multicolumn{2}{c}{1982} \\
\hline & $\mathbf{N}$ & \% do total & $\mathbf{N}$ & \% do total \\
\hline MDB & 61 & $88,4 \%$ & 53 & $76,8 \%$ \\
ARENA & 8 & $11,6 \%$ & 16 & $23,2 \%$ \\
Diretório & 69 & $100 \%$ & 69 & $100 \%$ \\
Nacional & & & & \\
\hline
\end{tabular}

Fontes: Mucinhato (2015: 104-105)

Por sua vez, a CEN, eleita por meio do DN, também apresentou mudanças. Com o ingresso de quatro ex-pepistas, que seguiam a liderança de Tancredo Neves, o campo moderado do PMDB passa a ter um reforço nesse que é o principal órgão de direção do partido, disputando os rumos da sigla com as alas que haviam permanecido no interior do PMDB na transição para o pluripartidarismo. Em entrevista a Melhem e Russo (2004: 404), Maria da Conceição Tavares, importante quadro intelectual do PMDB, confirmou essa nova partilha de poder:

"[O comando da Executiva] mudou depois que o PMDB incorporou o PP, depois que chegou o Tancredo. O grupo do Ulysses era o chamado 'Travessia', ao qual pertencíamos, que se situava mais à esquerda, e o do Tancredo era o grupo que veio do PP, que não me lembro mais como se chamava. Todos fomos convocados para a

\footnotetext{
${ }^{109}$ Ver Anexo 7.

${ }^{110}$ Ver Anexo 6.
} 
incorporação, porque havia resistências, gente que não queria. (...) Depois da fusão a Executiva do PMDB passou a ter sete membros do Grupo Travessia e sete que o Dr. Tancredo indicara."

Com essa nova composição o cargo de $1^{\circ}$ Vice-Presidente, que anteriormente era exercido por Teotônio Villela (AL), passa a ser ocupado por Tancredo Neves (MG), principal articulador do Partido Popular, após intermediação de Mauro Benevides (CE), Tesoureiro do partido ${ }^{111}$. Passavam a conviver mais uma vez sob a mesma sigla e em seu principal órgão de direção Miguel Arraes e Tancredo, que havia declarado anos antes, quando Arraes retornara do exílio, que "o MDB do senhor Miguel Arraes não é o

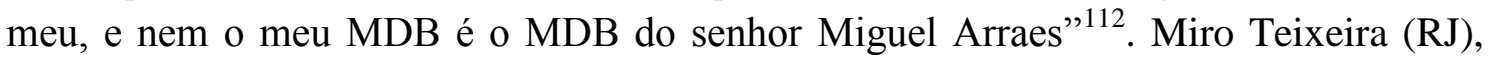
outro ex-pepista, assumiria a $1^{\text {a }}$ Secretaria do partido, substituindo Paulo Rattes (RJ). Entre os vogais seriam três os novos membros ex-arenistas: Teotônio Vilela (que havia deixado a vice-presidência do partido), o Senador Mendes Canale (MS) e o exgovernador do Rio Grande do Norte Aloisio Alves, que ocupariam o lugar do autêntico Fernando Cunha (GO) e de outros três ex-emedebistas. Por outro lado, o cargo de Secretário-Geral do partido permanece nas mãos do campo autêntico, com a saída de Pedro Simon (RS) e a entrada de Francisco Pinto (BA) ${ }^{113}$.

O impacto da incorporação também foi notado pelos políticos e intelectuais que acompanharam esse processo à época, dadas as diferenças no perfil dos políticos que passaram a fazer parte do partido a partir de então em relação à imagem que o PMDB buscava construir desde sua refundação. Para João Carlos Brum Torres, quadro teórico do PMDB gaúcho, a chegada desses políticos "promoveu uma ampliação do espectro ideológico dentro do partido" "114, o que, na visão Renato Archer, outro de seus fundadores, descaracterizava um partido "exclusivamente composto por pessoas que combateram a ditadura"115. Em relação a esse aspecto, o deputado Heráclito Fortes (PI), que testemunhou a incorporação, comentou sobre o novo perfil que o PMDB assumiu a partir de então:

"Havia tensões, inclusive setores do governo ameaçando os que queriam ir para a fusão. Alguns que capitularam, outros que resistiram. (...) O Brasil nunca foi chegado ao radicalismo e nada mais entraria como uma luva tão

\footnotetext{
${ }^{111}$ Entrevista de Mauro Benevides ao autor.

112 "100 anos Miguel Arraes", Jornal O Globo, 18/12/2016, disponível online em https://oglobo.globo.com/brasil/100-anos-miguel-arraes-eu-vi-pela-primeira-vez-na-vida-um-politicochorar-20666804.

${ }^{113}$ Segundo Leonelli e Oliveira (2004: 127) Francisco Pinto se torna Secretário-Geral por uma articulação de Teotônio Villela, que fora retirado da condição de vice-presidente para dar lugar a Tancredo Neves. A escolha foi vista com apreensão por parte do governo, que acreditava que o PMDB optara por uma linha mais "radicalizante" na sua nova composição (Folha de S. Paulo - 18/02/1982, p. 1), mas a análise da composição da Executiva como um todo evidencia justamente o contrário. Sobre a nova composição da CEN a partir de então, ver o Anexo 3.

${ }^{114}$ João Carlos Brum Torres, em entrevista ao autor.

${ }^{115}$ Entrevista a Melhem e Russo (2004: 404).
} 
perfeita quanto o PP do Tancredo, do Magalhães e com o reencontro com o PMDB. Aí o PMDB começou a ser um partido mais moderado." Heráclito Fortes, em entrevista ao autor.

As mudanças ocasionadas por esse processo, do ponto de vista dos políticos que faziam parte do campo dos chamados "autênticos", foram ainda maiores. As palavras de Jarbas Vasconcelos (PE), integrante desse grupo e que à época era membro do Diretório Nacional do partido, mostram qual o teor da incorporação para essa ala:

"O grupo mais agressivo, mais oposicionista, denominado de 'autênticos', já era minoritário e com a adesão desse grupo se tornou mais ainda minoritário. $O$ grupo aumentou a ala conservadora do partido. (...) A gente era minoria, mas era uma minoria que opinava. Éramos ouvidos, respeitados; e essa adesão foi inconveniente, foi ruim pra gente. Foi um episódio que marcou a nossa vida, porque, se era minoria, se tornou menor ainda, em termos numéricos. A gente já tinha uma posição de dificuldade, $e$ encontrou mais dificuldade ainda com o ingresso do grupo do Dr. Tancredo. ",116

Ademais, como apontou em entrevista o Senador Cássio Cunha Lima (PB) ${ }^{117}$, os acordos feitos para acomodar as elites locais e definir a composição dos órgãos de direção regional do partido podem também ter contribuído para dar início a um processo de desfiguração regional do partido, levando-o a ser caracterizado por políticos e pela literatura como uma "confederação regional". Se nos estados em que um dos dois partidos não existia não houve qualquer entrave à incorporação (como foram o caso de Goiás, Alagoas e Rondônia, onde o PP ainda não havia se organizado), a depender do tamanho que PMDB e PP apresentavam nos demais estados o processo de incorporação gerou resultados bastante distintos. Apenas a título de exemplo, enquanto em São Paulo o PP era praticamente inexistente e não chegou efetivamente a mudar o perfil do PMDB paulista, nos Estados de Minas Gerais, Rio Grande do Norte e Rio de Janeiro o PP era maior que o PMDB, e a consequência foi que na prática houve uma incorporação do PMDB por parte do $\mathrm{PP}^{118}$.

Como visto, a incorporação do Partido Popular em 1982, fato histórico muitas vezes tratado como minoritário ou até mesmo esquecido por parte da literatura que se

\footnotetext{
${ }^{116}$ Entrevista ao autor.

${ }^{117}$ Entrevista ao autor.

${ }^{118}$ Na seção regional do Rio Grande do Norte do PMDB parece ter ocorrido um processo que se assemelha aos casos mineiro e fluminense, com o PP "incorporando" o PMDB, mas que necessita de maiores investigações. Sobre a incorporação especificamente no Estado de São Paulo, ver Capistrano Filho e Citadini (1982). Para uma análise específica da história política mineira no período de transição, ver The traditional political elite and the transition do democracy, em Hagopian (1996, capítulo 7). Sobre o processo de incorporação nos estados citados ver Mucinhato (2015).
} 
debruçou sobre o PMDB, representou um primeiro turning point na história do partido. Exceção feita à Benevides (1986), que compreendeu aquele evento como o início de um processo de "deformação mórbida" do PMDB, não se tratou apenas de uma "reincorporação" como apontaram alguns autores (Fleischer, 1988a: 79; Marques e Fleischer, 1998: 16). Considerando-se a ressalva de que o PMDB não havia sido um sucedâneo direto do $\mathrm{MDB}$, a ideia de reincorporação se restringia apenas aos políticos que tiveram passagem pelo MDB e que agora ingressavam no PMDB. Ocorria naquela ocasião a primeira transformação na correlação de forças interna dos órgãos de direção do partido desde sua refundação em 1979, que teria consequências diretas nas estratégias adotadas pelo partido nos anos seguintes. Pois, enquanto até o final de 1981 o partido apresentava uma composição interna mais homogênea e de centro-esquerda, devido à saída de moderados e adesistas que passaram ao PP e ao PDS, a partir da incorporação cresceu o setor "moderado" no PMDB, com suas fileiras engrossadas por mais políticos ex-arenistas (Mucinhato, 2015: 103). Como consequência, as alas mais combativas no seu interior passaram a ter menor influência nos rumos tomados pelo partido a partir de então, com a sua nova coalizão dominante cumprindo um papel fundamental para a eleição de Tancredo Neves para o cargo de Presidente da República em 1985. Antes de analisarmos este aspecto, o que será feito na seção 1.7, cabe aqui apresentarmos um panorama geral do desempenho do PMDB em seu primeiro teste nas urnas, nas eleições de 1982.

\subsection{O primeiro teste nas urnas: panorama geral do PMDB nas eleicões de 1982}

Os anos 1980 representaram o período de ascensão eleitoral do PMDB. Nas eleições de 1982, as primeiras em que a sigla disputa e que foram também a primeira disputa eleitoral desde que o pluripartidarismo havia sido restabelecido em $1979^{119}$, o partido obtém um resultado expressivo, em parte como produto da incorporação do PP (Lima Jr., 1993: 50). Nelas, a oposição pela primeira vez alcançou muitos dos governos estaduais e também pela primeira vez o partido de sustentação do Regime perdeu a maioria absoluta na Câmara, em grande parte graças ao número de eleitos pelo PMDB, dada a fragilidade dos outros partidos de oposição. Por fim, a nova composição do Congresso também teria importantes implicações na correlação de forças do Colégio Eleitoral de 1985 (como será visto na próxima seção) e na posterior convocação de uma Assembleia Nacional Constituinte.

No pleito de 1982 cinco partidos apresentaram-se para o eleitorado: PDS, PMDB (já "pós incorporação"), PDT, PTB e PT. É importante relembrar que naquela

\footnotetext{
${ }^{119}$ Segundo Fleischer (1988a: 12-13), aquelas eleições foram "um divisor de águas mais ou menos no meio do caminho do processo de 'distensão-abertura'", que já durava 8 anos, sendo aquele o quarto de uma série de pleitos (ocorridos antes em 1974, 1976 e 1978) no contexto da "distensão lenta, gradual e segura" do Regime Militar. Pela conjuntura em que se deram, aquelas também podem ser consideradas como "eleições fundadoras", nos termos de Linz e Stepan (1992), por terem ajudado a criar agendas, atores, e organizações.
} 
eleição estariam em vigor as regras eleitorais aprovadas por meio do "Pacote de Novembro", que somadas a outros casuísmos adotados de última hora por parte do governo $^{120}$ tinham como objetivo final aumentar (ou se não, no mínimo manter) a representação do partido governista nas esferas legislativas e garantir nessa arena o apoio à agenda do Regime Militar. Tendo isso em mente, cabe lembrar também que o PMDB contava com uma forte base parlamentar, mantida desde sua fundação, e também com uma ampla rede organizativa, em parte herdada do Partido Popular. A partir disso, cabe a nós agora apresentar o desempenho obtido pelo partido em seu primeiro teste eleitoral $^{121}$.

Considerando as eleições para governador de estado, cargo que pela primeira vez desde 1965 seria disputado de maneira direta, o PMDB foi o único partido de oposição a apresentar em todos os estados da federação candidatos para este cargo ${ }^{122}$. Amapá e Roraima, por serem considerados Territórios Federais, e Rondônia, por um casuísmo do Regime, não tiveram eleições diretas para o cargo naquele ano. Rondônia, especificamente, teve o seu primeiro governador nomeado de maneira indireta pelo Presidente da República.

Dos dez governadores eleitos do campo da oposição em 1982, nove eram filiados ao PMDB. A exceção ocorreu no Rio de Janeiro, onde o vencedor foi Leonel Brizola, do $\mathrm{PDT}^{123}$. O partido chegava assim ao poder nos seguintes estados: Acre, Amazonas, Pará, Goiás, Mato Grosso do Sul, Minas Gerais, Espírito Santo, São Paulo e Paraná. Em dois desses estados os governadores eleitos haviam sido filiados ao PP antes da incorporação, Tancredo Neves em Minas Gerais e Gilberto Mestrinho no Amazonas, evidenciando mais uma vez o impacto da incorporação dos quadros do PP para o

\footnotetext{
${ }^{120}$ Entre outras coisas, o Regime aumentou a quantidade de cadeiras em disputa tanto na Câmara dos Deputados quanto no Senado em relação às eleições de 1978, por meio de duas medidas: elevando o Território de Rondônia à categoria de estado e alterando o cálculo utilizado para distribuição de cadeiras de acordo com a população de cada estado, sobrerrepresentando os estados menos populosos (nos quais o Regime historicamente tinha um bom desempenho em comparação com o MDB).

${ }^{121}$ Naquele momento o PMDB já contava com uma rede de mais de 3.200 diretórios - Folha de S. Paulo $-02 / 05 / 1982$, p.4.

${ }^{122}$ No campo da oposição, o PMDB também foi o partido que mais apresentou candidaturas como um todo, para todos os cargos em disputa (Mucinhato, 2015: 119).

${ }^{123}$ A respeito da eleição do candidato do PDT, a incorporação do PP por parte do PMDB também pode ter contribuído para a sua vitória. Naquele estado, o PMDB pré-incorporação era menor que o PP e apresentava uma forte ala de esquerda, com políticos claramente identificados com o MR-8 e o PCdoB. Após a incorporação, a "máquina chaguista" e o seu principal expoente, o governador nomeado Chagas Freitas, ingressam no PMDB e, apesar de trazerem consigo uma importante rede organizacional naquele estado, o PMDB pagou um preço. Importantes figuras e lideranças políticas evadem à sigla e o partido adquire uma nova feição "governista" e conservadora no estado. O eleitorado tradicionalmente oposicionista do Rio de Janeiro acaba por repelir o novo perfil do PMDB, que vinha construindo uma candidatura oposicionista e que a partir de então passava a construir uma candidatura de continuidade governista. Deve-se também acrescentar que a derrota do PMDB foi agravada pelo sacrifício dos candidatos mais expressivos de sua ala independente, com perfil ideológico mais nítido. Assim, embora o grupo chaguista perdesse o comando do voto oposicionista no estado, não o perdeu no partido, cabendo a seus candidatos significativa parcela dos cargos conquistados pelo PMDB nos legislativos estadual e federal (Souza, Lima Junior, Figueiredo, 1985: 11). Em relação à história política do Rio de Janeiro nesse período, ver Ferreira (2006) e Alkmin (2014).
} 
PMDB. Candidatos do PMDB ao governo em outros estados também haviam ingressado no partido com a incorporação do PP. Foi o caso do ex-arenista Aluísio Alves, no Rio Grande do Norte.

Tabela 11. Governadores eleitos em 1982

\begin{tabular}{|c|c|c|}
\hline Região/Estado & Eleito & Partido \\
\hline \multicolumn{3}{|l|}{ Norte } \\
\hline Acre & Nabor Teles & PMDB \\
\hline Amazonas & $\begin{array}{c}\text { Gilberto } \\
\text { Mestrinho* }\end{array}$ & PMDB \\
\hline Pará & Jáder Barbalho & PMDB \\
\hline \multicolumn{3}{|l|}{ Nordeste } \\
\hline Alagoas & Divaldo Suruagy & PDS \\
\hline Bahia & João Durval & PDS \\
\hline Ceará & $\begin{array}{c}\text { Luís Gonzaga } \\
\text { Mota }\end{array}$ & PDS \\
\hline Maranhão & $\begin{array}{c}\text { Luis Alves Coelho } \\
\text { Rocha }\end{array}$ & PDS \\
\hline Paraíba & Wilson Braga & PDS \\
\hline Pernambuco & $\begin{array}{l}\text { Roberto } \\
\text { Magalhães }\end{array}$ & PDS \\
\hline Piauí & Hugo Napoleão & PDS \\
\hline $\begin{array}{l}\text { Rio Grande do } \\
\text { Norte }\end{array}$ & $\begin{array}{c}\text { José Agripino } \\
\text { Maia }\end{array}$ & PDS \\
\hline Sergipe & João Alves Filho & PDS \\
\hline \multicolumn{3}{|l|}{ Centro-Oeste } \\
\hline Goiás & Íris Rezende & PMDB \\
\hline Mato Grosso & Júlio Campos & PDS \\
\hline $\begin{array}{l}\text { Mato Grosso do } \\
\text { Sul }\end{array}$ & $\begin{array}{c}\text { Wilson Barbosa } \\
\text { Martins }\end{array}$ & PMDB \\
\hline \multicolumn{3}{|l|}{ Sudeste } \\
\hline Minas Gerais & Tancredo Neves* & PMDB \\
\hline Espírito Santo & Gerson Camata** & PMDB \\
\hline Rio de Janeiro & Leonel Brizola & PDT \\
\hline São Paulo & Franco Montoro & PMDB \\
\hline \multicolumn{3}{|l|}{ Sul } \\
\hline Paraná & José Richa & PMDB \\
\hline Rio Grande do Sul & Jair Soares & PDS \\
\hline Santa Catarina & Espiridião Amin & PDS \\
\hline
\end{tabular}

Por sua vez, nas eleições para as Assembleias Legislativas (ALs), o desempenho geral do PMDB foi próximo ao desempenho do PDS no que concerne à porcentagem de votos obtidos (com uma diferença de menos de 100 mil votos entre os partidos), mas, com relação às cadeiras conquistadas, obteve 73 cadeiras a menos que o partido 
governista. Enquanto o PDS elegeu 477 deputados estaduais (em sua maioria concentrados na região Nordeste, uma força que diminuiria posteriormente com a formação do PFL), o PMDB elegeu outros 404, enquanto que os outros partidos de oposição dividiram entre si os outros 66 deputados (quase em sua totalidade concentrados nos estados do Sudeste).

É importante destacar que o desempenho dos partidos nas eleições para as ALs teria também implicações para a composição do Colégio Eleitoral que se reuniria em 1985 para eleger o sucessor do então Presidente João Figueiredo. As regras para a sua composição haviam sido alteradas pelo Regime em mais um dos casuísmos préeleitorais para beneficiar o partido governista, com a expectativa, por parte do Regime, de que se mantivesse uma maioria suficiente para eleger o seu próprio candidato na sucessão presidencial de Figueiredo. De acordo com as novas regras, passariam a compor o Colégio Eleitoral, além dos parlamentares das duas Casas do Congresso Nacional, seis representantes do partido majoritário nas ALs de cada estado ${ }^{124}$.

\section{Tabela 12. Cadeiras obtidas, percentual do total de cadeiras e votação total por partido nas eleições para as Assembleias Legislativas em 1982}

\begin{tabular}{|c|c|c|c|}
\hline Partido & $\begin{array}{l}\text { Cadeiras } \\
\text { obtidas }\end{array}$ & $\%$ & Total de votos \\
\hline PDS & 477 & 50,3 & 17.406 .058 \\
\hline PMDB & 404 & 42,7 & 17.313 .056 \\
\hline PDT & 35 & 3,8 & 2.320 .777 \\
\hline PTB & 18 & 1,9 & 1.787 .072 \\
\hline PT & 13 & 1,4 & 1.429 .363 \\
\hline Total & 947 & 100 & 40.256 .326 \\
\hline
\end{tabular}

Fonte: Nicolau (1998)

No que se refere às eleições em nível municipal, das 3.941 cidades que tiveram eleições para prefeito ${ }^{125}, 1.377(34,9 \%)$ tiveram prefeitos eleitos pertencentes à legenda do PMDB. O partido ficou até mesmo à frente do partido governista em alguns estados importantes, sobretudo nos mais urbanizados, como São Paulo, onde o PMDB elegeu 308 prefeitos, e o PDS, 249 (Mucinhato, 2015:119). No total, o PMDB ficou atrás apenas da sigla governista, que elegeu 2.533 prefeitos. Nesse sentido, aquelas eleições

\footnotetext{
124 A legislação que regia a composição do Colégio Eleitoral era a Lei Complementar no 15 de 13/08/1973 (disponível online em http://www.planalto.gov.br/cCivil_03/LEIS/LCP/Lcp15.htm), que fora alterada pelo Decreto-Lei no 1.539 de 14/04/1977 (http://www.planalto.gov.br/ccivil_03/DecretoLei/1965-1988/Del1539.htm) e que seria então complementada pela Lei Complementar no 47 de 22/10/1984 (http://www.planalto.gov.br/ccivil_03/Leis/LCP/Lcp47.htm) - acessados em 30/07/2018. Sobre a composição do Colégio Eleitoral de 1985, ver Fleischer (1988a).

${ }^{125}$ Apenas as capitais de estados e aqueles municípios que eram designados como "áreas de segurança nacional" e estâncias hidrominerais não puderam eleger seus prefeitos em 1982, algo em torno de 130 cidades.
} 
representam o marco inicial do expressivo desempenho eleitoral do PMDB no período após a implantação do pluripartidarismo. A partir de 1988, a sigla seria aquela que elegeria a maior quantidade de prefeitos no Brasil durante todo o recorte histórico definido para este estudo.

E por fim, mas não menos importante, temos também o resultado das eleições para o Congresso Nacional, também relevantes para a composição do Colégio Eleitoral de 1985. Com relação às eleições para o Senado Federal, 25 cadeiras estavam em disputa nas eleições de 1982, sendo que Rondônia elegeria três representantes (um senador com mandato de 8 anos e outros dois senadores com mandatos de 4 anos). Como resultado final daquele pleito, o PMDB logrou eleger nove senadores, o PDS quinze e o PDT elegeu um único senador (PT e PTB não elegeram nenhum) ${ }^{126}$. As novas bancadas dos partidos no Senado Federal mostravam que o governo havia conseguido manter sua maioria naquela casa, contando a partir de então com 46 senadores $(66,7 \%)$, frente aos 23 oposicionistas (21 do PMDB, 1 do PDT e 1 do PT).

Por sua vez, com relação às eleições para a Câmara dos Deputados, o PMDB contava com uma bancada de 180 deputados federais antes daquele pleito (após a incorporação do PP) e viu esse número aumentar após o resultado final. Das 479 cadeiras em disputa, o partido passou a ter uma bancada composta por duzentos deputados federais, apresentando um desempenho menor que o do PDS (que elegera 235), mas à frente dos outros partidos de oposição (que elegem os outros 44 deputados). Importante destacar também que a partir de então, na Câmara dos Deputados, o campo da oposição (reunindo todos os quatro partidos PMDB, PDT, PTB e PT) agora ultrapassava o campo do governo, representado pelo PDS, por 240 a 235, fazendo com que este perdesse a sua maioria absoluta (Skidmore, 1988: 454).

Tabela 13. Tamanho das bancadas partidárias na Câmara dos Deputados e no Senado Federal após as eleições de 1982

\begin{tabular}{l|cc|cc}
\hline \multicolumn{3}{c}{ Senado Federal } & \multicolumn{2}{c}{$\begin{array}{c}\text { Câmara dos } \\
\text { Deputados }\end{array}$} \\
\hline Partido & N & $\%$ & N & $\%$ \\
\hline PDS & 46 & $66,7 \%$ & 235 & $49,1 \%$ \\
PMDB & 21 & $30,4 \%$ & 200 & $41,8 \%$ \\
PDT & 1 & $1,4 \%$ & 23 & $4,8 \%$ \\
PTB & 0 & $0 \%$ & 13 & $2,7 \%$ \\
PT & 1 & $1,4 \%$ & 8 & $1,7 \%$ \\
Total & 69 & 100 & 479 & 100 \\
\hline
\end{tabular}

Fontes: Britto (1988: 245) e Folha de S. Paulo - 01/02/1983, p. 4 para os dados do Senado, e Nicolau (1998: 52, 73,85) para os dados da Câmara.

\footnotetext{
${ }^{126}$ Os três senadores eleitos pelo recém-criado Estado de Rondônia pertenciam ao partido do governo.
} 
Apesar de ter ocorrido uma ampliação da sua bancada nas duas casas do Congresso Nacional, o que manteve o PMDB na condição de maior partido de oposição até então, um exame mais atento do perfil dos parlamentares eleitos pelo PMDB em 1982 mostra que o mesmo processo de transformação que fora notado em seus órgãos de direção também ocorreu em sua representação no Poder Legislativo. Como mostram os dados das tabelas a seguir, o aumento da bancada do PMDB também foi um reflexo do ingresso dos ex-pepistas, que consistiam em políticos "moderados" do extinto MDB e ex-arenistas pouco presentes no partido até a incorporação.

Com relação aos eleitos para a Câmara dos Deputados em 1982, notamos que, dentre os duzentos deputados federais eleitos pelo PMDB, 32 (16\%) haviam sido filiados ao PP durante aquela curta experiência partidária centrista. Ou seja, 32 parlamentares da bancada do PMDB na Câmara fizeram parte de uma experiência partidária que possuía uma clara proposta de centro, portanto, diferente da sua. Essa bancada de ex-pepistas dentro do PMDB era formada por 13 políticos que haviam feito parte da ARENA durante o período de 1966 a 1979, e por 19 ex-emedebistas, representantes da ala dos moderados daquele extinto partido. Ainda que uma parcela dos ex-arenistas do PMDB em 1982 não tivesse ingressado no partido por meio da incorporação do PP (havia naquele momento 32 ex-arenistas na bancada do partido, dos quais 13 - 40,6\% - eram ex-pepistas), o ingresso de novos ex-emedebistas moderados reforçava esse mesmo campo no interior do partido.

Essa transformação na correlação de forças interna no PMDB em seus primeiros anos fica ainda mais evidente quando analisada de maneira comparativa em relação a sua bancada no momento de fundação do partido. Naquela ocasião, como visto na seção 1.3, o partido naquela Casa era formado majoritariamente por ex-emedebistas. Dos 115 deputados que participaram da primeira bancada do PMDB, 109 (94,78\%) eram filiados ao MDB e apenas $6(5,22 \%)$ eram filiados à ARENA. Índices diferentes em relação àqueles apresentados a respeito das eleições de 1982.

\section{Tabela 14. Filiação prévia da bancada do PMDB na Câmara dos Deputados (1980-1982)}

\begin{tabular}{l|cc|cc}
\hline \multicolumn{2}{c}{1980} & \multicolumn{2}{c}{1982} \\
\hline MDB & $\mathbf{N}$ & $\%$ do total & $\mathbf{N}$ & \% do total \\
\cline { 2 - 5 } $\begin{array}{l}\text { ARENA } \\
\begin{array}{l}\text { Nenhuma } \\
\text { filiação } \\
\text { anterior }\end{array}\end{array}$ & - & $94,78 \%$ & 148 & $74 \%$ \\
$\begin{array}{l}\text { Tamanho } \\
\text { da bancada }\end{array}$ & 115 & $109 \%$ & 200 & $16 \%$ \\
\hline
\end{tabular}

Fonte: Mucinhato (2015: 132) 
Com relação aos indicadores a respeito da nova bancada do PMDB no Senado Federal, dos seis ex-pepistas que passaram a compor a bancada do PMDB naquela Casa após as eleições de 1982, nada menos que cinco tiveram passagem pela ARENA em algum momento de sua trajetória política (três dos quais eram senadores "biônicos", nomeados pelo Regime). Assim, a nova bancada do PMDB no Senado, composta por 21 senadores, passou a ter 7 (33\%) políticos que haviam passado pela ARENA. As duas exceções de senadores arenistas no PMDB e que não foram do PP são o Senador Marcelo Miranda Soares, do Mato Grosso do Sul, que ingressou no PMDB imediatamente após sair da ARENA, e o Senador paulista Severo Gomes, que havia se transferido ao MDB poucos meses antes da extinção daquele partido. O processo de transformação fica ainda mais evidente quando comparado ao momento de refundação no partido em 1980. Naquela ocasião, dos 22 senadores que fizeram parte da primeira bancada do PMDB naquela Casa, 20 (91\%) eram ex-filiados ao MDB e apenas 2 (9\%) os ex-filiados à ARENA.

\section{Tabela 15. Filiação prévia da bancada do PMDB do Senado Federal (1980-1982)}

\begin{tabular}{l|cc|cc}
\hline \multicolumn{1}{c}{1} & \multicolumn{2}{c}{1980} & \multicolumn{2}{c}{1982} \\
\hline MDB & $\mathbf{N}$ & \% do total & N & \% do total \\
\cline { 2 - 5 } ARENA & 20 & $91 \%$ & 14 & $66,7 \%$ \\
$\begin{array}{l}\text { Tamanho } \\
\text { da bancada }\end{array}$ & 2 & $9 \%$ & 7 & $33,3 \%$ \\
\hline
\end{tabular}

Fonte: Mucinhato (2015:130)

À guisa de conclusão, os dados apresentados nesta seção mostram que o PMDB manteve com as eleições de 1982 a força parlamentar que possuía desde sua fundação, aumentando ainda mais sua bancada na Câmara graças a seu bom desempenho em seu primeiro teste nas urnas. Naquela Casa o partido possuía uma bancada de 115 deputados (27,38\% do total) no momento de sua fundação e, após o resultado dessas eleições, passou a ter uma bancada composta por 200 deputados federais $(41,8 \%$ da representação naquela Casa). No Senado, por outro lado, apesar de o partido ter perdido uma cadeira em relação ao momento de sua fundação, passando de $22(32,83 \%)$ para 21 senadores $(30,43 \%)$, ainda assim ele se manteve no posto de detentor da maior bancada dos partidos de oposição. Ademais, a sigla também demonstrava sua força eleitoral nos resultados das eleições para prefeituras, esfera na qual ficou apenas atrás do partido de sustentação do Regime, e nas eleições para governos de estado, nas quais elegeu nove governadores de Estado.

Porém, analisados de maneira mais ampla, os resultados eleitorais e o perfil daqueles eleitos pelo partido em 1982 evidenciam que as transformações que ocorreram em sua correlação de forças interna também se mostraram presentes nas esferas 
representativas, com a eleição de membros ex-pepistas (sejam eles ex-emedebistas moderados, sejam eles ex-arenistas). Assim, os resultados daquelas eleições proporcionaram substancial incremento na ala dos moderados (Rocha, 2013: 50), o que em outras palavras demonstra que a face pública do PMDB que vence aquelas eleições era sua faceta mais conservadora (Lima, 2009: 45). Como destacou um dos parlamentares do PMDB naquela ocasião:

"Se o governador Tancredo Neves de fato não está pensando na criação de um novo partido político, como declarou em uma coletiva de imprensa, pelo menos obteve sucesso em transformar o PMDB [em algo] mais próximo daquilo que seria o partido dos seus sonhos ${ }^{, 127}$.

Ademais, o processo de "inchaço" do partido, compreendido como a entrada de quadros não comprometidos com o seu programa e que será tratado adiante, tornava-se evidente. Diferentemente do que havia sido destacado pela literatura, que apontava que aquele processo teria tido início num momento posterior (Couto,1997: 35; Sadek, 1989a: 67; 1989b: 113; Bresser Pereira, 1993: 240; Lamounier, 1989: 52; Power, 1997: 77) e que será analisado no capítulo seguinte, o processo já estava em curso nas eleições de 1982.

\section{7. "Diretas-Já" ou Colégio Eleitoral? Surge o bloco "Unidade" e o PMDB chega ao poder pela via indireta (1983-1984)}

"Eu me lembro que quando nós estávamos na campanha das 'Diretas', houve combinação do Ulysses com o Tancredo. Se a eleição fosse direta, Ulysses era candidato, se fosse indireta, o Tancredo era o candidato. Foi cumprido. Era impressionante como eles dialogavam." Deputado Heráclito Fortes, em entrevista ao autor.

Como visto nas seções anteriores, o bloco conhecido genericamente como "moderado" no interior do PMDB durante o Regime Militar ganhou reforço após a incorporação do PP em 1982, contando com o ingresso de políticos ex-arenistas e exemedebistas moderados que haviam permanecido distantes do PMDB até então. A partir de então, como veremos nesta seção, esse grupo de políticos se organizou e ganhou mais espaço nos órgãos de direção do partido a partir de uma disputa interna na $3^{\text {a }}$ Convenção Nacional do PMDB, realizada no final de 1983. Essa nova coalizão dominante formada a partir daquele ano teria um papel fundamental na estratégia eleitoral adotada pelo partido de 1983 a 1984, que culminaria no lançamento de uma candidatura própria forte o suficiente para vencer a disputa do Colégio Eleitoral de 1985

127 Jornal Estado de Minas, 17/11/1983 apud Hagopian (1996: 231). 
e eleger, ainda que de maneira indireta, o primeiro Presidente da República civil depois de 21 anos de Regime Militar.

A disputa interna pelo controle do PMDB perdurou todo o ano de 1983 e se deu durante a campanha nacional pelas "Diretas-Já", movimento suprapartidário que reivindicava o restabelecimento de eleições diretas para a presidência da República por meio da aprovação da Emenda Dante de Oliveira ${ }^{128}$. A partir daquele momento o bloco dos moderados, inflados pela incorporação do PP e que seguiam a liderança de Tancredo Neves no interior do PMDB, localiza-se mais à direita no interior do partido. O bloco passou a se auto intitular a partir de então "Unidade" (Rocha, 2013: 50), sendo composto por pelo menos 108 deputados federais (Dimenstein et al, 1985: 67). Sua estratégia no interior do partido era excluir do controle da Executiva Nacional os elementos vistos por eles como sendo mais radicais e levar a esses cargos políticos mais identificados com eles ideologicamente, que buscariam uma saída da ditadura pela via da conciliação (que se materializaria por meio da disputa no Colégio Eleitoral de 1985), e não por meio de eleições diretas. Importante destacar que essa ideia de alijar do controle do partido os elementos mais à esquerda era cogitada por esse bloco do PMDB desde 1980, anos antes da incorporação do PP, quando os moderados do PMDB comentavam nos bastidores que "a presença de Tancredo no PMDB teria um significado especial para a corrente conservadora do partido e contribuiria para neutralizar a influência da Tendência Popular"129 no período de refundação da sigla.

Durante a campanha pelas "Diretas", enquanto uma parcela do PMDB se dedicava a construir aquele movimento nas ruas e lutar pela aprovação da Emenda Dante de Oliveira no Congresso, o grupo "Unidade" reunia-se rotineiramente em Brasília no apartamento do deputado federal baiano Carlos Sant'Ana (Dimenstein et al, 1985: 68), um de seus articuladores e futuro Ministro da Saúde no governo Sarney, contando sempre com a liderança de Tancredo Neves, figura de frente do bloco ${ }^{130}$. A estratégia do grupo e de Tancredo naquele momento se dividia em duas frentes: internamente, ocupar espaços na Executiva e, ao mesmo tempo, assumir a tese das "Diretas" publicamente, incorporando-se à campanha mas sem correr riscos para a retomada da tese do consenso para uma transição da ditadura para a democracia caso a Emenda fosse derrotada (Leonelli e Oliveira, 2004: 322). Dessa forma, Tancredo também demonstraria aos seus aliados externos ao partido e dissidentes dentro do PDS, que naquele momento já cogitavam a formação da Frente Liberal, que o PMDB também

\footnotetext{
${ }^{128}$ A atuação do PMDB no movimento das “Diretas-Já" não será aprofundada nesta pesquisa. Sobre o assunto ver Kotscho (1984), Leonelli e Oliveira (2004) e Bertoncelo (2007).

${ }^{129}$ Folha de S. Paulo - 15/08/ 1980, p.4. O mesmo bloco também teria um papel importante em 1985 exercendo pressão para que os comunistas saíssem do partido, como será visto no capítulo seguinte.

${ }^{130}$ Alguns dos políticos que fizeram parte do bloco foram os deputados Genebaldo Correa (ex- ARENA, ex-PP), Heráclito Fortes (ex-ARENA, ex-PP), João Agripino (ex- ARENA, ex-PP), Roberto Cardoso Alves (exARENA, ex-PP), Valber Guimarães (ex-PP), José Mendonça de Morais (ex- ARENA, ex-PP), Daso Coimbra (ex- ARENA, ex-PP), Roberto Gusmão (ex-PP e chefe do Gabinete Civil do governo de São Paulo).
} 
disputaria o Colégio Eleitoral caso a Emenda não fosse aprovada, tal como previa o próprio Tancredo $^{131}$.

Enfim, quando se realiza a $3^{a}$ Convenção Nacional do PMDB, no dia 4 de dezembro de 1983, a estratégia do bloco Unidade obtém êxito. A ala havia tentado desde outubro daquele ano montar uma chapa própria para disputar o controle dos órgãos de direção do partido, assim como mudar as regras de composição do DN de modo a favorecer o seu campo ${ }^{132}$. Apesar de as duas estratégias não terem logrado resultado e uma única chapa estar na disputa, as negociações anteriores pelo controle da Executiva com a ala "Travessia", liderada por Ulysses Guimarães, levam o grupo a conquistar um amplo espaço na Executiva Nacional do partido, mudando o equilíbrio de forças interno no $\mathrm{PMDB}^{133}$ naquele que representou um novo turning point em sua história.

Dos treze membros do órgão, o "Unidade" conquistou cinco postos e conseguiu colocar o senador biônico Affonso Camargo (PR), sob muitos protestos ${ }^{134}$, no cargo de Secretário-Geral do partido, substituindo o deputado Francisco Pinto (BA), membro da Tendência Popular. Nos termos do colunista Carlos Castello Branco, do Jornal do Brasil, mudava ali o "metabolismo" do PMDB, com destaque para o fato que "a partir dessa Convenção, o Secretário-Geral não será mais o deputado federal Francisco Pinto, notável pela sua capacidade de combate e será o Senador biônico Affonso Camargo Filho, notável por sua flexibilidade política”. A polêmica em torno dessa escolha foi confirmada pelo deputado Flaviano Melo (AC), que testemunhou esse processo e notou como havia ficado o PMDB a partir de então:

"Ele ficou, vamos dizer, se é que [se] pode dizer assim, um 'DNA misto' ou um 'duplo DNA'. Eram bem claras as divergências, bem claras as disputas. Eu via nesse plenário da Câmara, que eram ali feitas as convenções do partido, vi uma vez o Tancredo entrar embaixo de vaia, porque na composição que eles fizeram, a presidência era do PMDB, Ulysses Guimarães, e a secretaria era do PP; o Tancredo indicou um senador do Paraná, agora não me lembro o nome dele..., e a ala do PMDB não queria isso. O PMDB, cuja ala autêntica não era coesa, tinha uma parte muito mais radical e o Ulysses era quem equilibrava isso. Muita gente aqui se revoltou, foi uma vaia louca."

\footnotetext{
${ }^{131}$ Em relato feito em 1997 o ex-presidente Lula aponta como diagnóstico que um dos motivos para a derrota das Diretas foi o fato de Tancredo Neves sempre ter trabalhado contra elas, pois sabia que Ulysses seria o candidato natural de seu partido caso a Emenda fosse aprovada (Couto,1999: 331-333).

${ }^{132}$ Folha de S. Paulo - 1/10/1983 p.5 e 24/10/1983.

${ }^{133}$ Coluna do Castello, Jornal do Brasil, 04/12/1983.

${ }^{134}$ Folha de S. Paulo - 5/12/1983, p. 4.
} 
A nomeação também foi comentada pelo depoimento do deputado federal constituinte Fernando Gasparian (PMDB-SP), em entrevista a Melhem e Russo (2004: 85), que alegou que:

"Em 1983 há eleições para a direção do partido e o pessoal do Tancredo colocou de Secretário-Geral o Affonso Camargo, do Paraná. Foi uma vaia geral, uma confusão desgraçada na Convenção. Então, pra ser aceito pelo partido, percebendo que amadurecia a ideia da campanha pelas 'Diretas-Já', passou a promovê-la no Paraná."

Os membros da Tendência, aliás, repudiaram veementemente o caráter mais conservador que o partido adquiria a partir daquele momento, segundo seu ponto de vista. A deputada Cristina Tavares chegou a declarar à imprensa que o PMDB naquele momento "estava sendo assassinado pelo projeto de conciliação"135 e Francisco Pinto afirmou que a nova composição serviria para "nivelar o partido ao governo"136. A preocupação dos dois políticos com a mudança cada vez maior no perfil daqueles que dirigiam o órgão máximo do partido tinha respaldo na realidade empírica, se analisarmos a nova composição da CEN e o histórico de filiação partidária de seus membros. Se antes da Convenção os ex-arenistas que compunham o órgão ocupavam apenas vagas de vogais e suplentes, a partir de então os quatro ex-arenistas do órgão (Affonso Camargo, Roberto Cardoso Alves, Cid Sampaio e Heráclito Fortes) ocupariam também postos-chave, como a $1^{\text {a }}$ Secretaria e a própria Secretaria Geral, já mencionada. Apesar disso, por meio das negociações de bastidores, este provavelmente teria sido o preço a ser pago para que não houvesse uma disputa aberta entre duas chapas pelo controle da Executiva e para que Ulysses se mantivesse na presidência do partido, ao lado de dois de seus aliados na $1^{\mathrm{a}}$ e $2^{\mathrm{a}}$ vice-presidências ${ }^{137}$.

Concomitantemente ao avanço dessa ala nos órgãos de direção do PMDB, o sistema político também passava a dar sinais de que a Emenda das "Diretas-Já" não seria aprovada pelo Congresso ${ }^{138}$. A liderança de Tancredo Neves então começa a ganhar ainda mais força no interior do PMDB, com a possibilidade de que mais uma vez a escolha do próximo Presidente da República fosse dar se por meio do Colégio Eleitoral, previsto para janeiro de 1985. Segundo Hagopian (1992: 258, apud Mendonça, 2005) Tancredo fez o seguinte cálculo político naquele momento:

\footnotetext{
135 Idem.

${ }^{136}$ Idem.

137 Para Scartezini (1993) o político só aceitou a indicação em troca de que não houvesse disputa na convenção, para a qual por fim foi apresentada chapa única. Para Kotscho (1984: 84) aquela foi "a pior batalha da vida de Ulysses (se reeleger presidente do PMDB), porque apesar de derrotar os negociadores tancredistas, que ameaçavam lhe puxar o tapete, teve que engolir Affonso Camargo e Roberto Cardoso na Executiva". Sobre a composição da nova CEN do partido, ver Anexo 3.

138 Sobre a não aprovação da Emenda das Diretas-Já, ver Skidmore (2004: 465).
} 
“(...) nunca acreditando que o Congresso pudesse aprovar a emenda por eleições diretas, nem que os militares as permitissem (ele chamava de demonstrações 'líricas' a campanha), Neves deu suporte nominal à campanha, ao mesmo tempo em que nunca perdeu a perspectiva de sua candidatura no Colégio Eleitoral”.

Com seu perfil mais "moderado" em relação aos outros peemedebistas com maior projeção nacional (sobretudo Ulysses Guimarães, que se projetava como o candidato do PMDB caso as eleições fossem pela via direta ${ }^{139}$ ) ele se colocava como o nome mais forte do partido para a disputa no Colégio, cogitado pelo Regime como um dos possíveis sucessores de Figueiredo desde o início dos anos $1980^{140}$.

Sabendo disso, o próprio Tancredo e o então Presidente da República reúnem-se repetidas vezes ao longo de 1984 e, na véspera da votação da Emenda das Diretas pelo Congresso, Figueiredo dá uma declaração ao jornal Folha de S. Paulo na qual declara que "Tancredo seria um nome confiável para a conciliação nacional", demonstrando que o próprio Regime Militar considerava que o seu nome enquanto postulante ao cargo de presidente de maneira indireta seria aceitável pelo sistema ${ }^{141}$. Estava aberto o caminho para que o PMDB pela primeira vez em sua história tivesse reais chances de alcançar o cargo de presidência da República e para que finalmente o bloco "Unidade" pudesse levar adiante o processo de transição democrática tal como pretendiam os antigos membros do PP antes de sua extinção, por meio de uma conciliação sem rupturas.

Com a derrocada da Emenda Dante de Oliveira na sua votação no Congresso Nacional em 25 de abril de $1984^{142}$, o PMDB se prepara então para realizar uma nova Convenção, a quarta em sua história, aquela que decidiria seus futuros candidatos para a disputa do Colégio Eleitoral de 1985.

Tabela 16. Resultado da votação da Emenda Dante de Oliveira

\begin{tabular}{l|ccccc}
\hline Partido & SIM & NÃO & AUSÊNCIA & ABSTENÇÃO & TOTAL \\
\hline PDS & 55 & 65 & 112 & 3 & 235 \\
PMDB & 200 & 0 & 0 & 0 & 200 \\
PDT & 23 & 0 & 0 & 0 & 23 \\
PTB & 12 & 0 & 1 & 0 & 13 \\
PT & 8 & 0 & 0 & 0 & 8 \\
\hline
\end{tabular}

${ }^{139}$ Alguns dos entrevistados para esta tese, como Heráclito Fortes, Marcelo Barbieri e Pedro Simon, confirmaram que caso a Emenda Dante de Oliveira fosse aprovada, o candidato natural do PMDB para o cargo de Presidente da República seria Ulysses Guimarães.

${ }^{140}$ Folha de S. Paulo - 19/10/1980, p. 5.

${ }^{141}$ Folha de S. Paulo - 25/04/1984. Segundo Leonelli e Oliveira (2004: 518) o próprio Tancredo já havia abandonado a tese das "Diretas" poucos dias antes da votação na Câmara.

${ }^{142}$ A cobertura feita pela imprensa durante a campanha pelas "Diretas-Já" encontra-se disponível na internet em uma série de plataformas. O site da Câmara dos Deputados, local onde a Emenda acabou por não ser aprovada, disponibiliza uma série de conteúdos por meio da página http://www.camara.gov.br/internet/agencia/infograficos-html5/diretas/index.html 
Fonte: Pinto e Muniz (2008: 13)

No dia 12 de agosto de 1984 é realizada a convenção que homologa a chapa com Tancredo como candidato à presidência e José Sarney como seu candidato a vice ${ }^{143}$, sacramentando a criação da Aliança Democrática entre PMDB e $\mathrm{PFL}^{144}$. Contando com 656 de um total de 688 votos possíveis, Tancredo é escolhido com ampla aceitação interna no partido, demonstrando o quanto seu nome se tornara forte no interior do PMDB em apenas poucos anos desde o seu ingresso, fruto da incorporação do $\mathrm{PP}^{145}$. Com uma votação menor, mas ainda assim significativa, o nome de Sarney, um recémingressante na aliança, acaba aprovado por 543 votos $^{146}$. A votação obteve apoio também dos setores mais à esquerda do partido, como os membros da Tendência que faziam parte de organizações clandestinas ${ }^{147}$, que possivelmente vislumbravam na vitória do candidato peemedebista no Colégio a possibilidade futura de as regras de organização e fundação dos partidos políticos serem flexibilizadas, permitindo a sua posterior legalização.

Enfim, Tancredo renuncia ao cargo de governador do seu estado ${ }^{148}$ e após uma longa campanha ${ }^{149}$ o PMDB consegue eleger por meio de ampla margem o primeiro presidente civil em 21 anos, na votação do Colégio Eleitoral reunido em janeiro de $1985^{150}$. Contando com um "racha" nos votos dos ex-arenistas presentes no Colégio (Madeira, 2006: 87), que se dividiram entre a sua candidatura e a de Paulo Maluf pelo PDS, o ex-governador mineiro conseguiu ser eleito. De um total de 686 votos possíveis,

\footnotetext{
${ }^{143}$ Para contornar questões legais, dias antes da Convenção, Sarney havia se filiado ao PMDB, evento que será objeto de análise no próximo capítulo. Apenas a título de curiosidade, seu filho, o deputado Sarney Filho, havia votado a favor da Emenda pelas "Diretas-Já".

${ }^{144}$ Naquela conjuntura, a Aliança Democrática entre PMDB e PFL apenas fazia ajustes no seu programa. Sobre a formação do PFL ver Lavareda (1985), Ferreira (1998), Tarouco (1999), Catanhede (2001) e Ribeiro (2016).

${ }^{145}$ Folha de S. Paulo - 13/08/1984, p. 4.

${ }^{146} \mathrm{Na}$ Convenção seriam possíveis 791 votos. No entanto, só foram exercidos 688 direitos de voto. Deixaram de comparecer 103 convencionais. Resultados da Convenção do PMDB, para Presidente: Tancredo Neves, 656 votos; brancos e nulos, 32 votos. Para Vice-Presidente: José Sarney, 543 votos; brancos e nulos, 145 votos. Fonte: Folha de S. Paulo - 13/08/1984.

147 Idem. Segundo coluna de Carlos Castello Branco (11/05/1984) o grupo chamava-se "Pró-partido" e havia lançado um manifesto em 10 de maio de 1984 com o apoio inicial de 34 deputados. Embora estejam presentes no grupo representantes do PCB, o movimento é mais amplo politicamente. Apoiavam-no os deputados Cid Carvalho, Sinval Guazzelli e Márcio Braga, por exemplo, todos eles liberais com inclinações socialistas, mas nenhum deles integrante do PC. Sinval Guazzelli foi Governador do Rio Grande do Sul, selecionado para o posto pelo sistema. O objetivo principal do novo grupo era "negociar a transição".

${ }^{148}$ Ao se afastar do cargo, quem assume no lugar de Tancredo e passa a controlar o PMDB local é Hélio Garcia, outro ex-pepista e um ex-arenista, mostrando a força que essa ala tinha naquele Estado.

149 Sobre a quantidade de pessoas presentes nos comícios de Tancredo por todo o Brasil, ver http://atlas.fgv.br/marcos/governo-figueiredo-1979-1985/mapas/campanha-pro-tancredo-votos-porestado-em-tancredo - acessado em 23/4/2018.

${ }^{150}$ Sobre a eleição de Tancredo, ver Dimenstein et al. (1985), Skidmore (2004) e o documentário “Muda Brasil" (1985).
} 
Tancredo recebeu 480 votos, dentre os quais 175 votos de peemedebistas e 166 votos de pedessistas. Por sua vez, Paulo Maluf obteve 180 votos, dos quais 174 eram de membros do seu próprio partido, um número próximo da votação que Tancredo obteve por parte de dissidentes do PDS (Skidmore, 1988: 486). Foram ainda registradas dezessete abstenções e nove ausências.

Tendo visto o seu antecessor MDB passar mais de uma década na oposição ao Regime Militar, o PMDB enfim chegava ao poder, pouco mais de cinco anos após a sua fundação, por meio de Tancredo Neves, que segundo Ulysses Guimarães "tinha o perfil ideal para, ao mesmo tempo, tranquilizar os militares e soldar uma aliança com os dissidentes civis do regime" (Delgado, 2006: 306).

\subsection{Consideracões finais: o PMDB no Colégio Eleitoral de 1985}

Como discutimos ao longo deste capítulo, o PMDB atravessou um processo de transformação interno em seus primeiros cinco anos de funcionamento. Tomando como indicadores a composição dos seus principais órgãos de direção, a saber, seu Diretório e sua Executiva nacional, assim como dados a respeito das suas bancadas no Congresso Nacional, o partido que foi formado como principal herdeiro do MDB no final de 1979 chega ao poder por meio do Colégio Eleitoral de 1985 com uma correlação de forças interna e uma coalizão dominante bastante distintas das de sua origem.

A primeira transformação se deu ainda em seus primeiros anos de existência, período no qual a sigla ainda se organizava. A adoção do pluripartidarismo em 1979 levou ao que chamamos de "primeira onda" de evasão de quadros do partido. Naquele momento, parte dos ex-filiados ao MDB decide não participar da fundação do PMDB, optando por construir outras organizações partidárias. Essas evasões se deram de maneira minoritária para partidos localizados no campo à esquerda (PDT e PT), e foram mais significativas entre aqueles que optaram pela fundação de um partido à direita do PMDB, no campo do centro. Esse partido, denominado de Partido Popular, formou-se por ex-emedebistas moderados e ex-arenistas que buscavam promover a transição da ditadura para a democracia pela via da conciliação, dentro da institucionalidade vigente.

Com a decretação do "Pacote de Novembro" por parte do Regime Militar, que alterou as regras das eleições previstas para 1982, ocorre a extinção e posterior incorporação do PP pelo PMDB, que aumenta o campo mais à direita no interior do partido devido à entrada de novos quadros. Se até então a sigla tinha visto seu campo moderado ter se reduzido na passagem do bipartidarismo para o pluripartidarismo (o que se verifica no perfil daqueles que controlavam sua CEN durante seus primeiros anos), ele passaria a ganhar força a partir daquele momento com o ingresso de políticos ex-arenistas e ex-emedebistas moderados. Por outro lado, é importante destacar que essa transformação interna do partido contribuiu para seu bom desempenho nas urnas em seu primeiro teste eleitoral, em 1982, garantindo a eleição de uma grande bancada no 
Congresso Nacional e de seus primeiros governadores de estado. Mas em se tratando dos seus órgãos de direção, as consequências para o PMDB foram para além daquele ano, e a entrada dos pepistas seria determinante para a chegada do PMDB no poder nos anos seguintes.

Gradativamente, este mesmo campo mais à direita no interior do partido passou a se articular e a conquistar mais espaços no Diretório e na Executiva Nacional do PMDB. Assim, enquanto parte dos quadros do partido lutava nas ruas na campanha das "Diretas-Já" colocando como prioridade para a transição democrática e para o seu projeto político a aprovação da Emenda, o bloco Unidade conquistava quase a metade da Executiva do partido e, principalmente, a sua Secretaria Geral. A partir de então alterava-se o "metabolismo interno" do partido, que passava a ter um "duplo DNA", como nas palavras de um de seus parlamentares aqui entrevistado. $O$ projeto de transição via conciliação ganhava então mais força no interior do PMDB, sobretudo em torno da figura de Tancredo Neves, um dos moderados do partido.

Enfim, quando é chegada a hora da disputa do Colégio Eleitoral de 1985, o próprio Tancredo, um ex-pepista que ingressara no partido por meio da incorporação do PP em 1982, torna-se o candidato do PMDB e vence a disputa contra o candidato do Regime Militar, o pedessista Paulo Maluf. Elegia-se naquele momento, pela primeira vez em 21 anos, um civil para o cargo de Presidente da República. Pela primeira vez também em sua história o PMDB chegava ao poder, inaugurando o período conhecido como "Nova República"151.

\footnotetext{
${ }^{151}$ A expressão "Nova República" foi criada pelo publicitário Mauro Salles conforme depoimento de Fernando Lyra a Rocha (2013: 53).
} 


\section{Capítulo 2 - O PMDB no poder: novas saídas e novas entradas (1985-1988)}

"Era um período que dava muito orgulho a gente ser do $P M D B$. Porque é um partido que a gente achava que estava consertando o Brasil, que o Brasil finalmente estava se encaminhando para o rumo certo, depois de uma longa noite de trevas." Deputado Marcelo Castro, em entrevista ao autor.

"Era charmoso e era modismo ser do PMDB naquela época. Aquilo terminou não fazendo bem." Deputado Heráclito Fortes, em entrevista ao autor.

\subsection{Introducão}

Durante o período de 1985 a 1988 o PMDB passou por um processo de transformação interna que, em certa medida, foi uma continuidade das transformações observadas no período de 1979 a 1984 analisadas no capítulo anterior. Durante o recorte histórico adotado neste capítulo, que cobre desde a chegada do PMDB ao poder na esfera federal até a formação de uma dissidência interna do partido que leva ao surgimento do PSDB em 1988, houve dois processos concomitantes. Por um lado ocorre uma gradual perda de políticos para partidos à esquerda do PMDB (aquilo que chamamos de "segunda" e "terceira" ondas de evasão de quadros), e também um aumento do ingresso de políticos com um perfil ideológico pragmático (ou "centrista", em outros termos) ${ }^{152}$, que eram comprometidos com o Regime Militar até pouco tempo antes. Esses dois processos transformam ainda mais a composição interna do partido e, ao final desse período, apesar de alguns políticos dos seus setores internos mais à esquerda ainda se manterem no PMDB (como alguns remanescentes do grupo dos "autênticos" durante o Regime), eles passaram a ser minoritários, o que pode ter contribuído para a literatura caracterizar o PMDB a partir dos anos 1990 como um partido sem perfil algum (Carreirão e Kinzo, 2004: 158-159).

\footnotetext{
${ }^{152}$ Em entrevista ao autor, Flaviano Melo usa os termos "moderados" e "conservadores" para se referir a esses políticos, termos também utilizados por outros entrevistados. À época, alguns jornalistas também começaram a se referir a esses mesmos políticos como "fisiológicos" (Jânio de Freitas, "Tal como antes" - Folha de S. Paulo, 14/03/1989). Para evitar a dificuldade de atribuirmos uma série de características a esse termo e assim classificarmos ideologicamente como sendo "conservador" cada um desses políticos, optou-se por usar o termo "pragmático", em referência ao fato de esses políticos buscarem manter espaço dentro do governo federal, ainda que houvesse ocorrido uma mudança na coalizão governante em 1985 com a chegada da Aliança Democrática ao poder. O mesmo termo foi utilizado por Rodrigues (1987: 53), mencionado na Introdução.
} 
O ano de 1985 será adotado como ponto de partida deste capítulo pois além de ser uma sequência cronológica em relação ao capítulo anterior ele representa um marco importante para a história do PMDB. Assim como o ano de 1980 representou o que chamamos de "primeira onda", no ano de 1985, ao mesmo tempo em que o partido passava da oposição à situação, ocorria a "segunda onda" de evasão de quadros do PMDB, como consequência da aprovação da Emenda Constitucional $n^{\circ} 25 \operatorname{logo}$ no início do governo Sarney. A nova lei flexibilizava tanto a fundação de novos partidos políticos quanto as regras de fidelidade partidária. A aprovação da Emenda era um anseio do próprio PMDB no sentido de começar a remover o que era chamado de "entulho autoritário", compreendido como a legislação adotada durante o Regime Militar. Entretanto, do ponto de vista do partido, a medida também impactaria diretamente na sua composição interna de duas formas: permitindo a legalização dos partidos de esquerda que atuavam clandestinamente no seu interior e, com o flexibilizar as regras de fidelidade partidária, permitindo uma maior migração dos políticos de outros partidos para o PMDB, que se encontrava na administração do governo federal a partir daquele ano, por meio da figura de José Sarney.

A partir desse novo contexto pluripartidário, mais extremado em relação ao período entre 1979 e 1985, o bloco de políticos mais à direita no interior do PMDB (em parte composto pelos integrantes do "Unidade", o subgrupo do partido que seguia a liderança de Tancredo Neves) passa a crescer mais e se articular, beneficiando-se do ingresso no partido de políticos identificados com o seu campo. Como será mostrado neste capítulo, esse bloco aos poucos passou a ganhar terreno tanto nos órgãos de direção quanto nas bancadas do partido no Congresso Nacional, reduzindo o espaço ocupado pelos seus setores mais à esquerda e exigindo que os políticos do subgrupo da Tendência Popular que eram identificados com os recém-regularizados Partido Comunista Brasileiro (PCB) e Partido Comunista do Brasil (PCdoB) saíssem da sigla. Além de crescer quantitativamente durante o período, tal ala do partido também alcança postos de destaque na administração do governo Sarney e no próprio PMDB. A análise das informações referentes aos principais órgãos de direção do partido (a saber, sua Executiva Nacional e seu Diretório Nacional, evidências empíricas também utilizadas no capítulo anterior) e do resultado das eleições de 1986 serão importantes nesse sentido.

Por sua vez, o marco histórico final deste capítulo será o ano de 1988, ano que representa a "terceira onda" de evasão de quadros do PMDB, fechando esse ciclo de transformações ocorrido nos anos 1980. Nesse ano foi fundado o Partido da Social Democracia Brasileira (PSDB), a única dissidência partidária que surgiu do interior do $\mathrm{PMDB}^{153}$. O partido foi criado a partir do Movimento Unidade Progressista (MUP), composto por uma parcela dos políticos remanescentes do campo mais à esquerda do

\footnotetext{
${ }^{153}$ A legalização de PCB e PCdoB em 1985 e a formação do PPL em 2011 não podem ser considerados como dissidências partidárias, pois trataram-se de organizações que já eram articuladas no interior do PMDB antes de se regulamentarem, estando apenas abrigados no interior do PMDB devido aos impedimentos estabelecidos pelo Regime Militar (no caso de PCB e PCdoB) ou por questões estratégicas (no caso do PPL).
} 
PMDB (do qual fazia parte a "esquerda independente") que haviam optado por manterse dentro do partido. Devido a esse processo, no momento de sua fundação o PSDB acabou sendo caracterizado pela literatura como um partido de centro-esquerda, ou como um racha à esquerda do PMDB (Kinzo, 1989, 1993; Mayer, 2009; Rocha, 2015; e Martins, 2015), e o resultado final desse cisma foi um PMDB com uma nova composição interna e uma nova coalizão dominante, dado o perfil dos seus políticos remanescentes.

Nesse sentido, este capítulo se divide da seguinte forma: no tópico seguinte a esta introdução, apresentaremos a entrada de José Sarney no partido, como consequência do arranjo feito para que a chamada Aliança Democrática fosse vitoriosa no Colégio Eleitoral de 1985; em seguida, trataremos do contexto no qual se deu a aprovação da Emenda Constitucional $n^{\circ} 25$ e apresentaremos como os processos de regularização de PCB, PCdoB e PSB impactaram diretamente o PMDB; posteriormente, apresentaremos evidências que indicam o aumento e a ascensão de políticos da ala mais à direita no interior do PMDB e no governo Sarney, articulados em torno do bloco "Unidade"; no tópico subsequente apresentaremos o panorama geral do desempenho do partido nas eleições de 1986, momento no qual a sigla tem o melhor resultado de sua história; a seguir, analisaremos a atuação do partido durante a Assembleia Nacional Constituinte de 1987-1988 para ulteriormente analisarmos o processo de formação do PSDB e o seu impacto no PMDB; por fim, na última seção, apresentaremos nas considerações finais uma síntese do recorte histórico analisado neste capítulo.

\subsection{O PMDB chega ao poder com José Sarney (1985)}

"Quando chegou o Sarney as pessoas se surpreenderam um pouco, mas tiveram que cair na realidade de que o partido era aquilo mesmo." Jornalista Sônia Carneiro, em entrevista ao autor.

O PMDB chegou ao poder na esfera federal pela primeira vez em sua história no ano de 1985, com a confirmação da eleição da chapa de Tancredo Neves e José Sarney no Colégio Eleitoral de janeiro daquele ano. Sarney era considerado ainda um "novato" dentro da sigla peemedebista, tendo ingressado no partido por conta tanto de necessidades criadas pela legislação eleitoral vigente na época quanto pelos acordos firmados por meio da Aliança Democrática entre PMDB e a Frente Liberal (futuro PFL, dissidência interna do partido governista, o PDS, formada principalmente por sua ala "anti-malufista" $"$ ).

Os acordos definidos por meio da carta "Compromisso com a Nação"155 previam uma agenda política e econômica a ser adotada pelo futuro governo caso fosse

\footnotetext{
${ }^{154}$ O PDS àquela altura encontrava-se controlado pela ala ligada a Paulo Maluf, candidato indicado pelo partido para disputar o Colégio Eleitoral (Skidmore, 2004: 481).

${ }^{155}$ Ver Anexo 8.
} 
eleito. Previa ainda que caberia ao PMDB indicar o candidato para concorrer ao posto de Presidente da República, tarefa que coube a Tancredo, e caberia à Frente Liberal indicar o candidato para concorrer à vice-presidência, para o qual foi indicado José Sarney.

Porém, a formalização da chapa formada pelos dois encontrava uma série de entraves na legislação vigente à época, e foi necessária uma manobra por parte das lideranças de ambas as organizações para que eles fossem superados. Os partidos encontravam dificuldade para encontrar alguém disposto a tornar-se candidato a vicepresidente, pois além da exigência imposta pela legislação segundo a qual os dois candidatos de uma chapa deveriam estar filiados ao mesmo partido, os seus dirigentes se depararam com uma particularidade da legislação segundo a qual um político eleito por uma determinada sigla e que migrasse para outro partido perderia o seu mandato ${ }^{156}$. Dessa forma, uma chapa formada por um peemedebista e um dissidente do PDS não poderia ser formada por um parlamentar eleito por este partido, senão ele perderia o seu posto. Assim, o então senador José Sarney (MA), apesar de não ser a primeira escolha de Tancredo Neves para compor a sua chapa ${ }^{157}$, tornou-se a escolha mais propícia. Considerando o fato de que havia sido eleito senador ainda pela ARENA em 1978, portanto antes da reformulação da legislação partidária de $1979^{158}$, o político estava blindado à lei, e pôde, assim, filiar-se ao PMDB para concorrer na chapa sem abrir mão de seu mandato. A chapa então formalizada seria composta apenas por políticos filiados ao próprio partido, com a entrada de Sarney na sigla que tem sido a sua casa desde então ${ }^{159}$.

Apesar de ser uma nova figura no PMDB, José Sarney naquela ocasião era um político já com longa trajetória, e passaria a ser um personagem marcante na história do partido $^{160}$. Natural do estado do Maranhão, Sarney havia iniciado sua carreira na política ainda no período pré-Regime Militar, sendo eleito deputado federal pela UDN em 1958. Naquele partido, fizera parte da ala chamada de "bossa nova" nacionalista e reformista à esquerda do partido (Skidmore, 2004: 484-485), aderindo ao Regime Militar após o golpe de 1964. Em 1965 foi eleito governador em seu estado,

\footnotetext{
${ }^{156}$ Emenda Constitucional $n^{\circ} 11$ de 1978, disponível online em http://www2.camara.leg.br/legin/fed/emecon/1970-1979/emendaconstitucional-11-13-outubro-1978366947-publicacaooriginal-1-pl.html - acessado em 31/08/2018.

157 Há divergências quanto a preferência de Tancredo entre nossas fontes consultadas em relação à literatura. Em entrevista ao autor, o deputado Miro Teixeira alegou que Marco Maciel teria sido a sua primeira escolha, mas por ter sido eleito pelo PDS teve que ser descartado. A mesma visão de preferência por Maciel partia dos autênticos, de acordo com Rocha (2013: 51), para quem Tancredo preferira o próprio Sarney. Em se tratando de Marco Maciel, segundo Dimenstein et al (1985: 92-93), o político não queria ser candidato tanto por não querer perder seu mandato parlamentar, quanto pelo fato de já ter declarado inúmeras vezes que almejava disputar a presidência, e não a vice-presidência.

${ }^{158}$ Em entrevista ao autor, o deputado Heráclito Fortes argumenta que a sua entrada na chapa também pode ter sido uma exigência de Aureliano Chaves, então vice-presidente da República.

159 Segundo Rocha (2013: 51) Sarney se filia ao PMDB no dia 8 de agosto de 1984, dias antes da Convenção que formalizou a chapa do PMDB para a disputa da presidência.

${ }^{160}$ Sua atuação na Assembleia Nacional Constituinte é uma evidência nesse sentido, e será tratada ainda neste capítulo.

${ }^{161}$ Para uma história da UDN e da própria ala ver Benevides (1981).
} 
retornando a Brasília como senador após as eleições de 1970, e sendo posteriormente reeleito em 1978. Durante esse período ascendeu dentro do Regime Militar, chegando ao posto de presidente da ARENA em 1979, e posteriormente do PDS, após a aprovação da reforma partidária. Como líder nacional do PDS, Sarney se esforçou para dar ao partido um "moderno" programa reformista dentro de claros limites capitalistas (idem), passando a ter tensões internas com o partido conforme Paulo Maluf, presidenciável da sigla em 1985, começava a também ascender internamente ${ }^{162}$.

Na visão de alguns políticos e acadêmicos ligados ao PMDB a entrada de Sarney no partido naquele momento cumpriu um papel fundamental para gerar as condições possíveis e necessárias para a vitória de sua chapa com Tancredo no Colégio Eleitoral $^{163}$, dividindo os votos do PDS e dando ao PMDB a quantidade de votos que era necessária nesse sentido. Nas palavras do Deputado Flaviano Melo (AC), em entrevista ao autor:

"O Sarney (...) teve uma importância muito grande. Ele que garantiu a candidatura do Tancredo. Ele veio de lá [do Regime Militar], apesar de o Figueiredo ter ficado..., não passou nem a faixa para ele - mas ele tinha um trânsito muito grande do lado de lá, ele sabia nos momentos [certos].... Ele teve esse papel de compor aquela chapa e cumpriu muita coisa no PMDB."

Por outro lado, apesar de no início ter sido visto por alguns políticos como um "estranho no ninho" dentro do partido ${ }^{164}$, seu perfil conservador ${ }^{165}$ e seu poder de influência são considerados elementos-chave por parte de alguns políticos para compreender o processo de transformação interna pelo qual o PMDB atravessa durante a sua primeira década. Na visão de Pedro Simon (RS), sua entrada "mudou a história do partido", o que do ponto de vista de João Carlos Brum Torres significou um "empurrão do partido para a direita". Esse "empurrão" parece ter se dado pelo fato de sua entrada não ter ocorrido de maneira isolada. Na perspectiva de alguns políticos, com a chegada ao poder o partido teria começado a se transformar recebendo pessoas que entraram ao lado de Sarney ${ }^{166}$, desfigurando-se. As declarações dos deputados Marcelo Castro (PI) e Jarbas Vasconcelos (PE), assim como do economista Luiz Carlos Bresser-Pereira, ministro durante o governo Sarney, relatam esse processo:

"Essa foi a maior ironia que o destino pregou ao PMDB. Não tenha dúvida. Imagine, o MDB passa toda a

\footnotetext{
162 Para uma biografia (em versão autorizada) de José Sarney, ver Echeverria (2011). Para uma breve síntese de sua trajetória na política: https://oglobo.globo.com/brasil/sarney-da-presidencia-darepublica-aos-atos-secretos-no-senado-12994251.

163 Entrevistas ao autor com Flaviano Melo, Miro Teixeira, Raimundo Lira, Tonico Ramos e Mauro Benevides.

${ }^{164}$ Heráclito Fortes, em entrevista ao autor.

165 Marcelo Barbieri e Jarbas Vasconcelos em entrevista ao autor usam esse termo para se referir ao perfil ideológico do político.

${ }^{166}$ Celso Maldaner, Saraiva Felipe e Tonico Ramos em entrevistas concedidas ao autor.
} 
existência combatendo a ditadura. Depois o PMDB [passa a] ser comandado por um [homem] que serviu todo o tempo à ditadura. Jamais eles imaginaram que botaram o Sarney de vice para poder compor a chapa para se vencer no Colégio Eleitoral, porque a eleição não era direta. Então você imagine, pra fazer essa composição com o PFL, pra poder ganhar a eleição no Colégio Eleitoral, você imagina o MDB passar a vida inteira de um lado pra depois entregar o comando a um cara que toda vida passou do outro lado! Isso sem a menor dúvida desfigurou o PMDB. O PMDB perdeu aquele brilho, aquela garra, aquela fibra, sem a menor dúvida." Deputado Marcelo Castro, em entrevista ao autor.

"Ele entrou, quando escolhido naquela ocasião, ele dimensionou mais ainda essa desfiguração. O grupo [dos autênticos] sofreu um golpe porque aumentou o volume dos conservadores. Sarney tem a marca do conservadorismo. É um político muito hábil, e fez com que o grupo conservador aumentasse." Deputado Jarbas Vasconcelos, em entrevista ao autor.

“O PMDB chegou ao poder em 1985, 1986. Ai ele era um partido de massa, onde tinha de tudo um pouco. O partido que tinha se identificado com a transição democrática tinha sido o PMDB, e tiveram uma vitória. Quando se fica poderoso e se chega ao governo de tal modo, é fácil se corromper. É inevitável, e atrai muita gente. [O partido] perdeu o caráter social, com muitos oportunistas que só querem ganhar dinheiro na política, ganhar poder $e$ prestígio na política, mas para quem o interesse público não interessa muito. Porque você sempre deve lembrar o seguinte: segundo os cientistas políticos da rational choice, inclusive o meu querido amigo Adam Przeworski, o político é aquele que faz trade-offs, entre office seeking, e a vontade de ser reeleito. E eu acho isso falso. Acho que uma parte talvez preponderante dos políticos seja assim, mas há um outro grupo de políticos que faz trade-offs entre a vontade de ser reeleito e o interesse público. E esse tipo de gente [é] que existia de maneira substancial no PMDB até chegar ao poder; quando chega no poder aquilo começa a se esvaziar." Luiz Carlos BresserPereira.

A entrada de Sarney no partido, porém, talvez não tivesse tido o mesmo impacto caso Tancredo Neves tivesse de fato assumido a presidência da República após a vitória na disputa do Colégio Eleitoral. Internado inesperadamente na noite de 14 de março de 1985, véspera de sua posse, acaba sendo José Sarney quem assume o cargo em seu 
$\operatorname{lugar}^{167}$. A posse da presidência se daria de maneira definitiva poucas semanas depois, com o falecimento de Tancredo no dia 21 de abril daquele ano ${ }^{168}$. Com a saída de cena de Tancredo da política brasileira, ele levou consigo "o elo invisível” que unia a Aliança Democrática e a própria agenda da transição, com a qual a coalizão PMDB-PFL teria de lidar (Lamounier, 1989: 36). Com o PMDB chegando ao poder pela primeira vez em sua história por meio de Sarney, caberia a ele levar adiante a partir de então o programa da Aliança Democrática.

Nesse sentido, uma vez na presidência, com o intuito de colocar esse programa em prática, uma das primeiras medidas anunciadas pelo seu governo foi a reformulação da legislação partidária e eleitoral. Como visto, a legislação então em vigor havia sido sancionada em dezembro de 1979 pelo presidente João Batista Figueiredo, gerando a Lei 6.767, com rígidos critérios para a formação de novos partidos. A partir daquela data, apesar do restabelecimento do pluripartidarismo, apenas seis agremiações haviam conseguido se organizar e obter seu registro definitivo: PDS, PMDB, PP, PDT, PTB e PT. Porém, durante os cinco primeiros anos de vigência da Lei (do final de 1979 ao início de 1985), houve dois desdobramentos importantes no sistema partidário, que o mantiveram com apenas seis agremiações e que devem aqui ser mencionados: o curto período de vida do Partido Popular, incorporado ao PMDB em 1982 (como visto no Capítulo 1) e a formação do Partido da Frente Liberal (PFL), a partir do embrião criado pela Frente Liberal para apoiar a candidatura de Tancredo Neves no Colégio Eleitoral.

Assim, uma das primeiras medidas adotadas pelo governo Sarney ainda em maio de 1985 é a promulgação da Emenda Constitucional n ${ }^{\circ} 25^{169}$. A nova Emenda, de relatoria do deputado peemedebista João Gilberto Lucas Coelho (RS), fora elaborada por uma Comissão Interpartidária no Congresso contado com apoio maciço dos parlamentares ${ }^{170} \mathrm{e}$, entre outras coisas, flexibilizou as regras para a formação de novos partidos e também para sua própria interação na arena eleitoral. Junto a uma série de medidas (como a extensão do direito de voto aos analfabetos e o restabelecimento das eleições diretas para as capitais e prefeituras dos municípios considerados áreas de segurança nacional), a nova lei aumentou consideravelmente o grau de liberdade da vida

\footnotetext{
167 Sobre a indefinição quanto a quem assumiria o posto de Tancredo naquela ocasião, ver Pinheiro (1993) e Gaspari (2016). Em entrevista ao autor, Mauro Benevides argumenta que Ulysses Guimarães, presidente da Câmara naquela ocasião e que segundo algumas interpretações era quem deveria assumir o posto, reconhecia que Sarney seria melhor "assimilado" pelos militares do que ele próprio.

168 Sobre seu falecimento ver Brito (1985) e Edição Especial da Revista Veja, n 869A, 01/05/1985.

169 No documento intitulado "Compromisso com a Nação", quando da formalização da aliança entre PMDB e Frente Liberal, ainda em 1984, estabelecia-se que a Aliança, uma vez no governo, "iria reformar a legislação eleitoral de modo a possibilitar a formação de novos partidos" (Folha de S. Paulo, 08/08/1984, p. 5). Da mesma forma, os programas elaborados por PMDB e PFL também previam que nos primeiros meses de governo deveria haver mudanças constitucionais em questões críticas ainda num momento prévio à convocação de uma Constituinte, como no tema da formação dos partidos políticos.

170 Para uma relação dos votos dados pelos parlamentares na votação da Emenda ver Diário do Congresso Nacional, ano XL, $\mathrm{n}^{\circ} 45$ de 09/05/1985.
} 
partidária no país, assim como a quantidade de legendas disputando eleições (Braga, 2010: 50-51, 56; Maciel, 2014: 93) ${ }^{171}$.

De acordo com o artigo sexto da referida Emenda:

"Os partidos políticos que, até a data desta Emenda, tenham tido seus registros indeferidos, cancelados ou cassados, poderão reorganizar-se, desde que atendidos os princípios estabelecidos no 'caput' e itens do art. $152 \mathrm{da}$ Constituição".

Essa medida, ao facultar a organização de partidos cujos registros haviam sido cassados, indeferidos ou cancelados, abria caminho para a organização de novos partidos, o que, desde então, complexificou o quadro partidário brasileiro e trouxe consequências diretas para o PMDB. Se até o início de 1985 na maioria dos estados as disputas eleitorais se mantiveram em torno de, principalmente, PMDB e PDS, com PT, PDT e PTB contando com menor rede organizativa e menor desempenho, a partir de meados de 1985 novos partidos entrariam em cena na política brasileira e passariam a se organizar. No total, até meados de agosto de 1985, foram 31 os partidos que obtiveram o registro definitivo e tornaram-se habilitados para participar das eleições municipais daquele mesmo ano ${ }^{172}$, inflacionando por meio de micro-partidos a oferta partidária no mercado eleitoral (Nicolau 1996 apud Ferreira, Batista e Stabile, 2008: 436) ${ }^{173}$.

Entre os novos partidos que surgiram estavam os partidos comunistas até então clandestinos, que até a promulgação da Emenda haviam optado por se abrigar no interior do PMDB, e um novo partido socialista, aumentando a oferta de partidos localizados no campo da esquerda no espectro político-ideológico.

\subsection{A promulgacão da Emenda Constitucional $n^{\circ}$ 25: novos partidos entram em cena}

"A esquerda tem que formar o seu próprio partido $e$ deixar o PMDB como o partido do centrão." Roberto Cardoso Alves, então Secretário-Geral do $\mathrm{PMDB}^{174}$.

Como dito anteriormente, a Emenda 25 complexificou o sistema partidário brasileiro provocando uma pulverização de novas siglas ${ }^{175}$, o que gerou consequências

\footnotetext{
${ }^{171} \mathrm{O}$ texto original da Emenda encontra-se no site http://www.planalto.gov.br/ccivil_03/Constituicao/Emendas/Emc_anterior1988/emc25-85.htm ${ }_{172}$ Folha de S. Paulo, 16/08/1985, p. 7.

${ }^{173}$ Na visão de Ferreira, Batista e Stabile (2008), a proliferação da criação de novos partidos durante esse período e até o início dos anos noventa pode ser explicado, em grande parte, pelo hiperativismo das elites partidárias diante de um processo de rearranjo das forças políticas após a reforma de partidos.

${ }^{174}$ Folha de S. Paulo - 21/11/1985, p. 2.
} 
diretas para o PMDB. Poucos dias após a sua promulgação, pelo menos oito partidos já haviam publicado seus manifestos, programas e estatutos no Diário Oficial da União ${ }^{176}$, entre eles alguns novos partidos de esquerda. Como dito, essas organizações até então atuavam de maneira clandestina no interior do PMDB, e sua regularização impactou diretamente a composição interna do partido $^{177}$, fazendo com que a sigla passasse a perder gradativamente parte de seus políticos que possuíam um perfil ideológico mais progressista, ou, genericamente dizendo, de esquerda.

Esse processo de perda de políticos para novas agremiações era previsto por alguns políticos do PMDB ainda antes da aprovação da EC 25, como Fernando Henrique Cardoso, então líder do governo no Congresso, que em princípios de 1985 argumentava que:

"Com o avanço do processo democrático, é de esperar que os encarapitados partidos-fermento que vivem nas franjas do PMDB ganhem um lugar ao sol. Será pois o PMDB acossado, por um lado pela tentação de empreguismo, da fisiologia e do burocratismo, e por outro, pela carência de formuladores de proposta a nível partidário não só porque poderá perder quadros à esquerda, como porque boa parte de seus técnicos e intelectuais irá para o aparelho de Estado." (Folha de $S$. Paulo 19/02/1985, p. 3)

É importante destacar que a participação dessas agremiações no interior do PMDB sempre foi objeto de muitas divergências e negociações (Skidmore, 2004: 504). O bloco de políticos considerados moderados quando o partido se encontrava na oposição ao Regime sempre teve ressalvas quanto à atuação desses políticos no interior da sigla. A partir do momento em que a Emenda 25 foi aprovada, o bloco Unidade, que em parte era formado pelos chamados de "moderados" durante o Regime, passou a pressionar para que esses políticos deixassem o PMDB e rumassem para as organizações recém-fundadas ${ }^{178}$, articulando-se com vistas a expandir seu controle sobre a legenda ainda em $1985^{179}$ e torná-lo um partido com feições "de centro"180. Como escreveu à época o deputado federal Roberto Cardoso Alves (SP), um dos portavozes desse bloco no interior do partido, na Revista Veja:

\footnotetext{
${ }^{175}$ Para um resumo da multiplicação de siglas do multipartidarismo brasileiro a partir de 1982 , ver Melo (2010).

${ }^{176}$ Folha de S. Paulo - 12/05/1985, p. 9.

177 Importante destacar que, assim como em relação a muitos dos partidos que são fundados após a Reforma Partidária de 1979, foram encontradas poucas produções acadêmicas de caráter monográfico a respeito da maioria dos partidos fundados imediatamente após a aprovação da Emenda 25 em 1985, exceção feita a uma única obra publicada a respeito do PSB (Paim, 2000) e a três artigos sobre o PCdoB (Sales, 2007, 2008; Costa, 2017). Há ainda grandes lacunas a serem preenchidas na agenda de pesquisa sobre a história dos partidos políticos brasileiros.

${ }^{178}$ Folha de S. Paulo - 19/06/1985, p.6.

${ }^{179}$ Coluna do Castello, Jornal do Brasil, 02/08/1985.

${ }^{180}$ Folha de S. Paulo - 20/06/1985, p.8.
} 
"O PMDB permitiu que sob sua legenda, cedida em comodato, os comunistas pregassem a legalidade dos PCs. Eles agora são legais. Acabou-se a clandestinidade. Agora, cada político deverá lutar abertamente pela sociedade que propõe. $O$ PMDB não admite a dupla militância. A esquerda organizada, portanto, deverá deixar-nos (...).,"181

Como consequência das pressões exercidas por parte desse bloco de políticos ${ }^{182}$ e pelos próprios comunistas ${ }^{183}$ naquele novo contexto pluripartidário gerado pela promulgação da Emenda, começa a desintegrar-se o bloco "progressista" que se localizava no campo mais à esquerda no interior do PMDB. Como dito no capítulo anterior, esse grupo até então era formado por políticos ligados ao PCB, PCdoB, MR-8 e à chamada "esquerda independente", composta por políticos autodenominados "autênticos" ou "autênticos históricos", que não se filiavam a essas organizações, mas se localizavam no mesmo campo no interior do partido ${ }^{184}$. Com a promulgação da Emenda, enquanto os políticos ligados ao MR-8 avaliaram que seria melhor manteremse no interior do $\mathrm{PMDB}^{185}$, os dois partidos comunistas optam por sair da clandestinidade à qual estiveram sujeitos desde 1947 (Fleischer, 2007: 314). Ademais, a organização de um novo partido socialista, o PSB, que contava com quadros de diferentes partidos em sua formação, também fez com que o PMDB passasse a perder políticos para esse novo partido, sendo o PSB um dos três desaguadouros dos políticos do campo da esquerda que saíram do interior do PMDB no período de 1985 a 1987.

De maneira cronológica, o primeiro dos três partidos de esquerda ${ }^{186}$ a ser regularizado e que impactou na composição interna do PMDB é o Partido Comunista

\footnotetext{
181 Roberto Cardoso Alves, Secretário-Geral do PMDB, “Um PMDB sem comunistas", Revista Veja, 31/07/1985, p. 122

182 Ainda em julho de 1985, um dos vice-presidentes do partido (Milton Reis) e um dos vice-líderes na Câmara (José Maria Magalhães) declaram que na próxima reunião do órgão iriam propor a proibição da dupla militância no PMDB (Folha de S. Paulo - 19/07/1985, p. 4).

${ }^{183}$ José Paulo Neto, membro da Comissão Provisória Nacional do PCB declarou à época ao jornal Folha de S. Paulo: "Essa dupla militância - explicou - não nos agrada, porque nos foi imposta pelo regime autoritário. A partir de agora os comunistas devem ingressar no PCB, que é o seu lugar" (Folha de S. Paulo - 03/06/1985, p. 5).

${ }^{184}$ Entre os políticos que se definiam como pertencentes à "esquerda independente", podemos citar Francisco Pinto (BA), João Herrmann (SP), Manoel Costa Junior (MG), Airton Soares (SP), Alencar Furtado $(P R)$, Cristina Tavares (PE), João Gilberto (RS), Egídio Ferreira Lima (PE) e Miguel Arraes (PE), um de seus principais líderes. Sobre os princípios que mantinham unidos os políticos da "Esquerda Independente", ver o artigo "Esquerda Independente", em Folha de S. Paulo - 08/07/ 1985, p. 3, assinado por Márcio Moreira Alves, também um de seus membros.

${ }^{185}$ Como dito em nota do capítulo anterior, o MR-8 mantém-se no interior do partido até o ano de 2011, quando decide sair e fundar um novo partido, o Partido Pátria Livre (PPL). Importante destacar que não há qualquer estudo acadêmico sobre o MR-8 e o seu partido até o momento, mostrando mais uma das lacunas na agenda de estudos sobre os partidos políticos brasileiros.

${ }^{186}$ PCB, PCdoB e PSB são comumente caracterizados pela literatura como partidos de esquerda (Tarouco e Madeira, 2013).
} 
Brasileiro (PCB) ${ }^{187}$. No dia 8 de maio de 1985 , o PCB teve seu programa, estatuto e manifesto publicados no Diário Oficial da União, naquele que seria o primeiro passo a ser dado para a reconquista da legalidade perdida quase 40 anos antes ${ }^{188}$.

A perda de quadros do PMDB para o PCB se deu em todos os níveis de governo e de maneira disseminada por todo território nacional ainda no próprio ano de 1985 . Na Bahia, saem do PMDB e ingressam no PCB o deputado federal Fernando de Santana e o vereador de Salvador Paulo Fábio, que se torna presidente do PCB naquele estado. Em Pernambuco, o deputado federal Roberto Freire, o deputado estadual Hugo Martins, além de Byron Sarinho, então presidente do PMDB pernambucano e que passou a dirigir o PCB naquele estado. Em Brasília, Alberto Muller Lima Torres, presidente do diretório regional do PMDB, deixou o partido. Em São Paulo, o deputado federal Alberto Goldman ${ }^{189}$, o ex-deputado federal Marcelo Gatto (que naquele ano seria o candidato do PCB à prefeitura de Cubatão), o deputado estadual Antônio Rezk, e o vereador por São Paulo e líder sindical Luiz Tenório de Lima. No Rio Grande do Sul, o vereador Lauro Hagemann, importante liderança local e que se torna membro do diretório nacional do PCB. Em Minas Gerais, o então vereador de Belo Horizonte e também Secretário Municipal de Turismo da cidade, Arutana Cobelio Terezia. E por fim, no Rio de Janeiro, com a saída de Modesto da Silveira, ex-deputado federal e então diretor do INCRA.

O PCdoB é o segundo partido de esquerda a sair da clandestinidade no ano de 1985 e se tornar um dos desaguadouros de quadros oriundos do $\mathrm{PMDB}^{190}$. No dia 23 de maio o "novo" partido publica seus documentos fundacionais no Diário Oficial e passa a se organizar nacionalmente, naquilo que pode ser interpretado como um marco para consolidar sua estratégia de adesão aos processos formais de disputa pelo poder e da forma representativa de governo (Santos, 2011: 13). Diferentemente do que houve com o PCB, a saída de políticos do PMDB para ingresso no novo partido foi mais gradual. Desconfiados de que poderia haver um novo retrocesso na legislação partidária e também temendo as dificuldades para eleger parlamentares por meio de um partido

\footnotetext{
${ }^{187}$ Não foi encontrado na literatura de ciência política qualquer estudo que tratasse especificamente do PCB a partir do ano de 1985. Para um histórico do PCB anterior ao golpe de 1964, ver Rodrigues (1983). Para um panorama das organizações políticas de esquerda até 1984 ver Cardoso (1984). Para a atuação do PCB (assim como do PCdoB) no processo constituinte ver Lima (2003). Para a história oficial contada sob a ótica do próprio PCB ver http://pcb.org.br/portal/docs/historia.pdf, acessado em 12/09/2016.

${ }^{188}$ A título de conhecimento, entre os indicados para compor a primeira Comissão Diretora Nacional Provisória nesse novo período de legalidade do partido estão parte dos políticos que faziam parte dela em 1947, como Giocondo Dias e Hércules Correa dos Reis. Compõem ainda o órgão de direção do partido: Almir de Oliveira Neves, Givaldo Pereira de Siqueira, Ivan Martins Pinheiro, José Paulo Netto, Paulo Eliziário Nunes, Régis Savietto Frati, Salomão Malina, Sérgio Augusto de Moraes e Severino Theodoro Melo.

189 O deputado permaneceu no PCB até agosto de 1987, quando retornou ao PMDB para obter maior visibilidade política. O político amargou a perda de uma eleição para deputado federal em 1986, quando obteve boa votação mas não conseguiu eleger-se por falta de votos na legenda, retornando à sua legenda anterior e passando a orbitar em torno do grupo de Quércia até seu rompimento com ele em 1988 (Dicionário Histórico Biográfico Brasileiro do Centro de Pesquisa e Documentação de História Contemporânea do Brasil, CPDOC/FGV, verbete "Alberto Goldman", e Melhem, 1988: 149).

${ }^{190}$ Para um histórico do PCdoB, ver Sales $(2007,2008)$, Santos Jr. (2009) e Costa (2017).
} 
recém-criado ${ }^{191}$, a Conferência Nacional do partido deixa a critério de seus políticos o ingresso imediato ou posterior no PCdoB. Assim, de imediato, o PMDB perde para o PCdoB dois de seus deputados federais: Aurélio Peres (importante sindicalista, eleito por São Paulo) e Haroldo Lima (Bahia). Além disso, ainda no ano de 1985, perde outros políticos em nível local, como Benedito Cintra (deputado estadual em São Paulo) e a vereadora de Salvador Lídice da Mata (eleita deputada federal e constituinte em 1986). Ao longo dos anos seguintes, outros políticos seguem o mesmo caminho: os deputados federais Aldo Arantes (Goiás) e Eduardo Bonfim (AL) se elegem na legenda do PMDB em 1986 mas migram para o PCdoB em fevereiro de $1987^{192}$, assim como Luiz Caetano, que se elege prefeito de Camaçari/BA sob a legenda do PMDB em 1985 mas migra para o PCdoB em 1989.

Por fim, o PSB foi o terceiro partido a ser formado no ano de $1985^{193}$ que contribui para uma perda de quadros à esquerda do PMDB, ainda que em menor escala em comparação ao PCB e PCdoB. Enquanto os dois partidos comunistas citados anteriormente se abrigavam dentro do PMDB de maneira estratégica, o PSB por sua vez é formado em julho de $1985^{194}$ a partir de espólios de três partidos: PDT, PT e $\mathrm{PMDB}^{195}$. Saem do PMDB e ingressam no partido o deputado federal José Luiz Guedes (MG), o ex-deputado Marcelo Cerqueira (RJ, que pertenceu ao grupo dos "autênticos" na Câmara) e o vereador do Rio de Janeiro, Sérgio Cabral. Ademais, ingressaram no PSB um bloco de políticos progressistas do PMDB do Amazonas, que criticavam o controle exercido por políticos vistos por eles como mais conservadores no diretório regional do partido naquele estado (sobretudo Gilberto Mestrinho, que ingressara no PMDB após a incorporação do PP), como os deputados federais Artur Virgílio Neto (que posteriormente viria a ingressar no PSDB) e a deputada federal Beth Azize. O mesmo ocorreu no estado de Pernambuco, onde os peemedebistas progressistas criticavam a indicação de um candidato com perfil mais conservador para concorrer à Prefeitura de Recife em 1985 (Sérgio Murilo Santa Cruz, também um ex-pepista) ${ }^{196}$, o que fez com que o deputado federal Jarbas Vasconcelos migrasse para o PSB para

\footnotetext{
${ }^{191}$ Folha de S. Paulo-09/06/1985, p. 5.

192 Além dos nomes aqui citados, o também Deputado Célio de Castro (MG) atuou durante a ANC dentro do PMDB, mas tendo assumido compromissos de defender as posições do PCdoB (Dicionário Histórico Biográfico Brasileiro do Centro de Pesquisa e Documentação de História Contemporânea do Brasil, CPDOC/FGV, verbete Célio de Castro). O parlamentar porém se manteve no PMDB até se tornar um dos fundadores do PSDB em 1988.

193 Sobre a fundação do PSB, ver Paim (2000).

194 Para um histórico da "refundação" do partido sob sua própria ótica, ver http://www.psb40.org.br/quem-somos/nossa-historia-2/ acessado em 03/9/2018.

${ }^{195}$ Como exemplos de políticos que participaram da fundação do PSB, pode-se citar os pedetistas Jamil Haddad (RJ) e Rogê Ferreira (SP), e os petistas José Eudes (RJ), Paulo Frateschi (SP), entre outros.

${ }^{196}$ Apesar de não estar dentre os objetivos desta tese analisar as eleições daquele ano, a indicação de candidaturas do PMDB para concorrer nas eleições para as capitais de alguns dos estados nos quais concorreria em 1985 parece ter seguido o mesmo caminho de Recife, com indicações de candidatos com perfil mais conservador do interior do PMDB. Foi o caso, por exemplo, de Rio de Janeiro, Goiânia, Florianópolis e Salvador (Folha de S. Paulo - 10/07/1985, p. 2).
} 
concorrer e vencer a eleição à Prefeitura por essa sigla ${ }^{197}$, ainda que depois tenha retornado ao PMDB durante o seu mandato ${ }^{198}$.

Como consequência desse processo de perda de políticos do campo da esquerda do PMDB, alterava-se a correlação de forças no interior do partido ${ }^{199}$, que viu uma diminuição do seu campo mais progressista ${ }^{200}$. Ao analisar esse processo, o senador Cássio Cunha Lima (PB) o compara a algo, segundo ele, ocorreria décadas depois com o PT:

"Então a gente perde, de fato, um segmento mais à esquerda, como aconteceu com o próprio PT. Mais adiante, alguns anos à frente, o PT perdeu seu segmento mais à esquerda para o PSOL. (...) O PT terminou, em dado momento, sendo a grande frente de esquerda brasileira e depois se fragmentou. O mesmo aconteceu com o PMDB. Aí você tem um eixo mais de centro principalmente pela força de atração do governo. "201

Para além de uma mudança na sua correlação de forças, para o deputado Saraiva Felipe (MG) a saída desses políticos também teria resultado numa perda de sua consistência e de sua combatividade ${ }^{202}$, reflexo da saída de filiados identificados com o partido e que eram responsáveis por assumir responsabilidades nas campanhas eleitorais. O deputado Ubiratan Aguiar (CE) comenta sobre esse aspecto em entrevista de 1991, enquanto era membro da Executiva Nacional do partido:

"A Executiva [Nacional] avaliou que o PMDB ficou sem militantes desde 1985, quando os partidos clandestinos que se abrigavam dentro do PMDB foram legalizados. 'Sem o PCB e o PCdoB ficamos sem militância,", 203

Porém, na perspectiva de um dos secretários do partido, o deputado Roberto Cardoso Alves, representante de sua ala mais à direita, o partido se tornaria a partir de então "uma poderosa força de centro" no país. Um partido de centro olhando para a esquerda, dada a permanência em seu interior da chamada "esquerda independente",

\footnotetext{
197 Jarbas Vasconcelos, em entrevista ao autor, alegou que foi uma das decisões mais difíceis que já tomou em sua trajetória política.

198 Outra importante perda do PMDB para o PSB foi Miguel Arraes, político histórico da ala autêntica do PMDB, que migrou para seu novo partido apenas em 1990.

${ }^{199}$ Flaviano Melo, em entrevista concedida ao autor.

${ }^{200}$ Sônia Carneiro e Saraiva Felipe, em entrevistas ao autor.

${ }^{201}$ Entrevista ao autor.

202 Saraiva Felipe, em entrevista ao autor.

${ }^{203}$ Folha de São Paulo - 05/6/1991 - p.4. Figueiredo (2009: 97) aponta o mesmo aspecto.
} 
que teria as mesmas postulações do "centro", mas que apenas teria mais pressa para alcançar os mesmos objetivos ${ }^{204}$.

Ponto de vista distinto é apresentado pelo deputado Jarbas Vasconcelos (PE), remanescente da ala dos autênticos. Para ele, a aprovação da Emenda e seu impacto direto no PMDB com a legalização dos partidos clandestinos se inseriam numa estratégia anterior, do próprio Regime Militar, de pulverizar as forças de oposição em distintos partidos (tal como ocorrera com a Reforma Partidária de 1979). Segundo o político, com a flexibilização das regras para a formação de novos partidos "a intenção podia ser clara, lógica, nobre, de criar um pluripartidarismo, mas a intenção real não era essa. A intenção era dividir"205.

Para além desta segunda onda de evasão de quadros do PMDB, que quando comparada à primeira notamos que ela se deu mais à esquerda do que à direita do partido, há uma segunda medida implementada por meio da aprovação da Emenda 25 que também teria impacto na composição interna do PMDB. Tratou-se da queda da exigência de fidelidade partidária. A medida teve como consequência a entrada de políticos no PMDB que almejavam descolar sua imagem do moribundo Regime Militar e que se beneficiaram dessa brecha para entrar em um partido que se encontrava no governo federal e em ascensão eleitoral ${ }^{206}$. Esse grupo, formado por políticos que chamaremos de "pragmáticos", reforçou a ala mais à direita no interior do PMDB, que já tivera suas fileiras reforçadas a partir da incorporação do PP em 1982, aspecto este que será analisado no próximo tópico.

\subsection{Os "pragmáticos" crescem e ganham terreno nos órgãos de decisão do partido e no governo (1985-1986)}

“(...) Os moderados passaram e ter peso quando os moderados pegaram os ministérios do Sarney, os cargos do Sarney, e foi a época que começou o troca-troca do 'é dando que se recebe'." Pedro Simon, em entrevista ao autor.

\footnotetext{
${ }^{204}$ Revista Veja, 31/07/1985, p. 122. Flávio Bierrenbach, deputado federal do PMDB/SP, criticava as articulações que vinham sendo feitas por Roberto Cardoso Alves argumentando que "O que ele quer, na verdade, é recriar o PP, o último partido clandestino no Brasil." - Folha de S. Paulo, 24/11/1985, p. 2.

205 Jarbas Vasconcelos, em entrevista ao autor. A mesma visão à época parecia ser compartilhada por outros integrantes do partido representantes do seu bloco mais à esquerda, como Hugo Perez, integrante do Diretório Nacional do partido, que declara que "Tancredo quer limpar o PMDB legalizando os partidos clandestinos" (Jornal do PMDB SP, fevereiro de 1985, p.11). De fato, segundo Ronan Tito, o General Golbery do Couto e Silva, que havia sido um dos principais estrategistas do Regime e um interlocutor de Tancredo na cúpula militar, havia sugerido a ele anos antes para "se livrar dos comunistas", que, em contrapartida, "trabalharia por ele" na cúpula do Exército (Fundação Ulysses Guimarães, 2013: 21).

206 "Se a ARENA dá voto, a maioria vai pra lá. Se o PMDB dá voto, a maioria vem.", Tonico Ramos, em entrevista ao autor.
} 
Após a legalização dos dois partidos comunistas e da fundação do PSB, o PMDB passa a ter uma nova correlação de forças em seu interior, que já vinha em transformação desde a sua $3^{\mathrm{a}}$ Convenção Nacional, como apontado no capítulo anterior. Sua ala mais à esquerda, após perder políticos para as novas agremiações formadas, seria integrada a partir de então apenas pela chamada "esquerda independente", que perde espaço. Ademais, a partir da queda da exigência de fidelidade partidária estabelecida pela Emenda 25, há outro movimento que impacta diretamente o partido.

A partir daquele momento, no qual o PMDB pela primeira vez em sua história se encontrava na presidência da República, teve início uma nova onda de entrada de políticos, vistos como "pragmáticos". Ela surge como resultado de um processo de reacomodação de forças dentro do Congresso, com trocas de partido se dando mais em direção a PMDB e PFL, partidos que a partir de então estariam na coalizão governista (Araújo, 2000: 34-35) ${ }^{207}$. Apenas de fevereiro de 1985 a julho de 1986, período no qual não houve eleições, a bancada do PMDB no Congresso como um todo passou de 224 para 246 parlamentares (Mainwaring, 2001: 142) ${ }^{208}$, muitos dos quais ex-pedessistas ${ }^{209}$. Com a entrada desses novos filiados teve início o que parte da literatura e alguns políticos apontaram como sendo o "inchaço" do partido (Lamounier, 1989: 52; Araújo, 2000: 35), compreendido como a entrada no PMDB de quadros não comprometidos com o seu programa, que levaram ao seio do partido ex-arenistas e pedessistas "fiéis até a undécima hora" (Couto, 1997: 35) ${ }^{210}$.

As observações feitas pelos deputados Celso Maldaner (SC) e Miro Teixeira (RJ) sobre a entrada desses políticos no PMDB a partir daquele momento expressam o ponto de vista a respeito daquele processo por parte dos peemedebistas que já se encontravam no partido:

"Aí o MDB começou, claro, com a eleição indireta que houve no Colégio Eleitoral, o Tancredo aceitou, aí veio o Sarney e assumiu, e começou um inchaço natural. Virou governo, aí vieram os interesseiros. Muita gente entrou e ai se tornou o maior partido do Brasil." Deputado Celso Maldaner, em entrevista ao autor.

"Curiosamente o $P M D B$ se descaracterizou sem precisar da ajuda de ninguém! Não foi a incorporação do PP ao

\footnotetext{
207 "Aí você tem um eixo mais de centro principalmente pela força de atração do governo. Por exemplo, a Presidência da República era do PMDB, na época José Sarney, com sua trajetória mais conservadora, mais de centro, digamos assim(...)", Cássio Cunha Lima, em entrevista ao autor.

${ }^{208}$ Em entrevista ao autor, Bresser-Pereira, Ministro do governo Sarney, afirmou que "o PMDB chegou ao poder em 1985, 1986. Aí ele era um partido de massa, onde tinha de tudo um pouco. O partido que tinha se identificado com a transição democrática tinha sido o PMDB e tiveram uma vitória. Quando se fica poderoso e se chega ao governo de tal modo, é fácil se corromper. É inevitável e atrai muita gente". 209 No Senado, até agosto de 1985, já eram oito senadores que haviam ingressado no PMDB provenientes do PDS - Folha de S. Paulo - 04/08/1985, p. 16.

${ }^{210}$ A título de curiosidade, um dos ingressantes no PMDB neste período é o ex-arenista Fernando Collor de Mello, futuro governador do estado de Alagoas por meio da sigla e futuro Presidente da República, eleito em 1989.
} 
PMDB. Foi a filiação de quadros muito envolvidos com o golpe militar de 64. Foi essa filiação que começou a descaracterizar muito o PMDB. Porque o Tancredo e o Ulysses já conviviam antes. Tancredo e Ulysses conviviam desde o PSD, conviveram desde o parlamentarismo, de João Goulart. Tancredo foi Primeiro-Ministro, Ulysses foi ministro... Enfim, (...), a questão é que muita gente viu ali a oportunidade de resolver até [mais as] questões locais do que discussões nacionais, para se distanciar de velhas alianças e fazer novas alianças e se reinventar com a sigla $P M D B$. ” Deputado Miro Teixeira, em entrevista ao autor.

No entanto, como destacamos no capítulo anterior, cabe apontar que, diferentemente do ponto de vista do deputado Miro Teixeira, o ingresso de quadros provenientes de partidos à direita do PMDB representa a continuidade de um processo anterior. A incorporação do PP em 1982, se por um lado "compensou" a perda de políticos para as novas siglas de esquerda, por outro contribuiu para que houvesse um primeiro aumento significativo de políticos com ligações com o Regime Militar, dando início ao processo aqui descrito.

Cabe ressaltar ainda que no primeiro trimestre de 1985, 74 deputados deixaram o PDS oficialmente para fundar o PFL, contingente que posteriormente seria engrossado por outros 75 parlamentares que tomaram o mesmo caminho (Araujo, 2000: 32). Esse processo de migrações partidárias, atrelado ao crescimento do PMDB no período, fez com que o partido se tornasse pela primeira vez em sua história o detentor da maior bancada na Câmara dos Deputados, fenômeno que iria se repetir em outros momentos a partir de então. No mesmo período, em fevereiro, o PMDB também chegava pela primeira vez à presidência das duas Casas do Poder Legislativo (Fleischer, 2007: 314), outro fenômeno que iria se repetir mais vezes. Na Câmara dos Deputados, Ulysses Guimarães (SP) é quem assume o posto, enquanto que no Senado o cargo seria ocupado por um ex-pepista e ex-arenista, o Senador José Fragelli (MT) ${ }^{211}$.

Para além do "inchaço" verificado em suas bancadas no Poder Legislativo, uma vez no governo federal o PMDB e a Aliança Democrática (formada também pelo PFL) passaram a ocupar o Poder Executivo. Durante todo o mandato de José Sarney na presidência (1985-1990), no total, o PMDB ocupou 52\% dos ministérios e secretarias especiais com status de ministério (Oliveira, 2012: 102). A distribuição de cargos nos ministérios ocupados por peemedebistas evidencia mais uma vez o quanto os políticos do bloco Unidade, muitos dos quais provenientes do PP e com passagem pela ARENA passaram a ocupar espaços de proeminência por meio do partido ${ }^{212}$. Como exemplo,

${ }^{211}$ Folha de S. Paulo - 28/02/1985, p.1; 01/03/1985, pp 4-5.

${ }^{212}$ Em entrevista ao autor, Pedro Simon afirmou que "o Tancredo morreu e deixou o Sarney, e o Sarney foi um governo... e ele foi um Presidente da República, e os moderados passaram a ter peso quando os moderados pegaram os ministérios do Sarney, os cargos do Sarney, e foi a época que começou o trocatroca do 'é dando que se recebe'. O grupo do Sarney para pegar os caras, trazia os caras dando ministério, as emendas, e aí começou e não parou mais". 
Roberto Gusmão (ex-PP) torna-se Ministro de Indústria e Comércio; Carlos Santana (ex-PP, ex-ARENA), Ministro da Saúde, substituído posteriormente por Roberto Santos (ex-PP, ex-ARENA) ${ }^{213}$; Olavo Setúbal (ex-PP, ex-ARENA), Ministro de Relações Exteriores; Aluisio Alves (ex-PP e ex-ARENA) Ministro da Administração; Afonso Camargo (ex-PP, ex-ARENA), Ministro dos Transportes; e Raphael de Almeida Magalhães (ex-ARENA), Ministro da Previdência Social ${ }^{214}$.

Esse processo era notado e preocupava outras alas do partido ${ }^{215}$. O Senador e líder do partido no Congresso Fernando Henrique Cardoso argumentava à época que:

"Dizendo de modo direto: o PMDB, uma vez no governo, deve evitar o risco de tornar-se um 'Arenão', de inchar, de virar partido apoiado na burocracia. Sua dinâmica requer permanentemente a ação de grupos internos a ele que sejam 'autênticos', ideológicos, que esgrimam ideias e ideais capazes de transformar a sociedade."

Entretanto, essa mesma ala de políticos passa a ganhar terreno não só no governo Sarney e nas bancadas do partido, mas também nos órgãos de direção do PMDB, dando continuidade ao processo verificado no capítulo anterior.

Com relação à composição da sua CEN, que havia passado por transformações em 1982 com a entrada dos ex-pepistas e em 1983 com a formação do bloco Unidade, pode-se observar um gradual aumento do número de políticos com passagem pela ARENA nesse órgão. Enquanto no momento de sua fundação o PMDB possuía apenas um político ex-arenista na sua Executiva (Teotônio Vilela), na sua Convenção Nacional realizada em 1986 (a 5 a) já eram cinco os políticos com passagem pela ARENA. Com destaque para Affonso Camargo (ex-PP e ex-ARENA), e Roberto Cardoso Alves (exARENA), que durante o ano de 1985, por conta da ida de alguns políticos da Executiva para o Poder Executivo Federal, exercem o cargo de Secretário-Geral do partido. Para além dos ex-arenistas, os políticos vistos como aqueles com perfis mais à direita no PMDB (mesmo aqueles que não foram em algum momento filiados à ARENA ou ao PDS) também obtêm destaque. Exemplo disso é o acordo tácito firmado a partir de 1986 que colocou, a partir de então, a Secretaria Geral do partido (importante espaço para o núcleo decisório da máquina partidária) sempre sob o comando de um político de Minas

\footnotetext{
213 Roberto Santos é um perfeito exemplo de um político "duro", forte defensor do Regime, e que passou à sua oposição quando o apoio social ao Regime Militar já estava em franco declínio. Durante o seu mandato de governador da Bahia, indicado por Ernesto Geisel (1975-1979), a Polícia Militar, a seu mando, enviou cães para reprimir uma manifestação convocada pelo MDB que contaria com a presença de Ulysses Guimarães. Ambos, depois, seriam correligionários no PMDB.

214 Sobre a composição dos ministérios determinada por Tancredo antes de sua morte ver http://www.fgv.br/cpdoc/acervo/arquivo-pessoal/CTN/textual/documentos-que-tratam-dacomposicao-do-ministerio-do-governo-tancredo-neves-que-se-iniciaria-a-15-de-marco-de-1985reunem-indicacoes-de-nomes-e-os .

215 "Até mesmo pedaços grandes da antiga ARENA estão ocupando espaços junto ao futuro governo Tancredo Neves e isso nos preocupa", José de Alencar - Jornal do PMDB SP, fevereiro de 1985, p. 11.

${ }^{216}$ Folha de S. Paulo - 19/02/1985, p. 3.
} 
Gerais (Ribeiro, 2014: 140) 217 $^{17}$ estado no qual o campo proveniente do PP era hegemônico desde após a incorporação do partido em 1982.

Tabela 17. Filiação prévia dos membros da Executiva Nacional do PMDB (1980-1989)

\begin{tabular}{|c|c|c|c|c|c|c|c|c|}
\hline & \multicolumn{2}{|c|}{$1980-1982$} & \multicolumn{2}{|c|}{$1982-1983$} & \multicolumn{2}{|c|}{ 1983-1986 } & \multicolumn{2}{|c|}{ 1986-1989 } \\
\hline & $\mathbf{N}$ & $\%$ & $\mathbf{N}$ & $\%$ & $\mathbf{N}$ & $\%$ & $\mathbf{N}$ & $\%$ \\
\hline ARENA & 1 & $5 \%$ & 4 & $20 \%$ & 4 & $20 \%$ & 5 & $25 \%$ \\
\hline MDB & 19 & $95 \%$ & 16 & $80 \%$ & 16 & $80 \%$ & 15 & $75 \%$ \\
\hline Total & 20 & 100 & 20 & $100 \%$ & 20 & $100 \%$ & 20 & $100 \%$ \\
\hline
\end{tabular}

Fontes: elaboração própria a partir de dados levantados no acervo do TSE com cruzamento de informações coletadas no Centro de Pesquisa e Documentação de História Contemporânea do Brasil (CPDOC-FGV).

Para além das informações a respeito dos órgãos de direção do partido, os dados disponíveis das eleições de 1986 nos permitem mensurar tanto o crescimento do PMDB no momento em que ele atinge seu melhor desempenho eleitoral quanto explorar o tamanho de sua ala ex-arenista, tal como fizemos com relação a 1982, como reflexo do seu chamado "inchaço". O fenômeno é pouco explorado, ou mesmo ignorado, pela literatura acerca do PMDB e, como dito anteriormente, havia se iniciado ainda em 1982, quando da incorporação do Partido Popular (Mucinhato, 2015).

\subsection{O partido cresce e "incha" nas urnas: panorama geral do PMDB nas eleicões de 1986}

"O inchaço foi muito provocado pelo resultado das eleições de 86. O PMDB elegeu, salvo erro de memória, 26 dos 27 governadores. Acho que só não ganhou em Sergipe. (...) O resto, elegeu. Os governadores todos do Brasil eram do PMDB, fruto do sucesso do Plano Cruzado, aquela comoção com a morte de Tancredo. Fizemos maioria absoluta na Câmara e no Senado. Então o inchaço do PMDB foi em decorrência do espólio que o partido recebeu de combate à ditadura." Senador Cássio Cunha Lima, em entrevista ao autor.

De maneira geral, os dados apontam que os resultados eleitorais do ano de 1986 foram fortemente favoráveis ao PMDB. Naquelas que foram as primeiras eleições

\footnotetext{
${ }^{217}$ Como se pode ver no Anexo 3, com apenas uma exceção (João Henrique/PI), todas as gestões formadas desde então até o final dos anos 2000 tiveram no cargo apenas deputados federais mineiros, alguns dos quais entrevistados para esta pesquisa. Pela ordem: Milton Reis, Tarcísio Delgado, Joaquim de Mello Freire, Maria Elvira, Marcos Lima, Saraiva Felipe e Mauro Lopes - os dois últimos tendo sido entrevistados. Sobre a primeira eleição que conduziu ao cargo um peemedebista mineiro, em 1986, ver Folha de S. Paulo - 06/04/1986, p.6.
} 
realizadas após a flexibilização das regras eleitorais e partidárias (o que aumentou consideravelmente a oferta de siglas disputando o pleito em comparação às eleições de $1982^{218}$ ), o partido obteve o melhor desempenho eleitoral de sua história, aumentando consideravelmente a quantidade de cargos conquistados em relação ao seu primeiro teste nas urnas, em 1982. Além de conquistar quase todos os cargos de governador de estado do país, o PMDB aumentou a sua quantidade de parlamentares tanto na Câmara dos Deputados quanto no Senado Federal, o que fez com que o partido detivesse a maior bancada partidária em ambas as Casas pela primeira vez em sua história. Esse gigantismo gerou até temores em outros setores da política nacional ${ }^{219}$ e também do PFL, o outro partido integrante da Aliança Democrática, que alertava que a extensão da vitória peemedebista traria como consequência o risco de "mexicanização" do país $\left(\right.$ Sadek, 1989b) ${ }^{220}$.

Esse desempenho do PMDB em 1986 também teria consequências posteriores, por conta do Congresso Constituinte que se estabeleceria no ano seguinte.

A convocação de uma Assembleia Nacional Constituinte (ANC), que viria a se reunir futuramente durante os anos de 1987-1988, era um dos compromissos assumidos pela Aliança Democrática, e teve seu formato definido ainda em 1985. Em junho desse ano, o governo Sarney havia enviado ao Congresso uma proposta de Emenda Constitucional prevendo a concessão de poderes constituintes ao Congresso Nacional a ser eleito em novembro de 1986. Após disputa congressual em torno de qual seria a versão final da convocação, a proposta de uma Constituinte Congressual foi aprovada e tornou-se a Emenda Constitucional no 26 , promulgada em 27 de novembro de $1985^{221}$. Com a sua aprovação, os parlamentares eleitos tanto para a Câmara dos Deputados quanto para o Senado Federal em 1986 se reuniriam em uma única Câmara, a Assembleia Nacional Constituinte, até que a elaboração de uma nova Constituição fosse concluída.

Cabe apontar que a luta pela instauração de uma ANC havia sido uma bandeira histórica do extinto MDB desde os anos 1970. Em 1977 o partido havia publicado o "Manual da Constituinte" e em 1978 o documento "Constituinte com Anistia", documentos programáticos que apontavam as diretrizes pelas quais o partido lutaria dentro da institucionalidade do regime. Com a transição democrática e o fim do Regime Militar, caberia ao PMDB concretizar a pauta do seu antecessor.

Ademais, fator importante a ser levado em conta e que teve impacto direto no desempenho do PMDB nas eleições de 1986 foi a conjuntura econômica do país. Estava

\footnotetext{
${ }^{218}$ Sobre esse aspecto ver Braga (2010).

${ }^{219}$ Folha de S. Paulo - 18/11/1986, p. A-5.

${ }^{220}$ A comparação com o México se dava por conta da existência do Partido Revolucionário Institucional (PRI) naquele país da América Central, que havia se tornado hegemônico no seu sistema partidário, praticamente monopolizando os espaços de poder durante décadas. Sobre o PRI ver Vázquez (2003).

${ }^{221}$ A lei em sua íntegra encontra-se disponível no site http://www.planalto.gov.br/ccivll_03/Constituicao/Emendas/Emc_anterior1988/emc26-85.htm acessado em 10/09/1985. Para o contexto em torno da aprovação da Emenda ver Rocha (2013).
} 
em vigor durante aquele pleito o chamado "Plano Cruzado", que consistia em um conjunto de medidas adotadas pelo governo federal em fevereiro daquele ano que haviam sido elaboradas visando a estabilização da economia. O Plano até então vinha obtendo grande sucesso, conseguindo controlar a escalada inflacionária que o país vivera até o final de 1985 por meio do congelamento de preços e salários e do estabelecimento de uma nova moeda, o Cruzado ${ }^{222}$. Assim, graças aos efeitos do Plano, o PMDB gozava de elevadíssima popularidade (Rocha, 2013: 68) no momento em que as eleições se realizaram, tendo impacto direto nos resultados daquele pleito ${ }^{223}$.

Nesse sentido, dos 23 candidatos a governador lançados pelo partido, 22 foram eleitos, ainda que com uma margem de votos pequena perante seus concorrentes em alguns estados. O PMDB apenas não elegeu o governador de Sergipe, onde o vitorioso foi Antônio Carlos Valadares, do PFL. Nesse sentido, cabe destacar que muitos dos seus candidatos vitoriosos naquelas eleições não tiveram uma trajetória partidária que os levou ao PMDB por meio da extinção do MDB em 1979. Dentre os candidatos vitoriosos peemedebistas, sete $(31,8 \%)$ haviam tido passagem ou pelo PDS ou pela ARENA durante o Regime Militar ${ }^{224}$, muitos dos quais se beneficiaram da flexibilização das regras de fidelidade partidária para ingressar no PMDB. Além destes casos, deve-se citar também a indicação de outros candidatos peemedebistas de perfil mais pragmático, como Amazonino Mendes, candidato no Amazonas, um quadro indicado pelo governador Gilberto Mestrinho (ex-pepista), assim como Orestes Quércia, em São Paulo ${ }^{225}$. Portanto, assim como os resultados das eleições de 1982 levaram a literatura a concluir que o PMDB em sua faceta mais conservadora vencera aquelas eleições (Lima, 2009: 45), a mesma conclusão pode ser aplicada em relação aos resultados eleitorais obtidos pelo partido em $1986^{226}$.

\section{Tabela 18. Governadores eleitos em 1986}

\begin{tabular}{lcc}
\hline Região/Estado & Eleito & Partido \\
\hline Norte & Flaviano Melo & PMDB \\
$\begin{array}{l}\text { Acre } \\
\text { Amazonas }\end{array}$ & $\begin{array}{c}\text { Amazonino } \\
\text { Mendes }\end{array}$ & PMDB \\
$\begin{array}{l}\text { Pará } \\
\text { Rondônia } \\
\text { Nordeste }\end{array}$ & Hélio Gueiros & PMDB \\
\hline
\end{tabular}

\footnotetext{
222 Para mais detalhes sobre o Plano Cruzado, como o conjunto completo de medidas que foram adotadas, ver Marques (1988) e Averbug (2005).

${ }^{223}$ Para um panorama geral das eleições de 1986 ver Sadek (1989c).

${ }^{224}$ Entre os outros 15 peemedebistas vitoriosos, treze (59,1\% do total de peemedebistas eleitos) tiveram passagem pelo MDB durante o período de 1966 a 1979 e dois deles (9,1\% - Amazonino Mendes e Tasso Jereissati) não tiveram qualquer filiação prévia anterior à sua entrada no PMDB.

${ }^{225}$ Sobre a candidatura de Quércia em São Paulo, ver Melhem (1998) e Bizzarro Neto (2013).

${ }^{226}$ Além de as evidências nesta seção apontarem nesse sentido, Jarbas Vasconcellos, em entrevista ao autor, também afirmou que a vitória nas eleições de 1986 foi uma vitória amplamente dos conservadores.
} 


\begin{tabular}{|c|c|c|}
\hline Alagoas & $\begin{array}{l}\text { Fernando Collor } \\
\text { de Mello** }\end{array}$ & PMDB \\
\hline Bahia & Waldir Pires & PMDB \\
\hline Ceará & Tasso Jereissati & PMDB \\
\hline Maranhão & Epitácio Cafeteira & PMDB \\
\hline Paraíba & Tarcísio Buriti** & PMDB \\
\hline Pernambuco & Miguel Arraes & PMDB \\
\hline Piauí & Alberto Silva*** & PMDB \\
\hline $\begin{array}{l}\text { Rio Grande do } \\
\text { Norte }\end{array}$ & Geraldo Melo** & PMDB \\
\hline Sergipe & $\begin{array}{c}\text { Antônio Carlos } \\
\text { Valadares** }\end{array}$ & PFL \\
\hline \multicolumn{3}{|l|}{ Centro-Oeste } \\
\hline Goiás & Henrique Santillo & PMDB \\
\hline Mato Grosso & Carlos Bezerra & PMDB \\
\hline $\begin{array}{l}\text { Mato Grosso do } \\
\text { Sul }\end{array}$ & $\begin{array}{c}\text { Marcelo } \\
\text { Miranda*** }\end{array}$ & PMDB \\
\hline \multicolumn{3}{|l|}{ Sudeste } \\
\hline Minas Gerais & Newton Cardoso* & PMDB \\
\hline Espírito Santo & Max Mauro & PMDB \\
\hline Rio de Janeiro & $\begin{array}{c}\text { Moreira } \\
\text { Franco**** }\end{array}$ & PMDB \\
\hline São Paulo & Orestes Quércia & PMDB \\
\hline \multicolumn{3}{|l|}{ Sul } \\
\hline Paraná & Álvaro Dias & PMDB \\
\hline Rio Grande do Sul & Pedro Simon & PMDB \\
\hline Santa Catarina & Pedro Ivo & PMDB \\
\hline
\end{tabular}

Fontes: múltiplas fontes jornalísticas, com cruzamento de informações do Dicionário Histórico Biográfico Brasileiro do Centro de Pesquisa e Documentação de História Contemporânea do Brasil, CPDOC/FGV

*Ex-pepistas

**Ex-arenistas

***Ex-arenista e ex-pepista $* * * *$ Ex-PDS

Por sua vez, em relação ao resultado das eleições para as Assembleias Legislativas (ALs), o PMDB obteve um desempenho eleitoral muito acima das outras legendas. O partido conquistou 448 assentos no total, quase o dobro das cadeiras obtidas pelo outro partido integrante da Aliança Democrática, o PFL, que obteve 233. O PDS, que até 1985 era o partido governista, obteve apenas 90 assentos, desempenho muito aquém do apresentado pelos partidos governistas da conjuntura. Por sua vez, dos demais partidos que obtiveram representação parlamentar nessa esfera, os outros três a obter mais cadeiras foram partidos organizados a partir da reformulação partidária de 1979: PDT obteve 62, PTB 43, e o PT 39 parlamentares. Em seguida, dividindo os assentos restantes, encontravam-se partidos que haviam se organizado a partir da promulgação da $\mathrm{EC}^{\circ} 25$, compondo a lista completa reproduzida na tabela abaixo. 


\section{Tabela 19. Cadeiras obtidas, percentual do total de cadeiras e votação total por partido nas eleições para as Assembleias Legislativas em 1986}

\begin{tabular}{lccc}
\hline Partido & Cadeiras obtidas & $\%$ & Total de votos \\
\hline PMDB & 448 & 47,0 & 20.376 .778 \\
PFL & 233 & 24,4 & 8.349 .348 \\
PDS & 90 & 9,4 & 4.291 .044 \\
PDT & 62 & 6,5 & 3.652 .173 \\
PTB & 43 & 4,5 & 2.859 .852 \\
PT & 39 & 4,1 & 2.901 .375 \\
PDC & 11 & 1,2 & 658.550 \\
PL & 8 & 0,8 & 949.192 \\
PSB & 5 & 0,5 & 558.375 \\
PMB & 5 & 0,5 & 281.753 \\
PCdoB & 3 & 0,3 & 310.839 \\
PTR & 2 & 0,2 & 146.061 \\
PASART & 2 & 0,2 & 114.713 \\
PMN & 1 & 0,1 & 57.397 \\
PTN & 1 & 0,1 & 45.761 \\
Outros & - & - & 1.276 .230 \\
partidos & & 100 & \\
TOTAL & 953 & & 46.829 .441 \\
\hline
\end{tabular}

Fonte: Nicolau (1998)

Em se tratando dos resultados das eleições para o Congresso Nacional, que, como dito anteriormente, levariam à composição da ANC que se reuniria a partir de 1987, os resultados demonstram a hegemonia adquirida pelo PMDB na esfera legislativa a partir de então. Antes de passarmos aos resultados, cabe apontar que a quantidade de cargos eletivos em relação às eleições de 1982 aumentara, por conta dos primeiros parlamentares escolhidos para representar o Distrito Federal (três senadores, dos quais os dois mais votados teriam mandato de oito anos e o terceiro um mandato de quatro anos, e oito deputados federais). A mudança também estava incluída no conjunto de medidas implementadas por meio da Emenda Constitucional $n^{\circ} 25$.

Com relação às eleições para o Senado Federal, seriam 49 as cadeiras em disputa naquelas eleições, renovando os 2/3 de senadores eleitos em 1978 (dos quais a metade havia sido nomeada de maneira indireta - os já mencionados "senadores biônicos"), mais os parlamentares que pela primeira vez representariam o Distrito Federal. Dessas 49 cadeiras em disputa o PMDB elegeu 38 senadores. Este resultado mais que dobrou o tamanho da bancada do partido, aumentando de $30 \%$ para $62,5 \%$ a sua representação naquela Casa, ao alcançar um total de 45 senadores. A partir de então o partido se tornava pela primeira vez em sua história aquele a deter mais cadeiras na Câmara Alta.

Da mesma forma, na Câmara dos Deputados sua representação também aumentou, consolidando o partido também na Câmara Baixa como o detentor da maior bancada. O partido passava de 200 deputados eleitos em 1982 para 260 parlamentares 
após as eleições de 1986, detendo mais da metade das cadeiras e aumentando de $41,8 \%$ para $53,4 \%$ o tamanho de sua bancada. Os resultados também mostram uma maior pulverização de siglas em comparação aos resultados eleitorais de 1982, efeito da $E C \mathbf{n}^{\circ}$ 25 , que havia sido aprovada ainda em 1985. Dos trinta partidos que participaram do pleito, treze conseguiram eleger pelo menos um representante para a Constituinte (Rocha, 2013: 69).

\section{Tabela 20. Tamanho das bancadas partidárias na Câmara dos Deputados e no Senado Federal após as eleições de 1986}

\begin{tabular}{lcccc}
\hline & \multicolumn{2}{c}{ Senado Federal } & \multicolumn{2}{c}{$\begin{array}{c}\text { Câmara dos } \\
\text { Deputados }\end{array}$} \\
\hline Partido & $\mathbf{N}$ & $\%$ & $\mathbf{N}$ & $\%$ \\
\hline PMDB & 45 & $62,5 \%$ & 260 & $53,4 \%$ \\
PFL & 15 & $20,8 \%$ & 118 & $24,2 \%$ \\
PDS & 5 & $6,9 \%$ & 33 & $6,8 \%$ \\
PDT & 2 & $2,8 \%$ & 24 & $4,9 \%$ \\
PTB & 1 & $1,4 \%$ & 17 & $3,5 \%$ \\
PT & - & - & 16 & $3,3 \%$ \\
PL & 1 & $1,4 \%$ & 6 & $1,2 \%$ \\
PDC & 1 & $1,4 \%$ & 5 & $1 \%$ \\
PCB & - & - & 3 & $0,6 \%$ \\
PCdoB & - & - & 3 & $0,6 \%$ \\
PSB & 1 & $1,4 \%$ & 1 & $0,2 \%$ \\
PSC & - & - & 1 & $0,2 \%$ \\
PMB & 1 & $1,4 \%$ & - & - \\
Total & 72 & $100 \%$ & 487 & $100 \%$ \\
\hline
\end{tabular}

Fontes: elaboração própria a partir do cruzamento de dados fornecidos pelo CEDI, Nicolau (1998), e Mainwaring (2001).

Apesar do desempenho do partido nessas eleições ter sido superior àquele obtido nas de 1982, deve-se destacar que o processo notado naquelas eleições, a saber, o aumento da proporção de parlamentares eleitos com histórico de filiação partidária à ARENA ou ao PDS, seguia em curso. Como apontado por Sadek (1989a: 67), não havia como negar que, em muitos casos, os eleitos em 1986 tratavam-se de lideranças com tênues compromissos com as propostas históricas do PMDB. Esses eleitos, em última instância, falsearam a maioria obtida pelo partido no novo Congresso (Mainwaring, 2001: 142), levando ao que o deputado estadual Tonico Ramos (SP) chamou de "um crescimento falso do partido"227.

Com relação à Câmara dos Deputados, dentre os 260 parlamentares que foram eleitos pelo PMDB, 58 (22,3\%) fizeram parte da ARENA ou do PDS. Entre eles alguns ferrenhos defensores do Regime Militar, como Nelson Gibson (PE), e Prisco Viana (BA), este último ex-Secretário-Geral da ARENA e do PDS, que personificavam a contra-face das bandeiras históricas do partido (Sadek, 1989b: 113). Somados aos 17 ex-pepistas da bancada que não foram arenistas (tendo sido eles em sua maioria ex-

\footnotetext{
${ }^{227}$ Entrevista ao autor.
} 
emedebistas moderados), no total, os políticos com perfil "pragmático" representam pelo menos 28,8\% da bancada do PMDB na Câmara. Estes números representam um significativo aumento em relação aos dados encontrados para o momento da fundação do PMDB, em 1980, e nas eleições de 1982, o primeiro teste eleitoral do partido, também expostos na tabela abaixo. Ademais, nota-se também o crescimento na quantidade de parlamentares que não possuíam filiação prévia a nenhum dos dois partidos que compuseram o sistema bipartidário durante a maior parte do Regime Militar, provavelmente atraídos pelo PMDB pelo fato de a sigla ser o "carro-chefe" do processo de transição democrática então em curso.

\section{Tabela 21. Filiação prévia da bancada do PMDB na Câmara dos Deputados (1980-1986)}

\begin{tabular}{l|cc|cc|cc}
\hline \multicolumn{2}{c}{1980} & \multicolumn{2}{c}{1982} & \multicolumn{2}{c}{1986} \\
\hline \multirow{2}{*}{ ARENA/PDS } & $\mathbf{N}$ & $\%$ & $\mathbf{N}$ & $\%$ & $\mathbf{N}$ & $\%$ \\
\cline { 2 - 7 } MDB & 6 & $5,22 \%$ & 32 & $16 \%$ & 58 & $22,30 \%$ \\
Sem filiação prévia & 109 & $94,78 \%$ & 148 & $74 \%$ & 126 & $48,46 \%$ \\
\hline Total & - & - & 20 & $10 \%$ & 76 & $29,23 \%$ \\
\hline
\end{tabular}

Fontes: Schmitt (2000: 51) para os dados de 1980, Mucinhato (2015) para os dados de 1982 e elaboração própria para os dados de 1986 a partir do cruzamento de informações coletadas no Centro de Documentação e Informação da Câmara dos Deputados (CEDI) e Centro de Pesquisa e Documentação de História Contemporânea do Brasil (CPDOC-FGV).

Por sua vez, no que se refere ao Senado Federal, dos 38 senadores eleitos em 1986 pelo partido, dez tiveram passagem pela ARENA ou pelo PDS. Somados aos outros senadores do PMDB que não tiveram que renovar seus mandatos naquele ano, o total de parlamentares do partido naquela Casa que passaram pelas legendas de sustentação do Regime Militar passaria a ser de 13 (28,9\%). Apesar de uma diminuição percentual em relação aos dados de 1982 (momento no qual houve um salto no ingresso de ex-arenistas por conta da incorporação do PP), uma análise mais detida dos dados nos permite observar o perfil de outros políticos que passam a fazer parte da bancada do partido.

Entre os eleitos em 1986 destacam-se Alfredo José de Campos Melo (expepista), Nelson Carneiro (que apesar de ex-emedebista teve passagem pelo PTB do Rio, partido localizado no campo à direita do PMDB na época) e ainda os autointitulados "moderados" João Assis Meira Filho (DF), Olavo Gomes Pires Filho (RO) e Alfredo José de Campos Melo (MG), incluídos na porcentagem dos outros $71,1 \%$ de senadores que não possuíam histórico de filiação partidária à ARENA ou ao PDS. Assim, os ex-arenistas/pedessistas eleitos em 1986 se aliam aos outros senadores peemedebistas com perfil mais pragmático e formam um bloco composto por pelo menos 17 senadores, representando um total de 37,7\% do total da bancada do PMDB e que ficou conhecido como "Monobloco". Essa ala, que já havia conseguido eleger José Fragelli (ex-ARENA e ex-PP) como presidente do Senado em 1985 e alçar Alfredo Campos à condição de líder do governo e da bancada do PMDB no Senado (quando 
declara lealdade ao então presidente José Sarney) ${ }^{228}$, passa a ser reforçada após os resultados eleitorais de 1986.

\section{Tabela 22. Filiação prévia da bancada do PMDB no Senado} (1980-1986)

\begin{tabular}{l|cc|cc|cc}
\hline & \multicolumn{2}{c}{1980} & \multicolumn{2}{c}{1982} & \multicolumn{2}{c}{1986} \\
\hline \multirow{2}{*}{ ARENA/PDS } & $\mathbf{N}$ & $\%$ & $\mathbf{N}$ & $\%$ & $\mathbf{N}$ & $\%$ \\
\cline { 2 - 7 } MDB & 2 & $9 \%$ & 7 & $33,3 \%$ & 13 & $28,9 \%$ \\
Sem filiação prévia & 20 & $91 \%$ & 14 & $66,7 \%$ & 23 & $51,1 \%$ \\
Total & 22 & & - & & 9 & $20 \%$ \\
\hline
\end{tabular}

Fontes: Mucinhato (2015) para os dados de 1980 (momento de fundação do PMDB) e 1982 (após a incorporação do PP) e elaboração própria para os dados de 1986 a partir do cruzamento de informações coletadas no Centro de Documentação e Informação da Câmara dos Deputados (CEDI) e Centro de Pesquisa e Documentação de História Contemporânea do Brasil (CPDOC-FGV).

Nesse sentido, como apontado por parte da literatura, as eleições de 1986 representaram o momento de inchaço do PMDB, momento este no qual houve uma grande entrada de quadros não comprometidos com o seu programa, devido ao fato de o partido se encontrar na condição de governo federal desde 1985 (Sadek, 1989a: 67; Sadek, 1989b: 113; Bresser-Pereira, 1993: 240; Power, 1997: 77; Mainwaring et al, 2000: 53). Em sua grande maioria, os entrevistados para esta pesquisa também apontaram que o resultado das eleições de 1986 representaram um inchaço do partido, transformando a imagem de sua face pública. Em entrevista ao autor, o deputado federal Miro Teixeira (RJ), ao tocar nesse ponto, fez referência a esse processo fazendo uso do termo "infiltrações" para se referir a esses novos quadros que haviam entrado no partido.

"O resultado majoritário [em 1986] foi graças ao Plano Cruzado, mas como o partido sofreu aquelas infiltrações, inclusive no estado do Rio de Janeiro, eu saio do PMDB depois da Constituinte, porque os companheiros de MDB, especialmente no interior do estado, reclamavam que os inimigos, como eles diziam, estavam tomando o partido. Os que vieram das lutas estavam sendo colocados de lado pela direção regional."

Como demonstramos nesta seção, essa argumentação tem base empírica, sustentada pelos dados aqui apresentados. Entretanto, cabe aqui uma ressalva.

Diferentemente do que argumenta a literatura, que aponta que essa transformação se deu apenas a partir do momento em que o partido se tornou governo

228 Dicionário Histórico Biográfico Brasileiro do Centro de Pesquisa e Documentação de História Contemporânea do Brasil, CPDOC/FGV, verbete Alfredo José de Campos Melo. 
(um processo que teria dado ao PMDB pela primeira vez em sua história uma grande ala conservadora - Power, idem, ibidem), como demonstrado nesta pesquisa essa transformação na verdade já estava em curso anteriormente. Apesar de o "inchaço" ter se evidenciado após análises mais atentas sobre o resultado das eleições de 1986, tornase patente que o partido naquele ano já era bastante diferente do que havia sido em seu momento de fundação, em 1980, e o incremento da participação de políticos ex-pepistas e ex-arenistas desde o início do mandato de José Sarney são mais uma evidência nesse sentido.

Esse processo de crescimento do partido às custas de novos ingressantes pouco comprometidos com seu programa era notado por parte de seus quadros, sobretudo aqueles ligados às suas alas mais à esquerda, como a esquerda independente. As declarações de alguns políticos mostram sua preocupação nesse sentido.

Airton Soares, naquele momento com mandato de deputado federal pelo partido, alegava que o PMDB se encontrava em um "acelerado processo de 'direitização' e inchamento", que "levava o partido para a direita", o que poderia "afastá-lo das reivindicações populares" ${ }^{, 22}$. Francisco Pinto, ex-Secretário-Geral do partido, também argumentava que "não iria aceitar a 'direitização' do PMDB",230. De fato, aquela seria a última eleição disputada por ele, que ao encerrar o seu mandato abandonou a vida pública, desacreditado com os rumos tomados pelo seu partido ${ }^{231}$. O resultado das eleições também não teria agradado Ulysses Guimarães, então presidente do partido e uma de suas principais lideranças históricas. Segundo declaração do senador José Serra (SP), em entrevista a Melhem e Russo (2004: 168), apesar de anteriormente ter sido mais permissivo a respeito do assunto, aceitando a ideia de "porteira aberta", sua visão tinha mudado. Serra alega que Ulysses "não estava feliz com o resultado da eleição de 1986, pois achava que o PMDB tinha inchado demais: 'isso não foi crescimento, foi inchaço"”.

Como consequência desse processo, o Senador Cássio Cunha Lima (PB) destacou que o partido passou a ser muito heterogêneo a partir de então:

"Fizemos maioria absoluta na Câmara e no Senado. Então o inchaço do PMDB foi em decorrência do espólio que o partido recebeu de combate à ditadura. Houve aquele combate à ditadura, conseguimos o intento, que foi a vitória do Colégio Eleitoral. Não tínhamos alcançado nosso objetivo principal, que era, naturalmente, a eleição direta, mas o partido se apresentou ao Brasil como o grande credor da restauração da democracia, mesmo pela via indireta, já que o candidato oficial, Paulo Maluf, tinha sido derrotado. Aí sim teve um inchaço, o partido passou a ser muito heterogêneo. Forças políticas muito díspares

\footnotetext{
${ }^{229}$ Folha de S. Paulo-02/12/1985, p. 2, e 07/04/1986, p. 5.

${ }^{230}$ Idem.

231 Dicionário Histórico Biográfico Brasileiro do Centro de Pesquisa e Documentação de História Contemporânea do Brasil, CPDOC/FGV, verbete Francisco José Pinto dos Santos.
} 
em termos de comportamento e de ideologia. A partir daí vêm as várias fragmentações que se sucederam." ${ }^{232}$

O Deputado Marcelo Castro (PI), em entrevista concedida ao autor, encarou o processo de maneira similar:

"E o que era o PMDB? Era um amontoado de gente, uns remando para um lado e uns remando para outro, com forças contraditórias. Isso não faz bem ao partido. Não quer dizer que todo mundo deva pensar igual, mas o partido tem que ter certa identidade."

Esse desempenho do PMDB em 1986 e o novo perfil do partido, combinados ao seu crescimento, caracterizariam sua atuação ao longo de todo o processo Constituinte nos anos de 1987 e 1988, e colaboraram, em última instância, para a formação da sua primeira dissidência interna em sua história, o que será objeto de análise na próxima seção.

\subsection{O PMDB na Assembleia Nacional Constituinte (1987-1988): o inchaco se evidencia}

"E o que era o PMDB? Era um amontoado de gente, uns remando para um lado e uns remando para outro, com forças contraditórias." Deputado Marcelo Castro, em entrevista ao autor.

O PMDB inicia a Assembleia Nacional Constituinte em $1^{\circ}$ de fevereiro de 1987 como detentor da maior bancada partidária ${ }^{233}$. Dos 559 parlamentares que a compõem no momento de instalação dos seus trabalhos, 302 (54\%) eram filiados ao PMDB. Entretanto, apesar de ser o partido majoritário durante o começo dos seus trabalhos, o inchaço do partido, resultado das eleições de 1986, pouco a pouco passou a ser evidente, levando a cisões no decorrer da ANC (Power, 1990, apud Marques e Fleischer, 1999: $12)^{234}$.

\footnotetext{
${ }^{232}$ Entrevista concedida ao autor.

${ }^{233}$ A literatura produzida pela ciência política sobre a Constituinte de 1987-1988 é bastante vasta. Sobre o assunto ver Carvalho, Araújo e Simões (orgs., 2009), Lima (2009), Medeiros (2013) e Rocha (2013), entre outros.

${ }^{234}$ Reconhecemos a existência do debate na literatura a respeito dos índices de coesão e fidelidade partidária sobre os partidos políticos durante o período constituinte, como Samuels (1996) e Coelho (1999), por exemplo. Porém, não entraremos nesse debate, e tomaremos como referência o estudo de Madeira (2011), pelo fato do autor fazer uso do mesmo critério que temos utilizado até aqui para analisar o perfil da bancada do PMDB, no caso, o histórico de filiação partidária dos seus parlamentares.
} 


\section{Figura 3. Composição partidária da Assembleia Nacional Constituinte}

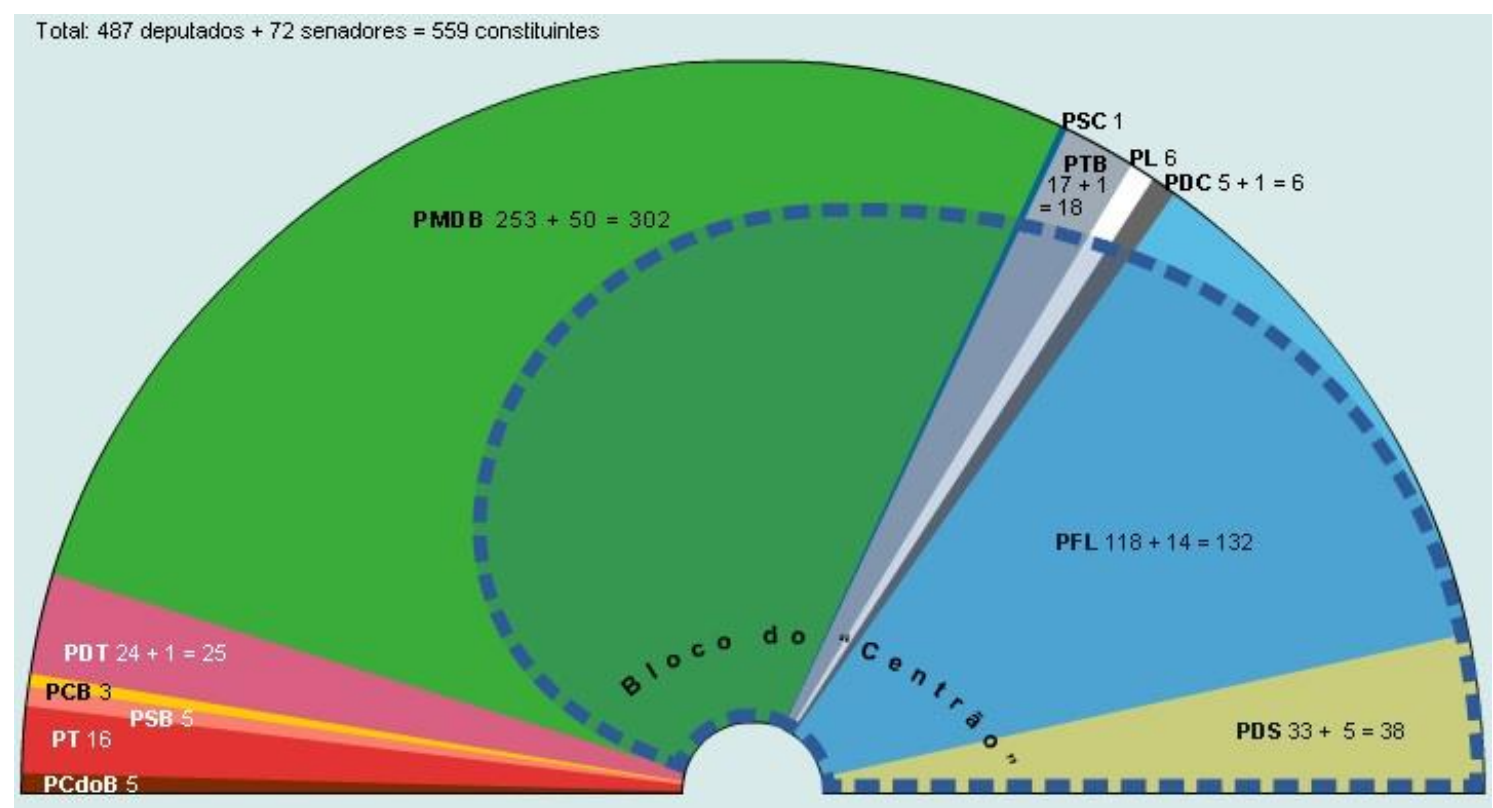

Fonte: reproduzido do Atlas Histórico do Brasil - FGV/CPDOC ${ }^{235}$.

O PMDB jamais conseguiu forjar uma sólida unidade política e programática durante a ANC e um elemento importante para compreender isso é o processo de entrada no partido de ex-arenistas, descrito nos dois primeiros capítulos deste estudo. Conforme apontou Power (1997: 77), os três maiores partidos da Constituinte tinham dentro de si a sua parcela de ex-arenistas: 20,9\% da bancada do PMDB, 77,1\% da bancada do PFL e 86,5\% do PDS. A presença desses políticos na Constituinte levou Fleischer (1988c: 31) a afirmar que a conclusão mais surpreendente dessa análise é que ao cabo a maior bancada partidária naquela Constituinte não era a do PMDB, mas sim, nos termos de 1979, a da ARENA.

Essa divisão na filiação partidária prévia no interior da bancada do PMDB também se refletiu na atuação dos seus parlamentares e começou a aflorar no momento das votações das matérias da ANC. Como apontou Madeira (2011: 197), a análise do posicionamento político dos parlamentares demonstra que, embora exista variação de um partido para outro, é possível identificar a existência de um padrão claro de comportamento, seja entre ex-arenistas, seja entre ex-emedebistas durante a Constituinte. Tal aspecto ajuda a explicar, inclusive, o fato de o PMDB ser a legenda mais afetada pela falta de homogeneidade de sua bancada. A coexistência de exarenistas e ex-emedebistas contribuía para a diminuição do grau de homogeneidade da atuação do partido, uma vez que esses grupos tenderam a seguir, nas votações em questão, o padrão de votação de suas antigas legendas.

\footnotetext{
${ }^{235}$ Disponível online em https://atlas.fgv.br/marcos/governo-jose-sarney-1985-1990/mapas/estruturae-bancadas-da-constituinte.
} 
A atuação heterogênea do PMDB durante a Constituinte também se expressou na formação de dois grandes blocos ideológicos durante os seus trabalhos, cada qual contando com uma parcela significativa de peemedebistas.

Por um lado, em julho de 1987, um grupo formado por 30 parlamentares da ala progressista do PMDB formaram o Movimento Unidade Progressista (Marques e Fleischer, 1999: 61). O MUP, como ficou conhecida essa ala, surge a partir de uma visão crítica que esse setor tinha em relação ao próprio PMDB, sobretudo a partir das decisões tomadas pelo partido na sua Convenção Nacional Extraordinária realizada nos dias 18 e 19 daquele mês. Na Convenção o partido optou por não tomar uma decisão formal a respeito de qual deveria ser a duração do mandato do presidente José Sarney ${ }^{236}$, matéria que seria votada durante a Constituinte, para evitar um racha entre suas lideranças.

A ala que compunha o MUP desde o princípio cogitou a fundação de um novo partido político, formado a partir desse núcleo ${ }^{237}$, que contava com lideranças de peso do PMDB, como o Senador Fernando Henrique Cardoso (SP), então líder partido no Senado, mas adiava sua decisão continuamente, sob a justificativa de não querer desamparar as lideranças do campo da esquerda que permaneceriam no partido, deixando-o inteiramente nas mãos do seu campo mais à direita ${ }^{238}$. No entanto, a consolidação do MUP ao longo do ano de 1988 acabaria por levar à formação da primeira dissidência partidária do PMDB em sua história, com a formação do PSDB, a ser descrito na próxima seção.

Por outro lado, em resposta à atuação articulada do MUP na ANC, uma parte dos filiados ao PMDB passou a compor o chamado Centro Democrático, ou "Centrão", um bloco suprapartidário formalizado em outubro de 1987 que se formou para apoiar as teses mais conservadoras durante a ANC e defender o mandato do presidente Sarney (Kinzo, 1993: 27). O bloco era formado por 152 parlamentares, dos quais 80 do PFL, 43 do PMDB, 19 do PDS, 6 do PTB, 3 do PDC e 1 do PL. A criação desse bloco esteve diretamente ligada à atuação do então presidente Sarney para a aprovação de pautas de seu interesse, como a definição em torno da duração do seu mandato (se seria de cinco ou seis anos) ${ }^{239}$. Segundo Kinzo (1990: 115) o então presidente havia forjado uma aliança com a ala conservadora e fisiológica do PMDB e buscado ampliar o espaço do PFL no seu governo, de modo a isolar os setores do seu próprio partido que tinham uma relação crítica com o governo e diminuir o peso político da liderança de Ulysses Guimarães.

Evidência nesse sentido são as reformas ministeriais promovidas por Sarney ao longo de seu mandato ${ }^{240}$, que pouco a pouco reduzem o espaço dos indicados por

\footnotetext{
${ }^{236}$ Folha de S. Paulo-20/07/1987, p. A-5.

${ }^{237}$ Folha de S. Paulo - 31/07/1987, p. A-4.

${ }^{238}$ Correio Braziliense-03/10/1987, p. 2.

239 Parlamentares do MUP defendiam que o mandato durasse quatro anos, e os do Centrão que durasse cinco, indo ao encontro da posição do Presidente - Jornal O Globo 19/05/1987.

${ }^{240}$ Sobre as reformas ministeriais do governo Sarney, ver Meneguello (1999).
} 
Ulysses Guimarães e por Tancredo Neves na composição dos ministérios do seu governo. Nesse sentido, elementos chave para compreender a força que Sarney passa a ter no interior do seu partido e na própria ANC a partir daquele contexto, ainda que fosse um peemedebista recém-filiado, seriam tanto a manutenção de Antonio Carlos Magalhães (PFL) no cargo de Ministro das Comunicações quanto as concessões de emissoras de radiodifusão feitas pelo governo.

As concessões foram usadas em muitos casos como forma de barganha com os parlamentares que compunham a $\mathrm{ANC}^{241}$. De 1985 a 1988, o Presidente da República fez 1.028 concessões - 30,9\% do total das 3.330 concessões outorgadas no Brasil até o governo Collor. Em apenas dois anos, 1987 e 1988, foram distribuídas 747 emissoras de rádio e TV. Em 1988, ano decisivo para a votação da nova Constituição, foram 539 (52\% do total do governo Sarney). Em três anos, 168 concessões foram outorgadas apenas para empresas ligadas a 91 deputados federais e senadores e, desses, $82(90,1 \%)$ votaram a favor da emenda que aumentou para cinco anos o mandato de Sarney (Motter, 1994, apud Pieranti, 2006: 108) ${ }^{242}$. Como apontou Moreira (1998: 95, apud Ferreira, 2007: 5) 243 , "nunca na história do Brasil como durante os cinco anos do mandato de José Sarney um número tão elevado de deputados, prefeitos, governadores e até ministros de Estado recebeu canais de rádio e televisão".

A distribuição de concessões foi mencionada pelo deputado federal Miro Teixeira (RJ), quando questionado a esse respeito:

"Na votação de cinco anos do mandato presidencial, que pela carta de 69 era de seis anos, aí reduziu para quatro, esse era o acordo da recessão, da Aliança Democrática, $e$ houve grande resistência das forças políticas que se organizaram em torno do Sarney. Foi oferecida aqui dentro muita nomeação. Teve uma reunião na sala da

\footnotetext{
${ }^{241}$ ACM foi o único ministro que se manteve no cargo durante todo o mandato de Sarney e anos mais tarde, em entrevista à Revista Veja (03/6/1998), admitiria que durante esse tempo as concessões eram feitas de acordo com os interesses políticos do governo. Lado a ele também esteve Romulo Vilar Furtado, que por 16 anos foi o segundo homem na hierarquia do Ministério das Comunicações (de 1974 a 1990) como secretário executivo (Folha de S. Paulo - 09/09/1995) sendo o homem forte das Organizações Globo no Ministério durante todo o período (http://pt.slideshare.net/julofego/concessesde-rdio-e-tv-intervozes). Para um amplo perfil do Ministério escolhido por Sarney, ver Meneguello (1998).

${ }^{242}$ Outro político peemedebista que se beneficiou diretamente da distribuição de concessões foi o então governador de São Paulo Orestes Quércia. Segundo matéria da Folha de S. Paulo, 02/6/1991 (citada em Melhem, 1998: 197), a concessão de uma TV em Santos foi dada pelo então Presidente José Sarney em reconhecimento ao apoio quercista na obtenção do mandato presidencial de cinco anos durante os trabalhos do Congresso Constituinte. Como Quércia à época exercia o cargo de governador, a TV ao final ficou em nome de Chico Santa Rita, amigo pessoal do ex-governador e responsável por sua propaganda política.

243 O relato de Delgado (2006: 355), que posteriormente viria a ser Secretário-Geral do partido, vai no mesmo sentido. O autor aponta que "a condução da transição estava nas mãos de José Sarney. O PMDB, em Convenção Nacional (durante a Constituinte), discutiu a possibilidade de afastar-se do governo Sarney, que buscava se fortalecer junto aos moderados e conservadores, que aceitavam, de muito bom grado, as concessões de rádio e TV outorgados pelo chefe do Executivo".
} 
liderança do PMDB, que talvez, não sei... entrou um ministro do Sarney dizendo que tinha 10 mil cargos para negociar e oferecer em troca do voto de seis anos ou, na pior hipótese, de cinco. Ele foi posto para fora da sala! Então aquelas práticas que eram denunciadas, como essa distribuição de nomeações, distribuição de estação de rádio, elas começaram a ser comuns. Aí houve o começo da grande descaracterização do PMDB. "244

Essa série de elementos aqui descritos, como a presença e a atuação coesa de parlamentares com passagem pela ARENA e que se encontravam no interior do PMDB, assim como a atuação dos constituintes peemedebistas em dois blocos ideológicos bastante distintos, levou o partido à sua baixa unidade durante a atuação na ANC. Como destacou Kinzo (1993: 27), o PMDB dividiu-se quase ao meio nas votações sobre o sistema de governo (manutenção do presidencialismo), sobre a confirmação de um mandato de cinco anos para o presidente Sarney e sobre a reforma agrária, e sofreu deserções substanciais em decisões que envolviam cunho nacionalista e apoio a direitos trabalhistas.

\section{Tabela 23. Posicionamento do PMDB em algumas votações no Congresso Constituinte}

\begin{tabular}{l|ccc}
\hline Votações & Sim & Não & Abstenções \\
\hline $\begin{array}{l}\text { Presidencialismo } \\
\text { (22/03/88) }\end{array}$ & 145 & 148 & 2 \\
$\begin{array}{l}\text { Cinco anos p/ Sarney } \\
\text { (02/06/88) }\end{array}$ & 168 & 123 & 2 \\
$\begin{array}{l}\text { Nacionalização da } \\
\text { mineração }\end{array}$ & 211 & 41 & 9 \\
$\begin{array}{l}\text { (28/04/88) } \\
\text { Direito irrestrito } \\
\text { de greve (16/08/88) }\end{array}$ & 133 & 29 & 5 \\
\hline \begin{tabular}{l} 
Reforma agrária \\
\hline
\end{tabular} & 85 & 83 & 8 \\
\hline
\end{tabular}

Fonte: Kinzo (1993: 27)

Essa divisão durante os trabalhos da ANC gerava uma permanente tensão no interior do partido, em última instância levando à ruptura de um de seus setores pela primeira vez em sua história, tema da próxima seção.

\subsection{O "racha" e o surgimento do PSDB (1988)}

"Foi essa queda de braço durante o processo da Constituinte que perdurou o tempo inteiro e que resultou,

\footnotetext{
${ }^{244}$ Entrevista concedida ao autor.
} 
inclusive, mais adiante, em saída de algumas dessas forças do próprio PMDB para outros partidos, $e$ o surgimento do PSDB." Senador Cássio Cunha Lima, em entrevista ao autor.

O marco final deste capítulo e da Parte 1 desta tese é o ano de 1988, momento no qual uma parcela dos remanescentes da esquerda independente do PMDB, organizados em torno do Movimento Unidade Progressista durante a ANC, decidiu sair do PMDB e fundar o Partido da Social Democracia Brasileira (PSDB), único partido a ser fundado a partir de uma dissidência interna da sigla ao longo de sua história. A formação dessa dissidência representou a "terceira onda" de evasão de quadros do partido e teve impacto ainda maior na sua composição interna do que as duas primeiras, ocorridas em 1979 e 1985 e descritas anteriormente, por conta do peso das lideranças que decidiram deixar o PMDB.

O PSDB formou-se a partir de lideranças importantes da história do PMDB, sobretudo por políticos com trajetórias no estado de São Paulo, que passariam a ser referências na política nacional por meio de sua nova legenda. Entretanto, antes de passarmos ao impacto da fundação desse novo partido em nosso objeto de estudo é importante destacar que o processo de formação do PSDB não é compreendido de maneira unânime, tanto pela literatura quanto pelos políticos que testemunharam aquele evento.

Como já mencionado, a fundação do PSDB se deu em meio ao processo de elaboração da Constituição de 1988, durante a Assembleia Nacional Constituinte de 1987-1988, período no qual o PMDB apresentava um comportamento bastante heterogêneo em sua bancada. Ao mesmo tempo em que isso ocorria, o diretório paulista do partido na ocasião se encontrava sob crescente predomínio da ala ligada a Orestes Quércia, então governador daquele estado, eleito em 1986, o que aliada à aspiração de Ulysses Guimarães a candidatar-se à Presidente da República em 1989 deixava pouco espaço para uma alternativa de centro-esquerda no interior do partido (Kinzo, 1993: 48).

Nesse sentido, os estudos que analisaram a origem do PSDB apontam para quatro fatores explicativos de seu surgimento, todos diretamente ligados ao PMDB. Por um lado, parte da literatura procurou privilegiar explicações centradas em aspectos ideológicos para elucidar sua fundação, centrando-se em divergências surgidas dentro do PMDB durante os trabalhos da ANC para justificar a formação dessa dissidência (Kinzo, 1993). Uma segunda perspectiva procurou dar mais ênfase ao controle obtido por Orestes Quércia no diretório paulista do partido, o que segundo esses autores acabou por marginalizar dentro da máquina partidária políticos bastante influentes no cenário político nacional (Melhem, 1998). Uma terceira vertente aponta que a aliança conservadora feita pelo PMDB com o PFL e com o prefeito de São Paulo Jânio Quadros para o lançamento de uma candidatura para a prefeitura da cidade em 1988 desagradou esse mesmo bloco de políticos, levando à formação da dissidência (Lamounier, 1989). Por fim, estudos mais recentes procuraram focar as explicações sobre o seu surgimento 
mais em objetivos pragmático-eleitorais do que em razões ideológicas. Para essa vertente, a origem do PSDB baseia-se no cálculo eleitoral de um grupo de deputados federais e senadores que acreditavam somente ter possibilidade de conquistar cargos no governo federal, principalmente a presidência da República, aproveitando-se do capital político acumulado pelo e no PMDB, mas por meio de outro partido (Roma, 2002: $74)^{245}$.

Aos cruzarmos as explicações dadas pela literatura com as declarações de políticos à época, torna-se patente o quanto esses fatores tiveram pesos diferentes na para aqueles que formaram a dissidência peemedebista e aqueles que optaram por permanecer no partido. No discurso adotado por parte dos peessedebistas, o elemento aglutinador desses políticos dissidentes foi a crítica a respeito do processo de "arenização" do PMDB, expressa no Programa de Fundação ${ }^{246}$ do novo partido. Segundo eles, esse processo pode ser compreendido de maneira genérica como a combinação de três aspectos: a adoção de práticas que eram comuns na ARENA e que eram criticadas pelas lideranças do MDB e do PMDB; o "inchaço" dos quadros do PMDB (com a incorporação de muitos políticos ex-arenistas) e a sua falta de posicionamento ideológico claro. Essa falta de clareza ideológica havia se expressado nas decisões da Convenção Programática do PMDB de 1987, realizada entre os dias 18 e 19 de julho daquele ano. Na Convenção, de acordo com José Gregori, que havia optado por permanecer no PMDB mas que posteriormente migraria ao PSDB, o partido não desenhou nenhuma linha de ação, nem mesmo para a Constituinte:

"Ganhou a linha de não ter linha nenhuma. Foi em julho de 1987. Se tinha que ser mandato presidencial de quatro anos, o partido não se definiu, se seria pelo parlamentarismo ou presidencialismo, também não se definiu. No fim, a solução do PMDB nesta convenção foi a mais mineira, mas sem o talento do PSD de Minas." (Melhem, 1998: 210).

Da mesma forma, Mário Covas (SP) justificou sua saída do partido dizendo que "o inchaço do PMDB foi o que o fez tucano" "247. Fernando Henrique Cardoso (SP) argumentou que seu grupo pleiteava que houvesse uma reunião do diretório nacional do partido para colocar questões doutrinárias, pontos do programa, o que foi negado por Ulysses Guimarães (Melhem e Russo, 2004: 97). Por sua vez, o Senador Cássio Cunha

\footnotetext{
${ }^{245}$ Sobre as inclinações ideológicas do PSDB desde sua fundação ver Vieira (2012).

246 "Receoso de enfrentar suas divergências internas, [o PMDB] deixou de tomar posição ou ao menos de debater as políticas de governo a que deveria dar sustentação. Invadido por oportunistas, dividiu-se desde os primeiros embates da Constituinte. Envolvido no jogo da ocupação de "espaços" na máquina governamental, acabou fornecendo massa de manobra ao continuísmo de oligarquias decrépitas e de burocratas acostumados ao mando irresponsável. Numa palavra, arenizou-se, atrelado a um governo que deixou de se constituir no primeiro da Nova República para se fazer o último da velha República". Publicado originalmente no Diário Oficial da União - Seção l, de 6/07/1988, pp. 12508/

12510 disponivel on-line em http://static.psdb.org.br/wp-

content/uploads/2010/04/Programa_250688.pdf

${ }^{247}$ Revista Visão s.n., Agosto de 1991.
} 
Lima (PB), que ainda permaneceria no PMDB por mais alguns anos antes de se transferir ao PSDB, também credita ao inchaço do partido a formação de sua dissidência:

"Aí sim teve um inchaço [em 1986], o partido passou a ser muito heterogêneo. [A ter] forças políticas muito díspares em termos de comportamento e de ideologia. A partir daí vêm as várias fragmentações que se sucederam. A mais importante delas, sem dúvida, a do PSDB. "248

Por outro lado, do ponto de vista de políticos que permaneceram no PMDB, o fator explicativo principal para a formação de sua dissidência parece recair mais sobre a falta de espaço deixada para essa ala por parte da ala quercista no Estado de São Paulo, indo ao encontro da argumentação de Roma (2002) mencionada anteriormente. As colocações a seguir, respectivamente dos senadores Airton Sandoval (SP) e Roberto Requião (PR) deixam clara essa perspectiva e vão nesse sentido:

"O PSDB saiu do PMDB mais por oportunismo, por causa das lideranças de São Paulo que acabaram levando o partido a sair, porque ali a gente tinha uns nomes políticos fortes: o Orestes Quércia, Franco Montoro, Ulysses Guimarães, Fernando Henrique, Mário Covas. Não tinha espaço pra todo mundo, então entendo que o PSDB divergiu e saiu do PMDB mais por oportunismo do que por uma questão ideológica ou qualquer outra coisa. Tinham reclamações da postura do Quércia, que era muito impositivo."

“O PSDB foi viabilizado fundamentalmente pela tentativa do grupo do Quércia de domínio absoluto do PMDB, não havia espaço para mais ninguém. Então ele acabou se constituindo em função disso." 249

A mesma visão é compartilhada por Pedro Simon, para quem "a fundação do PSDB foi por motivos de estratégia política”, e complementada por Bresser-Pereira, para quem "o PSDB nasceu por causa do Quércia, que tinha tomado conta do partido em São Paulo e, de certo modo, no Brasil"250.

Independentemente das múltiplas vertentes explicativas e das narrativas adotadas por parte dos políticos que acompanharam aquele processo ${ }^{251}$, o fato é que, em

\footnotetext{
${ }^{248}$ Entrevista ao autor.

249 Entrevistas ao autor.

250 Entrevistas ao autor. A mesma linha argumentativa foi usada por outros políticos entrevistados, como Jader Barbalho, Flaviano Melo, Miro Teixeira, Tonico Ramos, e Marcelo Barbieri, mas optou-se apenas por reproduzir trechos de entrevistas de alguns políticos, para evitar a repetição do texto.

${ }^{251}$ Além dos fatores mencionados pela literatura para a fundação do PSDB, existe um elemento que deve ser considerado. Durante todo o governo Sarney um grupo de políticos da sua base de apoio tentou a criação de um novo partido político, que pudesse servir à sustentação do seu governo. Esse
} 
meio aos debates constituintes, em 25 de junho de 1988, os integrantes do setor conhecido como MUP decidem formalizar sua saída do PMDB e, aliados a outros políticos, anunciam a fundação de um novo partido, o Partido da Social Democracia Brasileira (PSDB). A nova sigla, formada no final do processo constituinte, seria composta por 50 parlamentares, formando a terceira maior bancada do parlamento, dos quais $43(86 \%)$ eram egressos do $\mathrm{PMDB}^{252}$.

Dentre os senadores que fundam o PSDB (um total de oito), sete estavam filiados ao PMDB anteriormente, e desses sete, cinco $(71,4 \%)$ foram filiados ao MDB durante o Regime Militar, sendo que nenhum fora filiado à ARENA. Por sua vez, foram 42 os deputados federais que participaram da fundação do PSDB. Dentre esses 42, foram 36 os que fundaram o partido e que foram ex-peemedebistas, sendo 18 deles (50\%) ex-emedebistas e apenas um deles $(5 \%)$ um ex-arenista. Estes dados, de certa forma, corroboram o discurso dos fundadores do PSDB que argumentavam que o PMDB havia se "arenizado" e que isso não seria reproduzido no novo partido que estavam fundando ${ }^{253}$.

partido seria formado tanto por membros do PFL quanto do PDS e, acima de tudo, por uma ala mais à direita do interior do PMDB, o poderia gerar sua primeira dissidência interna. Porém, conforme a criação desse partido não se concretizou, acabou por ser outro de seus setores que optou por sair do partido, apostando que o capital político acumulado pela ala que migrava, aliado ao desgaste sofrido pelo PMDB e às críticas feitas por essa ala ao partido, seriam suficientes para que a nova sigla tivesse forças para se estruturar nacionalmente. Porém, investigar esse aspecto sobre a formação do PSDB não está entre os objetivos deste estudo.

${ }^{252}$ A literatura a respeito do PSDB apresenta números distintos a respeito da quantidade de parlamentares que fundou o partido. Os autores apontam que foram 45,47 ou 48 os seus fundadores. Martins (2015), porém, parece ser o autor que melhor supera o problema a respeito do número de fundadores do PSDB e aqui consideraremos os mesmos 50 parlamentares que o autor considera como sendo os membros originais do partido. $\mathrm{O}$ autor utiliza dois critérios para definir um constituinte como pertencente ao grupo do PSDB. O primeiro critério foi observar as atas da Constituinte e verificar quais eram os que foram definidos como pertencentes ao PSDB no final do processo constituinte. Foram identificados 49 nomes, todos pertencentes no mínimo a uma das listas mencionadas pelos outros autores que tentaram chegar a um número correto. $O$ segundo critério foi observar a página oficial do PSDB (http://www.psdb.org.br/) e checar quais fundadores do partido faziam parte da Constituinte, conforme a ata de reunião realizada em 24 e 25 de junho de 1988. Foram identificados os 49 nomes novamente, no entanto 1 novo nome surgiu em relação ao primeiro critério. Assim, ficamos com 50 nomes que seriam identificados como constituintes que teriam constituído o PSDB ainda durante o processo constituinte (Martins, 2015:5). A lista de fundadores utilizada pelo autor e por mim encontrase no Anexo 9.

${ }^{253}$ Curiosamente alguns dados e reportagens jornalísticas nos permitem suscitar a hipótese de que 0 PSDB também pode ter atravessado um processo de "arenização" em sua história, como "PSDB já diz temer inchaço", Folha de S. Paulo - 10/08/1994, e "Ex-presidente do partido critica política do inchaço a todo custo", Folha de S. Paulo - 2/07/1995, além do artigo disponível em http://atlas.fgv.br/marcos/governo-jose-sarney-1985-1990/mapas/primeiros-tempos-do-psdb acessado em $23 / 4 / 2018$. Porém, investigar esse processo está além dos objetivos deste estudo. Sobre o assunto, ver Madeira (2006). 


\section{Tabela 24. Filiação prévia dos parlamentares fundadores do PSDB que eram filiados ao PMDB}

\begin{tabular}{l|cc|cc}
\hline \multicolumn{2}{c}{ Senadores } & \multicolumn{2}{c}{$\begin{array}{c}\text { Deputados } \\
\text { Federais }\end{array}$} \\
\hline MDB & $\mathrm{N}$ & $\%$ & $\mathrm{~N}$ & $\%$ \\
ARENA & 5 & $71,4 \%$ & 18 & $50 \%$ \\
Sem filiação prévia & 0 & $0 \%$ & 2 & $5 \%$ \\
Total & 2 & $29,6 \%$ & 16 & $44 \%$ \\
\hline
\end{tabular}

Fonte: elaboração própria a partir do cruzamento de informações retiradas de Martins (2015) com informações coletadas no Centro de Pesquisa e Documentação de História Contemporânea do Brasil (CPDOC-FGV).

Os dados deixam claro que o impacto da saída do PSDB para o PMDB foi uma diminuição da ala do partido formada por políticos que tiveram suas origens no campo da oposição ao Regime Militar, aumentando o peso relativo dos ex-arenistas em relação aos remanescentes do MDB (Madeira, 2006: 88) ${ }^{254}$, fazendo com que o PMDB póscisão (do PSDB) fosse mais conservador que o PMDB pré-cisão (Lamounier, 1989: 77). Como mostra a tabela a seguir, após a conclusão dos trabalhos da ANC os parlamentares do PMDB que eram provenientes da ARENA, do PDS ou do PFL naquela ocasião já correspondiam a mais de um quarto da bancada do partido no Congresso Nacional.

Para além desses dados, a literatura apontou que a fundação do PSDB foi formada pela ala progressista (Power, 1997: 77), de centro-esquerda (Kinzo, 1990: 115) ou social-democrata (Bresser-Pereira, 1987: 17) de dentro do PMDB, levando o PSDB a ser caracterizado pela literatura como um partido de centro-esquerda, ou como um racha à esquerda do PMDB no momento de sua fundação (Kinzo, 1989, 1993; Mayer, 2009; Rocha, 2015; e Martins, 2015).

\section{Tabela 25. Filiação prévia dos membros da bancada do PMDB no último dia da Assembleia Nacional Constituinte $(5 / 10 / 1988)^{255}$}

\begin{tabular}{l|cc}
\hline & $\mathbf{N}$ & $\mathbf{\%}$ \\
\hline MDB & 113 & $51,36 \%$ \\
ARENA/PDS/PFL & 58 & $26,36 \%$ \\
Sem filiação prévia & 49 & $22,27 \%$ \\
\hline Total & 220 & $100 \%$ \\
\hline
\end{tabular}

Fonte: elaboração própria a partir do cruzamento de informações da Ata da $341^{\text {a }}$ Sessão da Assembleia Nacional Constituinte, em 5 de outubro de 1988 (último dia da Constituinte) ${ }^{256}$ com informações coletadas no Centro de Pesquisa e Documentação de História Contemporânea do Brasil (CPDOC-FGV).

\footnotetext{
${ }^{254}$ Saraiva Felipe, em entrevista ao autor, também defendeu que a fundação do PSDB foi uma perda significativa para o partido, e considerou o PMDB mais refém de posições mais conservadoras após a dissidência.

${ }^{255}$ As informações encontradas nas Atas da ANC não discriminavam quais dos membros da bancada eram deputados e quais eram senadores, então optou-se por apresentar os dados de maneira agregada, tal como eles foram obtidos.
} 
Do ponto de vista de alguns políticos que permaneceram no PMDB após a saída dos peessedebistas, o cisma também se deu à esquerda do partido. $\mathrm{O}$ deputado Jarbas Vasconcelos (PE) apontou que também saíram alguns conservadores, mas que aquele era um bloco majoritariamente de pessoas combatentes e consideradas "autênticas", "oposicionistas", o que representou um "baque" para esse campo dentro do partido ${ }^{257}$, gerando um PMDB mais "puro" do que antes, na visão do senador Raimundo Lira (PB). O Senador Garibaldi Alves ( $\mathrm{RN}$ ) encara o processo da mesma forma, porém, complementa que naquela ocasião o cerne do PMDB já não tinha mais essa perspectiva à esquerda, o que na visão do deputado Celso Maldaner (SC) pode ter contribuído para levá-lo mais ao centro.

Como já dito, além do impacto ideológico, a fundação do PSDB como um racha majoritariamente paulista do PMDB (dos seus 50 fundadores, 10 eram paulistas) fez com que esse partido perdesse boa parte de suas lideranças mais importantes no estado que possui o maior colégio eleitoral do país. Dos três senadores que compunham a bancada do partido em São Paulo, dois tornaram-se fundadores do PSDB: Mário Covas, líder do PMDB no Congresso Constituinte, e Fernando Henrique Cardoso, este também até então o presidente do Diretório Regional do partido naquele estado, com Covas se tornando o primeiro presidente da história da sigla tucana ${ }^{258}$.

O impacto regional da formação do PSDB, que no médio prazo acabou por “desidratar" o PMDB em São Paulo (de 1994 até 2014 todos os governadores eleitos em São Paulo foram peessedebistas ex-peemedebistas), e a transformação no partido como um todo são sintetizados pelo parlamentar Marcelo Castro (PI):

"A grande sangria que o $P M D B$ teve foi a diáspora, a saída do PSDB. [Saíram] as figuras mais proeminentes do $P M D B$, que eram o Fernando Henrique Cardoso, senador do MDB, o José Richa, Mário Covas, Franco Montoro, isso foi um baque. Saiu, digamos assim, uma parte boa do $P M D B$, da intelectualidade, turma da universidade, turma de maior cultura. [Em] São Paulo [saíram], digamos assim, os melhores, ficando o Quércia com o comando do partido, que era um politico 'faladeiro', mas com umas práticas... Quer dizer, aqueles mais progressistas, com maior ideal, sairam do PMDB., 259

Com a fundação do PSDB encerra-se o ciclo de evasão de quadros do PMDB, iniciado com a primeira onda em 1979. O partido perdia, assim, importantes lideranças históricas, principalmente no Estado de São Paulo, maior Colégio Eleitoral do país e um

\footnotetext{
${ }^{256}$ Disponível em http://imagem.camara.gov.br/Imagem/d/pdf/308anc05out1988.pdf\#page=1.

257 Entrevista ao autor.

${ }^{258}$ Folha de S. Paulo - 26/06/1988, p. A-10.

${ }^{259}$ Entrevista ao autor.
} 
estado onde o PMDB havia eleito os governadores de 1982 e 1986. Associado à entrada de novos quadros no partido a partir da sua chegada ao governo em 1985, alterava-se definitivamente a correlação de forças interna do partido.

\subsection{Consideracões finais: o PMDB pós-1988}

Como mostramos nesses dois primeiros capítulos, uma série de transformações ao longo dos anos 1980 levou o PMDB a ter uma composição interna bastante distinta ao final dos seus primeiros oito anos de existência se comparada ao momento de sua fundação. O PMDB que emerge após a conclusão dos trabalhos da ANC é diferente daquele que chega à presidência da República por meio de José Sarney em 1985 e é ainda mais distinto daquele partido (re)fundado no final de 1979, que congregava boa parte dos políticos autênticos do extinto MDB.

No primeiro capítulo mostramos que a sua primeira transformação interna se deu ainda em 1982. Após a incorporação do Partido Popular naquele ano, em decorrência do chamado "Pacote de Novembro", o PMDB cresceu. Porém, o partido incorporado trouxe consigo uma parcela de políticos ex-arenistas (que podem ser chamados de "adesistas às avessas", em contraposição aos políticos emedebistas que votavam sempre em favor das medidas apoiadas pelo Regime Militar, citados no início desse estudo na seção que se refere ao histórico do MDB) e um bloco de ex-emedebistas moderados, que tinham uma concepção distinta sobre como promover uma transição democrática para a derrocada da Ditadura Militar. Esse bloco de políticos consegue conquistar espaço no interior dos órgãos de direção do PMDB, sobretudo a partir de sua $3^{\text {a }}$ Convenção Nacional, em dezembro de 1983, tendo como ápice de seu projeto político o lançamento da candidatura de Tancredo Neves para a disputa do Colégio Eleitoral de 1985.

Mesmo após o falecimento de Tancredo, uma das principais lideranças políticas da ala chamada de "Unidade", esse bloco continuou crescendo principalmente conforme o PMDB chegou ao poder em 1985, com a posse de José Sarney no cargo de Presidente da República. Como argumentamos neste segundo capítulo, fator importante para esse crescimento foi a queda da exigência da fidelidade partidária promovida por meio da Emenda Constitucional $\mathrm{n}^{\circ} 25$, e uma das evidências que demonstram o espaço conquistado por essa ala foi a obtenção da Secretaria Geral do partido por parte de um de seus representantes em 1986. Naquele período, como apontado por um dos formuladores do Plano Cruzado, o economista João Manuel Cardoso de Mello em entrevista a Melhem e Russo (2004: 127), "não precisava argumentar, todo mundo que queria podia entrar (no PMDB),260.

\footnotetext{
${ }^{260}$ A exceção a essa regra é possivelmente Jânio Quadros, que tentou se filiar ao PMDB mas teve sua tentativa barrada pelo partido. Para detalhes deste processo, ver Delgado (2006).
} 
Concomitantemente, ao longo dos anos 1980, o PMDB perdeu políticos à sua esquerda em três ondas, cada qual com impactos distintos em diferentes estados: a primeira rumo ao PT e ao PDT, em 1980 (apresentada no primeiro capítulo), a segunda rumo ao $\mathrm{PCB}$, ao $\mathrm{PCdoB}$ e ao $\mathrm{PSB}$, em 1985, e a terceira rumo ao PSDB em 1988. Ao final desse período (1979-1988), como dito, a composição interna do partido no Congresso Nacional e nos seus principais órgãos de direção nos forneceram importantes pistas sobre o perfil que o partido teria a partir do ano de 1988.

Figura 4 - Transformações internas do PMDB de 1979 a 1988
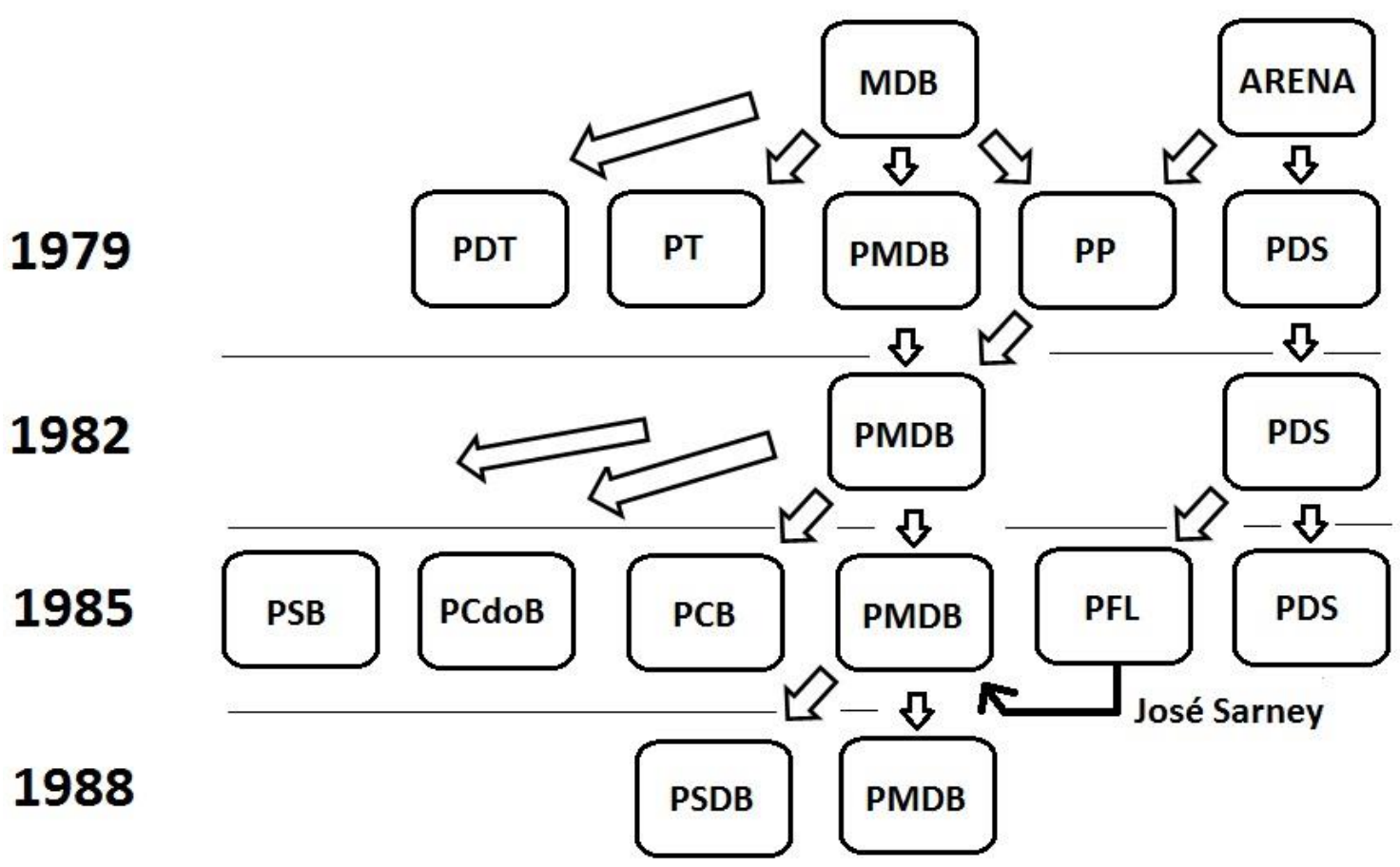

Fonte: elaboração própria

Dessa forma, analisando de maneira retrospectiva o período histórico de 1979 a 1988 conclui-se que de fato houve uma transformação na correlação de forças interna do PMDB, evidenciando o processo descrito por Rodrigues (1987: 53) e mencionado na Introdução. A pergunta que nos permitimos fazer, então, é: quais foram as consequências desse processo para o PMDB a partir da década de 1990 e qual a relação disso com a perda de protagonismo do partido? Há algum impacto disso no fato de o partido ter lançado candidaturas próprias em 1989 e em 1994, mas desde então não ter mais adotado essa estratégia durante o recorte histórico aqui utilizado? Qual a relação entre essas transformações e as candidaturas de 1989 e 1994? Esses são alguns dos questionamentos que orientarão a Parte 2 desta pesquisa, nos próximos capítulos que se seguem. 
Parte 2

Da Constituinte à primeira candidatura à vice-presidência:

a trajetória do PMDB de 1989 a 2002 


\section{Capítulo 3 - As breves hegemonias "ulyssista" e "quercista" (1989-1994)}

"Depois do Sarney vamos ter um presidente do PMDB no Planalto." Ulysses Guimarães, deputado federal e presidente nacional do partido em 27 de setembro de 1986 (Folha de S. Paulo - 1/05/1989).

"Às vezes um político mesmo sendo proeminente, o prestígio dele fica regionalizado, ou seja, numa região ou em um estado. Quércia é uma pessoa identificada como um agente político rigorosamente paulista e não conseguiu transpor essa barreira de São Paulo para o resto do Brasil." Senador Raimundo Lira, em entrevista concedida ao autor.

\subsection{Introducão}

O recorte histórico de que iremos tratar neste capítulo, que cobre o período entre o final dos anos 1980 e o ano de 1994, inclui duas candidaturas diretas apresentadas pelo PMDB ao cargo de Presidente da República. A primeira delas, a de Ulysses Guimarães em 1989, representa o reflexo de uma reviravolta da narrativa apresentada até aqui em relação à dinâmica interna do partido. Se até então se observava um aumento na quantidade de políticos com passagem pela ARENA nos órgãos de direção do partido e nas suas bancadas no Congresso Nacional, essa tendência se inverte na CEN quando Ulysses Guimarães consegue temporariamente o controle do órgão, alienando daquele espaço esses mesmos setores que vinham crescendo. Com isso, a coalizão dominante do partido passa a ser exclusivamente "ulyssista" e o político consegue a sua tão almejada candidatura direta à presidência da República, a primeira apresentada pelo PMDB em sua história.

Por sua vez, a segunda candidatura direta apresentada pela sigla, a de Orestes Quércia em 1994, materializa o resultado de um processo distinto, mas que resulta também num controle efêmero dos órgãos de direção do partido por parte do político. A ala "quercista" do PMDB, que seguia a liderança de Quércia no estado de São Paulo, passa por um período de ascensão nacional após conquistar o controle da seção estadual paulista do partido. Esse processo atinge o seu auge quando sua liderança máxima chega ao cargo de presidente nacional do PMDB, em 1991, substituindo a posição ocupada por Ulysses Guimarães desde a refundação do partido em 1979. Essa ascensão se deu em aliança com os setores que, durante os anos de 1989 a 1991, haviam sido alijados 
pela ala ulyssista tanto da Executiva Nacional do partido quanto da campanha para as eleições presidenciais de 1989.

O recorte histórico coberto por este capítulo também abrange um marco importante pra história do partido no que tange as diferentes tendências que o compõem. Enquanto durante o Regime Militar a divisão interna que o marcava se dera, grosso modo, entre as suas alas moderada e autêntica, que divergiam com relação ao modo como o partido deveria desempenhar sua oposição ao Regime, a partir dos anos 1990, quando o partido se vê na condição de integrante da coalizão governista durante o mandato-tampão de Itamar Franco, suas divergências internas mudam de teor. A partir de então se evidencia uma nova divisão no partido, que já vinha se engendrando desde o governo Sarney, e que biparte sua coalizão dominante em torno do apoio ou não ao governo Itamar. Essa divisão leva à formação de suas alas governista e oposicionista, mencionadas pela literatura que se debruçou sobre o PMDB, que constituem o partido durante o restante do recorte histórico abrangido nesta tese ${ }^{261}$.

Concomitantemente a esse processo de mudanças e divisões internas na coalizão dominante no interior do PMDB, o partido passa a perder o seu papel de protagonista na política partidária nacional, vendo seu desempenho eleitoral declinar e posteriormente se estabilizar num patamar abaixo daquele atingido nos anos 1980. Se até meados dessa década o partido havia sido um ator relevante em vários momentos da política brasileira, como na campanha pelas Diretas-Já em 1983 e 1984 e na candidatura vitoriosa da chapa Tancredo-Sarney no Colégio Eleitoral de 1985, a partir da década de 1990, como resultado da dinâmica interna do próprio PMDB somada à entrada de novos e fortes atores na cena partidária, o partido perde essa condição.

Com o crescente protagonismo adquirido por PT e PSDB na política nacional, as eleições presidenciais de 1994 até 2002 foram um período de bipolarização entre as candidaturas apresentadas pelos dois partidos, ao passo que o PMDB vira suas duas candidaturas diretas à presidência, nos pleitos de 1989 e 1994, terem desempenhos muito ruins, sempre distante dos principais candidatos no páreo. Como resultado final desse processo, percebe-se um PMDB que, apesar de passar para o "pano de fundo" da política brasileira, não mais apresentando um candidato próprio na disputa pela presidência da República, ainda se mantém como um ator extremamente relevante no sistema político. Evidências nesse sentido são o fato de o partido ter se mantido como o detentor da maior bancada no Congresso Nacional, participando regularmente das coalizões de governo a partir dos anos 1990, e integrando as chapas apresentadas pelos grandes partidos para a disputa da presidência da República na condição de Vice.

Para analisar o recorte histórico de 1989 a 1994, este capítulo foi dividido em nove seções, incluindo esta introdução. Na próxima seção, apresentamos o processo interno que levou à candidatura direta de Ulysses Guimarães em 1989, decorrência da

\footnotetext{
${ }^{261}$ Ferreira (2002) e Maciel (2014) também haviam notado a presença dessa divisão interna, mas diferentemente das autoras, apresentaremos evidências de que essa divisão se deu a partir do governo de Itamar Franco, e não de Fernando Henrique Cardoso (Ferreira, 2002: 151; Maciel, 2014: 20).
} 
sua breve hegemonia nos órgãos de direção do partido. Em seguida, apresentamos os resultados das eleições de 1990, que deram início ao ciclo de decremento eleitoral do PMDB. Na seção seguinte descrevemos o efêmero processo de ascensão nacional de Orestes Quércia e de seu grupo de apoio no interior do partido, que o leva a sua presidência em 1991. Em seguida, dissertamos sobre o desaparecimento de Ulysses Guimarães, uma das principais figuras históricas do PMDB, e o seu papel cumprido no partido. A seguir, tratamos da relação do PMDB com o governo Itamar, período no qual se torna evidente pela primeira vez em sua história a divisão entre suas alas governista e oposicionista. Na seção seguinte, apresentamos as consequências da efêmera ascensão nacional da ala quercista no interior do partido, que levaram à candidatura direta à presidência da República de Orestes Quércia em 1994. Na oitava seção, apresentamos os resultados eleitorais do partido nas eleições de 1994 e por fim, na seção subsequente, apresentamos as considerações finais deste capítulo.

\subsection{A breve hegemonia ulyssista: a candidatura direta do "Doutor Ulysses" (1989)}

"O Ulysses Guimarães de certa forma pagou o preço de ter dado suporte ao governo do Sarney." Deputado Saraiva Felipe, em entrevista ao autor.

No ano de 1989, pela primeira vez desde o golpe civil-militar de 1964 o Brasil foi às urnas para eleger de maneira direta o seu presidente da República. A eleição de 1989 marcou também a primeira eleição no Brasil a usar os dois turnos e, sendo também uma eleição solteira, ou seja, para apenas um cargo eletivo, nenhum partido viu motivos para deixar de apresentar seu próprio candidato (Limongi e Guarnieri, 2014: 8). Assim, um número recorde de 21 pleiteantes se apresentou para a disputa ${ }^{262}$, e o PMDB foi um deles, com a candidatura de Ulysses Guimarães, conhecido pelos seus pares como o "Doutor Ulysses".

Naquela ocasião, Ulysses era um dos políticos com maior projeção no cenário político brasileiro, e se tornava a primeira candidatura própria do seu partido em uma eleição direta para o cargo máximo do país. Um dos principais articuladores da fundação do PMDB, logrou ser eleito deputado federal por 10 mandatos consecutivos, e seria ainda reeleito novamente antes de sua morte, em 1990, mas nunca havia disputado uma eleição majoritária. Além disso, teve também forte atuação durante a ditadura sob a sigla do MDB, mantendo-se como presidente do partido durante quase toda sua existência ${ }^{263}$ e chegando a ser lançado como "anti-candidato" pelo partido no Colégio Eleitoral de 1974. O auge de sua trajetória até então havia sido tornar-se responsável

\footnotetext{
${ }^{262}$ O pleito teria contado com 22 candidaturas no total, caso a candidatura do PMB não houvesse sido cassada às vésperas das eleições.

263 Ulysses não foi presidente do MDB apenas durante o período de 1966 a 1970, quando o presidente foi o senador e general da reserva Oscar Passos.
} 
pela condução dos trabalhos da Assembleia Nacional Constituinte de 1987-1988 enquanto seu Presidente ${ }^{264}$.

Porém, a definição de seu nome para representar seu partido enquanto candidato à presidência em 1989 não foi um processo simples e sua escolha foi o resultado de um período "fora da curva" da trajetória pela qual o partido vinha atravessando desde sua fundação. Se até aquele momento houve um gradual aumento da porcentagem de políticos com passagem pela ARENA nos órgãos de direção do PMDB, a escolha de Ulysses como candidato só se tornou possível porque houve uma mudança radical na composição interna da Comissão Executiva Nacional da sigla após sua Convenção Nacional realizada no início de 1989, que inverteu temporariamente essa tendência.

A Convenção, realizada no dia 12 de março daquele ano, primeiro passo para a nomeação de "Doutor Ulysses" como candidato do seu partido para as eleições de 1989, apresentou, pela primeira vez na história do PMDB, uma disputa entre duas chapas para a eleição do Diretório Nacional (Ferreira, 2002: 202; Delgado, 2006: 364). Até então, durante todo o período em que Ulysses fora presidente da sigla, o partido sempre havia tido como prática a apresentação de uma única chapa nas suas disputas internas em Convenções Nacionais, definindo seus componentes por meio de uma negociação conciliatória prévia. Esse processo de escolha de seus dirigentes também era uma prática adotada no MDB (Cardoso, 1981), e foi por meio desse aspecto que o bloco formado pelos antes chamados de "moderados" durante o Regime Militar ir pouco a pouco conquistando espaço e ganhando força nos órgãos de direção do PMDB, processo descrito nos capítulos anteriores.

$\mathrm{Na}$ disputa pelo controle do partido, de um lado concorreram os integrantes da chapa "Compromisso PMDB", composta pelos remanescentes dos setores mais à esquerda do partido e por aliados de Ulysses Guimarães de diferentes matizes ideológicos. Entre os seus membros destacavam-se algumas das figuras de frente da sigla que tinham suas raízes ligadas ao grupo dos autênticos históricos, tal como Jarbas Vasconcelos (PE), Dante de Oliveira (MT), Fernando Gasparian (SP) e Pedro Simon (RS). Do outro lado estava a chapa "Unidade", mesmo nome utilizado pelo bloco mais à direita do partido na $3^{\text {a }}$ Convenção Nacional, em 1983, quando conquistou um amplo espaço na Executiva Nacional do PMDB. A chapa era encabeçada por Jader Barbalho (PA) e composta por setores que a imprensa à época denominou como "moderados", "governistas", ou "fisiológicos" do partido, dadas as suas ligações com o governo Sarney $^{265}$. Entre os seus membros encontravam-se alguns então governadores e exgovernadores, tais como o próprio Jader Barbalho, Íris Rezende (GO), naquele momento também Ministro da Agricultura do governo, e também Epitácio Cafeteira

\footnotetext{
${ }^{264}$ Para uma biografia mais detalhada da trajetória política de Ulysses Guimarães ver Scartezini (1993), Melhem e Russo (2004), Correa (2011), Folha de S. Paulo - 01/05/1989, p. A-7, e http://www2.camara.leg.br/camaranoticias/radio/materias/REPORTAGEM-ESPECIAL/453843-SENHORDIRETAS-A-HISTORIA-DE-ULYSSES-GUIMARAES-BLOCO-1.html.

${ }^{265}$ Folha de S. Paulo-13/03/1989, p. A-1, e 14/03/1989, p. A-5.
} 
(MA), assim como membros do chamado "Centrão" do período Constituinte, como Roberto Cardoso Alves (SP) e Prisco Viana (BA).

Ao final das votações da Convenção, o bloco Unidade conquistou 45 das 119 vagas do Diretório Nacional do PMDB (37\% do órgão), conseguindo manter assim certo espaço de influência na condução do partido ${ }^{266}$. Porém, rompendo com o procedimento que era praxe na partilha interna de poder no PMDB até então, os membros da chapa Compromisso, majoritária, não repartiram os cargos da Executiva Nacional do PMDB com o grupo dos moderados, componentes da chapa Unidade ${ }^{267}$. Com isso, efetuam uma inversão na tendência verificada nos primeiros 10 anos de história do partido, descrita nos capítulos anteriores. Até então, o número de políticos com histórico de filiação partidária na ARENA vinha crescendo na CEN do partido, mas quando ocorre a disputa entre duas chapas e uma delas se torna majoritária, a coalizão dominante que daria os rumos do partido passa a ser exclusivamente "ulyssista"268 e essa tendência se inverte.

Como mostra a tabela abaixo, apenas um dos componentes da Executiva formada naquela ocasião teve passagem pela ARENA, e a composição dessa nova CEN apresentava um perfil comparável ao dos primeiros anos do partido, quando o grupo autêntico controlava a legenda, até a incorporação do PP em 1982. Ademais, a composição da CEN apresentou também um razoável contraste com a composição do Diretório Nacional, que, como mencionamos, tinha entre os seus membros vários ministros e ex-ministros de Sarney, assim como membros do Centrão da Constituinte ${ }^{269}$.

\section{Tabela 26. Filiação prévia dos membros da Executiva Nacional do PMDB (1980-1991)}

\begin{tabular}{|c|c|c|c|c|c|c|c|c|c|c|}
\hline & \multicolumn{2}{|c|}{1980 - 1982} & \multicolumn{2}{|c|}{ 1982-1983 } & \multicolumn{2}{|c|}{ 1983-1986 } & \multicolumn{2}{|c|}{ 1986-1989 } & \multicolumn{2}{|c|}{ 1989-1991 } \\
\hline & $\mathbf{N}$ & $\%$ & $\mathbf{N}$ & $\%$ & $\mathbf{N}$ & $\%$ & $\mathbf{N}$ & $\%$ & $\mathbf{N}$ & $\%$ \\
\hline ARENA & 1 & $5 \%$ & 4 & $20 \%$ & 4 & $20 \%$ & 5 & $25 \%$ & 1 & $5 \%$ \\
\hline MDB & 19 & $95 \%$ & 16 & $80 \%$ & 16 & $80 \%$ & 15 & $75 \%$ & 18 & $95 \%$ \\
\hline Total & 20 & $100 \%$ & 20 & $100 \%$ & 20 & $100 \%$ & 20 & $100 \%$ & 19 & $100 \%$ \\
\hline
\end{tabular}

Fontes: elaboração própria a partir de documentos coletados na SEDAP/TSE com o cruzamento de informações coletadas no Centro de Pesquisa e Documentação de História Contemporânea do Brasil (CPDOC-FGV).

Tal composição em sua direção permitiu a aprovação de uma moção por parte da Executiva do partido declarando sua independência em relação ao governo Sarney e desautorizando seus filiados a participar do governo:

"O PMDB, pela sua Comissão Executiva Nacional, declara-se politicamente independente em relação ao

\footnotetext{
${ }^{266}$ Folha de S. Paulo-13/03/1989, p. A-5.

${ }^{267}$ Folha de S. Paulo - 14/03/1989, p. A-5.

${ }^{268}$ Sobre a composição da Comissão Executiva do PMDB eleita em 1989, ver Anexo 3.

269 Jornal O Liberal - 13/03/1989, p. 2, 9-10.
} 
governo federal, nele não se sente representado pelos seus filiados que integram o ministério, pela escolha do Sr. Presidente da República. Outrossim, reafirma seus compromissos com a transição democrática que se completará com a eleição do novo Presidente da República a 15 de novembro próximo. "270

A medida buscava, aparentemente, afastar a imagem do partido da alta rejeição ao governo federal que ocorria na época, mas ela não foi cumprida pela parte de seus quadros que de fato apoiava o governo Sarney, e que corresponde aos mesmos políticos que compunham a ala do partido que já integrava o governo e que havia sido alijada do comando da Executiva naquele momento. A tensão interna em relação à manutenção ou não da adesão ao governo Sarney era a primeira manifestação de uma nova divisão interna no PMDB, que só viria a se concretizar no governo Itamar Franco, anos depois.

A segunda etapa do processo de nomeação de Ulysses como candidato peemedebista nas eleições diretas de 1989 é a formalização da candidatura apresentada pelo partido na Convenção Nacional, realizada nos dias 29 e 30 de abril daquele mesmo ano $^{271}$, em uma votação em dois turnos. A Convenção, em um primeiro momento, se mostrou bastante pulverizada, evidenciando a falta de coesão interna do partido naquela conjuntura, e a consequente dificuldade em definir um nome de consenso que pudesse construir uma unidade partidária em torno de sua candidatura. De acordo com a Ata daquela reunião ${ }^{272}$, concorreram na convenção quatro peemedebistas dispostos a postular uma candidatura à presidência da República pelo partido: o governador da Bahia Waldir Pires (candidato com apoio da ala mais à esquerda do partido), o Ministro da Agricultura Íris Rezende (candidato apoiado pela ala ligada ao governo Sarney), o governador do Paraná, Álvaro Dias, e o próprio deputado federal por São Paulo Ulysses Guimarães (Scartezini, 1993: 237-238) ${ }^{273}$.

Ulysses desde o princípio mostrava-se convencido de que seria o nome mais forte do partido no páreo, apesar das dificuldades em construir um consenso em torno

\footnotetext{
${ }^{270}$ Ata da reunião da Comissão Executiva do Diretório Nacional realizada em 13/03/1989, em Ferreira (2002: 142).

${ }^{271}$ É digno de nota que em editorial de 29/04/1989, página 2, o jornal Folha de S. Paulo parece ter sido aquele que caracterizou o PMDB enquanto um partido de "centro" pela primeira vez na imprensa jornalística até então.

${ }^{272}$ Ata da 12a Convenção Nacional do PMDB - Acervo SEDAP/TSE.

${ }^{273}$ Orestes Quércia também tentou ser o candidato do PMDB naquela ocasião, com inúmeras manobras de bastidores que se estenderam até o momento da votação. Porém, tendo seu registro sido feito fora do prazo necessário para que sua candidatura interna fosse homologada, suas manobras não tiveram sucesso e os votos dos "quercistas" na Convenção se pulverizaram entre os candidatos. Porém, não se sabe se sua candidatura não foi levada adiante de fato por problemas na sua documentação ou se o próprio Quércia sabia que naquela ocasião uma candidatura própria do PMDB teria forte desgaste na opinião pública pela sua ligação com o governo Sarney. O político, porém, já demonstrava ali a força que havia adquirido dentro do partido, tendo se tornado a principal liderança do partido no estado de São Paulo (sobretudo após a ruptura da ala que fundou o PSDB) e sedimentado as bases para sua futura candidatura presidencial, que viria a ocorrer em 1994.
} 
de seu nome. Porém, conquista a indicação apenas no segundo turno das votações internas, recebendo apoio do bloco que havia apoiado a candidatura de Waldir Pires no primeiro turno das votações ao convidá-lo para o cargo de vice em sua chapa, bloco este que já o havia apoiado na composição feita para a distribuição dos cargos de direção da $\operatorname{sigla}^{274}$. A contrapartida imposta por eles para que concedessem o apoio determinante para a almejada candidatura de Ulysses teria sido que sua campanha adotasse um tom de oposição ao governo federal, apesar de o próprio presidente da República ser um quadro filiado ao PMDB, e que não tomassem parte dela os ministros de Sarney, assim como os representantes do partido que o apoiavam.

É importante destacar que a constatação de que havia um descompasso entre a candidatura de Ulysses e a sua representatividade entre as diferentes forças no interior do partido vai na contramão de parte da literatura sobre o PMDB e nos ajuda a explicar em parte o desempenho eleitoral da candidatura do partido naquela eleição. Para Melo (2013: 137), Ulysses tinha o maior apoio político possível para um candidato à presidência, com o apoio do Presidente em exercício José Sarney, de 48,1\% dos deputados federais e de 82,6\% dos governadores de estados (parte dos 22 governadores eleitos pelo PMDB em 1986 já havia migrado para outros partidos que haviam sido criados e naquele momento eram 19 os governadores do PMDB).

Porém, políticos que fizeram parte do PMDB naquele período apontaram que Ulysses não obteve apoio de seu próprio partido para uma candidatura que ambicionava há décadas, provavelmente desde que havia sido o anti-candidato do MDB no Colégio Eleitoral de 1974. As evidências apontam, assim, para uma "cristianização" da sua candidatura por parte do seu partido e de suas lideranças ${ }^{275}$.

Ao comentar sobre a candidatura de Ulysses, o deputado Heráclito Fortes (PI), amigo pessoal do presidenciável e integrante da sua campanha, declarou que sua candidatura foi renegada e esquecida pela quase totalidade do PMDB nos estados. $\mathrm{O}$ deputado estadual Tonico Ramos (SP) compartilha da mesma visão, afirmando que o PMDB naquela ocasião "não abraçou" a candidatura de Ulysses. As declarações do deputado mineiro Saraiva Felipe, outro entrevistado para este estudo, caminham no mesmo sentido, e sendo as que melhor sintetizam aquela conjuntura cabe que sejam reproduzidas em sua íntegra:

\footnotetext{
274 Para um relato pormenorizado sobre as circunstâncias que levaram Ulysses ao segundo turno das prévias do partido, ver Scartezini (1993: 238).

${ }^{275}$ O termo "cristianizado" na política brasileira surgiu nas eleições de 1950 e se refere a uma situação eleitoral na qual determinado partido (ou grande parte de suas lideranças) abandona sua própria candidatura partidária. O termo surgiu a partir da candidatura à presidência da República de Cristiano Machado pelo PSD, que teve sua candidatura abandonada por boa parte das lideranças do seu próprio partido que, a partir do momento em que Getúlio Vargas passou a ser candidato pelo PTB, com maiores chances eleitorais, passaram a apoiá-lo. Bernardo Cabral, membro da Executiva Nacional do PMDB, é um exemplo de político que durante a campanha daquelas eleições se aproximou da candidatura de Collor e após a sua eleição viria a se tornar um de seus ministros, tendo sido o único ministro do PMDB a participar daquele governo.
} 
"Em 89 você já tinha um desgaste fenomenal do governo Sarney. O Ulysses Guimarães de certa forma pagou o preço de ter dado suporte ao governo do Sarney. Isso eu vivi muito de perto. O Sarney estava numa situação muito ruim, próxima a que temos atualmente com o Temer na república. Então a candidatura do Ulysses estava completamente contaminada por esse desgaste. As pesquisas começaram a mostrar que o Ulysses não ia emplacar a candidatura dele. Sempre acontece esse fenômeno. Aconteceu com o Quércia mais tarde, que é da 'cristianização' do candidato. Aconteceu com o Cristiano Machado e você conhece a história, que tem até muito a ver com Minas Gerais [risos]. $O$ candidato é 'cristianizado'. As pessoas começam a migrar para a candidatura mais viável, e ele ficou parece que em $5^{\circ}$ lugar. Inclusive o Waldir Pires deixou o governo da Bahia para ser vice dele, e ficou desgastado no próprio estado da Bahia, que custou para se ver livre da hegemonia absoluta do Antonio Carlos Magalhães. O Waldir ganha, sai para ser vice do Ulysses e eles fracassam. De alguma forma, eu trabalhei, me empenhei, mas percebia que [não daria certo]... Agora (...), se a candidatura do Ulysses tivesse sido, por exemplo, em 1986, quando os governadores todos foram eleitos, você pode ter certeza que o Ulysses seria Presidente da República. Em 89 o desgaste do Sarney, que formalmente, era do PMDB, bateu em cheio na candidatura do Ulysses com o Waldir Pires. "276

Dentre os entrevistados para este estudo, apenas o ex-senador Mauro Benevides (CE), outro integrante da campanha de Ulysses, levantou dúvidas quanto a uma possível deserção por parte dos políticos do partido em relação à candidatura. Nesse sentido, nossos achados vão ao encontro do que apontou Melhem (1998: 198), que chegou à mesma conclusão sobre o abandono de Ulysses por parte do PMDB, apontando que segundo a quase totalidade de depoimentos coletados por ela isso se deu pela inviabilidade eleitoral de sua candidatura, após o desgaste do governo Sarney.

Por outro lado, deve-se mencionar que parte dos integrantes do PMDB à época afirma que caso naquela ocasião a candidatura do partido tivesse sido encabeçada por Orestes Quércia, que na ocasião era governador de São Paulo e contava com altos índices de popularidade, o resultado teria sido bastante distinto. Entretanto, a força e o prestígio de que Ulysses gozava no interior do partido impediram que suas principais lideranças (sobretudo os governadores de estado) questionassem a sua candidatura, e ao final tiveram que endossá-la, ainda que pretensamente. A esse respeito, em entrevista concedida ao autor, o senador Airton Sandoval (SP) declarou:

${ }^{276}$ Entrevistas ao autor. 
"O Ulysses foi consequência de uma divisão interna forte. Quem era pra ser candidato a presidente naquela eleição era o governador de São Paulo, Orestes Quércia. O que criava dificuldade é que todo mundo queria ser candidato, mas ninguém punha a cara pra apanhar. O [Miguel] Arraes, o Pedro Simon, ou o Ulysses, dentre outras expressões importantes do partido. Lembro até que eu era presidente do $P M D B$ de São Paulo nesse período, convenci o Ulysses a fazer uma reunião da Executiva Nacional juntamente abrigando todos os presidentes de Diretórios Estaduais, pra ver se a gente chegava a um candidato, ali teríamos de decidir. Enquanto não saísse o nome de um candidato, a reunião não acabaria (...). E foi feita a reunião. $O$ Ulysses convocou, fomos a um determinado lugar, a reunião começou e em certa altura da reunião um governador começa a conversar com outro e convenceram o Ulysses Guimarães a ir à sua residência com os governadores, nos deixando [aos presidentes do partido] esperando, e acabou saindo o próprio Ulysses como candidato à presidência. A história conta, não sei se é um fato real, mas contam que, naquela época, Dona Mora, esposa do Ulysses Guimarães, que levou o pessoal a apoiar a candidatura dele, conversando com cada um sobre a ajuda que o Ulysses já tinha dado a cada um deles, e assim o apoiaram."

As afirmações do deputado Marcelo Castro (PI) e do ex-deputado Marcelo Barbieri (SP) vão na mesma direção:

"O Quércia conseguiu ser governador de São Paulo, e quem chega a governador de São Paulo é um précandidato à presidência da República. Aí teve um problema: quatro anos antes, o Quércia estava muito bem na opinião pública, e o que acontecia? O Tancredo era velho, e o Ulysses, apesar de ser um grande nome, não estava bem na opinião pública. Acho que por ser velho também (...). Houve uma disputa: o Ulysses querendo ser candidato a presidente e muitas forças dentro do partido achando que quem deveria ser era o Quércia. Eu lembro que na época o Datafolha fez uma pesquisa e o Quércia estava bem no Brasil e o Ulysses não estava, mas ninguém tinha coragem de enfrentar Dr. Ulysses. Então a candidatura dele foi, digamos, porque ninguém teve coragem de enfrentá-lo, mas todo mundo sabia que era uma candidatura de pouca viabilidade eleitoral. E o Quércia tinha maior viabilidade. (...) Se o Quércia tivesse sido candidato nessa época em que o Ulysses foi, quem sabe tivesse mudado a história do PMDB e até do país. Quatro anos depois já não teve o mesmo desempenho." Deputado Marcelo Castro, em entrevista ao autor. 
"Na verdade teve um movimento para que o Quércia fosse candidato já em 89, ele estava muito bem avaliado em São Paulo. Havia um sentimento a favor do Quércia no partido, mas ninguém tinha coragem de enfrentar o Ulysses. Aí teve uma reunião na casa do Ulysses em Brasília e o Pedro Simon ficou encarregado de falar ao Ulysses para abrir mão da candidatura para o Quércia. Aí a Dona Mora peitou todo mundo! O Simon nem falou nada, ficou quieto e ninguém mais falou nada, mas essa reunião foi histórica. Era para o Ulysses sair e deixar o Quércia ser o candidato. Isso não aconteceu, aí ficou assim até o final, o Quércia apoiou o Ulysses, mas o Ulysses se desgastou, ficou, acho, em sexto lugar..." Exdeputado Marcelo Barbieri, em entrevista ao autor ${ }^{277}$.

Ademais, além desses fatores internos, sua campanha pode também ter sido prejudicada pela estratégia de marketing eleitoral adotada. A utilização de um estilingue como símbolo de sua campanha nas primeiras semanas, uma ideia que posteriormente foi repensada, e o seu próprio jingle na televisão, foram vistos como um erro por alguns entrevistados desta pesquisa ${ }^{278}$. Num momento em que o país havia perdido há poucos anos um presidente da República com mais de 75 anos de idade, Ulysses, com 73 no momento da eleição, adotou como slogan de campanha um refrão que justamente enfatizava a sua idade ${ }^{279}$.

Cabe apontar ainda que para além das estratégias de campanha e das variáveis internas ao partido, as conjunturas política e econômica também não favoreciam o desempenho da candidatura do PMDB. A escolha por Ulysses Guimarães não foi a melhor possível também porque as pesquisas apontavam que a população estava ávida por mudanças na política, que os ânimos da redemocratização não haviam de todo serenado e que queriam um novo nome para conduzir um novo país (Singer, 2002; Lavareda, 2009 apud Melo, 2013: 137). O perfil de Ulysses ia na contramão desse cenário, sobretudo quando o período de campanha já se encaminhava para um eventual segundo turno envolvendo a candidatura de Fernando Collor de Mello (PRN - Partido da Reconstrução Nacional) contra Luiz Inácio Lula da Silva (PT) ou Leonel Brizola (PDT), sendo que Ulysses era na ocasião um político de longa trajetória e que estava filiado a um partido que já se encontrava no poder naquele momento.

Em se tratando da conjuntura econômica, enquanto em 1986 o Plano Cruzado havia beneficiado diretamente o desempenho das candidaturas do PMDB, em 1989

\footnotetext{
277 Também argumentaram nesse sentido, em entrevistas ao autor, João Carlos Brum Torres (RS), senador Cássio Cunha Lima (PB), deputado Celso Maldaner (SC), e deputado Pedro Chaves (GO). Porém, para evitar a repetição de falas, optamos apenas por reproduzir as declarações de alguns entrevistados. ${ }^{278}$ Senador Airton Sandoval (SP), e deputado Marcelo Castro (PI), em entrevistas ao autor.

${ }^{279}$ O refrão do jingle dizia: “Bote fé no velhinho, / O velhinho é demais. / Bote fé no velhinho, /Que ele sabe o que faz. / Vai limpar o Brasil, / Do Oiapoque ao Chuí. / E acabar com a molecagem / Que tem por aí!". Disponível online em https://www.youtube.com/watch?v=8cQU0tPZe54 - acessado em 03/07/2017.
} 
parece ter ocorrido o inverso. O Plano Verão, que havia sido anunciado em janeiro de 1989 pelo Governo Sarney, havia fracassado na sua tentativa de conter a hiperinflação, e o ano se encerraria com o recorde histórico de inflação, com a taxa anual fechando o ano em 1.320\% (Maciel, 2008: 322) ${ }^{280}$. Com o fracasso de sua política econômica, o governo de José Sarney encontrava forte rejeição na população. Em setembro de 1989, dois meses antes do pleito, $68 \%$ dos eleitores achavam sua gestão ruim ou péssima de acordo com dados do Instituto Datafolha (Singer, 2002: 51), uma rejeição que parece ter contaminado a candidatura mais identificada ao governo naquele momento.

Dado esse cenário de "cristianização" por parte do partido e de uma conjuntura desfavorável, o resultado final daquelas eleições foi um fracasso para o PMDB. Apesar de ter conquistado a sua tão sonhada candidatura à presidência da República e estar à frente da coalizão dominante do partido, a tabela abaixo mostra como Ulysses terminou o pleito de 1989 com um desempenho muito aquém do esperado por ele. Amargando o sétimo lugar, seu nome passaria a partir de então a perder força no interior do seu partido, abrindo caminho para a chegada de Orestes Quércia à presidência do PMDB.

\section{Tabela 27. Resultados do primeiro turno da eleição presidencial de 1989}

\begin{tabular}{|c|c|c|c|c|c|}
\hline Posição final & Candidato & Partido & Votos & $\begin{array}{c}\text { Porcentagem } \\
\text { sobre o total } \\
\text { de votantes }\end{array}$ & $\begin{array}{c}\text { Porcentagem } \\
\text { sobre o total } \\
\text { de votos } \\
\text { válidos }\end{array}$ \\
\hline 1 & Collor & PRN & 20.611 .011 & 28,5 & 30,4 \\
\hline 2 & Lula & PT & 11.622 .673 & 16,1 & 17,1 \\
\hline 3 & Brizola & PDT & 11.168 .228 & 15,5 & 16,5 \\
\hline 4 & Covas & PSDB & 7.790.392 & 10,8 & 11,5 \\
\hline 5 & Maluf & PDS & 5.986 .575 & 8,3 & 8,8 \\
\hline 6 & Afif & PL & 3.272 .462 & 4,5 & 4,8 \\
\hline 7 & Ulysses & PMDB & 3.204 .932 & 4,4 & 4,7 \\
\hline 8 & Roberto Freire & PCB & 769.123 & 1,1 & 1,1 \\
\hline 9 & $\begin{array}{l}\text { Aureliano } \\
\text { Chaves }\end{array}$ & PFL & 600.838 & 0,8 & 0,8 \\
\hline 10 & Ronaldo Caiado & PSD & 488.846 & 0,7 & 0,7 \\
\hline 11 & $\begin{array}{l}\text { Affonso } \\
\text { Camargo }\end{array}$ & PTB & 379.286 & 0,5 & 0,5 \\
\hline Outros & & & 1.732 .283 & 2,3 & 2,5 \\
\hline $\begin{array}{l}\text { Votos } \\
\text { brancos/nulos }\end{array}$ & & & 4.654 .260 & 6,4 & \\
\hline Total & & & 72.280 .909 & & \\
\hline Abstenções & & & 9.793 .809 & & \\
\hline Eleitorado & & & 82.074 .718 & & \\
\hline
\end{tabular}

Fonte: Singer (2002: 63)

${ }^{280}$ Para uma síntese do Plano Verão, ver Moura (1990). 


\subsection{Comeca o ciclo de decadência eleitoral: panorama geral do PMDB nas eleicões de 1990}

"Então houve um emagrecimento dos grandes partidos com esse pluripartidarismo, a meu modo de ver, exagerado." Deputado Pedro Chaves, em entrevista ao autor.

Após o fracasso eleitoral nas eleições presidenciais de 1989, as eleições de 1990 inauguram um novo ciclo eleitoral no PMDB. Até então o partido vinha crescendo eleitoralmente desde sua refundação, aumentando gradualmente o tamanho de sua bancada no Congresso assim como o número de governadores eleitos, mas a partir das eleições de 1990 o partido viu uma queda na sua situação de hegemonia conforme o ambiente político se torna de maior competição (Simoni Jr. e Borges, 2011).

Ainda durante a $48^{\mathrm{a}}$ Legislatura (1987-1990) o partido fora um dos que mais perderam parlamentares de sua bancada proporcionalmente em relação àqueles que haviam sido eleitos em 1986. Em seu decurso, aproximadamente $40 \%$ dos parlamentares eleitos pela sigla abandonaram a legenda (Araújo, 2000: 62), num processo de refluxo do inchamento verificado no partido (idem: 48). Por sua vez, os resultados eleitorais de 1990 apresentam um agravamento desse cenário, patenteando diminuição do partido em todas as esferas representativas.

Ademais, é importante lembrar que na conjuntura daquela Legislatura, a 49a o PMDB se encontrava na oposição ao governo federal, uma vez que não participara da coalizão governista do presidente Fernando Collor de Mello (PRN) eleito em 1989 ${ }^{281}$, representando nesse sentido uma exceção dentro do recorte histórico da segunda parte deste estudo.

No que diz respeito às eleições para os governos estaduais, o PMDB concorreu naquela ocasião com candidaturas próprias em 18 estados e compôs coligações nos outros nove restantes. Venceu em oito deles com suas próprias candidaturas (29,6\% do total), compondo a coligação das candidaturas vitoriosas em apenas mais um estado. Entre os oito governadores eleitos pelo partido, dois haviam tido passagem pelo extinto PP: Gilberto Mestrinho (AM) e João Alves Filho (SE), este último também com passagem pela ARENA e pelo PDS. Ademais, três governadores eleitos haviam ocupado postos durante o governo de José Sarney: Jader Barbalho (PA), que havia sido Ministro da Reforma e Desenvolvimento Agrário, ex-presidente do INCRA e exMinistro da Previdência e Assistência Social, João Alves Filho (SE), mencionado

\footnotetext{
${ }^{281}$ Ver Tabela 4 na Introdução desta tese. Cabe apontar aqui que Fernando Collor havia sido um dos políticos com origem na ARENA que ingressaram no PMDB no seu processo de inchaço. O político havia sido prefeito nomeado de Maceió pela ARENA em 1979, transferindo-se para o PDS com o fim do bipartidarismo, e ingressando no PMDB em 1985, partido por meio do qual foi eleito governador de Alagoas em 1986.
} 
anteriormente e ex-Ministro do Interior, e Íris Resende (GO), ex-Ministro da Agricultura.

Tabela 28. Governadores eleitos em 1990

\begin{tabular}{|c|c|c|}
\hline Região/Estado & Eleito & Partido \\
\hline \multicolumn{3}{|l|}{ Norte } \\
\hline Acre & Edmundo Pinto & PDS \\
\hline Amapá & Anníbal Barcellos & PFL \\
\hline Amazonas & $\begin{array}{l}\text { Gilberto } \\
\text { Mestrinho* }\end{array}$ & PMDB \\
\hline Pará & Jader Barbalho & PMDB \\
\hline Rondônia & Oswaldo Piana & PTR \\
\hline Roraima & Ottomar Pinto & PTB \\
\hline Tocantins & Moisés Avelino & PMDB \\
\hline \multicolumn{3}{|l|}{ Nordeste } \\
\hline Alagoas & Geraldo Bulhões & PSC \\
\hline Bahia & $\begin{array}{c}\text { Antonio Carlos } \\
\text { Magalhães }\end{array}$ & PFL \\
\hline Ceará & Ciro Gomes & PSDB \\
\hline Maranhão & Edison Lobão & PFL \\
\hline Paraíba & $\begin{array}{l}\text { Ronaldo da Cunha } \\
\text { Lima }\end{array}$ & PMDB \\
\hline Pernambuco & Joaquim Francisco & PFL \\
\hline Piauí & $\begin{array}{c}\text { Antônio Freitas } \\
\text { Neto }\end{array}$ & PFL \\
\hline $\begin{array}{l}\text { Rio Grande do } \\
\text { Norte }\end{array}$ & $\begin{array}{c}\text { José Agripino } \\
\text { Maia }\end{array}$ & PDS \\
\hline Sergipe & $\begin{array}{l}\text { João Alves } \\
\text { Filho** }\end{array}$ & PMDB \\
\hline \multicolumn{3}{|l|}{ Centro-Oeste } \\
\hline Distrito Federal & Joaquim Roriz & PTR \\
\hline Goiás & Íris Rezende & PMDB \\
\hline Mato Grosso & Jaime Campos & PFL \\
\hline $\begin{array}{l}\text { Mato Grosso do } \\
\text { Sul }\end{array}$ & Pedro Pedrossian & PTB \\
\hline \multicolumn{3}{|l|}{ Sudeste } \\
\hline Minas Gerais & Hélio Garcia & PRS \\
\hline Espírito Santo & Albuíno Azeredo & PDT \\
\hline Rio de Janeiro & Leonel Brizola & PDT \\
\hline São Paulo & $\begin{array}{l}\text { Luiz Antônio } \\
\text { Fleury Filho }\end{array}$ & PMDB \\
\hline \multicolumn{3}{|l|}{ Sul } \\
\hline Paraná & Roberto Requião & PMDB \\
\hline Rio Grande do Sul & Alceu Collares & PDT \\
\hline Santa Catarina & Vilson Kleinubing & PFL \\
\hline
\end{tabular}

Fontes: Nicolau (1998) e múltiplas fontes jornalísticas, com cruzamento de informações do Dicionário Histórico Biográfico Brasileiro do Centro de Pesquisa e Documentação de História Contemporânea do Brasil, CPDOC/FGV.

*Ex-pepistas

** Ex-arenista, ex-pepista, ex-PDS 
Por sua vez, em relação às Assembleias Legislativas, o PMDB obteve nas eleições de 1990 resultado muito abaixo daquele alcançado nas eleições de 1986. Se nas eleições anteriores o partido teve o melhor desempenho de sua história dentro do recorte histórico deste estudo, conquistando 47\% das cadeiras em disputa, nas eleições de 1990 o partido obteve 214 cadeiras $(20,4 \%)$. O resultado ainda mantinha a sigla como a detentora da maior quantidade de parlamentares eleitos nessa esfera, porém vendo o PFL próximo da sua proporção de cadeiras obtidas, ainda que ele também tenha passado por uma queda acentuada em relação às eleições anteriores. As novidades daquelas eleições ficaram por conta de PSDB e PRN, partido do então presidente Fernando Collor, ambos recém-criados e que já em sua primeira eleição detentores de desempenho próximo ao dos partidos que haviam sido fundados no início do período pluripartidário.

Tabela 29. Cadeiras obtidas, percentual do total de cadeiras e votação total por partido nas eleições para as Assembleias Legislativas em 1990

\begin{tabular}{lccc}
\hline Partido & Cadeiras obtidas & $\%$ & Total de votos \\
\hline PMDB & 214 & 20,4 & 8.707 .058 \\
\hline PFL & 171 & 16,3 & 4.918 .738 \\
\hline PDT & 91 & 8,7 & 4.368 .831 \\
\hline PT & 83 & 7,9 & 4.177 .574 \\
\hline PDS & 80 & 7,6 & 3.804 .546 \\
PTB & 79 & 7,5 & 3.201 .703 \\
\hline PRN & 75 & 7,1 & 3.026 .536 \\
PSDB & 74 & 7,1 & 3.608 .982 \\
\hline PL & 51 & 4,9 & 2.094 .512 \\
PDC & 49 & 4,7 & 1.562 .564 \\
PSB & 17 & 1,6 & 669.486 \\
PTR & 15 & 1,4 & 646.263 \\
PSC & 13 & 1,2 & 421.991 \\
PST & 10 & 1,0 & 528.848 \\
PCdoB & 8 & 0,8 & 293.250 \\
PMN & 6 & 0,6 & 437.092 \\
PRS & 6 & 0,6 & 281.887 \\
PCB & 3 & 0,3 & 209.944 \\
\hline PSD & 2 & 0,2 & 164.232 \\
PCN & 1 & 0,1 & 100.289 \\
PNT & 1 & 0,1 & 33.396 \\
Outros & - & - & 471.203 \\
partidos & & $100 \%$ & \\
TOTAL & 1049 & & 43.728 .925 \\
\hline
\end{tabular}

Fonte: Nicolau (1998).

Por fim, quanto às eleições para o Congresso Nacional, os resultados mostram que o PMDB também teve uma acentuada queda no número de cadeiras ocupadas em 
comparação às eleições de 1986, momento do seu "inchaço". O partido ainda se manteve como o detentor da maior bancada partidária em ambas as Casas, porém viu outros partidos se aproximarem do seu percentual de representação. Cabe apontar ainda que naquelas eleições houve aumento na quantidade de cargos em disputa em relação às eleições anteriores. Os estados do Amapá e Roraima, que antes se enquadravam na categoria de Territórios Federais, elegeram pela primeira vez seus representantes, e o estado do Tocantins, que havia sido criado durante a ANC e eleito seus primeiros representantes em 1988, agora elegera um Senador e seus oito deputados federais.

Com relação às eleições para o Senado Federal, havia 27 cadeiras em disputa naquelas eleições, devido à renovação do mandato dos mesmos $1 / 3$ dos senadores eleitos em 1982 e o acréscimo dos parlamentares representantes dos novos estados. Das 27 cadeiras em disputa, o PMDB elegeu oito, que somados aos parlamentares que não renovaram os seus mandatos levaram o partido a ter uma representação composta por 27 senadores no total $(33,3 \%)$. Este resultado, apesar de manter o partido na condição de detentor da maior bancada naquela Casa, representou também uma acentuada queda em relação à bancada do partido pós-eleições de 1986, momento no qual o partido havia passado a ocupar 45 assentos no Senado Federal (62,5\%).

Em se tratando das eleições para a Câmara dos Deputados, enquanto nas eleições de 1986 o partido havia elegido 260 deputados federais (53,6\%), em 1990 foram 108 (21,5\%), menos da metade do tamanho da sua representação eleita anteriormente. O PMDB mantinha-se, assim, como a maior bancada partidária naquela Casa, mas a viu encolher 58,5\%, ao mesmo tempo que o PFL passava a se aproximar da sua proporção de cadeiras ocupadas na Câmara. Os resultados gerais reproduzidos na tabela abaixo mostram também aumento na pulverização de siglas que obtiveram representação no Poder Legislativo. Enquanto nas eleições de 1986 foram treze os partidos que conseguiram eleger pelo menos um representante, dessa vez foram 19. Porém, apenas PMDB e PFL conseguiram obter mais de $10 \%$ das cadeiras daquela Casa.

Tabela 30. Tamanho das bancadas partidárias na Câmara dos Deputados e no Senado Federal após as eleições de 1990

\begin{tabular}{lcccc}
\hline & \multicolumn{2}{c}{ Senado Federal } & \multicolumn{2}{c}{$\begin{array}{c}\text { Câmara dos } \\
\text { Deputados }\end{array}$} \\
\hline Partido & $\mathbf{N}$ & $\%$ & N & $\%$ \\
\hline PMDB & 27 & $33,3 \%$ & 108 & $21,5 \%$ \\
PFL & 15 & $18,5 \%$ & 83 & $16,5 \%$ \\
PDT & 5 & $6,2 \%$ & 46 & $9,1 \%$ \\
PDS & 3 & $3,7 \%$ & 42 & $8,3 \%$ \\
PRN & 3 & $3,7 \%$ & 40 & $8,0 \%$ \\
PTB & 8 & $9,9 \%$ & 38 & $7,6 \%$ \\
PSDB & 10 & $12,3 \%$ & 38 & $7,6 \%$ \\
PT & 1 & $1,2 \%$ & 35 & $7,0 \%$ \\
PDC & 4 & $4,9 \%$ & 22 & $4,4 \%$ \\
\hline
\end{tabular}




\begin{tabular}{lcccc}
\hline PL & - & - & 16 & $3,2 \%$ \\
PSB & 1 & $1,2 \%$ & 11 & $2,2 \%$ \\
PSC & - & - & 6 & $1,2 \%$ \\
PCdoB & - & - & 5 & $1,0 \%$ \\
PRS & - & - & 4 & $0,8 \%$ \\
PCB & - & - & 3 & $0,6 \%$ \\
PTR & - & - & 2 & $0,4 \%$ \\
PST & 1 & $1,2 \%$ & 2 & $0,4 \%$ \\
PMN & 1 & $1,2 \%$ & 1 & $0,2 \%$ \\
PSD & - & - & 1 & $0,2 \%$ \\
S/ Partido & 2 & $2,5 \%$ & - & - \\
TOTAL & 81 & $100 \%$ & 503 & $100 \%$ \\
\hline
\end{tabular}

Fontes: Nicolau (1998), e Mainwaring (2001: 137).

Tomando como ponto de partida esses dados, um olhar mais atento sobre os parlamentares eleitos pelo PMDB nas eleições de 1990 também nos evidencia outro aspecto importante da correlação de forças interna do partido que deve ser destacado. Enquanto a proporção de parlamentares com passado ligado ao MDB seguiu caindo, o processo de aumento na proporção de parlamentares com histórico de filiação partidária à ARENA ou ao PDS - que vinha sendo verificado no partido desde a sua fundação parece ter se estabilizado, com uma leve variação para baixo em ambas as Casas do Poder Legislativo. Ademais, dado o distanciamento histórico cada vez maior em relação ao momento de instauração do pluripartidarismo, verifica-se também aumento na proporção de parlamentares que entraram para a política partidária após a extinção do bipartidarismo, ou seja, que não foram filiados nem à ARENA, nem ao MDB.

Com relação aos parlamentares peemedebistas eleitos para a Câmara dos Deputados, dentre os 108 integrantes da sua bancada, 22 haviam feito parte da ARENA ou do PDS (20,37\%). Esse número representa uma queda na quantidade de parlamentares eleitos com esse histórico em comparação a 1986, quando a proporção havia sido de 22,3\%. Como dito anteriormente, verifica-se também uma queda na proporção de eleitos com passado ligado ao MDB, que naquela ocasião passaram a compor $46,3 \%$ da sua bancada. Em comparação aos outros partidos compreendidos como os principais herdeiros do bipartidarismo, esses números fizeram com que o PMDB fosse o partido mais "miscigenado" em sua composição interna (Madeira, 2006: 136) em se tratando de políticos com origem na ARENA e no MDB.

Tabela 31. Filiação prévia da bancada do PMDB na Câmara dos Deputados (1980-1990)

\begin{tabular}{l|cc|cc|cc|cc}
\hline & \multicolumn{2}{c}{1980} & \multicolumn{2}{c}{1982} & \multicolumn{2}{c}{1986} & \multicolumn{2}{c}{1990} \\
\hline \multirow{2}{*}{ ARENA/PDS } & $\mathbf{N}$ & $\%$ & $\mathbf{N}$ & $\%$ & $\mathbf{N}$ & $\%$ & $\mathbf{N}$ & $\%$ \\
\cline { 2 - 9 } MDB & 6 & $5,2 \%$ & 32 & $16 \%$ & 58 & $22,3 \%$ & 22 & $20,4 \%$ \\
\cline { 3 - 6 } & 109 & $94,8 \%$ & 148 & $74 \%$ & 126 & $48,5 \%$ & 50 & $46,3 \%$ \\
\hline
\end{tabular}




\begin{tabular}{|c|c|c|c|c|c|c|c|c|}
\hline Sem filiação prévia & - & - & 20 & $10 \%$ & 76 & $29,2 \%$ & 36 & $33,3 \%$ \\
\hline Total & 115 & $100 \%$ & 200 & $100 \%$ & 260 & $100 \%$ & 108 & $100 \%$ \\
\hline
\end{tabular}

Fontes: Schmitt (2000: 51) para os dados de 1980, Mucinhato (2015) para os dados de 1982 e elaboração própria para os dados de 1986 e 1990 a partir do cruzamento de informações coletadas no Centro de Documentação e Informação da Câmara dos Deputados (CEDI) e Centro de Pesquisa e Documentação de História Contemporânea do Brasil (CPDOC-FGV).

Por sua vez, no que diz respeito à bancada eleita pelo PMDB para o Senado Federal, dos 8 senadores eleitos em 1990 pelo partido três haviam ingressado na sigla sem qualquer filiação prévia, três haviam passado pelo MDB e dois pela ARENA durante o Regime Militar, incluindo o ex-Presidente da República e da própria ARENA José Sarney, eleito pelo estado do Amapá. Na sua bancada como um todo naquela Casa, o PMDB teria agora sete parlamentares $(25,93 \%)$ que haviam dado sustentação legislativa ao Regime em algum momento de sua história. Esse número corresponde a uma pequena queda na proporção de parlamentares com esse perfil em comparação aos eleitos em 1986, da mesma forma como ocorrera em relação aos eleitos para a Câmara dos Deputados.

\section{Tabela 32. Filiação prévia da bancada do PMDB no Senado Federal (1980-1990)}

\begin{tabular}{l|cc|cc|cc|cc}
\hline & \multicolumn{2}{c}{1980} & \multicolumn{2}{c}{1982} & \multicolumn{2}{c}{1986} & \multicolumn{2}{c}{1990} \\
\hline \multirow{2}{*}{ ARENA/PDS } & $\mathbf{N}$ & $\%$ & $\mathbf{N}$ & $\%$ & $\mathbf{N}$ & $\%$ & $\mathbf{N}$ & $\%$ \\
\cline { 2 - 9 } MDB & 2 & $9 \%$ & 7 & $33,3 \%$ & 13 & $28,9 \%$ & 7 & $25,9 \%$ \\
Sem filiação prévia & 20 & $91 \%$ & 14 & $66,7 \%$ & 23 & $51,1 \%$ & 13 & $48,2 \%$ \\
\hline Total & - & - & - & - & 9 & $20 \%$ & 7 & $25,9 \%$ \\
\hline
\end{tabular}

Fontes: Mucinhato (2015) para os dados de 1980 e 1982, Mainwaring (2001: 137) e elaboração própria para os dados de 1986 e 1990 a partir do cruzamento de informações coletadas no Centro de Documentação e Informação da Câmara dos Deputados (CEDI) e Centro de Pesquisa e Documentação de História Contemporânea do Brasil (CPDOC-FGV).

Nesse sentido, enquanto parte da literatura apontou que as eleições de 1986 representaram o momento de "inchaço" do PMDB, processo este que como demonstramos nos capítulos anteriores já estava em curso desde o início daquela década, as eleições de 1990 poderiam ser consideradas como o momento de refluxo desse processo. $\mathrm{O}$ crescimento constante do partido às custas da entrada de políticos com passado ligado à ARENA parece ter ocorrido enquanto o PMDB despontava eleitoralmente como futuro partido governista, e se encerrado a partir do momento em que o partido se viu na condição de oposição ao governo federal.

Ademais, a queda no tamanho das bancadas do partido parece estar também associada ao aumento da competitividade e à grande fragmentação que o sistema partidário brasileiro experimentou a partir do fim dos anos 80 (Simoni Jr. e Borges, 2011: 4). Considerando o fato de que o PSDB havia sido fundado enquanto uma dissidência interna do PMDB entre as eleições de 1986 e 1990, era de se esperar que o 
partido perdesse uma significativa parcela da sua bancada em ambas as Casas. Parcela esta que, como demonstramos no capítulo anterior, contribuiu para uma diminuição na quantidade de políticos com histórico de filiação ao MDB no PMDB, explicando em parte esse processo de mudanças na sua correlação de forças interna.

\subsection{Orestes Quércia assume a presidência do partido: a breve era "PMDB do Q" $\underline{(1991-1993)}$}

"O maior produto que um governo pode trazer aos brasileiros é a esperança, e a esperança chama-se PMDB, tendo Orestes Quércia à frente." Ulysses Guimarães, prestes a passar o cargo de presidente nacional do partido para Orestes Quércia, em 11 de março de $1991^{282}$.

Após uma fracassada candidatura à presidência em 1989 e o declínio em seu desempenho nas eleições de 1990, o ano de 1991 representou um momento de inflexão na história do PMDB (Ferreira, 2002: 203). Naquele ano, os setores mais conservadores do partido, ligados ao grupo dos moderados e aos governadores, passam a exercer o controle dos principais órgãos de direção da sigla, quando sua Executiva Nacional é renovada e Orestes Quércia é eleito presidente do PMDB no lugar de Ulysses Guimarães, presidente da sigla desde sua refundação em 1979, emblemando uma nova etapa de sua história. No ano de 1991 consuma-se então um processo que já vinha em curso desde a incorporação do Partido Popular em 1982: o aumento gradual dos políticos com perfil mais pragmático nos órgãos de direção do partido. Nesse sentido, fica ainda mais claro o quanto o breve período de 1989 a 1991 foi um ponto "fora da curva" em sua trajetória.

Como dito na primeira seção deste capítulo, a principal consequência da Convenção Nacional do partido realizada em 1989 foi o controle total da Executiva do PMDB por parte de uma coalizão dominante ligada à liderança de Ulysses Guimarães, que alijou de sua direção parte das lideranças do partido quando não se adotou a composição de uma chapa única e conciliatória para dirigir a sigla a partir de então. Por sua vez, a Convenção Nacional de 1991 reverte esse cenário, retomando a tendência anterior ao eleger Quércia para a presidência do partido e reincorporar os governistas do tempo de Sarney aos cargos de direção do partido (Scartezini, 1993: 261).

Antes de passarmos a uma análise dos resultados da Convenção Nacional do PMDB de 1991, é importante que dissertemos acerca da longa trajetória de Orestes Quércia no interior do partido, que culmina finalmente ao ser eleito para o cargo de presidente da sigla. Trajetória esta que está diretamente ligada às mudanças na coalizão dominante em nível nacional, que traz consequências para o lançamento de sua candidatura à presidência em 1994.

${ }^{282}$ Folha de S. Paulo - 24/03/1991. 
Nascido na cidade de Pedregulho no interior do estado de São Paulo, Quércia obteve gradual ascensão no interior do MDB paulista ao eleger-se vereador, deputado estadual e, finalmente, prefeito de Campinas em 1968. Essa vitória na Prefeitura de Campinas sintetiza a trajetória de Quércia e do grupo que granjeou em torno de si. Vindo de fora das elites políticas tradicionais da cidade, jornalista e empresário, valeuse de meticulosa construção em sua campanha para colocar-se como alternativa ao Executivo Municipal daquela cidade (Melhem, 1998). Apresentava-se como um homem do interior, próximo das pessoas mais simples e capaz de entender seus problemas como nenhum outro, especialmente quando comparado com membros da elite tradicional (Bizzarro Neto, 2013: 36).

A partir do momento em que se torna prefeito de Campinas, Quércia se utiliza da projeção que o cargo lhe confere e do período de ascensão eleitoral do MDB para percorrer o interior do estado de São Paulo e incentivar a abertura de Diretórios Municipais da sigla por todo o estado, atraindo para o MDB uma nova elite política que faria frente às elites tradicionais nesses municípios (Melhem, 1998). Essas novas lideranças locais, criadas sob a proteção de Quércia, passaram a constituir um grupo que apoiou o líder nas disputas internas do partido (Bizzarro Neto, 2013: 37), o chamado "quercismo". O quercismo então pode ser compreendido como um grupo interno do PMDB composto por um líder máximo e um conjunto de lideranças intermediárias pessoalmente associadas a ele por meio de um sistema de lealdades historicamente forjadas na vida partidária (Bizzarro Neto, 2013: 135). Este grupo, em sua totalidade, transferiu-se do MDB para o PMDB junto com o seu líder no momento da restauração do pluripartidarismo em $1979^{283}$, em especial o MR-8 paulista, que fazia parte da Tendência Popular do partido no período de refundação do PMDB e que se aliava a ele no interior da sigla ${ }^{284}$.

Porém, desde a aprovação da Lei de Anistia em 1979 e com o retorno de novas figuras ao cenário político nacional naquele mesmo ano, o grupo "quercista" passou a disputar o controle do Diretório Estadual do partido com outro grupo que também vinha crescendo eleitoralmente, do qual faziam parte figuras de expressão na política paulista, como Franco Montoro, Mário Covas e Fernando Henrique Cardoso. Em um primeiro momento, o grupo "montorista" passa a ter maior peso nas decisões daquela seção estadual do partido, com o próprio Montoro sendo eleito governador do estado pela sigla em 1982 e tendo Quércia como vice (que naquela ocasião já havia passado também pelo cargo de Senador, eleito em 1974 com a maior votação deste cargo na história de São Paulo até então - Sadek, 1989a: 69). Porém, num segundo momento o grupo "quercista" passa a ter mais força no interior da sigla, muito por conta dos diretórios criados com o seu apoio no interior do estado e também devido à derrota

\footnotetext{
${ }^{283}$ A criação dessa máquina partidária no interior do estado teve relação direta com a interiorização do voto do PMDB paulista nas eleições de 1986. Sobre o assunto ver Muszynski (1989) e Sadek (1989a).

${ }^{284}$ Cabe apontar ainda que ao longo de sua trajetória de ascensão na política nacional Quércia montou uma ampla rede de veículos de comunicação, em partes concedida durante o período da ANC (19871988) na presidência de José Sarney, como contrapartida ao seu apoio à duração de cinco anos de seu mandato presidencial (Melhem, 1998:197) mencionado no capítulo anterior.
} 
eleitoral de Fernando Henrique por Jânio Quadros na disputa pela prefeitura de São Paulo em $1985^{285}$.

Sendo assim, o próprio Quércia torna-se o candidato e é eleito governador de São Paulo em 1986, no momento em que o PMDB obteve o melhor desempenho eleitoral de sua história, impulsionado inclusive pela favorável conjuntura econômica nacional decorrente do Plano Cruzado. Essa disputa pelo controle da seção regional paulista da sigla prosseguiria até o ano de 1988 quando a ala não ligada a Quércia perde quase que toda sua representação na Comissão Executiva Estadual e, em conjunto com outros parlamentares peemedebistas da ANC, opta por sair da sigla e fundar um novo partido, o PSDB, levando do PMDB sua faceta mais ideológica e programática no estado (Bizzarro Neto, 2013: 103).

A partir de então, apesar do forte declínio eleitoral do partido em São Paulo ao longo dos anos 1990, o grupo quercista passa a ser a coalizão dominante na seção estadual paulista do PMDB, uma hegemonia que só seria encerrada em 2010, com sua morte (Bizzarro Neto, 2013: 46) ${ }^{286}$ e a saída de sua ala para fundar o Partido Pátria Livre (PPL) em 2011.

Com a conquista dessa hegemonia na seção estadual do partido desde o final dos anos 1980 e a eleição de seu sucessor para o cargo de governador de São Paulo em 1990 - seu então aliado Luiz Antônio Fleury Filho - Quércia fortalece sua liderança no PMDB nacionalmente. Contando com o enfraquecimento da figura de Ulysses a partir de sua derrota na eleição presidencial de $1989^{287}$ e a evasão de outras lideranças fortes do partido com a fundação do PSDB, o político passava a ser a grande figura do $\mathrm{PMDB}^{288}$.

Para consolidar sua liderança que vinha crescendo no interior do partido e preparar-se para ser sua futura candidatura à presidência da República em 1994 (uma posição que o político não havia logrado para as eleições de 1989), conquistar a presidência do partido em 1991 era elemento chave (Bizzarro Neto, 2013: 107). Contando com o apoio do próprio Ulysses Guimarães, segundo relato de Osvaldo Manicardi, seu secretário particular durante quase toda sua vida (Melhem e Russo, 2004: 358), Quércia consegue um efêmero controle da CEN do partido a partir da realização da sua Convenção Nacional de 24 de março de 1991.

Naquela ocasião, o PMDB retoma sua prática prévia de apresentar uma única chapa na disputa pelos cargos de direção. Chegando à Convenção em Brasília como um "rolo compressor", o poder de Quércia se fez manifesto na nova composição da direção,

\footnotetext{
${ }^{285}$ Depoimento de Luiz Carlos Bresser-Pereira para Melhem e Russo (2004: 216).

${ }^{286}$ Para uma compreensão mais detalhada sobre a ascensão de Quércia na regional paulista do partido até 1988 ver Melhem (1998). Para uma biografia do político consultar Pessoa (1994), Nunes, Lamounier e Studart (1994), Melhem (1998: 180-199) ou o excerto “Orestes Quércia” no Dicionário HistóricoBiográfico do CPDOC/FGV.

${ }^{287}$ Senador Cássio Cunha Lima (PB), em entrevista ao autor.

${ }^{288}$ Depoimento de Luiz Carlos Bresser-Pereira para Melhem e Russo (2004: 217).
} 
que passaria a ser formada a partir de então por parte dos representantes do quercismo, excluindo do órgão os apoiadores de outros prováveis presidenciáveis do partido ${ }^{289}$. Assim, na prática a Convenção acabou servindo não só para referendar sua liderança mas também como um pré-lançamento oficial de sua candidatura às eleições presidenciais de 1994, com faixas e discursos nesse sentido. A descrição daquela convenção em reportagem do jornal Folha de S. Paulo à época dá a tônica da força adquirida por Quércia:

"A $9^{a}$ Convenção Nacional do PMDB foi preparada para realçar um único personagem: o ex-governador de São Paulo, Orestes Quércia, que será escolhido hoje presidente do partido. Cartazes, faixas, camisetas, 'bottons' e adesivos exaltaram a figura de Quércia na Câmara dos Deputados. A tímida resistência ao 'rolo compressor' do quercismo existente nas bancadas de Minas Gerais e Paraná não encontrou ressonância na militância do PMDB, que marchou sobre Brasília. A multidão que lotou ontem o plenário do Salão Verde da Câmara se ocupou em lançar Quércia para a presidência da República em 1994. Parte da bancada do PMDB mineiro está seduzida pelo governador Hélio Garcia (PRS) que tenta engordar sua legenda. A bancada do Paraná foi excluída das negociações para os cargos da Executiva porque apoiou o adversário de Quércia, o exgovernador Álvaro Dias. Diferente do que ocorreu nas duas últimas convenções nacionais do PMDB, as divisões internas não tomaram este ano conta do cenário." Folha de S. Paulo-24/03/1991, p. 5.

No entanto, ainda que a passagem de Quércia pela presidência do PMDB tivesse sido suficientemente marcante para que este pudesse inclusive alterar a identidade visual da sigla ${ }^{290}$ e se lançar como o candidato oficial do partido nas eleições seguintes (como será mostrado nas próximas seções), ela seria mais curta do que se poderia imaginar. Após legar o governo de São Paulo ao seu sucessor em 15 de março de 1991 gozando de alto índice de aprovação popular e assumir a presidência do partido no dia 24 do mesmo mês, Quércia viu seu nome ser envolvido em uma série de escândalos de corrupção ligados a sua passagem pelo governo do estado. As denúncias iam desde questionamentos sobre a origem do seu patrimônio, que incluíam um grande

\footnotetext{
${ }^{289}$ Sobre a nova composição da CEN do partido a partir de então, ver Anexo 3.

${ }^{290}$ Durante a presidência de Quércia o PMDB adotou como símbolo um sol nascente, em substituição à chama que havia marcado sua identidade até então. Ademais, o político deu início à elaboração de um novo programa doutrinário que culminaria no documento "Democracia com Desenvolvimento", adotado em sua versão final a partir de 1996, quando este já não estava mais na presidência do partido.
} 
conglomerado de veículos de comunicação e uma infinidade de terrenos, até os problemas envolvendo irregularidades em licitações públicas ${ }^{291}$.

Os escândalos passaram a ser explorados por seus adversários políticos tanto fora do partido quanto dentro dele, especialmente por aqueles que haviam sido excluídos da sua coalizão dominante. Foi o caso do então governador do Paraná, Roberto Requião, um dos possíveis presidenciáveis do partido em 1994, que havia criado o chamado "Disque-Quércia", uma linha telefônica criada exclusivamente para receber denúncias contra o ex-governador paulista. Por fim, no dia 26 de abril de 1993, Quércia envia carta à CEN e renuncia à presidência do partido, assim como a qualquer tentativa de reeleição ao mesmo cargo $^{292}$. Sua saída de cena, apesar de ter sido interpretada pela imprensa à época como um possível abandono da corrida pelo Palácio do Planalto no ano seguinte ${ }^{293}$, tratava-se de uma manobra estratégica para se afastar dos holofotes e tentar recuperar sua imagem rearticulando suas bases de apoio no interior do partido e fora dele (Kinzo, 1993: 35).

Não à toa, alguns dos entrevistados para este estudo, quando questionados a respeito do perfil de Orestes Quércia à frente do partido, o caracterizam como um político pragmático, o que se reflete até numa certa ambiguidade em relação ao seu perfil ideológico. Quando perguntados a esse respeito, os Senadores Garibaldi Alves (RN) e Roberto Requião (PR) caracterizaram o político da seguinte forma:

"O Ulysses tinha um perfil mais ideológico, uma certa consciência, e o Quércia era muito pragmático." Senador Garibaldi Alves.

“(...) o Quércia não era um entreguista, não estava vinculado a interesse de capital financeiro. Era um conservador brasileiro, mas muitas vezes progressista." Senador Roberto Requião.

Ainda sobre o perfil de Quércia, o Senador Airton Sandoval (SP), integrante da ala quercista do partido e que ocupava a vice-presidência do PMDB de São Paulo enquanto Quércia assumia a presidência nacional ${ }^{294}$, comentou sobre como via a atuação dele e apontou os atritos que começavam a surgir entre ele e outro peemedebista paulista naquela época:

"É que o Ulysses tinha um perfil mais de Legislativo, de discutir, conversar e o Quércia era de fazer, de realizar. $O$ perfil dele não era de Legislativo. Foi senador, mas o negócio dele é prefeitura, governo do estado. (...) Sempre

\footnotetext{
291 Para uma síntese dos escândalos nos quais Quércia se viu envolvido consultar o verbete "Orestes Quércia" do Dicionário Histórico Biográfico Brasileiro do Centro de Pesquisa e Documentação de História Contemporânea do Brasil, CPDOC/FGV.

${ }^{292}$ Ver Anexo 10.

${ }^{293}$ Folha de S. Paulo - 27/04/1993.

294 Dicionário Histórico Biográfico Brasileiro do Centro de Pesquisa e Documentação de História Contemporânea do Brasil, CPDOC/FGV, verbete "Airton Sandoval".
} 
procurei moderar, esse é meu perfil, sempre procurar a melhor solução. Mesmo o Quércia eu conseguia acalmar, porque ele era muito personalista, muitas coisas eu conseguia acalmar. Às vezes como presidente do partido, o Secretário-Geral que era eu, eu ajudava a conduzir o partido. Mas de vez em quando ele escapava e dava umas espetadas no Michel [Temer]. "295

Para além das caracterizações feitas por esses entrevistados, a literatura, quando se refere a Quércia, usa termos semelhantes àqueles utilizados pelos políticos. Sadek (1989a: 69) o considera um político "provinciano", "fisiológico", "clientelista", que não era identificado com os setores "ideológicos" do partido. Melhem (1998), por sua vez, considera Quércia, durante sua atuação no MDB, alguém que:

"não tinha uma concepção ideológica de política (sic), mas sim estritamente eleitoral (...) e ao não participar do confronto de ideias que se desenvolvia na oposição ao Regime Militar isso the dava maleabilidade para fazer alianças com grupos considerados ideológicos desde que isso lhe fosse favorável na luta interna no partido, por razões eleitorais ou administrativas (idem: 182)."

"A maneira como Orestes Quércia conduziu todo esse trabalho organizacional revela claramente as características de empresário político da liderança quercista, que encara o partido essencialmente como uma organização que deve ser administrada tendo em mira a disputa no mercado eleitoral e ao acesso a cargos e poder (idem: 185)."

Porém, como mencionado anteriormente, apesar de sua ascensão "pragmática" no MDB e posteriormente no PMDB, o período no qual o PMDB teve a ala quercista à frente da direção do partido e o próprio Quércia enquanto seu presidente acabou sendo breve. Ao comentar sobre esse período, que ficou conhecido como a era "PMDBdoQ" ("PMDB do Quércia”), a jornalista Sônia Carneiro, que acompanhava o cotidiano do Congresso Nacional, declarou:

"Eu lembro que o Quércia veio com muita força, mas logo a força dele se esvaiu; veio como um 'boom', e logo foi um balão que furou, efêmero. Aqui no Congresso não colou. Talvez tenha colado em São Paulo, mas aqui no Congresso ele não liderava bancada, nem lideranças políticas. Ele não tinha protagonismo aqui. Aqui as pessoas brincavam com a figura dele, não faziam reverência à figura dele, um respeito. Não conseguiu construir o espaço dele aqui em Brasília, Câmara,

${ }^{295}$ Entrevista ao autor. 
Senado. Ele tentava subir na tribuna, fazer pronunciamento, mas ele tinha uma personalidade que se escondia, era arredio, não conversava muito com os jornalistas (...). Eu não me lembro dele liderando uma reunião de bancada ou defendendo uma posição importante. Talvez ele até tenha feito algo efêmero, mas nada que marcou, então acho que ele teve uma coisa muito breve, deixou o nome por ter essa construção e esse momento em São Paulo só."

O deputado estadual Tonico Ramos (SP) explica esse fenômeno, em sua visão, pela pouca credibilidade e capacidade de liderança de Quércia para conduzir o partido. Para ele:

"Pouca gente entende: não é porque você está na presidência que você tem força. Às vezes é uma vitória de Pirro $^{296}$. Você não tem credibilidade, não consegue conduzir o partido com essa quantidade de tendências."

Ainda que breve, o impacto da presidência de Quércia no partido é visto de maneira distinta pelos entrevistados para este estudo. Por um lado, na visão do Deputado Heráclito Fortes (PI), que deixou o PMDB em 1994, a passagem de Quércia pelo cargo teria ocorrido por tempo suficiente para que contribuísse para uma descaracterização do partido, tornando o partido "mais mercantilista do que ideológico". Por outro, para João Carlos Brum Torres, "Quércia fez uma primeira puxada [do partido para a direita], mas ele não prosperou o suficiente para ser um 'moldador' do partido" 297 . No entanto, independentemente de avaliações positivas ou negativas por parte dos políticos que estiveram ao seu lado no PMDB, o fato é que Quércia foi o segundo político a ocupar presidência do partido, após mais de uma década com o deputado paulista Ulysses Guimarães no cargo.

\subsection{O PMDB e a política perdem Ulysses Guimarães (1992)}

"O PMDB se divide, eu acho, entre antes e depois do Doutor Ulysses.” Jornalista Sônia Carneiro, em entrevista ao autor.

Antes de passarmos a uma análise da candidatura direta do PMDB à presidência da República em 1994, assim como da relação do partido com o breve governo Itamar,

\footnotetext{
${ }^{296}$ A metáfora da expressão "vitória de Pirro" se refere a uma conquista que foi obtida por um alto preço, na qual os prejuízos de uma vitória muitas vezes superam os benefícios.

${ }^{297}$ Entrevistas concedidas ao autor.
} 
cabe aqui tratarmos de um acontecimento marcante para a história do partido, que altera a dinâmica de disputas internas da sigla a partir de então. Trata-se do desaparecimento daquela que talvez tenha sido a principal liderança da história do PMDB, apontado por muitos entrevistados como o ponto de equilíbrio entre as diferentes alas do partido: Ulysses Guimarães.

Na tarde de 12 de outubro de 1992 Ulysses viajava de helicóptero de Angra dos Reis (RJ) a São Paulo acompanhado de sua esposa Mora, do ex-senador Severo Gomes e sua esposa Maria Henriqueta, e do piloto da aeronave Jorge Comemorato. Porém, poucos minutos depois da decolagem, o helicóptero desapareceu. Após ter enfrentado uma forte tempestade, a aeronave com todos os seus ocupantes caiu no litoral fluminense, levando todos a óbito. Nos dias que se seguiram, as buscas encontraram os corpos de quase todos os seus integrantes, exceto Ulysses Guimarães, que nunca foi encontrado. A política brasileira perdia assim um de seus principais personagens do processo de transição democrática, e o PMDB uma de suas principais lideranças históricas.

Nascido em 1916 na cidade de Rio Claro, interior paulista, Ulysses era formado em Direito pela Universidade de São Paulo. Na década de 1940 começou a ganhar maior projeção como vice-presidente da União Nacional dos Estudantes (UNE) e diretor do Santos Futebol Clube. Na mesma década iniciou sua trajetória na política, que o levaria a ser eleito por 12 vezes consecutivas para mandatos legislativos: uma vez enquanto deputado estadual e as onze vezes seguintes como deputado federal por São Paulo. A primeira vez que foi eleito para a Câmara dos Deputados foi em 1950 pelo PSD, partido ao qual esteve filiado até o início da instauração do bipartidarismo durante o Regime Militar. Antes disso ocupou ainda o cargo de Ministro da Indústria e Comércio durante o breve período parlamentarista em que Tancredo Neves ocupou o cargo de Primeiro Ministro, entre os anos de 1961 e 1962.

Após o golpe de $1^{\text {o }}$ de abril de 1964 e a edição do Ato Institucional nº1 (AI-1), Ulysses e uma ala de pessedistas votam a favor da eleição indireta para Presidente da República do marechal Humberto de Alencar Castelo Branco e do vice José Maria Alkmin. Pouco depois, setores do seu partido passam a entrar em atrito com o Regime Militar, e após a edição do Ato Institucional n² (AI-2) e do Ato Complementar no 4 (AC-4), que colocaram fim aos partidos então existentes, Ulysses passa a articular a oposição institucional ao regime, organizada em torno do MDB. Em 1971 assume a presidência do partido, função que exerceria até a sua extinção em 1979, com um crescente protagonismo na oposição à ditadura. Durante o ano de 1973 coloca-se como anti-candidato à presidência da República, percorrendo o Brasil para denunciar o Regime Militar até a eleição indireta do Colégio Eleitoral de 1974.

Em 1979, com a extinção do bipartidarismo, fez parte da ala que se transferiu do MDB para o PMDB, passando a exercer o cargo de presidente do partido até a eleição de Quércia para o posto em 1991. Durante esse período seguiu sendo um protagonista na luta pela transição e pela consolidação democrática, ganhando os apelidos de 
"Senhor Democracia" e "Senhor Diretas", pela sua atuação à frente da campanha pelas “Diretas Já" em 1983 e 1984, e "Tripresidente", por exercer ao mesmo tempo os cargos de Presidente do PMDB, da Câmara dos Deputados (posto que ocupara por três vezes), e da Assembleia Nacional Constituinte.

A atuação de Ulysses como figura de destaque durante tantos momentos marcantes da política nacional lhe rendeu a admiração não apenas de boa parte de seus colegas peemedebistas mas também de seus adversários. Essa admiração por ele foi expressa de maneira unânime pelos entrevistados para este estudo, que se referiram a ele da seguinte maneira:

"O Ulysses era o denominador comum dentro de todas as correntes do PMDB. Todo mundo confiava no comando dele." Deputado Marcelo Castro (PI).

“(...) com o Ulysses era diferente, o Ulysses era um Deus do partido, todo-poderoso do partido." Ex-Senador Pedro Simon (RS).

“(...) era questão de status, e acima de tudo charme, você chegar ao seu estado e ser comandado pelo Ulysses Guimarães! O homem era charmoso... [risos] Eu gozei desse privilégio, tinha uma amizade com ele, pessoal." Deputado Heráclito Fortes (PI).

"Doutor Ulysses vinha da história do velho PSD, de ouvir, de escutar, mas de só levar as coisas para um colegiado quando elas estivessem decididas no bastidor; ele tinha a capacidade de costurar com muita paciência, com muita competência, com muita capacidade. Eu costumo dizer que Dr. Ulysses nunca colocou na Assembleia Nacional Constituinte uma matéria em votação cujo resultado ele já não conhecesse previamente. Não é que ele fraudasse, é que ele sabia mapear bem o prognóstico do placar e tinha muito controle sobre isso. Fazia isso com multa competência, com muita mestria." Senador Cássio Cunha Lima (PB).

"O Dr. Ulysses tinha uma visão que o partido, para ser grande, precisava ter vida orgânica em todos os estados $e$, se possivel, em todos os municípios. Ele frequentemente ia aos estados com a desculpa de ver o PMDB; sempre que você convidava o Ulysses, ele ia. Aquela foto ali foi ele e o Tancredo! E estava eu ali, foi no começo das Diretas ou do Tancredo... e tem muitas fotos do Ulysses no palanque, em eleição de prefeito, ele ia... Ele mantinha viva, acesa a chama do PMDB. E essa ação local lá no Acre! No Acre, naquele fim de mundo você recebia o presidente do maior partido, o prestígio do Ulysses Guimarães, aquilo era uma 
alegria. Ia se enraizando, e isso que fez o PMDB existir e ser até agora o que é." Deputado Flaviano Melo (AC).

Da sua parte, Ulysses encarava o PMDB como parte central da sua vida. Cabe reproduzir aqui, na íntegra, suas últimas palavras à frente da presidência do partido, em seu discurso de despedida por conta da posse de Orestes Quércia, em março de 1991. Após declarar seu amor ao partido, seguiu dizendo:

"Este discurso eu escrevi com o coração e o leio com os olhos úmidos.

Na política, mais difícil do que subir é descer. É descer não carregando o fardo podre e fétido da vergonha. Descer não desmoralizado pela covardia. Não descer com as mãos esvaziadas pela preguiça e pela impostura. Não descer esverdeado pelas cólicas de inveja dos que nos emulam, nos sucedem ou nos superam. Não descer com a alma apodrecida pelo carcinoma do ressentimento.

Vou livre como o vento, transparente e cantando como a fonte.

Desço.

Vou para a planície, mas não vou para casa. Vou morrer fardado, não de pijama.

Política se faz na rua ou com a rua.

Vou para a rua porque o governo desgoverna a rua.

Para o povo, o PMDB escorraçou o autoritarismo castrense.

O PMDB, com o povo, removerá do Estado um século de carência republicana.

Meu filho PMDB!

Vá em frente. Caminhe rumo ao sol, que é luz, não rumo à lua, que é noite.

Que Deus te abençoe e a pátria ateste: cumpriste o teu dever!",298

Após sua derrota nas eleições presidenciais de 1989, o último grande ato de Ulysses Guimarães na política nacional antes do seu desaparecimento foi a sua participação na condução do processo de impeachment de Fernando Collor de Mello, seu adversário político naquela ocasião ${ }^{299}$. Após denúncias de corrupção em relação a Collor serem veiculadas na imprensa ${ }^{300}$, o Congresso instaurou uma CPI para apurar o caso. Inicialmente reticente em relação à proposta por temer pela saúde da jovem democracia brasileira ${ }^{301}$, com as evidências dos fatos e a crescente adesão popular à

\footnotetext{
${ }^{298}$ Câmara dos Deputados, 2016: 461-462.

${ }^{299}$ Sobre o processo de impeachment de Collor ver Salllum Jr e Casarões (2011).

${ }^{300}$ Revista Veja - 27/05/1992.

${ }^{301}$ Acervo do jornal O Globo - https://acervo.oglobo.globo.com/fatos-historicos/ulysses-senhor-diretasseis-decadas-de-protagonismo-na-politica-brasileira-20236265\#ixzz5UPDicJgw, acessado em $19 / 10 / 2018$.
} 
causa, Ulysses passou a ser um defensor do impedimento do presidente. Durante a tramitação do processo na Câmara, o político pressionou para que o STF definisse que a votação do processo de Collor fosse feita de maneira aberta, aumentando as chances de afastamento do presidente ${ }^{302}$. O STF por fim decidiu pela votação em aberto, e no dia 29 de setembro de 1992, por esmagadora maioria, com 441 votos a favor e 38 contra, Fernando Collor foi declarado impedido de continuar no cargo de Presidente da República. O presidente seria então substituído interinamente no cargo pelo vice Itamar Franco a partir do dia 2 de outubro de 1992, poucos dias antes do desaparecimento de Ulysses.

Após o seu desaparecimento, o PMDB além de perder uma de suas principais lideranças históricas (se não a principal), perdia também uma figura considerada insubstituível para o partido ${ }^{303}$, o grande referencial "que dava os rumos da sigla"304. Em homenagem a sua figura, o partido passa a intitular sua fundação acadêmica segundo o nome do grande político a partir da posse de Renan Calheiros na presidência da instituição, em setembro de 1999, em substituição ao nome de Pedroso Horta. A fundação passa a se chamar, assim, Fundação Ulysses Guimarães ${ }^{305}$.

Com a saída de cena de Ulysses evidencia-se uma nova divisão interna no partido, e inicia-se a partir de então uma disputa pelo controle nacional da sigla. Como será mostrado nas próximas seções, a disputa se daria em torno de vários nomes que buscavam hegemonia dentro do PMDB. Entretanto, como apontou o deputado estadual paulista Tonico Ramos, seriam dois políticos do seu estado, que conviviam com ele diretamente, que passariam a se destacar. De um lado Orestes Quércia, que já vinha ascendendo dentro do partido e havia chegado ao cargo de presidente da sigla pouco antes da morte de Ulysses. De outro, Michel Temer, que se tornaria presidente da Câmara dos Deputados no final dos anos 1990.

\subsection{O PMDB e o governo Itamar: as divisões internas se evidenciam (1993-1994)}

"O PMDB é como certos casais que brigam em casa, mas em público aparecem de braços dados". Ulysses Guimarães, em 6 de agosto de $1986^{306}$.

\footnotetext{
302 Dicionário Histórico Biográfico Brasileiro do Centro de Pesquisa e Documentação de História Contemporânea do Brasil (CPDOC/FGV), verbete "Ulysses Guimarães".

${ }^{303}$ Ex-parlamantar e fundador do partido Raimundo Urbano (BA), em entrevista concedida ao autor.

304 Jornalista Sônia Carneiro, em entrevista ao autor.

${ }^{305}$ Cabe apontar aqui que a quase totalidade dos políticos entrevistados para esta pesquisa possuíam em seu gabinete alguma foto ou quadro ao lado do político, numa tentativa evidente de vincular sua imagem a ele. Da mesma forma, a sede do Diretório Nacional do partido, assim como a da Fundação Ulysses Guimarães, está repleta de fotos e quadros de Ulysses; sua imagem se tornou onipresente por todo o partido até os dias de hoje.

${ }^{306}$ Folha de S. Paulo - 01/05/1989, p. A-8.
} 
Com o afastamento de Fernando Collor de Mello da presidência da República, seu vice Itamar Franco assume o seu posto. O político mineiro havia pertencido ao MDB durante todo o período em que o bipartidarismo esteve vigente, transferindo-se ao PMDB quando ocorre a refundação do partido em 1979. Porém, no ano de 1986, quando o PMDB mineiro opta por lançar o ex-prefeito de Contagem Newton Cardoso para a disputa do governo do estado, Itamar deixa seu partido e se transfere para o Partido Liberal (PL), posteriormente migrando para o PRN de Fernando Collor de Mello para ser seu companheiro de chapa nas eleições presidenciais de 1989. Em maio de 1992, após reforma ministerial efetuada por Collor, Itamar desligou-se do PRN e manteve-se ao longo dos anos seguintes sem qualquer filiação partidária, mesmo enquanto exercia o cargo de Presidente da República. Posteriormente, o político se filiaria mais uma vez ao PMDB, em $1997^{307}$.

No que concerne ao seu governo, dadas as características de crise que levaram à sua posse, sua sustentação se caracterizou por uma situação de cooperação partidária (Ferreira, 2002: 150) que levou o PMDB a ocupar a posição de partido integrante da coalizão governista mais uma vez. A base de apoio do governo seria formada a partir de então por PMDB, PSDB, PFL, PTB e PSB, o que permitiu ao PMDB ocupar 14,2\% dos ministérios ao longo de todo o mandato-tampão de Itamar Franco ${ }^{308}$. A montagem de sua equipe de governo já vinha ocorrendo ainda antes da conclusão do processo de impeachment, em constante diálogo com lideranças peemedebistas ${ }^{309}$, mas é necessário apontar que o apoio do PMDB ao seu governo não se deu de maneira unânime.

Apesar de declarar apoio ao governo em nota da sua Comissão Executiva Nacional $^{310}$ o apoio do PMDB ao governo se deu apenas por parte das lideranças de alguns estados, com um apoio mais efetivo partindo do PMDB do Rio Grande do Sul (Ferreira, 2002: 182). Assumiram postos em seu governo os peemedebistas gaúchos Pedro Simon, para a Coordenação Política, e Antônio Britto, no cargo de Ministro da Previdência Social, mas também o goiano Lázaro Barbosa, no Ministério da Agricultura e o paraense Fenando Jorge Coutinho, no Ministério do Meio Ambiente. Enquanto isso, o grupo ligado a Orestes Quércia, ainda hegemônico na CEN do partido, não se posicionava favoravelmente ao governo, pois o próprio Quércia julgava que seu apoio poderia ser prejudicial à sua pretensão de concorrer à sucessão de Itamar Franco nas eleições de 1994. Essa divisão reflete num "racha" na sua coalizão dominante, que pela primeira vez em sua história se daria entre as alas "governista" e "oposicionista" (ou "dissidente"), tal como a divisão entre "moderados" e "autênticos" se dera durante o

\footnotetext{
307 De maneira errônea, boa parte dos veículos de comunicação apontaram recentemente que a sua chegada a Presidência da República foi a segunda vez em que o PMDB ocupou o cargo máximo da política brasileira (por exemplo, Folha de S. Paulo 12/05/2016), comparando-a a posse de Michel Temer em 2016. Entretanto, Itamar só se filiou novamente ao PMDB em setembro de 1997 (Folha de S. Paulo 27/09/1997 - https://www1.folha.uol.com.br/fsp/1997/9/27/brasil/13.html).

${ }^{308}$ Ver tabelas 4 e 5 na Introdução desta tese.

309 Acervo do jornal O Globo - 27/04/2016 - disponível em https://acervo.oglobo.globo.com/emdestaque/itamar-comecou-montar-governo-um-mes-antes-do-impeachment-de-collor-19180527.

${ }^{310}$ Nota de 07/10/1992 - Maciel, 2014: 70.
} 
Regime Militar, definidas pela sua posição quanto a participar ou não da coalizão de governo de Itamar.

Ferreira (2002) e Maciel (2014) também haviam notado a presença dessa divisão interna, destacando que a questão central que passa dividir o PMDB mais claramente a partir da década de 1990 é se a organização deve ou não fazer parte do governo. Entretanto, diferentemente da visão apresentada pelas autoras (Ferreira, 2002: 151; Maciel, 2014: 20, 73), que apontam que essa divisão se deu de maneira mais clara a partir do primeiro mandato de Fernando Henrique Cardoso, apontamos nesta seção evidências que demonstram que ela já estava presente no partido durante o governo de Itamar Franco.

Cabe apontar ainda que a divisão entre as duas alas não se dava de maneira estanque, pelo fato de haver políticos que com o passar do tempo migraram de uma posição para a outra. Porém, em linhas gerais, podemos traçar as características que as diferenciam em sua atuação política a partir do seu momento de formação.

A ala dos governistas passa a ser aquela que prega a participação do PMDB enquanto integrante formal da coalizão de governo, um comportamento que se repetiria ao longo do recorte histórico deste estudo em relação aos dois governos de Fernando Henrique Cardoso. Essa ala pregava que o partido não apresentasse candidaturas próprias nas disputas pela presidência da República, e que focasse seus esforços nas eleições legislativas. Essa estratégia viria a permitir que a sigla continuasse elegendo grandes bancadas dentro do Congresso Nacional, beneficiando o partido na distribuição de ministérios e mantendo-o como um dos principais interlocutores do Poder Executivo dentro do Poder Legislativo, fosse qual fosse o Presidente da República em exercício. Com relação a sua composição interna, a ala teve como suas principais lideranças políticos que ingressaram no PMDB após a refundação do partido em 1979, como Michel Temer (SP) - que passa a ganhar destaque a partir do governo de FHC - e Geddel Vieira Lima (BA), mas também políticos que não se mantiveram apenas no MDB ou no PMDB ao longo de sua trajetória política, como Moreira Franco (RJ, que teve passagem pelo PDS), Romero Jucá (RR, com passagem por PDS, PPR, PSDB, e PFL), José Sarney (AP, ex-arenista), Renan Calheiros (AL, ex-filiado ao PSDB e ao PRN), e Henrique Eduardo Alves (RN, que teve passagem pelo PP de Tancredo Neves). Porém, há exceções, como o gaúcho Eliseu Padilha e o paraense Jader Barbalho.

Por sua vez, a ala dos oposicionistas defendia a não participação do PMDB na coalizão de governo, um posicionamento que se repetiria durante os governos seguintes. Para essa ala, o partido deveria resgatar o seu protagonismo político e lançar candidaturas próprias ao cargo de Presidente da República. No que se refere a sua composição interna, suas principais lideranças apresentam um perfil mais homogêneo em comparação aos governistas, sendo formada principalmente por políticos que tiveram uma longa atuação no campo da oposição ao Regime Militar sob a sigla do MDB e se transferiram posteriormente para o PMDB quando este foi refundado. Encaixam-se nesse perfil o próprio Itamar Franco (MG), então presidente e que 
posteriormente ingressaria no PMDB, Pedro Simon (RS, que passaria a integrar o grupo após ter dado apoio ao governo Itamar), Roberto Requião (PR), Orestes Quércia (SP) e Paes de Andrade (CE).

A divisão entre essas duas alas no interior do partido se tornou evidente em duas ocasiões ainda no ano de 1993. A primeira delas se deu quando o PMDB realizou sua Convenção Nacional em setembro, e a segunda quando o partido realizou uma das primeiras reuniões do seu Conselho Nacional, órgão consultivo que havia sido recémcriado.

Após o afastamento de Orestes Quércia da presidência do partido em abril de 1993, o PMDB se reuniu em Convenção no dia 12 de setembro do mesmo ano para definir os novos componentes do seu Diretório Nacional e da sua Comissão Executiva Nacional, pela primeira vez em sua história sem poder contar com a figura de Ulysses Guimarães para apaziguar os conflitos entre seus diferentes grupos internos. Apesar de haver mais uma vez apenas uma chapa na disputa, a Convenção se deu de maneira tumultuada $^{311}$ e os integrantes do PMDB gaúcho, que na ocasião participavam do governo Itamar, decidiram não participar da composição da $\mathrm{CEN}^{312}$. Assim, o partido elegeu pela primeira vez em sua história um político sem origem no estado de São Paulo para ocupar a sua presidência, que fica a cargo do catarinense Luiz Henrique da Silveira. A composição do órgão como um todo, porém, acaba refletindo as divisões que se davam em relação ao governo.

Dentre os quinze componentes do órgão, sete defendiam abertamente 0 rompimento com o governo Itamar, enquanto outros sete defendiam a manutenção do apoio ao Presidente, com apenas um político indeciso quanto a essa questão ${ }^{313}$. Essa divisão também se tornaria manifesta durante a reunião do Conselho Nacional, reunido poucos dias depois, no dia 21 de setembro, para colocar um fim à questão. Na ocasião, em um resultado bastante apertado que evidenciava mais uma vez sua dissensão interna, o PMDB define manter o seu apoio ao governo. Foram 25 votos a favor, 22 contra e uma abstenção. A derrota da tese de rompimento com o governo foi interpretada pela imprensa à época como uma vitória da cúpula do partido frente aos governadores de estado, sobretudo o então governador de São Paulo Fleury Filho, que começava a vislumbrar a possibilidade de ser ele próprio o candidato do partido nas eleições presidenciais que se realizariam no ano seguinte ${ }^{314}$. Ademais, as declarações de peemedebistas que compunham então a ala oposicionista e que vinham tencionando em prol do rompimento com o governo Itamar evidenciam a posição desse grupo:

"O partido se vendeu. Venceram os que queriam cargos $e$ negócios.” Senador Gilberto Miranda (PMDB - PA).

\footnotetext{
311 Dicionário Histórico Biográfico Brasileiro do Centro de Pesquisa e Documentação de História Contemporânea do Brasil (CPDOC/FGV), verbete "Luis Henrique da Silveira".

${ }^{312}$ Folha de S. Paulo - 13/09/1993, p. 6.

${ }^{313}$ Idem.

${ }^{314}$ Folha de S. Paulo-22/09/1993, p. 6.
} 
"O governo Itamar é como um cavalo pangaré. E o pior é que o PMDB resolveu 'engalopar' este pangaré, mesmo sabendo que ele vai morrer na próxima esquina". Deputado João Natal (PMDB - GO) ${ }^{315}$.

Assim, naquela ocasião, evidenciou-se pela primeira vez a cisão interna que marcaria o PMDB pelo restante do recorte histórico tratado nesta tese. Apesar de dissensões já se fazerem presentes desde a fundação do partido, como a diferenciação feita grosso modo entre "moderados" e "autênticos" até o ano em que a chapa Tancredo Neves-José Sarney é eleita pelo Colégio Eleitoral pondo fim ao Regime Militar, esse novo teor que dividiria o partido de maneira acirrada vem à tona durante o governo Itamar. Suas novas alas, a "governista", que pregava a participação do partido nas coalizões de governo, e a "oposicionista", que pregava uma atuação independente do partido e que poderia levá-lo a manter o seu protagonismo político adquirido nos anos 1980, disputarão os rumos do partido pelos anos seguintes e marcarão o caráter do partido nos anos vindouros.

Antes de passarmos à próxima seção e analisarmos a candidatura direta apresentada pelo PMDB nas eleições presidenciais de 1994, cabe aqui apontar outro aspecto importante da presidência exercida por Itamar Franco, que teria consequências diretas no resultado desse pleito. Como mencionamos, entre os partidos que compuseram a coalizão de governo esteve presente o PSDB, que pela primeira vez em sua história iria compor um governo. Entre os postos ocupados pelo partido estava o Ministério da Fazenda, pasta que seria ocupada pelo ex-peemedebista Fernando Henrique Cardoso, empossado em maio de 1993.

Com a sua posse, teria início o décimo terceiro plano de estabilização econômica posto em prática no Brasil desde o momento em que a crise econômica fora desencadeada em 1979 (Bresser Pereira, 1994: 132) ${ }^{316}$, o Plano Real. Apesar da desconfiança inicial, o Plano pouco a pouco se mostrou eficiente no controle da inflação, deliberadamente fugindo dos movimentos bruscos e do elemento surpresa que levaram aos efêmeros sucessos e fracassos dos seus antecessores, tal como o Plano Cruzado. Assim, a candidatura partidária que soubesse atrelar sua imagem à significativa melhora nas condições do quadro econômico teria grandes chances nas eleições presidenciais de 1994, a serem analisadas na próxima seção.

\subsection{A segunda candidatura direta do PMDB: a hora e a vez de Orestes Quércia} $\underline{(1994)}$

"Ele presidiu o partido e ganhou a simpatia de muitos, visava um objetivo e buscava incessantemente, mas isso

\footnotetext{
315 Idem.

${ }^{316}$ Sobre o Plano Real, ver Bresser Pereira (1994), Batista Jr. (1996), e Bacha (1997).
} 
não foi suficiente para garantir trazer ao seu nome aquilo que se poderia chamar de 'a força' do PMDB." Exsenador Mauro Benevides, em entrevista ao autor.

As eleições gerais de 1994 marcaram a segunda vez em sua história que o PMDB apresentou uma candidatura direta para disputar o cargo de Presidente da República. Desta vez a tarefa coube a Orestes Quércia, ex-presidente da sigla que, apesar de estar fora dos holofotes desde sua renúncia à presidência do PMDB em 1993, ainda mantinha sua ambição de disputar o cargo. Aquelas eleições marcaram também o início do período de polarização e protagonismo das candidaturas apresentadas por PT e PSDB para a disputa presidencial (Cervi, 2016). Este aspecto marca o pano de fundo dos últimos anos do recorte histórico adotado neste estudo, e terá consequências diretas nas estratégias usadas pelas diferentes coalizões dominantes no interior do PMDB desde então.

Após a conquista da presidência do partido em 1991 e sua saída de cena estratégica em 1993, o passo seguinte dado por Orestes Quércia para se tornar o candidato do partido à presidência da República no pleito de 1994 foi vencer as eleições prévias estabelecidas pelo partido. As eleições, realizadas na Convenção Nacional do PMDB em 15 de maio de 1994, tinham como objetivo equacionar as disputas internas do partido (Ferreira, 2002: 150) e colocaram Quércia frente a frente com o peemedebista paranaense Roberto Requião, mencionado anteriormente como o criador do "Disque-Quércia" poucos anos antes. José Sarney, outro político do partido pleiteante ao posto, retirou sua candidatura às vésperas da disputa ${ }^{317}$.

Adversário de Quércia, o ex-governador do Paraná Roberto Requião vinha tentando construir seu nome como postulante do partido à presidência tanto fora quanto dentro da legenda. Exemplo da sua tentativa de se fazer mais conhecido no eleitorado paulista, principal reduto de Quércia, foi a carta publicada na imprensa paulista assinada pelo PMDB paranaense, controlado por Requião ${ }^{318}$. A seção paranaense do PMDB, aliás, vinha sendo um dos principais focos de resistência no interior do partido ao nome de Quércia, e contribui para que o político não conseguisse construir uma unidade em torno do seu nome (Bizzarro Neto, 2013: 107). A candidatura do paranaense, porém, não havia conseguido construir nos anos anteriores a mesma dimensão que Quércia havia conquistado, sobretudo por conta de sua passagem na presidência do partido.

\footnotetext{
${ }^{317}$ Sarney despontava à época com bons índices de intenção de votos nas pesquisas pré-eleitorais. Porém, sem ter o apoio majoritário em torno de seu nome dentro do partido, o ex-presidente da República retirou seu nome da disputa aparentemente apostando numa decisão do STF que o favoreceria. Enquanto os partidos definiam suas candidaturas, o órgão decidia também se seria reaberto o prazo de filiação partidária, o que favoreceria Sarney, abrindo a ele a possibilidade de migrar para uma legenda menor e ainda assim ser candidato a presidente da República. Porém, com a decisão contrária definida pelo STF no dia 18 de maio de 1994, Sarney ficou virtualmente fora da disputa nas eleições de 1994.

${ }^{318}$ Folha de S. Paulo - 06/04/1994, ver Anexo 11.
} 
Após serem contabilizados os resultados das prévias, Quércia se sagrou vencedor. O político venceu Roberto Requião em 25 dos 27 estados, obtendo 8.554 votos contra 1.953 do seu adversário ${ }^{319}$. Porém, os índices de abstenção de mais de $50 \%$ dos votantes em boa parte dos estados ${ }^{320}$ - com destaque para os da região Sul e do Nordeste, respectivamente redutos eleitorais de Requião e Sarney - apontavam para as dificuldades que Quércia enfrentaria em torno de sua candidatura. O resultado das prévias foi referendado pela CEN do PMDB poucos dias depois em menos de 15 minutos $^{321}$, e finalmente aprovado na Convenção Nacional do PMDB de 22 de maio de 1994. A Convenção também definiu Íris de Araújo, outra filiada ao PMDB e exprimeira dama de Goiás, como a candidata a vice-presidente na chapa do partido.

Quércia finalmente conquistava, assim, o posto de candidato direto do PMDB à presidência da República nas eleições de 1994. Seria a segunda vez em sua história que o partido apresentaria candidatura própria ao cargo.

O político teria pela frente uma disputa com outros sete candidatos naquele pleito. Entre os principais partidos no páreo, o Partido Democrático Trabalhista lançara mais uma vez Leonel Brizola como seu presidenciável. O candidato lançado pelo Partido dos Trabalhadores fora Luís Inácio Lula da Silva, segundo colocado nas eleições de 1989 e que liderava as pesquisas de intenção de voto no início do ano. O Partido da Social Democracia Brasileira havia decidido lançar, em coligação com o PFL e o PTB, o sociólogo Fernando Henrique Cardoso, político com longa trajetória no MDB e no PMDB antes de fazer parte da dissidência que levou à fundação do PSDB. Para além desses grandes partidos, algumas siglas menores optaram por também lançar candidatos próprios, como foi o caso de Enéas Carneiro, lançado pelo PRONA (Partido de Reedificação da Ordem Nacional), legenda criada em 1989.

Com o início oficial da disputa eleitoral, na agenda das campanhas as propostas políticas acabaram sendo substituídas por resultados de política econômica (Cervi, 2016: 30). Tal como havia ocorrido nas eleições de 1986, quando o impacto positivo do Plano Cruzado havia beneficiado diretamente as candidaturas que se identificaram com ele, o mesmo ocorreu em 1994. Porém, se naquela ocasião o PMDB havia sido o beneficiário direto dessa estratégia, alcançando um bom desempenho nas urnas, dessa vez a conjuntura econômica prejudicava o partido e favorecia o candidato Fernando Henrique Cardoso, do PSDB, ex-Ministro da Fazenda do governo Itamar Franco, identificado pela população como responsável direto pelo sucesso do Plano Real.

Como mencionado anteriormente, o programa econômico denominado Plano Real, estabelecido para colocar um fim ao ciclo inflacionário vivido pelo Brasil, estava obtendo sucesso no momento em que as eleições se realizaram. Como mostra o gráfico abaixo, após a adoção de uma unidade monetária de caráter transitório, a Unidade Real de Valor (URV), e a posterior implantação definitiva da nova unidade monetária a partir

\footnotetext{
${ }^{319}$ Folha de S. Paulo - 16/05/1994, p. A-1.

${ }^{320}$ Estado de São Paulo - 17/05/1994, p. A-4. O resultado geral das prévias pode ser visto no Anexo 12.

${ }^{321}$ Correio Braziliense - 19/05/1994.
} 
de julho de 1994, a inflação desabou de $40 \%$ a $50 \%$ ao mês no primeiro semestre de 1994 para $1 \%$ a $2 \%$ ao mês no final do ano (Bacha, 1997).

\section{Gráfico 3. Evolução do índice de inflação em 1994}

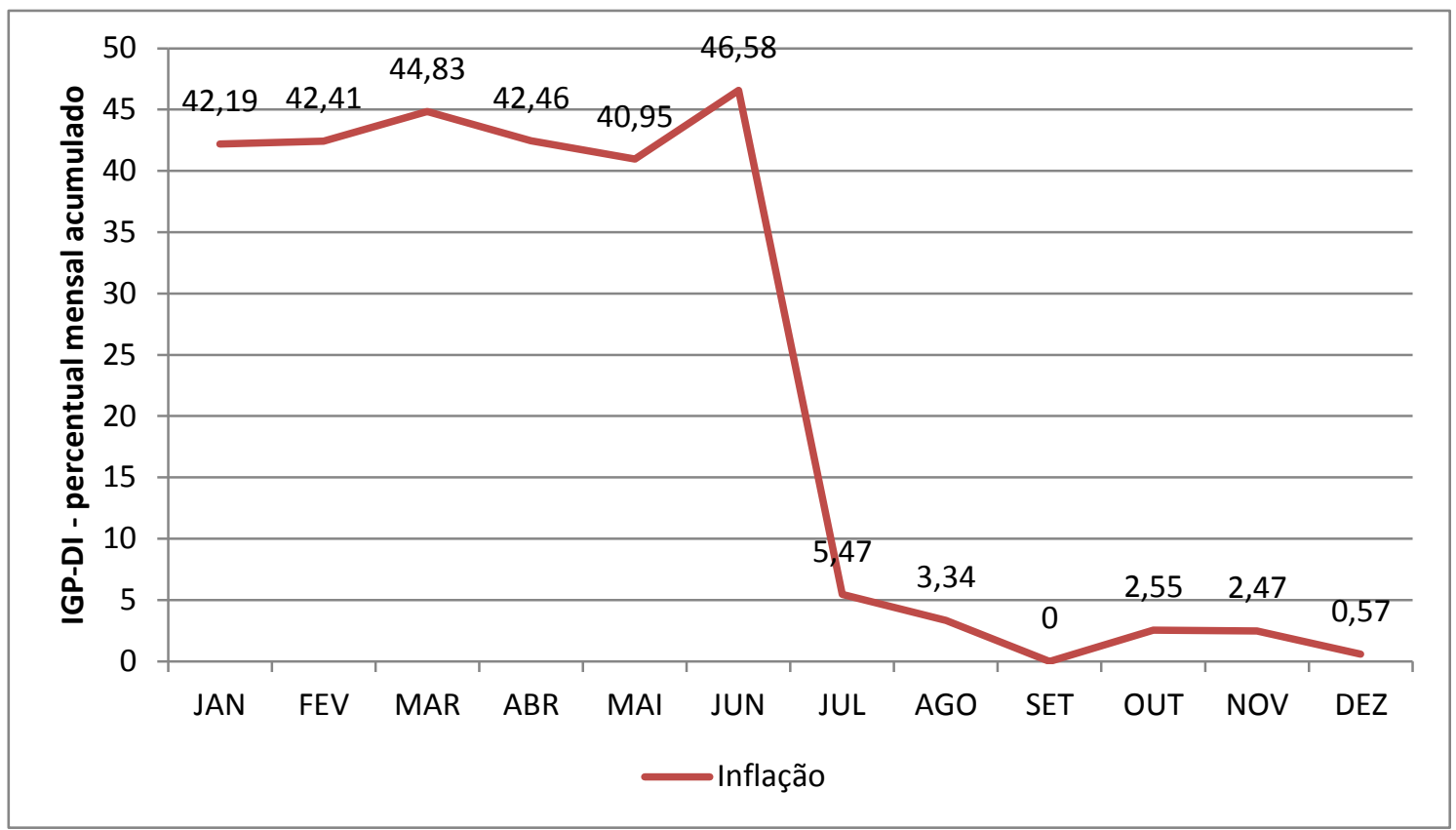

Fonte: Índice geral de preços IGP-DI/FGV - https://www.portalbrasil.net/igp.htm

Enquanto o desempenho do Plano Real fortalecia a candidatura de Fernando Henrique Cardoso e o levava a ultrapassar Lula nas pesquisas, Quércia via sua imagem ser cada vez mais desgastada pelas denúncias de corrupção envolvendo o seu nome. Em edição do dia 22 de maio de 1994, quando o jornal Folha de S. Paulo elabora um perfil de cada um dos pleiteantes ao cargo de Presidente, a manchete atrelada ao seu nome o colocava como "o político mais investigado do país", um fardo que já carregava desde 1993, quando uma pesquisa feita pelo Ibope no início daquele ano apontou-o como o "político corrupto mais popular do Brasil",322.

Sem conseguir muita adesão tanto das bases do seu partido ${ }^{323}$ quanto da opinião pública, Quércia se manteve com um baixo patamar de intenção de votos até o dia do pleito. Com a abertura das urnas no dia 3 de outubro, a tabela abaixo mostra o quanto o resultado foi desastroso para o candidato do PMDB. Enquanto nas eleições de 1989 a candidatura de Ulysses havia amargado um $7^{\circ}$ lugar entre os 21 candidatos, dessa vez a candidatura de Quércia, numa disputa com outros sete presidenciáveis, terminava a eleição em $4^{\circ}$ lugar, com uma porcentagem de votos próxima àquela obtida pelo candidato do partido em 1989. O grande vitorioso nas urnas foi Fernando Henrique

322 Dicionário Histórico Biográfico Brasileiro do Centro de Pesquisa e Documentação de História Contemporânea do Brasil, CPDOC/FGV, verbete "Orestes Quércia”.

${ }^{323}$ Mauro Benevides, em entrevista concedida ao autor. 
Cardoso, candidatura que era a mais identificada pelos eleitores com a implementação e a provável continuidade do sucesso do Plano Real (Mendes e Venturi, 1994).

Tabela 33. Resultados do primeiroturno da eleição presidencial de 1994

\begin{tabular}{|c|c|c|c|c|c|}
\hline Posição final & Candidato & Partido & Votos & $\begin{array}{l}\text { Porcentagem } \\
\text { sobre o total } \\
\text { de votantes }\end{array}$ & $\begin{array}{c}\text { Porcentagem } \\
\text { sobre o total } \\
\text { de votos } \\
\text { válidos }\end{array}$ \\
\hline 1 & $\begin{array}{l}\text { Fernando } \\
\text { Henrique } \\
\text { Cardoso }\end{array}$ & PSDB & 34.377 .198 & 44,0 & 54,3 \\
\hline 2 & Lula & PT & 17.126 .291 & 21,9 & 27,0 \\
\hline 3 & Enéas Carneiro & PRONA & 4.672 .026 & 5,9 & 7,4 \\
\hline 4 & $\begin{array}{l}\text { Orestes } \\
\text { Quércia }\end{array}$ & PMDB & 2.773 .793 & 3,5 & 4,4 \\
\hline 5 & Leonel Brizola & PDT & 2.016 .386 & 2,5 & 3,2 \\
\hline 6 & Espiridião Amin & PPR & 1.740 .210 & 2,2 & 2,7 \\
\hline 7 & Carlos Gomes & PRN & 387.927 & 0,4 & 0,6 \\
\hline 8 & $\begin{array}{l}\text { Almirante } \\
\text { Fortuna }\end{array}$ & PSC & 238.323 & 0,3 & 0,4 \\
\hline $\begin{array}{l}\text { Votos } \\
\text { brancos/nulos }\end{array}$ & & & 14.639 .514 & 18,8 & \\
\hline Total & & & 77.971 .668 & & \\
\hline Abstenções & & & 16.770 .019 & & \\
\hline Eleitorado & & & 94.743 .043 & & \\
\hline
\end{tabular}

Fonte: Singer (2002: 99).

Assim como ocorrera em 1989 com a candidatura de Ulysses, há indícios de que a candidatura de Quércia também pode ter passado por um processo de "cristianização". O ex-presidente José Sarney, importante liderança, após retirar-se da disputa para se tornar o candidato à presidência pelo PMDB, empenhou-se na eleição da sua filha Roseana Sarney (PFL) ao governo do estado do Maranhão, e ambos se colocaram abertamente em campanha para $\mathrm{FHC}^{324}$. Para o então senador Mauro Benevides, que posteriormente viria a aderir ao governo FHC, "não houve empolgação nem em São Paulo [com] uma candidatura majoritária à presidência da República, então isso se refletiu na votação pequena que ele teve e que não expressou o poder eleitoral do PMDB",325. Outra evidência nesse sentido, esta até mais explícita da cristianização de Quércia, seria matéria publicada no jornal Folha de S. Paulo ainda antes do pleito, contendo declarações do então candidato do PMDB ao governo do estado do Rio Grande do Sul, Antônio Britto. O político declara: "eu rompi com [Quércia] há muito

\footnotetext{
${ }^{324}$ Folha de S. Paulo - 28/06/1994 e 02/10/1994.

${ }^{325}$ Entrevista ao autor.
} 
tempo. (...) Se der Fernando Henrique, o PMDB o apoiará como eu já estou apoiando" 326 . Britto passaria ao segundo turno da eleição estadual naquele ano, contando com o apoio do PSDB em sua coligação para ser eleito governador do estado.

De acordo com Bizzarro Neto (2013: 107), o desempenho ruim de Quércia minou qualquer chance de manutenção da força do ex-governador nas disputas nacionais. Posteriormente, o declínio eleitoral do partido em São Paulo, que perde a hegemonia que o fizera eleger três governadores de estado consecutivamente, levaria à diminuição do número de delegados que o partido naquele estado dispunha na Convenção Nacional, o que restringiria ainda mais a capacidade de manutenção da participação de Quércia nas disputas nacionais do partido.

Este processo, por sua vez, teve como consequência de médio prazo o surgimento de uma nova coalizão dominante no interior do partido. A coalizão seria encabeçada por outro político paulista, o então deputado Michel Temer.

\subsection{Estabilidade nas urnas: panorama geral das eleicões de 1994}

"O partido passou a ser essa federação de partidos e nos estados com muita força, mas no âmbito nacional, ele não teve uma liderança a nível nacional que o promovesse perante o país e a população" Senador Garibaldi Alves, em entrevista ao autor.

Após a acentuada queda no seu desempenho eleitoral nas eleições de 1990 em comparação às anteriores, os resultados das eleições de 1994 mostram um resultado ambíguo para o PMDB. Por um lado, o partido mantém sua vocação enquanto força regional, ampliando a quantidade de governos estaduais conquistados. Porém, além da baixa votação da candidatura de Orestes Quércia para Presidente da República, o partido apresentou nova queda no seu desempenho em relação às eleições para o Congresso Nacional, e passa a ver reduzida a sua porcentagem de assentos ocupados em ambas as Casas.

Com relação às eleições para os governos estaduais, o PMDB concorreu em 1994 com candidaturas próprias em 19 estados e compôs coligações em outros cinco. Em três o partido optou por não lançar candidato próprio e nem mesmo se coligar. Contabilizados os votos, o partido elegeu nove governadores no total $(33,3 \%)$, e esteve presente na coligação vencedora em outros dois. Entre os eleitos pelo partido, encontravam-se quatro ex-arenistas (Divaldo Suruagy/AL, Antônio Mariz/PB, Francisco de Assis/PI e Maguito Vilela/GO), o que evidencia a proeminência que os políticos com essa origem foram adquirindo no partido; dois ex-emedebistas (Garibaldi Alves/RN e Wilson Martins/MS) e outros três políticos que entraram na vida pública por meio do PMDB (Valdir Raupp/RO - que apesar de entrar na política por meio do

${ }^{326}$ Folha de S. Paulo - 07/08/1994. 
PMDB havia tido uma passagem recente pelo PRN de Fernando Collor, Antônio Britto/RS - este um ex-ministro do governo Itamar - e Paulo Afonso/SC).

Ademais, cabe apontar ainda que entre os governadores de estado eleitos pelo PSDB, partido que elegeu a segunda maior quantidade deles, encontravam-se quatro políticos que haviam iniciado sua trajetória político-partidária após a implantação do pluripartidarismo por meio do PMDB. Tratavam-se dos governadores Almir Gabriel, Tasso Jereissati, Eduardo Azeredo e Mário Covas. Este último, eleito governador em São Paulo, vencendo o candidato indicado pelo PMDB e colocando um fim à hegemonia do partido naquele estado.

Tabela 34. Governadores eleitos em 1994

\begin{tabular}{|c|c|c|}
\hline Região/Estado & Eleito & Partido \\
\hline \multicolumn{3}{|l|}{ Norte } \\
\hline Acre & $\begin{array}{l}\text { Oleir Messias } \\
\text { Cameli }\end{array}$ & PPR \\
\hline Amapá & João Capiberibe & PSB \\
\hline Amazonas & $\begin{array}{l}\text { Amazonino } \\
\text { Mendes }\end{array}$ & PPR \\
\hline Pará & Almir Gabriel & PSDB \\
\hline Rondônia & Valdir Raupp & PMDB \\
\hline Roraima & Neudo Campos & PTB \\
\hline Tocantins & Siqueira Campos & PPR \\
\hline \multicolumn{3}{|l|}{ Nordeste } \\
\hline Alagoas & Divaldo Suruagy* & PMDB \\
\hline Bahia & Paulo Souto & PFL \\
\hline Ceará & Tasso Jereissati & PSDB \\
\hline Maranhão & Roseana Sarney & PFL \\
\hline Paraíba & Antônio Mariz** & PMDB \\
\hline Pernambuco & Miguel Arraes & PSB \\
\hline Piauí & $\begin{array}{l}\text { Francisco de Assis } \\
\text { de Moraes Sousa* }\end{array}$ & PMDB \\
\hline $\begin{array}{l}\text { Rio Grande do } \\
\text { Norte }\end{array}$ & $\begin{array}{c}\text { Garibaldi Alves } \\
\text { Filho }\end{array}$ & PMDB \\
\hline Sergipe & Jackson Barreto & PDT \\
\hline \multicolumn{3}{|l|}{ Centro-Oeste } \\
\hline Distrito Federal & $\begin{array}{l}\text { Cristovam } \\
\text { Buarque }\end{array}$ & PT \\
\hline Goiás & Maguito Vilela* & PMDB \\
\hline Mato Grosso & Dante de Oliveira & PDT \\
\hline $\begin{array}{l}\text { Mato Grosso do } \\
\text { Sul }\end{array}$ & Wilson Martins & PMDB \\
\hline \multicolumn{3}{|l|}{ Sudeste } \\
\hline Minas Gerais & Eduardo Azeredo & PSDB \\
\hline Espírito Santo & Vítor Buaiz & PT \\
\hline Rio de Janeiro & Marcelo Alencar & PSDB \\
\hline São Paulo & Mário Covas & PSDB \\
\hline Sul & & \\
\hline
\end{tabular}




\begin{tabular}{lcc}
\hline Paraná & Jaime Lerner & PDT \\
Rio Grande do Sul & Antônio Britto & PMDB \\
Santa Catarina & $\begin{array}{c}\text { Paulo Afonso } \\
\text { Vieira }\end{array}$ & PMDB \\
\hline
\end{tabular}

Fontes: Nicolau (1998) e múltiplas fontes jornalísticas, com cruzamento de informações do Dicionário Histórico Biográfico Brasileiro do Centro de Pesquisa e Documentação de História Contemporânea do Brasil, CPDOC/FGV

*Ex-arenista

** Ex-arenista, ex-pepista

Quanto às eleições para as Assembleias Legislativas, o PMDB obteve nas eleições de 1994 um resultado próximo àquele obtido nas eleições de 1990. Conquistando 205 cadeiras (19,6\%), o percentual obtido pelo partido ficou apenas um pouco abaixo da quantidade conquistada em 1990, quando elegeu 214 parlamentares $(20,4 \%)$. O resultado o manteve mais uma vez como detentor da maior quantidade de parlamentares eleitos nessa esfera. Além do PMDB, apenas outros dois partidos conseguiram obter mais de $10 \%$ das cadeiras: o PFL e o PPR (Partido Progressista Reformador), criado em 1993 a partir da fusão entre PDS e PDC.

Tabela 35. Cadeiras obtidas, percentual do total de cadeiras e votação total por partido nas eleições para as Assembleias Legislativas em 1994

\begin{tabular}{lccc}
\hline Partido & Cadeiras obtidas & $\%$ & Total de votos \\
\hline PMDB & 205 & 19,6 & 9.132 .676 \\
\hline PFL & 158 & 15,1 & 5.755 .218 \\
\hline PPR & 112 & 10,7 & 4.471 .170 \\
\hline PSDB & 97 & 9,3 & 6.072 .646 \\
\hline PT & 92 & 8,8 & 5.486 .924 \\
\hline PDT & 88 & 8,4 & 4.307 .094 \\
\hline PTB & 72 & 6,9 & 3.774 .633 \\
\hline PP & 54 & 5,2 & 2.897 .450 \\
\hline PL & 50 & 4,8 & 2.572 .431 \\
PSB & 32 & 3,1 & 1.359 .175 \\
\hline PSD & 20 & 1,9 & 965.315 \\
\hline PSC & 19 & 1,8 & 804.881 \\
\hline PMN & 18 & 1,7 & 711.710 \\
\hline PCdoB & 8 & 0,8 & 323.013 \\
\hline PRP & 7 & 0,7 & 536.252 \\
PV & 4 & 0,4 & 236.102 \\
\hline PPS & 3 & 0,3 & 314.736 \\
\hline PRONA & 3 & 0,3 & 351.940 \\
\hline PRN & 2 & 0,2 & 203.402 \\
\hline PRTB & 1 & 0,1 & 38.734 \\
\hline Outros & - & - & 57.881 \\
partidos & & $100 \%$ & 50.373 .383 \\
\hline TOTAL & 1045 & &
\end{tabular}

Fontes: Nicolau (1998) 
Por fim, com relação às eleições para o Congresso Nacional, o resultado das eleições de 1994 mostrou uma queda na proporção de cadeiras ocupadas pelo PMDB em ambas as Casas. Apesar disso, o partido se manteve mais uma vez na condição de detentor da maior quantidade de parlamentares tanto na Câmara dos Deputados quanto no Senado Federal.

Nas eleições para o Senado, não houve alteração na quantidade de parlamentares a serem eleitos nessa esfera em comparação às eleições anteriores. Assim, foram renovadas 54 cadeiras (2/3 do total), das quais o PMDB elegeu 14, que somados aos senadores peemedebistas que não tiveram seus mandatos renovados representaram uma bancada composta por 22 senadores no total (27,2\%). Esse número representa queda em relação às eleições de 1990, quando o PMDB passou a ter uma bancada composta por 27 senadores (33,3\%), mas menos acentuada que a observada entre as eleições de 1990 e 1986, quando o PMDB detinha uma bancada composta por 45 senadores $(62,5 \%)$.

Por sua vez, na Câmara dos Deputados houve aumento em comparação a 1990 na quantidade de cadeiras em disputa. Se naquela ocasião foram 503 deputados federais eleitos, dessa vez seriam 513, após definição da Lei Complementar $n^{\circ} 78$ de 30 de dezembro de $1993^{327}$. A nova lei esteve em vigor durante todo o restante do recorte histórico tratado nesta tese e estipulou o número máximo e mínimo de parlamentares eleitos por estado, assim como a quantidade total de parlamentares daquela Casa baseada no cálculo da distribuição geográfica da população brasileira.

Assim, naquelas eleições o PMDB elegeu 107 deputados federais (20,9\%), o que representa uma pequena queda em relação às eleições de 1990, quando elegeu 108 deputados $(21,5 \%)$. Como já dito, o partido se manteve, dessa forma, como detentor da maior bancada eleita para a Câmara mais uma vez. Os resultados reproduzidos abaixo mostram também que apenas quatro partidos conseguiram eleger mais de $10 \%$ dos parlamentares, sendo eles, além do próprio PMDB, o PSDB, o PFL e o PPR.

Tabela 36. Tamanho das bancadas partidárias na Câmara dos Deputados e no Senado Federal após as eleições de 1994

\begin{tabular}{lcccc}
\hline & \multicolumn{2}{l}{ Senado Federal } & \multicolumn{2}{c}{$\begin{array}{c}\text { Câmara dos } \\
\text { Deputados }\end{array}$} \\
\hline Partido & $\mathbf{N}$ & $\%$ & $\mathbf{N}$ & $\%$ \\
PMDB & 22 & $27,2 \%$ & 107 & $20,9 \%$ \\
PFL & 18 & $22,2 \%$ & 89 & $17,3 \%$ \\
PSDB & 11 & $13,6 \%$ & 62 & $12,1 \%$ \\
PDT & 6 & $7,4 \%$ & 34 & $6,6 \%$ \\
PPR & 6 & $7,4 \%$ & 52 & $10,1 \%$ \\
PTB & 5 & $6,2 \%$ & 31 & $6,0 \%$ \\
PT & 5 & $6,2 \%$ & 49 & $9,6 \%$ \\
PP & 5 & $6,2 \%$ & 36 & $7,0 \%$ \\
\hline
\end{tabular}

${ }^{327}$ http://www.planalto.gov.br/CCivil_03/Leis/LCP/Lcp78.htm consultado em 31/10/2018. 


\begin{tabular}{lcccc}
\hline PPS & 1 & $1,2 \%$ & 2 & $0,4 \%$ \\
PSB & 1 & $1,2 \%$ & 15 & $2,9 \%$ \\
PL & 1 & $1,2 \%$ & 13 & $2,5 \%$ \\
PCdoB & - & - & 10 & $1,9 \%$ \\
PMN & - & - & 4 & $0,8 \%$ \\
PSD & - & - & 3 & $0,6 \%$ \\
PSC & - & - & 3 & $0,6 \%$ \\
PRN & - & - & 1 & $0,2 \%$ \\
PV & - & - & 1 & $0,2 \%$ \\
PRP & - & - & 1 & $0,2 \%$ \\
TOTAL & 81 & $100 \%$ & 513 & $100 \%$ \\
\hline
\end{tabular}

Fontes: Nicolau (1998), e Mainwaring (2001: 137).

Ao analisarmos esses dados de maneira mais aprofundada, podemos verificar mais uma vez as alterações na correlação de forças internas do partido em suas bancadas por meio do histórico de filiação partidária de seus parlamentares. Dado o distanciamento histórico em relação ao momento de adoção do pluripartidarismo em 1979, era de se esperar mais uma vez um aumento na proporção de parlamentares que ingressaram na política partidária após esse marco. Os dados de fato apontam nesse sentido, mas também nos mostram processos distintos que ocorriam no interior das bancadas do PMDB na Câmara dos Deputados e no Senado Federal.

Em se tratando da Câmara dos Deputados, dos 107 parlamentares eleitos pela sigla, 21 tinham um histórico de filiação à ARENA ou ao PDS durante o Regime Militar (19,6\%). Esse número representa uma pequena queda em relação aos parlamentares eleitos pelo partido com esse histórico nas eleições de 1990, quando a proporção havia sido de 20,4\%. Porém, com relação aos parlamentares com histórico de filiação ao MDB, verifica-se uma queda mais acentuada. Como se pode ver na tabela abaixo, enquanto nas eleições de 1990 a proporção de ex-emedebistas era de 46,3\% na sua bancada, dessa vez eles representariam $35,5 \%$ dos eleitos pelo partido.

Tabela 37. Filiação prévia da bancada do PMDB na Câmara dos Deputados (1980-1994)

\begin{tabular}{|c|c|c|c|c|c|c|c|c|c|c|}
\hline & \multicolumn{2}{|c|}{1980} & \multicolumn{2}{|c|}{1982} & \multicolumn{2}{|c|}{1986} & \multicolumn{2}{|c|}{1990} & \multicolumn{2}{|c|}{1994} \\
\hline & $\mathbf{N}$ & $\%$ & $\mathbf{N}$ & $\%$ & $\mathbf{N}$ & $\%$ & $\mathbf{N}$ & $\%$ & $\mathbf{N}$ & $\%$ \\
\hline ARENA/PDS & 6 & $5,2 \%$ & 32 & $16 \%$ & 58 & $22,3 \%$ & 22 & $20,4 \%$ & 21 & $19,6 \%$ \\
\hline MDB & 109 & $94,8 \%$ & 148 & $74 \%$ & 126 & $48,5 \%$ & 50 & $46,3 \%$ & 38 & $35,5 \%$ \\
\hline $\begin{array}{l}\text { Sem } \\
\text { filiação } \\
\text { prévia }\end{array}$ & - & - & 20 & $10 \%$ & 76 & $29,2 \%$ & 36 & $33,3 \%$ & 48 & $44,9 \%$ \\
\hline Total & 115 & $100 \%$ & 200 & $100 \%$ & 260 & $100 \%$ & 108 & $100 \%$ & 107 & $100 \%$ \\
\hline
\end{tabular}

Fontes: Schmitt (2000: 51) para os dados de 1980, Mucinhato (2015) para os dados de 1982 e elaboração própria para os dados de 1986, 1990 e 1994 a partir do cruzamento de informações coletadas no Centro de Documentação e Informação da Câmara dos Deputados (CEDI) e Centro de Pesquisa e Documentação de História Contemporânea do Brasil (CPDOC-FGV). 
Por sua vez, com relação à bancada eleita pelo PMDB para o Senado Federal, dos 14 parlamentares eleitos, dez haviam ingressado na política partidária por meio do MDB, um por meio da ARENA, e outros três haviam ingressado diretamente no PMDB quando ocorreu o restabelecimento do pluripartidarismo no Brasil. Cabe apontar ainda que dois dos paramentares eleitos apresentavam passagem pelo PRN de Fernando Collor: Renan Calheiros (AL) e Gilvam Borges (AP). No que concerne à bancada do PMDB como um todo, como demonstrado na tabela abaixo, podemos notar uma acentuada queda na quantidade de parlamentares de sua bancada que haviam sido filiados à ARENA ou ao PDS durante o Regime Militar. Estes compõem uma pequena minoria dentro do partido a partir de então, com apenas dois senadores (9\%). Por outro lado, apesar do distanciamento histórico cada vez maior em relação ao período bipartidário, a quantidade de parlamentares do PMDB naquela Casa que haviam estado no MDB cresceu. Seriam agora 12 senadores (54\%), o que representava mais da metade da bancada do partido.

\section{Tabela 38. Filiação prévia da bancada do PMDB no Senado Federal (1980-1994)}

\begin{tabular}{l|cc|cc|cc|cc|cc}
\hline & \multicolumn{2}{c}{1980} & \multicolumn{2}{c}{1982} & \multicolumn{2}{c}{1986} & \multicolumn{2}{c}{1990} & 1994 \\
\hline \multirow{2}{*}{ ARENA/PDS } & $\mathbf{N}$ & $\%$ & $\mathbf{N}$ & $\%$ & $\mathbf{N}$ & $\%$ & $\mathbf{N}$ & $\%$ & $\mathbf{N}$ & $\%$ \\
\cline { 2 - 11 } & 2 & $9 \%$ & 7 & $33,3 \%$ & 13 & $28,9 \%$ & 7 & $25,9 \%$ & 2 & $9,1 \%$ \\
MDB & 20 & $91 \%$ & 14 & $66,7 \%$ & 23 & $51,1 \%$ & 13 & $48,2 \%$ & 12 & $54,5 \%$ \\
Total filiação prévia & - & - & - & - & 9 & $20 \%$ & 7 & $25,9 \%$ & 8 & $36,4 \%$ \\
\hline
\end{tabular}

Fontes: Mucinhato (2015) para os dados de 1980 e 1982, Mainwaring (2001: 137) e elaboração própria para os dados de 1986 a 1994 a partir do cruzamento dos resultados eleitorais com informações coletadas no Centro de Pesquisa e Documentação de História Contemporânea do Brasil (CPDOC-FGV).

Dessa forma, os resultados das eleições de 1994 para o Congresso Nacional nos apontam processos distintos ocorrendo na bancada do PMDB na Câmara dos Deputados e no Senado Federal, que em conjunto compõem a chamada face pública do partido (Katz e Mair, 1993). Na Câmara, nota-se a permanência de um "núcleo duro" na bancada do partido, formado por parlamentares com histórico de filiação partidária ligado aos partidos de sustentação do Regime Militar durante a existência deste. Ao mesmo tempo, verifica-se uma queda constante desde a refundação do partido em 1980 na quantidade de parlamentares com histórico de filiação ao MDB. Por outro lado, no Senado Federal, ocorria um processo inverso. Houve uma constante queda desde 1982 na proporção de senadores do PMDB que integraram os partidos de sustentação do Regime. Concomitantemente, a proporção de parlamentares com histórico de filiação ao MDB inverteu sua tendência de queda e cresceu em 1994 se comparada às eleições anteriores, atingindo um patamar ainda acima daquele obtido como resultado das eleições de 1986, momento de "inchaço" do partido. 


\subsection{Consideracões finais: o PMDB após as eleicões de 1994}

Na primeira parte desta tese, que cobriu os anos de 1979 a 1988, evidenciamos o constante processo de entradas e saídas do PMDB. Este processo teve consequências diretas nas mudanças ocorridas na sua coalizão dominante, que entre outras coisas levaram o partido a adotar a estratégia de lançar um candidato próprio para disputar o Colégio Eleitoral de 1985. Porém, diferentemente daquilo que ocorreu no período de 1979 a 1988, a partir da saída dos peessedebistas em 1988 as transformações internas e as consequentes mudanças na coalizão dominante do partido seguiram existindo, mas passaram a se dar de outra maneira.

Como demonstramos ao longo deste capítulo, a estratégia utilizada pelo PMDB de lançar candidaturas próprias nas eleições presidenciais de 1989 e 1994 esteve ligada à ascensão e ao efêmero controle de seus órgãos de direção por parte de duas de suas principais lideranças do período. Nas eleições de 1989, a coalizão dominante do partido passa a ser temporariamente composta por figuras ligadas diretamente a Ulysses Guimarães, liderança histórica do MDB e do PMDB. Com o controle de sua CEN, o político conquistou sua tão almejada candidatura à presidência da República, mas obteve uma votação muito aquém daquela almejada pelo político, com evidências de que houve "cristianização" de sua candidatura por um segmento do PMDB. Da mesma maneira, Orestes Quércia e os setores ligados a ele no partido conquistaram outro efêmero controle dos seus órgãos de direção no início dos anos 1990. Esse controle levou o político a se tornar a segunda candidatura direta da história do PMDB, em 1994. Entretanto, tal como Ulysses Guimarães, sua votação acabou distante das principais candidaturas do pleito, com evidências que mais uma vez apontavam para uma "cristianização" da candidatura.

Ademais, no período entre a apresentação das duas candidaturas próprias houve um fenômeno novo no seu interior. Pouco a pouco passou a se tornar evidente uma cisão interna, que se refletiu num racha em sua coalizão dominante. Enquanto uma parcela das suas lideranças decidiu apoiar a participação do PMDB no governo-tampão de Itamar Franco, empossado após o impeachment de Fernando Collor, outra parte dos seus líderes defendeu abertamente o rompimento e o distanciamento do partido em relação ao governo.

Assim, surgiu uma nova divisão interna no partido. Dessa vez, entre as suas alas governista e oposicionista, análoga àquela que havia no partido enquanto a sigla estava na condição de oposição ao Regime Militar dez anos antes, quando o partido se dividia entre moderados e autênticos. No entanto, enquanto durante o Regime Militar essa cisão referia-se ao modo como o MDB deveria desempenhar seu papel de oposição ao Regime (Kinzo, 1988: 57), dessa vez a divisão se dava em torno de dois posicionamentos partidários distintos quanto à adesão ou não do PMDB à coalizão governista e quanto ao lançamento de uma candidatura própria do partido à presidência da República. Essa divisão seria marcante no partido durante todo o governo de Fernando Henrique Cardoso, eleito em 1994, encerrando-se, pelo menos no que tange 
aos seus órgãos de direção, a partir do momento em que a sua ala governista passa a ser hegemônica no seu interior, período este que será analisado no próximo e último capítulo deste estudo. 


\section{Capítulo 4 - A ala governista se torna hegemônica (1994 a 2002)}

"Eles procuram dar uma aparência disso [de que a CEN é uma sintese de suas principais lideranças], mas sempre com pessoas que não têm expressão eleitoral forte, mas que têm fidelidade a esse grupo que domina o PMDB há muitos anos, por conta do Michel Temer." Deputado Marcelo Castro, em entrevista ao autor.

"O partido fez uma espécie de renúncia à candidatura própria, e encontrou um meio ali, via tamanho global do partido e presença no Congresso, de preservar uma função muito importante na dinâmica política brasileira." João Carlos Brum Torres, em entrevista ao autor.

\subsection{Introdução}

A partir das eleições de 1994, iniciou-se um período no qual formou-se um padrão estável de competição nas eleições para a presidência da República, basicamente entre candidatos do PT e do PSDB (Braga, 2010; Melo, 2010; Limongi e Cortez, 2010; Carreirão, 2014; Cervi, 2016 entre outros), cada qual apoiado por um determinado bloco de partidos. No que diz respeito ao PMDB, após o lançamento das candidaturas presidenciais de Ulysses Guimarães em 1989 e de Orestes Quércia em 1994, o partido abdicou de lançar candidato próprio à presidência da República. Nas eleições de 1998, o partido não se coligou nacionalmente com nenhum outro nas eleições presidenciais e nas eleições de 2002 integrou na condição de candidato a vice-presidente com Rita Camata a chapa presidencial lançada pelo PSDB e encabeçada pelo tucano José Serra.

A oscilação entre esses dois comportamentos se repetiu nas eleições seguintes, inclusive para além do limite do recorte histórico adotado nesta tese, mantendo-se constante, salvo nas eleições de 2018, na quais o partido apresentou novamente uma candidatura própria. Nas eleições de 2006, com a aprovação da verticalização das coligações que foi aplicada àquele pleito, o PMDB mais uma vez não se coligou nacionalmente com qualquer partido, tampouco declarou apoio formal a alguma candidatura $^{328}$. Entretanto, nas eleições de 2010 e 2014 o partido retomou a sua estratégia utilizada nas eleições de 2002, dessa vez integrando na condição de vice em ambas as vezes a chapa lançada pelo Partido dos Trabalhadores e encabeçada por Dilma

328 http://memoria.ebc.com.br/agenciabrasil/noticia/2006-06-12/eleicoes-2006-executiva-nacional-dopmdb-decide-que-partido-nao-tera-candidato-presidencia. 
Rousseff $^{329}$. O candidato a vice nas duas ocasiões foi o próprio presidente do PMDB, o ex-deputado paulista Michel Temer, que exerce o cargo no partido desde que foi eleito no ano de 2001.

A mudança no comportamento da sigla em relação às eleições presidenciais verificada a partir de meados dos anos 1990 coincide com uma queda no seu desempenho eleitoral no âmbito legislativo. De 1986 até as eleições de 1994 o partido se manteve como aquele que elegia a maior bancada partidária tanto na Câmara dos Deputados quanto no Senado Federal. Em 1998, porém, o PMDB manteve esse posto no Senado mas pela primeira vez o partido não foi mais o detentor da maior bancada da Câmara. Apesar dessa queda no seu desempenho e da perda do seu protagonismo nas eleições presidenciais (que já se verificara no baixo desempenho das suas candidaturas de 1989 e 1994), a sigla ainda assim se manteve como a detentora de uma das maiores bancadas no Congresso Nacional. Assim, com a eleição de Fernando Henrique Cardoso (PSDB) nas eleições presidenciais de 1994, o partido rapidamente foi convidado a integrar a coalizão governista que daria a tônica da política nacional a partir de então.

Esses dois fenômenos aqui descritos, tanto o fato de não mais lançar candidatos próprios quanto a manutenção de uma forte bancada congressual, são o reflexo direto de uma estratégia adotada pela coalizão que passara a ser dominante no interior do partido. A divisão interna entre seus segmentos governista e oposicionista que veio à tona durante a presidência de Itamar Franco mais uma vez emerge, desta vez durante o mandato de FHC. Entretanto, pouco a pouco a ala governista, encabeçada por Michel Temer, passou a se tornar hegemônica no interior do partido, controlando as suas instâncias de decisão e apaziguando seus conflitos internos. Assim, o comportamento adotado pelo partido nas eleições presidenciais após 1994 esteve diretamente ligado à ascensão dessa ala específica no seu interior, levando o PMDB ao pano de fundo da política nacional, mas mantendo-o sempre um ator importante do sistema político brasileiro.

Nesse sentido, para analisarmos esses processos dentro do recorte histórico de 1994 a 2002, o último capítulo desta tese será dividido em sete seções além desta introdução. A próxima seção analisará a tensão existente entre as duas alas internas do PMDB após a eleição de FHC em 1994. Na seção subsequente, descreveremos a gradual ascensão do grupo governista no interior do partido, evidenciada por meio da chegada de Michel Temer à presidência da Câmara dos Deputados em 1997. Em seguida, descreveremos a indefinição quanto à estratégia a ser adotada pelo partido em relação às eleições presidenciais de 1998. Na seção seguinte analisaremos os resultados eleitorais do partido nas eleições de 1998, com um balanço geral do que foi apontado por este estudo em relação ao desempenho eleitoral do PMDB em todo o recorte histórico desta pesquisa. Em seguida, descreveremos como a ala governista no interior

\footnotetext{
${ }^{329}$ http://g1.globo.com/especiais/eleicoes-2010/noticia/2010/06/pmdb-oficializa-michel-temer-comovice-na-chapa-de-dilma.html e http://g1.globo.com/distritofederal/eleicoes/2014/noticia/2014/06/apesar-de-ala-dissidente-pmdb-aprova-apoio-dilma-naseleicoes.html.
} 
do partido se tornou hegemônica nos seus órgãos de direção, no ano de 2001. Na seção subsequente, analisaremos como a hegemonia obtida por essa ala se refletiu na estratégia eleitoral adotada pelo partido nas eleições presidenciais de 2002, ocasião em que o PMDB pela primeira vez em sua história lançou um candidato ao cargo de vicepresidente da República coligado a outro partido. Por fim, nas considerações finais, apresentamos uma síntese deste capítulo.

\subsection{Participacão no primeiro governo FHC: governistas versus oposicionistas $\underline{(1994-1997)}$}

“(...) Acaba que nenhum candidato eleito à presidência da República fica sem o PMDB. O partido está sempre participando, dada a sua grandeza." Deputado Mauro Lopes, Secretário-Geral do PMDB, em entrevista ao autor.

Com a eleição de Fernando Henrique Cardoso para o cargo de Presidente da República em 1994, o PMDB se viu mais uma vez dividido entre aderir ou não ao futuro governo. De fato, essa questão já havia sido colocada ainda antes da realização daquelas eleições, quando alguns setores do PMDB haviam iniciado conversas com o PSDB para o lançamento de uma candidatura conjunta dos dois partidos, compondo uma coligação e sinalizando para uma aproximação nacional entre as duas siglas. $\mathrm{Na}$ ocasião, o próprio presidente do PMDB, o deputado catarinense Luiz Henrique, havia relatado que havia se reunido com o presidente do PSDB, Tasso Jereissati, ainda antes da definição da candidatura de Orestes Quércia como representante do partido naquelas eleições ${ }^{330}$. Entretanto, com a hegemonia adquirida pelo segmento quercista no interior do partido, as conversas não prosperaram, e seria após a eleição de FHC que a divisão interna no PMDB entre as suas alas governista e oposicionista se tornaria ainda mais evidente.

Pouco após a confirmação dos resultados daquela eleição presidencial, setores do PMDB já sinalizavam uma incorporação do partido à futura coalizão de governo. Ainda antes da realização das disputas estaduais para as quais haveria um segundo turno, os governadores eleitos pelo PMDB em primeiro turno demonstravam apoio a essa posição, como era o caso de Garibaldi Alves (RN), Divaldo Suruagy (AL) e Wilson Martins (MS). A posição também tinha o apoio dos peemedebistas gaúchos e do ex-presidente da República e senador José Sarney. Os novos governadores, porém, demonstravam preocupação quanto à imagem recente que o PMDB vinha transmitindo, aparentando ser uma sigla dividida nos governos de Sarney e Itamar, e pedindo para que houvesse uma adesão total do partido ao futuro governo ${ }^{331}$. Assim, uma decisão definitiva quanto a se incorporar ou não ao governo de FHC viria no final daquele ano, em reunião do Conselho Nacional do partido.

\footnotetext{
${ }^{330}$ Ata da reunião da Comissão Executiva Nacional do PMDB - 02/03/1994.

${ }^{331}$ Folha de S. Paulo-24/10/1994.
} 
Reunidos em 9 de dezembro de 1994 para definir sua posição em relação ao assunto, os peemedebistas do órgão declararam que o PMDB apoiaria o futuro governo, com a intenção de ocupar o seu "núcleo de poder" 332 , e divulgando nota pública nesse sentido (Ferreira, 2002: 183) ${ }^{333}$. Entretanto, apesar da declaração de apoio formal, o acordo estabelecido por meio do Conselho Nacional não foi totalmente aceito por alguns setores da sigla (Ferreira, 2002: 151). Assim, o governo não incorporou efetivamente o PMDB e suas diferentes correntes ao ministeriado de FHC. As pastas recebidas pelo partido na composição inicial do governo foram vistas mais como representativas da cota pessoal do presidente da República do que do PMDB, e certas correntes da sigla não apoiaram o governo em nenhum momento (Limongi e Figueiredo, 1999: 219).

O apoio ao governo FHC partiu então do setor governista do interior do PMDB, ala que descrevemos no terceiro capítulo. Evidências nesse sentido foram os peemedebistas ocupantes das pastas durante aquele primeiro mandato de Fernando Henrique. O PMDB ocuparia sete Ministérios e Secretarias Especiais com status de Ministério $(15,9 \%$ ) ao todo durante o primeiro mandato de FHC na presidência da República $^{334}$. Entre os ocupantes estavam os peemedebistas gaúchos Odacir Klein, Eliseu Padilha e Nelson Jobim, integrantes do Diretório do partido que já havia apoiado a eleição de FHC em 1994 e não integraram a campanha de Orestes Quércia.

A ocupação de Ministérios pelo PMDB estava diretamente ligada à leitura feita pelo novo presidente da República do arranjo institucional do sistema político brasileiro, conhecido como presidencialismo de coalizão (Limongi e Figueiredo, 1999). Como visto no capítulo anterior, as eleições de 1994 levaram o PMDB a se manter na condição de detentor da maior bancada partidária tanto na Câmara dos Deputados quanto no Senado Federal. Os 22 senadores do partido representavam 27,2\% da Casa, enquanto na Câmara os 107 deputados federais representavam 20,9\% dos representantes dessa esfera do Poder Legislativo. Adotando uma estratégia distinta daquela adotada por Fernando Collor, presidente eleito em 1989 que havia julgado ser possível governar sem o concurso do PMDB (Limongi e Figueiredo, 1999: 116), FHC teria então avaliado que era necessário estender sua base de apoio incluindo uma parte importante do PMDB e que, caso não o fizesse, nem ele, nem quem o sucedesse poderia governar o Brasil (Cardoso, 2015: 703). Essa avaliação também é compartilhada pela parcela governista do PMDB, que obviamente se beneficia dessa estratégia. Em entrevista ao autor, o deputado federal Mauro Lopes (MG), Secretário-Geral do partido enquanto este estudo foi desenvolvido, declarou:

"Mas tenho o PMDB na conta de um partido das grandes decisões nacionais. Quando qualquer circunstância (...) ocorre no país, qualquer dificuldade, é o partido que sempre tem um equilíbrio. É o partido do equilíbrio.

\footnotetext{
${ }^{332}$ Folha de S. Paulo - 10/12/1994.

${ }^{333}$ Ver Anexo 14.

${ }^{334}$ Ver Tabela 5 na Introdução deste estudo.
} 
Nenhum governante de nenhum outro partido consegue governar o Brasil sem o PMDB. É o partido mais importante desse país. Você pode ver que em todos os casos de presidentes do passado sempre teve uma participação do $P M D B$ ".

Nesse sentido, com o seu ingresso na coalizão governista, o PMDB passava a ser o detentor da maior bancada entre todos os partidos que a integravam, maior ainda que o próprio PSDB de FHC. O partido se tornava, assim, um interlocutor importante para que o governo obtivesse sustentação legislativa para a aprovação de sua agenda políticoeconômica, beneficiando-se, por conta do seu tamanho, da distribuição de pastas ministeriais. Ademais, enquanto o partido se tornava imprescindível para o governo e passava a ocupar espaços no Poder Executivo, a ala governista no interior da sigla passou a ganhar destaque dentro do Congresso e no interior da sua bancada eleita.

Em 1995, o senador escolhido para ser o líder do partido nessa Casa seria o governista Jader Barbalho (PA), enquanto o ex-presidente José Sarney (AP) era eleito para o cargo de Presidente do Senado para o biênio 1995-1997, cargo que voltaria a ocupar em mais duas oportunidades futuras ${ }^{335}$. Na Câmara dos Deputados, começava a ganhar destaque o deputado paulista Michel Temer, escolhido como líder da bancada peemedebista, que havia ingressado no PMDB décadas antes por intermédio do próprio FHC (Cardoso, 2015: 69) ${ }^{336}$.

Em entrevista ao autor, o Senador Cássio Cunha Lima (PSDB-PB), que durante o primeiro mandato de FHC na presidência ocupou o posto de vice-líder do PMDB na Câmara dos Deputados, acredita que foi a partir de então que o partido passou a ocupar o centro do espectro político partidário, "adotando como estratégia de sobrevivência a política da composição e da coalizão". Nas suas palavras:

"Acho que o PMDB acabou ficando caracterizado como um grande partido de centro. (...) Por ter essa posição de centro, a característica do partido foi essa sobrevivência no que diz respeito à bancadas na Câmara e no Senado, que sempre foram bancadas importantes e numerosas, $e$ [foi também] essa capacidade de ser o fiel da balança na sustentabilidade de governos que em tese são governos que na política tinha[m] muito confronto. Estou me referindo é que o PMDB foi base do governo FHC como foi base importante do governo Lula."

\footnotetext{
335 https://oglobo.globo.com/brasil/sarney-da-presidencia-da-republica-aos-atos-secretos-no-senado12994251.

${ }^{336}$ Cabe apontar que o ex-presidente Fernando Henrique Cardoso se encontra na relação de políticos que não encontraram tempo em sua agenda para conceder entrevista a esta pesquisa, apesar dos 18 meses de tentativas da parte do autor.
} 
Apesar de seu segmento governista estar em ascensão nacional, ocupando espaços estratégicos tanto no Poder Legislativo quanto no Poder Executivo, nos órgãos de decisão do partido ainda havia divisões em sua coalizão dominante, tal como havia ocorrido durante o mandato de Itamar Franco enquanto presidente da República. A eleição de uma nova Comissão Executiva Nacional do PMDB ainda no final de 1995 deixaria claras essas divisões na sua composição assim como a tensão interna entre as suas alas governista e oposicionista.

No dia 1 de outubro daquele ano, em Convenção Nacional, o partido definiu quais seriam os integrantes do seu Diretório Nacional. Por sua vez, os integrantes do DN elegeriam aqueles que iriam comandar o partido por meio da sua CEN e, pela segunda vez em sua história, tal como havia ocorrido em 1989, o PMDB teve uma disputa entre duas chapas para definir os componentes do seu órgão máximo de direção $^{337}$. De um lado havia a chapa dos oposicionistas (também chamados de "dissidentes"), que pregavam a não adesão do partido ao governo FHC. A chapa era encabeçada pelo deputado Paes de Andrade (CE) e era composta por remanescentes do quercismo, como o deputado Marcelo Barbieri (SP), contando com o apoio de alguns senadores, como o alagoano Renan Calheiros. Do outro, a chapa dos governistas, que apoiavam a aproximação que havia ocorrido entre o partido e o governo federal e era vista pela imprensa como aquela mais "afinada" com o presidente FHC. A chapa era encabeçada pelo deputado paulista Alberto Goldman e apoiada por Maguito Vilela (GO) e pelo senador Ronaldo Cunha Lima (PB), entre outros. Com uma diferença de apenas um voto, por 76 a 75, a chapa de Paes de Andrade, ferrenho opositor de FHC (Maciel, 2014: 76) sagrou-se vitoriosa ${ }^{338}$.

Segundo a ata daquela reunião, o resultado da disputa levou o deputado João Almeida (BA), fiscal da chapa derrotada, a questionar e pedir a impugnação do resultado daquela eleição, enquanto a chapa vencedora sinalizava que estaria disposta a exigir uma "participação mais efetiva nos centros de decisão do governo",339, talvez procurando fazer frente ao espaço já conquistado dentro do governo por parte da ala governista do partido. Meses depois, parte da imprensa creditou a derrota da chapa governista a uma estratégia equivocada do governo FHC, que havia buscado fortalecer as bancadas de PFL e PSDB por meio da migração de políticos peemedebistas, mas que em última instância levou a um enfraquecimento da ala governista no interior do PMDB $^{340}$, que apoiava o governo.

Entretanto, apesar da posse de um oposicionista na presidência do partido a partir de então, Paes de Andrade não foi capaz de unificar o posicionamento do partido nessa direção (Maciel, ibidem). De fato, tal como Ferreira (2002: 152-153) havia apontado e como reproduzido na tabela abaixo, a maioria da bancada peemedebista continuaria a votar com o governo no Congresso Nacional, evidenciando a força da ala

\footnotetext{
${ }^{337}$ Ata de reunião do Diretório Nacional do PMDB - 01/10/1995.

${ }^{338}$ Folha de S. Paulo - 02/10/1995. Sobre a nova composição do órgão, ver Anexo 3.

${ }^{339}$ Follha de S. Paulo-03/10/1995.

${ }^{340}$ Folha de S. Paulo-24/03/1996.
} 
governista no interior da bancada do partido. Das 266 votações nominais realizadas na Câmara dos Deputados durante a sua presidência para apreciação de matérias de diversos tipos, como PLs (projetos de lei), PECs (Proposta de Emenda Constitucional), PLPs (Projeto de Lei Complementar) e DVSs (destaques para votação em separado), etc., que incluem apenas as votações nas quais não houve unanimidade (excluindo aquelas consideradas inválidas ou aquelas nas quais o líder do governo indicou voto), $78,66 \%$ da bancada do PMDB votou com o governo e $21,34 \%$ votou contra ${ }^{341}$.

Tabela 39. Comportamento da bancada do PMDB na Câmara dos Deputados na votação das reformas constitucionais

\begin{tabular}{l|c|c|c}
\hline Reformas aprovadas & Sim & Não & Abstenção \\
\hline $\begin{array}{l}\text { Quebra do monopólio } \\
\text { estatal das } \\
\text { comunicações (20 } \\
\text { turno) }\end{array}$ & 72,4 & 26,5 & 1,1 \\
$\begin{array}{l}\text { Quebra do monopólio } \\
\text { estatal do petróleo (20 } \\
\text { turno) }\end{array}$ & 82 & 18 & 0 \\
$\begin{array}{l}\text { Reeleição/cargos do } \\
\text { Poder Executivo }\end{array}$ & 87,5 & 10,4 & 2,1 \\
$\begin{array}{l}\text { Reforma } \\
\text { administrativa / } \\
\text { Quebra da } \\
\text { estabilidade dos } \\
\text { servidores públicos }\end{array}$ & 68,6 & 29,1 & 2,3 \\
\hline
\end{tabular}

Fonte: Ferreira (2002: 152).

Ademais, a composição da Comissão Executiva Nacional do partido que havia sido eleita em outubro de 1995 durou pouco. O deputado paulista Alberto Goldman, que encabeçava a chapa derrotada, seguiu questionando os resultados daquela eleição, contestando o voto decisivo que havia levado ao resultado de 76 a 75 a favor de Paes. Da sua parte, Paes de Andrade alegava que não abriria mão de exercer a presidência do partido $^{342}$. Assim, como solução de consenso para evitar que o partido implodisse, em 7 de dezembro daquele mesmo ano o Diretório Nacional elegeu novos membros para a CEN do PMDB, com uma composição que posteriormente seria prorrogada até o final de $1998^{343}$. A nova composição do órgão mantinha o oposicionista Paes de Andrade como presidente da sigla, mas incluiria a partir de então alguns dos membros da chapa

\footnotetext{
${ }^{341}$ Agradeço à cientista política Joyce Luz por ceder os dados do Banco de Dados do Legislativo do Cebrap, fonte a partir da qual as informações foram extraídas, e ao cientista político Sérgio Simoni Jr. por processá-los, permitindo nossa análise.

${ }^{342}$ Folha de S. Paulo - 09/11/1995.

343 Dicionário Histórico Biográfico Brasileiro do Centro de Pesquisa e Documentação de História Contemporânea do Brasil, CPDOC/FGV, verbete "Paes de Andrade".
} 
derrotada em outubro, como o Senador Ronaldo Cunha Lima (PB) e o próprio Alberto Goldman, que havia encabeçado a chapa derrotada. Além disso, o DN também decidiu que aumentaria o tamanho do principal órgão de direção do partido. Foram criadas naquela ocasião mais quatro vagas de vogal na $\mathrm{CEN}$, o que, segundo a imprensa, foi feito como uma solução para apaziguar as disputas entre os dois grupos ${ }^{344}$. A Convenção Nacional de 24 de março de 1996 ratificou essa nova composição ${ }^{345}$.

Como se pode ver, a divisão interna que havia marcado o PMDB durante o governo de Itamar Franco veio à tona mais uma vez durante o governo FHC. De um lado, o seu setor oposicionista não pode impedir que logo após as eleições de 1994 o partido definisse a sua adesão ao governo, mas ainda assim, em eleição apertada, conseguiu manter o controle do seu principal órgão de direção, a CEN. De outro, o seu setor governista, que cada vez mais ganhava força tanto no interior do partido quanto no Congresso Nacional, conseguiu uma adesão da sigla ao governo federal e preparava o terreno para futuramente se tornar hegemônico nos órgãos de direção do partido.

\subsection{A gradual ascensão da ala governista: Michel Temer chega à presidência da Câmara dos Deputados (1997-1998)}

"Nossa ala do partido em São Paulo com o Quércia sempre propugnava por candidatura própria. Essa, aliás, era a grande reclamação do Michel [Temer] contra o Quércia." Senador Airton Sandoval, em entrevista ao autor.

Para além da derrota nas eleições presidenciais de 1994, Orestes Quércia e o próprio PMDB passaram também a perder força naquele que vinha sendo o seu principal reduto eleitoral desde a refundação do partido: o estado de São Paulo ${ }^{346}$. Como dito anteriormente, o ex-peemedebista Mário Covas (PSDB) é quem vence as eleições daquele ano para o cargo de governador de São Paulo, derrotando o candidato do PMDB Barros Munhoz e dando início à hegemonia dos tucanos. Apesar disso, outro peemedebista paulista, ligado à ala governista no interior do partido, passava pouco a pouco a ganhar maior expressão nacional durante o primeiro mandato de FHC. Tratavase do então deputado e futuro presidente do partido Michel Temer.

Michel Miguel Elias Temer Lulia nasceu em 1940 na cidade de Tietê, interior de São Paulo. Formado em Direito pela mesma escola que havia formado Ulysses Guimarães, a Faculdade de Direito da Universidade de São Paulo, passou a atuar na sua profissão por meio de um escritório de advocacia na própria cidade de São Paulo. Em 1964, não apoiou nem resistiu ao golpe, ingressando pouco depois no quadro da

\footnotetext{
${ }^{344}$ Folha de S. Paulo - 08/12/1995.

345 Acervo SEDAP/TSE - Ofício 091/96, de 02/05/1996.

${ }^{346}$ Sobre o assunto, ver Meneguello e Bizzarro Neto (2012).
} 
Pontifícia Universidade Católica de São Paulo enquanto professor de Direito Constitucional $^{347}$. Enquanto lecionava começou a se aproximar de Franco Montoro, à época também professor da mesma universidade e quadro político do MDB. Pouco depois, no início dos anos 1980, começa a despontar em sua carreira política, filiando-se ao PMDB em 1981 (Doria, 2009: 17).

No ano seguinte à eleição de Montoro para governador de São Paulo em 1982 pelo PMDB, Temer é nomeado Procurador Geral do estado, e passa ao cargo de Secretário de Segurança em 1984. Valendo-se da ocupação de uma secretaria com grande estrutura e penetração territorial suficiente para capitalizar suas chances de vitória eleitoral (Bizzarro Neto, 2013: 108), em 1986 candidatou-se a deputado federal pela primeira vez, alcançando a suplência. Assumiu o mandato quando seu colega de partido Tidei de Lima licenciou-se para chefiar a Secretaria de Agricultura de São Paulo, em tempo para participar da Assembleia Nacional Constituinte de 1987-1988. Em 1990, concorreu mais uma vez a uma vaga de deputado federal, mas mais uma vez conquistou apenas a suplência.

Em 1992 Temer retorna ao cargo de Secretário de Segurança Pública do estado de São Paulo, nomeado pelo então governador Fleury Filho após o massacre do Carandiru, no qual 111 detentos daquele estabelecimento prisional paulista foram assassinados pela Polícia Militar durante uma rebelião. Licenciou-se do seu cargo para se candidatar mais uma vez ao cargo de deputado federal em 1994, dessa vez obtendo votação suficiente para exercer o seu mandato a partir do ano seguinte.

Eleito deputado federal, em 1995 torna-se líder da bancada do PMDB na Câmara dos Deputados, primeiro ano do mandato presidencial de FHC. No mesmo ano, o Departamento Intersindical de Assessoria Parlamentar (DIAP, 1995) aponta o político pela primeira vez como sendo um integrante da elite parlamentar do Congresso, conhecidos como os "Cabeças do Congresso", grupo formado pelos 100 congressistas mais influentes do Poder Legislativo. Temer é caracterizado pela publicação como um político "formulador", "formador de opinião" e "hábil negociador", e seguiu sendo apontado como membro dessa elite ininterruptamente até o ano de $2011^{348}$, quando deixa a Câmara para assumir o posto de vice-presidente da República na presidência de Dilma Rousseff.

Ainda no ano de 1995, Temer estabeleceu um acordo com o PFL, que detinha a segunda maior bancada da Câmara, para que houvesse rotatividade entre os dois partidos na presidência daquela Casa e assim um equilíbrio de poder entre os três principais partidos governistas. Segundo esse acordo, enquanto o PSDB estivesse à frente do Poder Executivo, um deputado do PFL presidiria a Câmara no primeiro biênio do governo, de 1995 a 1997, posto que coube a Luís Eduardo Magalhães, e um peemedebista presidiria a Casa no segundo biênio, a partir de 1997, posto que coube ao

\footnotetext{
${ }^{347}$ Revista Piauí - Edição 45/Junho 2010: “A cara do PMDB”.

348 Para uma relação da lista completa dos "Cabeças do Congresso" elaborada pelo DIAP consultar http://www.diap.org.br/images/stories/historico_cabecas.pdf, acessado em 06/11/2018.
} 
próprio Temer (Maciel, 2014: 74). Enquanto isso, no Senado Federal, o mesmo rodízio seria feito, com o peemedebista e ex-presidente da República José Sarney assumindo a presidência da Casa no primeiro biênio, e um pefelista assumindo no segundo, posto que coube a Antonio Carlos Magalhães ${ }^{349}$.

Como resultado desse processo, se por um lado as disputas entre os peemedebistas para as presidências da Câmara e do Senado Federal acirravam o conflito interno do PMDB entre os governistas e os oposicionistas, por outro o grupo oposicionista começava a perder cada vez mais espaço nos loci de poder disponíveis ao PMDB (Maciel, 2014: 76). A gradual ascensão dos governistas nesse período, porém, foi encarada por alguns políticos como algo negativo para o partido como um todo. Para o deputado Heráclito Fortes (PI), filiado ao partido até 1994 e integrante da CEN nos anos 1980, durante aquele período "a parte fisiológica e pragmática (do partido) passava a predominar. A parte que já pensava no governo, e servia ao governo que entrava".

Ao assumir a presidência da Câmara dos Deputados, a partir de 1997, Michel Temer passava a ser assim um dos principais interlocutores do governo FHC dentro do Congresso Nacional, adquirindo cada vez maior proeminência dentro do segmento governista do seu partido. Seu perfil de atuação dentro da Câmara era visto pelos seus colegas de bancada como o de um político "conciliador" 350 " e extremamente habilidoso. Nas palavras do senador Roberto Requião (PR), entrevistado para este estudo:

"Por exemplo, o Temer, conheço ele há muitos anos. Ele era um político extremamente habilidoso para lidar com a Câmara Federal. Ele negociava com todo mundo. $O$ Roger Gerard Schwartzenberg, no livro 'O Estado Espetáculo', chama esse tipo de político de 'rolha de cortiça', porque não afunda nunca! Ele está sempre flutuando. Extremamente flexivel."

Essa atuação na Câmara já havia dado destaque ao político pouco antes da sua chegada à presidência daquela Casa, e estava também ligada diretamente a sua atuação próxima ao governo federal enquanto relator da Reforma da Previdência de 1996 mas sobretudo por conta de sua atuação no ano de 1997. Ainda em janeiro daquele ano a Câmara havia aprovado em primeira votação a proposta de emenda à Constituição conhecida como "emenda da reeleição", dispositivo que permitiria a partir de então que os ocupantes de cargos do Poder Executivo (prefeitos, governadores de estado e presidentes da República) disputassem o segundo mandato de maneira consecutiva ${ }^{351}$. A

\footnotetext{
${ }^{349}$ Folha de S. Paulo - 19/12/2002. Para uma lista completa dos políticos que exerceram a presidência tanto da Câmara quanto do Senado durante o mandato de FHC, ver https://fernandorodrigues.blogosfera.uol.com.br/2013/02/01/oposicao-nunca-ganhou-presidencia-dosenado/.

${ }^{350}$ Deputado Mauro Lopes, em entrevista concedida ao autor.

${ }^{351}$ A emenda seria aprovada pelo Senado em junho do mesmo ano, tornando-se a Emenda Constitucional $n^{\circ} 16$, de 4 de junho de 1997 http://www.planalto.gov.br/ccivil_03/constituicao/Emendas/Emc/emc16.htm.
} 
atuação de Temer ainda enquanto líder da bancada do seu partido, trazendo os votos necessários para a sua aprovação e indo na contramão de uma moção que havia sido proposta pelo PMDB (Maciel, 2014: 77) ${ }^{352}$, levou a uma atuação ostensiva do governo em prol da sua eleição para o cargo de presidente daquela Casa no mês seguinte. Tal atuação foi vista pela imprensa como uma forma de compensação ao líder do PMDB por sua atuação em favor da aprovação da "emenda da reeleição"353.

Poucos meses depois de sua eleição, em maio de 1997, a aprovação da emenda foi colocada sob suspeição de compra de votos. O PMDB, de sua parte, atuou no sentido de barrar a instalação de uma CPI que investigasse o assunto e, poucos dias após a denúncia, possivelmente cedendo a pressões do partido que foram relatadas posteriormente por FHC em seus diários (Cardoso, 2016), o presidente nomeou como ministros os peemedebistas governistas Eliseu Padilha para a pasta de Transportes, e Íris Resende para a pasta da Justiça ${ }^{354}$. A emenda seria aprovada pelo Senado em junho ${ }^{355}$, contando com posição contrária dos senadores peemedebistas oposicionistas Roberto Requião e Pedro Simon (que se absteve), e permitindo a FHC, caso assim desejasse, que concorresse a um segundo mandato à frente do Palácio do Planalto.

Além da ascensão dentro do governo e do Congresso Nacional, a ala governista buscava deter também o controle completo dos órgãos de direção do partido. A estratégia teria sucesso apenas em 2001, mas no ano de 1998, assim como havia ocorrido em 1995, essa ala já ensaiara esse movimento na disputa pelos órgãos de direção do PMDB na Convenção Nacional do partido, realizada em 15 de setembro daquele ano. Na ocasião, os membros da sigla elegeram o seu Diretório Nacional, que por sua vez definiria os integrantes da Comissão Executiva Nacional. A disputa pelo controle da CEN mais uma vez se deu por meio de uma chapa única, definida em negociações prévias. Assim, eleita pela unanimidade dos 108 votantes possíveis ${ }^{356}$, o PMDB definiu os novos integrantes da sua CEN.

Dessa vez, diferentemente do que havia ocorrido em 1995, a composição do órgão como um todo fazia com que o grupo governista passasse a dominar quase com exclusividade a nova executiva peemedebista ${ }^{357}$, tendo como principais articuladores nesse sentido os deputados Michel Temer (SP) e Geddel Vieira Lima (BA) e o Ministro dos Transportes Eliseu Padilha (Ferreira, 2002: 159) ${ }^{358}$. Além disso, pela primeira vez em sua história até então, o PMDB teria como seu novo presidente um integrante da ala

\footnotetext{
${ }^{352}$ Folha de S. Paulo - 13/01/1997.

${ }^{353}$ Folha de S. Paulo - 05/02/1997.

${ }^{354}$ Folha de S. Paulo - 19/12/2002. Para uma cronologia da aprovação da "emenda da reeleição", assim como das denúncias envolvendo o caso, ver https://fernandorodrigues.blogosfera.uol.com.br/2014/06/16/conheca-a-historia-da-compra-de-votosa-favor-da-emenda-da-reeleicao/.

${ }^{355}$ https://www12.senado.leg.br/noticias/materias/1997/06/04/reeleicao-tem-aprovacao-final-62votos-a-favor-e-14-contra.

${ }^{356}$ Ata de reunião da Comissão Executiva Nacional do PMDB - 15/09/1998.

357 Dicionário Histórico Biográfico Brasileiro do Centro de Pesquisa e Documentação de História Contemporânea do Brasil, CPDOC/FGV, verbete "Jader Barbalho".

${ }^{358}$ Sobre a composição do órgão eleita naquela ocasião, ver o Anexo 3.
} 
governista. Tratava-se do senador Jader Barbalho, ex-deputado federal, ex-governador do Pará em duas ocasiões, ex-ministro do governo de José Sarney e na ocasião Senador pelo seu estado. A estratégia de fazer com que o grupo governista detivesse o controle dos rumos do partido também fazia parte de um plano específico de Jader Barbalho, de postular-se para se tornar integrante da chapa presidencial que fosse apresentada pelo PSDB em $2002^{359}$. Sua presidência à frente do partido, porém, não durou até o final do mandato para o qual havia sido eleito. Em 15 de maio de 2001, envolto em escândalos de corrupção que também o levariam a renunciar à presidência do Senado e ao seu próprio mandato $^{360}$, o Senador renunciou ao cargo ${ }^{361}$, levando à posse do seu vice, o exarenista Maguito Vilela, pouco antes do momento no qual os governistas passaram a deter o controle completo dos órgãos de direção da sigla.

\subsection{As eleicões presidenciais de 1998: lançar ou não um candidato próprio?}

"Quando fracassou a candidatura direta do Quércia em 1994, foi uma votação absolutamente inexpressiva. Posso te falar que eu trabalhei pelas candidaturas do PMDB e acho que o partido se consolidou um pouco como ele é hoje: abdicou de ter um projeto nacional e virou um partido de linha auxiliar." Deputado Saraiva Felipe, em entrevista ao autor.

Muito embora tenha ocorrido o crescimento da ala governista nos seus órgãos de direção, o PMDB chegou nas eleições presidenciais de 1998 mais uma vez dividido quanto a qual estratégia adotar. Assim como em 1994, setores do partido e algumas de suas principais lideranças do grupo oposicionista pressionavam para que a sigla tivesse uma candidatura própria ao cargo de presidente da República. Do outro lado, o grupo governista defendia que o partido seguisse em aliança com o governo FHC, apoiando a sua tentativa de reeleição ao Planalto para focar as forças do partido nas eleições legislativas, locus no qual a sigla tivera um bom desempenho.

Os primeiros sinais de divisão no partido quanto às eleições daquele ano surgiram ainda em meados de 1997. Quando o partido se encontrava sob a presidência de Paes de Andrade, a ala oposicionista do PMDB começou a articular um movimento em prol de uma candidatura única à presidência da República que conglomerasse todos os partidos de oposição à FHC (Maciel, 2014: 78). Com esse intuito, o próprio Paes de Andrade organizou durante aquele período uma série de encontros com os principais líderes dos maiores partidos, como Luís Inácio Lula da Silva, do PT, e Leonel Brizola, do $\mathrm{PDT}^{362}$. Ao mesmo tempo, nomes como Itamar Franco, José Sarney, Orestes Quércia

\footnotetext{
${ }^{359}$ Folha de S. Paulo - 20/07/2001.

${ }^{360}$ Folha de S. Paulo - 16/05/2001; 18/09/2001; 4/10/2001.

${ }^{361}$ Ofício n $76 / 01$ - Acervo SEDAP/TSE.

362 Dicionário Histórico Biográfico Brasileiro do Centro de Pesquisa e Documentação de História Contemporânea do Brasil, CPDOC/FGV, verbete "Paes de Andrade".
} 
e Roberto Requião, que pleiteavam que o partido tivesse uma candidatura própria, passaram a ser ventilados como os possíveis presidenciáveis do partido ${ }^{363}$ caso fosse o PMDB o responsável por encabeçar a chapa.

Entretanto, a questão viria à tona de maneira mais clara a partir da Convenção Nacional do PMDB realizada no dia 8 de março de 1998, quando o partido se reuniu pela primeira vez para definir sua posição na eleição presidencial daquele ano. Em uma tumultuada Convenção, que incluiu episódios de confrontação física e terminou com a depredação da sede do Poder Legislativo, por 389 votos a favor, 303 contra e cinco votos em branco, o partido definiu que não teria candidato próprio à presidência da República $^{364}$. Na prática, o resultado significava uma vitória do setor governista, que apoiava a reeleição do presidente Fernando Henrique Cardoso e que contou com o apoio dos seus oito governadores de estado eleitos e dos ministros que integravam o governo $\mathrm{FHC}^{365}$. O resultado impunha, assim, uma derrota aos oposicionistas, liderados pelo presidente nacional do partido, o ex-deputado Paes de Andrade (CE), e que contavam com o apoio do senador Roberto Requião (PR), do ex-presidenciável pelo partido Orestes Quércia (SP) ${ }^{366}$ e do ex-presidente Itamar Franco $(\mathrm{MG})^{367}$, que havia retornado ao PMDB em 1997 e que era então o mais cotado para ser o futuro presidenciável do partido. Por seu lado, com a decretação da vitória na votação a comemoração do segmento governista se deu no gabinete de um dos principais articuladores da ala, o deputado federal e então presidente da Câmara Michel Temer, contando com a presença dos também governistas Henrique Eduardo Alves (RN), Geddel Vieira Lima (BA), e Eliseu Padilha (RS) ${ }^{368}$.

Em entrevista ao autor, o Deputado Marcelo Castro (PI) confirmou que "a précandidatura de Itamar foi barrada por essa turma do Michel, que estava, entre aspas, muito dentro do governo do Fernando Henrique, e foi barrada". Do seu ponto de vista, o lançamento de uma candidatura própria por parte do partido naquelas eleições poderia ter sido um turning point positivo na história do partido. Segundo ele:

"Era uma chance do PMDB, entre aspas, de limpar sua imagem. Aí o PMDB cometeu seu grande equívoco, por conta do seu fisiologismo. Aí o PMDB se descaracterizou de vez e de lá para cá o PMDB tem sempre [sido] ligado à imagem de um partido de fisiologismo, sem programa, ao ponto de se fazer piada: 'não sei quem vai ganhar a presidência da República, sei que o PMDB será governo'. Isso é ruim para o partido. E o que eu acho pior pro

\footnotetext{
${ }^{363}$ Folha de S. Paulo - 22/06/1997; Folha de Londrina - 23/08/1997.

${ }^{364}$ Valor Econômico - 12/03/2007; Estado de São Paulo - 09/03/1998.

${ }^{365}$ Folha de S. Paulo - 09/03/1998; Jornal do Commercio - 09/03/1998.

366 Dicionário Histórico Biográfico Brasileiro do Centro de Pesquisa e Documentação de História Contemporânea do Brasil, CPDOC/FGV, verbete "Orestes Quércia". O Diretório Estadual do PMDB paulista chegou a deliberar de maneira informal, em Convenção do dia 24/05/1998, a sua posição em apoio a uma candidatura presidencial própria do partido (Folha de S. Paulo - 25/05/1998, p. 6).

${ }^{367}$ Folha de S. Paulo - 08/03/1998.

${ }^{368}$ Idem.
} 
partido é que essa imagem de fisiologismo ao longo do tempo vem se juntando com a imagem de oportunista, essa associação agora à corrupção faz mal ao partido."

A estratégia de não ter candidato próprio ao cargo de presidente da República também estava atrelada a outra estratégia eleitoral a ser adotada de maneira consciente por parte do partido. Reconhecendo o bom desempenho historicamente obtido na disputa por assentos dentro do Poder Legislativo, os peemedebistas (e sobretudo os governistas) apostavam que mais uma vez o PMDB elegeria uma grande bancada em 1998, mantendo sua condição de partícipe importante qualquer que fosse a candidatura vitoriosa ao Planalto naquelas eleições. Nas palavras do deputado estadual Tonico Ramos (SP) e do deputado federal Mauro Lopes (MG), evidencia-se assim a estratégia eleitoral peemedebista:

"[O PMDB] compõe o poder, com o poder constituído e trabalha para ser o braço de operação do Executivo dentro do Legislativo." Deputado estadual Tonico Ramos.

"Realmente, sempre no Legislativo [o PMDB] teve maioria. E através do Legislativo veio o poder do partido, porque um presidente eleito (...) precisa do Legislativo e convidar elementos do PMDB para participar do Executivo. Essa participação do PMDB no Executivo vem através da força no Legislativo. (...) Você, através do Legislativo, acaba influenciando com força o Poder Executivo. Pra você ter uma ideia, pra você eleger ministros, por exemplo, maioria de ministros do judiciário, isso passa pelo Legislativo. Os grandes órgãos, grandes empresas do país, se têm que ser sabatinadas, passam pelo Senado, e a maioria [é] comandada pelo $P M D B$. Um partido muito forte. (...) Realmente, não quer dizer que o Executivo é refém do Legislativo, mas toda vida o Poder Executivo esteve focando no PMDB, o maior partido tanto no Senado quanto na Câmara. Ele é convidado a participar do Executivo. Isso acaba ajudando a comandar o país. Já te falei que é o partido do equilibrio. ${ }^{\text {} 369}$ Deputado federal Mauro Lopes.

Com pontos de vista semelhantes, a jornalista Sônia Carneiro e o deputado mineiro Saraiva Felipe, à época o Secretário-Geral do partido, também comentaram sobre a estratégia eleitoral adotada pelo PMDB a partir de então:

“O PMDB optou por eleger sempre a maior bancada, [e] se preservar como o maior partido. Toda a luta do PMDB

${ }^{369}$ Entrevistas concedidas ao autor. 
após ter conquistado a redemocratização foi pelo espaço político como maior bancada no congresso." Sônia Carneiro.

"Quando fracassou a candidatura direta do Quércia em 1994, foi uma votação absolutamente inexpressiva, posso te falar que eu trabalhei pelas candidaturas do PMDB e acho que o partido se consolidou um pouco como ele é hoje: abdicou de ter um projeto nacional e virou um partido de linha auxiliar. Elegia governadores, vereadores, deputados, sobretudo bancada federal grande, abdicou desse projeto de poder nacional e passou a ser uma linha auxiliar de outros governos. O Fernando Henrique teve que negociar com o PMDB, o Itamar negociou com o PMDB. [O partido] passou a ter esse perfil que tem hoje. Está sempre barganhando. (...) [O PMDB] abdicou de cargos majoritários, sobretudo nas esferas federal e estaduais, e passou a ser um partido de composição, mas vou dizer até com certa intencionalidade isso: o partido sempre lutou muito para ter muito deputado federal, muito senador, para dominar a Câmara, dominar o Senado e a partir daí forçar uma composição e levar nacos de poder.” Deputado Saraiva Felipe (MG).

Ainda sobre o resultado adverso para o setor oposicionista na Convenção realizada em março de 1998, a decisão definitiva em relação a qual posição seria tomada pelo partido naquela eleição presidencial se daria numa segunda Convenção, realizada em 28 de junho de 1998, dentro do prazo estipulado para que os partidos definissem suas candidaturas. Porém, a Convenção não teve qualquer deliberação sobre qual posição o partido tomaria nas eleições presidenciais de 1998, fosse para que a sigla lançasse uma candidatura própria, fosse para que apoiasse de maneira formal a reeleição de Fernando Henrique Cardoso. Houve um claro boicote da parte da ala governista: dos 523 convencionais credenciados, apenas 211 compareceram. Isso representou 256 votos dos 705 possíveis (alguns convencionais teriam direito a mais de um voto). O quórum mínimo para deliberação era de 353 votos e, sem atingi-lo, não houve qualquer definição oficial sobre a posição que seria adotada pelo partido naquele pleito presidencial $^{370}$. O próprio segmento governista do partido havia cogitado a realização de uma Convenção Extraordinária paralela, mas isso acabou não sendo, portanto, necessário para barrar a proposta dos oposicionistas.

Nesse sentido, é importante destacar que assim como havia ocorrido em 1989, havia um descompasso entre o Diretório Nacional do PMDB, com relação ao qual os resultados da Convenção realizada em março evidenciaram que a ala governista já se encontrava em condição de maioria, e a sua Comissão Executiva Nacional, na ocasião

${ }^{370}$ Folha de S. Paulo-29/06/1998. 
presidida por um representante do grupo oposicionista. Ademais, as decisões tomadas nas convenções realizadas naquele ano também são evidência de que a coalizão dominante do partido se encontrava cindida de acordo com duas estratégias eleitorais distintas. Por parte dos oposicionistas, não houve força suficiente para que o partido repetisse o que havia feito em 1989 e 1994 e concorresse nas eleições presidenciais com uma candidatura própria. Já por parte dos governistas, apesar de a sua ala estar em crescimento e se encontrar em condição de maioria, os políticos não conseguiram concretizar seu objetivo de definir uma coligação formal com a candidatura à reeleição de FHC. Os resultados finais desse processo foram a perda sofrida pela coligação governista do tempo de campanha televisiva que caberia ao PMDB e que seria somado ao da coligação ${ }^{371}$, e ao mesmo tempo um PMDB mais uma vez fragmentado durante a campanha daquele ano.

Sobre a posição adotada por seu partido naquelas eleições, em entrevista a Pereira (2002: 207) Michel Temer confirmou que o fato de FHC ter sido candidato foi decisivo para que o PMDB deixasse de ter candidato próprio em 1998. Para o político, caso não fosse Fernando Henrique o candidato, o PMDB teria tomado outro caminho naquele momento. Assim, da parte dos governistas, seus políticos declararam apoio à candidatura de FHC e ingressaram na sua campanha pela reeleição, declarando serem os representantes do "PMDB real, que tem votos", nas palavras do Deputado Geddel Vieira Lima (BA), líder do partido na Câmara ${ }^{372}$. Por parte dos oposicionistas, os aliados de Itamar Franco apoiaram a candidatura de Lula, do Partido dos Trabalhadores $^{373}$, assim como o fez o então candidato ao governo de seu estado, o paranaense Roberto Requião ${ }^{374}$. A divisão no partido fica evidente quando alguns dos entrevistados pelo autor comentam sobre aquela eleição presidencial:

"Em 98, com a sucessão do Fernando Henrique ao governo, uma parte do PMDB apoiou o Fernando Henrique. Então, em 98, na reeleição do Fernando Henrique, praticamente a grande maioria do PMDB apoiou não lançar candidato. Lembro que, em Goiás mesmo, nós apoiamos a reeleição do Fernando Henrique. (...) Pelo que eu percebi aqui, muita gente, muitos líderes falavam o seguinte: não tinha candidato do PMDB que despontasse a nível nacional. Falava-se na época no Pedro Simon. Quando pesquisavam o nome dele, dava 'traço' na pesquisa. Então não surgiu uma liderança nacional. Depois que o Ulysses faleceu, [e] o Quércia, aí praticamente nós ficamos sem nome. Tinha nomes importantes, como Pedro Simon, Itamar Franco, governador de Minas Gerais, mas quando [os] colocavam [na] pesquisa nacional, estava o Lula disparado na frente, de um lado, e o PSDB com o outro nome. Então o partido,

\footnotetext{
${ }^{371}$ Folha de S. Paulo - 30/06/1998.

${ }^{372}$ Folha de S. Paulo - 03/07/1998.

${ }^{373}$ Valor Econômico - 12/03/2007.

${ }^{374}$ Folha de S. Paulo-09/06/1998.
} 
para não passar o vexame que passou com a candidatura do Dr. Ulysses e do Quércia, era preferível salvar os mandatos de governadores, senadores e deputados. E tem uma coisa interessante: você não conseguia unir os 27 estados. Metade queria composição com um, metade com outro. Se tivesse candidato a presidente, podia-se unir tudo, mas como não tinha esse nome que despontava na pesquisa...” Deputado Pedro Chaves (GO).

"Sim, em 98 nós tentamos lançar primeiro o Itamar, também tentamos lançar o Requião, mas também não conseguimos. A Convenção não deu quórum, foi uma guerra, e [o partido] ficou sem candidato. Em 98 foi a candidatura de reeleição do $\mathrm{FH}$, o partido ficou liberado, ficou dividido. (...) Aí lança um vice do Serra em 2002; em 2006 apoia o Lula, não lança candidato, também libera. Em alguns lugares apoia o Alckmin, também libera, fica meio liberado. Parecido com 1998." Ex-deputado Marcelo Barbieri (SP).

Antes da realização daquelas eleições haveria ainda uma última vitória do segmento governista em sua estratégia eleitoral, ocorrida a poucas semanas do pleito, durante a já citada segunda Convenção Nacional do PMDB naquele mesmo ano. Nessa Convenção do dia 15 de setembro, mencionada na seção anterior como aquela em que Jader Barbalho tomou posse como o novo presidente do partido, foi lida uma moção assinada por 2/3 dos membros do Diretório Nacional do partido declarando seu apoio à reeleição de $\mathrm{FHC}^{375}$. A moção tinha caráter mais simbólico que formal, afinal o prazo para uma coligação entre os partidos já havia se encerrado há bastante tempo e a data do pleito já se encontrava próxima. No entanto, o documento evidenciava a força que a ala governista cada vez mais adquiria no corpo do partido, ao mesmo tempo que um de seus membros, que havia ajudado a barrar a candidatura direta do partido, agora assumia a presidência da sigla ${ }^{376}$.

Em se tratando das eleições presidenciais de 1998 propriamente ditas, o então presidente Fernando Henrique Cardoso enfrentou outras onze candidaturas na sua tentativa de se reeleger ao cargo. Mais uma vez, assim como em 1994, a principal candidatura capaz de fazer frente a ele era aquela representada por Lula, do Partido dos Trabalhadores. No entanto, também como em 1994, o pleito foi decidido já no primeiro turno. Apesar de ambos partidos terem conseguido expandir o tamanho de suas coligações em relação às eleições anteriores (Limongi e Cortez, 2010), a tabela abaixo mostra que FHC foi reeleito com $53,1 \%$ dos votos ${ }^{377}$. Com a sua vitória, o setor governista do PMDB seguiria como um integrante do governo federal.

\footnotetext{
${ }^{375}$ Ata de reunião da Comissão Executiva Nacional do PMDB - 15/09/1998.

${ }^{376}$ Folha de S. Paulo - 20/07/2001.

${ }^{377}$ Sobre as eleições de 1998 ver Miguel (1999), Carreirão (2002), e Rennó e Spakanos (2006).
} 


\section{Tabela 40. Resultados do primeiro turno da eleição presidencial}

de 1998

\begin{tabular}{lllcc}
\hline Posição final & Candidato & Partido & Votos & $\begin{array}{c}\text { Porcentagem } \\
\text { sobre o total } \\
\text { de votantes }\end{array}$ \\
\hline $\mathbf{1}$ & Fernando & PSDB & 35.922 .692 & 53,1 \\
& $\begin{array}{l}\text { Henrique } \\
\text { Cardoso }\end{array}$ & & & \\
$\mathbf{2}$ & Lula & PT & 21.470 .333 & 31,7 \\
$\mathbf{3}$ & Ciro Gomes & PPS & 7.424 .783 & 11,0 \\
$\mathbf{4}$ & Enéas Carneiro & PRONA & 1.446 .783 & 2,1 \\
$\mathbf{5}$ & Ivan Frota & PMN & 251.276 & 0,4 \\
$\mathbf{6}$ & Alfredo Sirkis & PV & 212.866 & 0,3 \\
$\mathbf{7}$ & José Maria de & PSTU & 202.614 & 0,3 \\
$\mathbf{8}$ & Almeida & & & \\
$\mathbf{9}$ & João de Jesus & PTdoB & 198.830 & 0,3 \\
\hline $\mathbf{1 0}$ & José Maria & PSDC & 171.814 & 0,3 \\
$\mathbf{1 1}$ & Eymael & & & 0,2 \\
$\mathbf{1 2}$ & Theresa Ruiz & PTN & 166.053 & 0,2 \\
\hline $\begin{array}{l}\text { Votos } \\
\text { brancos/nulos }\end{array}$ & Sérgio Bueno & PSC & 124.546 & 0,2 \\
\hline Total & Vasco Neto & PSN & 108.969 & \\
\hline Abstenções & & & 15.574 .370 & \\
\hline Eleitorado & & & 83.275 .929 & \\
\hline Basede & & 22.777 .177 & \\
\hline
\end{tabular}

Fonte: Base de dados online do Prof. Jairo Nicolau (disponível em https://jaironicolau.github.io/deb/).

\subsection{Nova queda nas urnas: panorama geral do PMDB nas eleicões de 1998}

"Por falta de liderança [o PMDB perde força eleitoral]. Porque quem ficou na liderança depois que o Ulysses faleceu foram o Michel [Temer] e o Quércia, brigando constantemente." Deputado estadual Tonico Ramos, em entrevista ao autor.

Diferentemente das eleições de 1994, quando os resultados demonstraram certa estabilidade no desempenho do partido em relação às eleições de 1990, os resultados de 1998, de maneira geral, demonstraram mais uma vez uma queda no desempenho eleitoral do PMDB. O partido ainda manteve sua forte vocação regional, mas piorou seu desempenho na quantidade de governadores de estado eleitos. Da mesma forma, o PMDB também viu seu espaço no Poder Legislativo diminuir, com uma diminuição na proporção de parlamentares estaduais eleitos e no tamanho da sua bancada na Câmara dos Deputados, perdendo sua condição de hegemonia nessa Casa, mas ainda assim melhorando seu resultado em relação às eleições para o Senado Federal. 
Com relação à disputa para os cargos de governadores de estado, momento no qual pela primeira vez na história os governadores em exercício puderam concorrer a reeleição, o PMDB lançou candidaturas próprias em dezenove estados, e coligou-se com outros partidos nos oito restantes. O partido se sagrou vitorioso em seis deles $(22,2 \%)$ e compôs a coligação vitoriosa em outros quatro. Esse número representou redução na quantidade de governadores eleitos em comparação às eleições anteriores, quando a sigla havia elegido nove governadores. Assim, apesar de o partido mais uma vez manter sua forte vocação regional, tornando-se o segundo maior partido em quantidade de governadores eleitos, empatado nesse posto com o PFL, o PMDB pela primeira vez desde 1986 perdia a condição de sigla com a maior quantidade de governadores eleitos. $\mathrm{O}$ posto naquela eleição coube ao PSDB.

No que concerne aos novos governadores do PMDB, quatro dos eleitos o fizeram em estados da região Nordeste. Dentre eles, três haviam sido reeleitos para o posto: o ex-emedebista Garibaldi Alves Filho ( $\mathrm{RN})$, o ex-arenista reeleito Francisco de Assis (PI) e o ex-emedebista José Maranhão (PB), que havia sido empossado após o falecimento do governador Antônio Mariz durante o exercício do seu mandato. O outro governador eleito no Nordeste, Jarbas Vasconcelos (PE), fora um integrante do grupo autêntico do MDB durante o Regime Militar. Por sua vez, os dois demais governadores eleitos pelo PMDB naquelas eleições também possuíam uma longa trajetória na política. Tratavam-se do ex-emedebista e ex-presidente da República Itamar Franco (MG) e do ex-emedebista e ex-Ministro de Fernando Collor de Mello, em breve passagem pelo Ministério da Agricultura enquanto esteve filiado ao PTR, Joaquim Roriz (DF).

Tabela 41. Governadores eleitos em 1998

\begin{tabular}{|c|c|c|}
\hline Região/Estado & Eleito & Partido \\
\hline \multicolumn{3}{|l|}{ Norte } \\
\hline Acre & Jorge Viana & PT \\
\hline Amapá & João Capiberibe & PSB \\
\hline Amazonas & $\begin{array}{c}\text { Amazonino } \\
\text { Mendes }\end{array}$ & PFL \\
\hline Pará & Almir Gabriel & PSDB \\
\hline Rondônia & José Bianco & PFL \\
\hline Roraima & Neudo Campos & PPB \\
\hline Tocantins & Siqueira Campos & PFL \\
\hline \multicolumn{3}{|l|}{ Nordeste } \\
\hline Alagoas & Ronaldo Lessa & PSB \\
\hline Bahia & César Borges & PFL \\
\hline Ceará & Tasso Jereissati & PSDB \\
\hline Maranhão & Roseana Sarney & PFL \\
\hline Paraíba & José Maranhão & PMDB \\
\hline Pernambuco & $\begin{array}{c}\text { Jarbas } \\
\text { Vasconcelos }\end{array}$ & PMDB \\
\hline Piauí & $\begin{array}{l}\text { Francisco de Assis } \\
\text { de Moraes Sousa* }\end{array}$ & PMDB \\
\hline
\end{tabular}




\begin{tabular}{|c|c|c|}
\hline $\begin{array}{l}\text { Rio Grande do } \\
\text { Norte }\end{array}$ & $\begin{array}{c}\text { Garibaldi Alves } \\
\text { Filho }\end{array}$ & PMDB \\
\hline Sergipe & Albano Franco & PSDB \\
\hline \multicolumn{3}{|l|}{ Centro-Oeste } \\
\hline Distrito Federal & Joaquim Roriz & PMDB \\
\hline Goiás & Marconi Perillo & PSDB \\
\hline Mato Grosso & Dante de Oliveira & PSDB \\
\hline $\begin{array}{l}\text { Mato Grosso do } \\
\text { Sul }\end{array}$ & Zeca & PT \\
\hline \multicolumn{3}{|l|}{ Sudeste } \\
\hline Minas Gerais & Itamar Franco & PMDB \\
\hline Espírito Santo & $\begin{array}{l}\text { José Ignácio } \\
\text { Ferreira }\end{array}$ & PSDB \\
\hline Rio de Janeiro & $\begin{array}{l}\text { Anthony } \\
\text { Garotinho }\end{array}$ & PDT \\
\hline São Paulo & Mário Covas & PSDB \\
\hline \multicolumn{3}{|l|}{ Sul } \\
\hline Paraná & Jaime Lerner & PFL \\
\hline Rio Grande do Sul & Olívio Dutra & PT \\
\hline Santa Catarina & Espiridião Amim & PPB \\
\hline
\end{tabular}

Fontes: Dados eleitorais do Brasil, base de dados online de Jairo Nicolau (disponível em https://jaironicolau.github.io/deb/), com cruzamento de informações do Dicionário Histórico Biográfico Brasileiro do Centro de Pesquisa e Documentação de História Contemporânea do Brasil, CPDOC/FGV

*Ex-arenista

Passando agora à análise do desempenho do partido nas outras esferas, no que se refere às eleições para as Assembleias Legislativas, verificamos uma pequena queda no desempenho do PMDB em comparação com seu resultado obtido nas eleições de 1994. Enquanto naquelas eleições o partido conquistara 205 assentos $(19,6 \%)$, dessa vez o partido elegeu 176 parlamentares $(16,7 \%)$. Como podemos ver na tabela abaixo, o resultado manteve o partido mais uma vez com a maior quantidade de deputados estaduais do país como um todo. Juntamente com o PMDB, desta vez outros três partidos conseguiram eleger mais de $10 \%$ dos parlamentares. Foram eles o PFL, o PSDB e o PPB (mais uma nova denominação adotada pela antiga ARENA).

Tabela 42. Cadeiras obtidas, percentual do total de cadeiras e votação total por partido nas eleições para as Assembleias Legislativas em 1998

\begin{tabular}{lcc}
\hline Partido & Cadeiras obtidas & $\%$ \\
\hline PMDB & 176 & $16,7 \%$ \\
PFL & 173 & $16,5 \%$ \\
PSDB & 153 & $14,6 \%$ \\
PPB & 107 & $10,2 \%$ \\
PT & 90 & $8,6 \%$ \\
PTB & 74 & $7,0 \%$ \\
PDT & 73 & $6,9 \%$ \\
\hline
\end{tabular}




\begin{tabular}{lcc}
\hline PSB & 46 & $4,4 \%$ \\
\hline PL & 44 & $4,2 \%$ \\
\hline PSD & 21 & $2,0 \%$ \\
PPS & 21 & $2,0 \%$ \\
\hline PSC & 17 & $1,6 \%$ \\
\hline PMN & 11 & $1,0 \%$ \\
\hline PC do B & 10 & $0,9 \%$ \\
PSL & 10 & $0,9 \%$ \\
\hline PRONA & 4 & $0,4 \%$ \\
\hline PT do B & 4 & $0,4 \%$ \\
\hline PV & 4 & $0,4 \%$ \\
\hline PST & 4 & $0,4 \%$ \\
\hline PRP & 3 & $0,3 \%$ \\
\hline PSDC & 3 & $0,3 \%$ \\
\hline PRTB & 2 & $0,2 \%$ \\
\hline PSN & 1 & $0,1 \%$ \\
\hline TOTAL & 1051 & $100 \%$ \\
\hline FOT TSE & & \\
\hline
\end{tabular}

Fonte: TSE

Ao analisarmos o desempenho do PMDB nessa esfera desde a primeira eleição em que disputou, em 1982, verificamos constante queda na proporção de cadeiras ocupadas a partir das eleições de 1986. Apesar de se manter na condição de partido com a maior quantidade de parlamentares eleitos desde as eleições de 1986, o partido atravessou uma forte queda nas eleições seguintes, em 1990, talvez por conta da fundação do PSDB no ano de 1988. Analisando o recorte histórico deste estudo como um todo, o partido seguiu em queda nas eleições de 1994 e 1998, num patamar bem mais abaixo do verificado nas eleições dos anos 1980, mas ainda assim mantendo sua condição hegemônica.

\section{Gráfico 4. Evolução na porcentagem de cadeiras ocupadas pelo PMDB nas Assembleias Legislativas estaduais (1982-1998)}

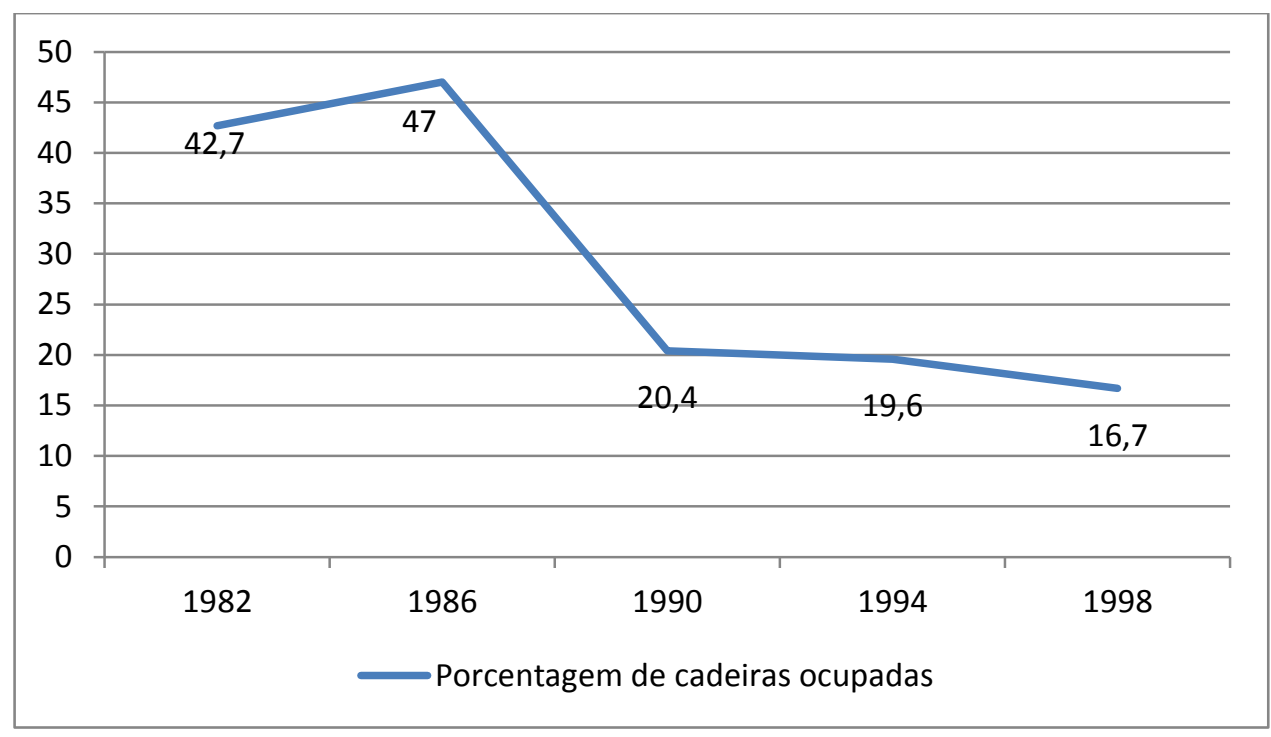


Fonte: elaboração própria.

No que concerne às eleições de 1998 para o Congresso Nacional, verificamos uma ambiguidade nos resultados obtidos pelo PMDB. Se por um lado o partido apresentou mais uma vez queda na proporção de cadeiras ocupadas na Câmara dos Deputados, perdendo sua condição de partido detentor da maior bancada dessa Casa pela primeira vez desde 1986, o partido manteve esse posto no Senado Federal, uma vez que houve crescimento no tamanho da sua bancada.

Para o Senado Federal, foram renovados naquela ocasião 1/3 dos assentos. Destes, o PMDB elegeu 12. Assim, no momento da posse da legislatura seguinte, o partido possuía em sua bancada um total de 27 senadores (33,3\%). Esse número representa crescimento em relação ao tamanho da bancada que tomou posse após as eleições de 1994, quando a sigla ocupou 22 assentos (27,2\%). O resultado de 1998 fez com que o PMDB mais uma vez detivesse a maior bancada da Casa, mantendo a sua condição de hegemonia na Câmara Alta do Poder Legislativo e ficando à frente de PSDB e PFL, os dois principais partidos governistas.

Por sua vez, em relação à Câmara dos Deputados, o PMDB elegeu 83 deputados federais $(16,2 \%)$. O número representa uma redução em relação à quantidade de eleitos pelo partido nas eleições de 1994, quando a sigla elegeu 107 parlamentares (20,9\%). Mais do que isso, como se pode ver na tabela abaixo, pela primeira vez desde as eleições de 1986 o PMDB encontrou-se na condição de não ser o detentor da maior bancada dessa Casa. O partido foi ultrapassado pelo PFL e pelo PSDB, que passariam a deter respectivamente $105(20,5 \%)$ e $99(19,3 \%)$ assentos.

Tabela 43. Tamanho das bancadas partidárias na Câmara dos Deputados e no Senado Federal após as eleições de 1998

\begin{tabular}{lcc|c|c|}
\hline & \multicolumn{2}{l}{ Senado Federal } & \multicolumn{2}{c}{$\begin{array}{c}\text { Câmara dos } \\
\text { Deputados }\end{array}$} \\
\hline Partido & $\mathrm{N}$ & $\%$ & $\mathrm{~N}$ & $\%$ \\
\hline PFL & 19 & $23,5 \%$ & 105 & $20,5 \%$ \\
\hline PSDB & 16 & $19,7 \%$ & 99 & $19,3 \%$ \\
\hline PMDB & 27 & $33,3 \%$ & 83 & $16,2 \%$ \\
\hline PPB & 4 & $4,9 \%$ & 60 & $11,7 \%$ \\
\hline PT & 7 & $8,6 \%$ & 58 & $11,3 \%$ \\
\hline PTB & 1 & $1,2 \%$ & 31 & $6 \%$ \\
\hline PDT & 3 & $3,7 \%$ & 25 & $4,9 \%$ \\
\hline PSB & 3 & $3,7 \%$ & 19 & $3,7 \%$ \\
\hline PL & - & - & 12 & $2,3 \%$ \\
\hline PC do B & - & - & 7 & $1,4 \%$ \\
\hline PPS & 1 & $1,2 \%$ & 3 & $0,6 \%$ \\
\hline PSD & - & - & 3 & $0,6 \%$ \\
\hline PSC & - & - & 2 & $0,4 \%$ \\
\hline PMN & - & - & 2 & $0,4 \%$ \\
\hline
\end{tabular}




\begin{tabular}{|c|c|c|c|c|}
\hline PST & - & - & 1 & $0,2 \%$ \\
\hline PV & - & - & 1 & $0,2 \%$ \\
\hline PSL & - & - & 1 & $0,2 \%$ \\
\hline PRONA & - & - & 1 & $0,2 \%$ \\
\hline Total & 81 & $100 \%$ & 513 & $100 \%$ \\
\hline
\end{tabular}

Fontes: Base de dados online do Prof. Jairo Nicolau (disponível online em https://jaironicolau.github.io/deb/) para os dados da Câmara dos Deputados, e elaboração própria a partir do Diário do Senado Federal no 21, de 02/02/1999 (disponível online em https://legis.senado.leg.br/diarios/PublicacoesOficiais\#), para os dados do Senado.

Analisando o perfil dos parlamentares eleitos pelo PMDB de maneira mais atenta podemos mais uma vez verificar as transformações ocorridas. Continuamos a constatar gradual aumento na proporção de eleitos que iniciaram sua militância partidária após o restabelecimento do pluripartidarismo em 1979. Entretanto, apesar do maior distanciamento histórico em relação ao Regime Militar, ainda verificamos a presença entre os parlamentares peemedebistas de políticos que haviam feito parte tanto da ARENA quanto do MDB durante aquele período.

Com relação aos eleitos para a Câmara dos Deputados, dos 83 deputados federais eleitos pela sigla em 1998, 14 (16,9\%) estiveram filiados ou à ARENA ou ao PDS (e em alguns casos a ambos) enquanto esses partidos deram sustentação parlamentar à ditadura. Como podemos ver na tabela abaixo, esse número mais uma vez representa diminuição em relação aos eleitos com esse perfil em comparação às eleições de 1994. Porém, tratou-se de uma queda menos acentuada se comparada à dos parlamentares peemedebistas que fizeram parte do MDB durante o Regime. Estes representavam, em 1998, 21,7\% dos eleitos pelo partido.

\section{Tabela 44. Filiação prévia da bancada do PMDB na Câmara dos Deputados (1980-1998)}

\begin{tabular}{l|cc|cc|cc|cc|cc|cc}
\hline \multicolumn{3}{|c}{1980} & \multicolumn{2}{c}{1982} & \multicolumn{2}{c}{1986} & \multicolumn{2}{c}{1990} & \multicolumn{2}{c}{1994} & \multicolumn{2}{c}{1998} \\
\hline $\begin{array}{l}\text { ARENA/ } \\
\text { PDS }\end{array}$ & $\mathrm{N}$ & $\%$ & $\mathrm{~N}$ & $\%$ & $\mathrm{~N}$ & $\%$ & $\mathrm{~N}$ & $\%$ & $\mathrm{~N}$ & $\%$ & $\mathrm{~N}$ & $\%$ \\
\hline MDB & 109 & $94,8 \%$ & 32 & $16 \%$ & 58 & $22,3 \%$ & 22 & $20,4 \%$ & 21 & $\begin{array}{c}19,6 \\
\%\end{array}$ & $\begin{array}{c}16,9 \\
\%\end{array}$ \\
$\begin{array}{l}\text { Sem } \\
\text { filiação } \\
\text { prévia }\end{array}$ & - & - & 20 & $10 \%$ & 76 & $29,2 \%$ & 36 & $33,3 \%$ & 48 & $\begin{array}{c}44,9 \\
\%\end{array}$ & 51 & $\begin{array}{c}61,4 \\
\%\end{array}$ \\
Total & 115 & $100 \%$ & 200 & $100 \%$ & 260 & $100 \%$ & 108 & $100 \%$ & 107 & $100 \%$ & 83 & $\begin{array}{c}21,7 \\
\%\end{array}$ \\
\hline
\end{tabular}

Fontes: Schmitt (2000: 51) para os dados de 1980, Mucinhato (2015) para os dados de 1982 e elaboração própria para os dados de 1986, 1990, 1994 e 1998 a partir do cruzamento de informações coletadas no Centro de Documentação e Informação da Câmara dos Deputados (CEDI) e Centro de Pesquisa e Documentação de História Contemporânea do Brasil (CPDOC-FGV). 


\section{Gráfico 5. Filiação prévia em porcentagem dos parlamentares do PMDB na Câmara dos Deputados (1980-1998)}

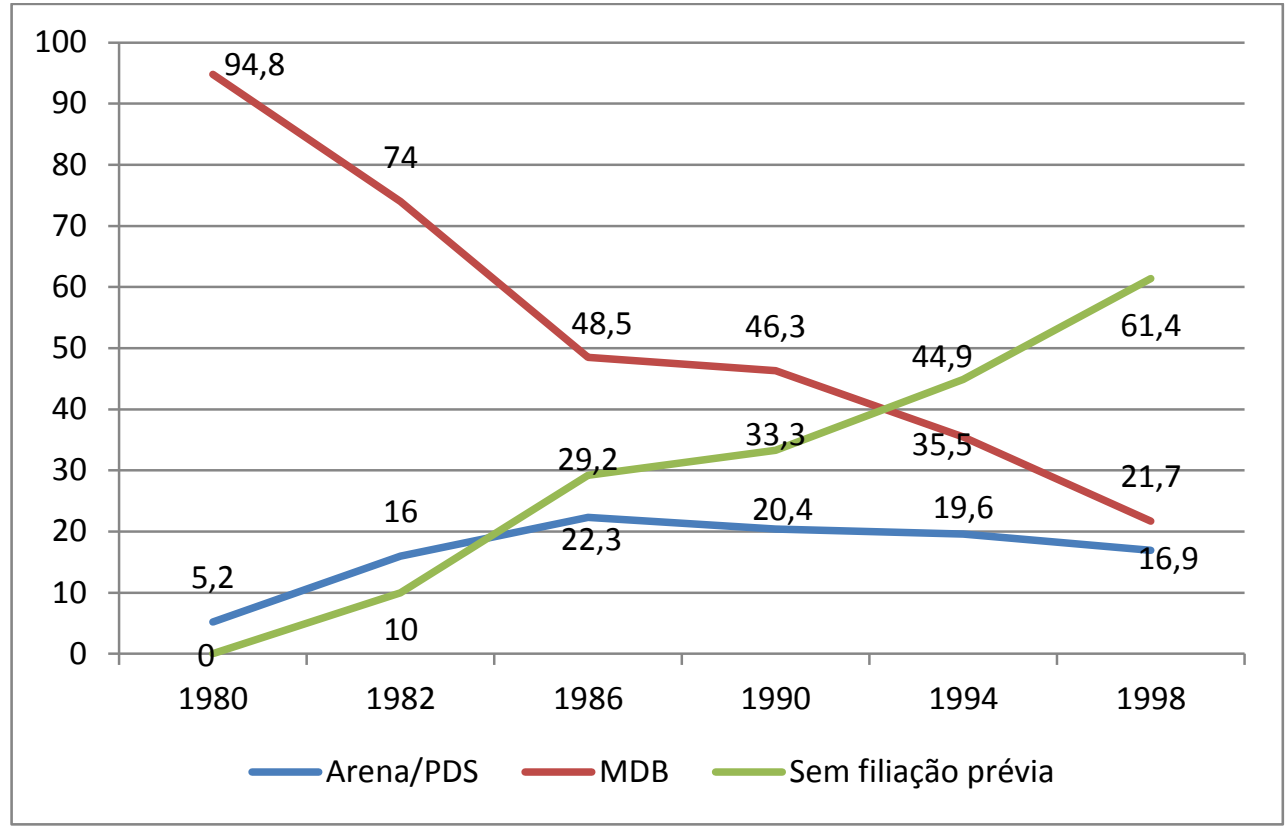

Fontes: Schmitt (2000: 51) para os dados de 1980, Mucinhato (2015) para os dados de 1982 e elaboração própria para os dados de 1986, 1990, 1994 e 1998 a partir do cruzamento de informações coletadas no Centro de Documentação e Informação da Câmara dos Deputados (CEDI) e Centro de Pesquisa e Documentação de História Contemporânea do Brasil (CPDOC-FGV).

Por sua vez, no Senado verificamos uma inversão na tendência observada até 1994 em relação aos senadores eleitos pelo partido que estiveram filiados à ARENA ou ao PDS. Enquanto de 1982 a 1994 a quantidade de parlamentares eleitos com esse perfil vinha caindo, nas eleições de 1998 esse número voltou a crescer. Dos 12 senadores eleitos naquele ano, três haviam passado pela ARENA, sete iniciado sua trajetória partidária pós-1979 (dois dos quais com passagem pelo PP e um pelo PRN) e apenas um esteve filiado ao MDB durante o Regime Militar (o autêntico histórico Pedro Simon).

Em relação à bancada como um todo, os dados abaixo evidenciam o aumento na proporção de senadores que tiveram passagem pelos partidos de sustentação do Regime Militar. Enquanto os senadores que haviam feito parte do MDB seguiram em queda, com um grupo representado a partir de então por 11 senadores(40,7\%), os ex-arenistas ou ex-pedessistas agora seriam 5 (18,5\%).

Tabela 45. Filiação prévia da bancada do PMDB no Senado (1980-1998)

\begin{tabular}{|c|c|c|c|c|c|c|c|c|c|c|c|c|}
\hline & \multicolumn{2}{|c|}{1980} & \multicolumn{2}{|c|}{1982} & \multicolumn{2}{|c|}{1986} & \multicolumn{2}{|c|}{1990} & \multicolumn{2}{|c|}{1994} & \multicolumn{2}{|c|}{1998} \\
\hline & $\mathbf{N}$ & $\%$ & $\mathbf{N}$ & $\%$ & $\mathbf{N}$ & $\%$ & $\mathbf{N}$ & $\%$ & $\mathbf{N}$ & $\%$ & $\mathbf{N}$ & $\%$ \\
\hline
\end{tabular}




\begin{tabular}{l|cc|cc|cc|cc|cc|cc}
$\begin{array}{l}\text { ARENA/ } \\
\text { PDS }\end{array}$ & 2 & $9 \%$ & 7 & $33,3 \%$ & 13 & $28,9 \%$ & 7 & $\begin{array}{c}25, \\
9 \%\end{array}$ & 2 & $\begin{array}{c}9,1 \\
\%\end{array}$ & 5 & $\begin{array}{c}18,5 \\
\%\end{array}$ \\
\hline MDB & 20 & $91 \%$ & 14 & $66,7 \%$ & 23 & $51,1 \%$ & 13 & $\begin{array}{c}48, \\
2 \%\end{array}$ & 12 & $\begin{array}{c}54, \\
5 \%\end{array}$ & 11 & $\begin{array}{c}40,7 \\
\%\end{array}$ \\
$\begin{array}{l}\text { Sem } \\
\text { filiação } \\
\text { prévia }\end{array}$ & - & - & - & - & 9 & $20 \%$ & 7 & $\begin{array}{c}25, \\
9 \%\end{array}$ & 8 & $\begin{array}{c}36, \\
4 \%\end{array}$ & 11 & $\begin{array}{c}40,7 \\
\%\end{array}$ \\
\hline Total & 22 & $100 \%$ & 21 & $100 \%$ & 45 & $100 \%$ & 27 & $\begin{array}{c}100 \\
\%\end{array}$ & 22 & $\begin{array}{c}100 \\
\%\end{array}$ & 27 & $\begin{array}{c}100 \\
\%\end{array}$ \\
\hline
\end{tabular}

Fontes: Mucinhato (2015) para os dados de 1980 e 1982, Mainwaring (2001:137), e elaboração própria para os dados de 1986 a 1998 a partir do cruzamento dos resultados eleitorais com informações coletadas no Centro de Pesquisa e Documentação de História Contemporânea do Brasil (CPDOC-FGV).

\section{Gráfico 6. Filiação prévia em porcentagem dos parlamentares do PMDB no Senado Federal (1980-1998)}

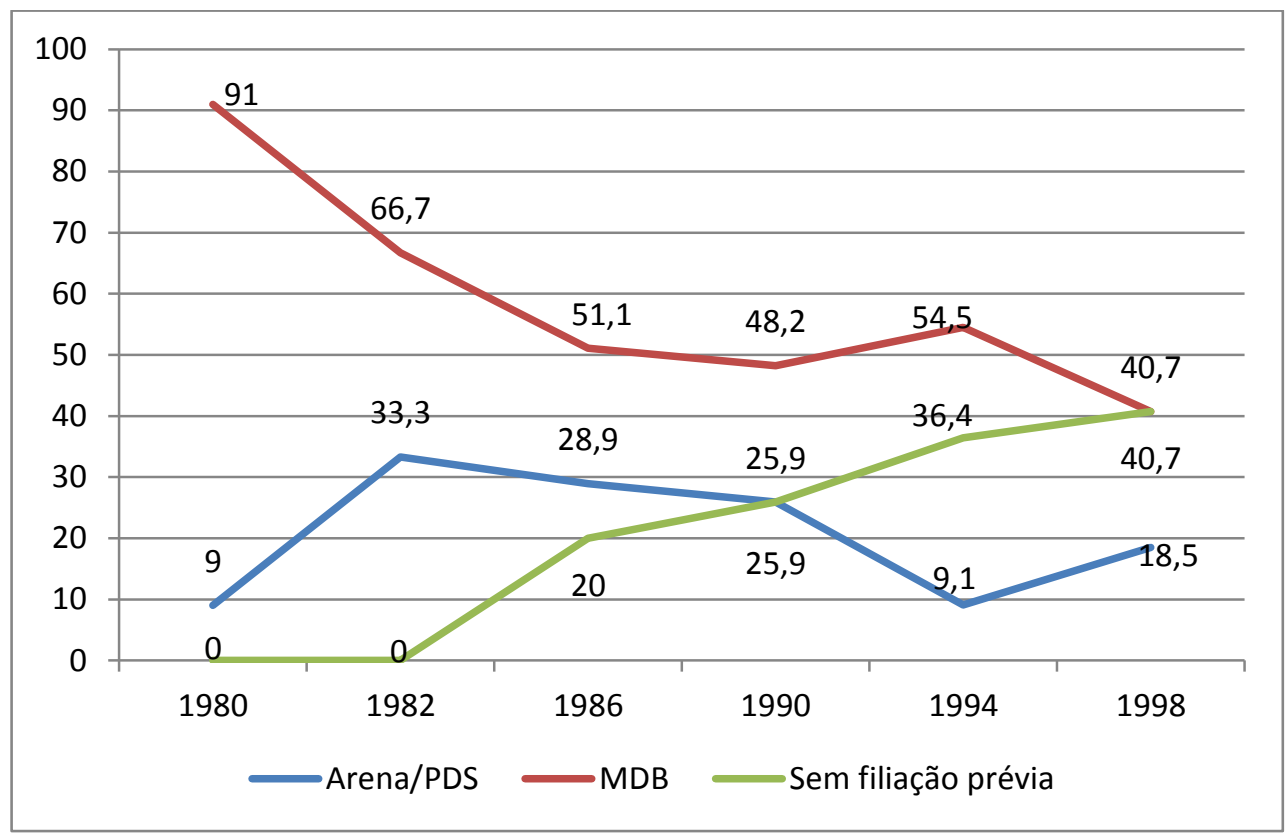

Fontes: Mucinhato (2015) para os dados de 1980 e 1982, Mainwaring (2001:137), e elaboração própria para os dados de 1986 a 1998 a partir do cruzamento dos resultados eleitorais com informações coletadas no Centro de Pesquisa e Documentação de História Contemporânea do Brasil (CPDOC-FGV).

Ao analisarmos o recorte histórico tratado nesta tese como um todo, incluindo as eleições de 1998, que serão as últimas a serem consideradas nesta pesquisa, notamos as sucessivas mudanças na correlação de forças no interior das bancadas do PMDB no Congresso Nacional. Como descrevemos até aqui, na Câmara dos Deputados houve constante queda desde 1980 na proporção de parlamentares eleitos pelo PMDB que tiveram passagem pelo MDB. Por outro lado, da refundação do partido até 1986 houve um crescimento na proporção de parlamentares que tiveram filiação à ARENA ou ao PDS, um processo de "infiltração", como denominaram alguns autores (Madeira, 2006), que levou à manutenção do que chamamos de um "núcleo duro" de parlamentares com esse perfil dentro da bancada ao longo dos anos seguintes. No Senado Federal, porém, 
esse processo não se deu de maneira tão nítida. Houve de fato queda na proporção de senadores com passagem pelo MDB, mas as eleições de 1994 representaram uma breve inversão nessa tendência. Por sua vez, a porcentagem de senadores com passagem pela ARENA ou pelo PDS caiu de 1982 a 1994, mas voltou a crescer nas eleições de 1998.

Indo além da análise da composição interna das bancadas do PMDB no Congresso e analisando a sua bancada no Poder Legislativo, naquilo que Katz e Mair (1993) denominaram como parte da face pública de um partido, nota-se quanto peso essa dimensão tem para a formação das coalizões dominantes do PMDB. Mantendo-se desde a sua refundação em 1979 enquanto uma das maiores (e na maioria das vezes a maior) bancadas do Congresso, foi a partir daquela esfera que foram formadas boa parte das principais lideranças do partido em nível nacional, e que posteriormente passaram a disputar espaços nos seus órgãos de direção nacional (o party in central office). Ribeiro (2014) já havia demonstrado essa sobreposição entre as duas esferas no que concerne aos partidos políticos brasileiros, mas, para além disso, podemos notar também como o Poder Legislativo serviu para que políticos com passagem pelos partidos de sustentação do Regime Militar se mantivessem ocupando espaços na política nacional por meio do PMDB, muitas vezes adquirindo projeção por meio de sua nova legenda. Cabe mencionar aqui os exemplos de José Sarney, ex-presidente da ARENA e com passagem pelo PDS, que por meio do PMDB tornou-se presidente da República, senador e presidente do Senado, e o ex-deputado federal Genebaldo Correa (BA), político que teve origem na ARENA e passagem pelo PP antes de ingressar no PMDB após a incorporação de 1982, e que se tornou vice-líder (1985-1990) e líder (1991-1993) da bancada do seu partido, assim como membro da Executiva Nacional do PMDB.

\subsection{Os governistas conquistam a hegemonia no interior do partido (2001)}

"Eu lembro que nessa eleição do Michel Temer, em 2001, (...) ele disputou contra o Maguito Vilela, de Goiás. Foram duas chapas: o Maguito apoiado pelo governador de Minas na época, Itamar Franco, e o Michel Temer, com apoio do Fernando Henrique. A do Fernando Henrique ganhou, o Michel ganhou. Acho que a última disputa que nós tivemos foi essa, em 2001. De lá para cá, praticamente existe consenso." Deputado Pedro Chaves, em entrevista ao autor.

O controle completo dos órgãos de direção do PMDB por parte do grupo governista se estabeleceria no ano de 2001. Naquele ano, com a chegada de Michel Temer ao cargo de presidente do partido, a coalizão dominante do PMDB e as estratégias eleitorais adotadas pela sigla a partir de então passam a ser um reflexo da hegemonia adquirida por esse segmento no interior do partido. Porém, já antes disso, durante o segundo mandato de FHC, o grupo continuava a ganhar maior projeção tanto no Congresso quanto no próprio governo. 
Com a reeleição de Fernando Henrique em 1998, a cúpula peemedebista, agora composta em grande medida pelo grupo governista, passa a negociar maior participação do partido no governo. Enquanto isso, o grupo interno dissidente começou a perder cada vez mais espaço nas instâncias de decisão do partido e nas negociações dentro das bancadas do Congresso quanto à posição da organização frente aos projetos do governo (Maciel, 2014: 79-80).

No Congresso Nacional, as lideranças da coalizão governista estabeleceram mais uma vez um acordo para a distribuição dos cargos de presidência nas duas Casas, por meio do qual seriam reeleitos os presidentes em exercício tanto na Câmara dos Deputados quanto no Senado Federal ${ }^{378}$. Assim, Michel Temer (PMDB-SP) foi eleito mais uma vez presidente da Câmara em 1999, dessa vez como candidato único ${ }^{379}$, mantendo a hegemonia dos governistas na condução dos trabalhos daquela Casa, com o mesmo ocorrendo com Antonio Carlos Magalhães (PFL-BA) no Senado. O acordo visava mais uma vez manter o equilíbrio de poder entre os três principais partidos que compunham a coalizão de governo de FHC: PFL, PMDB e PSDB. Enquanto isso, as bancadas do PMDB também seriam mais uma vez lideradas por representantes da sua ala governista, com Geddel Vieira Lima (BA) na Câmara e Jader Barbalho (PA) no Senado, que viria a se tornar presidente da Casa em 2001, iniciando uma hegemonia do partido naquele posto que perdurou por quase duas décadas ${ }^{380}$.

Por sua vez, no Poder Executivo, enquanto PFL e PSDB tiveram aumentada a quantidade de ministros nomeados em comparação ao espaço que esses partidos ocuparam no primeiro mandato de FHC (Oliveira, 2012: 115), o PMDB teve leve diminuição. $O$ partido passou de sete para seis ministérios ocupados, mas teve representantes de seu segmento governista ocupando esses postos. Entre eles, Eliseu Padilha (RS) no Ministério dos Transportes, Renan Calheiros (AL) no Ministério da Justiça e Ramez Tebet (MS) com breve passagem pelo Ministério da Integração Nacional. Entretanto, seria nas instâncias internas do próprio partido que o segmento governista do PMDB lograria ocupar mais espaços durante o segundo mandato presidencial de FHC.

O fim da querela pelo controle dos órgãos de direção do PMDB entre as alas governista e oposicionista que levou à hegemonia dos governistas deu-se na Convenção Nacional de 2001, ocorrida entre os dias 9 e 11 de setembro. Naquela ocasião não houve consenso para a formação de uma chapa única e, pela terceira vez em sua história, duas chapas concorreram pelo controle dos órgãos de decisão da sigla, colocando em lados opostos na disputa duas estratégias eleitorais distintas. De um lado, os oposicionistas, na chapa "Unidade pela Candidatura Própria", que defendiam uma candidatura própria do PMDB nas eleições presidenciais de 2002 e a definição de um nome para ocupar esse posto o quanto antes. Do outro, os governistas, na chapa "Unidade PMDB", que

\footnotetext{
${ }^{378}$ Folha de S. Paulo - 02/02/1999.

${ }^{379}$ Folha de S. Paulo - 03/02/1999.

380 Jornal O Globo - https://oglobo.globo.com/brasil/onze-senadores-do-pmdb-que-ja-comandaramcongresso-20850751.
} 
pretendiam que a legenda permanecesse fiel ao presidente Fernando Henrique Cardoso e apoiavam a ideia de uma candidatura única da base aliada do governo, formada principalmente por PFL, PSDB e $\mathrm{PMDB}^{381}$, mas que possivelmente contasse com a presença de outros partidos.

A chapa dos oposicionistas era então encabeçada pelo Senador Maguito Vilela (GO), que na ocasião já exercia o posto de presidente do partido de maneira interina, após o afastamento de Jader Barbalho (PA) do cargo. Sua chapa contava com o apoio de outros políticos oposicionistas, que pregavam desde o início do governo FHC uma atuação independente. Entre eles, o governador mineiro e ex-presidente da República Itamar Franco ${ }^{382}$, o ex-governador de São Paulo e ex-presidente do partido Orestes Quércia, assim como os quercistas seus seguidores ${ }^{383}$, e o ex-governador do Paraná Roberto Requião.

Por sua vez, a chapa dos governistas era encabeçada pelo próprio deputado paulista Michel Temer, presidente da Câmara dos Deputados em duas ocasiões durante o governo FHC e visto por aliados e adversários como "o Fernando Henrique do $\mathrm{PMDB}^{\text {,384 }}$. A chapa havia sido articulada pelo próprio presidente $\mathrm{FHC}^{385}$ e contava com o apoio do senador José Alencar (MG), de cinco dos seis governadores eleitos pelo PMDB em 1998 (a exceção era Itamar Franco), do líder do PMDB no Senado, o senador Renan Calheiros (AL), e dos deputados Henrique Eduardo Alves (RN) e Geddel Vieira Lima (BA), líder da bancada do PMDB na Câmara dos Deputados, entre outros $^{386}$.

Em uma convenção tensa, que contou mais uma vez com ataques verbais e até confronto físico entre os dois grupos do partido ${ }^{387}$, a chapa de Temer alcançou expressiva vitória. Obteve 411 votos $(59,91 \%$ do total) contra $244(35,57 \%)$ do senador Maguito Vilela. Excluídos os votos em branco, nulos e as abstenções e contabilizando apenas os votos nas chapas para efeito de cálculo da proporção que cada grupo teria direito no Diretório Nacional do partido, a vantagem de Temer e seu grupo passava a ser de $63 \%$, contra $37 \%$ da chapa de Maguito Vilela ${ }^{388}$. Ademais, além de conquistar a maioria do DN do partido, os governistas adotaram uma manobra regimental que lhes garantiu o comando total da CEN do partido.

Com a declaração do resultado, a chapa de Temer adotou a mesma medida que havia sido levada a cabo por Ulysses Guimarães para obter o controle absoluto da cúpula da sigla em 1989 e que garantiu a ele a sua candidatura à presidência da República naquele ano. A chapa vencedora definiu que a Executiva Nacional do PMDB

\footnotetext{
${ }^{381}$ Folha de S. Paulo - 18/07/2001; Estado de S. Paulo - 15/08/2001.

${ }^{382}$ Estado de São Paulo - 28/09/2001.

${ }^{383}$ Marcelo Barbieri, em entrevista ao autor.

${ }^{384}$ Folha de S. Paulo - 09/09/2001.

385 Deputado Pedro Chaves, em entrevista ao autor, e Folha de S. Paulo - 24/06/2001.

${ }^{386}$ Folha de S. Paulo - 24/06/2001.

${ }^{387}$ Folha de S. Paulo - 10/09/2001.

${ }^{388}$ Idem.
} 
seria composta integralmente pelos membros da chapa que venceu a Convenção, não partilhando o poder com a chapa derrotada ${ }^{389}$. Assim, além de retomar a tradição peemedebista de ter políticos paulistas no mais alto posto no interior do partido, Temer fazia também com que a coalizão dominante fosse exclusivamente formada pela ala governista do partido ${ }^{390}$, que na ocasião também já controlava postos-chave dentro do Congresso Nacional.

A chegada ao poder e a hegemonia obtidas pelos governistas representaram uma mudança de paradigma no interior dos órgãos de direção, que levou até à alteração na identidade visual do partido $^{391}$, algo que não ocorria desde a presidência de Quércia. Como apontou em entrevista o deputado Mauro Lopes (MG), integrante desse segmento e Secretário-Geral do partido a partir de 2007, a partir de então o PMDB "pacificou-se" internamente, não sendo mais palco de mais disputas pelo controle da sua CEN. Em suas palavras:

"O Michel [Temer] foi o grande companheiro desde o primeiro dia aqui na Câmara. Ocorreu que (...) em 2001 o Michel se candidatou a presidente do partido e nessa época me convidou para ser o companheiro de chapa como Secretário-Geral do partido. Aconteceu e tá ali naquela foto minha e dele [o deputado aponta para um quadro na parede de seu gabinete]. Foi quando, então, nós ganhamos as eleições, e estamos até hoje, desde 2001 até agora, eu de Secretário-Geral e o Michel de presidente do partido."

Em outro aspecto, de acordo com a visão de outros parlamentares, apesar da "pacificação" interna, a composição da CEN não estaria ligada ao peso que cada Diretório Regional possuía no interior do partido. A composição estaria mais ligada a critérios de fidelidade por parte desses políticos do que a critérios federalizados de composição que contemplassem as diferentes forças regionais do partido em cada estado. A visão expressa pelos deputados Rogério "Peninha” Mendonça (SC) e Marcelo Castro (PI), em entrevistas ao autor, sintetizam essa perspectiva, mencionando os componentes da coalizão dominante do partido a partir de então:

"Como o PMDB é um partido cômodo de se estar, porque ele não tem uma definição clara ideológica, as pessoas que vão ter a direção [o fazem] mais por conveniências e acordos do que propriamente por outro aspecto. Eu acredito, inclusive, que o fato do $P M D B$ de Santa Catarina ser proporcionalmente o maior PMDB do Brasil, mais bem organizado, proporcionalmente ter o maior

\footnotetext{
${ }^{389}$ Folha de S. Paulo - 12/09/2001.

${ }^{390}$ Sobre a nova composição da CEN, ver Anexo 3.

${ }^{391}$ Em substituição ao sol nascente, símbolo que marcava a identidade visual do partido desde 1991, o PMDB passou a adotar como logomarca a sigla do partido com uma chama acima da letra "M" e com o mapa do Brasil ao fundo.
} 
número de deputados federais, estaduais, prefeitos, senadores, [em] tudo que você imaginar, é Santa Catarina o mais forte. Se fizer todas as pesquisas, tu vai ver. Só que isso infelizmente não é respeitado, né."

"Eles procuram dar uma aparência disso [de que a CEN é uma sintese de suas principais lideranças], mas sempre com pessoas que não têm expressão eleitoral forte, mas que têm fidelidade a esse grupo que domina o PMDB há muitos anos, por conta do Michel Temer. Então ele bota uma liderança como o José Maranhão, da Paraíba, que faz parte da Executiva, Valdir Raupp, de Rondônia, que faz parte da Executiva. Ele bota na liderança, botam algumas pessoas que não têm força, mas têm fidelidade. É o grupo que domina o PMDB há muitos anos, o grupo do Michel Temer. Os nomes são conhecidos: Michel, Geddel, Moreira, Padilha, Henrique Eduardo Alves, essa é a turma da Câmara. E tem a turma do Senado: Sarney, Renan, Jucá, Jader, são esses que dominam o PMDB. $O$ PMDB são dois: o da Câmara e o do Senado. São essas figuras que vêm dominando o partido há muito tempo ${ }^{\text {"392 }}$.

Novamente, apesar da vitória e da hegemonia conquistadas pelos governistas, a mesma Convenção em 2001 também aprovou uma moção em prol de uma candidatura própria, a ser apresentada nas eleições de 2002 por meio de consulta a ser realizada no ano seguinte, o que aparentou se tratar de uma vitória da ala oposicionista. A tese recebeu 542 votos, e teve 17 votos contrários ${ }^{393}$. Entretanto, reportagem do jornal Folha de S. Paulo à época descreve a aprovação da medida como uma manobra bem sucedida realizada pelo grupo dos oposicionistas que irritou os governistas, mas que ainda poderia ser revogada futuramente:

\begin{abstract}
"Apesar de haver margem para uma aliança com os tucanos em 2002, o discurso público dos peemedebistas é de que terão candidato próprio à presidência, tese que recebeu ontem 542 votos. Houve 117 votos em branco, 17 contra, 1 nulo e 9 abstenções. A prévia para definir o postulante peemedebista foi motivo 'de um golpe baixo de Maguito', segundo o líder do PMDB na Câmara Geddel Vieira Lima (BA). A Executiva do partido decidira fazer uma consulta apenas sobre a possibilidade de prévia na data de 20 de janeiro. Mas uma manobra de Maguito levou à impressão de duas cédulas. Uma ao molde da Executiva, controlada pelos aliados de FHC, e outra com
\end{abstract}

\footnotetext{
${ }^{392}$ Cabe apontar aqui que, em entrevista ao autor, uma alta funcionária do partido que é próxima de sua cúpula e portanto não terá seu nome mencionado, quando questionada a respeito desse aspecto optou por não responder à pergunta.

${ }^{393}$ Folha de S. Paulo - 10/09/2001.
} 
as opções de 20 de janeiro e de 21 de outubro. Venceu a opção de 20 de janeiro - foram 357 a favor dessa opção (52\%). Outros 251 (37\%) votaram pela prévia em 21 de outubro, 64 votos foram em branco, 4 nulos, 1 contra e houve 9 abstenções. (...) Do ponto de vista prático, a convenção serviu apenas para eleger a nova direção. Os outros itens aprovados - como moções, candidatura própria a presidente e prévia - podem ser revogados por outra convenção nacional."

Assim, apesar de a ideia de uma candidatura própria do PMDB ser uma demanda dos oposicionistas, ela teve que ser mencionada, ainda que de maneira vaga, no discurso de posse do novo presidente da sigla, o governista Michel Temer. Porém, como apontou Ferreira (2002: 232), apesar de Temer se comprometer a defendê-la, na prática, articulava a aliança com o PSDB:

"Conclamo os militantes do PMDB a integrar, a partir de hoje, com paixão e determinação, com força $e$ desprendimento, a grande campanha de mobilização nacional pelo:

Desenvolvimento com inclusão social - a inserção de milhões de brasileiros no seio da comunidade social $e$ política!

Pelo fortalecimento dos programas em defesa da cidadania,

Pela segurança, harmonia e paz social!

Com esta bandeira, com estes compromissos, com o vigor e a força das nossas bases, elegeremos em 2002 o nosso Presidente da República, a maior bancada de governadores, a maior bancada de deputados federais, e a maior bancada de deputados estaduais! "394

Ademais, como a decisão final quanto à estratégia a ser adotada pelo partido nas eleições presidenciais se daria somente no ano de 2002, dessa maneira o PMDB evitava também a defecção de políticos seus para outros partidos por meio dos quais pudessem ser candidatos. Como o prazo final para a filiação que permitisse a um político concorrer nas eleições de 2002 era o de um ano antes do pleito, sabendo que o próximo se realizaria no dia 6 de outubro daquele ano, faziam com que restasse pouco tempo para que encontrassem outra legenda para se acomodarem. A medida afetava diretamente Itamar Franco, que preferencialmente seria candidato à presidência da República pelo PMDB, mas que cogitava mantê-la ainda que fosse enquanto filiado a outro partido, possivelmente o Partido Liberal (PL), caso perdesse a disputa daquela Convenção ${ }^{395}$. Entretanto, a medida não foi suficiente para manter no PMDB outro político mineiro, o Senador José Alencar, que se filiaria ao PL poucos meses depois e se

\footnotetext{
${ }^{394}$ Acervo da sede nacional da FUG/Brasília.

${ }^{395}$ Folha de S. Paulo-09/09/2001.
} 
tornaria o candidato à vice-presidência da República na chapa com Luís Inácio Lula da Silva, do $\mathrm{PT}^{396}$.

\subsection{A estratégia dos governistas se consolida: a candidatura de Rita Camata à vice-presidência da República (2002)}

"O PMDB é de centro? De esquerda? De direita? De esquerda diria que não é, mesmo, mas a grande maioria talvez de centro. Ou oportunisticamente onde estiver o poder." Deputado Rogério "Peninha" Mendonça, em entrevista ao autor.

Com a vitória da ala à qual Michel Temer estava ligado na disputa pelos órgãos de direção do partido, os governistas se fortaleceram, e passaram a ser hegemônicos na condução do PMDB a partir de $2001^{397}$. Essa hegemonia se evidencia na estratégia eleitoral adotada pelo partido nas eleições presidenciais de 2002, ocasião na qual pela primeira vez em sua história a sigla compôs uma coligação eleitoral lançando um candidato ao cargo de vice-presidente da República de uma chapa presidencial, no caso, aquela encabeçada pelo tucano José Serra (SP). O posto coube à deputada capixaba Rita Camata, vista pelo núcleo de poder do partido como uma outsider ${ }^{398}$, que antes da nomeação era muitas vezes reconhecida como uma integrante da ala oposicionista, como quando fizera parte da chapa encabeçada por Alberto Goldman na disputa pela CEN do PMDB em $1995^{399}$. Michel Temer cumpriu papel fundamental na articulação da coligação com o PSDB nas eleições de 2002 (Pereira, 2002: 203), um processo cheio de idas e vindas (Ferreira, 2002: 232) e desencadeado após a Convenção Nacional de 2001.

Em 3 de março de 2002, o grupo oposicionista realizou uma pré-Convenção extraordinária em São Paulo na tentativa de definir a data para uma prévia interna do partido para poucos dias depois, prévia na qual, por sua vez, seria escolhido um candidato a presidente para ser apresentado pelo partido, caso optasse por uma candidatura própria. A iniciativa foi encabeçada pelo governador mineiro Itamar Franco, pelo senador gaúcho Pedro Simon e pelo então Ministro Raul Jungmann, todos pré-candidatos ao posto de presidente, mas também contou com o apoio de outras figuras de frente dos oposicionistas, como Orestes Quércia, Roberto Requião e Maguito Vilela. A primeira resposta dada a essa iniciativa por parte da coalizão dominante do partido foi tentar barrá-la na justiça, porém, em vão ${ }^{400}$.

\footnotetext{
${ }^{396}$ Folha de S. Paulo - 29/09/2001.

${ }^{397}$ Deputado Marcelo Castro, em entrevista ao autor.

${ }^{398}$ Folha de S. Paulo - 23/05/2002.

${ }^{399}$ Ata de reunião do Diretório Nacional do PMDB - 01/10/1995.

${ }^{400}$ Folha de S. Paulo - 03 e 04/03/2002.
} 
Entretanto, poucos dias depois, no dia 8 de março, os governistas realizaram a sua própria pré-Convenção em Brasília, com quórum maior do que a patrocinada pela ala oposicionista dias antes, organizada com vistas a barrar a estratégia dos oposicionistas. Dessa vez, por maioria absoluta, com 356 votos de um total de 691, os governistas cancelaram a prévia presidencial prevista para ocorrer no dia 17 daquele mês, sepultando, assim, temporariamente as articulações dos oposicionistas. Na ocasião, o deputado Geddel Vieira Lima (BA), líder do PMDB na Câmara e um dos principais articuladores daquela ala deixou clara sua posição: "Na minha posição pessoal, Serra é que pode assumir um projeto com o PMDB para os próximos quatro anos" ${ }^{401}$.

Poucas semanas depois, o jornal Folha de S. Paulo abriu espaço em sua edição para que um representante de cada ala do PMDB expressasse a opinião do seu grupo quanto a qual estratégia deveria ser adotada pela sigla na eleição presidencial que se aproximava. Por serem evidências importantes da tensão interna existente entre aqueles que defendiam uma candidatura própria e aqueles que se posicionavam em favor de uma coligação formal com o PSDB, além de serem documentos históricos sobre o período, reproduzimos abaixo trechos de cada um dos dois artigos:

"O PMDB deve se aliar ao PSDB na disputa pela presidência da República? Não.

Não existe partido sem candidatos. Eliminem-se as candidaturas e o partido deixa de existir. É a participação do partido com candidatos em todos os níveis que o fortalece, que o faz um protagonista, com papel de maior ou menor destaque, na cena política.

Se isso vale para todos os partidos, imagine o quanto é verdade para o PMDB. Temos a maior bancada no Senado Federal, a segunda ou terceira maior bancada na Câmara dos Deputados, o maior número de deputados estaduais, prefeitos, vereadores e diretórios municipais, além de uma tradição de luta que já é história.

(...)

De qualquer forma, seja como for, saibam todos aqueles interessados no apoio do PMDB que nós temos um candidato à presidência da República, o senador Pedro Simon. Na convenção de junho procuraremos fazer valer a vontade da quase totalidade dos convencionais que querem candidato próprio.

No entanto, caso essa tendência seja mudada, a aliança do PMDB com que partido seja deve ser feita em cima de propostas bem claras, de um programa a favor do Brasil. Qualquer outra coisa é acerto, é conchavo, é oportunismo."

Senador Roberto Requião (PR).

${ }^{401}$ Folha de S. Paulo-09/03/2002. 
"O PMDB deve se aliar ao PSDB na disputa pela presidência da República? Sim.

O caráter da democracia de um país é fruto do esforço da articulação social promovida por suas instituições. $O$ PMDB, sem nenhum demérito a outras instituições sociais e políticas, ao liderar o movimento pela redemocratização brasileira, é responsável direto pela qualidade da nossa democracia, habilitando-se, dessa forma, a pleitear o comando da nação, seja com um candidato próprio, seja como parceiro principal de uma aliança interpartidária.

(...)

A trajetória viável, neste momento, não é a da candidatura própria. E a razão é muito simples: não nos preparamos de maneira adequada para tornar competitivo o nosso candidato. Ademais, as graves dissensões internas inviabilizaram a candidatura própria. Já tivemos duas experiências de candidaturas próprias, uma delas liderada por Ulysses Guimarães, o símbolo maior de nossas lutas democráticas, mas acabamos amargando o insucesso.

Diz o ditado que errar é humano, mas insistir no erro é burrice. $O \mathrm{PMDB}$, sob a liderança competente $e$ equilibrada de Michel Temer, procura caminhos que possam oferecer melhores chances ao partido, mesmo que não se chegue ao consenso, o que, aliás, seria um fato inusitado em nossa história. A alternativa de coligação interpartidária apresenta-se, pois, como a mais sensata." Deputado Henrique Eduardo Alves (RN) ${ }^{402}$.

Após conseguirem neutralizar a proposta de uma candidatura própria do PMDB na pré-Convenção do partido, o grupo dos governistas teve seu caminho aberto para seguir nas tratativas com a cúpula do PSDB em prol de uma coligação formal entre os dois partidos. Em entrevista a Pereira (2002: 208-209), o presidente do partido Michel Temer explicou a estratégia eleitoral adotada pela coalizão que controlava o partido:

"A aliança nos coloca em posição de vantagem em relação às eleições anteriores. Em 1994, o PMDB teve um candidato que disputou as eleições presidenciais, Orestes Quércia, e chegou depois para compor com o governo numa condição subsidiária. Em 1998, voltamos a compor com o governo numa condição secundária. Porque houve tanto tumulto no partido que não foi possível sequer apoiar um candidato. (...) A divisão prejudicou enormemente o partido, que partilhou seu tempo de propaganda eleitoral com todas as outras agremiações. $O$ PMDB apoiou a reeleição de Fernando Henrique numa posição secundária e, secundariamente, exerceu suas

${ }^{402}$ Folha de S. Paulo - 06/04/2002. As notas em sua íntegra se encontram no Anexo 15. 
tarefas no governo. Agora não. Desde o momento em que conversamos sobre uma eventual aliança, o que ajustamos é que queremos ser parceiros. Parceiros no sentido de pares, e pares são aqueles que caminham juntos para chegar ao poder e exercê-lo juntos."

Poucos dias depois de sua pré-convenção, após convite formal dos tucanos nesse sentido, os governistas passam a discutir qual seria o melhor nome a ser indicado pelos peemedebistas para ocupar o posto de candidato a vice-presidente da República na coligação entre os dois partidos. Assim, o PMDB passava a ser o principal parceiro da sigla tucana e potencialmente adquirir maior protagonismo num eventual novo governo. Ademais, o partido passaria a ocupar, a partir da eleição presidencial de 2002, o espaço que havia ficado a cargo do PFL em 1994 e 1998 por meio de sua coligação com os peessedebistas, após os pefelistas abandonarem a coalizão de governo de FHC.

A partir de então, os nomes dos peemedebistas especulados pela imprensa para ocupar esse posto passaram a ser Jarbas Vasconcelos (PE), Juraci Magalhães (CE), Luiz Henrique (SC), Ramez Tebet (MT), Garibaldi Alves (RN), Henrique Eduardo Alves (RN - este o preferido da cúpula peemedebista e ligado aos governistas, mas inviabilizado após surgirem denúncias contra ele de ocultação de patrimônio), Pedro Simon (RS) e Itamar Franco (MG), os dois últimos representantes da ala dos oposicionistas e cortejados por parte dos tucanos, mas vetados pela cúpula do $\mathrm{PMDB}^{403}$.

Em maio de 2002, a cúpula do partido define que nenhum desses nomes seria aquele indicado pelo partido. O posto caberia à deputada capixaba Rita Camata, em decisão que ainda deveria ser referendada futuramente pela Convenção Nacional do partido. A definição, que preteriu figuras históricas do PMDB, foi interpretada pela imprensa como uma tentativa dos governistas de enfraquecer a ala oposicionista, que se opunha a uma coligação com o PSDB. Entre os tucanos, a opção por Rita era vista como arriscada, dadas as denúncias especuladas pela imprensa envolvendo o seu marido, mas teria pesado na decisão final a opinião do marqueteiro da campanha de Serra e a dele próprio, que buscaram por meio da escolha atrair uma fatia maior do eleitorado feminino ${ }^{404}$.

Apesar de não ser a primeira opção da cúpula do seu partido e ser vista como uma outsider na disputa, a deputada se tornava então a primeira peemedebista a ser indicada para compor uma chapa presidencial encabeçada por um candidato à presidência da República filiado a outro partido que não o próprio PMDB. Filiada à sigla desde 1981, sem nunca ter pertencido a qualquer outro partido, Rita era casada com Gerson Camata, governador do estado do Espírito Santo eleito em 1982. Em 1986, com apenas 25 anos, inicia sua carreira legislativa sendo eleita deputada federal constituinte, tendo sido a candidata mais votada no estado, com mais de 115 mil votos. O fato se repetiria por mais três vezes consecutivas, nas eleições de 1990, 1994 e

\footnotetext{
${ }^{403}$ Folha de S. Paulo - 19 e 21/03/2002, 01, 03 e 04/04/2002, 23/05/2002.

${ }^{404}$ Folha de S. Paulo - 23/05/2002.
} 
$1998^{405}$. Sua atuação parlamentar teve destaque quando a deputada foi relatora do Estatuto da Criança e do Adolescente (ECA) na Câmara dos Deputados, sancionado em $1990^{406}$, assim como da "Lei Camata", incorporada à Lei Complementar $n^{\circ} 101$ e mais conhecida como "Lei de Responsabilidade Fiscal" "407. Internamente no PMDB, durante muito tempo fora vista como mais próxima dos oposicionistas do que dos governistas, tendo votado contra o governo FHC na "emenda da reeleição" e na proposta de quebra da estabilidade do servidor público ${ }^{408}$, mas ao aceitar o convite decretou sua aproximação definitiva com a ala dos governistas ${ }^{409}$.

Por fim, em 15 de junho de 2002, o PMDB se reuniu em Convenção Nacional para referendar a sua coligação com o PSDB e definir a candidatura de Rita Camata. Entretanto, a decisão final foi mais uma vez conturbada. A fim de evitar a coligação com o PSDB, Roberto Requião (PR), representante do segmento dissidente, levou à apreciação da Executiva a sua pré-candidatura à presidência da República poucos dias antes da convenção. Tendo em vista o acirramento do conflito entre os dois grupos, numa tentativa de apaziguar as disputas o presidente do partido Michel Temer propôs que a votação sobre a candidatura de Roberto Requião fosse realizada caso a coligação com o PSDB não fosse aprovada. A resolução não descartava a possibilidade de prévias, porém, o presidente do partido sabia que a maioria apoiaria a coligação com o PSDB, o que ao final de fato ocorreu (Maciel, 2014: 81-82). Apesar de mais uma vez se realizar sob muitos tumultos, agressões e tentativas de última hora de barrar a realização da convenção, a proposta de coligação com o PSDB foi ao final aprovada, obtendo 433 de um total de 662 votos dos convencionais $(66,5 \%)$, enquanto a tese da candidatura do senador Roberto Requião obteve apenas $218 \operatorname{votos}^{410}$.

Assim, como resultado final do processo descrito nesta seção, o PMDB integraria a chapa presidencial apresentada pelo PSDB nas eleições de 2002, pela primeira vez na sua história na condição de ter um candidato a vice-presidente ${ }^{411}$. Diferentemente do que havia ocorrido nas eleições de 1998, quando nenhuma de suas alas teve força suficiente para emplacar sua própria estratégia eleitoral a ser adotada pelo partido naquela eleição presidencial, dessa vez a estratégia defendida pelos governistas foi colocada em prática. Entretanto, apesar de sua coalizão dominante ser composta exclusivamente pelos governistas, as divisões internas entre os oposicionistas e os governistas seguiriam ainda existindo e refletindo-se na posição adotada por alguns dos oposicionistas.

\footnotetext{
405 Dicionário Histórico Biográfico Brasileiro do Centro de Pesquisa e Documentação de História Contemporânea do Brasil, CPDOC/FGV, verbete "Rita Camata".

${ }^{406}$ Disponível online em http://www.planalto.gov.br/ccivil_03/LEIS/L8069.htm.

407 Disponível online em http://www.planalto.gov.br/ccivil_03/LEIS/LCP/Lcp101.htm.

${ }^{408}$ Folha de S. Paulo - 23/05/2002.

${ }^{409}$ Anos depois, em 2009, a ex-deputada sairia do PMDB para se filiar ao PSDB.

${ }^{410}$ Folha de S. Paulo - 16, 17/06/2002 e Agência Reuters https://noticias.uol.com.br/inter/reuters/2002/06/15/ult27u23156.jhtm.

${ }^{411}$ Para um amplo panorama das eleições presidenciais de 2002, ver Aguiar (2006).
} 
Em entrevista concedida ao autor, o ex-Deputado Marcelo Barbieri (SP), pertencente à ala ligada a Orestes Quércia, descreveu o comportamento dela naquela eleição:

"Em 2002, a maioria decide por apoiar o Serra e fica a Rita Camata de vice. O presidente já é Michel. Mas São Paulo apoiou o Lula em 2002. Quércia foi candidato a senador e eu fui a deputado federal. Tanto que eu fui do governo do Lula, fiquei no gabinete da Casa Civil um ano em 2003 por indicação do PMDB de São Paulo, apoiado pela Executiva, e aí fiz uma aproximação do PMDB com o governo do Lula."

O ex-presidente José Sarney, que muitas vezes oscilou entre as alas governista e oposicionista, foi outro peemedebista que declarou apoio ao candidato petista. Ainda no primeiro turno, o então senador pelo Amapá afirmou à imprensa que:

"Quando o PMDB apoiou o outro candidato [José Serra] eu disse que era um apoio errado e que não levaria a lugar nenhum. $O$ PMDB tem uma boa oportunidade, agora e no segundo turno, de ser uma ponte decisiva para que possamos ter um momento de tranquilidade no país". ${ }^{412}$

Seguiram o mesmo caminho o paranaense Roberto Requião e o mineiro Itamar Franco, que, como dito, tentaram em vão ser os candidatos a presidente pelo PMDB caso o partido optasse por uma candidatura própria em $2002^{413}$.

\subsection{Consideracões finais}

$\mathrm{Na}$ segunda parte desta tese evidenciamos o quanto as disputas internas entre os diferentes grupos do PMDB se refletiram nas estratégias adotadas pela sigla a partir de 1989. Enquanto nas eleições presidenciais de 1989 e de 1994 a estratégia do partido de ter um candidato próprio se deveu ao efêmero controle dos seus órgãos de direção por parte de dois segmentos de diferentes caracteres, a partir de 1994 iniciou-se uma disputa entre dois grupos que já vinham se delineando incipientemente desde o governo de Itamar Franco.

De um lado passaram a estar os oposicionistas, também chamados de "dissidentes", que pregam uma atuação independente por parte do partido em relação ao governo federal e que acreditam que a sigla deveria sempre apresentar um candidato próprio nas eleições presidenciais, para resgatar o seu protagonismo político. E, do

\footnotetext{
${ }^{412}$ Folha de S. Paulo - 27/08/2002.

${ }^{413}$ Folha de S. Paulo - 27 e 28/08/2002, 29/10/2002.
} 
outro, os governistas, que passaram a ganhar espaço dentro dos órgãos de direção do partido enquanto ocupavam cargos importantes durante o governo de Fernando Henrique Cardoso e que pregavam que o partido deveria integrar a coalizão de governo encabeçada pelo PSDB. Essa divisão da coalizão dominante do PMDB se fez presente durante todo o período abarcado por este capítulo e manteve uma constante tensão entre os dois grupos, expressas nas tumultuadas convenções nacionais do PMDB.

Nesse tempo, pouco a pouco os governistas passaram a crescer ainda mais e, após duas tentativas vãs de deter o controle absoluto da CEN do PMDB, a ala se tornou hegemônica a partir de 2001. Com isso, apesar da divisão entre os dois grupos se manter presente, expressa no apoio declarado por parte de alguns peemedebistas à candidatura de Lula em 2002, a estratégia eleitoral defendida pelos governistas passa a ser adotada. Evidência nesse sentido foi a candidatura a vice-presidente da República apresentada pelo PMDB e representada pela deputada federal Rita Camata na eleição presidencial de 2002, quando o partido se coligou à chapa encabeçada pelo tucano José Serra. 


\title{
Considerações finais:
}

\section{De partido protagonista a partido congressual}

\author{
"O PMDB não é um partido ideológico. Um partido \\ ideológico é aquele que não muda. [Ele] é um partido \\ democrático, é o que mais discute." Deputado Flaviano \\ Melo, em entrevista ao autor.
}

"Na hora que o PMDB sai do governo, cai o governo." Marcelo Barbieri, em entrevista ao autor.

Esta tese teve como objetivo geral desvendar as transformações pelas quais o PMDB atravessou e a dinâmica interna dos seus principais órgãos de direção nacional por meio de uma abordagem diacrônica, cobrindo um recorte histórico de mais de 20 anos. Argumentamos na Introdução que o comportamento eleitoral adotado pela sigla na disputa das eleições presidenciais seria um reflexo de aspectos internos ao partido, explicado pelas mudanças na sua correlação de forças e pelas disputas entre suas diferentes alas, e que as diferentes coalizões dominantes no seu interior nos ajudariam a entender como o partido passou pouco a pouco ao pano de fundo da política brasileira. Em outras palavras, o partido "para fora" poderia ser explicado pelo partido "pra dentro", e auxiliar na compreensão tanto da perda do protagonismo político adquirido no início dos anos 1980 quanto da sua manutenção enquanto um dos maiores e mais relevantes partidos políticos brasileiros a partir dos anos 1990. De fato, ao longo da narrativa apresentada nos quatro capítulos que compõem esta tese, nossa abordagem se mostrou profícua para a compreensão desses fenômenos.

A princípio, demonstramos como o início do processo de transformação do PMDB teve início já no ano de 1982. Com a sua refundação em 1979, a cúpula do partido inicialmente foi controlada pela sua ala autêntica, que detinha maioria na Comissão Executiva Nacional após ocorrer aquilo que chamamos de "primeira onda" de evasão de quadros do PMDB. Porém, com a incorporação do Partido Popular em 1982 iniciou-se na sigla um processo de transformação interna, com a entrada no partido de políticos que até então haviam se mantido afastados do PMDB e que o levaram a ser em seus primeiros anos algo distinto daquilo que havia sido seu antecessor no momento de sua extinção. Essa entrada reforçou a sua ala moderada com o ingresso na sigla de políticos ex-arenistas e ex-emedebistas moderados, dentre os quais se destacava Tancredo Neves, mas da qual faziam parte outros políticos que décadas depois teriam destaque na sua atuação política, como Henrique Eduardo Alves, que viria a se tornar presidente da Câmara dos Deputados décadas depois. Essa mesma ala pouco a pouco foi conquistando espaços dentro dos órgãos de direção do partido fazendo com que ele passasse a ter um "DNA misto", nos termos do deputado Flaviano Melo (AC), um dos entrevistados para este estudo, e após a derrota da campanha pelas Diretas-Já em 1984 o próprio Tancredo Neves cacifou-se para disputar a presidência da República por meio 
do Colégio Eleitoral em 1985. Em janeiro daquele ano Tancredo foi eleito o primeiro presidente da República civil depois de 21 anos de Regime Miliar, tendo como seu vice o recém-peemedebista José Sarney.

Em seguida, analisamos o impacto dessa entrada de Sarney no partido ao longo do período em que ocupou a presidência da República, após o falecimento de Tancredo Neves. Em seu primeiro ano de mandato, ainda em 1985, o então presidente cumpriu uma das promessas de campanha da Aliança Democrática (coalizão formada por PMDB e PFL) e liberalizou a legislação partidária, permitindo a regularização e a formação de novos partidos. Como consequência, os partidos que ainda se mantinham sob o abrigo do PMDB optaram por sua legalização, no caso o PCB e o PCdoB, e em conjunto com a fundação do PSB ocorre uma segunda onda de evasão de quadros do PMDB. Ao mesmo tempo, a flexibilização das regras de fidelidade partidária proporcionada enquanto o partido se encontrava na condição de governo na esfera federal, atrelada ao bom desempenho econômico do Brasil alcançado por meio do Plano Cruzado, levaram a um aumento no processo de "inchaço" do partido. Este processo, compreendido como a entrada de políticos pouco comprometidos com o programa partidário do PMDB e que já vinha em curso desde a incorporação do PP em 1982, atingiu seu clímax nas eleições de 1986, momento no qual a sigla obteve o melhor resultado eleitoral de sua história, e proporcionando a ela destaque durante os trabalhos da Assembleia Nacional Constituinte de 1987-1988. Entretanto, durante os trabalhos do Congresso Constituinte o partido se dividiu em sua atuação, e enquanto parte dos seus políticos atuava no bloco conservador conhecido como "Centrão", outros participavam do bloco conhecido como "Movimento Unidade Progressista". Essa divisão, em última instância, contribuiu para a formação da primeira dissidência da história do PMDB, que levou à fundação do PSDB em 1988 e compreende aquilo que chamamos de terceira onda de evasão de quadros do partido.

Após a conclusão dessas três ondas de evasão de quadros, no ano de 1989, o PMDB apresentou a sua primeira candidatura direta ao cargo de presidente da República, no momento no qual se realizaram as primeiras eleições presidenciais brasileiras desde o golpe civil-militar de 1964. Naquela ocasião, Ulysses Guimarães, uma de suas principais lideranças históricas, e a ala ligada a ele conseguiram reverter brevemente o processo de transformação pelo qual os órgãos de direção nacional do partido passavam após sucessivos ingressos e evasões da sigla. Conseguindo um efêmero controle da Comissão Executiva Nacional do PMDB, após o partido ter pela primeira vez em sua história duas chapas disputando o controle do seu principal órgão de direção, Ulysses tornou-se o primeiro candidato do partido a concorrer em uma eleição direta à presidência da República. Entretanto, seu desempenho naquele pleito ficou muito aquém do esperado por ele, em parte como resultado de um processo de "cristianização" por parte de seus correligionários. Como consequência disso outro peemedebista paulista, Orestes Quércia, ascendeu dentro do partido.

Com o apoio da ala quercista no interior da sigla, Quércia alcançou a presidência da Comissão Executiva Nacional no ano de 1991. Apesar de ter sua imagem pública 
afetada por escândalos de corrupção que o levaram inclusive a renunciar à presidência do partido em 1993, o controle obtido dos órgãos de direção internos o tornou o candidato presidencial apresentado pelo PMDB nas eleições de 1994, fazendo dele a segunda candidatura direta apresentada pela sigla em eleições presidenciais desde sua refundação em 1979. Seu desempenho, porém, acabou sendo similar àquele obtido por Ulysses em 1989: um cômputo de votos distante das principais candidaturas na disputa e com sinais de que ele também havia sido "cristianizado" pelos membros de seu partido durante a campanha.

Durante o seu período à frente da sigla, que coincidiu com o governo tampão de Itamar Franco, o partido começou a dar sinais de que havia se dividido em duas alas internas. De um lado os governistas, que pregavam que o partido deveria participar do mandato de Itamar e não apresentar candidaturas próprias nas eleições presidenciais, focando-se nas eleições legislativas, e do outro os oposicionistas, que pregavam um distanciamento do partido em relação ao governo federal e uma atuação independente por parte da sigla. Apesar de alguns membros do partido migrarem de uma ala para outra ao longo de sua trajetória, essa divisão marcaria a disputa pelo controle dos órgãos de direção do partido ao longo de todo o recorte histórico restante deste estudo, encerrando-se a partir do momento em que uma delas passou a ser hegemônica nesses órgãos. A presença das duas alas no interior do PMDB já havia sido notada por Ferreira (2002) e Maciel (2014), mas, diferentemente das autoras, acreditamos que essa divisão se deu a partir do governo de Itamar Franco, e não do de Fernando Henrique Cardoso (Ferreira, 2002: 151; Maciel, 2014: 20).

Com a vitória de FHC nas eleições presidenciais de 1994, tornaram-se evidentes já no início do seu mandato as diferentes posições adotadas por essas duas alas. Enquanto parte do partido preferiu se manter distante do governo de FHC, nunca vindo a integrá-lo, a ala dos governistas negociou e ingressou na sua coalizão de governo. A disputa pelo controle dos órgãos de direção do partido entre as duas alas se refletiu nas duas chapas que concorreram pelo controle da Comissão Executiva Nacional da sigla em 1995, algo que não ocorria desde 1989. Como resultado dessa disputa, os oposicionistas conquistaram a presidência do partido, o que gerou um descompasso com a atuação do PMDB dentro do Congresso Nacional. Apesar de ocuparem a presidência do seu principal órgão de direção nacional, a atuação da bancada do partido no Congresso, esfera na qual a ala dos governistas já se encontrava em maioria e passava a cada vez mais ocupar postos de poder, alinhava-se ao governo federal nas votações realizadas no Poder Legislativo.

Essa divisão entre as duas alas se tornaria evidente mais uma vez no momento em que partido definia a sua estratégia para as eleições presidenciais de 1998. Enquanto a ala dos oposicionistas defendia que o partido pleiteasse uma candidatura própria, a ala dos governistas, por sua vez, defendia uma coligação formal do partido com a chapa de FHC, que disputava a reeleição. Nenhuma das duas alas acaba tendo força suficiente para que sua estratégia eleitoral fosse adotada, e a sigla não se define nem por uma candidatura própria nem por uma composição com alguma das chapas na disputa 
presidencial de 1998. Entretanto, aquele ano se encerraria com uma vitória dos governistas. Jader Barbalho chega à presidência do partido, tornando-se o primeiro representante dos governistas a ocupar aquele posto e aprovando no momento de sua posse, às vésperas do pleito de 1998, uma declaração de apoio à candidatura de FHC.

A disputa entre as duas alas dentro do recorte histórico aqui adotado se encerrou em 2001, ano a partir do qual a ala dos governistas se tornou hegemônica nos órgãos de direção do PMDB e passou a deter o controle da CEN do partido, determinando a estratégia eleitoral adotada pela sigla nas eleições presidenciais. Numa disputa ocorrida mais uma vez entre duas chapas, a ala dos governistas, liderada por Michel Temer, passou a deter o controle exclusivo da Comissão Executiva Nacional do PMDB em setembro de 2001, com o próprio Temer passando a ocupar a sua presidência e sendo reeleito sucessivas vezes até a conclusão deste estudo ${ }^{414}$. Assim, justifica-se o marco final desta pesquisa. A partir de 2002 temos a primeira evidência empírica de que a estratégia adotada pelo bloco governista passou a ser aquela adotada pelo partido, com a sigla se focando nas eleições legislativas e com o lançamento da candidatura à vicepresidência da deputada Rita Camata na chapa de José Serra, do PSDB, reflexo da hegemonia obtida por essa ala. A mesma estratégia viria a se repetir em 2010 e 2014 (a exceção nas eleições presidenciais de 2006 se deu por conta da adoção da verticalização das coligações adotada apenas naquele pleito), com o PMDB lançando Michel Temer como candidato a vice-presidente de Dilma Rousseff pelo PT. A definição dessa estratégia fez com que o PMDB passasse a adotar um comportamento "pendular" no sistema partidário brasileiro em se tratando das disputas nacionais, ora se coligando ao PT, ora ao PSDB, enquanto seus órgãos de direção se mantiveram sob o controle da ala dos governistas.

A expressão "pêndulo", uma das mais representativas da atuação do partido, foi utilizada pelo ex-deputado federal Marcelo Barbieri (PMDB-SP), um dos entrevistados para estudo:

"Houve mudanças, mas o PMDB ainda é um grande pêndulo do centro. Uma hora mais no centro-esquerda, uma hora mais no centro-direita. Ora pende para a direita, ora para a esquerda. Essa é a história do PMDB, é um pêndulo. Mas nunca foi de extrema direita ou extrema esquerda. Teve até alguns membros que eram de extrema direita ou de extrema esquerda, mas o partido continua sendo uma referência de centro na política brasileira."

Atrelado a esse comportamento pendular nas disputas presidenciais, sugerimos também que outra consequência dessa hegemonia foi o fato de o partido pouco a pouco

\footnotetext{
414 http://g1.globo.com/politica/noticia/2016/03/temer-e-reconduzido-presidencia-do-pmdb-pelosproximos-2-anos.html e http://www2.planalto.gov.br/conheca-a-presidencia. Cabe apontar que durante seu mandato à frente do PMDB, Temer se licenciou do cargo algumas vezes, sendo sempre substituído por Romero Jucá, um de seus principais aliados na CEN do partido.
} 
passar a se focar nas eleições legislativas, esfera na qual a sigla sempre teve destaque. Entre os entrevistados mencionados que evidenciaram esse processo, a entrevista com o Senador Raimundo Lira (PMDB-PB) foi uma das que foi ao encontro desse ponto de vista:

"O PMDB passou a ser um partido predominantemente congressual. Então para o PMDB era importante, porque as estratégias mudam a cada momento e a cada época, então para o PMDB passou a ser importante ser o partido mais forte no Congresso Nacional, na Câmara e no Senado. Elegeu maior número de governadores e sem essa preocupação de eleger Presidente da República, até porque, de fato, não surgiu dentro do PMDB um nome que empolgasse a população como um possível candidato à presidência da República. E o PMDB é um partido pragmático, não quis artificializar isso ou importar um nome que tivesse essas condições de empolgar a população, seja por serviços prestados ao país ou por veio populista. Então o PMDB, sempre dentro de seu pragmatismo, não quis artificializar essa questão de eleger um presidente da República."

Como consequência desse comportamento e das transformações pelas quais atravessou, o PMDB é caracterizado hoje em dia, tanto por muitos políticos quanto pela literatura sobre os partidos políticos brasileiros, como um partido que ocupa o centro do espectro político partidário. Algumas das declarações dos entrevistados para este estudo foram ilustrativas nesse sentido, indo ao encontro do que aponta atualmente a literatura:

"Acho que o PMDB acabou ficando caracterizado como um grande partido de centro. Ainda hoje tem essa característica, tanto é que o PMDB participa do governo FHC com papel importantíssimo com a mesma facilidade e importância que participa do governo Lula, do governo Dilma e que agora tem o presidente Michel Temer como seu comandante. Por ter essa posição de centro, a característica do partido foi essa sobrevivência no que diz respeito a bancadas na Câmara e no Senado, sempre foram bancadas importantes e numerosas e [foi também] essa capacidade de ser o fiel da balança na sustentabilidade de governos que, em tese, são governos que na política tinham muito confronto. Estou me referindo (...) que o PMDB foi base do governo $F H C$ como foi base importante do governo Lula. No governo Lula, o PMDB migrou pós-eleição, porque até então formalmente mantinha aliança com o PSDB. Passada a eleição, foi garantir a governabilidade do governo Lula e teve papel fundamental assim como teve no governo Dilma." Senador Cássio Cunha Lima (PB). 
"Olha, na realidade o PMDB só era considerado partido de esquerda na ditadura, porque tinha a direita e do outro lado todo mundo junto no PMDB. Então ele ficou [sendo] 'de esquerda'. Tinha guerrilheiro, tinha de tudo. Depois desse momento o PMDB ficou sendo isso: um partido de centro. Uns foram saindo, foram deixando, e foram deixando porque não conseguiram puxar o partido para onde eles queriam." Deputado Flaviano Melo (AC).

"Houve mudanças fortes. O PMDB ficou mais num centro. $O$ PMDB sempre foi um centro-esquerda, hoje eu diria que o PMDB está mais no centro-direita. Mais à direita do que à esquerda. [Antes do] rompimento com o governo PT, [da] ruptura com o governo Dilma, foi de centro esquerda, porque foi vice, e apoiou o Lula, e apoiou Dilma, mas hoje eu diria que o PMDB está mais no centro. Ninguém vai governar o Brasil sem o PMDB em uma próxima legislatura, até porque no Senado vai continuar tendo uma presença forte." Ex-deputado Marcelo Barbieri (SP). ${ }^{415}$

Assim, desde 2001 a coalizão dominante do partido segue sendo formada pelos governistas. Uma hegemonia que tem-se dado sobretudo por meio de dois mecanismos: a prorrogação dos mandatos dos componentes dos órgãos de direção do partido, determinada por eles próprios, e disputas em chapa única, sempre encabeçadas e tendo em seus principais postos representantes dos governistas ${ }^{416}$. Desde 2001 a prorrogação dos mandatos dos seus dirigentes já ocorreu seis vezes (2003, 2005, 2008, 2011, 2014 e 2018), e nos anos em que houve Convenção para renovação da Comissão Executiva Nacional do partido não houve mais disputa entre duas chapas desde 2001, sendo que a chapa única, em todas as ocasiões, foi encabeçada por Michel Temer (2004, 2007, 2010, 2013 e 2016$)^{417}$.

Entretanto, nossa análise não se restringiu apenas à compreensão sobre a face diretiva do partido, o party in central office, nos termos de Katz e Mair (1993). Dado o controle exercido por parte de parlamentares do PMDB sobre suas instâncias centrais (Ribeiro, 2014), que corresponde a uma sobreposição das lideranças da sua face diretiva e da sua face pública, apontamos também para as transformações ocorridas na composição de suas bancadas no Congresso Nacional e as relações entre essas duas esferas. Evidenciamos assim, por meio da análise do histórico de filiação partidária dos parlamentares eleitos pelo PMDB desde sua refundação em 1979, o perfil das suas

\footnotetext{
${ }^{415}$ Para além dos entrevistados citados, outros também utilizaram o termo "centro" para caracterizar o partido, como os deputados Rogério Mendonça (SC), Celso Maldaner (SC) e o senador Raimundo Lira (PB), mas para evitar a repetição de falas optamos por não incluí-las aqui.

${ }^{416}$ Ver Anexo 3.

${ }^{417}$ Dados obtidos no acervo da SEDAP/TSE.
} 
bancadas tanto na Câmara dos Deputados quanto no Senado Federal, elemento que constitui a faceta party in public office do partido.

Destacamos, assim, que a proporção de parlamentares com histórico de filiação ao MDB, partido que congregava a oposição institucional ao Regime Militar, eleitos pela sigla encontrou-se em queda de 1980 até as eleições de 1998, último pleito analisado neste estudo. Por outro lado, ocorreu a manutenção de um "núcleo duro" de parlamentares com histórico de filiação à ARENA ou ao PDS, partidos de sustentação do Regime. Dentre os parlamentares com este histórico alguns se tornaram figuras de destaque do partido, como José Sarney, eleito senador sucessivas vezes por meio do PMDB e que chegou ao posto de presidente do Senado Federal, e Genebaldo Correa, que viria a se tornar líder da bancada do PMDB na Câmara.

Evidenciamos também como o Poder Legislativo constituiu um locus importante para a formação de lideranças do partido que posteriormente passaram a ocupar espaços nos seus principais órgãos de direção. Isso ficou evidente quando notamos que os dois mais longevos presidentes do partido, os peemedebistas paulistas Ulysses Guimarães e Michel Temer, ganharam destaque por sua atuação dentro da Câmara dos Deputados. Indo além na relação entre as faces pública e diretiva do partido, a ambiguidade gerada pela sobreposição de lideranças dessas duas esferas notada por Katz e Mair (1993) também pode ser observada neste estudo.

Os autores haviam apontado que nas ocasiões em que um partido estivesse unido as suas instâncias centrais poderiam também se beneficiar dos recursos provenientes de suas outras faces, fazendo com que seus órgãos centrais de direção se tornassem de fato o principal espaço onde as decisões partidárias seriam tomadas. $\mathrm{O}$ oposto ocorreria nas ocasiões nas quais o partido não estivesse unido. Nesses momentos, essas instâncias centrais podem se tornar verdadeiros "campos de batalha". Trazendo essa lógica para o PMDB, pudemos notar o quanto a divisão entre as alas dos governistas e dos oposicionistas da sigla gerou disputas e até confrontação física nas suas Convenções Nacionais, refletindo-se na disputa entre duas chapas tanto em 1995 quanto em 2001 pelo controle de sua CEN. No entanto, no momento em que os governistas, que já se encontravam em condição de maioria no Congresso, tornaram-se também hegemônicos nas suas instâncias centrais de decisão, a estratégia definida por essa nova coalizão dominante foi aquela adotada nas eleições presidenciais, em 2002, levando o partido a indicar uma candidatura sua ao posto de vice-presidente na chapa com o PSDB, ocupando o lugar que anteriormente havia ficado nas mãos do PFL.

A compreensão da história interna e das estratégias adotadas pelas sucessivas coalizões dominantes do PMDB ao longo de mais de duas décadas também nos ajuda a compreender tanto o processo de transição democrática brasileiro quanto o próprio funcionamento do sistema partidário do país como um todo. Como demonstramos, o partido cumpriu um papel fundamental na transição para a democracia em 1985, ao eleger a chapa Tancredo Neves-José Sarney por meio do Colégio Eleitoral, fenômeno que esteve diretamente ligado à incorporação do Partido Popular em 1982 e às 
estratégias adotadas pelo bloco Unidade, formado a partir de então. Afinal, o próprio Tancredo Neves só havia ingressado no PMDB após a incorporação do PP. De maneira similar, a convocação de uma Assembleia Nacional Constituinte havia sido uma bandeira das lideranças do PMDB desde sua fundação, e dentro do partido consolidouse uma dissidência interna durante os trabalhos da ANC, em parte decorrência do seu processo de "inchaço" verificado até então, que levou à formação de um dos partidos políticos de maior protagonismo em nosso sistema partidário.

Na década seguinte à $\mathrm{ANC}$, o próprio $\mathrm{PMDB}$ perdeu seu protagonismo político e passou ao pano de fundo da política nacional, deixando de apresentar candidaturas próprias ao cargo de presidente da República, mas seguiu elegendo grandes bancadas no Congresso, compondo as coalizões de governo quase que initerruptamente desde sua chegada ao poder em 1985. Nesse sentido, o próprio comportamento adotado pelo partido frente ao gradual processo de bipolarização da política nacional, expresso pelo desempenho das candidaturas apresentadas por PT e PSDB nas disputas presidenciais nacionais desde 1994, torna-se mais compreensível a partir do momento em que levamos em conta a ala do partido que se tornou hegemônica no interior do PMDB a partir de 2001.

Por fim, cabe destacar que essa perda de protagonismo não se deu de modo "isolado", mas sim ocorreu dentro de um sistema partidário no qual houve uma interação entre o PMDB e as outras siglas mencionadas, no caso, PT e PSDB, que passaram a exercer esse protagonismo. Como consequência, para avançarmos na produção de conhecimento sobre o fenômeno da transformação do PMDB, ele poderia agora ser explorado de outras formas, ainda que de maneira indireta, por meio do estudo desses outros partidos. Afinal, até que ponto a ambição de sempre lançar candidaturas próprias por parte de PT e PSDB levou o PMDB a repensar suas próprias estratégias eleitorais? Em outras palavras, a perda de protagonismo por parte do PMDB teria ocorrido como consequência da ambição por parte desses dois partidos de se tornarem protagonistas desde que foram fundados?

Indo além do recorte histórico aqui adotado, para compreendermos a interação entre o PMDB e esses dois partidos, faz-se necessário também analisar agora as relações construídas entre a coalizão dominante no interior do PMDB a partir de $2001 \mathrm{com}$ aquelas dominantes no interior dos partidos que bipolarizaram as disputas nacionais até 2014. Considerando o fato de que a mesma ala controla o PMDB desde 2001, até que ponto se manteve a relação próxima entre a coalizão dominante do partido com a cúpula dirigente do PSDB? Como essa coalizão "migrou" e passou a orbitar em torno do PT a partir do momento em que este elegeu o Presidente da República em 2002? Quais negociações foram necessárias para que o partido lançasse Michel Temer enquanto candidato à vice-presidência da República nas chapas apresentadas pelo PT tanto em 2010 quanto em 2014? Entretanto, essas são questões a serem respondidas por outros cientistas políticos e historiadores que se dediquem a estudar a dinâmica interna desses dois partidos, tal como fizemos aqui em relação ao PMDB. 


\section{Posfácio}

\section{O ocaso do PMDB e as eleições de 2018}

O período de conclusão deste estudo coincidiu com dois eventos importantes para a história do PMDB, ambos ocorridos durante o mandato do peemedebista Michel Temer à frente da presidência da República (2016-2018). O primeiro deles foi a mudança de nome da legenda, renomeada MDB em 19 de dezembro de 2017 a partir de uma Convenção Nacional Extraordinária ${ }^{418}$. O segundo foram as eleições gerais de 2018, nas quais o partido lançou a terceira candidatura própria de sua história ao cargo de Presidente da República, tarefa que coube a Henrique Meirelles. Seu desempenho eleitoral, porém, ficou abaixo daqueles obtidos por Ulysses Guimarães em 1989 e Orestes Quércia em 1994, o que somado ao desempenho obtido pelo partido nas eleições para o Congresso Nacional nos levam a concluir que este foi o pior desempenho eleitoral obtido pelo PMDB de todas as eleições que disputou desde sua refundação. Tendo em vista o quanto foi particular o processo eleitoral de 2018 e o modo como esses dois acontecimentos tangenciam o escopo determinado para esta tese, cabe neste posfácio explorá-los, sem ter como preocupação central explicar esses eventos, apontando para possíveis abordagens futuras nos estudos sobre o partido.

O resultado das eleições de 2018 foi impactante para o partido. Adotando uma estratégia à qual não recorria desde 1994, o agora renomeado MDB teve como candidato à presidência o economista e banqueiro Henrique Meirelles, ex-ministro da Fazenda no governo do seu correligionário Michel Temer e ex-presidente do Banco Central nos dois mandatos de Lula ${ }^{419}$. Seu vice foi Germano Rigotto, ex-governador do Rio Grande do Sul que havia tentado ser o candidato à presidência nas eleições de 2006. A estratégia de lançar candidato próprio foi definida em Convenção no dia 2 de agosto de 2018 e aprovada por ampla maioria ${ }^{420}$, numa conjuntura em que a coalizão dominante do partido ainda se mantém sob controle da ala ligada ao governista Michel Temer.

Assim, tal como ocorreu em 1989, o partido disputou a eleição estando à frente da presidência da República. Entretanto, também como ocorrera naquela ocasião em relação a José Sarney, a presidência de Temer também enfrentava baixíssimos índices de aprovação. A pouco mais de três meses do fim de seu mandato, pesquisa do Instituto Datafolha mostrava que Temer havia se tornado o presidente mais impopular da história

\footnotetext{
${ }^{418}$ https://g1.globo.com/politica/noticia/pmdb-aprova-mudanca-de-nome-e-passa-a-ser-chamadomdb.ghtml.

${ }^{419}$ https://www.nexojornal.com.br/expresso/2018/08/12/A-trajet\%C3\%B3ria-de-Meirelles-candidatodo-MDB-\%C3\%A0-Presid\%C3\%AAncia.

${ }^{420}$ https://veja.abril.com.br/politica/com-85-dos-votos-mdb-aprova-candidatura-de-meirelles-apresidencia.
} 
do Brasil, já que $82 \%$ dos brasileiros avaliavam sua gestão como ruim ou péssima ${ }^{421}$. Como resultado disso, conforme deu-se a campanha eleitoral, muitos dos candidatos, inclusive ex-aliados do impopular presidente, procuraram evitar que sua imagem fosse associada a ele $\mathrm{e}^{422}$.

Abertas as urnas do primeiro turno, os resultados reproduzidos abaixo mostram um MDB muito aquém do potencial que a estrutura do partido proporciona, e tal como nas eleições de 1989 e de 1994 a votação do candidato emedebista ficou muito distante das principais candidaturas no páreo. Henrique Meirelles obteve apenas 1,2\% dos votos válidos, uma votação ainda menor do que aquela obtida pelas outras candidaturas diretas apresentadas pelo PMDB anteriormente, próximas dos 4\%. Ademais, os resultados mostraram também uma alteração na já tradicional polarização entre as candidaturas de PT e PSDB que marcou as disputas presidenciais desde 1994, conforme passaram ao segundo turno as candidaturas de Jair Bolsonaro, do anteriormente nanico PSL, e de Fernando Haddad, formalizado candidato do Partido dos Trabalhadores após a candidatura de Lula ter sido barrada judicialmente.

\section{Tabela 46. Resultados do primeiro turno da eleição presidencial de 2018}

\begin{tabular}{|c|c|c|c|c|c|}
\hline Posição final & Candidato & Partido & Votos & $\begin{array}{l}\text { Porcentagem } \\
\text { sobre o total } \\
\text { de votantes }\end{array}$ & $\begin{array}{c}\text { Porcentagem } \\
\text { sobre o total } \\
\text { de votos } \\
\text { válidos }\end{array}$ \\
\hline 1 & Jair Bolsonaro & PSL & 49.276 .990 & & $46,0 \%$ \\
\hline 2 & $\begin{array}{l}\text { Fernando } \\
\text { Haddad }\end{array}$ & PT & 31.342 .005 & & $29,3 \%$ \\
\hline 3 & Ciro Gomes & PDT & 13.344 .366 & & $12,5 \%$ \\
\hline 4 & $\begin{array}{l}\text { Geraldo } \\
\text { Alckmin }\end{array}$ & PSDB & 5.096 .349 & & $4,8 \%$ \\
\hline 5 & João Amoedo & NOVO & 2.679 .744 & & $2,5 \%$ \\
\hline 6 & Cabo Daciolo & Patriota & 1.348 .323 & & $1,3 \%$ \\
\hline 7 & $\begin{array}{l}\text { Henrique } \\
\text { Meirelles }\end{array}$ & MDB & 1.288 .948 & & $1,2 \%$ \\
\hline 8 & Marina Silva & Rede & 1.069 .577 & & $1 \%$ \\
\hline 9 & Alvaro Dias & Podemos & 859.601 & & $0,8 \%$ \\
\hline 10 & $\begin{array}{l}\text { Guilherme } \\
\text { Boulos }\end{array}$ & PSOL & 617.122 & & $0,6 \%$ \\
\hline 11 & Vera & PSTU & 55.762 & & $0,05 \%$ \\
\hline 12 & Eymael & DC & 41.710 & & $0,04 \%$ \\
\hline 13 & $\begin{array}{l}\text { João Goulart } \\
\text { Filho }\end{array}$ & PPL & 30.176 & & $0,03 \%$ \\
\hline Votos válidos & & & 107.050 .673 & & $91,2 \%$ \\
\hline
\end{tabular}

\footnotetext{
${ }^{421}$ https://exame.abril.com.br/brasil/com-82-de-rejeicao-temer-se-torna-presidente-mais-impopularda-historia/.

422 https://www.nexojornal.com.br/podcast/2018/09/26/Fim-de-governo-Temer-reprovado-na-ruarejeitado-na-elei\%C3\%A7\%C3\%A3o.
} 


\begin{tabular}{lcc}
\hline Votos brancos & 3.106 .936 & $2,6 \%$ \\
Nulos & 7.206 .205 & $6,1 \%$ \\
\hline Abstenções & 29.941 .265 & $20,3 \%$ \\
\hline
\end{tabular}

Fonte: https://politica.estadao.com.br/eleicoes/2018/cobertura-votacao-apuracao/primeiro-turno.

Mais uma vez, tal como ocorrera com os candidatos lançados pelo PMDB em 1989 e 1994, há indícios de que a candidatura de Henrique Meirelles pode ter sido cristianizada. Evidência nesse sentido seria o fato de parte dos parlamentares do MDB, alguns dos quais incluídos entre os entrevistados para esta tese, terem abertamente feito campanha para candidaturas de outros partidos ao cargo de presidente da República, sobretudo para as candidaturas que lograram passar para o segundo turno ${ }^{423}$. Resta saber quais as motivações da coalizão dominante da sigla em lançar a candidatura de Meirelles, mas fica evidente que mais uma vez ela esteve longe de representar um projeto político partidário que tivesse unificado o partido.

Com relação às eleições legislativas, espaço no qual o PMDB já se consolidara na posição de um dos principais atores do sistema político brasileiro, a tabela e o gráfico abaixo mostram que a sigla obteve o pior resultado de sua história na Câmara dos Deputados, ao ter sua bancada reduzida pela metade em comparação aos eleitos em 2014. Se naquela ocasião o partido havia elegido 66 deputados federais, desta vez o partido elegeu $34(6,6 \%)$, ficando atrás de outros três partidos em termos de representação, algo que nunca antes havia ocorrido. O partido seguiu, portanto, também na eleição de 2018 a trajetória declinante no tamanho de sua bancada na Câmara dos Deputados que vinha ocorrendo desde a década de 1990.

Por sua vez, as eleições de 2018 renovaram 2/3 das cadeiras no Senado Federal, e os resultados mantiveram o partido como a sigla hegemônica naquela esfera, apesar de sua trajetória declinante. $\mathrm{O}$ então renomeado MDB elegeu sete senadores, que somados aos seus parlamentares que não tiveram seus mandatos renovados fazem com que sua bancada tenha um total de 12 representantes $(14,8 \%)$. Esse resultado o mantém o $1^{\circ}$ colocado em número de representantes no Senado mais uma vez ${ }^{424}$, mas perpetua o processo de subtração de sua bancada.

\footnotetext{
${ }^{423}$ https://www.deputadopeninha.com.br/noticias/peninha-leva-bolsonaro-a-santa-catarina-pararoteiro-de-dois-dias-22.html e https://noticias.uol.com.br/politica/eleicoes/2018/noticias/2018/09/02/haddad-recebe-apoio-derenan-pai-e-renan-filho-e-e-chamado-de-presidente.htm.

${ }^{424}$ https://g1.globo.com/politica/eleicoes/2018/eleicao-em-numeros/noticia/2018/10/08/mdb-rede-epp-elegem-o-maior-numero-de-senadores.ghtml ; https://g1.globo.com/politica/eleicoes/2018/eleicaoem-numeros/noticia/2018/10/08/pt-perde-deputados-mas-ainda-tem-maior-bancada-da-camara-pslde-bolsonaro-ganha-52-representantes.ghtml .
} 
Tabela 47. Bancadas do PMDB na posse após cada eleição e porcentagem de cadeiras conquistadas (1982-2018)

\begin{tabular}{|c|c|c|c|c|c|c|c|c|c|c|}
\hline Eleições & $\begin{array}{c}1982 \\
\text { Leg47 }\end{array}$ & $\begin{array}{c}1986 \\
\text { Leg48 } \\
\end{array}$ & $\begin{array}{c}1990 \\
\text { Leg49 }\end{array}$ & $\begin{array}{c}1994 \\
\text { Leg50 } \\
\end{array}$ & $\begin{array}{r}1998 \\
\text { Leg51 } \\
\end{array}$ & $\begin{array}{c}2002 \\
\text { Leg52 }\end{array}$ & $\begin{array}{c}2006 \\
\text { Leg53 }\end{array}$ & $\begin{array}{c}2010 \\
\text { Leg54 }\end{array}$ & $\begin{array}{c}2014 \\
\text { Leg55 }\end{array}$ & $\begin{array}{c}2018 \\
\text { Leg56 }\end{array}$ \\
\hline $\begin{array}{l}\text { Cadeiras } \\
\text { na } \\
\text { Câmara }\end{array}$ & 200 & 260 & 108 & 107 & 83 & 74 & 89 & 79 & 66 & 34 \\
\hline $\begin{array}{l}\text { Porcenta } \\
\text { gem }\end{array}$ & 41.8 & 53.4 & 21.5 & 20.9 & 16.2 & 14.4 & 17.3 & 15.3 & 12.8 & 6.6 \\
\hline $\begin{array}{l}\text { Cadeiras } \\
\text { no } \\
\text { Senado }\end{array}$ & 21 & 45 & 27 & 22 & 27 & 20 & 15 & 20 & 18 & 12 \\
\hline $\begin{array}{l}\text { Porcenta } \\
\text { gem }\end{array}$ & 30.4 & 62.5 & 33.3 & 27.2 & 33.3 & 24.7 & 18.5 & 24.7 & 22.2 & 14.8 \\
\hline
\end{tabular}

\section{Gráfico 7. Bancadas do PMDB na posse após cada eleição (1982 - 2018 )}

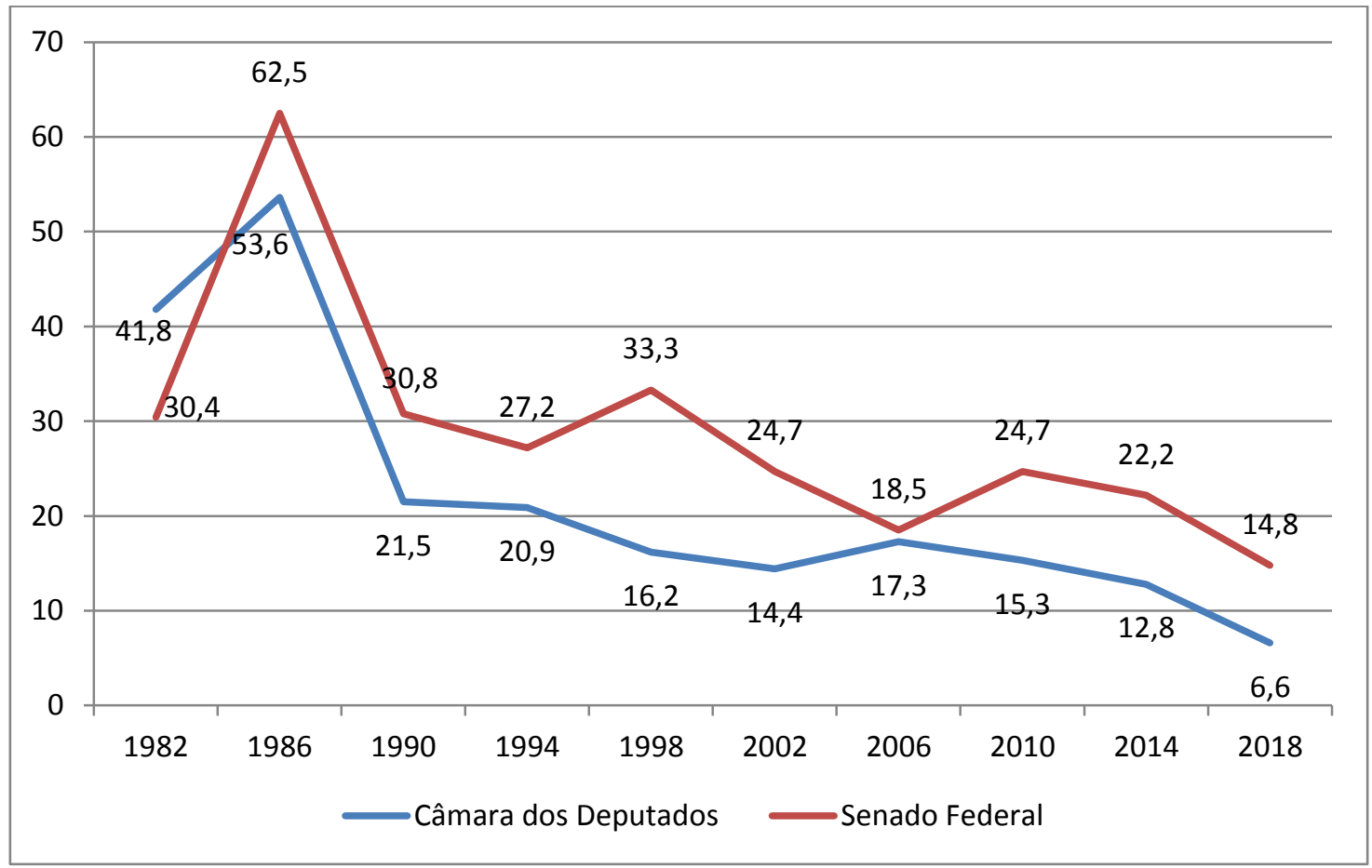

Fontes: Elaboração própria com dados do Tribunal Superior Eleitoral (TSE), Nicolau (1998), Mucinhato (2015), Mainwaring (2001), base de dados online do Prof. Jairo Nicolau (disponível em https://jaironicolau.github.io/deb/) e múltiplas fontes jornalísticas.

Essa queda no seu desempenho parece ter sido prevista por alguns dos entrevistados para este estudo, dada a conjuntura de desgaste da imagem da legenda já evidente enquanto as entrevistas foram realizadas. As declarações do Senador Airton 
Sandoval (PMDB-SP) quando questionado a respeito das eleições que então se aproximavam são ilustrativas nesse sentido:

“(...) Essa transformação [pela qual o partido atravessou] não foi suficiente para fazer o partido que a gente sonhou, que a gente espera. Acho que a gente tem que fazer isso a partir de agora, esperar essa transição difícil que estamos passando, que vai ser muito pesada pro PMDB. Apesar de ser hoje o maior partido do Brasil, vamos pagar o preço pelo que está acontecendo hoje. Todos os partidos vão pagar, mas nós, mais, porque o atual presidente é do PMDB. ”

No que diz respeito à mudança de nome do PMDB, que a partir de dezembro de 2017 retirou a palavra "partido" da sigla e passou a chamar-se apenas MDB, a estratégia foi interpretada pela imprensa como um rebranding da sigla, uma estratégia de lógica comercial na qual é realizada uma mudança de nome para tentar assumir, aos olhos do público, uma nova identidade ${ }^{425}$. De fato, diferentemente do que havia ocorrido em 1979, não houve mudanças na sua cúpula dirigente com a mudança de nome e, assim como o fizeram outras legendas do sistema partidário brasileiro nos últimos dois $\operatorname{anos}^{426}$, o partido aparentava tentar se desvencilhar de sua imagem recente, bastante negativa a partir da posse de Michel Temer na presidência da República em 2016.

Durante seu mandato no cargo, período no qual a sigla passou à "linha de frente" da política nacional, o partido se viu envolvido em uma série de escândalos de corrupção diretamente associados a sua elite dirigente. Poucos dias após sua posse, em maio de 2016, uma série de vazamentos de áudios e conversas particulares vieram à tona por meio da imprensa. Os áudios continham diálogos entre Sérgio Machado, expresidente da subsidiária da Petrobrás conhecida como "Transpetro" e indicado ao cargo pelo PMDB, com integrantes da alta cúpula do próprio partido ${ }^{427}$. Os áudios correspondiam a conversas e articulações com vistas a articular a queda da então presidenta Dilma Rousseff para que houvesse um cessar da Operação Lava Jato ${ }^{428}$, investigação levada adiante pelo Ministério Público Federal e pela Polícia Federal desde 2014 que combate desvios e lavagem de dinheiro envolvendo empresas públicas e privadas $^{429}$. A operação pouco a pouco avançava sobre as principais lideranças do PMDB em suas investigações e, meses depois, ainda durante o mandato de Temer,

\footnotetext{
425 Jornal El País - 19/12/2017, em

https://brasil.elpais.com/brasil/2017/12/19/politica/1513695154_142381.html.

${ }^{426}$ https://g1.globo.com/politica/noticia/diante-de-crise-politica-partidos-mudam-de-nome-para-atraireleitores-em-2018.ghtml.

${ }^{427}$ https://www1.folha.uol.com.br/poder/2016/05/1774018-em-dialogos-gravados-juca-fala-em-pactopara-deter-avanco-da-lava-jato.shtml; http://g1.globo.com/jornal-da-globo/noticia/2016/05/audioindica-que-sergio-machado-teria-ajudado-aliados-politicos.html.

${ }^{428}$ https://brasil.elpais.com/brasil/2016/05/24/politica/1464058275_603687.html.

${ }^{429}$ http://arte.folha.uol.com.br/poder/operacao-lava-jato/.
} 
levaria à prisão de integrantes da coalizão dominante do partido, como Henrique Eduardo Alves (RN), Geddel Vieira Lima (BA) e Eduardo Cunha (RJ) ${ }^{430}$.

Os sucessivos escândalos levaram a três denúncias contra Michel Temer oriundas da Procuradoria Geral da República (PGR) e apresentadas ao Superior Tribunal Federal (STF), que tornaram Temer o primeiro presidente brasileiro no exercício de seu mandato a ser denunciado por um crime comum $^{431}$. A primeira delas, de junho de 2017, baseou-se em delações premiadas da Operação Lava Jato para acusar o presidente de ter cometido o crime de corrupção passiva ${ }^{432}$. A segunda, em setembro do mesmo ano, acusava o presidente, a alta cúpula do partido e os executivos da empresa JBS de crime de organização criminosa e obstrução à Justiça ${ }^{433}$. Ambas as denúncias não avançaram e foram rejeitadas pela Câmara dos Deputados ${ }^{434}$. Na terceira delas, apresentada a poucos dias do término do seu mandato presidencial, o presidente foi denunciado pelos crimes de corrupção passiva e lavagem de dinheiro, em inquérito que investiga sua relação com o Porto de Santos ${ }^{435}$.

Dado esse cenário, que não impediu o MDB de mais uma vez ser convidado a integrar o governo do presidente eleito em 2018 e ocupar um de seus ministérios ${ }^{436}$, é possível então suscitarmos alguns questionamentos em relação ao futuro do partido. Com a prisão de integrantes da sua coalizão dominante e a saída de Temer da presidência da República, haverá mudanças na cúpula do partido a partir de 2019? A gradual aproximação ocorrida entre PSDB e MDB durante o mandato de Temer na presidência, que poderia ter levado o partido a repetir uma coligação em nível nacional tal como ocorrera em 2002, teve alguma relação com o lançamento da candidatura própria apresentada pelo MDB? Como demonstramos ao longo desta tese, os achados desta pesquisa apontam que o estudo aprofundado da dinâmica interna do partido pode responder a essas questões, mas a tarefa fica como sugestão aos futuros pesquisadores da história interna do partido.

\footnotetext{
${ }^{430}$ https://veja.abril.com.br/politica/descubra-quais-sao-os-9-politicos-ainda-presos-na-lava-jato/.

${ }^{431}$ https://brasil.elpais.com/brasil/2017/06/26/politica/1498485882_380890.html.

432 https://g1.globo.com/politica/noticia/relembre-a-semana-em-que-pela-1-vez-um-presidente-foidenunciado-pela-pgr.ghtml.

${ }^{433}$ https://noticias.uol.com.br/politica/ultimas-noticias/2017/09/14/janot-denuncia-temer-e-mais-seisdo-pmdb-por-obstrucao-da-justica-e-organizacao-criminosa.htm.

${ }^{434}$ https://noticias.uol.com.br/politica/ultimas-noticias/2017/10/25/deputados-analisam-segundadenuncia-contra-temer.htm.

${ }^{435}$ https://noticias.uol.com.br/politica/ultimas-noticias/2018/12/19/pgr-temer-inquerito-portos.htm.

${ }^{436}$ https://g1.globo.com/politica/noticia/2018/11/28/ex-ministro-de-temer-osmar-terra-e-escolhidopara-ministerio-da-cidadania-e-acao-social.ghtml.
} 


\section{$\underline{\text { Referências Bibliográficas }}$}

ABAIDE, J. P. 1990. Partidos políticos no Brasil: 1979-1988. Dissertação de mestrado - Centro de Ciências Jurídicas (UFSC);

AGUIAR, I. 2006. Eleições presidenciais de 2002: Partidos, elites e a perspectiva de mudança. Tese de Doutorado - Departamento de Sociologia Politica - UFSC;

ALKMIN, A.C. 2014. De Brizola a Cabral. De Collor a Dilma. A geografia do voto no Rio de Janeiro de 1982 a 2010. Rio de Janeiro: Editora PUC Rio;

AMARAL, O. M. E. do. 2010. As transformações na organização interna do Partido dos Trabalhadores entre 1995 e 2009. Tese de Doutorado, Unicamp;

AMOROSO, M. 2010. Ação política e convivência tática: os grupos de esquerda no Borel durante a reabertura. O Social em Questão - Ano XIII - nº 24 - Jul-Dez 2010, pg 135 - 158;

ARAÚJO, M. 2000. Mudanças partidárias. A evolução das migrações partidárias na Câmara dos Deputados: 1979/1999. 2000. Dissertação (Mestrado) - Universidade de São Paulo, São Paulo;

AVERBUG, M. 2005. Plano Cruzado: crônica de uma experiência. Revista do BNDES, Rio de Janeiro, v. 12, n. 24 , p. [211]-240, dez.;

BACHA, E. 1997. Plano Real: uma segunda avaliação. In: O Plano Real e outras experiências internacionais de estabilização - Brasília : IPEA/CEPAL, p. 177-204;

BARBOSA, T. A. L. 2014. Dirigentes Partidários e Parlamentares do PMDB no Mato Grosso do Sul (1980-2010): Uma análise da origem social dos membros da Comissão Executiva,Deputados Estaduais e Federais eleitos no Estado. Dissertação (Mestrado) Universidade Federal do Paraná, Curitiba;

BATISTA JR., P. N. 1996. O Plano Real à luz da experiência mexicana e argentina. Estud. av., São Paulo, v. 10, n. 28, p. 127-197, Dez. Available from $<$ http://www.scielo.br/scielo.php?script=sci_arttext\&pid=S0103-

40141996000300007\&lng=en\&nrm=iso > access on 16 Oct. 2018. http://dx.doi.org/10.1590/S0103-40141996000300007;

BENEVIDES, M. 1981. A UDN e o udenismo. Rio de Janeiro: Paz e Terra;

Junho;

1986. Ai que saudade do MDB!. Lua Nova vol.3 no.1 São Paulo

BERTONCELO, E. 2007 A campanha das Diretas e a democratização. São Paulo: Humanitas; Fapesp;

BIZZARRO NETO, F.A. 2013. PMDB: organização e desenvolvimento em São Paulo (1994-2010). Dissertação de mestrado do Programa de Pós-Graduação em Ciência Política do Instituto de Filosofia e Ciências Humanas da Universidade Estadual de Campinas (IFCH-UNICAMP);

BONAVIDES, P. 1968. As eleições cearenses de 1966. In: Revista brasileira de estudos políticos. Numero 23/24, UFMG;

BOUCEK, F. 2009. Rethinking Factionalism: Typologies, Intra-Party Dynamics and Three Faces of Factionalism. Party Politics Vol. 15 (4) 455-485; 
BRAGA, M. do S. S. 2010. Eleições e democracia no Brasil: a caminho de partidos e sistema partidário institucionalizados. Revista Brasileira de Ciência Política, $\mathrm{n}^{\mathbf{0}} 4$. Brasília, julho-dezembro de 2010, pp. 43-73;

2013. A agenda dos estudos sobre partidos políticos e sistemas partidários no Brasil. Revista de Discentes de Ciência Política da UFSCAR | Vol. 1 - n. 1

BRAGA, M. do S. S., COSTA, V. M., FERNANDES, J. L. M. 2017. Dinâmicas de funcionamento e controle do poder nos partidos políticos: Os casos do PT e PSDB no Estado de São Paulo. RBCS Vol. 33 n 96;

BRESSER-PEREIRA, 1984. Definição ideológica necessária para o PMDB. Jornal do PMDB, 01.08.1984;

Pedroso Horta;

1987. O PMDB e as eleições de 1986. São Paulo: Fundação 1993. A Nova República: 1985-1990. São Paulo: Edições CEP;

Política, vol. 14, no. 4 (56);

1994. A economia e a política do Plano Real. Revista de Economia

BRITTO, L. N. de. 1988. As eleições de 1982 e as suas consequências. In: Fleischer (Org.) Da distensão à abertura: as eleiçõos de 1982. Brasília: Editora UnB;

BRITO, A. 1985. Assim Morreu Tancredo. Antônio Britto. Depoimento a Luís Claudio Cunha. L\&PM, Porto Alegre;

CÂMARA DOS DEPUTADOS, 2009. Perfis parlamentares 54 - Franco Montoro. Brasília: Edições Câmara;

CÂMARA DOS DEPUTADOS, 2010. Perfis parlamentares 56 - Tancredo Neves. Brasília: Edições Câmara;

CÂMARA DOS DEPUTADOS, 2012. Perfis parlamentares 66 - Ulysses Guimarães. Brasília: Edições Câmara;

CÂMARA DOS DEPUTADOS, 2016. Perfis parlamentares 66 - Ulysses Guimarães Edição comemorativa. Brasília: Edições Câmara;

CAMPELLO DE SOUZA, M.C. et al. 1992. The right and democracy in Latin America. New York: Pragers Publishers;

CAMURÇA, M. A. e REIS FILHO, D. A. 2007. O Movimento Revolucionário 8 de Outubro (MR-8). Da luta armada contra a ditadura à luta eleitoral no PMDB”. In: FERREIRA, Jorge \& REIS FILHO, Daniel Aarão (orgs.). Revolução e democracia (1964-...). Rio de Janeiro: Ed. Civilização Brasileira, 2007. (coleção "As esquerdas no Brasil", v. 3);

CANTALEJO, M. H. de S. 2008. O município de Duque de Caxias e o Regime Militar: 1964-1985. Dissertação de mestrado, Universidade Federal do Rio de janeiro (UFRJ), Instituto de Filosofia e Ciências Sociais (IFCS);

CANTANHÊDE, E. 2001. O PFL. São Paulo: Publifolha;

CAPISTRANO FILHO e CITADINI. 1982. São Paulo: PMDB no poder. São Paulo: Cerifa-Oboré; 
CARDOSO, F. H. 1981. Os Partidos Políticos e a Participação Popular. In: FLEISCHER, D. (org.). Os partidos políticos no Brasil. Brasília, Editora Universidade de Brasília, Vol.2;

2015. Diários da presidência (1995-1996), Volume 1. São Paulo: Companhia das Letras;

2016. Diários da presidência (1995-1996), Volume 2. São

Paulo: Companhia das Letras;

CARDOSO, H. 1984. Um pouco da história da esquerda. Lua Nova, São Paulo, v. 1, n. 3, p. 41-49, Dec. 1984 Available from <http://www.scielo.br/scielo.php?script=sci_arttext\&pid=S0102-

64451984000300012\&lng=en\&nrm=iso>. access on 16 Aug. 2015.

CARREIRÃO, Y de S. \& KINZO, M. D. 2004. Partidos Políticos, Preferência Partidária e Decisão Eleitoral no Brasil (1989/2002). DADOS - Revista de Ciências Sociais, Rio de Janeiro, Vol. 47, n. 1, pp. 131 a 168;

CARREIRÃO, Y. 2002. A decisão do voto nas eleições presidenciais brasileiras. Rio de janeiro: Fundação Getúlio Vargas;

2014. O sistema partidário brasileiro: um debate com a literatura recente. Revista Brasileira de Ciência Política, $\mathrm{n}^{\circ} 14$. Brasília, maio - agosto, pp. 255295 ;

CARVALHO, M.A.Z. ARAUJO, C. e SIMOES, J. A. (Orgs.), 2009. A Constituição de 1988. Passado e futuro. São Paulo: Editora Hucitec Anpocs;

CERVI, E.U. 2016. PSDB e PT em eleições nacionais: fatores geográficos, políticos e sócio econômicos na polarização partidária no Brasil (1994 e 2014). España: FLACSO;

COELHO, R. Partidos políticos, maiorias parlamentares e tomada de decisão na constituinte. Tese de Doutorado em Ciência Política - FFLCH/USP;

COELHO, S. A. 2003. O Partido Democrata Cristão: teores programáticos da terceira via brasileira (1945-1964). Rev. Bras. Hist., São Paulo , v. 23, n. 46, p. 201-228. Available from <http://www.scielo.br/scielo.php?script=sci_arttext\&pid=S010201882003000200009\&lng=en\&nrm=iso>. access on 14 May 2018.

CORRÊA, I da S. M. 2011. Ulysses Guimarães: trajetória política de um liberaldemocrata na luta contra a ditadura militar (1971-1984). Dissertação de mestrado, programa de História Social da Universidade Federal Fluminense;

COSTA, I.C.G. da. 2017. PCdoB: a travessia do comunismo entre a ortodoxia e a revisão. São Paulo: Fundação Perseu Abramo, Revista Perseu No 14, Ano 11;

COUTO, C.G. 1997. A agenda constituinte e a difícil governabilidade. In: Lua NovaRevista de Cultura e Política, n. 39, p.33-52, São Paulo;

COUTO, R. 1999. Memória viva do Regime Militar. Rio de Janeiro: Editora Record;

D’ARAUJO, M. C. 1996. Sindicatos, carisma e poder. O PTB de 1945-65. Rio de Janeiro: Fundação Getúlio Vargas;

DELGADO, T. 2006. A história de um rebelde. Brasília: Fundação Ulysses Guimarães;

DIAP. Série Os “Cabeças” do Congresso Nacional (1995-2015). Publicação anual do Departamento Intersindical de Assessoria Parlamentar - DIAP, Brasília, disponível online para download em www.diap.org.br ; 
DIEGUEZ, C. 2010. A cara do PMDB. Revista Piauí. Edição 45, Junho;

DIMENSTEIN, G. NEGREIROS, J., NOBLAT, R. LOPES, R. E FERNANDES, R. 1985. O complô que elegeu Tancredo. Rio de Janeiro: Editora JB;

DINIZ, E. 1982. Voto e máquina política: patronagem e clientelismo no Rio de Janeiro. Rio de Janeiro: Paz e Terra;

DORIA, P. 2009. Honoráveis bandidos. São Paulo: Geração Editorial.

DUVERGER, M. 1970. Os Partidos Políticos. Rio de Janeiro: Zahar/UnB;

ECHEVERRIA, R. 2011. Sarney, a biografia. São Paulo: Editora Leya;

FERREIRA, A. M. S. 1998. Partido da Frente Liberal: um facção bem-sucedida. Dissertação de Mestrado - Universidade de Brasília;

FERREIRA, D. P., 2001. Descentralização Partidária e Federalismo no Brasil: PFL X PMDB (1982-2000), Tese de Doutorado - Departamento de Ciência Política FFLCH/USP;

Alternativa;

2002. PFL X PMDB: Marchas e contramarchas. Goiânia: Editora

FERREIRA, M. de M. 2006 A fusão do Rio de Janeiro, a ditadura militar e a transição política. In: ABREU, A. A. (Org.). A democratização no Brasil: atores e contextos. Rio de Janeiro: FGV, cap. 6, p. 163 - 203;

FERREIRA, G.S.N. 2007. Sarney, FHC e Lula: 22 anos de "conversas ao pé do rádio" e democracia. Intercom - Sociedade Brasileira de Estudos Interdisciplinares da Comunicação, V Congresso Nacional de História da Mídia - São Paulo - 31 maio a 02 de junho;

FERREIRA, D. P., BATISTA, C. M., STABILE, M. 2008. A evolução do sistema partidário brasileiro: número de partidos e votação no plano subnacional 1982-2006. OPINIÃO PÚBLICA, Campinas, vol. 14, nº 2, Novembro, 2008, p.432-453;

FLEISCHER, D. 1980. A evolução do bipartidarismo no Brasil, 1966-79. Revista Brasileira de Estudos Políticos, N. ${ }^{\circ} 51$ (julho de 1980), pp. 154-85;

1988a. As desventuras da Engenharia política: sistema eleitoral versus sistema partidário. In: Fleischer (org.), Da distensão à abertura - As eleições de 1982. Brasília: Editora UnB;

Editora UnB;

1988b. Da distensão à abertura - As eleições de 1982. Brasília:

1988c. Perfil Socio-Economico e Politico da Constituinte. In: Guran. (Org.). O Processo Constituinte, 1987- 1988. Brasília: AGIL/CEAC/Univ. de Brasília, v. , p. 29-40;

2002. As eleições municipais no Brasil: uma análise comparativa (1982-2000). OPINIÃO PÚBLICA, Campinas, Vol.VIII, nº1, pp.80-105;

2007. "Os partidos políticos" in AVELAR, Lúcia e CINTRA, Antônio Octávio. Sistema Político Brasileiro: uma introdução. Rio de Janeiro: Konrad Adenauer Stiftung; São Paulo: Editora UNESP, p. 303-348;

FIGUEIREDO, C.A.S. 2009. A relação dos PC's com o MDB-PMDB no cenário da transição e as eleições de 1982 no RS. - Dissertação de Mestrado - Instituto de 
Filosofia e Ciências Humanas da Universidade Federal do Rio Grande do Sul, Porto Alegre;

FUNDAÇÃO ULYSSES GUIMARÃES, 2013. Tancredo Neves - Pensamentos e fatos. Brasília: Editora Fundação Ulysses Guimarães;

FUNDAÇÃO ULYSSES GUIMARÃES, 2016. PMDB 50 anos. O partido que muda o Brasil. Brasília: Editora Positiva;

GASPARI, E. 2016. A Ditadura acabada. Rio de Janeiro: Editora Intrínseca.

GRAÇA, M. C. da. 2013. Roberto Freire - Esquerda sem dogma. Brasília: Fundação Astrojildo Pereira;

GRAMSCI, A. 2000. Cadernos do cárcere Vol. 3: Maquiavel. Notas sobre o Estado e a política. Rio de Janeiro: Civilização Brasileira;

GRINBERG, L. 2009. Partido político ou bode expiatório: um estudo sobre a Aliança Renovadora Nacional (ARENA), 1965-1979. Rio de Janeiro: Mauad X;

GOMES, A. de C. 2005. A Invenção do Trabalhismo. Rio de Janeiro: FGV Editora;

GUARNIERI, F.H.E. 2009. A força dos "partidos fracos" - um estudo sobre a organização dos partidos brasileiros e seu impacto na coordenação eleitoral. Tese de Doutoramento. Departamento de Ciência Política - Universidade de São Paulo;

GUNTHER, R; MONTERO, J. R. 2002. Introduction: Reviewing and Reassessing Parties. In: __ LINZ, Juan (Ed.). Political Parties: Old Concepts and New Challenges. Oxford: OUP;

HAGOPIAN, F.1992. "The compromised consolidation: the political class in Brazilian transition". In: S. Mainwaring, G. O'Donnell, A. Valenzuela. Issues in democratic consolidation: the south american democracies in comparative perspective. Notre Dame: University of Notre Dame Press;

Cambridge University Press;

1996. Tradition Politics and regime change in Brazil. Cambridge:

HIPPOLITO, L. 2012. De Raposas e Reformistas: o PSD e a experiência democrática brasileira (1945-64). Rio de Janeiro: Ed. Paz e Terra, 2ªEd.;

IBGE. 2011. Evolução da Divisão Territorial do Brasil 1872-2010 - IBGE. Disponível online em https://ww2.ibge.gov.br/home/geociencias/geografia/default_evolucao.shtm;

KAPISZEWSKI, D., MacLEAN, L. M., e READ, B.L. Field research in political science. New York and Cambridge: Cambridge University Press;

KATZ, R.S. e MAIR, P. 1992. Party Organizations: a data handbook on party organizations in western democracies, 1960-1990. Londres: Sage;

1993. The Evolution of Party Organizations in Europe: The

Three Faces of Party Organization. The American Review of Politics, v. 14, p. 593-617, winter;

1994. How parties organize: change and adaptation in party organizations in western democracies. Londres: Sage;

1995. Changing Models of Party Organization and Party Democracy: The Emergence of the Cartel Party. Party politics, vol. 1 n. 1, p 5-28; 
2002. The Ascendancy of the Party in Public Office: Party Organizational Change in Twentieth-Century Democracies. In: GUNTHER, R; MONTERO, J. R. e LINZ, J. (Ed.). Political Parties: Old Concepts and New Challenges. Oxford: OUP;

KAYSEL, A. 2015. Regressando ao Regresso: elementos para uma genealogia das direitas brasileiras, In: Velasco e Cruz S., Kaysel A. e Codas G. (Orgs.) Direita volver, São Paulo: Fundação Perseu Abramo;

KECK, M. 1991. A Lógica da Diferença: O Partido dos Trabalhadores na Construção da Democracia no Brasil. São Paulo: Ática;

KINZO, M.D.G. 1980. Novos partidos: o início do debate. In: B. LAMOUNIER (org.), Voto de desconfiança: eleições e mudança política no Brasil, 1970-1979. Petrópolis: Vozes;

1988. Oposição e autoritarismo: gênese e trajetória do MBD, 1966 1979. São Paulo: Vértice;

1989. Quadro partidário brasileiro na Nova República. Documento de trabajo - Clacso, Buenos Aires;

1990. O quadro partidário e a constituinte. In: Lamounier (org.), De Geisel a Collor: o balanço da transição. São Paulo: Idesp;

1993. Radiografia do quadro partidário brasileiro. Fundação Konradadenauerstiffung, Centro de Estudos;

2005. Os partidos no eleitorado: percepções públicas e laços partidários no Brasil. Revista Brasileira de Ciências Sociais, vol. 20, nº 57, p. 65-81;

KIRCHHEIMER, O. 1966. The transformation of the Western European party systems. In: LaPalombara, J. e Weiner, M., Political parties and political development. Princeton: Princeton University Press, p. 177-200;

KOTSCHO, R. 1984. Explode um novo Brasil: Diário da campanha das Diretas. São Paulo:Brasiliense;

KUSCHNIR, K. 2014. "Dez lições da vida acadêmica", Publicado em karinakuschnir.wordpress.com, url "http://wp.me/p42zgF-68". Acesso em 28/05/2018;

LAMOUNIER, B. 1989. Partidos e Utopias: o Brasil no limiar dos anos 90. São Paulo: Edições Loyola;

(Org.) 1990. De Geisel a Collor: o balanço da transição. São Paulo: IDESP, Editora Sumaré;

LAVAREDA, A. 1985. O Partido da Frente Liberal: o dissenso dos governadores pedessistas nordestinos e a busca de uma nova imagem. In: Falcão e Sá (Orgs.) Nordeste: eleições, Recife: Ed. Massangana, pp. 39-60;

Objetiva;

2009. Emoções Ocultas e Estratégias Eleitorais. São Paulo: Ed.

LAWSON, K. e MERKL, P. (Ed.). 1988. When Parties Fail: Emerging Alternative Organizations. Princeton: PUP;

LEONELLI, D. \& OLIVEIRA, D. 2004. Diretas Já: 15 meses que abalaram a ditadura. Rio de Janeiro: Record; 
LIMA, L. P. M. 2003. Congresso Constituinte brasileiro (1986-1988): expectativas, atuação e avaliação dos partidos comunistas e do partido dos trabalhadores. ANPUH XXII SIMPÓSIO NACIONAL DE HISTÓRIA - João Pessoa;

2009. A atuação da esquerda no processo constituinte: 1986-1988. Brasília: edições Câmara; LIMA JR, O. B. de.1993. Democracia e Instituições Políticas no Brasil dos Anos 80. São Paulo: Loyola;

LIMONGI, F. e FIGUEIREDO, A. 1999. Executivo e Legislativo na Nova Ordem Constitucional. Rio de Janeiro/São Paulo, FGV/FAPESP, 1999;

LIMONGI, F. e CORTEZ, R. 2010. As eleições de 2010 e o quadro partidário. Novos Estudos Cebrap, n. 88, p. 21-37;

LINZ, J, e STEPAN, A. 1992. Estados em vias de integração e de desintegração. Estud. av., São Paulo, v. 6, n. 14, p. 59-77, Apr. 1992 . Available from $<$ http://www.scielo.br/scielo.php?script=sci_arttext\&pid=S0103-

40141992000100005\&lng=en\&nrm=iso $>$ access on 16 Aug. 2018. http://dx.doi.org/10.1590/S0103-40141992000100005;

MACIEL, N.R.A. 2014. Velhas raposas, novos governistas: o PMDB e a democracia brasileira. Tese de doutorado, IESP-UERJ;

MACIEL, D. 2008. De Sarney a Collor: reformas políticas, democratização e crise (1985-1990). Tese de Doutorado em História - Universidade Federal de Goiás;

MADEIRA, R.M. 2006. Vinhos antigos em novas garrafas: a influência de ex-arenistas e ex-emedebistas no atual multipartidarismo brasileiro. Tese de doutoramento: PPGCPUFGRS;

2011. A atuação de ex-arenistas e ex-emedebistas na Assembleia

Nacional Constituinte. RBCS Vol. $26 \mathrm{n}^{\circ} 77$ Outubro;

MAINWARING, S. 2001. Sistemas partidários em novas democracias. O Caso do Brasil. Rio Grande do Sul e Rio de Janeiro: Mercado Aberto/ FGV;

MAINWARING, S., MENEGUELLO, R. e POWER, T. 2000. Partidos conservadores no Brasil contemporâneo. Quais são, o que defendem, quais são suas bases. São Paulo: Paz e Terra;

MAINWARING, S. P. \& LIÑAN, A. P. 1998. Disciplina partidária: o caso da Constituinte. Lua Nova, n.44, p.107-136;

MANFFRÉ, D.C. 2014. ARENA paulista: a trajetória do partido sob o ponto de vista dos conflitos na coalizão dominante estadual (1965-1979). Dissertação de mestrado apresentada ao Programa de Pós-Graduação em Ciência Política da UFSCAR;

MARQUES, J. R. \& FLEISCHER, D. V. 1999. De facção a partido: o Partido da Social Democracia Brasileira (PSDB) (1987/1995). Brasília: Instituto Teotônio Vilela;

MARQUES, M.S.B.. 1988. O Plano Cruzado: teoria e prática. Revista de Economia Política, vol. 8, n. 3, julho-setembro;

MARTINS, R. 2015. O PSDB na Origem: uma análise do período Constituinte. Trabalho preparado para o V Seminário Discente do Programa de Pós-Graduação em Ciência Política da Universidade de São Paulo de 13 a 17 de abril de 2015; 
MAYER, R. 2009. PSDB: TRAJETÓRIA POLÍTICA (1988-2008). I Seminário Nacional Sociologia e Política 2009 - UFPR.

MEDEIROS, D. B. 2013. Organizando maiorias, agregando preferências: a Assembleia Nacional Constituinte de 1987-1988. Dissertação de mestrado, Departamento de Ciência Política da FFLCH - USP;

MEDEIROS, D.B., FREITAS. A.M., IZUMI, M.Y. 2013. Coalizões e Comportamento Legislativo No Brasil (1988-2010). Trabalho apresentado no III Seminário Discente da Pós- Graduação em Ciência Política da USP, de 22 a 26 de abril;

MELHEM, C. S. 1998. Política de botinas amarelas - o MDB-PMDB paulista de 1965 a 1988. São Paulo: Hucitec;

MELHEM, C. S. \& RUSSO, S. M.1987. PMDB, democracia sempre. São Paulo: Global Editora;

São Paulo: Artemeios;

2004. Dr. Ulysses - o homem que pensou o Brasil.

MELO, C. R. 2000. Partidos e Migração Partidária na Câmara dos Deputados. Dados vol.43 n.2 Rio de Janeiro;

2006. Sistema partidário, presidencialismo e reforma política no Brasil. In: SOARES, G. e RENNÓ, L. (orgs.) Reforma política: lições da história recente. Rio de Janeiro: Fundação Getúlio Vargas;

2010. Eleições presidenciais, jogos aninhados e sistema partidário no Brasil, Revista Brasileira de Ciência Política, Brasília, nº 4, pp. 13-41;

MELO, P.V.T.P. 2011. (P) MDB: de rebelde a status quo. Revista Eletrônica de Ciência Política, vol. II, n. 2;

2013. O PMDB e a sua manutenção no centro do jogo político: de catch all a cartel. Dissertação de mestrado apresentada ao Programa de Pós-Graduação em Ciência Política, da Faculdade de Filosofia e Ciências Humanas da Universidade Federal Minas Gerais;

MENDES, A. M. T e VENTURI, G. 1994. Eleição presidencial: o Plano Real na sucessão de Itamar Franco. Opinião Pública, Campinas, vol. II, nº 2, Dezembro, p. 5972 ;

MENDONÇA, D. A vitória de Tancredo Neves no Colégio Eleitoral e a posição política dos semanários Veja e Isto É. ALCEU - v.5 - n.10 - p. 164 a 185 - jan./jun.;

MENEGOZZO, C.H.M. 2013. Partido dos Trabalhadores - Bibliografia comentada (1978-2002). São Paulo: Fundação Perseu Abramo;

2017. Bibliografia sobre o PT: balanço e parâmetros para novas abordagens. São Paulo: Fundação Perseu Abramo, Revista Perseu No 14, Ano 11;

MENEGUELLO, R. 1989. PT: a formação de um partido (1979-1982). Rio de Janeiro: Paz e Terra;

São Paulo: Paz e Terra;

1998. Partidos e Governos No Brasil Contemporâneo (1985-1997).

1999. Governo Sarney: dilemas e virtudes de uma transição negociada. Secuencia: Revista de Historia y Ciencias sociales, n. 44, mayo-agosto, 3772 ; 
MENEGUELLO, R. e BIZZARRO NETO, F. 2012. Contexto e competição na política paulista. Dados, Rio de Janeiro , v. 55, n. 1, p. 119-171. Disponível em: <http://www.scielo.br/scielo.php?script=sci_arttext\&pid=S0011-

52582012000100004\&lng=en\&nrm=iso>. Acessado em $08 \quad$ Nov. 2018. http://dx.doi.org/10.1590/S0011-52582012000100004.

MESQUITA, E. 2016. Ideologia do centro. Fundação Ulysses Guimarães, disponível online em http://pmdb.org.br/artigos/ideologia-do-centro/ - consultado em 20 de dezembro de 2017;

MEZAROBBA, G. 2003. Um acerto de contas com o futuro. A anistia e suas consequências: um estudo sobre o caso brasileiro. Dissertação de Mestrado Departamento de Ciência Política da USP;

2006. Um acerto de contas com o futuro: a anistia e suas consequências. São Paulo: Humanitas/Fapesp;

MIYAMOTO, S. 1980. Eleições de 1978 em São Paulo: a campanha. In: LAMOUNIER, B. (org.), Voto de desconfiança: eleições e mudança política no Brasil, 1970-1979. Petrópolis: Vozes;

MICHELS, R, 1915. Political Parties - A sociological study of the oligarchical tendencies of modern democracies. New York: Hearst's International Library Co.;

MIGUEL, L. F. 1999. Mídia e Eleições: A Campanha de 1998 na Rede Globo. Dados, vol. 42, n 2, pp. 253-276;

MOREIRA, S.V. 1998. Rádio Palanque - fazendo política no ar. Rio de Janeiro: Mil Palavras;

MOURA, A.R.1990. Rumo à entropia: a política econômica de Geisel a Collor. In: Lamounier (org.) 1990. De Geisel a Collor: o balanço da transição. São Paulo: IDESP, Editora Sumaré;

MOTTA, R. P. S. 1997. Partido e sociedade. A trajetória do MDB. Ouro Preto: Editora UFOP;

MOTTA, M. S. da. 2000. Mania de estado: o chaguismo e a estadualização da Guanabara. História Oral. São Paulo: v. 3;

MOTTER, P. 1994. O uso político das concessões das emissoras de rádio e televisão no governo Sarney. Comunicação \& Política, Brasília, vol. 1, n. 1, p. 89-116;

MOURA, A. R. 1990. Rumo à entropia: a política econômica, de Geisel a Collor. In: LAMOUNIER, Bolivar (Org.). De Geisel a Collor: o balanço da transição. São Paulo: IDESP, pp. 37-59;

MUCINHATO, R. M. D. 2015. Um passo adiante, dois passos para trás: o PMDB de 1979 a 1982. Dissertação (Mestrado em Ciência Política) - Faculdade de Filosofia, Letras e Ciências Humanas, Universidade de São Paulo, São Paulo, 2015. Disponível em: <http://www.teses.usp.br/teses/disponiveis/8/8131/tde-02062015-175330/>.

MUSZYNSKI, M.J de B. 1989. Os eleitores paulistanos em 1986: a marca do oposicionismo. In: Eleições 1986. São Paulo: IDESP/Vertice;

NADER, A.B. 1998. Autênticos do MDB, semeadores da democracia - história oral de vida política. São Paulo: Paz e Terra; 
NICOLAU, J. 1996. Multipartidarismo e Democracia: Um Estudo Sobre O Sistema Partidário Brasileiro (1985-94). Rio de Janeiro: Ed. FGV, 1996;

1998. Dados eleitorais no Brasil (1982-1996). Rio de Janeiro: Editora Revan e IUPERJ/UCAM;

2010. Partidos e Sistemas Partidários: 1985-2009. In: LESSA, Renato (Org.). Horizontes das Ciências Sociais no Brasil: Ciência Política. São Paulo: Barcarolla;

NUNES, A., LAMOUNIER, B. e STUDART, H. 1994. Os presidenciáveis: vida, obra e promessas dos candidatos ao Palácio do Planalto. Rio de Janeiro: Francisco Alves;

OLIVEIRA, B.K.V. 2012. Da transição democrática ao governo Lula: a trajetória e o papel político do PMDB. Dissertação de mestrado, DCS - UFCE;

OSTROGORSKI, M. J. 1970. Democracy and the Organization of Political Parties. New York: Haskell;

PAIM, A. 2000. O socialismo brasileiro (1979-1999). Brasília: Instituto Teotônio Vilela;

PALMEIRA, A.F. 2015. A Trajetória do MDB/PMDB e a política brasileira nas últimas décadas. Revista Convergência Crítica - Dossiê História Urbana, v. n. 7;

PANEBIANCO, A. 2005. Modelos de partido. Organização e poder nos partidos políticos. São Paulo: Martins Fontes;

PASQUARELI, B. e BIZZARRO NETO, F. 2012. O PMDB no centro do sistema político brasileiro (1986-2010). $8^{\circ}$ Encontro da ABCP, 01 a 04/08/2012, Gramado, RS;

PEREIRA, A. 2002. Depois de FHC. São Paulo: Geração Editorial;

PESSOA, N. 1994. Quércia - A trajetória de um vencedor. Rio de Janeiro: Civilização Brasileira;

PIERANTI, O. P. 2006. Políticas para a mídia: dos militares ao governo Lula. Lua Nova, São Paulo, 68: 91-121;

PINHEIRO, L. A. 1993. A República dos golpes. São Paulo: Círculo do Livro;

PINTO, A.A. e MUNIZ, M.L. 2008. Democracia partida: divergências e conciliações no processo de liberalização do regime militar e de reestruturação dos espaços de representação. III Seminário Internacional Organizações e Sociedade: Inovações e Transformações Contemporâneas, Porto Alegre, 11 a 14 de novembro;

POWER, T. 1990. A direita política: discurso e comportamento, 1987-1990. Apresentado no Seminário Nacional sobre comportamento político, UFSC, março;

1997. The political right in postauthoritarian Brazil. Elites, Institutions and democratization. University Park: Pennsylvania University Press;

REIS, F.W. 2010. Identidade política, desigualdade e partidos brasileiros. Novos Estudos, n. 87, Julho;

RENNO, L. e SPANAKOS, A. P. 2006. Fundamentos da economia, mercado financeiro e intenção de voto: as eleições presidenciais brasileiras de 1994, 1998 e 2002. Dados, Rio de Janeiro , v. 49, n. 1, p. 11-40. Available from <http://www.scielo.br/scielo.php?script=sci_arttext\&pid=S0011- 
52582006000100002\&lng=en\&nrm=iso>. access on $20 \quad$ Nov. 2018. http://dx.doi.org/10.1590/S0011-52582006000100002.

RIBEIRO, P. F. 2010. Dos sindicatos ao governo. A organização nacional do PT de 1980 a 2005. São Carlos: EdUFSCAR;

2013. Organização e poder nos partidos brasileiros: uma análise dos estatutos. Revista Brasileira de Ciência Política, nº10. Brasília, janeiro - abril, pp. 225265 ;

2014. Em nome da coesão: parlamentares e comissionados nas executivas nacionais dos partidos brasileiros. Rev. Sociol. Polit., v. 22, n. 52, p. 121158, dez.;

RIBEIRO, R. L. M. 2011. A Decadência Longe do Poder - Refundação e Crise do PFL. Dissertação de mestrado, DCP - FFLCH - Universidade de São Paulo;

2016. PFL: do PDS ao PSD. Tese de doutorado, DCP - FFLCH Universidade de São Paulo;

RIVERA, S., KOZYREVA, P., \& SAROVSKII, E. 2002. Interviewing Political Elites: Lessons from Russia. PS: Political Science and Politics, 35(4), 683-688. Disponível online em http://www.jstor.org/stable/1554810, acesso em 29/05/2018;

ROCHA, A.S. 2013. Genealogia da Constituinte: do autoritarismo à democratização. Lua Nova, São Paulo, 88: 29-87;

ROCHA, C. 2015. A breve esquerda tucana: MUP/socialistas-democráticos (19871990). Trabalho preparado para o V Seminário Discente do Programa de Pós-Graduação em Ciência Política da Universidade de São Paulo de 13 a 17 de abril de 2015;

RODRIGUES, L. M. 1983. O PCB: dirigentes e organização. In: Fausto, B. (Org.) História da civilização brasileira. O Brasil republicano, Vol. 3 Tomo III, São Paulo: Difel;

1987. Quem é quem na Constituinte. Uma análise sócio-política dos partidos e deputados. São Paulo: OESP/MALTESE;

2002;

2002. Partidos, Ideologia e Composição Social. São Paulo: Edusp,

ROMA, C. 1997. A social democracia no Brasil: organização, participação no governo e desempenho eleitoral do PSDB, 1988-1998 . Dissertação de mestrado, DCP - FFLCH Universidade de São Paulo;

2002. A institucionalização do PSDB entre 1988 e 1999. Revista Brasileira

de Ciências Sociais 17(49), junho, p. 71-92;

SADEK, M. T. 1989a. A interiorização do PMDB nas eleições de 1986 em São Paulo. In: Eleições 1986. São Paulo: IDESP/Vertice;

1989b. Eleições 1988: retórica ou rumo pluripartidário. In: Lua NovaRevista de Cultura e Política, n.17, p.111-132, São Paulo; (org.) 1989c. Eleições 1986. São Paulo: IDESP/Vertice;

1993. Sistema Partidário Brasileiro: a debilidade institucional. Instituto de Estudios Económicos, Sociais e Politicos, São Paulo; Working Paper n.72 Barcelona; 
SÁ, J. M. de. 2011. A organização institucional do Partido do Movimento Democrático Brasileiro (PMDB) e sua atuação na ARENA eleitoral do estado do Piauí: 1986-2006. Dissertação de mestrado, Programa de Pós-Graduação em Ciência Política do Centro de Ciências Humanas e Letras da Universidade Federal do Piauí, UFPI;

SALES, J. R. 2007. Entre o fechamento e a abertura: a trajetória do PCdoB da guerrilha do Araguaia à Nova República (1974-1985). História, São Paulo, v. 26, n. 2, p. 340365 ;

2008. Entre a revolução e a institucionalização: a participação eleitoral do PC do B na história recente do Brasil. Estudos Históricos, Rio de Janeiro, vol. 21, no 42, julho-dezembro de 2008, p. 241-260;

SALLUM JR. B. e CASARÕES, G. S. P. e. 2011. O impeachment do presidente Collor: a literatura e o processo. Lua Nova, São Paulo, 82: 163-200;

SAMPAIO, R. 1982. Adhemar de Barros e o PSP. São Paulo: Global Editora;

SAMUELS, D. 1996. "Legislative Lilliputians?" Toward a theory of party cohesion in the brazilian Chamber of Deputies. Paper apresentado na 1996 Annual Meeting of the American Political Science Association, august 29 -september 1;

SAMUELS, D. \& ZUCCO, C. 2013. The Power of Partisanship in Brazil: Evidence from Survey Experiments. American Journal of Political Science, pp. 1-14, disponível online em: http://www.fgv.br/professor/cesar.zucco/files/PaperAJPS2014.pdf

SANTOS, A.C., 2011. A transição do regime militar para a democracia: o Partido Comunista do Brasil (PC do B) entre enlaces e jogos da política. Anais do XXVI Simpósio Nacional de História - ANPUH • São Paulo, julho 2011;

SANTOS Jr., J. de O. 2009. A Subalternização da Classe Operária na Autocracia Burguesa: A Política de Alianças Eleitorais do PCdoB (1962 - 1987). Dissertação de mestrado em Ciências Sociais - UNESP Marília;

SARMENTO, C.E. 1999. A morte e a morte de Chagas Freitas : a (des)construção de uma imagem pública : trajetória individual e reelaboração memorialística. Rio de Janeiro , CPDOC, apresentado no XXIII Encontro Anual da Anpocs e disponível online em https://cpdoc.fgv.br/producao_intelectual/arq/1158.pdf ;

2002. O espelho partido da metrópole: Chagas Freitas e o campo político carioca (1950-83): liderança, voto e estruturas clientelistas. Tese (Doutorado) IfcsfUFRJ, Rio de Janeiro;

SCARTEZINI, A.C. 1993. Dr. Ulysses - uma biografia. São Paulo: Marco Zero;

SCHMITT, R. 2000. Partidos Políticos no Brasil (1945-2000). Rio de Janeiro: Jorge Zahar Editora;

SCULLY, T. R. 1992. Rethinking the Center: Party Politics in Nineteenth- and Twentieth-Century Chile. Stanford: Stanford University Press;

SILVA, A.O. da. 1987. História das tendências no Brasil (origens, cisões e propostas). São Paulo: Proposta Editorial;

SILVA, V.A.C. e DELGADO, L. de A. N., 1985. Tancredo Neves: a trajetória de um liberal. Petrópolis: Editora Vozes e Editora UFMG; 
SIMONI JR, S. \& BORGES, T.D.P. 2011. O PMDB e sua evolução frente à bipolarização da competição partidária brasileira. II Fórum Brasileiro de Pós-Graduação em ciência política, UFSCAR - São Carlos;

SINGER, A. 2002. Esquerda e Direita no Eleitorado Brasileiro: a identificação ideológica nas disputas presidenciais de 1989 e 1994. São Paulo: EDUSP;

SKIDMORE, T. E. 2004. Brasil: De Castelo a Tancredo, 1964-1985. São Paulo: Paz e Terra, $8^{\mathrm{a}}$ ed;

SOARES, G. A. 1984. Colégio eleitoral, convenções partidárias e eleições diretas. Petrópolis: Vozes;

SOUZA, A., LIMA JÚNIOR, O. B. \& FIGUEIREDO, M. 1985. Brizola e as eleições de 1982. Rio de Janeiro: IUPERJ;

TANSEY, O. 2007. Process Tracing and Elite Interviewing: A Case for Non-probability Sampling. PS: Political Science \& Politics, 40(4), 765-772. doi:10.1017/S1049096507071211;

TAROUCO, G. da S. 1999. O Partido da Frente Liberal: trajetória e papel no sistema político. Dissertação de mestrado. IFCH - Unicamp;

TAROUCO, G. da S. \& MADEIRA, R. M. 2013. Partidos, programas e o debate sobre esquerda e direita no Brasil. Revista de Sociologia e Política, V. 21, No 45 : 149-165 março;

TRINDADE, H. 1981. Eleições e partidos no Rio Grande do Sul: do sistema multipartidário à criação do bipartidarismo (1950-1976). In: Fleischer, D. (org.). Os partidos políticos no Brasil. Brasília: Editora UnB;

1985. Partidos políticos e transição democrática: populismo/antipopulismo na política brasileira. Reunião GT - Elites políticas da Associação Nacional de Pós-Graduação e Pesquisa em Ciências Sociais - Águas de São Pedro São Paulo - outubro;

VALLE, V. S. M. do. 2015. Partidos Cristãos do Brasil recente: o caso do PRB e do PSC. Trabalho apresentado no V Seminário Discente da Pós-Graduação em Ciência Política da USP, de 4 a 8 de maio de 2015;

VÁZQUEZ, F.R. (org.) 2003. Partido Revolucionario Institucional: crisis y refundación. México: UNAM/Gernika;

VIANA FILHO, L. 1975. O governo Castelo Branco. Rio de Janeiro : J. Olympio;

VIEIRA, S. M. 2012. O Partido da Social Democracia Brasileira: entre a Social Democracia e o Neoliberalismo. Revista STUDIA POLITICÆ, n. 27;

YAZBECK, I. 2011. O real Itamar. Belo Horizonte: Editora Gutenberg/Grupo Autêntica.

\section{$\underline{\text { Entrevistas realizadas }}$}

Pedro Simon - 10 de setembro de 2015 - Porto Alegre/RS

João Carlos Brum Torres - 11 de setembro de 2015 - Porto Alegre/RS

Tonico Ramos - 27 de julho de 2017 - São Paulo/SP 
Luiz Carlos Bresser Pereira - 1 de agosto de 2017 - São Paulo/SP

Jarbas Vasconcelos - 9 de agosto de 2017 - Brasília/DF

Airton Sandoval - 16 de agosto de 2017 - Brasília/DF

Sônia Carneiro - 16 de agosto de 2017 - Brasília/DF

Roberto Requião - 18 de agosto de 2017 - Brasília/DF

Jader Barbalho - 23 de agosto de 2017 - Brasília/DF

Mauro Benevides - 24 de agosto de 2017 - Brasília/DF

Marcelo Barbieri - 7 de dezembro de 2017 - São Paulo/SP

Pedro Pinheiro Chaves - 20 de fevereiro de 2018 - Brasília/DF

Flaviano Melo - 21 de fevereiro de 2018 - Brasília/DF

Marcelo Castro - 21 de fevereiro de 2018 - Brasília/DF

Rogério Peninha Mendonça - 28 de fevereiro de 2018 - Brasília/DF

Saraiva Felipe - 28 de fevereiro de 2018 - Brasília/DF

Raimundo Lira - 6 de março de 2018 - Brasília/DF

Rose de Freitas - 7 de março de 2018 - Brasília/DF

Raymundo Urbano - 13 de março de 2018 - Brasília/DF

Celso Maldaner - 13 de março de 2018 - Brasília/DF

Mauro Lopes - 13 de março de 2018 - Brasília/DF

Funcionária 1 - 19 de março de 2018 - Brasília/DF (alta funcionária do partido há mais de 30 anos)

Garibaldi Alves - 21 de março de 2018 - Brasília/DF

Miro Teixeira - 21 de março de 2018 - Brasília/DF

Cássio Cunha Lima - 27 de março de 2018 - Brasília/DF

Heráclito Fortes - 28 de março de 2018 - Brasília/DF

\section{$\underline{\text { Entrevistas coletadas em acervos }}$}

Almino Affonso - 23 de agosto de 2007 - Programa Memória Política da TV Câmara (transcrição disponível online em http://www2.camara.leg.br/acamara/conheca/historia/historia/historiaoral/Memoria\%20Politica/Depoimentos/copy_ of_almino-affonso/texto.html) 
Francisco Dornelles - 29 de março de 2007 - Programa Memória Política da TV Câmara (transcrição disponível online em http://www2.camara.leg.br/acamara/conheca/historia/historia/historiaoral/Memoria\%20Politica/Depoimentos/francis co-dornelles/texto)

Josaphat Marinho - 23 de agosto de 2007 - Programa Memória Política da TV Câmara (transcrição disponível online em http://www2.camara.leg.br/acamara/conheca/historia/historia/historiaoral/Memoria\%20Politica/Depoimentos/josaph at-marinho.html/texto.html)

Mário Covas - 29 de novembro de 1999 - Programa Roda Viva (transcrição disponível online

http://www.rodaviva.fapesp.br/materia/726/entrevistados/mario_covas_1999.htm)

Paulo Affonso Martins de Oliveira - 11 de outubro de 2000 - Programa Memória Política da TV Câmara (transcrição disponível online em http://www2.camara.leg.br/acamara/conheca/historia/historia/historiaoral/Memoria\%20Politica/Depoimentos/pauloaffonso-martins-de-oliveira/texto)

Roberto Freire - 6 de março de 2005 - Jornal do Comércio (disponível online em http://www.camara.gov.br/sileg/integras/303766.pdf)

Tancredo Neves - setembro de 1984 - Revista Lua Nova vol. 1 n. 2. (disponível online em http://www.scielo.br/scielo.php?script=sci_issuetoc\&pid=0102-644519840002)

\section{Legislacão Consultada:}

Lei Complementar $\mathrm{n}^{\circ} 15$ de 13/08/1973, Decreto-Lei $\mathrm{n}^{\circ} 1.539$ de 14/04/1977 e Lei Complementar $n^{\circ} 47$ de 22/10/1984. Legislação que rege a composição do Colégio Eleitoral durante o Regime Militar.

Lei $n^{\circ}$ 6.767, de 20 de dezembro de 1979 - Altera a Lei Orgânica dos Partidos Políticos de 1971 e restabelece o pluripartidarismo - disponível online em http://www2.camara.leg.br/legin/fed/lei/1970-1979/lei-6767-20-dezembro-1979357280-publicacaooriginal-1-pl.html acessado em 20/06/2016

Resolução Eleitoral do TSE n 10.786 , de 15 de fevereiro de 1980. Cancela os registros dos partidos criados durante o bipartidarismo. Disponível online em http://www.tse.jus.br/hotSites/registro_partidario/mdb/arquivos/Cancelamento.pdf acessado em 11/07/2018

Lei $n^{\circ}$ 6.978, de 19 de janeiro de 1982 - Conhecido como o "Pacote de Novembro" (de 1981), aprovado por decurso de prazo - disponível online em http://www2.camara.leg.br/legin/fed/lei/1980-1987/lei-6978-19-janeiro-1982-356689publicacaooriginal-1-pl.html acessado em 20/04/2016 
Emenda Constitucional $\mathrm{n}^{\mathrm{o}} 22$, de 29 de junho de 1982 - Reabre as filiações parlamentares (permite migrações rumo ao PDS sem que houvessem punições), e adiava o Colégio Eleitoral previsto para outubro de 1984 para janeiro de 1985 - disponível online em http://www2.camara.leg.br/legin/fed/emecon/19801987/emendaconstitucional-22-29-junho-1982-363993-publicacaooriginal-1-pl.html acessado em 04/05/2018

Emenda Constitucional $\mathrm{n}^{\circ}$ 25, de 15 de maio de 1985 - Flexibiliza as regras de fundação dos partidos, trazendo à legalidade os partidos clandestinos, e também as regras de fidelidade na filiação partidária - disponível online em http://www2.camara.leg.br/legin/fed/emecon/1980-1987/emendaconstitucional-25-15maio-1985-364956-publicacaooriginal-1-pl.html consultado em 3/04/2017

Emenda Constitucional $\mathrm{n}^{\mathrm{o}}$ 26, de 27 de novembro de 1985 - Convoca a Assembleia Nacional Constituinte, estipulando seu formato congressual a partir do resultado das eleições $\quad$ de $1986 \quad-\quad$ disponível $\quad$ online http://www.planalto.gov.br/ccivIl_03/Constituicao/Emendas/Emc_anterior1988/emc2685.htm

Lei no 9.096, de 19 de setembro de 1995 - Lei dos Partidos Políticos - disponível online em http://www.tse.jus.br/legislacao/codigo-eleitoral/lei-dos-partidos-politicos/lei-dospartidos-politicos-lei-nb0-9.096-de-19-de-setembro-de-1995 acessado em 04/05/2018

Para ver toda a legislação partidária detalhada, ver: http://www2.camara.leg.br/legin/fed/lei/1970-1979/lei-5682-21-julho-1971-357872norma-pl.html acessado em 23/4/2018

\section{Documentos históricos ou partidários consultados:}

Ata da $341^{a}$. Sessão da Assembleia Nacional Constituinte, em 5 de outubro, de 1988 Diário da ANC - Ano II, n. 308

Pedido de Registro Partidário Definitivo - RGP n 38 - Resolução/TSE no 11.042

Pedido de Registro Definitivo - RGP nº 40 - Resolução/TSE nº 11.075

Processo 6.371 - Resolução/TSE n ${ }^{\circ} 11.192$

Revista do PMDB - publicação da Fundação Pedroso Horta

Jornal São Paulo Hoje - publicação do Diretório Regional do PMDB de SP

Revista do Cinquentenário do PMDB Catarinense - Democracia 1966-2016: Essa chama nunca se apaga. Publicação comemorativa do Diretório Regional do PMDB de Santa Catarina

Manual de Identidade Visual do PMDB - 2001, Fundação Ulysses Guimarães

Manual de Identidade - 1997, Fundação Pedroso Horta 
Estatuto do Partido do Movimento Democrático Brasileiro - 1996

\section{$\underline{\text { Acervos consultados: }}$}

Acervo digital da revista Veja -

http://veja.abril.com.br/complemento/acervodigital/index-novo-acervo.html

Acervo digital da Coluna do Castello -

http://www.carloscastellobranco.com.br/sec_coluna.php

Centro de Pesquisa e Documentação de História Contemporânea do Brasil, CPDOC/FGV - http://www.fgv.br/cpdoc/acervo/arquivo

Acervo digital do jornal Estadão - http://acervo.estadao.com.br/

Acervo digital do jornal Folha de S. Paulo - acervo.folha.uol.com.br

Acervo da Seção de Gerenciamento de Dados Partidários do Tribunal Superior Eleitoral - SEDAP/TSE

Acervo da Sede Nacional da Fundação Ulysses Guimarães - FUG Brasília

Acervo da Sede Estadual da Fundação Ulysses Guimarães de São Paulo - FUG SP

Acervo digital - Memória Orestes Quércia - http://ninive.selfip.com:8080/quercia/ 


\section{ANEXO 1}

\section{MANIFESTO DOS FUNDADORES DO PMDB À NAÇÃO}

A luta pela democracia no Brasil inicia, hoje, mais uma etapa com a fundação do Partido do Movimento Democrático Brasileiro. Com a extinção do MDB, o regime autoritário tomou a mais violenta de uma longa série de medidas que se assemelham todas no fundamental. Sempre que as oposições, fiéis à vontade popular, ameaçaram o poder discricionário e se constituíram em alternativa de governo, o sistema, mudando casuisticamente as regras vigentes, procurou impedir essa alternância. Agora, perpetra-se, repete-se e perpetua-se o golpe de estado com flagrante ofensa aos princípios constitucionais.

Enquanto o governo preserva o controle sobre o aparelho do Estado através de expedientes que esvaziam de conteúdo real as instituições republicanas, tornando-as verdadeira farsa para deturpar a vontade popular, procura, ainda que de maneira confusa e vacilante, assegurar um crescimento econômico, afastando as maiorias populares da riqueza e do poder. Este, sustentado pela aliança entre a burocracia estatal, as classes ricas e as empresas multinacionais, propõe-se a manter inalterada a situação social e utiliza a retórica de que o país se transformou numa potência emergente. As forças dominantes, embora acenando com a ampliação do acesso ao consumo, na verdade não sacrifica o luxo de poucos para abolir a miséria de muitos. Exige que as formas limitadas do pluralismo político tolerado se desenvolvam dentro dos estreitos, porém variáveis limites impostos pelos governantes para que a maioria não se torne militante e mobilizada. Nesse sentido procura reduzir os cidadãos a uma massa inerme e obediente, construir a nação-potência sobre a base das desigualdades sociais e regionais existentes. E não hesita em usar todas as armas do golpismo pseudoconstitucional para impedir que a luta da oposição, dentro ou fora dos partidos, frustre essas intenções liberticidas.

Bem poderiam as oposições sentir desalento ao ver tantas vezes mudadas as condições da vida política para sofismar as manifestações e fugir às consequências do repúdio popular. 0 Movimento Democrático Brasileiro foi o grande instrumento das oposições. Cresceu apesar de todas as adversidades e todas as descrenças, até tornar-se, pelo voto, representante inequívoco da maioria da Nação. Superou todos os casuísmos com que se procurou detê-lo, até que o governo teve que recorrer ao expediente fascista e final da dissolução partidária.

Os fundadores do PMDB lembram à Nação que a fé e a esperança dos brasileiros insubmissos fizeram de cada um desses motivos de desalento uma oportunidade para um novo avanço contra o governo, o regime discricionário e a ordem social que o regime e o governo querem manter. E declaram que a maior truculência de todas - a dissolução coercitiva do Movimento Democrático Brasileiro - será transformada, pela mesma esperança e pela mesma fé, de um número cada vez maior de brasileiros revoltados, no maior de todos os avanços: a construção do Partido do Movimento Democrático Brasileiro.

A nação não esquece que cada arbitrariedade do regime permitiu sempre uma definição mais nítida das forças oposicionistas. Enquanto alguns, nominalmente da oposição, fraquejavam e transigiam, outros, muitas vezes vindo das bases partidárias e dos novos movimentos sindicais 
e comunitários, engajavam-se na luta. Agora, esse mesmo avanço dar-se-á em dimensão maior. O PMDB congregará todas as correntes verdadeiramente populares e democráticas. Não servirá de instrumento aos que colaboram, direta ou indiretamente, com o governo, nem aos que não estejam realmente dispostos a participar de uma obra de mobilização popular. $\mathrm{E}$ ganhará novos quadros que, até hoje, permanecem afastados da política partidária por não identificá-la como veículo adequado aos movimentos de base.

A nação não esquece que o combate ao autoritarismo ensinou a todos que a eficácia da resistência contra um regime que usa as próprias formas constitucionais como armas do arbítrio, dependeu sempre da capacidade de transformar a política partidária num meio de organização e conscientização em profundidade. E, como tal, começar superando o imenso abismo entre a política das cúpulas e a política das bases, entre as aspirações das minorias marginalizadas.

Portanto, o PMDB deseja ser o grande instrumento de aprofundamento da resistência democrática e será sobretudo o estuário de todas as correntes do pensamento livre, inconformados com a tutela a que a Nação esta submetida. Haverá de romper cada vez mais o círculo fechado da política das elites e integrando a atividade partidária e parlamentar numa tarefa maior de pregação e militância. Tarefa que há de ser executada não só no âmbito parlamentar, mas em todos os lugares onde os brasileiros moram e trabalham e em íntima ligação com os movimentos sindicais e comunitários.

O PMDB será o caminho das oposições que compreendam que a luta contra o autoritarismo há de ter o seu desfecho não apenas na reconstitucionalização do Estado, mas na democratização da sociedade, através de um engajamento cada vez mais combativo e organizado de todos os brasileiros e em especial das camadas populares e da classe média. Os compromissos que norteiam o nosso partido e a concepção de sua prática política são o fruto de um duro aprendizado, ganho no curso de uma resistência a que se incorporam lideranças dos movimentos sociais emergentes. As reivindicações definidoras do partido nos campos político e econômico-social serão formuladas à luz dessa experiência histórica concreta. E, se o partido terá por objeto imediato opor-se ao autoritarismo, perfigurará, através da própria maneira de fazer oposição, as linhas mestras de uma sociedade e uma cultura democratizadas, emancipadas não só das desigualdades cruas, como também dos paternalismos sutis.

O Partido do Movimento Democrático Brasileiro:

1) Prosseguirá e intensificará a luta travada pelo Movimento Democrático Brasileiro em prol das grandes teses democráticas: manutenção do calendário eleitoral, eleições diretas em todos os níveis, defesa da autonomia dos Municípios e fortalecimento da Federação, democratização do ensino, anistia ampla, geral e irrestrita, liberdade de informação, restauração dos poderes do Congresso e convocação de uma Assembleia Nacional Constituinte.

2) Surgirá disposto a uma política de organização e de mobilização, sobretudo frente aos conflitos, sempre pela via de militância pacífica e democrática.

3) Terá como tarefa fazer uma oposição confiável ao povo, não aos detentores do poder. 
4) Dará primazia à obra de mobilização popular, com o fortalecimento das bases partidárias e o avanço e aprofundamento da auto-organização sindical e comunitária dos setores não organizados do povo.

5) Lutará pelas garantias econômicas e jurídicas - a erradicação da miséria e a liberdade de organização - que permitam a execução da tarefa mobilizadora e assegurem a autonomia associativa; defenderá os direitos dos trabalhadores rurais e urbanos, a autonomia e a liberdade dos sindicatos perante o Estado e os empresários, a instituição do delegado sindical nos locais de trabalho, a negociação direta entre patrões e empregados e o direito de greve.

6) Adotará uma forma de organização interna que afirme o princípio do colegiado efetivo na sua direção, que estabeleça um debate participativo e permanente sobre o programa e a ação partidária e que engaje, em todos os níveis, os quadros não parlamentares e as lideranças dos movimentos sociais em formação.

7) Propugnará um programa que aponte o caminho para a democratização das formas de poder, a produção e a erradicação da miséria, sem cair em fórmulas pré concebidas, nem se satisfazer com a mera redistribuição do consumo.

8) Procurará fazer-se o grande instrumento de uma força majoritária de transformação social que se contraponha não só ao estado autocrático e à ordem econômica iníqua, como também a uma cultura paternalista e autoritária: um partido combativo e popular, que fale uma linguagem e desenvolva uma prática aberta às classes médias, ao operariado organizado e às massas miseráveis e marginalizadas.

9) Exigirá que a integração da nação - eliminados os abismos entre classes e regiões - se realize por uma política de acumulação e investimento que associe os centros decisórios do Estado às necessidades e à participação dos assalariados e dos pequenos e médios proprietários, em vez de associá-los aos grandes oligopólios nacionais e estrangeiros, que participam do sistema da miséria e da desnacionalização. Lutará pela defesa intransigente dos nossos recursos naturais, hoje explorados de forma predatória e entreguista por grupos internacionais.

10) Proporá frente democrática com outros partidos de oposição que vierem a surgir, respeitando os compromissos partidários de cada um e lutando por um pluripartidarismo absolutamente livre da tutela estatal e da influência do poder econômico.

Buscamos, na fidelidade a esses compromissos, uma sociedade que, através de sua batalha contra o Estado autocrático, seja capaz de organizar-se para praticar a democracia não apenas no governo, mas em todas as instituições onde os homens exercem poder uns sobre os outros. Uma sociedade em que a estrutura constitucional discipline o poder pela rápida resolução dos impasses e pela multiplicação das formas de representação e consulta popular. Uma sociedade em que a eliminação da miséria e das grandes desigualdades seja condição e consequência da militância partidária, sindical e comunitária de base. Uma sociedade, portanto, em que a justa redistribuição do consumo se faça simultaneamente com o fortalecimento da autoorganização coletiva e com a multiplicação das formas de participação popular no poder. Uma sociedade em que se estabeleça o controle político democratizado sobre os fluxos básicos de 
investimento para assegurar que as diretrizes do processo de acumulação obedeçam as decisões majoritárias. Isso para impedir que a retração dos investimentos subverta os planos reformadores; para orientar o perfil da produção e do consumo, bem como a relação entre indústria e agricultura e entre a economia brasileira e a estrangeira. Tudo para servir às necessidades populares. Mas, ao mesmo tempo, uma sociedade em que se promovam o poder decisório dos operários sobre a organização e a hierarquia do trabalho e os vínculos cooperativistas entre pequenos e médios proprietários, nas cidades e nos campos. Uma sociedade que aproveite a indefinição política de suas classes como oportunidade para a execução de um projeto de democracia mais mobilizante e portanto mais capaz de penetrar o sistema produtivo e a vida quotidiana. Uma sociedade, por isso mesmo, que multiplique tanto quanto possível, os mecanismos de polêmica e deliberação que permitam aos homens exercer sua liberdade coletiva na reconstrução da vida social.

Os fundadores do PMDB têm consciência da imensa dificuldade do projeto de militância e mobilização que os anima. Mas sabem que sem uma prática intensa de organização popular dificilmente se conseguirá atingir sequer o grau de democracia representativa e de redistribuição da renda e da riqueza que distingue as democracias consolidadas. Sem essa mobilização, o povo estará impotente diante da máquina do Estado ou disponível e lideranças demagógicas e agitações superficiais que só provocam novas reações autoritárias.

As desigualdades de riqueza de renda, bem como de acesso à segurança, às oportunidades e ao poder no sistema produtivo, são tamanhas e tão enraizadas no Brasil que só cederão a uma força popular combativa e organizada.

Os fundadores do PMDB comprometem-se perante a Nação a construir um partido que seja, pelos seus métodos de atividade e pela sua estrutura interna, um prenúncio da ordem social que ele advoga para o País. Assumem esse compromisso conscientes dos perigos e obstáculos que enfrentam: a dificuldade de executar qualquer obra mobilizadora num regime de arbítrio sempre disposto às manipulações e perversões institucionais ao capricho de suas conveniências a enorme distância que ainda separa a militância partidária e a experiência quotidiana dos brasileiros humildes; o despreparo, resultante da descontinuidade democrática, para penoso trabalho de estruturação partidária, de luta em defesa da autoorganização sindical e comunitária e de participação nos conflitos sociais.

A constância e a inconformidade de muitos transformaram um partido indefeso, numa organização vigorosa que o regime teve que extinguir para poder, por mais algum tempo, sobreviver. A constância e inconformidade transformarão o sucessor desse partido num movimento que emancipará o País não só do governo, mas do regime despótico, não só do regime, mas da ordem social vigente.

Dezembro de 1979

Senadores: Adalberto Sena (AC); Evandro Carreira (AM); Mauro Benevides (CE); Agenor Maria (RN); Cunha Lima e Humberto Lucena (PB); Marcos Freire (PE); Teotônio Vilela (AL); Nelson Carneiro e Roberto Saturnino (RJ); Itamar Franco (MG); Franco Montoro e Orestes Quércia (SP); Henrique Santillo e Lázaro Barboza (GO); José Richa e Leite Chaves (PR); Jaison Barreto (SC); Paulo Brossard e Pedro Simon (RS). 
Deputados: ACRE - Aluízio Bezerra, Geraldo Fleming, Nabor Júnior; AMAZONAS - Mário Frota; PARÀ - Jader Barbalho; CEARÁ - Iranildo Pereira, Paes de Andrade; PARAÍBA - Arnaldo Lafayette, Marcondes Gadelha, Octacílio Queiroz; PERNAMBUCO - Cristina Tavares, Fernando Coelho, Fernando Lyra, José Carlos Vasconcelos, Marcus Cunha, Roberto Freire; ALAGOAS José Costa, Mendonça Neto, Murilo Mendes; SERGIPE - Jackson Barreto; BAHIA - Elquisson Soares, Francisco Pinto, Hilderico Oliveira, Jorge Viana, Marcelo Cordeiro, Raimundo Urbano, Roque Aras; ESPÍRITO SANTO - Gerson Camata, Mário Moreira, Max Mauro; RIO DE JANEIRO Celso Peçanha, Délio dos Santos, Edson Khair, Felippe Penna, Jorge Gama, José Maria de Carvalho, Marcelo Cerqueira, Modesto da Silveira, Oswaldo Lima, Paulo Rattes, Walter Silva; MINAS GERAIS - Edgard Amorim, Fued Dib, João Herculino, Júnia Marise, Pimenta da Veiga, Ronan Tito, Tarcísio Delgado; SÃO PAULO - Airton Sandoval, Alberto Goldman, Antônio Russo, Audálio Dantas, Aurélio Peres, Cardoso Alves, Carlos Nelson, Del Bosco Amaral, Flávio Chaves, Freitas Nobre, Horácio Ortiz, Israel Dias Novaes, Mário Hato, Octacílio Almeida, Pacheco Chaves, Ralph Biasi, Ruy Côdo, Samir Achôa, Santilli Sobrinho, Tidei de Lima, Ulysses Guimarães, Valter Garcia; GOIÁS - Adhemar Santillo, Fernando Cunha, Iran Saraiva, Iturival Nascimento, José Freire, Paulo Borges; MATO GROSSO - Carlos Bezerra, Gilson de Barros; PARANÁ - Álvaro Dias, Amadeu Geara, Ernesto Dall'Oglio, Euclides Scalco, Heitor Alencar Furtado, Hélio Duque, Maurício Fruet, Nivaldo Kruger, Olivir Gabardo, Osvaldo Macedo, Paulo Marques, Sebastião Rodrigues Júnior; SANTA CATARINA - Ernesto de Marco, Francisco Libardoni, Juarez Furtado, Pedro Ivo, Walmor de Luca; RIO GRANDE DO SUL - Aldo Fagundes, Cardoso Fregapani, Carlos Santos, Eloar Guazzelli, Harry Sauer, Jairo Brum, João Gilberto, Jorge Uequed, Júlio Costamilan, Odacir Klein, Rosa Flores, Waldir Walter; RONDÔNIA - Jerônimo Santana.

Não-Parlamentares: Fernando Gasparian, Mauro Borges Teixeira, Jarbas de Andrade Vasconcelos, José Alencar Furtado, José Carlos Mesquita Teixeira, Miguel Arraes de Alencar, Renato Bayma Archer da Silva, Roberto Mangabeira Unger, Pedro Moreno Gondin, Wilson Barbosa Martins, José Serra, Djacir Cavalcante de Arruda, Mário Covas Júnior,

Amaury de Oliveira e Silva, Raphael de Almeida Magalhães, Almino Monteiro Alvarez Affonso, Paulo de Tarso Santos, Fernando Henrique Cardoso, Severo Fagundes Gomes, Djalma Marinho Muniz Falcão, Milton Reis, Marcos Wellington de Castro Tito.

Reproduzido a partir da:

REVISTA DO PMDB - Publicação da Fundação Ulysses Guimarães / Edição - Abril de 2005 


\section{ANEXO 2}

\section{Pedido de Registro Definitivo do PMDB no TSE}

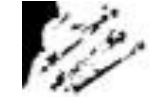

0

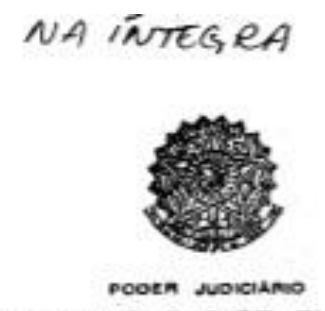

TRIBUNAL SUPERIOR ELEITORAL

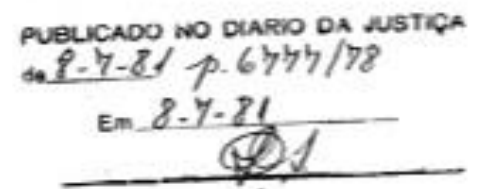

PUELUCADO NO DLARTO DA NUSTIGA

Em 8-7-81

RESOLUÇAOO N: 11.042

PROCESSO DE REGISTRO DE PARTIDO NQ 3 B - CLASSE VII - DISTRITO FEDERAL (Brasilia).

- Defere o registro definitivo do Partido do Movinento Denocrático Brasileiro(

Vistos, etc.

RE S OL VE M OS Ministros do Tribunal Superior Eleitoral. por unanimidade de votos, deferir o registro definitivo do PMDB,nos termos do voto do relator, que fica fazendo parte integrante da de cisāo.

SALA DAS SESSOES DO TRIBUNAL SUPERIOR ELEITORAL

Brastlifa, 30 de funho de 1981.
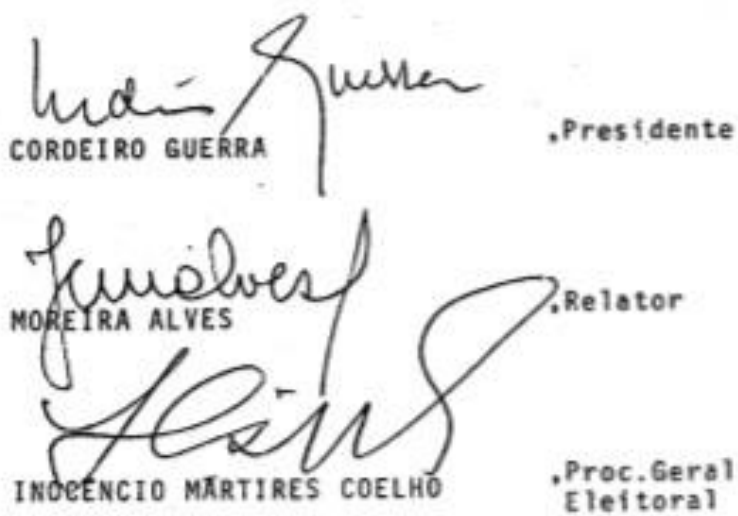
D SEMHOR MINISTRO HOREIRA ALVES (RLLATOR): Senhor Pre sidente, $\vec{E}$ este o teor do requerimento do registro definitivo opresentado pelo PнDB (fls. 2/5):

- Diretōrio Nacional do PARTIDO DO NO VIMENTD DENOCRATICO BRASILE:RO-PHOArepresentado pelo presidente e pelo secretario-Geral de sua Comissão Executiva, que esta subscrevem. Deputado ULYYSSES GUINARXES E SEnador PEDRO SI HON, respectivamente, pede vênia a Vossa Exceléncia para expor e, finalmente, requerer o seguinte:

1. Tendo obtido o registro provisórto, conforne decisăo desse Egregio Tribuhal (res. no 10.B41 - Proc. no 31-jul gado en 06.05.80 e publicado no diar rio da Justifa de $11,06,80)$ - doc. 01 - tomol o PHDB as denais providencias do TSE (Res. it? 10.785/BO), assin resumidas: reallzacäo do Convençóes Hunicipais e Regionais, con a aprovaçäo dos documentos básícos do Partido = No nifesto, Programo e Estatuto, ben cono a eleição dos respectívos Diretōrí os e Conissobes Executívas, en nümerō superior oo minimo estaboiecido naque les diplomas.

2. Cumpridas essas formalidades, reaifzou o Partido, na Capital da República, nos dias 06 e 07 do corrente. a sua Convença Nacianal. antecedida das seguintes providéncias:

a jedital de convocaça publicado no 00 U de 28.11. 00 (doc, 02): b)edital de convocação publicado nos Jornats "Correto Braziliense" - "Jornal de Brasflia", de 28. 11. $\mathrm{BO}$ : (docs 03 e 04)

c) telegramas de notificaço aos convencionals com data de 13.11. 80 . 1B.11.a0; (docs. 05 e 06 ) d) offcio do Excelentissino senhor Presidente do TSE pedindo a dosignaço do observador da Justiça Eleftoral. (doc. OT)

3. A Convença Nactonol, assin, regulormente convocada, reuniu-se nas da tas supra mencionadas e decidiu aprovar as docunentos bäsicos do Partido" - Manffesto, Prograna e Estatuto. eleger o Díretórío Kacional, tudo con farme consta en cōpla autêntica das 


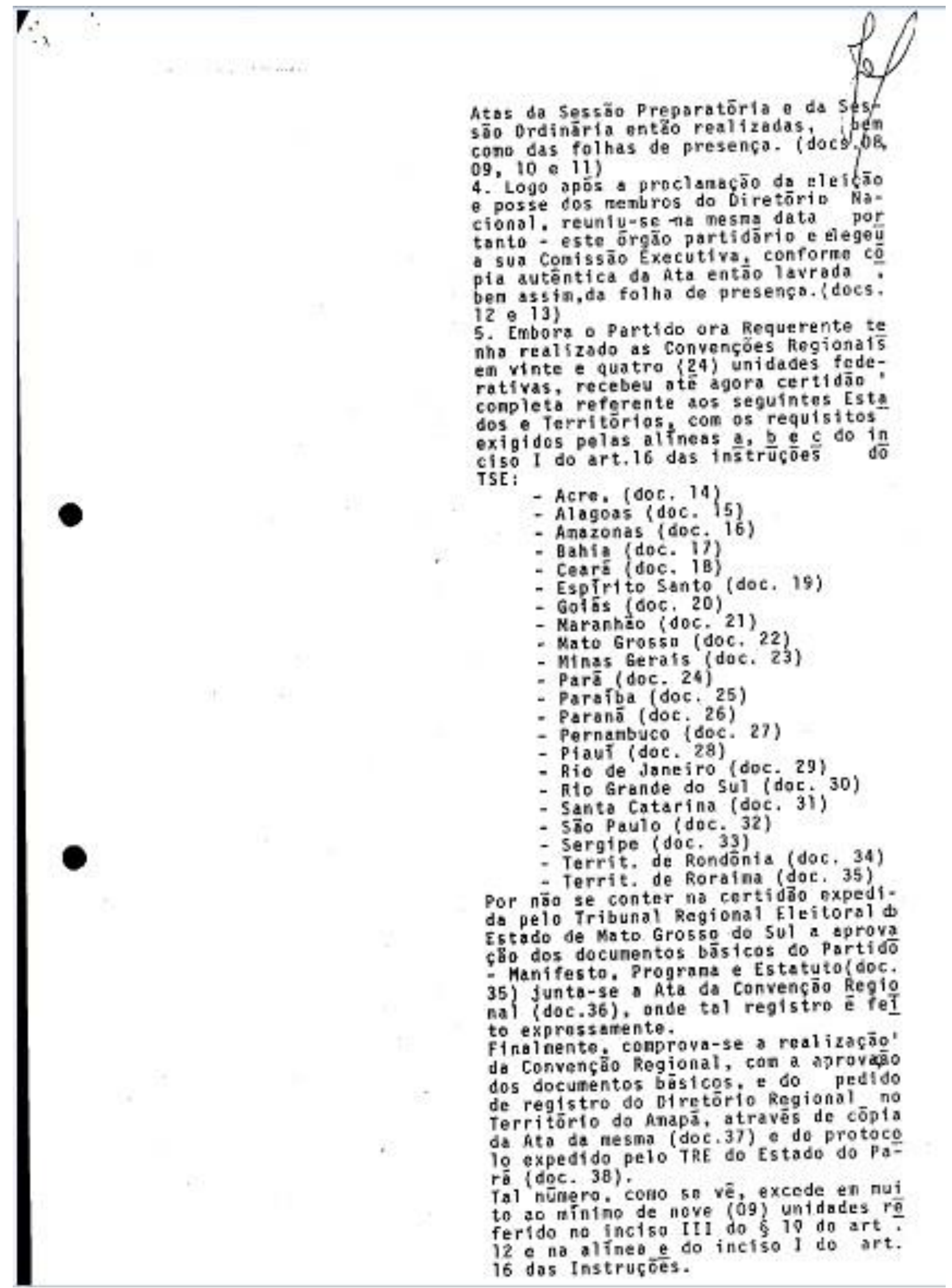




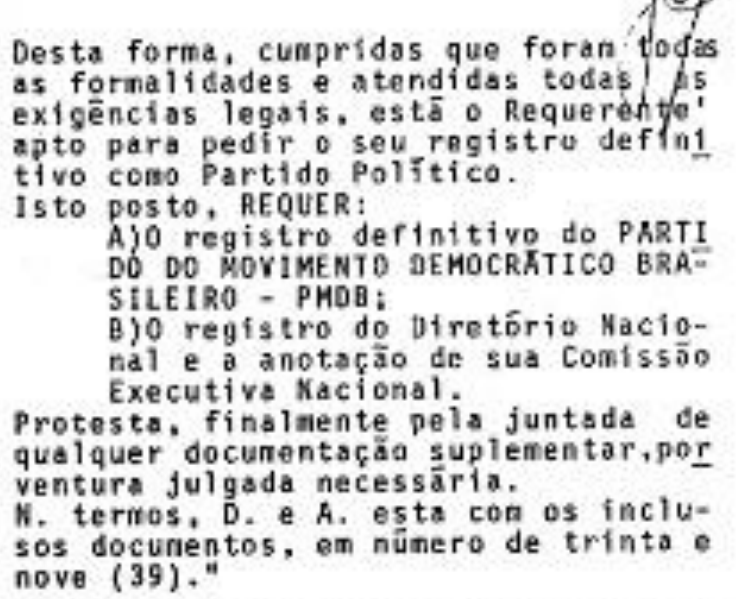

A documentaço aludida nesse requerimento se encontro

a $f 15,6 / 101$.

A 715,104 , requereu-se a juntada de certidão referen te à organizaçăo do Partido en Mato Grosso do Sul.

Publicado o edital para conhecimento do pedido e even tual impugnação $(f 1 s .107$ e certidāo de publicaçäo a fls.108), de correu o prazo de vinte dias, sem que houvesse inpugnaçäo (certiđāo a fis. 109).

A $f 15,113 / 116$, assim se nanfesta a Procuradoria- Ge ral Eleitoral. en parecer do Dr. Valin Teixeira:

- O partsdo do novimento Democratico gra SILEIRO - PHDB - por seu Presidento e Secretarta-Geral, respectivanente Deputado Federal víysses Guimaräes e Senador Pedro Stmon, requer o seu registro dofinitivo, nos termos do art. 13 , da Lef no 5.682 , de 21.7 .71 , reda çăo da Leit no 6,767 , de 20.12 .79 , com binado com o art. 16, da Resoluçắn no $10.785 / 80$.

Para tanto, esclarece o requerente qe, tendo obtido o seu registro proviso rio, conforme decisăo do Colendo Tri bunal Superior Eleitoral en 6.5.80 real1zou convençōes en 24 ( $v$ inte quatro) Estados da Federaçăo e en 3 (trềs) Territörios Federaís, e en mis de $1 / 5$ (un quinto) dos respectivos nu nicipios, tendo elefto o seu oiretorio Nacional e Comissōo Executiva en converça regularmante realizada, fazendo juntar toda a documentagão refe rido no artigo 16 , do Resoluçáo nब $10.385 / 80$, que assim preceitua: - Art. 16 - Realizadas as conven çöns nunicipais, regionais e na = cional, con a sproveçäo do mani festo, do prograta e do estatuto. 


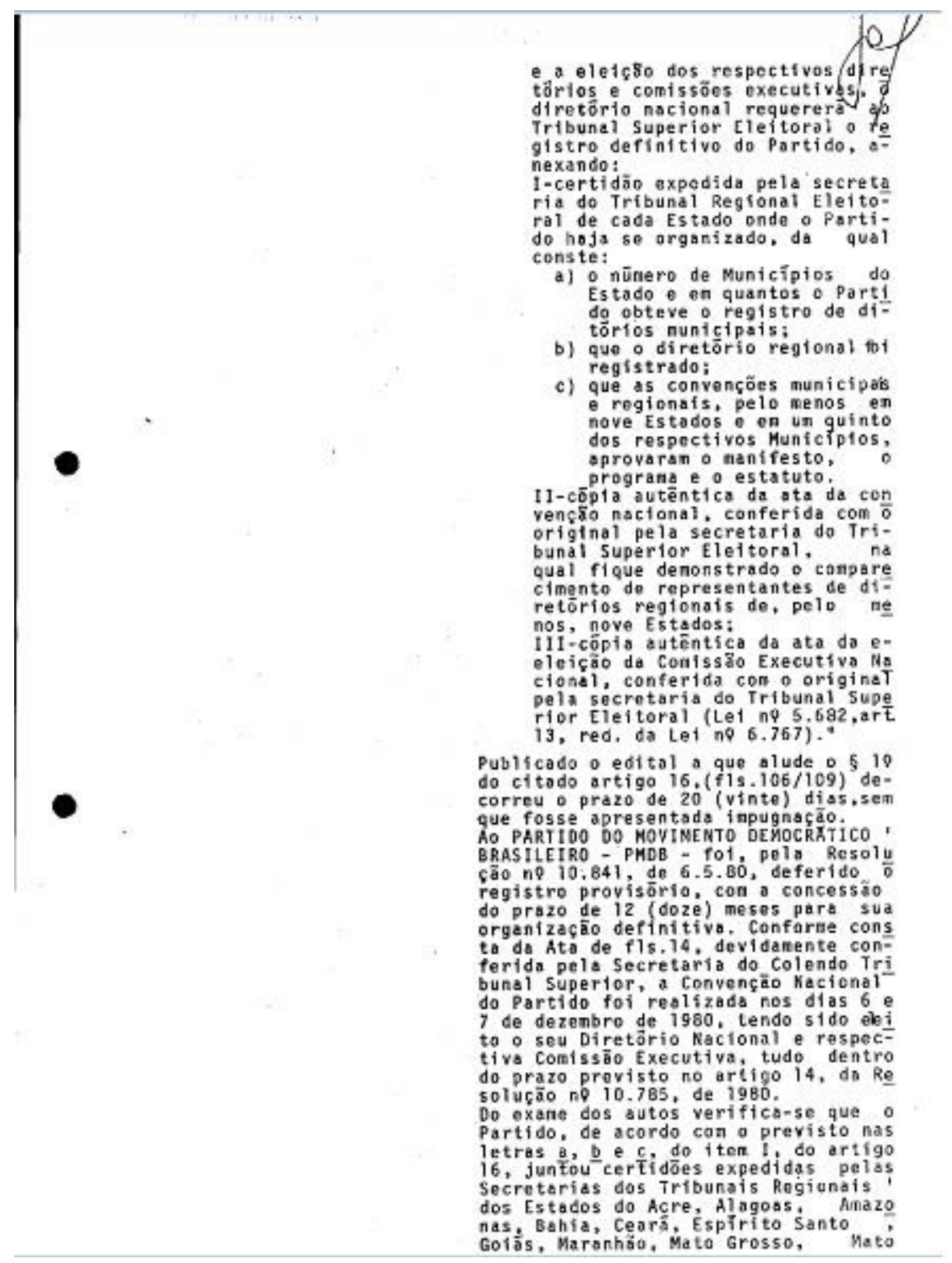






$\begin{array}{llll}V & 0 & T & 0\end{array}$

0 SENHOR MINISTRO MOREIRA ALVES (RELATOR): SEnhor Pre sidente, como ben denonstra a parecer da Procuradoria-beral Eleitoral - que acolho, por estar on confornidade coa os elementos constantes dos autos - foran proenchidos os requisitos legais par 
ra a obtençăo do registro definitivo do Partido do Movimento Demo crätico Brasileiro, razāo por que o defiro, deterninando que sc tomem as providêncilss a que slude o artigo 17 da Resoluçós $10,785 / 80$.

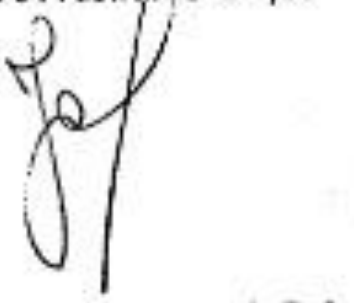

DECISR̆O URZHANE.

EXTRATO DA ATA

PROC. NQ 38 - CL. VII - DF - Rol. Min. Moretra Alves.

Decisăo: Deferida a reglstro definltivo, decisão unânime.

Presidência do Ministro Cordefro Guerra. Presentes os Ministros : Moreira Alves, Cunha Peixoto, Carlos Madelra, Josë Fernandes Dantas. Pedro Gordtiho. J.M. Souza Andrade o Dr. Inocéncio Märtires Coelho, Procurador Garal Eleftoral. 
PARTIDO DO MOV DEEMTO DEMDCGATICO BRASILEIRD - YYDB

\section{DIRETUKIO MACIOQUL}

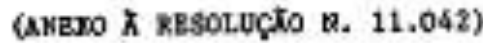

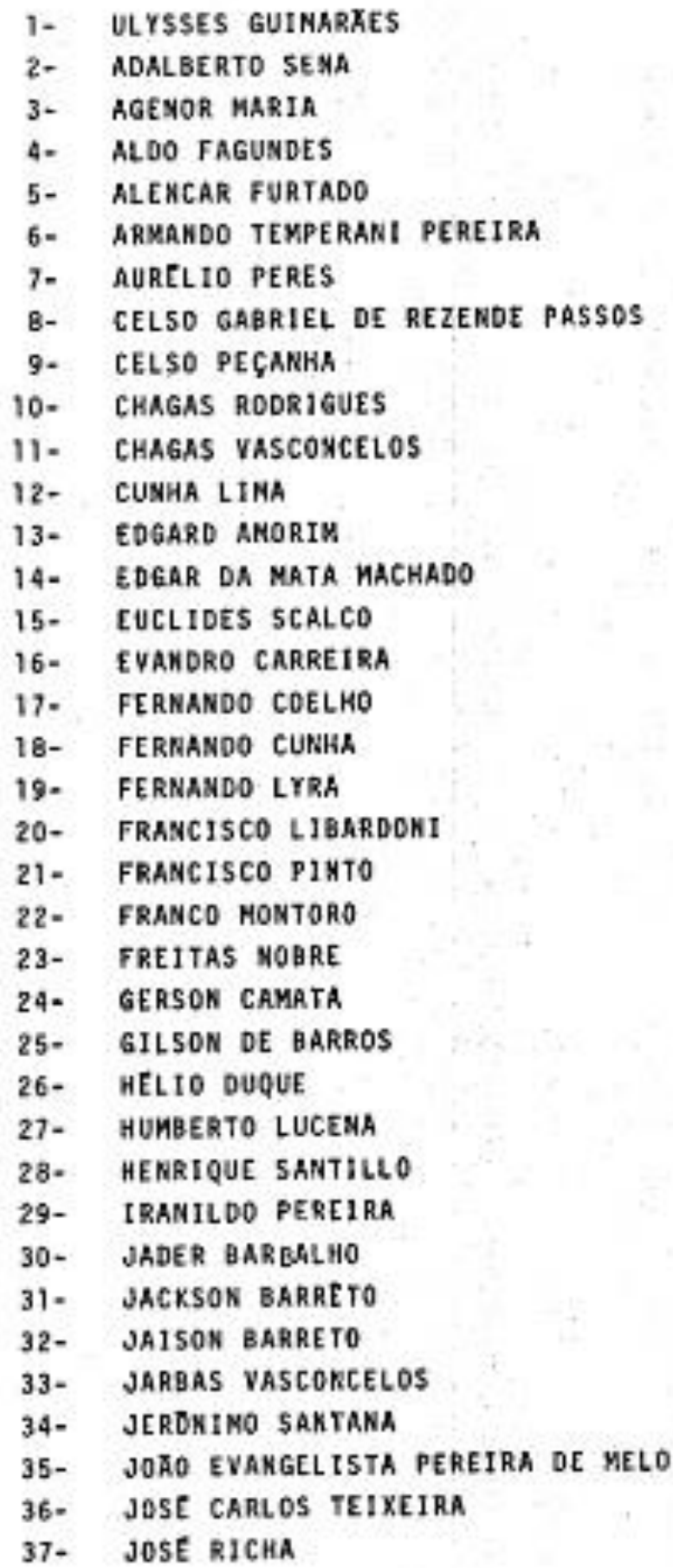




\begin{tabular}{|c|c|}
\hline $38-$ & LRZARO BARBOZA \\
\hline 39- & LETTE CHAVES \\
\hline 40- & LEO DE ALMEIDA NEVES \\
\hline $41-$ & LUTZ MARIANO PAES DE CARYALHO FILHC \\
\hline 42:- & HARIO COVAS \\
\hline 43- & MARIO MOREIRA \\
\hline 44- & MARIO FROTA \\
\hline 45- & NARCOS FREJRE \\
\hline 46- & MAURO BENEVIDES \\
\hline $47-$ & NAURO BORGES TEIXEIRA \\
\hline $48-$ & MARCELO CERQUETRA \\
\hline 49- & MI DUEL ARRAES \\
\hline 50- & KABOR JOMIOR \\
\hline 51- & ORESTES QUERCIA \\
\hline 52- & OCTACTLIO QUEIROZ \\
\hline $53-$ & PAULO BROSSABO \\
\hline 54- & PAULO RATTES \\
\hline 55- & PEDRO SIMON \\
\hline 56- & RAPHAEL DE ALKEIDA MAGALHXES \\
\hline 57- & RAIMUNDO AZEVEDO COSTA \\
\hline 58- & RENATO ARCHER \\
\hline $59-$ & ROBERTO CARDOSO ALVES \\
\hline 60- & ROKNULO OE ALMEIDA \\
\hline 61- & SEVERO GOMES \\
\hline 62- & SIEGFRIED EMHAKUEL HEUSER \\
\hline $63-$ & SIMRO DA CUKHA PEREIRA \\
\hline $64-$ & TARCISIO DELGADO \\
\hline $65-$ & TEOTONIO VILELA \\
\hline $66-$ & TIDEI DE LIMR \\
\hline $67=$ & VALDICE MACEDO NOBRE \\
\hline $68-$ & NALDIR PIRES \\
\hline 69- & HILSON MARTINS \\
\hline $70-$ & LIDER MA CIMURG DOS DEPUTADDS \\
\hline $71-$ & LIOER NO SENADO FEDERAL \\
\hline
\end{tabular}




\section{SUPLENTES}

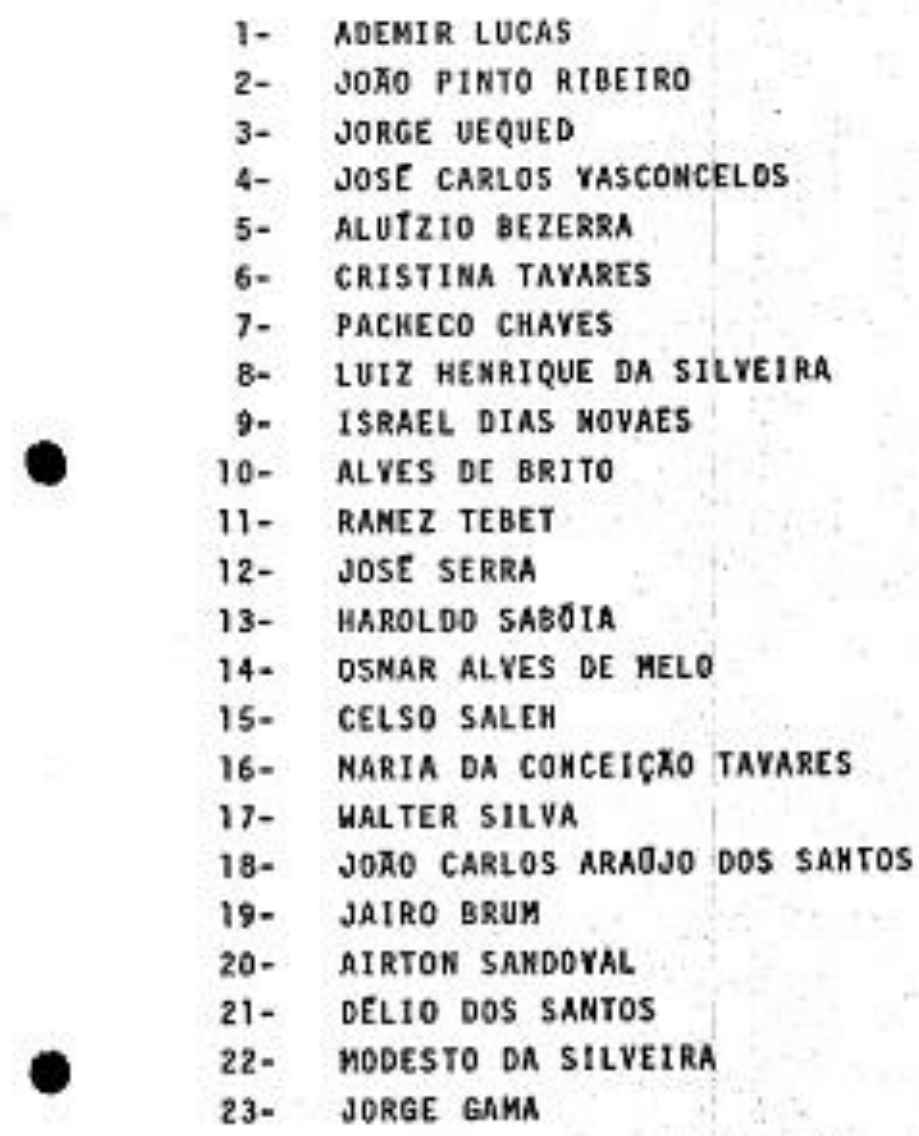




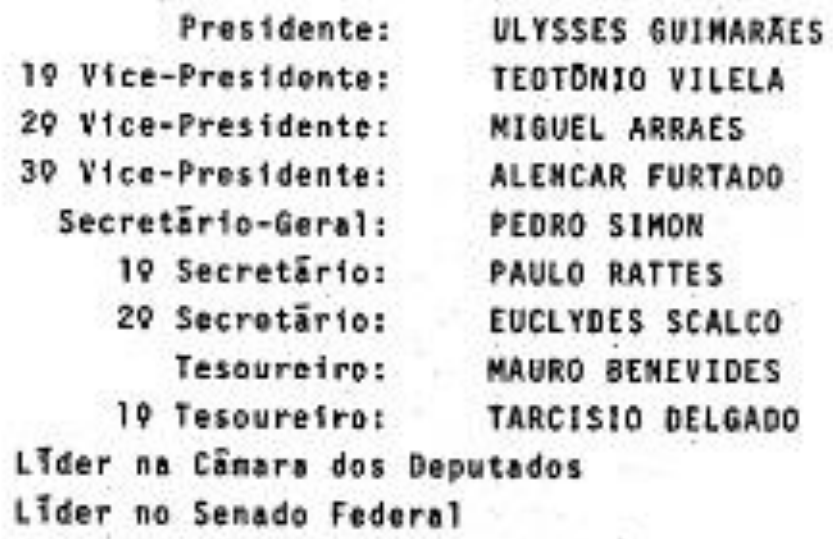




\section{ANEXO 3}

Membros da Comissão Executiva Nacional do PP (1980-1981):

\begin{tabular}{llc}
\hline \multicolumn{1}{c}{ Cargo } & \multicolumn{1}{c}{ Nome } & $\begin{array}{c}\text { Filiação } \\
\text { partidária } \\
\text { anterior }\end{array}$ \\
\hline Presidente & Tancredo Neves & MDB \\
\hline Presidente de Honra & Magalhães Pinto & ARENA \\
$\mathbf{1}^{\circ}$ Vice-presidente & Aluisio Alves & MDB \\
$\mathbf{2}^{\circ}$ Vice-presidente & Paulo Egydio & ARENA \\
$\mathbf{3}^{\circ}$ Vice-presidente & Affonso Camargo & MDB \\
\hline Secretário geral & Miro Teixeira & MDB \\
$\mathbf{1}^{\circ}$ Secretário & João Linhares & ARENA \\
$\mathbf{2}^{\circ}$ Secretário & Jorge Vargas & ARENA \\
$\mathbf{1}^{\circ}$ Tesoureiro & Gastão Muller & ARENA \\
$\mathbf{2}^{\circ}$ Tesoureiro & Alberto Silva & ARENA \\
\hline Vogais & João Menezes & MDB \\
& Antônio Mariz & ARENA \\
& Celso Carvalho & ARENA \\
& Antônio Moraes & MDB \\
Suplentes & Carlos Sant'Ana & ARENA \\
& Márcio Macedo & MDB \\
\hline & Rubem Figueiró & ARENA \\
& Louremberg Nunes Rocha & ARENA \\
& Lúcia Viveiros & ARENA \\
\hline edido de Registro Definitivo - RGP no 40 - Resolução/TSE no 11.075 e Acervo \\
& CPDOC/FGV & \\
\hline
\end{tabular}

Membros da última Comissão Executiva Nacional do MDB (1979):

\begin{tabular}{ll}
\hline \multicolumn{1}{c}{ Cargo } & \multicolumn{1}{c}{ Nome } \\
\hline Presidente & Ulysses Guimarães \\
$\mathbf{1}^{\circ}$ Vice-presidente & Teotônio Vilela \\
$\mathbf{2}^{\circ}$ Vice-presidente & Alencar Furtado \\
$\mathbf{3}^{\circ}$ Vice-presidente & Tancredo Neves \\
Secretário-Geral & Tales Ramalho \\
$\mathbf{1}^{\circ}$ Secretário & Jarbas Vasconcelos \\
$\mathbf{2}^{\circ}$ Secretário & Itamar Franco \\
$\mathbf{1}^{\circ}$ Tesoureiro & Mauro Benevides \\
$\mathbf{2}^{\circ}$ Tesoureiro & Marcondes Gadelha \\
Vogais & Franco Montoro \\
& João Gilberto \\
& Valter Guimarães \\
& Lazaro Barbosa \\
\hline
\end{tabular}

Fontes: Folha de S. Paulo, 5 de novembro de 1979 
Membros da Comissão Executiva Nacional do PMDB (1980-1989): 22 membros*

\begin{tabular}{|c|c|c|c|c|c|c|c|c|}
\hline Cargo & $1980-1982$ & UF & $1982-1983$ & UF & $1983-1986$ & UF & $1986-1989$ & UF \\
\hline Presidente & $\begin{array}{l}\text { Ulysses } \\
\text { Guimarães }\end{array}$ & $\mathrm{SP}$ & $\begin{array}{l}\text { Ulysses } \\
\text { Guimarães }\end{array}$ & $\mathrm{SP}$ & $\begin{array}{l}\text { Ulysses } \\
\text { Guimarães }\end{array}$ & $\mathrm{SP}$ & $\begin{array}{l}\text { Ulysses } \\
\text { Guimarães }\end{array}$ & $\mathrm{SP}$ \\
\hline $\begin{array}{l}1^{\circ} \text { Vice } \\
\text { Presidente }\end{array}$ & $\begin{array}{l}\text { Teotônio } \\
\text { Vilela }\end{array}$ & PB & $\begin{array}{c}\text { Tancredo } \\
\text { Neves }\end{array}$ & MG & $\begin{array}{l}\text { Pedro } \\
\text { Simon }\end{array}$ & $\mathrm{RS}$ & $\begin{array}{l}\text { Pedro } \\
\text { Simon }\end{array}$ & RS \\
\hline $\begin{array}{l}2^{\circ} \text { Vice } \\
\text { Presidente }\end{array}$ & $\begin{array}{l}\text { Miguel } \\
\text { Arraes }\end{array}$ & $\mathrm{PE}$ & $\begin{array}{l}\text { Miguel } \\
\text { Arraes }\end{array}$ & $\mathrm{PE}$ & $\begin{array}{l}\text { Miguel } \\
\text { Arraes }\end{array}$ & $\mathrm{PE}$ & $\begin{array}{l}\text { Miguel } \\
\text { Arraes }\end{array}$ & PE \\
\hline $\begin{array}{l}3^{\circ} \text { Vice } \\
\text { Presidente }\end{array}$ & $\begin{array}{l}\text { Alencar } \\
\text { Furtado }\end{array}$ & PR & $\begin{array}{l}\text { Pedro } \\
\text { Simon }\end{array}$ & RS & Milton Reis & MG & $\begin{array}{l}\text { Affonso } \\
\text { Camargo }\end{array}$ & $P R$ \\
\hline $\begin{array}{l}\text { Secretário- } \\
\text { Geral }\end{array}$ & $\begin{array}{l}\text { Pedro } \\
\text { Simon }\end{array}$ & RS & $\begin{array}{c}\text { Francisco } \\
\text { Pinto }\end{array}$ & $\mathrm{BA}$ & $\begin{array}{l}\text { Affonso } \\
\text { Camargo }\end{array}$ & $P R$ & Milton Reis & MG \\
\hline $1^{\circ}$ Secretário & $\begin{array}{l}\text { Paulo } \\
\text { Rattes }\end{array}$ & $\mathrm{RJ}$ & $\begin{array}{c}\text { Miro } \\
\text { Teixeira }\end{array}$ & RJ & $\begin{array}{c}\text { Roberto } \\
\text { Cardoso } \\
\text { Alves }\end{array}$ & SP & $\begin{array}{c}\text { Euclides } \\
\text { Scalco }\end{array}$ & $P R$ \\
\hline $2^{\circ}$ Secretário & $\begin{array}{c}\text { Euclides } \\
\text { Scalco }\end{array}$ & PR & $\begin{array}{c}\text { Euclides } \\
\text { Scalco }\end{array}$ & $P R$ & $\begin{array}{l}\text { Casildo } \\
\text { Maldaner }\end{array}$ & SC & $\begin{array}{c}\text { Maria da } \\
\text { Conceição } \\
\text { Tavares }\end{array}$ & RJ \\
\hline $1^{\circ}$ Tesoureiro & $\begin{array}{c}\text { Mauro } \\
\text { Benevides }\end{array}$ & CE & $\begin{array}{c}\text { Mauro } \\
\text { Benevides }\end{array}$ & $\mathrm{CE}$ & $\begin{array}{c}\text { Mauro } \\
\text { Benevides }\end{array}$ & $\mathrm{CE}$ & $\begin{array}{c}\text { Mauro } \\
\text { Benevides }\end{array}$ & $\mathrm{CE}$ \\
\hline $2^{\circ}$ Tesoureiro & $\begin{array}{l}\text { Tarcisio } \\
\text { Delgado }\end{array}$ & MG & $\begin{array}{l}\text { Tarcisio } \\
\text { Delgado }\end{array}$ & MG & $\begin{array}{l}\text { Márcio } \\
\text { Braga }\end{array}$ & RJ & $\begin{array}{l}\text { Walmor de } \\
\text { Luca }\end{array}$ & SC \\
\hline $1^{\circ}$ Vogal & $\begin{array}{l}\text { Franco } \\
\text { Montoro }\end{array}$ & SP & $\begin{array}{l}\text { Teotônio } \\
\text { Vilela }\end{array}$ & $\mathrm{AL}$ & $\begin{array}{c}\text { Francisco } \\
\text { Pinto }\end{array}$ & BA & $\begin{array}{c}\text { Francisco } \\
\text { Pinto }\end{array}$ & BA \\
\hline $2^{\circ}$ Vogal & $\begin{array}{l}\text { Orestes } \\
\text { Quércia }\end{array}$ & SP & $\begin{array}{l}\text { Paulo } \\
\text { Rattes }\end{array}$ & RJ & $\begin{array}{l}\text { Pimenta da } \\
\text { Veiga }\end{array}$ & MG & $\begin{array}{c}\text { Roberto } \\
\text { Cardoso } \\
\text { Alves }\end{array}$ & $S P$ \\
\hline $3^{\circ} \mathrm{Vogal}$ & $\begin{array}{c}\text { Francisco } \\
\text { Pinto }\end{array}$ & $\mathrm{BA}$ & $\begin{array}{c}\text { Mendes } \\
\text { Canale }\end{array}$ & MS & $\begin{array}{c}\text { Cid } \\
\text { Sampaio }\end{array}$ & $\mathrm{PE}$ & $\begin{array}{c}\text { Cid } \\
\text { Sampaio }\end{array}$ & $\mathrm{PE}$ \\
\hline $4^{\circ}$ Vogal & $\begin{array}{l}\text { Fernando } \\
\text { Cunha }\end{array}$ & GO & $\begin{array}{l}\text { Aloisio } \\
\text { Alves }\end{array}$ & $\mathrm{RN}$ & $\begin{array}{l}\text { Carlos } \\
\text { Vinagre }\end{array}$ & PA & $\begin{array}{l}\text { Jorge } \\
\text { Medauar }\end{array}$ & BA \\
\hline $1^{\circ}$ Suplente & $\begin{array}{c}\text { Ivandro } \\
\text { Cunha Lima }\end{array}$ & PB & $\begin{array}{l}\text { Fernando } \\
\text { Cunha }\end{array}$ & GO & $\begin{array}{l}\text { Renato } \\
\text { Archer }\end{array}$ & MA & $\begin{array}{l}\text { Hélio } \\
\text { Gueiros }\end{array}$ & PA \\
\hline $2^{\circ}$ Suplente & $\begin{array}{l}\text { Jackson } \\
\text { Barreto }\end{array}$ & SE & $\begin{array}{l}\text { Nabor } \\
\text { Junior }\end{array}$ & $A C$ & $\begin{array}{l}\text { Heráclito } \\
\text { Fortes }\end{array}$ & $\mathrm{PI}$ & $\begin{array}{l}\text { João } \\
\text { Gilberto }\end{array}$ & RS \\
\hline $3^{\circ}$ Suplente & $\begin{array}{l}\text { Renato } \\
\text { Archer }\end{array}$ & MA & $\begin{array}{l}\text { Chagas } \\
\text { Rodrigues }\end{array}$ & $\mathrm{PI}$ & $\begin{array}{c}\text { Jarbas } \\
\text { Vasconcelo } \\
\text { s }\end{array}$ & $\mathrm{PE}$ & $\begin{array}{l}\text { Heráclito } \\
\text { Fortes }\end{array}$ & $\mathrm{PI}$ \\
\hline $4^{\circ}$ Suplente & $\begin{array}{l}\text { Nabor } \\
\text { Junior }\end{array}$ & $A C$ & $\begin{array}{l}\text { Mario } \\
\text { Moreira }\end{array}$ & ES & $\begin{array}{l}\text { Geraldo } \\
\text { Fleming }\end{array}$ & $A C$ & $\begin{array}{c}\text { Márcio } \\
\text { Braga }\end{array}$ & RJ \\
\hline $5^{\circ}$ Suplente & $\begin{array}{l}\text { Chagas } \\
\text { Rodrigues }\end{array}$ & $\mathrm{PI}$ & $\begin{array}{c}\text { João } \\
\text { Linhares }\end{array}$ & SC & $\begin{array}{l}\text { Plinio } \\
\text { Martins }\end{array}$ & MS & $\begin{array}{l}\text { Plínio } \\
\text { Martins }\end{array}$ & MS \\
\hline $6^{\circ}$ Suplente & $\begin{array}{l}\text { Mario } \\
\text { Moreira }\end{array}$ & ES & $\begin{array}{l}\text { Renato } \\
\text { Archer }\end{array}$ & MA & $\begin{array}{l}\text { Paulo } \\
\text { Mincarone }\end{array}$ & RS & $\begin{array}{l}\text { Geraldo } \\
\text { Flemming }\end{array}$ & $A C$ \\
\hline $7^{\circ}$ Suplente & $\begin{array}{c}\text { Jeronimo } \\
\text { Santana }\end{array}$ & RO & $\begin{array}{c}\text { João } \\
\text { Menezes }\end{array}$ & PA & $\begin{array}{c}\text { Maria da } \\
\text { Conceição } \\
\text { Tavares }\end{array}$ & RJ & $\begin{array}{c}\text { Fernando } \\
\text { Cunha }\end{array}$ & GO \\
\hline
\end{tabular}


Membros da Comissão Executiva Nacional do PMDB (1989-1996): 19 membros

\begin{tabular}{|c|c|c|c|c|c|c|c|c|}
\hline Cargo & 1989-1991 & UF & 1991-1993 & UF & 1993-1995 & UF & $\begin{array}{l}1995- \\
1995\end{array}$ & UF \\
\hline Presidente & $\begin{array}{l}\text { Ulysses } \\
\text { Guimarães }\end{array}$ & $\mathrm{SP}$ & $\begin{array}{l}\text { Orestes } \\
\text { Quércia }\end{array}$ & $\mathrm{SP}$ & Luiz Henrique & $\mathrm{SC}$ & $\begin{array}{l}\text { Paes de } \\
\text { Andrade }\end{array}$ & $\mathrm{CE}$ \\
\hline $\begin{array}{l}1^{\circ} \text { Vice } \\
\text { Presidente }\end{array}$ & $\begin{array}{c}\text { Jarbas } \\
\text { Vasconcelo } \\
\text { s }\end{array}$ & PE & $\begin{array}{c}\text { Jarbas } \\
\text { Vasconcelo } \\
\text { s }\end{array}$ & $\mathrm{PE}$ & Antônio Mariz & PB & $\begin{array}{l}\text { Marcelo } \\
\text { Barbieri }\end{array}$ & $\mathrm{SP}$ \\
\hline $\begin{array}{l}2^{\circ} \text { Vice } \\
\text { Presidente }\end{array}$ & José Fogaça & RS & José Fogaça & RS & $\begin{array}{l}\text { Jorge Tadeu } \\
\text { Mudalen }\end{array}$ & SP & $\begin{array}{l}\text { Carlos } \\
\text { Bezerra }\end{array}$ & MT \\
\hline $\begin{array}{l}3^{\circ} \text { Vice } \\
\text { Presidente }\end{array}$ & $\begin{array}{l}\text { Hélio } \\
\text { Duque }\end{array}$ & PR & $\begin{array}{c}\text { Luiz } \\
\text { Henrique }\end{array}$ & SC & Rita Camata & ES & $\begin{array}{l}\text { Henrique } \\
\text { Eduardo } \\
\text { Alves }\end{array}$ & $\mathrm{RN}$ \\
\hline $\begin{array}{l}\text { Secretário } \\
\text {-geral }\end{array}$ & $\begin{array}{l}\text { Tarcisio } \\
\text { Delgado }\end{array}$ & MG & $\begin{array}{l}\text { Joaquim de } \\
\text { Mello } \\
\text { Freire }\end{array}$ & MG & $\begin{array}{l}\text { Tarcisio } \\
\text { Delgado }\end{array}$ & MG & $\begin{array}{l}\text { Maria } \\
\text { Elvira }\end{array}$ & MG \\
\hline $\begin{array}{l}1^{\circ} \\
\text { Secretario }\end{array}$ & $\begin{array}{c}\text { Francisco } \\
\text { Pinto }\end{array}$ & $\mathrm{BA}$ & $\begin{array}{c}\text { Lázaro } \\
\text { Barbosa }\end{array}$ & GO & $\begin{array}{c}\text { Haley Margon } \\
\text { Vaz }\end{array}$ & $\mathrm{GO}$ & $\begin{array}{l}\text { Nicias } \\
\text { Ribeiro }\end{array}$ & PA \\
\hline $\begin{array}{l}2^{\circ} \\
\text { Secretario }\end{array}$ & $\begin{array}{l}\text { Nelson } \\
\text { Wedekin }\end{array}$ & $\mathrm{SC}$ & $\begin{array}{l}\text { Nicias } \\
\text { Ribeiro }\end{array}$ & PA & $\begin{array}{l}\text { Nicias Lopes } \\
\text { Ribeiro }\end{array}$ & PA & $\begin{array}{l}\text { Lidia } \\
\text { Quinan }\end{array}$ & GO \\
\hline $\begin{array}{l}1^{\circ} \\
\text { Tesoureiro }\end{array}$ & $\begin{array}{c}\text { Mauro } \\
\text { Benevides }\end{array}$ & $\mathrm{CE}$ & $\begin{array}{l}\text { Paes de } \\
\text { Andrade }\end{array}$ & $\mathrm{CE}$ & $\begin{array}{l}\text { Paes de } \\
\text { Andrade }\end{array}$ & CE & $\begin{array}{l}\text { Alberico } \\
\text { Filho }\end{array}$ & MA \\
\hline $\begin{array}{l}2^{\circ} \\
\text { Tesoureiro }\end{array}$ & $\begin{array}{l}\text { Bete } \\
\text { Mendes }\end{array}$ & SP & $\begin{array}{l}\text { Nabor } \\
\text { Júnior }\end{array}$ & $A C$ & Flaviano Melo & $A C$ & $\begin{array}{l}\text { Mauri } \\
\text { Sérgio }\end{array}$ & $A C$ \\
\hline $1^{\circ}$ Vogal & $\begin{array}{l}\text { Renato } \\
\text { Archer }\end{array}$ & $\mathrm{MA}$ & $\begin{array}{l}\text { Geraldo } \\
\text { Melo }\end{array}$ & MG & $\begin{array}{c}\text { Airton } \\
\text { Sandoval }\end{array}$ & SP & $\begin{array}{l}\text { Airton } \\
\text { Sandoval }\end{array}$ & SP \\
\hline $2^{\circ}$ Vogal & $\begin{array}{l}\text { Humberto } \\
\text { Lucena }\end{array}$ & PB & $\begin{array}{c}\text { Rita } \\
\text { Camata }\end{array}$ & ES & $\begin{array}{c}\text { Henrique } \\
\text { Eduardo Alves }\end{array}$ & $\mathrm{RN}$ & $\begin{array}{l}\text { Valdir } \\
\text { Colatto }\end{array}$ & SC \\
\hline $3^{\circ}$ Vogal & $\begin{array}{l}\text { Genebaldo } \\
\text { Correa }\end{array}$ & $\mathrm{BA}$ & $\begin{array}{l}\text { Alberto } \\
\text { Goldman }\end{array}$ & $S P$ & $\begin{array}{c}\text { Maurílio } \\
\text { Ferreira Lima }\end{array}$ & $\mathrm{PE}$ & $\begin{array}{l}\text { Ramez } \\
\text { Tebet }\end{array}$ & MS \\
\hline $4^{\circ}$ Vogal & $\begin{array}{l}\text { Márcio } \\
\text { Braga }\end{array}$ & RJ & Nilo Coelho & BA & Nilo Coelho & BA & $\begin{array}{l}\text { José } \\
\text { Dutra }\end{array}$ & AM \\
\hline $\begin{array}{l}1^{\circ} \\
\text { Suplente }\end{array}$ & $\begin{array}{c}\text { Bernardo } \\
\text { Cabral }\end{array}$ & AM & $\begin{array}{l}\text { Valter } \\
\text { Pereira }\end{array}$ & MT & Valter Pereira & MS & $\begin{array}{l}\text { Olavo } \\
\text { Calheiros }\end{array}$ & $\mathrm{AL}$ \\
\hline $\begin{array}{l}2^{\circ} \\
\text { Suplente }\end{array}$ & $\begin{array}{l}\text { Dante de } \\
\text { Oliveira }\end{array}$ & $\mathrm{MT}$ & $\begin{array}{l}\text { Ubiratan } \\
\text { Aguiar }\end{array}$ & CE & $\begin{array}{l}\text { Ubiratan } \\
\text { Aguiar }\end{array}$ & CE & $\begin{array}{c}\text { Remi } \\
\text { Ribeiro de } \\
\text { Oliveria }\end{array}$ & MA \\
\hline $\begin{array}{l}3^{\circ} \\
\text { Suplente }\end{array}$ & $\begin{array}{l}\text { Fernando } \\
\text { Gasparian }\end{array}$ & $\mathrm{SP}$ & José Dutra & AM & José Dutra & AM & $\begin{array}{l}\text { Noel de } \\
\text { Oliveira }\end{array}$ & RJ \\
\hline $\begin{array}{l}4^{\circ} \\
\text { Suplente }\end{array}$ & $\begin{array}{l}\text { Maria } \\
\text { Eugênia } \\
\text { Teixeira }\end{array}$ & SE & $\begin{array}{c}\text { Cid } \\
\text { Carvalho }\end{array}$ & $\mathrm{MA}$ & Cid Carvalho & MA & $\begin{array}{l}\text { Regina } \\
\text { Amelia } \\
\text { D’Alencar }\end{array}$ & $A C$ \\
\hline $\begin{array}{l}\text { Líder na } \\
\text { Câmara }\end{array}$ & $\begin{array}{c}\text { Ibsen } \\
\text { Pinheiro }\end{array}$ & RS & $\begin{array}{c}\text { Ibsen } \\
\text { Pinheiro }\end{array}$ & RS & $\begin{array}{c}\text { Genebaldo } \\
\text { Correa }\end{array}$ & BA & $\begin{array}{l}\text { Michel } \\
\text { Temer }\end{array}$ & SP \\
\hline
\end{tabular}




\begin{tabular}{|c|c|c|c|c|c|c|c|c|}
\hline $\begin{array}{l}\text { Líder no } \\
\text { Senado }\end{array}$ & Ronan Tito & MG & $\begin{array}{c}\text { Mauro } \\
\text { Benevides }\end{array}$ & CE & $\begin{array}{c}\text { Mauro } \\
\text { Benevides }\end{array}$ & CE & $\begin{array}{c}\text { Jader } \\
\text { Barbalho }\end{array}$ & PA \\
\hline
\end{tabular}

Membros da Comissão Executiva Nacional do PMDB (1996-2007):

\begin{tabular}{|c|c|c|c|c|c|c|c|c|}
\hline Cargo & $1995-1998$ & UF & $1998-2001$ & UF & 2001-2004 & UF & 2004-2007 & UF \\
\hline Presidente & $\begin{array}{l}\text { Paes de } \\
\text { Andrade }\end{array}$ & $\mathrm{CE}$ & $\begin{array}{c}\text { Jader } \\
\text { Barbalho }\end{array}$ & PA & $\begin{array}{l}\text { Michel } \\
\text { Temer }\end{array}$ & SP & $\begin{array}{l}\text { Michel } \\
\text { Temer }\end{array}$ & $\mathrm{SP}$ \\
\hline $\begin{array}{l}1^{\circ} \text { Vice } \\
\text { Presidente }\end{array}$ & $\begin{array}{l}\text { Marcelo } \\
\text { Barbieri }\end{array}$ & SP & $\begin{array}{l}\text { Maguito } \\
\text { Vilela }\end{array}$ & GO & $\begin{array}{l}\text { José de } \\
\text { Alencar }\end{array}$ & MG & $\begin{array}{l}\text { Eliseu } \\
\text { Padilha }\end{array}$ & RS \\
\hline $\begin{array}{l}2^{\circ} \text { Vice } \\
\text { Presidente }\end{array}$ & $\begin{array}{c}\text { Ronaldo } \\
\text { Cunha Lima }\end{array}$ & PB & $\begin{array}{c}\text { Wagner } \\
\text { Rossi }\end{array}$ & SP & $\begin{array}{c}\text { Cézar } \\
\text { Schirmer }\end{array}$ & $\mathrm{RS}$ & $\begin{array}{l}\text { Maguito } \\
\text { Vilela }\end{array}$ & GO \\
\hline $\begin{array}{l}3^{\circ} \text { Vice } \\
\text { Presidente }\end{array}$ & $\begin{array}{c}\text { Henrique } \\
\text { Eduardo } \\
\text { Alves }\end{array}$ & $\mathrm{RN}$ & $\begin{array}{l}\text { Cézar } \\
\text { Schirmer }\end{array}$ & $\mathrm{RS}$ & $\begin{array}{c}\text { Ana } \\
\text { Catarina }\end{array}$ & $\mathrm{RN}$ & $\begin{array}{c}\text { Gustavo } \\
\text { Fruet }\end{array}$ & PR \\
\hline $\begin{array}{l}\text { Secretário- } \\
\text { geral }\end{array}$ & $\begin{array}{c}\text { Marcos } \\
\text { Lima }\end{array}$ & MG & $\begin{array}{l}\text { Saraiva } \\
\text { Felipe }\end{array}$ & MG & $\begin{array}{c}\text { João } \\
\text { Henrique }\end{array}$ & $\mathrm{PI}$ & $\begin{array}{l}\text { Saraiva } \\
\text { Felipe }\end{array}$ & MG \\
\hline $\begin{array}{l}1^{\circ} \\
\text { Secretário }\end{array}$ & $\begin{array}{c}\text { Barbosa } \\
\text { Neto }\end{array}$ & GO & $\begin{array}{c}\text { Henrique } \\
\text { Eduardo } \\
\text { Alves }\end{array}$ & $\mathrm{RN}$ & $\begin{array}{l}\text { Renato } \\
\text { Vianna }\end{array}$ & SC & $\begin{array}{l}\text { Sérgio } \\
\text { Cabral }\end{array}$ & RJ \\
\hline $\begin{array}{l}2^{\circ} \\
\text { Secretário }\end{array}$ & $\begin{array}{l}\text { Carlos } \\
\text { Bezerra }\end{array}$ & MS & $\begin{array}{l}\text { Carlos } \\
\text { Bezerra }\end{array}$ & MS & $\begin{array}{l}\text { Carlos } \\
\text { Bezerra }\end{array}$ & MS & $\begin{array}{c}\text { Henrique } \\
\text { Eduardo } \\
\text { Alves }\end{array}$ & $\mathrm{RN}$ \\
\hline $\begin{array}{l}1^{\circ} \\
\text { Tesoureiro }\end{array}$ & $\begin{array}{l}\text { Casildo } \\
\text { Maldaner }\end{array}$ & SC & $\begin{array}{l}\text { Eunício } \\
\text { Oliveira }\end{array}$ & $\mathrm{CE}$ & $\begin{array}{l}\text { Eunício } \\
\text { Oliveira }\end{array}$ & $\mathrm{CE}$ & $\begin{array}{c}\text { Mônica } \\
\text { Paes de } \\
\text { Andrade } \\
\text { Lopes } \\
\text { Oliveira }\end{array}$ & $\mathrm{CE}$ \\
\hline $\begin{array}{l}2^{\circ} \\
\text { Tesoureiro }\end{array}$ & $\begin{array}{l}\text { Mauri } \\
\text { Sérgio }\end{array}$ & $A C$ & $\begin{array}{l}\text { Nabor } \\
\text { Júnior }\end{array}$ & $A C$ & $\begin{array}{l}\text { Nabor } \\
\text { Júnior }\end{array}$ & $A C$ & $\begin{array}{l}\text { Renato } \\
\text { Vianna }\end{array}$ & SC \\
\hline $1^{\circ}$ Vogal & $\begin{array}{l}\text { Humberto } \\
\text { Lucena }\end{array}$ & PB & $\begin{array}{l}\text { Alberico } \\
\text { Filho }\end{array}$ & MA & $\begin{array}{l}\text { Dorany } \\
\text { Sampaio }\end{array}$ & $\mathrm{PE}$ & $\begin{array}{l}\text { Orestes } \\
\text { Quércia }\end{array}$ & $\mathrm{SP}$ \\
\hline $2^{\circ}$ Vogal & $\begin{array}{c}\text { Airton } \\
\text { Sandoval }\end{array}$ & $\mathrm{SP}$ & $\begin{array}{l}\text { Casildo } \\
\text { Maldaner }\end{array}$ & SC & $\begin{array}{l}\text { Alberico } \\
\text { Filho }\end{array}$ & MA & $\begin{array}{c}\text { Jader } \\
\text { Barbalho }\end{array}$ & PA \\
\hline $3^{\circ}$ Vogal & Nilo Coelho & BA & $\begin{array}{l}\text { Ramez } \\
\text { Tebet }\end{array}$ & MS & $\begin{array}{l}\text { Asdrúbal } \\
\text { Bentes }\end{array}$ & PA & $\begin{array}{c}\text { Geddel } \\
\text { Vieira Lima }\end{array}$ & $\mathrm{BA}$ \\
\hline $4^{\circ}$ Vogal & $\begin{array}{c}\text { Alberico } \\
\text { Filho }\end{array}$ & MA & $\begin{array}{c}\text { Ney } \\
\text { Suassuna }\end{array}$ & PB & $\begin{array}{c}\text { Ney } \\
\text { Suassuna }\end{array}$ & PB & $\begin{array}{c}\text { Ney } \\
\text { Suassuna }\end{array}$ & PB \\
\hline $5^{\circ}$ Vogal & $\begin{array}{c}\text { Rita } \\
\text { Camata }\end{array}$ & ES & $\begin{array}{c}\text { Luiz } \\
\text { Estevão }\end{array}$ & DF & $\begin{array}{c}\text { Carlos } \\
\text { Alberto } \\
\text { Muniz }\end{array}$ & $\mathrm{RJ}$ & $\begin{array}{l}\text { Ramez } \\
\text { Tebet }\end{array}$ & MS \\
\hline $6^{\circ}$ Vogal & $\begin{array}{l}\text { Alberto } \\
\text { Goldman }\end{array}$ & SP & & & & & & \\
\hline $7^{\circ}$ Vogal & $\begin{array}{l}\text { José } \\
\text { Tavares }\end{array}$ & $P R$ & & & & & & \\
\hline $8^{\circ} \mathrm{Vogal}$ & $\begin{array}{l}\text { Ramez } \\
\text { Tebet }\end{array}$ & MS & & & & & & \\
\hline
\end{tabular}




\begin{tabular}{|c|c|c|c|c|c|c|c|c|}
\hline $1^{\circ}$ Suplente & $\begin{array}{c}\text { Remi } \\
\text { Ribeiro }\end{array}$ & MA & $\begin{array}{l}\text { Silvoney } \\
\text { Sales }\end{array}$ & BA & $\begin{array}{c}\text { Marluce } \\
\text { Pinto }\end{array}$ & $\mathrm{RR}$ & $\begin{array}{l}\text { Tadeu } \\
\text { Filipelli }\end{array}$ & $\mathrm{DF}$ \\
\hline $2^{\circ}$ Suplente & $\begin{array}{c}\text { João } \\
\text { Fagundes }\end{array}$ & $\mathrm{RR}$ & $\begin{array}{c}\text { Remi } \\
\text { Ribeiro }\end{array}$ & MA & $\begin{array}{l}\text { Tadeu } \\
\text { Filipelli }\end{array}$ & DF & $\begin{array}{c}\text { Dorany } \\
\text { Sampaio }\end{array}$ & PE \\
\hline $3^{\circ}$ Suplente & $\begin{array}{l}\text { Divino } \\
\text { Alves }\end{array}$ & DF & $\begin{array}{l}\text { Marluce } \\
\text { Pinto }\end{array}$ & $\mathrm{RR}$ & $\begin{array}{c}\text { Olavo } \\
\text { Calheiros }\end{array}$ & $\mathrm{AL}$ & $\begin{array}{c}\text { João } \\
\text { Alberto }\end{array}$ & MA \\
\hline $4^{\circ}$ Suplente & $\begin{array}{l}\text { Noel de } \\
\text { Oliveira }\end{array}$ & RJ & $\begin{array}{l}\text { Edson Bez } \\
\text { de Oliveira }\end{array}$ & SC & $\begin{array}{l}\text { Juvêncio da } \\
\text { Fonseca }\end{array}$ & MS & $\begin{array}{c}\text { Olavo } \\
\text { Calheiros }\end{array}$ & $\mathrm{AL}$ \\
\hline $5^{\circ}$ Suplente & & & & & & & $\begin{array}{c}\text { João } \\
\text { Henrique } \\
\text { de Almeida } \\
\text { Souza }\end{array}$ & $\mathrm{PI}$ \\
\hline $6^{\circ}$ Suplente & & & & & & & $\begin{array}{c}\text { José } \\
\text { Maranhão }\end{array}$ & PB \\
\hline $7^{\circ}$ Suplente & & & & & & & $\begin{array}{l}\text { Carlos } \\
\text { Bezerra }\end{array}$ & MT \\
\hline $8^{\circ}$ Suplente & & & & & & & $\begin{array}{l}\text { Rose de } \\
\text { Freitas }\end{array}$ & ES \\
\hline $\begin{array}{l}\text { Líder na } \\
\text { Câmara }\end{array}$ & $\begin{array}{l}\text { Michel } \\
\text { Temer }\end{array}$ & $\mathrm{SP}$ & $\begin{array}{c}\text { Geddel } \\
\text { Vieira Lima }\end{array}$ & BA & $\begin{array}{c}\text { Geddel } \\
\text { Vieira Lima }\end{array}$ & BA & José Borba & PR \\
\hline $\begin{array}{l}\text { Líder no } \\
\text { Senado }\end{array}$ & $\begin{array}{c}\text { Jader } \\
\text { Barbalho }\end{array}$ & PA & $\begin{array}{c}\text { Jader } \\
\text { Barbalho }\end{array}$ & PA & $\begin{array}{c}\text { Renan } \\
\text { Calheiros }\end{array}$ & $\mathrm{AL}$ & $\begin{array}{c}\text { Renan } \\
\text { Calheiros }\end{array}$ & $\mathrm{AL}$ \\
\hline
\end{tabular}

Membros da Executiva Nacional do PMDB (2007-2016):

\begin{tabular}{|c|c|c|c|c|c|c|c|c|}
\hline Cargo & $2007-2010$ & UF & $2010-2013$ & UF & $2013-2016$ & UF & 2016- & UF \\
\hline Presidente & $\begin{array}{l}\text { Michel } \\
\text { Temer }\end{array}$ & SP & $\begin{array}{l}\text { Michel } \\
\text { Temer }\end{array}$ & $\mathrm{SP}$ & $\begin{array}{l}\text { Michel } \\
\text { Temer }\end{array}$ & $\mathrm{SP}$ & $\begin{array}{l}\text { Michel } \\
\text { Temer }\end{array}$ & SP \\
\hline $\begin{array}{l}1^{\circ} \text { Vice } \\
\text { Presidente }\end{array}$ & $\begin{array}{l}\text { Íris de } \\
\text { Araújo }\end{array}$ & GO & $\begin{array}{l}\text { Valdir } \\
\text { Raupp }\end{array}$ & RO & $\begin{array}{l}\text { Valdir } \\
\text { Raupp }\end{array}$ & RO & $\begin{array}{l}\text { Romero } \\
\text { Jucá Filho }\end{array}$ & $\mathrm{RR}$ \\
\hline $\begin{array}{l}2^{\circ} \text { Vice } \\
\text { Presidente }\end{array}$ & $\begin{array}{l}\text { Joaquim } \\
\text { Roriz }\end{array}$ & DF & $\begin{array}{l}\text { Íris de } \\
\text { Araújo }\end{array}$ & GO & $\begin{array}{l}\text { Íris de } \\
\text { Araújo }\end{array}$ & GO & $\begin{array}{l}\text { Eliseu } \\
\text { Padilha }\end{array}$ & RS \\
\hline $\begin{array}{l}3^{\circ} \text { Vice } \\
\text { Presidente }\end{array}$ & $\begin{array}{l}\text { Eduardo } \\
\text { Pinho } \\
\text { Moreira }\end{array}$ & SC & $\begin{array}{l}\text { Romero } \\
\text { Jucá Filho }\end{array}$ & $\mathrm{RR}$ & $\begin{array}{l}\text { Romero } \\
\text { Jucá Filho }\end{array}$ & $\mathrm{RR}$ & $\begin{array}{l}\text { João } \\
\text { Arruda }\end{array}$ & PR \\
\hline $\begin{array}{l}\text { Secretário- } \\
\text { geral }\end{array}$ & $\begin{array}{l}\text { Mauro } \\
\text { Lopes }\end{array}$ & MG & $\begin{array}{l}\text { Mauro } \\
\text { Lopes }\end{array}$ & MG & $\begin{array}{l}\text { Mauro } \\
\text { Lopes }\end{array}$ & MG & $\begin{array}{l}\text { Mauro } \\
\text { Lopes }\end{array}$ & $\begin{array}{l}M \\
G\end{array}$ \\
\hline $\begin{array}{l}1^{\circ} \\
\text { Secretário }\end{array}$ & $\begin{array}{l}\text { Nelson } \\
\text { Bornier }\end{array}$ & RJ & $\begin{array}{c}\text { Wellington } \\
\text { Salgado de } \\
\text { Oliveira }\end{array}$ & MG & $\begin{array}{c}\text { Geddel } \\
\text { Vieira Lima }\end{array}$ & BA & $\begin{array}{c}\text { Geddel } \\
\text { Vieira Lima }\end{array}$ & BA \\
\hline $\begin{array}{l}2^{\circ} \\
\text { Secretário }\end{array}$ & $\begin{array}{l}\text { Anthony } \\
\text { Garotinho }\end{array}$ & RJ & $\begin{array}{l}\text { Nelson } \\
\text { Bornier }\end{array}$ & RJ & $\begin{array}{l}\text { Leonardo } \\
\text { Picciani }\end{array}$ & RJ & $\begin{array}{l}\text { Leonardo } \\
\text { Picciani }\end{array}$ & RJ \\
\hline $\begin{array}{l}1^{\circ} \\
\text { Tesoureiro }\end{array}$ & $\begin{array}{c}\text { Mônica } \\
\text { Paes de } \\
\text { Andrade } \\
\text { Lopes } \\
\text { Oliveira }\end{array}$ & $\mathrm{CE}$ & $\begin{array}{c}\text { Eunício de } \\
\text { Oliveira }\end{array}$ & $\mathrm{CE}$ & $\begin{array}{l}\text { Eunício de } \\
\text { Oliveira }\end{array}$ & $\mathrm{CE}$ & $\begin{array}{c}\text { Eunício de } \\
\text { Oliveira }\end{array}$ & $\mathrm{CE}$ \\
\hline $\begin{array}{l}2^{\circ} \\
\text { Tesoureiro }\end{array}$ & $\begin{array}{c}\text { Caíto } \\
\text { Quintana }\end{array}$ & PR & $\begin{array}{c}\text { Rodrigo } \\
\text { Rocha } \\
\text { Loures }\end{array}$ & PR & $\begin{array}{c}\text { Rodrigo } \\
\text { Rocha } \\
\text { Loures }\end{array}$ & PR & $\begin{array}{l}\text { Valdir } \\
\text { Raupp }\end{array}$ & RO \\
\hline
\end{tabular}




\begin{tabular}{|c|c|c|c|c|c|c|c|c|}
\hline $1^{\circ} \mathrm{Vogal}$ & $\begin{array}{l}\text { Orestes } \\
\text { Quércia }\end{array}$ & $\mathrm{SP}$ & $\begin{array}{l}\text { Darcísio } \\
\text { Perondi }\end{array}$ & RS & $\begin{array}{l}\text { Moreira } \\
\text { Franco }\end{array}$ & $\mathrm{RJ}$ & $\begin{array}{c}\text { Moreira } \\
\text { Franco }\end{array}$ & $\mathrm{RJ}$ \\
\hline $2^{\circ}$ Vogal & $\begin{array}{c}\text { Dorany } \\
\text { Sampaio }\end{array}$ & $\mathrm{PE}$ & $\begin{array}{c}\text { Henrique } \\
\text { Eduardo } \\
\text { Alves }\end{array}$ & $\mathrm{RN}$ & $\begin{array}{l}\text { Darcísio } \\
\text { Perondi }\end{array}$ & RS & $\begin{array}{l}\text { Darcísio } \\
\text { Perondi }\end{array}$ & RS \\
\hline $3^{\circ}$ Vogal & $\begin{array}{l}\text { Darcísio } \\
\text { Perondi }\end{array}$ & RS & $\begin{array}{c}\text { Jader } \\
\text { Barbalho }\end{array}$ & PA & $\begin{array}{c}\text { Jader } \\
\text { Barbalho }\end{array}$ & PA & $\begin{array}{c}\text { Jader } \\
\text { Barbalho }\end{array}$ & PA \\
\hline $4^{\circ} \mathrm{Vogal}$ & $\begin{array}{c}\text { Geddel } \\
\text { Vieira Lima }\end{array}$ & BA & $\begin{array}{c}\text { Moreira } \\
\text { Franco }\end{array}$ & RJ & $\begin{array}{c}\text { Henrique } \\
\text { Eduardo } \\
\text { Alves }\end{array}$ & $\mathrm{RN}$ & $\begin{array}{c}\text { Henrique } \\
\text { Eduardo } \\
\text { Alves }\end{array}$ & $\mathrm{RN}$ \\
\hline $5^{\circ}$ Vogal & & & & & $\begin{array}{c}\text { João } \\
\text { Alberto }\end{array}$ & MA & $\begin{array}{l}\text { Lelo } \\
\text { Coimbra }\end{array}$ & ES \\
\hline $6^{\circ} \mathrm{Vogal}$ & & & & & $\begin{array}{c}\text { Lelo } \\
\text { Coimbra }\end{array}$ & ES & $\begin{array}{c}\text { Eduardo } \\
\text { Braga }\end{array}$ & $\begin{array}{l}\text { A } \\
M\end{array}$ \\
\hline $7^{\circ}$ Vogal & & & & & $\begin{array}{c}\text { Eduardo } \\
\text { Braga }\end{array}$ & AM & $\begin{array}{l}\text { Mauro } \\
\text { Mariani }\end{array}$ & SC \\
\hline $8^{\circ}$ Vogal & & & & & $\begin{array}{l}\text { Mauro } \\
\text { Mariani }\end{array}$ & SC & $\begin{array}{l}\text { Íris de } \\
\text { Araújo }\end{array}$ & $\begin{array}{l}\text { G } \\
\text { O }\end{array}$ \\
\hline $9^{\circ}$ & & & & & & & $\begin{array}{c}\text { Roseana } \\
\text { Sarney }\end{array}$ & $\begin{array}{l}M \\
A\end{array}$ \\
\hline $10^{\circ}$ & & & & & & & $\begin{array}{c}\text { João } \\
\text { Henrique }\end{array}$ & $\mathrm{PI}$ \\
\hline $11^{\circ}$ & & & & & & & $\begin{array}{c}\text { José } \\
\text { Maranhão }\end{array}$ & PB \\
\hline $12^{\circ}$ & & & & & & & $\begin{array}{c}\text { Raimundo } \\
\text { Lyra }\end{array}$ & PB \\
\hline $13^{\circ}$ & & & & & & & $\begin{array}{l}\text { Waldemir } \\
\text { Moka }\end{array}$ & $\begin{array}{c}M \\
S\end{array}$ \\
\hline $1^{\circ}$ Suplente & $\begin{array}{l}\text { Wilson } \\
\text { Santiago }\end{array}$ & PB & $\begin{array}{c}\text { Tadeu } \\
\text { Filippelli }\end{array}$ & DF & $\begin{array}{l}\text { Waldemir } \\
\text { Moka }\end{array}$ & MS & $\begin{array}{l}\text { Tadeu } \\
\text { Filippelli }\end{array}$ & DF \\
\hline $2^{\circ}$ Suplente & $\begin{array}{l}\text { Gerson } \\
\text { Camata }\end{array}$ & ES & $\begin{array}{c}\text { Wilson } \\
\text { Santiago }\end{array}$ & PB & $\begin{array}{l}\text { Tadeu } \\
\text { Filippelli }\end{array}$ & DF & Baleia Rossi & $\mathrm{SP}$ \\
\hline $3^{\circ}$ Suplente & $\begin{array}{l}\text { Carlos } \\
\text { Bezerra }\end{array}$ & MT & $\begin{array}{l}\text { Rose de } \\
\text { Freitas ES }\end{array}$ & & $\begin{array}{c}\text { Marcelo } \\
\text { Castro }\end{array}$ & $\mathrm{PI}$ & $\begin{array}{l}\text { Fernando } \\
\text { Jordão }\end{array}$ & RJ \\
\hline $4^{\circ}$ Suplente & $\begin{array}{l}\text { Rose de } \\
\text { Freitas }\end{array}$ & ES & $\begin{array}{l}\text { Paes de } \\
\text { Andrade }\end{array}$ & $\mathrm{CE}$ & $\begin{array}{l}\text { Rose de } \\
\text { Freitas }\end{array}$ & ES & $\begin{array}{l}\text { Wellington } \\
\text { Salgado }\end{array}$ & $\begin{array}{l}M \\
G\end{array}$ \\
\hline $5^{\circ}$ Suplente & $\begin{array}{l}\text { Moisés } \\
\text { Avelino }\end{array}$ & TO & $\begin{array}{l}\text { Carlos } \\
\text { Bezerra }\end{array}$ & MT & $\begin{array}{c}\text { João } \\
\text { Henrique }\end{array}$ & $\mathrm{PI}$ & $\begin{array}{l}\text { Carlos } \\
\text { Bezerra }\end{array}$ & $\begin{array}{c}M \\
T\end{array}$ \\
\hline $6^{\circ}$ Suplente & & & $\begin{array}{l}\text { Gerson } \\
\text { Camata }\end{array}$ & ES & $\begin{array}{l}\text { Carlos } \\
\text { Bezerra }\end{array}$ & $\mathrm{MT}$ & $\begin{array}{c}\text { Dulce } \\
\text { Miranda }\end{array}$ & TO \\
\hline $7^{\circ}$ Suplente & & & $\begin{array}{l}\text { Moisés } \\
\text { Avelino }\end{array}$ & TO & $\begin{array}{l}\text { Wellington } \\
\text { Salgado }\end{array}$ & MG & $\begin{array}{c}\text { Olavo } \\
\text { Calheiros }\end{array}$ & $\mathrm{AL}$ \\
\hline $8^{\circ}$ Suplente & & & $\begin{array}{c}\text { Lelo } \\
\text { Coimbra }\end{array}$ & ES & $\begin{array}{c}\text { Osvaldo } \\
\text { Reis }\end{array}$ & TO & $\begin{array}{c}\text { Flaviano } \\
\text { Melo }\end{array}$ & $A C$ \\
\hline $9^{\circ}$ Suplente & & & Átila Lins & AM & Renan Filho & $\mathrm{AL}$ & Raul Henry & $\mathrm{PE}$ \\
\hline $\begin{array}{l}10^{\circ} \\
\text { Suplente }\end{array}$ & & & $\begin{array}{l}\text { Osvaldo de } \\
\text { Souza Reis }\end{array}$ & TO & $\begin{array}{l}\text { Wilson } \\
\text { Santiago }\end{array}$ & PB & Fabio Reis & SE \\
\hline $\begin{array}{l}11^{\circ} \\
\text { Suplente }\end{array}$ & & & & & $\begin{array}{c}\text { Flaviano } \\
\text { Melo }\end{array}$ & $A C$ & $\begin{array}{l}\text { Fátima } \\
\text { Pelaes }\end{array}$ & $\begin{array}{l}\mathrm{A} \\
\mathrm{M}\end{array}$ \\
\hline $\begin{array}{l}12^{\circ} \\
\text { Suplente }\end{array}$ & & & & & Raul Henri & $\mathrm{PE}$ & $\begin{array}{c}\text { Lúcio Vieira } \\
\text { Lima }\end{array}$ & BA \\
\hline
\end{tabular}




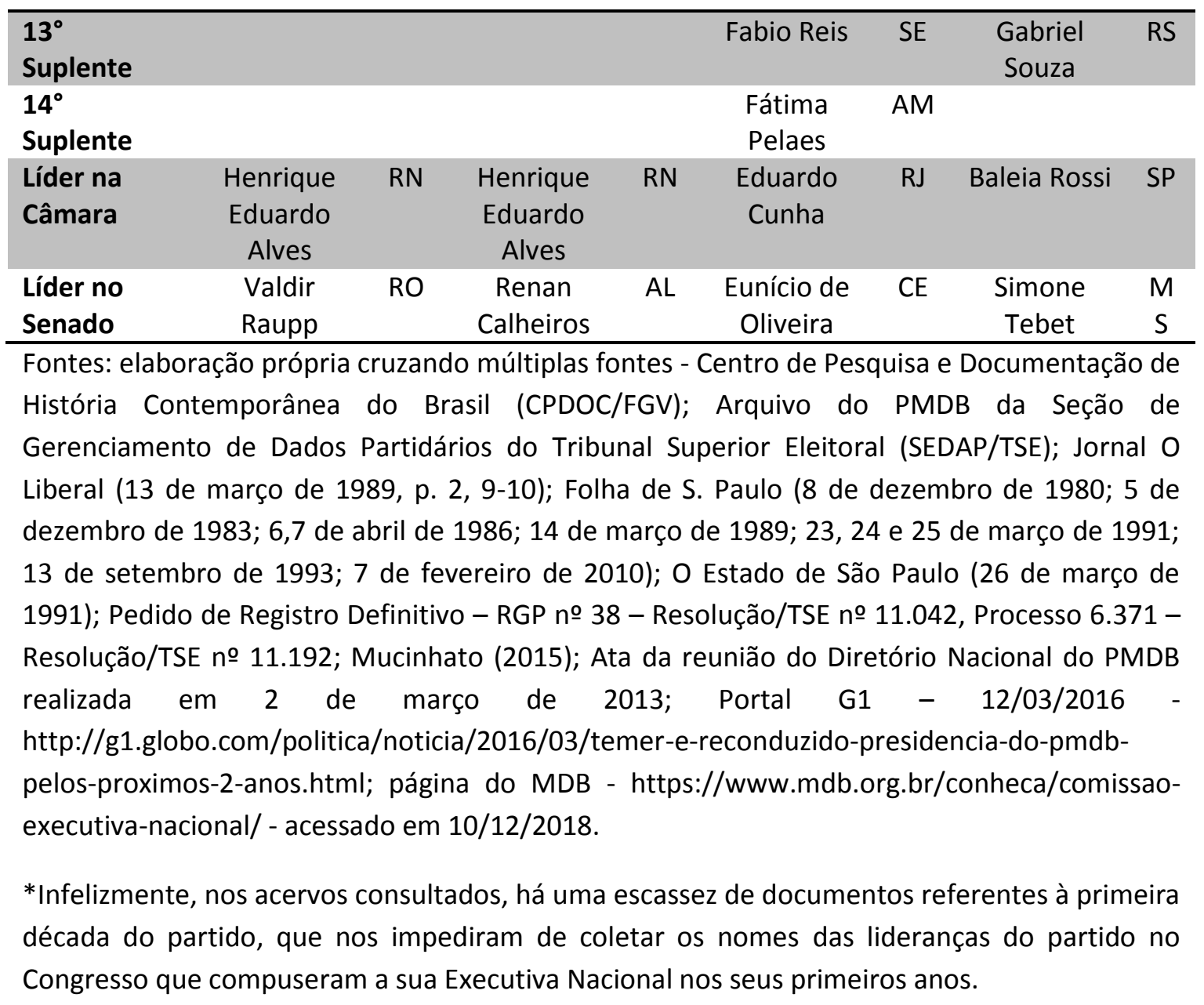




\section{ANEXO 4}

\section{Pedido de Registro Definitivo do PP no TSE}

$i$
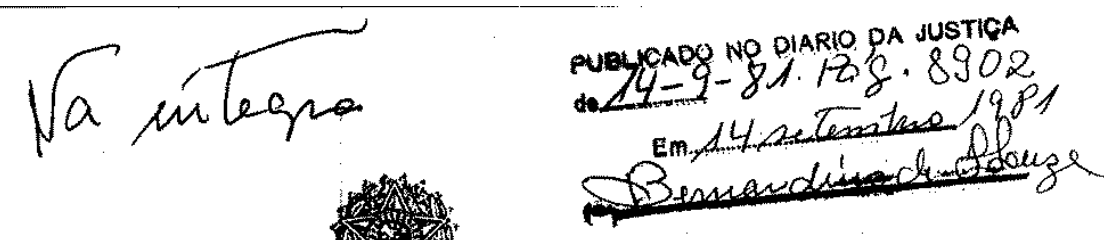

PODER JUDICIARTO

TRIBUNAL SUPERIOR ELEITORAL

RESOLUÇÄO N: 11.075

PROCESSO DE REGISTRO DE PARTIDO NQ 40 - CLASSE VII - DISTRITO FEDE RAL (Brasilia).

Defere o registro definitivo do Partido Popular (PP).

Vistos, etc.

RE S OLVEM OS Ministros do Tribunal Superior Eleitoral, por unanimidade de votos, deferir o registro definitivo do PP, nos termos do voto do Relator, que fica fazendo parte integrante da decisão.

SALA DAS SESSUES DO TRIBUNAL SUPERIOR ELEITORAL.

Brasilia, 10 de setembro de 1981 .

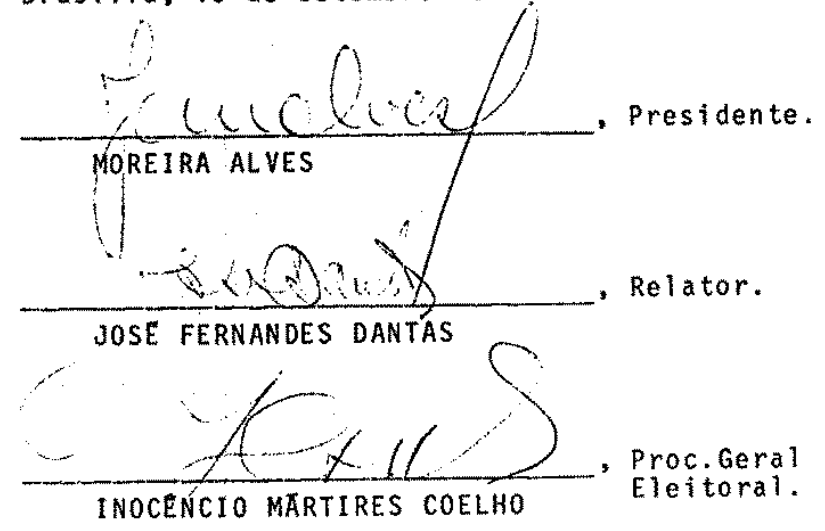


PROCESSO ELEITORAL NQ 40 - DISTRITO FEOERAL

CLASSE VII

ASSUNTO : PEDIDO DE REGISTRO DEFIMITIVO DO PARTIDO POPULAR (PP)

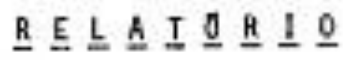

O SR. MIKISTRO JOSE DAMTAS :

D Diretōrio Mactonal do Partido Popular, a requerimento firnado polo seu Presidente, Senador Tancredo Yeves, pretende 0 registru definitivo do Partido.

Para 1sso, orrolou as provas de cuaprimento das exigēn cfas estabelecidas no art. $16, t$, e suas altheas, da seguinte forma :

"a) certidóes expedidas pelas secretarias dos Tribunais Regtonats Elcitorsfs, atestando o atendirtento das exigôncias contidas nas letras a, o e c, do inciso $I$, do artigo 16, da Re $+2$ solução $10.785 / 80$, dos soguintes Estados da Federação -

1) 84HIA (doc.1):

2) CEAPA (dot. 23$)$

3) ESPIRITO \$ANTO (dec.3);

4) NARAKLOO (doc.4);

5) suTo geosso do sul. (doc, 5);

6) MIMAS GERAIS (doc,6);

7) PMRA (đoc.7);

8) PARARA (doc.8):

9) PRRAIBA (סOc.9);

10) PERTWMLUCO (6oc.10); 
11) PIAUI (doc.11) ;

12) RIO DE JANEIRO (do.12);

13) STio PALTO (doc.13);

14) NลTо GROSS0 (døc.14);

15) SAMTA CATARINA (doc.15);

16) SERGIPE (doc.16);

17) RIO GRANOE DO NORTE (dac.17).

Protosta, porön, pelo oferecinento de certidäo relativa ao Estado do Río Grando do Sul, no qual o Partído Popular foi, tan bän, regular e tenpestivanente organizado.

b) côpta sutêntica da Ata da Convençà̃o Xacional do Partido Popular, reslizada en 7 de junho de 1981. conferida pelo secre taria desta c.Corte, que denonstra o comparecinanto do represen tantes de Diretórtas Reglonats 60 Partido, en rúntero mito supe rior ao minfino legal (doc. 18);

c) cōpia autêntica de Ata da eletçāo da Conissäo Executiva

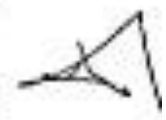
Nacional do Partíso Popular, rasilizada na mesria data, fgualente conferida pela Secretaria deste c. Tribunal (doc.19)" - fts.2/ 3.

A f1s. 39, a Secrotaria deste Tribunal fez juntada do comuntcaçāo da boa orden en que transcorreu a Cenvençăo kacto nal do Partido, como a observou, elt nome deste Egrēgto Tribu nal, a Precuradora Ceçila zarur.

Publicado o odftal de que trats o \$ 19 do art, 16 ds pracitads Resoluçäo, decarrou o respectivo prazo legal sea impugnaçāo - f1s. 42/44.

A fis. 47, o requerente voltou a peticionar, oferecen do certidōes cosiplenentares, relativas à formaçă do portido nos Estados do lito Grande do Morte o Espirito Santo. 
Subnetido o pedido ã Procuradoria Geral Eleitoral, esta 50 manifestou a f1s. 52, en parecer do Subprocurador-Geral Valin Teixeira, assin rundanentado:

4 Ao PARTtO0 POPULAR - PP - fo1, pola Resolução nQ 10,889, do 2.9.80, deferido o registro provisörto, con a concessấo do prazo de 12 (doze) nases pare sua organizaçốo definitiva. Conforne consta do Ata de fls. 22 e seguintes, devidanente conferida pela Secretaria da Colendo Tribunal superfor Eleftora1, a Convenção Racional do Partido realizou-se en 7.6.81, tendo sido eleito o Diretörio Nacional e res poct.1va Conissäo Executiva, tudo dentro do prazo previsto no artigo 14 , de Resolução no 10.785/80.

Rosults esclarecido, do exane dos autos, que o PART 200 POPULAR - PP - de sconde con o previsto nas letras a , $\underline{b}$ e c․ do iter l, do artigo 16. Juntou certidöes expedidas pelas Secretarias dos Triben nais Regianais nas Estados da Bshia, Coará, Espirito Santo, Maramĩo, Nato Grosso. Nato Grosso do Sul, Ninas Gerais, Pará, Paraná, Paraiba, Pernambuco, Piauf, Rio de Janeiro, Rio Grande do Korto, São Paula San ta Catarina e Sergipe, num total de 17 (deressete) Estados, as quais atenden às exigēncias legsis, a exceçāo dos Estados do Cerá e Espíri to santo, que nāo certifican a aprovaçāo do manifesto, do estatuto e do prograna pelas respectivas convencöes regionais, e do Rio Grande do Norte, que apenas certifica quanto to registro dn dirotório rogionsl. defictênctas que, no entanto, näo chegan a prejudicar o pedido, una vez cue o Partido conseguiu organizar-se en un nimero de Estados superior ao exigido.

Por outro lado, no que diz respelto so 0iretörio kacionat e respoctiva Conissio Exocutiva, tenos que se conforman con as extgên cias legais. Cono se vẽ das Atas de fls. 22 e seguintes. o Diretärio Yacional foi eleito cen 71 (setenta e un) nerbros, incluindo os lifo res na cānora dos Deputados e Senado Federal, conposto con un aenbro, pelo nenos, de coda seçs̄o part1dăria regionsl, e 23 (vinte e três) ș 


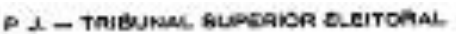

plentes, en cunsonāncis, pois, con o disposto nos artigos 72,1 ten II. caput e 619 do 79,081 , da Resolução no 10,785/B0. Da mesna forna, fol a Coniss̄̄o Executiva Nacionsl corposta segundo o dis posto no iten 111 do art. B5, e, com relaçāo sos suplentes, de a condo con o disposto no seu 5 29. Da documentaça anexada friferese tambēn çuo, da Convenģăo Naciona1, participaran ropresentsntes de diretörios regíonals de, pela menos, nove Estados - Iten II do artigo 16 .

Pejo exposto, tendo sido otendidos todos os requisitos legsis pertinentes ao assunto, somos pelo deferimento do pedido." $-115,53 / 54$.

Relatei.

\section{$\underline{v} \underline{\mathbf{I}} \underline{0}$}

0 SR. NIRISTRO JOSE DANTAS (RELATOR): - SEnhor Pres1 dente, anoto o equivoco do parecer, tocante a ressalva fefta às certidōes dos Tribunals Regionats Eleitorais do Rio Grande do Narte espirito Santo. Na verdade, as certidöes conplenen tares roferidas no relatōrta vieran sanar a falha indicada e deran conta de que, tanbēm naqueles Estados, foran intogral mente cunpridas as exigências en causa-fis. 48 e 49.

Doi que, con nafor razäo, se inpãe a conclusäo fovoră vel do deferimenta. consoante o denonstrado precnchimento dos requisitos legais pelo Partido Popular, cumpridos con vistos à obtençöo do suplicado registro definitivo.

Acolho, pois, o parecer, para deferir o podido, polo que deternino a efetivaçäo das nedidas previstas no artigo 17 da Resoluçăo no $10.785 / 80$.

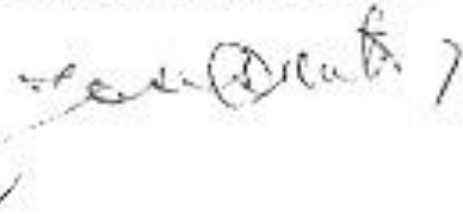

Nhat, wan 191 


\section{EXTRATO DA ATA}

Proc, Reg.Part.nQ 40- Cl.VIt- DF - Rel. Min. Fernandes Dantas. Decisăo: Deferida o pedido. Votação unânino,

Presidencta da Ministro Moratra Alves. Presantes os Ministras Cunha Peixoto, Soares Muñoz. Fernandes Dantas, Carlos Hadeira, Pedro Gorditho, J.H.de Souza Andrade e o Dr, Procurador Geral E leitoral Inocêncio Märtires Coelho.

SESSROO DE $10,9,8]$ 


\section{PRRTIDO POPULAR - PP}

\section{DIRETORIO NACIOYAL}

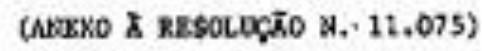

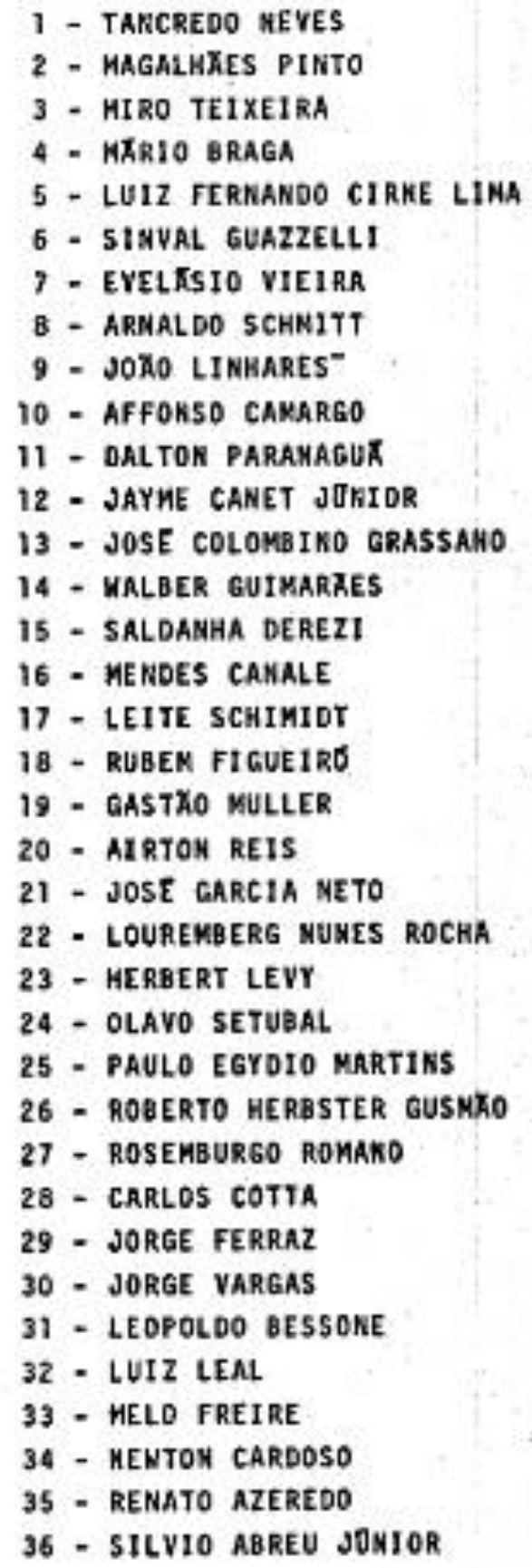

Wod wat att 


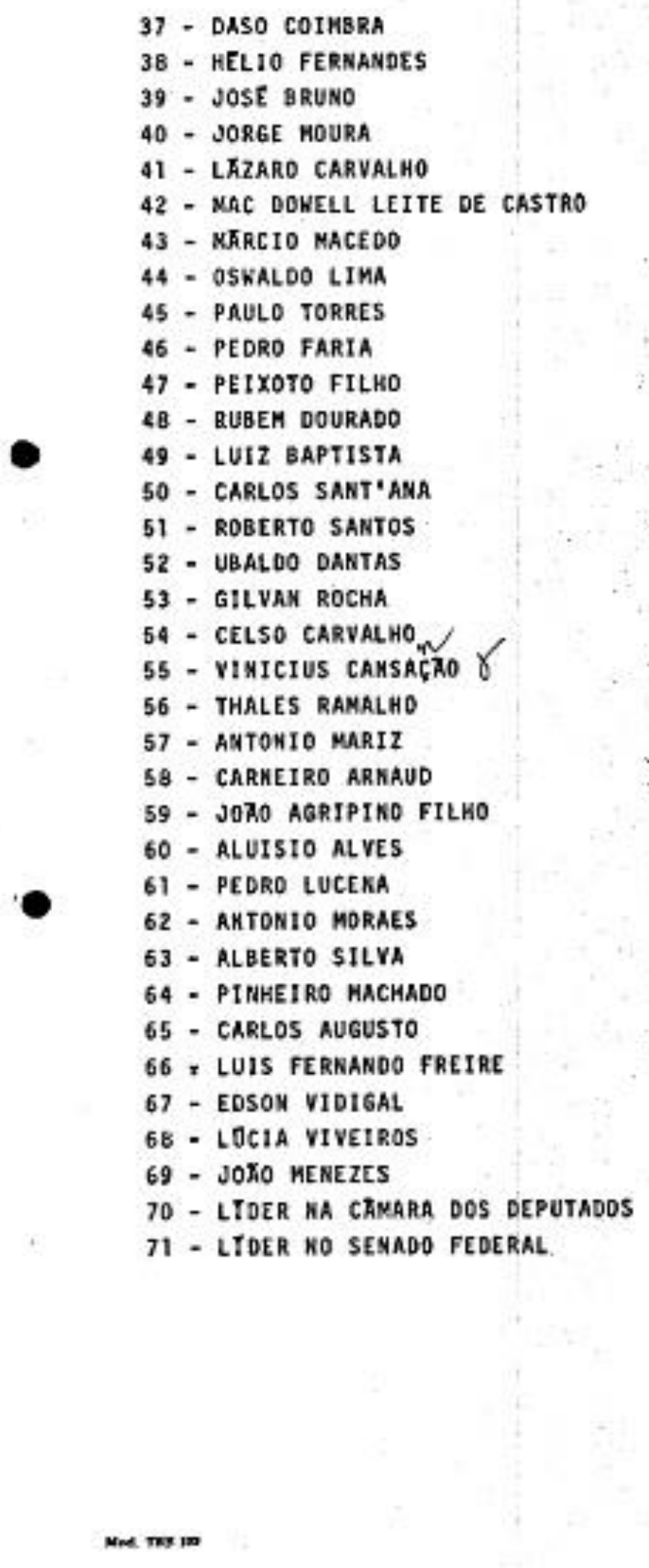




\section{SUPLEMTES}

$$
\begin{aligned}
& 1 \text { - JOSE FRAGELLI } \\
& 2 \text { - BENRIQUE ALVES } \\
& 3 \text { - CARLOS NILSOM } \\
& 4 \text { - TERTULIANO AZEVEDO } \\
& 5 \text { - ALCIR PIMENTA } \\
& 6 \text { - DAMIEL SILVA } \\
& 7 \text { - JOEL VIVAS } \\
& 8 \text { - LEOMIDAS SAMPAIO } \\
& 9 \text { - MARCELO MEDEIROS } \\
& 10 \text { - PERICLES GOMCALYES } \\
& 11 \text { - HELIO GARCIA } \\
& 12 \text { - JUAREZ BATISTA } \\
& 13 \text { - LUIZ BACCARIKI } \\
& 14 \text { - BEHTO GOMGAL YES } \\
& 15 \text { - SERGIO FERRARA } \\
& 16 \text { - CAIO POMPEU } \\
& 17 \text { - FRAKCISCO ANARAL } \\
& 18 \text { - GERTO LOBO } \\
& 19 \text { - HELIO LOBATO } \\
& 20 \text { - GDRGES DA SILVEIRA } \\
& 21 \text { - MRRIO STAKM } \\
& 22 \text { - PEDRO SAKPAIO } \\
& 23 \text { - MENDES MELO }
\end{aligned}
$$




\section{ANEXO 5}

Reprodução da nota pública emitida pelo Palácio do Planalto na qual o Presidente anuncia as medidas conhecidas como "Pacote de Novembro".

"Encaminhei ao Congresso Nacional projetos de lei dispondo sobre modificações na legislação eleitoral. Diante das dificuldades verificadas na tramitação desses projetos, autorizei negociações para que, mediante acordos, se editassem, desde logo, as alterações nas regras concernentes ao pleito eleitoral de 1982. As negociações não surtiram, porém, até aqui, quando iminente fim da sessão legislativa, o efeito desejado.

Diante do impasse criado, resolvi adotar, quando ao pleito de 1982, a seguinte decisão, que tem por fim não só resolver o problema institucional que o quadro político apresenta, como imprimir maior rigor às linhas estruturais do pluripartidarismo, consagrado pela Constituição Federal:

1- O voto será vinculado em todas as eleições municipais, estaduais e federais, majoritárias ou proporcionais.

2- Será indeferido o registro da chapa em que não se inscreverem conjuntamente candidatos a todas as eleições.

3- O voto será dado, obrigatoriamente, em todos os casos, e sob pena de nulidade, aos candidatos de um só partido político.

4- A desistência da candidatura dependerá de pedido simultâneo do candidato e do partido. A desistência, tácita ou expressa, da candidatura a governador importará a anulação dos votos dados ao partido.

5- A Justiça Eleitoral disporá quanto ao processo de votação.

6- Recomendo que o PDS feche a questão, na forma da lei, não só em torno dessa decisão que, com suas regras complementares, será objeto de projeto de lei, a ser encaminhado ao Congresso Nacional, nos termos do art. 51, parágrafo 2, da Constituição, como também as proposições, em trânsito no Congresso, relativas as modificações na Lei de Inelegibilidades e criação do Estado de Rondônia."

Reproduzido a partir da Folha de S. Paulo - 26/11/1981, p.4 


\section{ANEXO 6}

Composição do Diretório Nacional do PMDB eleito em 7/12/1980 (1ª Convenção)

Adalberto Sena

Aldo Fagundes

Armando Temperani Pereira

Celso Gabriel de Rezende Passos

Chagas Rodrigues

Edgar da Mata Machado

Euclides Scalco

Fernando Coelho

Fernando Lyra

Francisco Pinto

Freitas Nobre

Gilson de Barros*

Henrique Santillo

Iranildo Pereira

Jader Barbalho

Jarbas Vasconcelos

João Evangelista Pereira de Melo

José Richa

Leite Chaves

Luiz Mariano Paes de Carvalho Filho

Marcos Freire

Mário Frota

Mauro Benevides

Miguel Arraes

Octacílio Queiroz

Paulo Brossard

Pedro Simon

Raphael de Almeida Magalhães*

Roberto Cardoso Alves*

Severo Gomes*

Simão da Cunha Pereira

Teotônio Vilela*

Ulysses Guimarães

Waldir Pires

\author{
Agenor Maia* \\ Alencar Furtado \\ Aurélio Peres \\ Celso Peçanha \\ Cunha Lima \\ Edgard Amorim \\ Evandro Carreira* \\ Fernando Cunha \\ Francisco Libardoni \\ Franco Montoro \\ Gerson Camata* \\ Hélio Duque \\ Humberto Lucena \\ Jackson Barreto \\ Jaison Barreto \\ Jerônimo Santana \\ José Carlos Teixeira \\ Lázaro Barboza \\ Léo de Almeida Neves \\ Marcelo Cerqueira \\ Mário Covas \\ Mário Moreira \\ Mauro Borges Teixeira \\ Nabor Júnior \\ Orestes Quércia \\ Paulo Rattes \\ Raimundo Azevedo Costa \\ Renato Archer \\ Rômulo de Almeida \\ Siegfried Emmanuel Heuser \\ Tarcísio Delgado \\ Tidei de Lima \\ Valdice Macedo Nobre \\ Wilson Martins
}

*Políticos com passagem pela ARENA

Retirado do Pedido de Registro Definitivo - RGP no 38-Resolução/TSE no 11.042

Composição do Diretório Nacional eleito em 14/2/1982 (2a Convenção - Convenção conjunta com PP)

Affonso Camargo (PP-PR Senador biônico, ex- Agenor Maria (RN, ex-arenista) arenista)*

Aldo Fagundes (RS)

Alencar Furtado (PR)

Aluizio Alves (PP-RN Governador nomeado,

Antonio Morais (PP-CE, ex-emedebista)* 
ex-arenista)*

Armando Temperani Pereira (RS)

Bento Gonçalves Filho (PP-MG ex-arenista)*

Chagas Rodrigues (PI)

Dejanir Dalpasquale (SC)

Edson Vidigal (PP-MA, ex-arenista)*

Evandro Carreira (AM, ex-arenista)

Fernando Cunha (GO)

Francisco Pinto (BA)

Gilberto Mestrinho (PP-AM, ex-PTB

Varguista)*

Hélio Fernandes (PP-RJ, ex-emedebista)*

Humberto Lucena (PB)

Jackson Barreto (SE)

Jarbas Vasconcelos (PE)

João Agripino Filho (PP-PB, ex-arenista)*

João Evangelista Pereira de Melo (PP-RR)*

Leite Chaves (PR)

Luiz Baptista (PP-ES, ex-emedebista)*

Marcelo Miranda (MS)

Mário Covas (SP)

Mauro Benevides (CE)

Miguel Arraes (PE)

Nabor Júnior (AC)

Paulo Rattes (RJ)

Raimundo Azevedo Costa (AP)

Renato Archer (MA)

Roberto Figueira Santos (PP-BA Governador

nomeado, ex-arenista)*

Ronan Tito (MG)

Sérgio Murilo (PP-PE, ex-emedebista)*

Tancredo Neves (PP-MG, ex-emedebista)*

Teotônio Vilela (AL, ex-arenista)

Ulysses Guimarães (SP)

Wilson Martins (MS)

*Ex-pepistas

Reproduzido a partir do Processo 6.371 - Resolução/TSE no 11.192

\section{Composição do Diretório Nacional eleito em 4/12/1983 (3ạ Convenção)}

Ademir Andrade

Alberto Goldman

Aldo Arantes

Alfredo Campos

Amazonas Brasil

Antonio Russo

Casildo Maldaner

Celso Saleh
Aurélio Peres (SP)

Celso Peçanha (RJ)

Cid Sampaio (PP-PE, ex-arenista)*

Edgard da Mata Machado (MG)

Euclides Scalco (PR)

Evelasio Vieira (PP-SC, ex-emedebista)*

Fernando Lyra (PE)

Gastão Muller (PP-MG Senador biônico, exarenista)*

Gilson de Barros (MT)

Henrique Santillo (GO)

Iranildo Pereira (CE)

Jader Barbalho (PA)

Jerônimo Santana (RO)

João de Paiva Menezes (PP-PA, ex-

emedebista)*

João Linhares (PP-SC, ex-arenista)*

Léo de Almeida Neves (PR)

Marcelo Cerqueira (RJ)

Márcio Macedo (PP-RJ, ex-emedebista)*

Mário Moreira (ES)

Mendes Canale (PP-MT, ex-arenista)*

Miro Teixeira (PP-RJ, ex-emedebista)*

Octacílio Queiroz (PB)

Pedro Simon (RS)

Raphael Almeida Magalhães (RJ, ex-arenista)

Roberto Cardoso Alves (SP, ex-arenista)

Roberto Herbster Gusmão (PP-SP, ex-

emedebista)*

Sérgio Ferrara (PP-MG, ex-emedebista)*

Severo Gomes (SP, ex-arenista)

Tarcísio Delgado (MG)

Tidei de Lima (SP)

Waldir Pires (BA)
Affonso Camargo

Alberto Silva

Alencar Furtado

Aloisio Alves

Antônio Mariz

Carlos Mosconi

Celso Furtado

Chagas Rodrigues 
Cid Sampaio

Epitacio Cafeteira

Fernando Santana

Franco Montoro

Garcia Neto

Gilberto Mestrinho

Haroldo Lima

Helio Gueiros

Humberto Lucena

Irajá Rodrigues

Itamar Franco

Jader Barbalho

Jaison Barreto

Jeronimo Santana

João Herrmann

João Menezes

José Fogaça

Luis Guedes

Márcio Braga

Marcos Freire

Mário Frota

Mauro Benevides

Miguel Arraes

Odacir Klein

Odilon Salmoria

Padre Pombo

Paulo Brossard

Paulo Rattes

Pimenta da Veiga

Raul Ferraz

Roberto Freire

Roberto Santos

Severo Gomes

Tancredo Neves

Waldir Pires

Wilson Martins
Dante de Oliveira

Fabio Lucena

Francisco Pinto

Freitas Nobre

Gerson Camata

Gilvan Rocha

Hélio Duque

Hugo Perez

Ibsen Pinheiro

Iris Resende

Jackson Barreto

Jaime Canet

Jarbas Vasconcelos

João Elisio

João Linhares

José Costa

José Richa

Márcia Valeria

Márcio Santilli

Maria Conceição Tavares

Mario Martins

Mauro Borges

Nabor Junior

Odilon Coutinho

Orestes Quércia

Paes de Andrade

Paulo Mincarone

Pedro Simon

Plinio Martins

Renato Archer

Roberto Rolemberg

Saldanha Derzi

Sinval Guazeli

Ulysses Guimarães

Miro Teixeira

Retirado de Folha de S. Paulo - 5/12/1983, p.4 


\section{ANEXO 7}

\section{Pedido de Registro Definitivo do PMDB no TSE após a incorporação do PP}

TRIBUNAL SUPERIOR ELEITORAL

RESOLUÇÄO N: 11.192

PROCESSO NO 6.371 - CLASSE 10a. - DISTRITO FEDERAL (BrasIl1a).

- Registro do Diretóxio Nacional e da Comissão Executiva do Partido do Mo vimento Democrätico Brasıleiro. Impugnação não conhecida, por falta de legitimi dade do impugnante. Pedido de registro deferido, uma vez que foram satisfeitas as formalidades legais.

Vistos, ete.

RE S O I VEM Os Ministros do Tribunal superior Eleitoral, por unanimidade de votos, não conhecer da Impugnação e deferir $\circ$ re gistro đo Díretórío Nacional e da Comissão Executiva do PMDB, nos termos do voto do relator, que fica fazendo parte integrante da de ci.são.

SALA DAS SESSÖES DO TRIBUNAL SUPERIOR ELEITORAL.

Brasílıa, 16 de março de 1.982 .

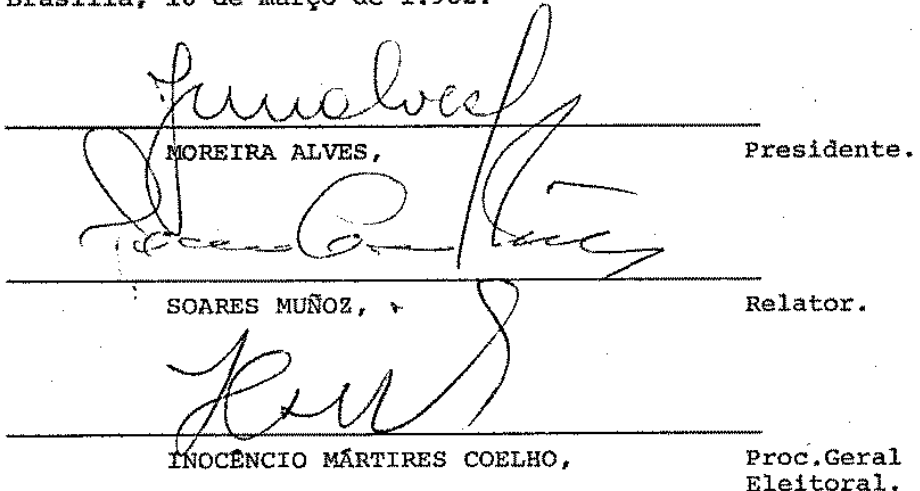


PROCESSO NQ 6.371 - CLASSE 10a. - DISTRITO ERDERAL. (BrasR11a).

REI A T O R I O

O sexhor MINISTRO sonpss MUNoz (Relator):Senhor Dre sidente, o parecer so 11ustre subprocurador-Goral Dr. A. G. Valim Te1xe1ra, aprovado pelo eminente procurador-Geral Eleitoral profes sor Inocênelo Marttres ceelho, expōe a espểcie e sobre ela op1na $(218+153 / 155)=$

*1. O PARTIDD do MOVINENTO DENOCRATzCO BRASILBIRO - PMDB - por aau Preasdente, Deputado 므 1ysacs Gu1narãcs, requer so Colendo Iribunal Su perior o repietro de seu Diretório Nacional e respectiva Consssäo Executiva, elefto em Conven Ł̧āo Nacional conjunta realizada em 14 de feverolro ultino, nos ternos do artigo 160, da Reso luģăo ne $10.735 / 80$.

2. Para tanto, fax funtar cópla das atas da Convençäo vacional para esoolha do diretsrio e da ele1६̧̄o da conissāo executiva, devidanente autenticada pela sccretaria do Tribunal superlor, aoumanthada dos editeis de convecą̧̄o pu b1ieados na imerensa local, bem assim 11sta de presença comprobatobria do comparecittento to nû́ mero ginino de convencionais, encerrada pelo ar. Cbaervador da Juatiça Eleltoral.

3. Publicado o edital a que alude o axtigo 91. da eltada Resoluçāo, apresentou 1mpugnaçāo, no prazo legal, o sEwhor clovis srzkzEL, dizen do-se elaitor inearito no PARTIDo POPULaR e nem bro do Diretćrlo Regionel daquele partiao no rio Grange $a \varphi$ sul, aob on fundsnentos a eeguir arrolados:

18) gue a convençāo Waclona1, ranl1zada por arbos es partidos, no d1a 14 do corrente ๓êิs, fol constituida llegalmente, pois da ncema partioinaran os genhores: Fernando Remog Paraira a Jansl José de salee, do pP; João Evangelista Pereira de Melo a aIlvio Sebastiāo de Castro Leite, do PMDB, todos de foraina, e ainda o $\mathrm{gr}$. Mírio Farsando 


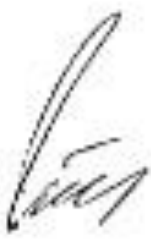

Gongalves Sraga, do PP de Jonabinia, os quala näo tinham logit:imidade para da Donvençäo participar, una vez gue as atas das convan çöese raylofala que on elegeran delegados, nāo havian corrido a tramitaç̄o setabelec1 da pela lei, para que pudessen produzir to dos os afeitos exigidos.

4. $\operatorname{~Im~favor~de~sua~prinofpal~alegaçāo,~abuz~o~}$ impugnante:

18) que a 4scisāo do Tribunal Bleitoral que aprovou os dois delegados do paxtido Do pular do território Pederal de Roraima E de 09 de fevereiro as 19B2, acan que o reg

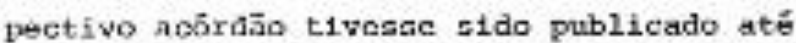
a data da Convenction

20) que o Sr. Marlo Fernando Conçalves, de gado do partido popular de flondônia, teria participado da Convençāo sem que o diretō rio regiunal tivesse aldo rogietrado até a AaLa da Convençió;

32) que a deciseno de Tribunal Meglonal do Anaronas, que aprovou os dois delegados do Partido do Movinento Denocrătico Brasilei ro de Roraima, E te 18 de fovereiro do cor rente sno, 4 dias apös a data da tenlizal ६ָ̧̄o da Canvençä́o.

Por esses motiwos, entende o impugnante ser nula a deliberação tomada pelos dols partidos no aentido da 1roorporação, porgue apurados, $\infty$ no välidos, votos de quein tāo tinha legttimida de para votar, trazendo, de consequênoia, a hu lidade de tedos of atos pratioados a pertix da Convenção.

5. Preliminarnente, tata venla,parece-noe fal tar wo impagnante lagitinidade, noe ternos do artigo 92, ds Resoluçio ne 10,785/80, ums vez que näo denonstra sua qualidade de convencional, a tal riāo se infere da cocumentaçäc apreaentada pelo Pertido requerante.

6. No ménico, caso docida o Colendo Tribunal Siparior co stastar a prelininar sA 1legitimi dade do impugnarte, entendenos niso the essistir razล̄o. As auas primeiras alegaçర̄es aāo, a nog so ver, de todo improcedentes: en priantro, pox que a juriaprudâncta do colendo Tribuas 2 supe- 


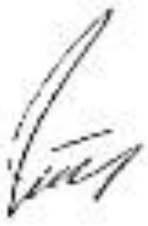

xior a no sertido de que é da data da sessão de julgamento, 1rdependentenerte de publiesçōo, a validade da decisế que concele registm $\mathrm{B}$, na 8a, E te 9.2.82, conforme comprova a eertidão de 115.120 : en segundo, porque a participaça do sr. Mário Pernando Gonçalves Braga na Conven çāo, Asu-ge na qualidade de menbro do Diretório Nacional do Partido Popular, e nảo cono 4h legucio, o que teribian $\tilde{a}$ provado con o documento de $11=$. 123/149. Con relaçio à terceira alega ção tenos que, de fato, razão assiste no $1 \mathrm{~m}$ pugnante, conforme comprova a certidäo de fls. 118, fornccida pelo pröprio Lnpugnado, 0 asretō rio regional to partiso do Movinento Donocrät $\infty$ Brasila1ro no Territörlo Federal de Roraima fol registrado somente a 16 de fevereiro, 4 (qua tro) dias spốs a realizaçāo Aa Convençāo sendo, nessaล conAlęöea, vodada a part1clpaç̃̃o de seus delagados. O fato de ter o gartido solier tado o regietro do diretór 10 regional en data enterior nāo afasta, en princfpio, essa 1rregu larıdado. Entretanto, cono da Convenęio partiel param convencionais en nûmero superior ao quo rus minimo exigido, temoa gue easa 1rrepularida As ns̄o ten a condäo de irvalidar tode a Conven จุão, una vez que nēo resulta en fraude comprova a. .

7. Quanto aos aspectos formals to pedido, te noe que se conformem com as exigänctas logals.

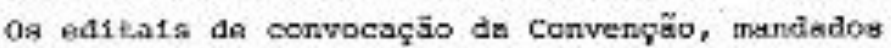
publicar por atrbos os partitos, atondem as ext gências do axt1go 39, da Resoluçäo (f1s. 13/14). o Diretörio Nacional, conforme o dispeato no 518 do artigo 79, foi eleito eom 71 (setenta e um) nenbrus, incluindo os lfapara na cjnara dos Deputados e senado Foderal, e con 23 (vinte a träa) suplentes, segundo o disposto nos artigos 72 , item 11 , e 81 , tondo aido composto, por cutro lado, com un mambro, polo nenos, de cada

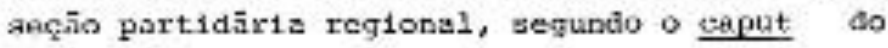
sutino 79 .

No tocante a Con1ssăo Executiva tenos que fo1, da mesina forma, eleita segunco a regra do iten $\mathrm{XX}$ do axtigo $85 \mathrm{e,} \mathrm{con} \mathrm{relação} \mathrm{aos} \mathrm{suplen}$ 
tes, de acordo con o dispoeto no seu 529.

8. sonos, pelo exposto, pelo deferinento do pedido do registro do Direkbrio Nacional a res fectiva Coniasīo Exccutiva do PAkPLOO DO MOVINEWTO DENDCFÉTICO BRASHETAO - PMDB.-

E o relatörio.
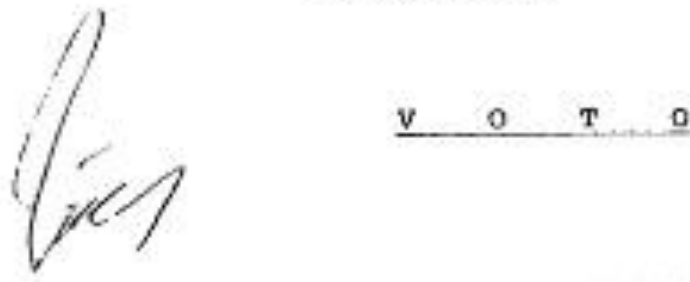

O SFNHOR MTNISTRO sLAREs nutios (helator): Senhor pre sidente, de conforzldade con o parecer, cufos fundanentos adoto, não corheço da impugnaçāo oferecida por clóvis stenzel, por falta de legltinfaade do trpugnante, una ver que $e 16$ năo prcenche as oon

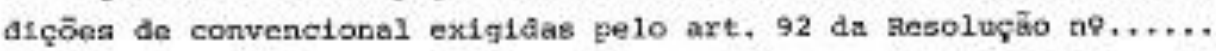
10.785. No mexito, eunprials que forar todas as formaliadea ie ga1s, ceriro o regtetro do Diretório Neeional a da respectiva co mise ão Executiva do Partią do kovinento Denoorático BraaileiroPMDB. Determino, outrossin; al que neja averbato no registro do partico popular que ele fol incerporado ao partido do Novimento De mocrätico Braeiletro, b) que seja comunicada eeta decisäo aOe Trí bunaie Reyjones A A, por satca, sos juizes elefibrata lorta. 17 e 161 da Resoluçāo no 10.785/80).

E o voto.

DECISRีO WXAిNINR.

\section{EXTRA $=0$ DA A I A}

Proc. no 6.371-C1s+10a.-DF- Rel. Min. Soares Muñoz.

Dec18aีo: Não ae conheceu da inpugnação por falta de legitimaçño do Impugnante, c se deferiralh os regiatros requeridos, noa tarmos do voto do relator. Doc1as̄o unänime.

presidência do Miristro Moreira A1ves. Presentes os Kinistros:Sosres Murioz, Decio Mranda, Carloa Madeira, Guelros Leite,Fedro Gor dilho, J.M. de souza Andrade c o Dr. Inockincla Märtires Coelho,Pro curador-coral Eleitural. 


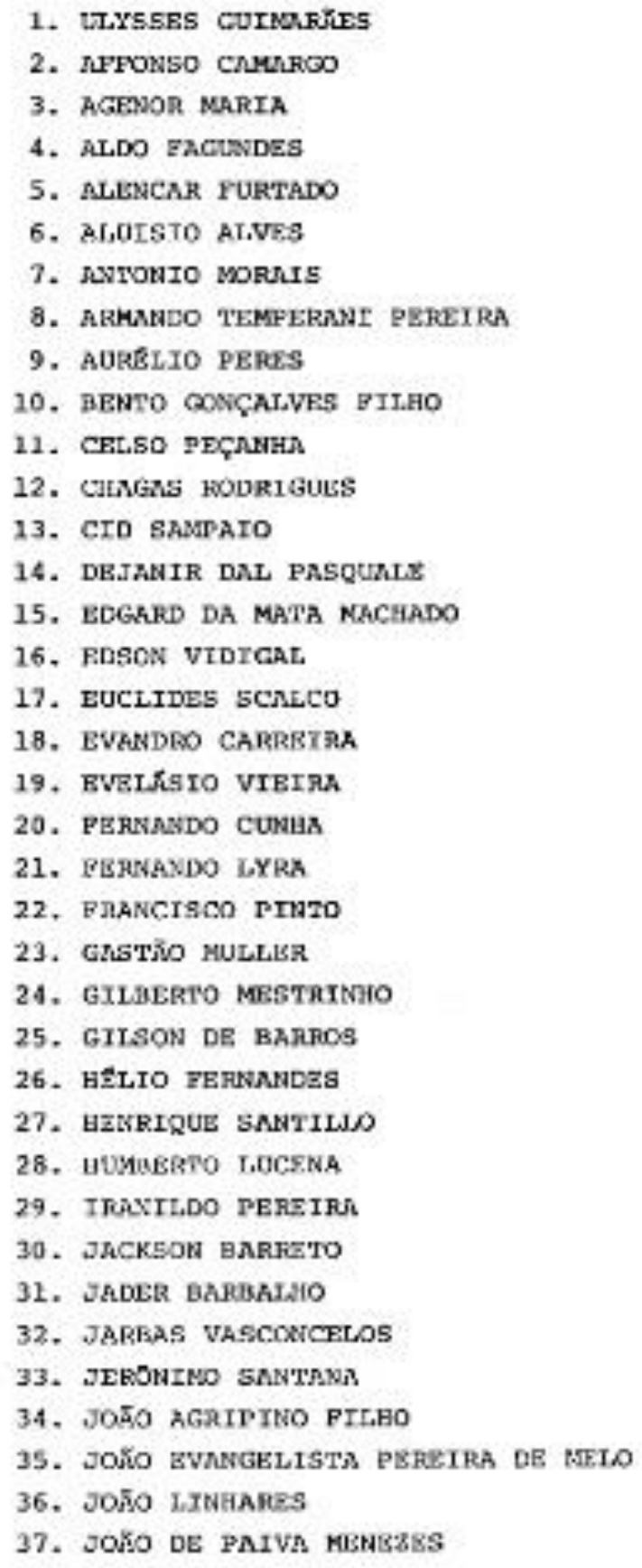


38. LE TTE CHAVES

39. LẨ DE ALMEIDA NEVES

40. LUIE RAPTISTR

41. MaRceTo cERectrika

42. MARCELO MIRAMDa

43. MKRCIO MRCEdo

44. MKRIO COVAS

45. MЁТО NDREIAA

46. MNUEO BENEVIDES

47. MENDES CANALE

48. MICUEL ARRAES

49. МIFO TEIXEIMA

50. NABOR JONIOR

51. OCTACTLIO gUEIEOE

52. PRULO FATTES

53. PEDPO SIMON

54. RAIMUVDO AEEVEDO COSTR

55. RAFHAEL ALREIDA MAGAJARES

56. RENATO ARCHER

57. ROBERTO CMRDOSO RLVES

58. ROMERTO PIGUEIRA SANTOS

59. RORERTO HENRSTER CUSMKO

60. RONAK TINO

61. SERGIO FERRARA

62. SERGIO MUKLLO

63. SEVERO COMRS

64. TANCEEDO DE ALNEIDA NEVES

65. TARCIS TO DELGado

66. TZOTONIO VILRHIA

67. TIDET DE LTMR

68. KILLIR PIBES

69. KYLSON NATTIMS

70. Lfoer na chinasa dos deputados

71. LICER NO SEMZDO FEDERAL 


\section{PARTIDO DO NOVIMEMTO DEXOCRXIICO BRASILEIRD}

\section{SUPLENTES}

1. LUIR GENRIQUE DA 5ILVEXRA

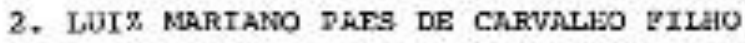

3. FILOAR GUAZELLI

4. CARLOS SANT" ANEA

5. CRISTINA TAVARES

6. MORRSTO DA SILVEIRA

7. CARHEIRO ARMAUD

8. JOSB CARTOS VASCONCELOS

9. JOKО РACHDCO CHAVES

10. ENBAS PARIAS

11. MUISIO EEZERRA

12. PRANCISCO AMARAI.

13. TOSE SEFEA

14. WMLTER SILVA

15. CRILOS COT⿰A

16. JAIFO aRUA

17. NLRIA OA CONCEICEO TAVARES

18. LOURRMERRG NCRUSS ROCHA

19. csma nLVEs da tietio

20. CELSO SALBH

21. TABTANO VILAMOVA

22. JOKO CARLOS TLADJO DOS SANTOS

23. JORGE LEITE 
OOMISGR̈O EXECOFTVA MACIOARL

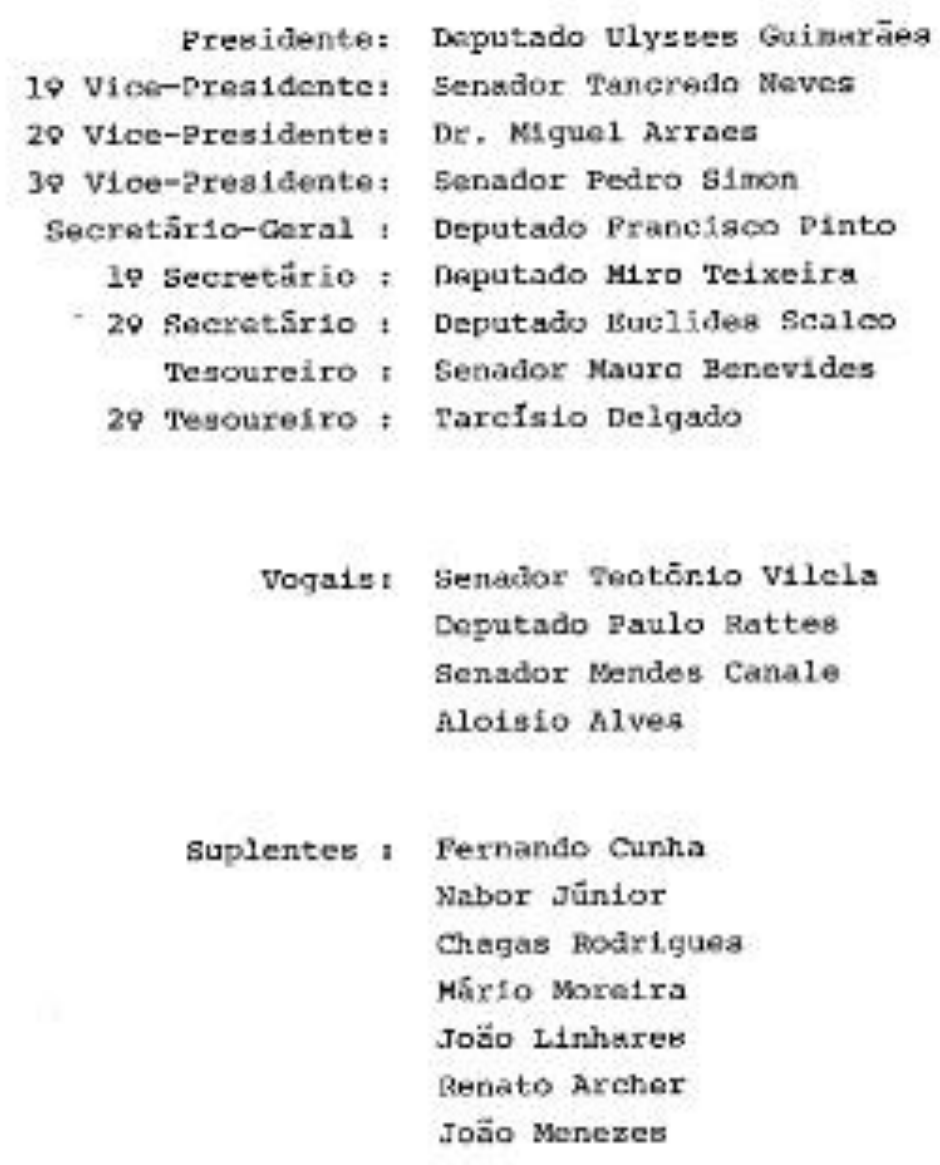




\title{
ANEXO 8
}

\author{
COMPROMISSO FIRMADO PELO PARTIDO \\ DO MOVIMENTO DEMOCRÁTICO BRASILEIRO \\ COM A FRENTE LIBERAL
}

Os signatários deste documento, representantes do Partido do Movimento Democrático Brasileiro (PMDB) e da Frente Liberal, objetivando a consolidação das instituições democráticas, o desenvolvimento econômico de Brasil e a realização da justiça social deliberaram constituir uma "Aliança Democrática", aberta aos Partidos Políticos e demais forças democráticas, para eleger o Presidente e Vice-Presidente da República às próximas eleições e instituir um Governo que promova o encontro do Estado com a sociedade e concretize o bem comum.

Fundamenta-se esta Aliança Democrática nos seguintes princípios:

\section{"COMPROMISSO COM A NAÇÃO"}

O PMDB e a Frente Liberal conscientes de suas responsabilidades perante a Nação, decidiram reunir seus esforços no propósito de promover as inadiáveis mudanças que a sociedade brasileira exige.

O entendimento que selam, neste momento, é o primeiro passo para a constituição de uma Aliança Democrática, que se compromete com o destino nacional. Ao formalizá-lo, os signatários conclamam os Partidos Políticos e demais forças democráticas, animados pelo sentimento de patriotismo, a se irmanarem nesta caminhada de fé e esperança do povo brasileiro.

O País vive gravíssima crise na história republicana. A hora não admite vacilações. Só a coesão nacional, em torno de valores comuns e permanentes, pode garantir a soberania do País, assegurar a paz, permitir o progresso econômico e promover a justiça social. Este pacto político propugna a conciliação entre a sociedade e o Estado, entre o Povo e o Governo Sem ressentimentos, com os olhos voltados para o futuro, propõe o entendimento de todos os brasileiros.

É indispensável que se efetive o congraçamento nacional baseado na liberdade, na igualdade sob a lei, no escrupuloso respeito pela coisa pública, na justa participação de todos nos frutos do progresso, na solidariedade entre os brasileiros. Congraçamento nacional capaz de propiciar, em clima democrático. as mudanças que a Nação reclama. É urgente a necessidade de proceder-se a reorganização institucional do Pais. Uma nova Constituição fará do Estado, das Leis, dos Partidos Políticos, meios voltados para a realização do homem - sua dignidade, sua segurança e seu bem-estar.

O Brasil deve ser um País para seu próprio povo, em que seja assegurado o exercício pleno da cidadania. respeitados os direitos humanos, preservadas a identidade e a cultura nacionais. Em uma Nação marcada pela pobreza e ameaçada pelo desespero dos marginalizados, a Administração Pública deve se caracterizar pela credibilidade e pela participação e se pautar sempre pela austeridade e moralidade.

É dever do Estado erradicar a miséria que afronta a dignidade nacional, assegurar a igualdade de oportunidades, propiciar melhor distribuição da renda e da riqueza, proporcionar o reencontro com as valores da nacionalidade. Esse Brasil será edificado com o sacrificio, a coragem e as inesgotáveis reservas de patriotismo de sua gente. 
Esta é a tarefa que cumpre empreender.

Esse entendimento possibilita a Aliança Democrática estabelecer como compromisso impostergáveis e fundamentais com a Nação brasileira:

- Restabelecimento imediato das eleições diretas. livres e com sufrágio universal, para Presidente da República, Prefeitos das Capitais dos Estados e dos Municípios considerados estâncias hidrominerais e dos declaradas de interesse da segurança nacional. Representação política de Brasília;

- Convocação de Constituinte, livre e soberana, em 1986, para elaboração de nova Constituição;

- Restabelecimento da independência e prerrogativas do Poder Legislativo e do Poder Judiciário,

- Fortalecimento da Federação e efetiva autonomia política e financeira dos Estados e Municipios;

- Reforma da legislação eleitoral de modo a possibilitar a formação de novos Partidos, permitir as coligações partidárias e assegurar às agremiações políticas o acesso democrático ao rádio e a televisão;

- Retomada e reordenamento do processo de desenvolvimento, como opção fundamental da sociedade brasileira;

- Reprogramação global da dívida externa, em condições que preservem o povo de sacrificios insuportáveis e resguardem a soberania nacional;

- Combate à inflação, através de medidas que considerem, não apenas sua origem financeira, mas sobretudo seu caráter prioritariamente social. Saneamento financeiro interno e redução do custo do dinheiro;

- Reforma tributária, como instrumento básico de realização dos objetivos de política social e econômica. Correção das desigualdades regionais e pessoais de renda;

- Prioridade ao Nordeste e reconhecimento de sua capacidade na formulação das soluções mais adequadas ao resgate da dívida nacional para com a Região;

- Adoção de medidas de emergência contra a fome e o desemprego;

- Desconcentração do Poder e descentralização do processo decisório. Desburocratização;

- Apoio à livre iniciativa. Fortalecimento das empresas nacionais. Tratamento favorecido às pequenas e médias empresas;

- Revisão da política salarial com eliminação do processo de compressão do poder aquisitivo dos trabalhadores, dos servidores públicos e da classe média. Garantia da autonomia e liberdade sindicais e do direito de greve;

- Educação fundamental para todos. Fortalecimento da Universidade e efetivação da sua autonomia. Apoio à pesquisa, ao desenvolvimento científico, tecnológico, artístico e cultural. Defesa do patrimônio histórico, artístico e cultural brasileiro. Adoção de um Plano nacional de cultura;

- Combate a qualquer espécie de discriminação e preconceito quanto a religião, sexo e raça. Proteção aos direitos das minorias;

- Direcionamento de recursos e estímulos para o aumento substancial da oferta dos bens e serviços indispensáveis à satisfação das carências básicas da população no campo da alimentação, saúde, educação e habitação;

- Proteção do meio ambiente. Defesa da Amazônia. Política urbana. Melhoria da qualidade de vida e das condições de segurança individual;

- Reestruturação da previdência social e do sistema financeiro da habitação, com adoção de medidas que thes propiciem condições de estabilidade e fidelidade aos objetivos sociais;

- Execução de política agropecuária que assegure a fixação de preços mínimos realistas e a formação de estoques reguladores adequados. Reforma Agrária mediante 
cumprimento do Estatuto da Terra e melhoria das condições de vida do homem do campo;

- Política externa voltada para a preservação da soberania dos Estados, segurança e justiça internacionais, e busca da paz.

Acordaram os signatários que o candidato a Presidente da República seja proposto pelo PMDB, que indica o Governador Tancredo Neves, e o candidato a Vice-Presidente da República seja apresentado pela Frente Liberal, que indica o Senador José Sarney.

Estabeleceram, igualmente, que o programa governamental venha a ser conjuntamente elaborado pelo PMDB, Frente Liberal e Partidos Políticos que venham a integrar a Aliança Democrática, orientando-se pelos princípios constantes do "Compromisso com a Nação".

Finalmente, manifestaram a determinação no sentido de desenvolver gestões com o objetivo de alcançar a participação dos Partidos políticos e outras forças democráticas que, identificados com estes propósitos, desejem unir esforços através da Aliança Democrática, para solucionar os graves e urgentes problemas que afligem Brasil e, integrados, pugnarem pela vitória dos compromissos e das candidaturas que, para esse fim, indicam.

Brasília-DF, 07 de agosto de 1984

\author{
ULYSSES GUIMARÃES \\ Presidente do PMDB \\ T ANCREDO NEVES \\ Governador do Estado de Minas Gerais \\ ANTÕNIO AURELIANO CHAVES DE MENDONÇA \\ Vice-Presidente da República \\ MARCO MACIEL \\ Senador pelo Estado de Pernambuco
}




\section{ANEXO 9}

Lista de parlamentares fundadores do PSDB:

\begin{tabular}{|c|c|c|c|}
\hline Nome & $\begin{array}{l}\text { Partido de } \\
\text { origem }\end{array}$ & Estado de origem & $\begin{array}{l}\text { Mandato (Senado } \\
\text { Federal ou Câmara } \\
\text { dos Deputados) }\end{array}$ \\
\hline Afonso Arinos & PFL & RJ & SF \\
\hline Ana Maria Rattes & PMDB & RJ & $C D$ \\
\hline Antônio Perosa & PMDB & SP & $C D$ \\
\hline Arthur da Távola & PMDB & RJ & $C D$ \\
\hline Carlos Cotta & PMDB & MG & $C D$ \\
\hline Carlos Mosconi & PMDB & MG & $C D$ \\
\hline Célio de Castro & PMDB & MG & $C D$ \\
\hline Dirce Maria Tutu Quadros & PTB & SP & $C D$ \\
\hline Elizabeth Azize & PSB & AM & $C D$ \\
\hline Euclides Scalco & PMDB & PR & $C D$ \\
\hline Fábio Feldman & PMDB & SP & $C D$ \\
\hline Francisco Kuster & PMDB & SC & $C D$ \\
\hline Geraldo Alckmin & PMDB & SP & $C D$ \\
\hline Hermes Zaneti & PMDB & RS & $C D$ \\
\hline Jayme Santana & PFL & MA & $C D$ \\
\hline José Carlos Grecco & PMDB & SP & $C D$ \\
\hline José Costa & PMDB & $\mathrm{AL}$ & $C D$ \\
\hline José Guedes & PMDB & RO & $C D$ \\
\hline José Serra & PMDB & SP & $C D$ \\
\hline Koyu Iha & PMDB & SP & $C D$ \\
\hline Maria Cristina Tavares & PMDB & PE & $C D$ \\
\hline Maria de Lourdes Abadia & PFL & DF & $C D$ \\
\hline Mauro Campos & PMDB & MG & $C D$ \\
\hline Moema São Thiago & PDT & CE & $C D$ \\
\hline Nelton Friedrich & PMDB & PR & $C D$ \\
\hline Octávio Elisio & PMDB & MG & $C D$ \\
\hline Pimenta da Veiga & PMDB & MG & $C D$ \\
\hline Pompeu de Toledo & PMDB & DF & $C D$ \\
\hline Renan Calheiros & PMDB & $\mathrm{AL}$ & $C D$ \\
\hline Robson Marinho & PMDB & SP & $C D$ \\
\hline Ronaldo Cesar Coelho & PMDB & RJ & $C D$ \\
\hline Rose de Freitas & PMDB & ES & $C D$ \\
\hline Saulo Queiroz & PFL & MS & $C D$ \\
\hline Sigmaringa Seixas & PMDB & DF & $C D$ \\
\hline Sílvio Abreu & PMDB & MG & $C D$ \\
\hline Vasco Alves & PMDB & ES & $C D$ \\
\hline
\end{tabular}




\begin{tabular}{|c|c|c|c|}
\hline Vicente Bogo & PMDB & RS & $\overline{C D}$ \\
\hline Vilson Souza & PMDB & SC & $C D$ \\
\hline Virgildásio de Senna & PMDB & BA & $C D$ \\
\hline Ziza Valadares & PMDB & MG & $C D$ \\
\hline Chagas Rodrigues & PMDB & $\mathrm{PI}$ & SF \\
\hline $\begin{array}{l}\text { Fernando } \quad \text { Henrique } \\
\text { Cardoso }\end{array}$ & PMDB & SP & SF \\
\hline Geraldo Campos & PMDB & DF & $C D$ \\
\hline Jorge Hage & PMDB & $\mathrm{BA}$ & $C D$ \\
\hline Jose Ignacio Ferreira & PMDB & ES & SF \\
\hline José Paulo Bisol & PMDB & RS & SF \\
\hline José Richa & PMDB & PR & SF \\
\hline Mário Covas & PMDB & SP & SF \\
\hline Paulo silva & PMDB & $\mathrm{PI}$ & $C D$ \\
\hline Pompeu de Souza & PMDB & DF & SF \\
\hline
\end{tabular}




\section{ANEXO 10}

Carta renúncia de Orestes Quércia à presidência do PMDB, reproduzida no jornal Folha de S. Paulo no dia 27 de abril de 1993:

\section{'Os que se dizem fiéis e me apunhalam pelas costas'}

Leia a carta de Qucreia ao secretírio-geral do PMDB: Campinas, 26 de abril de 1993

Meu caro Joaquirn de Mello Freire

Solicito ao prezado anige infor mar ¿ Comisso Executiva Nacional do PMDB, para as providencias normais, que decidi nẩo me candidatar a reeleiglo e que a partir de hoje deixo a presidetncia do partido.

Em toda a minha vida polatica, coloquei os interesses partidario acima des pesscais. Fui vereador. deputado estadual, prefelto, sena dor, vice-governador e govemadoe, sempre leal aos meus companheiros c honrando o partido que ajudei a fundar.

Posso dizer com tranyuilidade que poucos trabalharam tanto e por tanto teinpo em favor do PMDB. Em S3̄o Paulo, fui responsivel pela criacto da maioria dos diretórios municipais e distritals, numa fpoe: $\mathrm{em}$ que muita gente tinha medo de falar com os emedebistas, pelo riseo de despertar a ira da ditadura mili. tar.

Cono prefeito de Campinas - dos maces eleitos pelo MDBpercorri o Estado e causava perplexidade por desaflar os poderosos. que prendiam, torturavam e mata. vam, acobertados pelas leis de excesilo. Eu pruprio nío escapei à perseguicão da ditudura.

Fin Campinas, realirei uma ad. ministrasĩo que revolucionou s municipio. Fui um senador que exigiu investigaçues sobre os preçon politicos desaparecidos $e$ autor do primeiro projeto convocundo Constituiço, sem qualquer receio da fúria que assuntos como esses provocavam no regime militar, Go. vemei Silo Paulo fionradamente durante a crise da chamada deeada perdida dos anos 80. realizando uma administres.3o sem provedente na hisuória do Estado. Como prefer. to e governador, conclui os manda. tos com alticsimen indices de apro. vacilo popalar e a meu partibu elezeu os meus sucessares.

Terminado o goserno de Süs Paulo, todos os governadores eler. tos, as mais expresusas Inferancas nacionais do partido e o dr. thysue Guimardes, grande Ibter de fodes nis. vieram exigir que eu assamese a presiletencia do PMDB, Jefink, jo praticamente unânine das bases

Dírieindo o partido, procurci um rumo atualizado para a nossa legen. da. mediante a elaboracio de um novo programa, que deverd set aprovado na provima conicncto Ao PMDB est́ reservada a taref: historica de proenover a de envol. vimento do Brasul, crescimento com cquilibrio social e jestica.

Durante meu mandalo, percurri o pais e tudo fiz visundo reoreanizar e preparar o PMDA pata sua eranile mistaso de imstrumenta politico do poyo brasuleiro na constroç̇o de un pals melhor.

Mais recentemente, eneajei-me as luta republicana e presudencialista. absolutamente convicto de falar pela maioria dos peemedebistas e em sintonia com a povs hravleiro, que, no últime 21 de abril, ae consaerr nossa vituria deu uma grande liçio a centos politicos deste pais

Cologiaer-me camo candidito of reelencio a proation do purtida, para dar provicguinentso as trabalho que vinha dexensoliendo devele क्शि

Apesar de abvilutumente cento de que seria recletio ma consencia de 30 de maio. faco have uma neavalua. sio da deviso de me candidatar

O privene de stacevia ne parti.

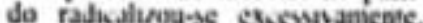
Por outro Lab, enyuinto os adier.

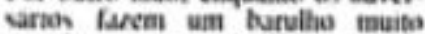
grande, as conapunhsiro, Ulve al. gumas excries, farem um silincio ainds maier lvo para nas mencionur os que se direm fién e tentam me apunhalar pelas contas.

Eispeto que o partido encontre a unidade ncressiria para seu fortalecimento, neste instante decissu cia que $e$ preciso fazer uma revisuo de scu refacionamento com o coverno federal, pelo bem do Brasil, cujo prese está cafrendo maiti

Sigo como e yoldado de sempre.

Cordalimente.

Oreues Quiricia. 


\section{ANEXO 11}

Carta do PMDB paranaense publicada no jornal Folha de S. Paulo no dia 6 de abril de 1994:

\section{Porque Requião vai ganhar a Convenção do PMDB}

Hoje Requião è o único nome do Partido com reais condições de ganhar a eleição para Presidente da República. $\mathrm{O}$ ex-governador do Paraná com seu projeto moderno e de centro-esquerda, firme no enfrentamento ao neoliberalismo e a esquerda radical, tem efetivas condiçōes de mobilizar as bases partidárias, e por extensão a sociedade brasileira, ainda perplexa diante das candidaturas presidenciais postas até agora

Imagem calcada na seriedade e austeridade, Requião tem sua aprovação administrativa com os melhores indices do Pais e realizações no Governo do Paraná, que vão do estímulo à produção agricola com financiamento que os agricultores pagam com equivalência em milho, ao desenvolvimento da agroindustria. O Paraná é o único estado que constrói uma ferrovia com recursos próprios, a Ferroeste, constrói pontes e duplica rodovias de responsabilidade do Governo Federal, sem nenhum repasse da União, com recursos oriundos exclusivamente do tesouro estadual. Tudo isso acoplado ao maior programa de obras já desenvolvido por um estado brasileiro.

Esta é uma candidatura capaz de alavancar o Partido e ganhar a eleiçảo. Com Roberto Requião, a unidade vem da base partidária, e associada à credibilidade popular, vai revitalizar o PMDB para renovar o respaldo social de nossa legenda

Por outro lado, a candidatura do ex-governador de São Paulo, Orestes Quércia, dada como definitiva por setores da grande imprensa, que procuram escalar o candidato do PMDB para mais facilmente chegarem com seu candidato, o ex-ministro Fernando Henrique Cardoso ao $2^{\circ}$ turno - mesma técnica utilizada nas eleiçôes de 89 - quando optaram por Lula, contra Brizola, para garantir a vitória de Collor.

Companheiros, è evidente que os problemas da imagem pública de Quércia. em plena era dos anôes da CPI da corrupção, fazem sua candidatura ferida de morte. E não só isso - põe oPMDB na retranca, com um discurso de explicação do enriquecimento do candidato, e ainda mais, transfere a toda nossa legenda os problemas de sua imagem pessoal. Facilmente seremos transformados na "Geni" da eleição. Quércia é o flanco sonhado por nossos inimigos para aniquilar o nosso Partido

Dispensa comentários a candidatura do ex-presidente José Sarney. À primeira lembrança de que em seu governo a inflaçāo chegou à $80 \%$ ao mês, sabemos qual será a reação da opinião pública.

PMDB Velho de Guerra, levanta-te! Nós podemos e vamos ganhar as eleiçōes! Para isto, temos a disposiçāo o nome de Roberto Requião

PMDB do Paraná.

Aos Peemedebistas do Brasil.

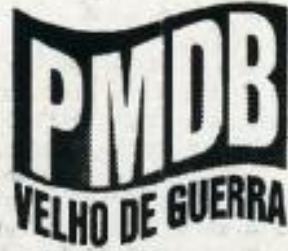




\section{ANEXO 12}

Resultado das eleições prévias do PMDB para escolha do candidato à presidência da República em 1994:

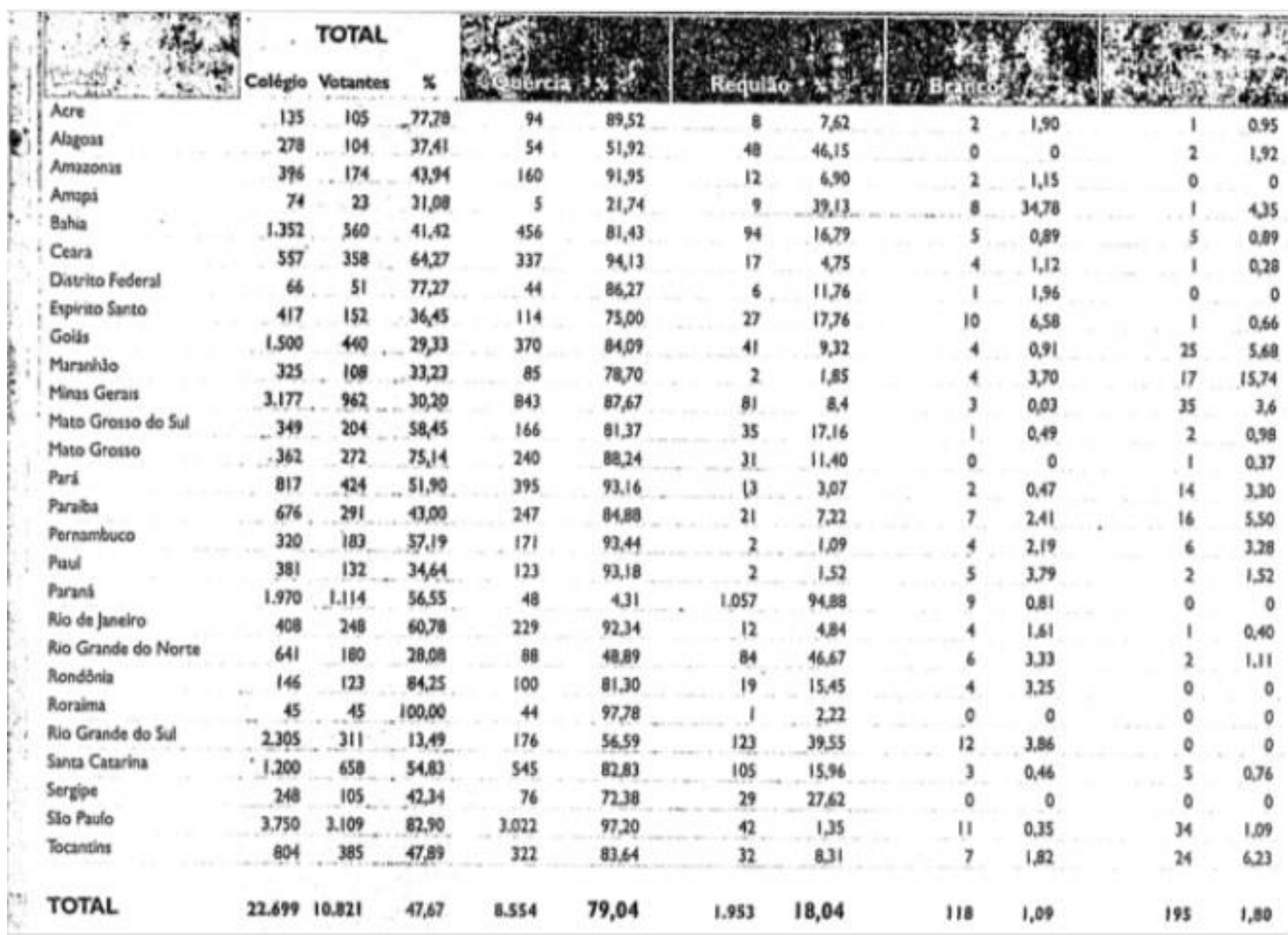

Retirado de Folha de S. Paulo - 16/05/1994, p.5 


\section{ANEXO 13}

Votação interna do Conselho Nacional do PMDB reunido em 21 de setembro de 1993 para definir a manutenção do seu apoio ao governo de Itamar Franco:

\section{COMO FOIAVOTACุÃO}

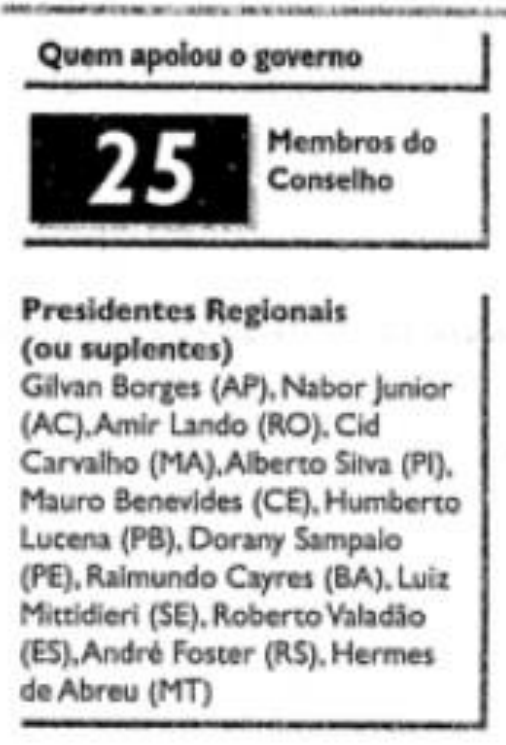

Membros da Executiva Maurilio Ferreira Lima (PE). Flaviano Melo (AC), Nilo Coelho (BA), Ubiratan Aguiar (CE). Garibaldi Alves (RN)

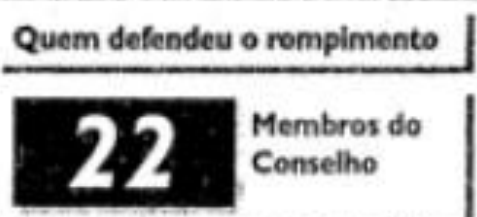

Presidentes Regionais Cesar Dias (RR), Jose Dutra (AM), Nicias Ribeiro (PA), Djalma Falcio (AL).Armando Costa (MG), Roberto Rollemberg (SP). Nivaldo Kruger (PR), Valter Pereira (MS), Odilon Ayres (DF). Luiz Soyer (GO)

Membros da Executiva Rita Camata (ES). Jorge Mudalen (SP). Haley Margon (GO). Paes de Andrade (CE),Airton Sandoval' (SP)

\begin{tabular}{l} 
Governadores \\
Molsés Avelino (TO) e Ronaldo \\
Cunha Lima (PB) \\
\hline Ex-presidentes do partido \\
Jose Fogaça (RS) e jarbas \\
Vasconcelos (PE) \\
\hline Ex-Presidente do Senado \\
Nelson Carneiro (R) \\
\hline Ex-lideres na Câmara \\
Odacir Klein (RS) \\
\hline Lider na Carmara \\
Genebaldo Correla (BA)
\end{tabular}

\section{Governadores} Luz.Antonic Fleury Filho (Slo Paulo) Jider Barbaiho (Pan) Iris Rezonde (Goiss) Gilberto Mestrinho (Amazonas) Roberto Requiso (Parana)

\section{Ex-lideres no Senado}

Ronan Tito (MG) e Alfredo Campos (MG)

\section{Quem se absteve}

Tareisio Dalgado (MG) e Lurz Hennque (SC)

Retirado de Folha de S. Paulo - 22/09/1993, p. 7. 


\section{ANEXO 14}

Nota pública do Conselho Nacional do PMDB declarando seu apoio e ingresso no governo eleito de FHC:

“(...) O PMDB recebeu convite do Presidente eleito, sr. Fernando Henrique Cardoso, para integrar a base de sustentação do governo, participando do núcleo das decisões governamentais. Entende, o PMDB, que a consolidação do plano econômico, gerador da nova moeda, é fundamental para o país, na convicção de que o povo brasileiro não suportará mais uma decepção econômica, com a volta da espiral inflacionária, o que poderá ensejar caos social.

Sabe-se que o PMDB foi fundamental para a viabilização do plano econômico, aprovando o Fundo Social de Emergência e a medida provisória instituidora do URV. Aprimorou essas preposições com uma série de emendas de seus parlamentares, que culminaram com a implantação do Real e na queda significativa da inflação. O PMDB tem consciência de que a implementação de medidas constitucionais e legais complementares é urgentemente inadiável para consolidação da estabilidade econômica; outrossim, tem convicção de que o governo dificilmente poderá levar a bom termo essas medidas se não obtiver apoio das maiores bancadas partidárias, na Câmara e no Senado, que garanta forte base de sustentação no Congresso. Mais uma vez, ciente de sua responsabilidade perante o povo brasileiro e na busca da construção de uma democracia com desenvolvimento e justiça social, o PMDB, depois de ampla consulta aos seus quadros dirigentes e bases partidárias resolve por unanimidade atender o convite do Presidente eleito para que o partido tenha voz ativa na formulação das políticas governamentais, bem como na sua implementação, sem afastar das diretrizes do PMDB, como tal propostas no seu novo programa 'Democracia com Desenvolvimento",

(Resolução n6/94 do Conselho Nacional do PMDB, 09/12/1994 - reproduzido a partir de Maciel, 2014, p. 73). 


\section{ANEXO 15}

Íntegra das notas publicadas pelas alas governista e oposicionista quanto a postura a ser adotada pelo partido na eleição presidencial de 2002, retiradas do jornal Folha de S. Paulo (6/04/2002):

“O PMDB deve se aliar ao PSDB na disputa pela presidência da República? NÃO.

Uma aliança com o Brasil

\section{ROBERTO REQUIÃO}

Não existe partido sem candidatos. Eliminem-se as candidaturas e o partido deixa de existir. É a participação do partido com candidatos em todos os níveis que o fortalece, que o faz um protagonista, com papel de maior ou menor destaque, na cena política.

Se isso vale para todos os partidos, imagine o quanto é verdade para o PMDB. Temos a maior bancada no Senado Federal, a segunda ou terceira maior bancada na Câmara dos Deputados, o maior número de deputados estaduais, prefeitos, vereadores e diretórios municipais, além de uma tradição de luta que já é história.

Ainda assim, concordo que os partidos não devam se fechar à possibilidade de se coligarem. Afinal, alianças, frentes, composições também fazem parte da vida política. Também são formas de os partidos se firmarem, fortalecerem-se, tornarem viáveis as suas idéias, as suas propostas.

Enfim, não sou contra o PMDB fazer coligações. A oposição à coligação não é uma questão de princípio. É uma circunstância.

O que não tem sentido é a coligação que, antes de princípios, de programas, leve em conta se a parceria representa ou não "um bom negócio". Recentemente, no final de uma reunião que discutiu a coligação com o PSDB, um dirigente do PMDB saiu do encontro dizendo que o nosso partido "estava fazendo um bom negócio".

O país, a vida dos brasileiros não devem ser objetos de negócio. Qualquer aliança deve dizer respeito ao país. Aliança não é negócio, não é simples acomodação eleitoreira. Não tem sentido, por exemplo, a escolha de um candidato a vice de determinada chapa presidencial só por ser ele do Nordeste ou do Sul do país.

Seja com quem o PMDB se coligue, essa aliança deve ser feita a partir de um programa de governo bem claro, com propostas definidas e que representem fielmente as demandas dos brasileiros. Essa aliança e esse programa também devem levar em conta o que aconteceu no país nos últimos oito anos. 
Não podemos esquecer, entre outras coisas, que a participação brasileira no comércio mundial caiu de 1,2\% ao 0,8\% de hoje; que 50 milhões de brasileiros estão abaixo da chamada linha da pobreza, recebendo menos de $\mathrm{R} \$ 80$ por mês para viver; que o salário dos trabalhadores sofreu um achatamento superior a $20 \%$; que os ganhos da classe média foram dramaticamente reduzidos; que o número de desempregados triplicou nesse último quadriênio; que as leis trabalhistas não existem para a maioria, e ainda assim o governo quer estripar a CLT; que a desnacionalização da economia atingiu índices argentinos; que as privatizações à brasileira notabilizaram-se, mundialmente, pelas facilidades concedidas aos compradores das estatais.

Volto à CLT e destaco aqui alguns números levantados por recente pesquisa do Datafolha, reafirmando o país injusto e pobre que temos, onde faltam -e não sobramdireitos aos trabalhadores, onde há um escandaloso desrespeito às leis vigentes.

Dizem os dados do Datafolha: $53 \%$ dos trabalhadores não recebem 13으 salário; $54 \%$ não têm férias remuneradas. É o país dos "direitos de papel", em que a maioria dos trabalhadores "vive na pré-história da CLT", em que o desemprego triplica, formando um exército de desempregados de perto de 13 milhões de pessoas, e o emprego melhor remunerado cai $35 \%$.

Não levar informações tão terríveis como essas na discussão de uma aliança com quem quer que seja é criminoso.

De qualquer forma, seja como for, saibam todos aqueles interessados no apoio do PMDB que nós temos um candidato à presidência da República, o senador Pedro Simon. Na convenção de junho procuraremos fazer valer a vontade da quase totalidade dos convencionais que querem candidato próprio.

No entanto, caso essa tendência seja mudada, a aliança do PMDB com que partido seja deve ser feita em cima de propostas bem claras, de um programa a favor do Brasil. Qualquer outra coisa é acerto, é conchavo, é oportunismo.

\section{$X X X X X X X X X X X X X X X X X$}

Roberto Requião, 61, jornalista e advogado, é senador pelo PMDB do Paraná. Foi governador do Estado do Paraná (1991-94), secretário de Desenvolvimento Urbano (1989) e prefeito de Curitiba (1985-88)."

“O PMDB deve se aliar ao PSDB na disputa pela presidência da República? SIM

Uma coligação para os avanços

HENRIQUE ALVES 
O caráter da democracia de um país é fruto do esforço da articulação social promovida por suas instituições. O PMDB, sem nenhum demérito a outras instituições sociais e políticas, ao liderar o movimento pela redemocratização brasileira, é responsável direto pela qualidade da nossa democracia, habilitando-se, dessa forma, a pleitear o comando da nação, seja com um candidato próprio, seja como parceiro principal de uma aliança interpartidária.

Mercê da pluralidade de visões que, desde os tempos do velho MDB, tem acentuado sua identidade democrática, nosso partido ainda é o mais capilar do país; portanto, o PMDB possui as condições para definir e seguir uma trajetória de conquista de poder.

A trajetória viável, neste momento, não é a da candidatura própria. E a razão é muito simples: não nos preparamos de maneira adequada para tornar competitivo o nosso candidato. Ademais, as graves dissensões internas inviabilizaram a candidatura própria. Já tivemos duas experiências de candidaturas próprias, uma delas liderada por Ulysses Guimarães, o símbolo maior de nossas lutas democráticas, mas acabamos amargando o insucesso.

Diz o ditado que errar é humano, mas insistir no erro é burrice. O PMDB, sob a liderança competente e equilibrada de Michel Temer, procura caminhos que possam oferecer melhores chances ao partido, mesmo que não se chegue ao consenso, o que, aliás, seria um fato inusitado em nossa história. A alternativa de coligação interpartidária apresenta-se, pois, como a mais sensata.

Entendemos coligação como comunhão de propósitos, como integração de princípios e doutrina e estabelecimento de compromissos públicos. Coligar pressupõe uma agenda de conceitos programáticos aceitos entre as partes. A coligação mais lógica deve ser com uma agremiação que compartilhe dos mesmos ideais e com a qual tenhamos afinidade programática. Diante dessa hipótese, surge o PSDB como o partido mais assemelhado e próximo do PMDB, de quem, aliás, se originou.

Saímos de uma mesma célula-mãe, temos no sangue um mesmo DNA político e, de certa forma, estamos sob o mesmo guarda-chuva da democracia social. Fizemos e ainda fazemos parte de uma aliança que garantiu à sociedade uma base de modernização institucional. São inegáveis os avanços dados pelo Brasil, garantidos pelas reformas econômicas, a partir do programa de privatizações, pelo esforço contínuo de remodelação do Estado, pelo reaparelhamento da estrutura social, pelas mudanças no campo e pelas políticas setoriais, particularmente nos campos da saúde e da educação.

Esse reconhecimento público é também o registro de nossa presença, por meio de apoio efetivo, aos avanços conseguidos pelo país. O Brasil, sob o comando de um homem preparado e com visão abrangente dos problemas mundiais, voltou a conquistar respeito nos fóruns internacionais. 
É claro que o PMDB tem críticas a fazer a ênfases impressas no manejo macroeconômico, que castigam parcelas ponderáveis da sociedade e dos setores produtivos. Os custos sociais de um rígido programa de estabilidade monetária são muito altos, refletindo-se em altas taxas de desemprego e em grandes desajustes nas esferas sociais, a partir da equação de distribuição de renda, que cria distâncias absurdas entre as classes sociais. Nesse ponto, cabe assinalar que o PMDB apresenta um conjunto de diretrizes para ajustar a equação social, para cuja implantação exige compromisso do PSDB, condição, aliás, para a coligação que queremos formar.

O Nordeste, com seus 44 milhões de habitantes, mais de $17 \%$ do PIB nacional e $27 \%$ do eleitorado nacional, tem muito a esperar do futuro governo. Os nove Estados nordestinos, uns mais que outros, avançam na implantação de estruturas públicas modernas, sedimentadas nos conceitos de eficácia, custo/ benefício, racionalidade, agilidade e qualidade dos serviços.

Podemos dizer que a região está preparada para alçar vôo e melhorar os indicadores sociais, que ainda se apresentam bem abaixo das macrorregiões brasileiras. Para tanto, precisa reforçar o crescimento econômico amparado em investimentos fixos na infraestrutura básica, na indústria de transformação e no setor de serviços, particularmente o eixo do turismo.

Com a experiência de oito legislaturas na Câmara Federal, participando ativamente das grandes questões nacionais, posso afiançar que nunca o país esteve tão perto de ingressar no ciclo do desenvolvimento auto-sustentado. Por isso mesmo, há de apostar na continuidade com avanços, que é o lema básico do candidato José Serra. Trata-se, sem dúvida, do mais preparado e orgânico perfil entre os candidatos -e o melhor ministro da Saúde que o Brasil já teve.

O PMDB oferece à sua candidatura um complemento-chave, que é a estratégia de inserção social e um projeto de integração harmônica do desenvolvimento, a começar por uma clara política de desenvolvimento regional, que é uma das carências da gestão. E o faz com a força de um partido de capilaridade nacional. Os compromissos com a região Nordeste haverão de fortalecer a coligação com o PSDB, mobilizando a força de mais de 30 milhões de eleitores.

\section{$x X X X X X X X X X X X X X X X X$}

Henrique Eduardo Alves, 53, é deputado federal pelo PMDB do Rio Grande do Norte. Foi presidente da Comissão de Constituição e Justiça e secretário de Governo e Projetos Especiais do Rio Grande do Norte. 